\title{
Subversive Sainthood and Tantric Fundamentalism: An Historical Study of Tibet's Holy Madmen
}

\author{
David Michael DiValerio \\ Upper Darby, Pennsylvania \\ B.A., Wesleyan University, 2003 \\ M.A., University of Virginia, 2005
}

A Dissertation presented to the Graduate Faculty of the University of Virginia in Candidacy for the Degree of

Doctor of Philosophy

Department of Religious Studies

University of Virginia

May, 2011

Professor Kurtis Schaeffer

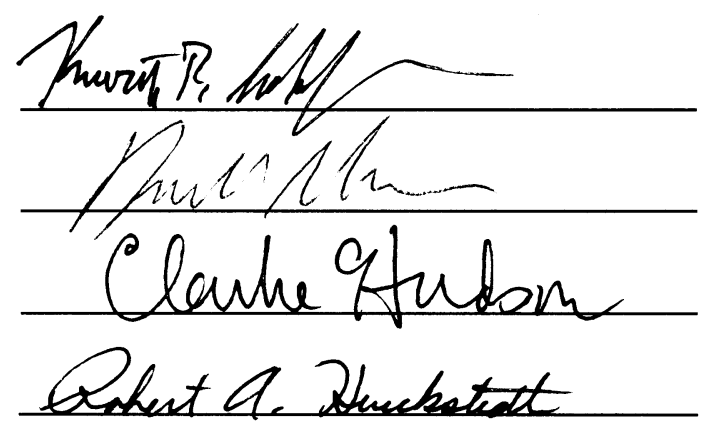

Professor Robert Hueckstedt 
(C) Copyright by

David Michael DiValerio

All Rights Reserved

May 2011 


\begin{abstract}
This dissertation is an historical study of Tibetan Buddhists generally referred to as "madmen" (smyon pa), whose "madness" carries a positive valuation more often than a negative one. Technically they are referred to as "mad siddhas" (grub thob smyon pa) or "mad yogis" (rnal 'byor smyon pa). This study seeks to uncover the purpose behind the eccentric behavior that got these ascetics labeled "madmen"; this understanding is arrived at through a systematic consideration of the ascetics' eccentric behavior in the context of their actual lives, and the greater context of the historical moment in which they lived. This study views this eccentric behavior as strategic, purposeful activity, rather than being the byproduct of a state of enlightenment. This study also considers how these holy madmen have been understood by Tibetans and Euro-Americans, with the purpose of highlighting certain lines of thinking that have become commonplace within those respective discourses.
\end{abstract}

This study takes into consideration "madmen" living from the 12 th century to the present, but with a special focus on the three most famous exemplars of the tradition: Sangyé Gyeltsen (better known as the Madman of Tsang, 1452-1507), Drukpa Künlé (better known as the Madman of the Drukpa, 1455-1529?) and Künga Zangpo (better known as the Madman of Ü, 1458-1532). I argue that the distinctive eccentric behavior of the Madmen of Ü and Tsang is best understood as a form of "tantric fundamentalism" in that it was based on following a literal reading of the Highest Yoga tantras, enacted as a strategic response to changes taking place in late 15 th-century Tibetan religious culture. The "madness" of Drukpa Künlé resulted from his taking a critical stance towards Tibetan religious culture in general. This study concludes that the "holy madman" 
tradition is constituted by highly self-aware individuals making strategic use of the theme of madness in the construction of their public personas. 
Dedicated to the memories of two great friends and teachers Julian Paul Green and Gen Dawa 


\section{Table of Contents}

Acknowledgments viii

Introduction

Chapter 1: Popular Conceptions, Scholarly Presumptions 13

1.I. The Contemporary Tibetan Understanding of Holy Madmen 14

1.II. The Popular Euro-American View 26

$\begin{array}{ll}\text { 1.II.1 Keith Dowman } & 27\end{array}$

1.II.2 Georg Feuerstein 33

1.III. The Modern Academic Discussion of Holy Madmen 39

$\begin{array}{ll}\text { 1.III.1 Geoffrey Samuel } & 40\end{array}$

1.III.2 Ardussi and Epstein $\quad 43$

1.III.3 The Historical Perspective $\quad 63$

$\begin{array}{ll}\text { 1.IV Conclusion } & 66\end{array}$

Chapter 2: The Lives of the Madmen of Ü and Tsang 69

2.I. The Life of the Madman of Ü 69

2.II. The Life of the Madman of Tsang 88

Chapter 3: Mad Behavior, Tantric Fundamentalism 106

$\begin{array}{ll}\text { 3.I. Introduction } & 107\end{array}$

3.II. Eccentric Behavior, Engaged Asceticism 108

3.II.1 Engaged Asceticism in the Lives of the Madmen of Ü and Tsang 112

3.II.2 "...there is no rivaling the Madman of Tsang or the Madman of Ü in engaged asceticism..." 136

3.III. Macabre Herukas and Tantric Fundamentalists: Engaged Asceticism continued

3.III.1 The Garb of the Heruka 144

3.III.2 Tantric Fundamentalism 156

3.III.3 In the Image of the Siddhas? 175

3.III.4 "You, the hero, glorious Heruka himself..." 181

3.IV. Crazy Behavior $\quad 185$

3.V. South Asian Precedent: Pāśupatas, Kāpālikas and the Origins of

$\begin{array}{ll}\text { Buddhist Tantra } & 202\end{array}$

3.V.1 The Pāśupatas $\quad 202$

3.V.2 Kāpālika-style practice 209

3.V.3 The Question of Influence 215

3.V.4 The Rhetoric of "Madness" in the Śaivite Tradition 223

3.VI. Conclusion: The Inherent Ambiguity of Sainthood 227

Chapter 4: Madmen in the Marketplace: Fame, Patronage and Civil War in 15th-century Tibet 
4.I. The Drumsound of their Fame: "Holy Madmen" in the Religious Marketplace

4.II. Tantric Fundamentalism in Context: Competing Models of Buddhist Life

4.III. Tantric Fundamentalism: A Creative Response to 15th Century

Circumstances

4.III.1 The Geluk-Pakmodru Partnership

4.III.2 The Rinpungpa Revolt and anti-Gelukpa Antagonism

4.III.2.i Rinpungpa Military Campaigns Under Dönyö Dorjé

4.III.2.ii Sectarian Aggression Under the Rinpungpas

4.III.2.iii Rinpungpas and Sakyapas

4.III.3 The Holy Madmen and their Patrons

4.III.3.i The Patrons of the Madman of Ü

4.III.3.ii The Patrons of the Madman of Tsang

4.III.3.iii The Significance of these Patronage Relationships

4.III.4 The Madmen of Ü and Tsang in their Time 350

4.IV. A Madman Movement? 355

4.IV.1 The Relationship Between the Madmen of Ü and Tsang 358

4.IV.2 The First Pawo, Chöwang Lhündrup 368

4.IV.3 Drakpa Tayé

4.IV.4 The Madman Movement 389

4.V. Conclusion

392

Chapter 5: The Curious Case of Künga Lekpa, "Madman of the Drukpa"

5.I. Popular Representations of Drukpa Künlé in the Oral Tradition and Collections of "Dirty Stories"

5.I.1 The Southern Collection

5.I.2 Geshé Chaphu's Version of the Life 403

5.II. Drukpa Künlé's “Collected Works” 413

5.II.1 The Colophons and Structures 414

5.II.2 The Contents of the "Collected Works" 431

5.II.2.i Drukpa Künlé's Family and the Trajectory of his Life 432

5.II.2.ii Drukpa Künlé's Wife and Son 435

5.II.2.iii Drukpa Künlé's Position in Politics 440

5.II.2.iv Drukpa Künlé's Critical Attitude 444

5.II.2.v Drukpa Künlé's Attitude Towards Holy Madmen; Drukpa

Künlé's Madness

5.III. Conclusion: Who Was Drukpa Künlé? 470

Chapter 6: The Holy Madmen's Cultural Project: Constructing History 474

$\begin{array}{ll}\text { 6.I. Text and Representations } & 474\end{array}$

6.II. The Literary Project of the Madmen of Ü and Tsang and their Disciples 484

6.II.1 The Agenda of the Madman of Tsang's Literature 498

6.II.1.i The Madman of Tsang's Compositions 498

6.II.1.ii The Madman of Tsang's Strategic Innovations in the Life and 
6.II.1.ii.2.a Gampopa Over Rechungpa: Strengthening the Lineage

6.II.2 The Material Circumstances of Printing; the Madman's Bigger Picture

6.II.3 For the Good of the Kagyü; Redefining the Kagyü

6.II.3.i Kagyü and Drukpa Kagyü Affiliations?

6.II.3.ii The Aural Transmission $\quad 546$

6.III. Milarepa the Madman

6.III.1 The Madman of Tsang as Milarepa

Chapter 7: Who's Mad? A Survey of Tibet's "Holy Madmen," and Almost Madmen

7.I. Other "Madmen" in Tibetan History

7.I.1 Madmen in the Cutting, Pacification and Treasure Revelation Traditions

7.II. Not Quite Crazy? Would-Be Madmen of Tibet's Past

7.III. "Madwomen"

7.IV. Are there "Madmen" Today?

665

7.V. "Madman" as a Pen Name

7.VI. Chögyam Trungpa Rinpoché

7.VII. Conclusion: "Madman”: A Floating Signifier

\section{Conclusion}

Afterword

I. Tibetan-language Sources

I.1 Biographies of the Madman of Ü

I. 2 Biographies of the Madman of Tsang

I.3 Biographies of the Madman of the Drukpa 698

I.4 Other Tibetan Texts $\quad 699$

$\begin{array}{ll}\text { II. European-language Sources } & 706\end{array}$

III. Interviews 


\section{Acknowledgments}

In the fall of 2001 Ben Bogin, Kabir Heimsath and Hubert Decleer introduced me to Tibetan culture in such a way that from then on it would always be interesting. Just as importantly, they showed me that one could make a career of studying Buddhism and traveling in Asia, which had not occurred to me before then.

At the University of Virginia there were many professors who played an important role in my formation as a scholar. I would like to thank Jeffrey Hopkins, Karen Lang, Paul Groner, John Nemec, Bob Hueckstedt and Clarke Hudson. I owe a particular debt to David Germano, who has challenged me like no one else. Most of all I must thank my advisor Kurtis Schaeffer, who is an inspiration, a source of encouragement, and who provides a model of the kind of work I aspire to do.

I also thank Andy Quintman and Stefan Larsson, colleagues who have also dedicated years to the study of the Madman of Tsang and who have shared openly with me since I first became interested in this topic.

I graciously thank the many Tibetan language instructors I have had over the years, without whom I could not have developed the most essential skills needed to do my research. I thank Rinchen (Dharamsala), Steve Weinberger, Tsering Wangchuk, Sönam Yanki, Slava Komarovski, David Germano, and the staff in the Foreign Students' Department at Tibet University. Thanks also to Nawang Thokmey, Tibetan language materials librarian at the University of Virginia. 
I express heartfelt thanks to the learned Tibetans who have kindly volunteered their time to work with me over the years. These are Khensur Wangdak Rinpoché (Middletown, CT, who patiently read Tibetan texts with me before I knew anything), Lama Ngawang Rinchen and the other members of Bengen Monastery, Kenpo Ngawang Dorjé and Sangyé Tendar Naga. Very special thanks to Kenpo Tsülnam Rinpoché of Sherab Ling Monastery, who took time to meet with me during what was a very busy few months for him. I also thank the many other Tibetan lamas with whom I spoke about holy madmen during my fieldwork in India.

Thanks to the many graduate student friends I have made in Tibet, India and especially at UVA. You have helped make the journey both meaningful and fun. Graduate students are like birds gathered in a tree at night, chatting all the more noisily because they know that in the morning they will have to go their separate ways. A very special thanks to the friends with whom I have had the most important conversations over the years, the conversations about ideas: John Wade, Victor Mungen, Jeremy Saucier, Ann Schlegelmilch, Gabe Popkin, Jongbok Yi, Zach Rowinski, Erin Burke, Nic Bommarito, David Tomlinson, Jann Ronis, Alison Melnick, Adam Newman, Matt McMullen, David Slatkin and Alison Broach.

Thanks to the Charlottesville bike polo crew, with whom I had countless hours of fun that had nothing to do with writing my dissertation.

Fieldwork for this project was carried out thanks to a grant from the American Institute for Indian Studies. My graduate education was also supported by a Presidential Fellowship and a Dissertation Acceleration grant from the University of Virginia, as well as Foreign Language and Area Studies grants from the federal government. 


\section{Introduction}

Sangyé Gyeltsen, known to the world primarily as "the Madman of Tsang, the Heruka," became famous for walking around central and western Tibet smeared with corpse ash, adorned with bones and other human remains, and performing shocking behavior like eating feces in the middle of a bustling marketplace. Künga Zangpo, the Madman of Ü, slapped powerful lords in the face and was brutally beaten for it. Drukpa Künlé, the Madman of the Drukpa, composed verses that overturned all sense of religious propriety, paying homage to an old man's impotent member rather than to the all-perfect Buddha.

The central question this dissertation seeks to answer is what motivated the eccentric behavior of these so-called "holy madmen"? Why did these three and other Tibetans behave in odd ways that would get them labeled "madmen," with that term carrying positive or at least ambiguous connotations? In what sense were they "mad"? In this dissertation I will explore Tibetan "holy madness" by focusing on the men (and a few women) behind these mad personas. We will consider the religious practices and literary works of these holy madmen in the context of the times and places in which they lived. We will also pay close attention to how we have come to know about these misfits. Our search to understand the history of the holy madman phenomenon will bring us from South Asian ascetic practices predating Buddhism to 15th century Tibet to 20th- 
century America; we will range from the complexities of central Tibetan politics to lesser-known tantric practices to the literary analysis of hagiographies.

The traditional Tibetan worldview holds that there are a number of factors that could cause mental derangement in an individual. In some cases madness was thought to result from problems inside an individual's body, as understood from the perspective of the Tibetan medical tradition. Often this would be articulated as an imbalance of the three humors. This includes the most commonly-cited cause of madness, a disorder in the psycho-physical winds (rlung), which carry thoughts and animate the body. ${ }^{1}$ (In the Tibetan medical tradition a line between "mental" and "physical" afflictions is not often drawn.) Another main cause of madness in the traditional Tibetan worldview is harm (gdon) coming from outside the individual. These range from witches to demons to the adverse influence of the movements of celestial bodies. One can also go mad because of ingesting poison or coming into contact with pollution (grib smyo). ${ }^{2}$ One can also go mad in the course of advanced tantric meditation. Madness in this context may be attributed to the meditator's committing an error in his manipulation of the psycho-

\footnotetext{
${ }^{1}$ According to menpa Tsewang Tadrin (sman pa tshe dbang rta mgrin), former principal of the College of Medicine and Astrology (sman brtsis khang) in Dharamsala, rlung gi nad account for 60 to 70 percent of all cases of madness in the traditional Tibetan view (interview, 7 September 2009).

There can also be a disorder of the channels in which the winds circulate (rtsa smyo).

Complicating matters, some cases of "wind disorder" are perceived as having been caused by demonic attack, raising the question of how they should be classified. See Kim Gutschow, "The Practice of Tibetan Medicine in Zangskar: A Case of Wind Disorder" in Healing the Periphery: Ethnographies of Tibetan Medicine in India, edited by Laurent Pordie (Durham, NC: Duke University Press, 2009).

${ }^{2}$ Very similar structurally speaking, the anthropologist Stanley Royal Mumford was told by some Tibetans living in highland Nepal that if he spent too much time around the local non-Buddhist shamans, he would go crazy. Himalayan Dialogue: Tibetan Lamas and Gurung Shamans in Nepal (Madison: The University of Wisconsin Press, 1989), p 9.
} 
physical winds within his body, or to a demonic attack while he was in a vulnerable state. $^{3}$

Distinct from all of these possibilities, there were individuals called "mad" whose apparent mental unwellness was seen as being not the result of any unfortunate circumstance, but symptomatic of having achieved a more exalted state of existence through religious practice. Although they are called "mad," that term, through a series of reversals, comes to bear mainly positive connotations. It is these individuals whose lives this dissertation explores.

When using precise terminology, Tibetans refer to these figures as grub thob smyon pa, which is most accurately rendered in English as "mad siddhas." A siddha is traditionally understood as one who has achieved a different ontological state through advanced tantric practice; he is enlightened and can perform supernatural feats.

However, Tibetans most often refer to the figures that are the subject of this dissertation simply as "madmen" (smyon pa), using the full term "mad siddhas" only infrequently. Nevertheless, it is clear from context that the meaning "mad siddha" is to be understood; when Tibetans speak about figures like the Madman of Tsang or the Madman of the Drukpa as "madmen" (smyon pa) it is obvious that they mean "madmen" in an exalted rather than a mundane sense. Those writing in English about these figures have variously referred to them as crazy siddhas, divine madmen, saintly madmen, Mad Yogins, "Crazy Yogins," and so on. Each of these renderings has advantages and disadvantages. In this dissertation I mostly use the term "holy madman" (sometimes with the parentheses,

\footnotetext{
${ }^{3}$ On the various causes of madness in the traditional Tibetan worldview, see John Ardussi and Lawrence Epstein, "The Saintly Madmen in Tibet," in Himalayan Anthropology: The Indo-Tibetan Interface, edited by James Fisher (The Hague: Mouton, 1978), pp 329-31.
} 
sometimes without), as this seems the most neutral and accessible phrasing. To be most accurate I would use only the Tibetan, grub thob smyon $p a$, but this would prove tiresome for most readers. Although the term "mad siddha" has the advantage of being very literal, I do not use it because it is too delimiting. The term "holy madman," although less literal, will allow us to come to our own understanding of who these men were. When calling them "holy madmen" I use the term "holy" not to imply that from my perspective these are in fact holy beings, but rather that they tend to be revered as such by Tibetans (although we will see that they often had their critics).

Here I offer only a rough definition of the topic of this dissertation by distinguishing "holy madmen" from what they are not. The following seven chapters constitute a description of what they are. A more succinct description of the phenomenon will be offered in Chapter Seven.

This dissertation is not a Foucault-style study of the shifting conceptions of madness in Tibetan culture historically. That is would be a worthy project in its own right, but falls well outside the confines of the present study, as the "madness" of these "holy madmen" is of a specific, rarefied type and has little to do with the other sorts of madness perceived by traditional Tibetan thinking listed above. This study does not include individuals commonly understood as "mad" in the unfortunate sense; no one would mistake the subjects of this dissertation as really crazy (although they constantly bring attention to the question of how one draws the line between sane and insane, deluded and enlightened).

Nor does this dissertation address the "mad saint" traditions of other religions and cultures. There are comparable traditions of "crazy" Buddhist saints in India, China and 
Japan. There are also crazy saints and holy fools in Hinduism, Islam, in the Christianity of Russia, pre-modern Greece, and other of the world's cultures. Each of these traditions is worthy of sustained study in its own right. A synthetic or comparative study of mad saints across these various traditions may also be a worthwhile project. However, until due diligence has been done on the holy madman tradition in Tibet, there is little value in comparing it to these other traditions.

The goal of this dissertation is to trace the long history of "holy madness" in the Tibetan Buddhist context, from roughly the 10th century to the present. A secondary question addressed herein is how the tradition of "holy madmen" in Tibet has been understood by Euro-American commentators. The idea of Buddhist holy madness has caught the imaginations of many westerners who have encountered this religion. In Dharma Bums, Ray Smith, the voice of Jack Kerouac, narrates: "I wrote a pretty poem addressed to all the people coming to the party: 'Are in your eyelids wars, and silk... but the saints are gone, all gone, safe to that other.' I really thought myself a kind of crazy saint." Smith often refers to his friends as "Zen Lunatics," indicating how in their freespiritedness they emulated the ways of past Buddhist sages. For Smith-and Kerouac, who is an influential figure in shaping Euro-Americans' perception of Buddhism-holy madness is a natural part of this religion. But the goal of this dissertation is explore this tradition as manifest on Tibetan soil. The way Tibetan Buddhist holy madness has been imagined by modern-day Euro-Americans is a related topic that will be only touched upon only briefly. This question, along with those of how the Tibetan version of holy madness might compare to Ch'an or Zen iterations, must be put off until some later time.

\footnotetext{
${ }^{4}$ The Dharma Bums (New York: Penguin Books, 1986), p 186.
} 
One observation that catalyzes the research presented in this dissertation is that most Buddhist renunciants still live within the matrix of worldly activity. Some Buddhist anchorites surely did turn their backs on the world and free themselves from all social ties. But those living entirely off the grid are rarer than one might think. This is due to the simple fact that a hermit, no matter how dedicated to the ideal of extricating himself from society, still needs food with which to sustain himself, and that sustenance in most cases comes as a gift generously donated by others. Moreover, the hermit participates in a craft that is usually taught to him by others, and by making an outward display of leaving mundane society, he enters into the community of renouncers. Nevertheless, in the course of Buddhist history there have been some individuals who did realize the hermetic ideal to its fullest. But about them we do not know, as they by definition would not have been involved with the production of literature or have associated with communities or institutions that would have related their legacies to us.

The ascetics discussed in this dissertation (as with the vast majority of all Buddhist ascetics, despite what rhetoric they may espouse) had various social ties, were engaged in worldly activities and displayed concerns about their legacies - all of this while claiming their lifestyles to be the truest form of Buddhist renunciation. The Madman of Tsang, for example, mass-produced Tibetan-language literature using the most advanced technology available during his time; he also performed his provocative, shocking behavior in the most public of all venues. Clearly this was not a man striving for anonymity. With these holy madmen and many figures like them, the significance of their claims about ascetic ideals are only fully understood when we consider the social 
circumstances in which they were articulated. Never in their lives did these holy madmen escape the social matrix, despite what they claimed to be striving towards. Publicly announcing one's rejection of the world is a social act. Keeping this in mind makes possible many new ways of understanding the history of Buddhism and other religions, including new answers to the question of why our holy madmen behaved the way they did.

This dissertation assumes that individuals living in literate cultures of any time or place (including 15th- and 16th-century Tibet) would be driven by the same most fundamental set of concerns and desires. This research assumes that people will strive towards success (however that is defined by the culture and the various communities in which they participate), and that people will attempt to gain more control over the circumstances of their individual lives rather than willfully surrender to the control of others. Most basically, this dissertation takes it for granted that a drive towards selfpreservation is universal to the human experience. At a given moment the person might take action to ensure her own self-preservation; at other moments she will act in the interests of the greater community or corporate body of which she is a part. But both instances are witness to the same most fundamental concern.

This dissertation does not assume that simply because an individual has been ordained as a monk or lives as an ascetic he somehow stops being motivated by these concerns, having replaced them completely with an altogether different set. Rather, this dissertation sees religious rhetoric and ideals to be expressed in the midst of and profoundly affected by real-world circumstances. Moreover, it sees those whose livelihood comes from religious practice - monks, ascetics, ritualists, and so on-as 
themselves being aware of these dynamics more often than not. I assume this kind of awareness to be possessed even by those individuals who became renowned as "holy madmen." As we will see in the course of this dissertation, many of these "holy madmen" were hyperaware of these dynamics, with their taking on identities as "holy madmen" being the result of a purposeful, strategic decision made amidst real-world circumstances at a specific moment in history.

In this dissertation I maintain that while conducting our research it is best to assume that although history has been witness to a broad spectrum of human capabilities and intelligence, there is no moment in a person's development when he or she takes on supernatural abilities or omniscience. In the world constructed by the pages that follow there is no moment at which an individual achieves a different ontological state as a siddha or a Buddha. Rather, for the purpose of academic research we assume that these ideas and categories exist and are variously used within the understandable realm of human culture and history. This research assumes that everyone in human history can be located on the same basic spectrum, that there is no one who has fallen off the table (or flown up into the sky). Any claim of an ontological change of state through extraordinary religious achievement is more fully understood when one considers the needs and intentions of those making such claims, which necessarily brings us back into the domain of language, culture and the history of people.

The argument put forward by this dissertation proceeds as follows: Chapter One begins with a description of the popular contemporary Tibetan understanding of the "holy madman" tradition. It then surveys and analyzes popular and academic explanations of the Tibetan "holy madman" phenomenon offered by Euro- 
Americans. I argue that Euro-Americans addressing "holy madmen" have been reluctant to view the phenomenon from perspectives meaningfully divergent from the traditional Tibetan understanding. As a result, little effort has been put into the task of understanding Tibet's holy madmen from a historical perspective.

Chapter Two contains brief biographies of the two holy madmen who occupy the most central role in this dissertation: the Madman of $\ddot{U}$ (1458-1532) and the Madman of Tsang (1452-1507).

Chapter Three begins by describing some of the shocking, antinomian behavior for which the Madmen of $\ddot{U}$ and Tsang were famous. It then analyzes the terms and categories used to refer to that activity in their respective biographies, along with statements by the Madmen of $\ddot{U}$ and Tsang about the reasons for their eccentric behavior also contained therein. I argue that the seemingly-odd behavior of the Madmen of Ü and Tsang is best understood as their enacting a form of "tantric fundamentalism," in that it resulted from their following a literal reading of certain passages of tantric Buddhist texts that were most often taken figuratively in Tibet.

Chapter Four puts the Madmen of Ü and Tsang's decisions to embody this tantric fundamentalism in the context of the broader religious and socio-political events that defined late 15 th- and early 16 th-century Tibet. I argue that the Madmen of Ü and Tsang's decisions to embody such a literal reading of the tantras was part of an attempt to reimagine and redefine the Kagyü sect in light of their waning fortunes brought on by the aggressive growth of the Geluk sect and the brand of Buddhism they offered. This chapter traces the Madmen of Ü and Tsang's relationships with their various patrons, 
which situates them in the broader sweep of events that characterized the historical moment in which they lived.

Chapter Five explores what is known about Drukpa Künlé, the Madman of the Drukpa (1455-1529?). An attempt is made to separate the historical Drukpa Künlé from more recent and popular representations of him. I argue that although he was a contemporary of the Madmen of Ü and Tsang, Drukpa Künlé enacted a very different model of "madness."

Chapter Six describes the greater cultural project the Madman of Tsang was engaged in during his lifetime. This includes his writing the Life and Songs of Milarepa, the printing projects initiated by him and continued by his disciples, and his renovation of the Swayambhūnāth stūpa in Nepal in 1504. I argue that the Madman of Tsang's editorial decisions in creating and mass-printing the Life and Songs of Milarepa and other texts belie a specific agenda, which was to spread the renown of the Kagyü sect while offering a reimagining of that sect's history and founding ideals. The Madman of Tsang's tantric fundamentalist behavior and his broader cultural projects are seen as driven by the same basic motivation, as parts of the same body of work.

Chapter Seven offers a survey of the entire breadth of the holy madman phenomenon in Tibet, from 10th-century Tibetan meditators employing a rhetoric of madness all the way up to late 20th-century eccentrics who did the same. This chapter considers many Tibetan religious practitioners who engaged in the same antinomian behavior as the famous "holy madmen," and even referred to themselves as "madmen," but were not popularly renowned as such. In light of this I argue that one becomes a "holy madman" not because of having achieved an exalted state as a religious 
practitioner, but as a result of a social process. "Holy madness" is, in the end, best understood as a form or rhetoric.

The Conclusion returns to discuss the assumptions and theoretical convictions that underlie this project.

During the three years I have spent researching Tibetan "holy madmen" I have faced a wide variety of reactions from people with whom I have spoken about the topic. I have debated with other Buddhologists about fundamental assumptions, spoken to dozens of lamas and kenpos of the various Tibetan Buddhist sects, and given lectures about my findings to Tibetan scholars. I have also had countless conversations with average Tibetan folks I met, mostly in India, in which they asked me, "What is it that you're doing here?" Some thought holy madmen an odd subject to spend one's time studying. (I was successful by varying degrees in convincing them that it was not actually so pointless an endeavor.) Among Tibetans there was a strong but not universal sentiment that there was no sense to be made out of a tradition like the holy madmen: these are enlightened masters - what hope do we have of fully understanding their behavior? One of the basic goals of this dissertation is to show that there is, despite immediate appearances, a plentitude of meaning and coherence to the holy madman tradition.

My goal in this project is to bring these "holy madmen" down to earth, to borrow a phrase from Robert Ford Campany, who was done similar work on Taoist transcendents. ${ }^{5}$ My aim is to understand these "holy madmen" as real historical

\footnotetext{
${ }^{5}$ Robert Ford Campany, Making Transcendents: Ascetics and Social Memory in Early Medieval China (Honolulu: University of Hawai'i Press, 2009).
} 
individuals — as, above all else, humans. In so doing I go squarely against the traditional Tibetan understanding of these figures. I am driven by my conviction that seeing these holy madmen as ordinary human beings is the only way to appreciate how truly creative and brilliant they were. Seeing the holy madmen as enlightened siddhas robs them of their agency as historically-situated human beings.

There is no skirting the fact that the research presented in this dissertation is the locus of a clash between two discourses. One is modernist, secular and rooted in the Euro-American scientific tradition; the other discourse is traditional, based on Tibetan cultural formations and Buddhist ideals. In this dissertation the discussion of the latter discourse takes place within the confines of the former. For this I make no apology. I only ask that the value of my approach be judged not by a priori assumptions about what the modern academic study of Buddhism should be, but on the basis of whether or not a convincing argument is made in the pages that follow.

One Tibetan with whom I spoke about the holy madman phenomenon one morning as we walked down the steep hill behind the Library of Tibetan Works and Archives in Dharamsala told me that the holy madmen were very important, because "if there were no madmen, there would be no new [ways of thinking]" (smyon pa med na gsar pa yod ma red). I hope to show in the pages that follow that many of these "holy madmen" were forward thinking individuals who challenged the status quo that surrounded them - albeit not in the way many of us would assume. Let what follows in this dissertation be an offering to that same ideal of always searching for new modes of understanding. 


\section{Chapter 1: Popular Conceptions, Scholarly Presumptions}

He went to a big assembly at Tsari, his naked body rubbed with corpse ash, dabbed with blood and smeared with fat; he wore the intestines from a dead body as a necklace, and ornamenting his wrists and ankles; he cut off the fingers and toes, and having strung them together as a garland, tied up his hair with it. He wore on his body fine ornaments made of bone, which someone had offered to him. Sometimes laughing, sometimes crying, he did all sorts of nonsensical things (? gyam tho? gya mtho?), especially in the marketplace. Because of this, although the people of Tsari were untrained and very rough, he subdued them with his abilities and conquered them with his compassion. Thus they became faithful, and as they unanimously praised him as "the Madman of Tsang," in every direction that name became as renowned as the sun and the moon. ${ }^{6}$

\section{- The Life of the Madman of Tsang}

An important term, or principle, employed by the siddhas is sahaja, literally meaning 'born-together'. This was taken to denote the innate and spontaneous nature of the awakened mind. This idea underlies much of the unconventional behavior of the siddhas. From the perspective of conventional society, they appeared to be crazy. From their point of view, however, they were delighting in the spontaneity of non-dual cognition.

-Anthony Tribe ${ }^{7}$

What attitudes and ideas characterize the way people have thought about Tibet's grub thob smyon pa (crazy siddhas, Mad Yogins, divine madmen)? This chapter begins

\footnotetext{
${ }^{6}$ Götsang Repa, The Life of the Madman of Tsang, the Heruka, Who is Victorious in All Directions: the Essence of the Sun that Elucidates the Vajrayāna (gtsang smyon he ru ka phyogs thams cad las rnam par rgyal ba'i rnam thar rdo rje theg pa'i gsal byed nyi ma'i snying po), edited by Lokesh Chandra (New Delhi: Sharada Rani, 1969), pp 37.6-38.1. Written in 1547. This passage will be discussed further in Chapter Three, with the Tibetan provided then. This passage is translated in Andy Quintman in Mi la ras pa's Many Lives: Anatomy of a Tibetan Biographical Corpus (Ph.D. dissertation, University of Michigan, 2006), p 193.

${ }^{7}$ Paul Williams, with Anthony Tribe, Buddhist Thought: A Complete Introduction to the Indian Tradition (London and New York: Routledge, 2000). Tribe's chapter, "Mantranaya/Vajrayāna - tantric Buddhism in India" is pp 192-244. This quotation is from $\mathrm{p} 216$.
} 
by considering the ways modern-day Tibetans speak about holy madmen. We will then briefly consider the way holy madmen have been characterized by more popular EuroAmerican commentators. Lastly we will examine the ways they have been described in modern scholarly literature. In each case we will pay close attention to what has been said about crazy yogis, but also what has been left unstated, what various participants in this conversation assume about these seemingly eccentric figures. In this way we can uncover what has come to be common knowledge about Tibet's holy madmen in these different, overlapping spheres of discourse. Throughout this discussion special attention will be paid to the way these various commentators have understood the reason behind the mad behavior of the holy madmen, for this plays a crucial role in defining one's approach to the subject matter, determining which questions one asks and what kind of answers are possible.

\section{I. The Contemporary Tibetan Understanding of Holy Madmen}

In this section we will consider the ways Tibetans without extensive experience in Euro-American-style education and scholarship talk about "holy madmen," to get a sense of the mix of ideas that are most important for how they understand the holy madman tradition.

Tibetans today tend to be remember the holy madmen with great fondness. When asked what they thought about holy madmen (grub thob smyon pa), many of the Tibetans with whom I spoke immediately laughed. In some cases this was because they found humor in the fact that I would spend years of my life studying such a thing, but more often it was because my question brought to mind tales of the irreverent Drukpa Künléthe Madman of the Drukpa [Kagyü sect]—or some other crazy saint about whom they 
had heard. Drukpa Künlé is by far the most well-known of all the holy madmen. The Madman of Tsang and the Madman of Ü are a distant second- and third best-known, respectively. A few religious specialists mentioned these three saints together under the grouping "the Three Madmen" (smyon pa gsum) ${ }^{8}$ Some mentioned the famous saint Tangtong Gyelpo. Others mentioned some eccentric lama of recent times in their home region. The saint Milarepa was often mentioned by the people I interviewed and plays a major role in the way Tibetans understand the holy madman phenomenon, as will be seen shortly.

Tibetans often point out that the term I am translating as "holy madman," grub thob smyon $p a$, is an oxymoron bearing an impossible contradiction. Being a grub thob (a Tibetan rendering of the Sanskrit term siddha, which means one who is "accomplished [in meditation]"), means that one has achieved super-intelligence. An insane person cannot be a siddha; and a siddha, by definition, cannot be insane. ${ }^{9}$ This contradiction provides the basis for the most predominant way in which Tibetans interpret the crazy

\footnotetext{
${ }^{8}$ Choegyal Rinpoché, interview at Changchub Jong, H.P., India, 15 August 2009; Kenpo Könchok Namdak, interview at Phyang Monastery, Ladakh, 22 July 2009.

My comments here are based on interviews and less formal conversations I have had with Tibetans regarding the topic of holy madmen, and a few written sources as well. Most of the lamas, kenpos and rinpochés I interviewed were from the major branches of the Kagyü sect (Drikung, Drukpa and Karma). Among religious specialists, those with the greatest interest in Tibet's "holy madmen" tend to be from the Kagyü, especially the Drukpa Kagyü. This is no surprise, for this is the sect with which the most famous of Tibet's holy madmen were all associated. (During an interview I mentioned to Choegyal Rinpoché that he seemed to have an especially acute interest in the holy madmen, to which he replied, "Of course I'm interested in them-I'm a Drukpa!") I also interviewed a few Nyingma kenpos. In addition, I had many less-formal conversations with monks of the other schools (Geluk, Sakya, Jonang, as well as Bönpo), as well as with laypeople with varying degrees of formal education. Although all of my formal interviews on the subject were conducted in India in 2009, I believe they represent a fair cross-section of the Tibetan community. Most of my interviews and informal conversations were with people who were born in Tibet, some of whom were recent arrivals in India. I also interviewed a handful of Ladakhis, most of whom had undergone monastic education other places in India.

${ }^{9}$ Kenpo Losel Tsegyel, interview at Mindröl Ling Monastery, Clement Town, Uttaranchal, 10 October 2009; Kenpo Orgyen Tsering, interview at Nyinggön Pelyül Chökor Ling, Bir, H.P., 22 September 2009; Kenpo Tsülnam Rinpoché, interview at Sherab Ling Monastery, Bir, H.P., 23 September 2009; Öntrul Rinpoché, interview at Drikung Kagyü Monastery, Rewalsar, H.P. 30 September 2009.
} 
behavior of holy madmen: the holy madmen are highly-realized beings (grub thob, siddhas) who see everything as it truly is. Their way of seeing things is radically different from our deluded, unenlightened way of viewing things, which positions them out-of-step with our conventional expectations and makes them appear crazy. Seen from our usual perspective they seem insane. But from the perspective of truth, it is us, the unenlightened, who are truly mad. In this understanding their being labeled (and labeling themselves) "mad" is ironic, pointing out the radical disjunction between enlightenedness and non-enlightenedness. It is at once a symbol of the saint's state of awakening and a reminder of our own lack of it.

Based on this view, Tibetans often say that we, as ordinary beings, cannot comprehend the thoughts, actions or words of an enlightened being like Drukpa Künlé, for they are literally "inconceivable" (bsam gyis mi khyab pa). Many of my interviewees who would go on to offer an interpretation of the madman's behavior made clear their feeling that anything we might say on the subject is only provisional, that the truth is beyond what any of us might claim to know. ${ }^{10}$

The high level of spiritual realization that the madness of the holy madman represents gets described by Tibetans with a variety of related terms. It is often said to result from the fact that they have abandoned all rnam rtog (in Sanskrit, vikalpa), meaning conceptual formations or false ideations. Rnam rtog are preconceptions, which are, from the Buddhist perspective, misconceptions. ${ }^{11}$ These conceptual thoughts act like lenses that distort our vision of the world around us; only those who are free of these

\footnotetext{
${ }^{10}$ Kenpo Tinlé Tarchen, interview at Drikung Kagyü Monastery, Rewalsar, H.P., 29 September 2009.

${ }^{11}$ Kenpo Losel Rinpoché, interview at Kamgar Druk College, Tashijong, H.P., 13 August 2009; Kenpo Losel Tsegyel interview.
} 
thoughts can experience reality directly. Thus while unenlightened beings like us try to order our experience of the world by relying on such relative distinctions as big and small, hot and cold, dirty and clean, pleasant and unpleasant, comfort and pain, sin and virtue, a highly advanced Buddhist practitioner lives without such discursive categories mediating and distorting his experience of reality. Thus the advanced practitioner's mode of existing in the world is radically different from ours. Thus when the Madman of Tsang or the Madman of Ü eats the brains out of a human corpse, it shows that he has overcome the unenlightened way of experiencing the world and no longer sees this as disgusting, as we unenlightened people certainly would. Further, from the perspective of ultimate truth, there is no such thing as virtue or sin, which is why Drukpa Künlé, the Madman of the Drukpa, can sleep with other men's wives with impunity. This state is often described as their having transcended "worldly concerns" ('jig rten gyi chos). ${ }^{12}$ Sometimes it is said that because the holy madmen have abandoned "misconceptions" (rnam rtog) they have only "pure vision" (dag snang) or see everything as a buddharealm (zhing khams). ${ }^{13}$ This same basic idea can be formulated in a more general way by stating that the holy madmen behave in their distinctive, eccentric ways because they have "realization" (rtogs pa). ${ }^{14}$

Some learned Tibetans with whom I spoke mentioned Saraha, Virūpa, Nāropā or some other Indian mahāsiddha in the process of explaining the nature of holy madness. Often these siddhas were cited as individuals who appeared strange to the world but

\footnotetext{
${ }^{12}$ Kenpo Nyima Gyeltsen, interview at Kagyü College, Dehradun, 4 October 2009.

${ }^{13}$ Kenpo Losel Tsegyel interview.

${ }^{14}$ Kenpo Könchok Namdak interview.
} 
secretly harbored great wisdom. ${ }^{15}$ On other occasions they were referred to because of their ability to perform great miracles, which is taken as an indication of their having complete control over worldly appearances due to their realization of the emptiness of all phenomena. $^{16}$

One particular episode in the Tibetan Buddhist canon that has had a tremendous effect in shaping the way Tibetans think about holy madness comes from the life story of the 11th-century saint Milarepa. Although Milarepa is not often himself considered a "madman," he plays a key role in the entire history of the holy madman phenomenon, as will be discussed in Chapters Six and Seven. As was related to me numerous times in my interviews, once Milarepa was practicing in a cave by himself. He had no food or clothing and spent all of his time meditating. When his sister Peta arrived to visit him she was shocked at his appearance, bone-thin and naked. Peta left him with a length of cloth out of which to make a loincloth, for the sake of modesty. When she returned some time later, she found that he had not made a loincloth but crude sheaths for his fingers and penis. The furious Peta said that Milarepa was no longer human and did not know what shame (ngo tsha) was, chastising him for wasting the cloth she had worked so hard to acquire. Mila responded by saying that he, as a yogi dedicated only the practice of virtue, had nothing to be ashamed about. He saw no difference between any of the parts of his body, so what is there to cover up? His nudity is natural. On the other hand, the ones who should be ashamed are worldly people, who never cease to engage in sinful activity.

\footnotetext{
${ }^{15}$ Kenpo Könchok Namdak interview; Kenpo Nyima Gyeltsen interview.

${ }^{16}$ Wangdül Rinpoché, interview at the retreat center above Rewalsar Lake, H.P, 28 September 2009.
} 
Milarepa's asceticism is all for the sake of practicing religion, and he refuses to be judged by a system that is so hypocritical and ultimately dedicated to all the wrong things.

Tibetans often cite this story to make the point that we are the ones who are truly mad, not the great saints who may appear crazy from our conventional, deluded perspective. ${ }^{17}$ Milarepa's eccentricity here is merely an indication of his transcendence. The dictates of Buddhist practice may put one at odds with social conventions, but this is no reason to not pursue them. It is worth introducing to our consideration the fact that the man responsible for mass-printing and disseminating The Life of Milarepa in which this story is told was himself famous as a holy madman, the Madman of Tsang. The Madman of Tsang's composing and printing the Life and Collected Songs of Milarepa will be discussed in detail in Chapter Six. ${ }^{18}$

Those adhering to this basic understanding of holy madness - that it is a symptom of the saint's being enlightened and having transcended ordinary worldly delusions - tend to see the irreverent behavior of the holy madman as occurring naturally (rang bzhin gyis) rather than having some sort of purpose or intentionality behind it. ${ }^{19} \mathrm{He}$ is enlightened, experiences all phenomena as empty, and therefore behaves in ways that appear strange to our conventional perspective. This interpretation represents the most widely-held understanding of holy madmen espoused by Tibetans today.

\footnotetext{
${ }^{17}$ Kenpo Losel Rinpoché interview; Kenpo Nyima Gyeltsen interview; Kenpo Tsülnam Rinpoché mentioned this on multiple occasions, including 22 August 2009; Kenpo Sönam Tashi, interview at Zigar Monastery, Rewalsar, H.P., 29 September 2009.

${ }^{18}$ According to the record of his life, the Madman of Tsang was fully aware of the explanatory value of this story, but used it to exemplify something different from this. The Madman of Tsang used this story to teach what it means to be without shame (ngo tsha), but did not connect it to his eccentric, "madman" behavior, Götsang Repa, $\mathrm{p}$ 244.6. This points to the rift between current popular conceptions of the nature of the eccentric behavior of the holy madmen and the understanding of that behavior we arrive at from looking more closely the actual lives of those saints. This disjunct will be discussed further in this chapter. ${ }^{19}$ Kenpo Nyima Gyeltsen interview.
} 
This is not the only interpretation, however. Tibetans sometimes see this eccentric behavior as something engaged in with a very specific purpose in mind, either to help unenlightened beings realize the true emptiness of phenomena and overcome the misconceptions that keep then within the cycle of suffering and rebirth, or as part of the yogi's own training towards having that realization himself. I will now discus each of these interpretations in turn.

The idea that the behavior of the holy madman is by nature pedagogicalultimately for the sake of teaching other beings - is articulated in a few different ways. The most common way is to say that the madman does and says these wild, unexpected things in order to dispel the conceptual thoughts or misconceptions (rnam rtog) of his audience. ${ }^{20} \mathrm{He}$ is "simulating mad behavior" (smyon pa'i spyod pa 'khrab). ${ }^{21}$ Drukpa Künlé is often cited as one who exemplified this. He is said to have once lead a donkey to sit at the position of honor before a monastic assembly, which provoked the anger of the monks who felt themselves to have been disrespected. Their reaction served as a lesson that they had a long way to go towards achieving basic Buddhist humility, let alone the higher ideals that they, as monks, were supposed to represent. This basic interpretation has also been applied to another act for which some holy madmen became famous: eating the brains of corpses. We have notions about what is and is not appropriate to eat. By eating the brains of corpses the yogi reminds us that those notions are based on worldly conventions rather than on objective truth. Thus the eccentric yogi performs certain acts in order to challenge and help us overcome our usual thinking about

\footnotetext{
${ }^{20}$ Kenpo Könchok Norbu interview; Kenpo Sönam Tashi interview; Kenpo Tinlé Tarchen interview.

${ }^{21}$ Kenpo Tinlé Tarchen interview.
} 
pure and impure and other conventional distinctions, and thereby come closer to realizing the emptiness of all phenomena. In this view, the yogi's purposeful crossing of boundaries and calling into question the student's expectations and preconceptions (rnam rtog) is sometimes said to constitute the "introduction [to the nature of reality]" (ngo sprod) that is essential for the student's progress down the path to realization. ${ }^{22}$

A yogi can also teach others by performing a miracle. Many Tibetan yogis like our holy madmen are said to have had the ability to tie a metal sword into a knot with their bare hands, or to leave impressions on boulders with their hands and feet. This is sometimes interpreted as a lesson to the unenlightened, teaching that because everything is ultimately empty, nothing is impossible. Even that which seems to be most solid is, in truth, malleable. The yogi's purpose is not to show off, but to teach others the important truth of emptiness. It is for their benefit.

The third major way in which Tibetans today explain the behavior of the holy madman also involves an element of intentionality, but the yogi's concern is directed inward rather than outward. In this reading the crazy behavior is an aspect of the madman's own development, as part of a deliberate process through which he trains himself to see all phenomena as empty. In the previous reading it was suggested that a madman's eating brains from a human corpse would be for the sake of helping others abandon their conceptual formations (rnam rtog); in this third reading it is for the sake of the yogi's abandoning his own. By embracing the impure and the disgusting, by doing the utterly unimaginable - like removing one's clothes in the middle of a bustling city street, or slapping a king in the face, things our holy madmen became famous for having

\footnotetext{
${ }^{22}$ Kenpo Nyima Gyeltsen interview.
} 
done- one can have the invigorating experience of crossing some of the invisible lines we draw around us and which define the way we live and experience the world. By purposefully crossing those lines we can begin to erase them and move into a more immediate way of experiencing the world - a way that is based on truth rather than mere convention. In this reading the madman's behavior can be said to be for the sake of abandoning conceptuality (rnam rtog), ${ }^{23}$ or for changing one's “experiential understanding" (nyams myong), ${ }^{24}$ or for "training in experiencing [all phenomena] to be of a single taste" (ro snyoms) (in other words, to experience everything as empty). ${ }^{25}$

In describing the holy madman's crazy behavior as being for the sake of his own practice, some contemporary Tibetans see it as primarily about cultivating the sort of jarring experience just described. Others explain it in a way that emphasizes the fact that the holy madman is placing himself at odds with the dictates and concerns of society (spyi tshogs). ${ }^{26}$ By wearing rags and letting one's hair and nails grow long one can cultivate the feeling of living free from the usual worldly concerns ('jig rten gyi chos). This is ultimately for the sake of being more fully committed to one's religious goals. ${ }^{27}$ All commentators recognize that the holy madmen appear to live outside the concerns that define life for individuals fully participating in society; the question is whether this disjuncture is a natural byproduct of the yogi's state of realization or his mode of

\footnotetext{
${ }^{23}$ Choegyal Rinpoché interview; Kenpo Könchok Norbu interview; Kenpo Nyima Gyeltsen interview; Kenpo Tsülnam Rinpoché, interview 19 August 2009.

${ }^{24}$ Lama Tsültrim Topden Rinpoché, interview at Karma Dupgyud Choeling Monastery, Choklamsar (near Leh), Ladakh, 19 July 2009; Öntrul Rinpoché interview.

${ }^{25}$ Lama Tsültrim Topden Rinpoché interview.

${ }^{26}$ Kenpo Könchok Norbu interview.

${ }^{27}$ Lama Tsültrim Topden Rinpoché interview.
} 
teaching, or whether it is something purposefully cultivated for the sake of his own experience.

For example, in the story mentioned above in which Milarepa was living naked, with no possessions, completely unconcerned with what anyone might think of him, it is assumed that Milarepa was already fully enlightened at that point, and so he lived naturally free from such concerns. Few would suggest that it was something Milarepa was doing purposefully. What defines this third basic way of understanding the behavior of holy madmen is the notion that the yogi in question lives outside societal expectations purposefully for the sake of advancing towards liberation. This interpretation is not applied to beings thought of as fully liberated, but to the actions of those that are still on the path to enlightenment. For this reason this third interpretation of the holy madman's crazy behavior is less often applied to more famous saints like Milarepa and Drukpa Künlé, whom people assume to be fully enlightened beings; it is more often applied to the behavior of lesser-known "holy madmen," who do not have such well-established reputations for holiness.

These are the three basic modes through which Tibetans most often interpret the eccentric behavior of so-called holy madmen: it is either a natural result of their being highly realized individuals who experience all phenomena as empty; or it is done with the intention of teaching and liberating other beings; or it is part of their own training in learning to see everything as empty. There are variations in ways they are formulated, but these basic interpretations represent the main modes through which Tibetans understand the subject. The first interpretation described here is cited most often, and is nearly ubiquitous; the third is the least most appealed to. It must be borne in mind that 
many of those I interviewed stated uncertainty about whether we can ever be sure which of these interpretations is most accurate in a given situation. There is apt to be some overlap or conjunction between the first and second possible reasons for crazy behavior: is the yogi in question an enlightened being who has taken it upon himself to teach others $?^{28}$ Or is he teaching, regardless of whether or not we can determine that he is fully awakened? There can also be ambiguity with respect to the first and third possibilities: is the yogi fully awakened, or still training towards that goal? The same is true of the second and third possible reasons for crazy behavior: is this behavior performed for others or for the yogi himself? We have no means of determining how far along in his spiritual development the yogi is, nor can we really plumb his intentions. With respect to a being as famous and well-respected as Drukpa Künlé or Milarepa, it is generally agreed that he is a fully awakened being, free from all conceptualities and afflictive emotions. ${ }^{29}$ But for those of lesser stature, how could we say? This notion was expressed many times in the course of my interviews. ${ }^{30}$

There is also ambiguity with respect to the question of "real" and "fake" crazy yogis. Some say it is impossible to tell whether or not an eccentric individual is a holy

\footnotetext{
${ }^{28}$ In the Foreword to Keith Dowman's translation of a version of the Life of the Madman of the Drukpa (The Divine Madman: The Sublime Life and Songs of Drukpa Kunley, Varanasi and Kathmandu: Pilgrims Publishing, 2000), Choegyal Rinpoché (whom I interviewed and cite multiple times in this chapter) writes: "Drukpa Kunley's life shows us a liberated mind that is free from the preconceptions, preferences, bias, and mental activity that bind us in tension and fear, and shows us a way of life that frees us from emotional attachments and family ties. He gives us a vision of mad indiscipline and free wandering, and having accomplished the goal of his Dharma in one lifetime, he demonstrates a deceptively simple example and inspiration," pp 22-3. The possibility that Drukpa Künlé's mad behavior may be a natural byproduct of his being enlightened is offered directly alongside the suggestion that it may be engaged in for the purpose of teaching other beings, showing that there is little concern to differentiate between these two possibilities. ${ }^{29}$ Wangdül Rinpoché interview.

${ }^{30}$ His Holiness the 17th Karmapa stated that any of these three might motivations might lie behind the mad behavior of a crazy yogi, and it is only by specific context that one could determine which of the three was operative at that moment, interview at Gyutö Monastery, H.P., 4 August 2009; Kenpo Nyima Gyeltsen interview; Kenpo Tsülnam Rinpoché, interview 19 August 2009; Öntrul Rinpoché interview.
} 
madman, for there are no limitations to how a real crazy yogi might act or disguise himself. ${ }^{31}$ The behavior of the real holy madman will appear the same as that of the pretender; the only thing that differentiates them is the reason or the motivation behind their behavior. This can also be posited as a question of faith: it is not the motivations of the yogi that matters so much as the attitude with which one chooses to view him. As one Tibetan lama with a strong interest in this subject told me, those who are open to being taught will be taught a valuable lesson by the holy madman; those who are not will walk away unchanged. ${ }^{32}$ Other Tibetans, see a more concrete distinction, maintaining that if you were to put a "real" holy madman (who is either himself fully enlightened, or inspired by the motivation to teach others, or sincerely acting mad as part of his training) alongside a "fake" one, it would become obvious which is which. ${ }^{33}$

The most famous holy madmen (figures like Drukpa Künlé, the Madman of Tsang, the Madman of Ü and Tangtong Gyelpo) tend to be given the benefit of the doubt: they are accepted as "real" holy madmen, driven by some combination of the motivations listed above. There is less certainty regarding lesser-known and more recent figures sometimes said to be holy madmen.

The fact is that for Tibetans these questions are of little consequence. Tibetans tend to regard the famous holy madmen with respect, assume that they are fully liberated beings, and see no need to speculate about the reasons behind their actions. In the case of lesser-known figures sometimes identified as grub thob smyon pa or bla ma smyon pa who are not regarded as being on the distant shore of saintliness, there is less certainty,

\footnotetext{
${ }^{31}$ Choegyal Rinpoché interview; Kenpo Könchok Namdak interview.

${ }^{32}$ Choegyal Rinpoché interview.

${ }^{33}$ Kenpo Losel Rinpoché interview; Kenpo Nyima Gyeltsen interview; Kenpo Tsülnam Rinpoché, interview 9 August 2009.
} 
but an attitude of respect prevails. Looking for more definitive answers about the nature of their eccentric behavior is in a sense a purely academic exercise. Asking this direct if unnatural question helps bring to light the underlying, almost subconscious ways of thinking that shape Tibetan religious life.

In the preceding pages I have cited interviews with Tibetan religious specialists I questioned about the holy madman phenomenon. It has been my experience that among Tibetan laypeople with more or less formal education, the exact same ideas abound. Among laypeople the best-known mad saint by far is Drukpa Künlé; the most common understanding is that their madness is a symptom of their high state of realization, that in fact we are the ones who are truly crazy, not them; and Milarepa is often cited as one who exemplified this (although very few would say that he was a crazy yogi himself). The idea that enacting madness may be a special kind of teaching is also offered occasionally. In my experience it seems that there is no significant difference in the way holy madmen are understood by Tibetan religious specialists and non-specialists. The former may give more detailed explanations, but the fundamental ways of understanding them are the same throughout.

\section{II. The Popular Euro-American View}

We will now consider some of the ways the Tibetan holy madman phenomenon has been described by Euro-Americans. In this section we consider discussions of Tibetan holy madmen offered by two popular authors whose primary means of engagement with Buddhism is as practitioners and advocates. In the subsequent section we will examine comments by authors with a more academic relationship with the subject matter. 


\section{II.1 Keith Dowman}

The single most influential document in shaping how Euro-Americans have come to think about Tibetan holy madman phenomenon is The Divine Madman: The Sublime Life and Songs of Drukpa Kunley. This is a translation of a popular version of the biography of the 15th-century holy madman, Drukpa Künlé, renowned as the Madman of the Drukpa [Kagyü sect]. Keith Dowman, the translator of this text, teaches the Great Perfection system at Dharma centers all over the world. He is the author or translator of over a dozen books on Tibetan Buddhism. In addition to being engaging, provocative and easily-accessible (complete with cartoonish illustrations, some of which are rather lewd), this translation has achieved wide currency because of the mere fact that for many years it was the only English-language book on the topic of Tibetan holy madmen. Even to this day it seems to be the first book most people come across when beginning to investigate Tibet's holy madmen. As an index of its great popularity, the book has been printed four times in English (1982, 1983, 1998 and 2000). Further adding to its significance in shaping the Euro-American discourse on holy madmen, Dowman's rendering of Drukpa Künlé's Life has undergone two printings in German translation (1983 and 2005), two in Spanish (1988 and 2001), one in French (1984) and one in Romanian (2005). ${ }^{34}$ It has been cited many times in academic studies and periodicals. ${ }^{35}$

\footnotetext{
${ }^{34}$ First published by Rider \& Co, London, 1982; Dawn Horse Press, 1983; second edition by Dawn Horse Press, Middletown, California, 1998; published by Pilgrims Publishing, Varanasi and Kathmandu, 2000. Published in German as Der Heilige Narr (Barth, 1983); reprinted by Barth in 2005; published in French as Le Fou Divin (Albin Michel, Paris, 1984); published in Spanish as La Divina Locura Drukpa Künléy: Andanzas de un Yogui Tántrico Tibetano del siglo XVI (Madrid: Miraguano Ediciones, 1988 and 2001); published in Romanian as Nebunul Divin: viața sublimă a marelui maestru tantric Drukpa Kunley, translated by Octavian Creț, Firul Ariadnei, 2006.

${ }^{35}$ In her 2003 dissertation, Possession, Immersion, and the Intoxicated Madness of Devotion in Hindu Traditions (University of California, Santa Barbara) Marcy Alison Braverman quotes Dowman's evocative lines, "If insanity is defined as deviation from a psychological norm, the divine madman is truly crazy; but if a spiritual ideal is used as a yardstick, undoubtedly, it is the vast majority of us who are insane," in
} 
The document Dowman has chosen to translate is a version of Drukpa Künlé's biography written by a learned Bhutanese monk in the 1960s, although it is based on some earlier collections of stories as well as oral traditions. It presents an image of the holy madman as an iconoclast and a libertine. This text will be discussed in detail in Chapter Five.

Here we will limit our consideration to Dowman's comments in the Introduction to the text, which have had a great influence on how many have come to think about the Tibetan holy madman tradition. In these pages Dowman simultaneously presents a few slightly varying interpretations of the reason behind Drukpa Künlé's lewd and eccentric behavior. For one, Dowman makes statements that echo the most popular mode through which Tibetans explain holy madmen. Dowman writes evocatively of the entire holy madman phenomenon, concluding that: "If insanity is defined as deviation from a psychological norm, the divine madman is truly crazy; but if a spiritual ideal is used as a

defense of a relativist understanding of "mad" Śaivite siddhas (p 253). Braverman uses this quotation in her conclusion, positioning it in such a way that it serves the climax of her entire study.

In a 2006 volume that will be mentioned again below, Holy Madness: Portraits of Tantric Siddhas, edited by Rob Linrothe (New York: Rubin Museum of Art, 2006), Dowman is cited by various authors as an authority on the subject of enlightened madmen in Tibet.

In a 1991 article Hildegard Diemberger cites Dowman's work on Drukpa Künlé, "Ihakama [lha$b k a{ }^{\prime}-m a$ ] and khandroma [mkha'-'gro-ma]: the Sacred Ladies of Beyul Khenbalung [sbas-yul-mKhan-palung]," in Tibetan History and Language: Studies Dedicated to Uray Géza on his Seventieth Birthday (Wien: Arbeitskreis für tibetische und buddhistische studien universität wien, 1991), p 138.

Brook Larmer's March 2008 National Geographic article "Bhutan's Enlightened Experiment" clearly uses The Divine Madman as a source without formally citing it. The article talks of people "steeped in the ancient mysticism of Bhutan, land of the flying tigress and the divine madman...", p 128. The author maintains that "A sense of humor, even mischief, runs through Bhutanese Buddhism, whose earthly exuberance differs sharply from the ethereal calm of the better known Theravada Buddhism. The profusion of deities and demons can leave other Buddhists dazed. Sexual imagery also abounds, reflecting the tantric belief that carnal relations can be the gateway to enlightenment. Nobody embodied this idea more provocatively than the 16th-century lama Drukpa Kunley, better known as the Divine Madman, who remains a beloved saint in much of Bhutan. Carousing across the countryside, Kunley slew demons and granted enlightenment to young maidens with the magical powers of his 'flaming thunderbolt.' To this day, many Bhutanese houses are adorned with signs of protection: an enormous painted phallus, often wrapped in a jaunty bow," $\mathrm{p} 132$.

The discussion of Drukpa Künlé's “flaming thunderbolt" comes directly from Dowman's introduction, $\mathrm{p} 30$. 
yardstick, undoubtedly, it is the vast majority of us who are insane." ${ }^{36}$ From our unenlightened perspective these saints may appear mad; but from the perspective of truth it is just the opposite. Although Dowman's comments here are made about Drukpa Künlé specifically, he would likely apply the same explanations towards understanding the behavior of the other most famous of Tibet's "holy madmen," including the Madman of Ü and the Madman of Tsang, whom Dowman states are "revered equally with Drukpa Kunley as divinity incarnate to teach through crazy-wisdom."37 Dowman refers to Drukpa Künlé as "the archetypal divine madman.,"38

Dowman's explanation of Drukpa Künlé's crazy behavior suggests that it may have been driven by other motivations as well. These include making a critique of institutionalized religion and working to liberate the minds of his audience in a more direct way.

Regarding the first of these perceived motivations, in Dowman's understanding one aim of Drukpa Künlé's mad behavior was to help people turn away from the stuffiness and decadence that sometimes threaten to swallow up what he considers to be genuine religious practice. Dowman explains that much of Drukpa Künlé's behavior amounted to "attacks upon monasticism and organized religion." ${ }^{39}$ Like Saraha and other famous Indian siddhas of the past, Drukpa Künlé sang songs that condemned academic scholasticism, empty ritual, and self-righteousness; he pointed out hypocrisy and excesses within the monastic community, the pursuit of worldly wealth, and other forms of what

\footnotetext{
${ }^{36}$ Ibid., pp 28-9.

${ }^{37}$ Ibid., p 184.

${ }^{38}$ Ibid., p 28.

${ }^{39}$ Ibid., p 26.
} 
Dowman calls “"spiritual materialism.”, 40 Drukpa Künlé’s aim, we are told, "was to free the human spirit's divinity from slavery to religious institutions, and moral and ritual conventions, that had originally been designed to support spiritual endeavour," but had, over time, been corrupted. ${ }^{41}$ In Dowman's reading, Drukpa Künlé's concern was to promote a true, authentic Buddhism that was free from institutional concerns and rigid expectations. His way of doing this was to criticize wrong-headed Buddhism in Tibet, which was embodied mainly in monasticism and scholasticism.

As Dowman would have it, when Drukpa Künlé's mad behavior was not engaged in specifically for the sake of criticizing institutionalized religion it was done with the intention of liberating the minds of individuals. The first of these two aims is subordinate to this second one; Drukpa Künlé criticism of institutionalized Buddhism is just one of the ways in which he works for the benefit of other beings. For example, when addressing the question of Drukpa Künlé's many sexual exploits, Dowman casts this behavior as part of the yogi's skillful use of desire, part of the "positive aspect" of Drukpa Künlé's "mystic path, the Path of Tantra" (as opposed to the path of monastic Buddhism, which is more restrictive and negative). ${ }^{42}$ Through his use of sex Drukpa Künlé shocks people in such a way that it leads them to examine their usual ways of thinking. When our expectations are challenged, the conventions they are based on are brought to light. By becoming aware of these conventions we can leave them behind, and begin to experience reality more directly and correctly, and let our inherent buddhanature, our "divinity," shine through.

\footnotetext{
${ }^{40}$ Ibid.

${ }^{41}$ Ibid.

${ }^{42}$ Ibid.
} 
Thus it seems that the primary way in which Dowman suggests we understand Drukpa Künlé's mad behavior is the same as the second mode through which Tibetans tend to interpret the phenomenon, which is to see it as something done for the sake of teaching other beings. Whether it is to help us see the faults of overly-bookish monasticism or to free our minds from other misconceptions, Drukpa Künlé performs his mad behavior for us. Dowman states that the ribald stories about Drukpa Künlé would have had a "therapeutic effect" on their original Tibetan audience; he refers to Drukpa Künlé's eccentric activity as his "therapeutic craft." ${ }^{, 43}$ His teaching can come in nearly any form, depending on what kind of "shock-therapy" is needed by those he is trying to help.

Here we see that the way Keith Dowman would have us understand Tibet's "divine madmen" has much in common with the explanations most often given by Tibetans. Dowman takes pains to show how Drukpa Künlé's crazy behavior can be understood as a means for teaching other beings; he also suggests that it may be a natural result of Drukpa Künlé's enlightenedness. We also see some uncertainty as to whether Drukpa Künlé is himself a completely perfected being or one still traversing the path to that goal. The one significant difference between Dowman's explanation and those most often offered by Tibetans is the way he highlights Drukpa Künlé's criticism of mainstream Tibetan religious life. Tibetans are fully aware that holy madmen like Drukpa Künlé often represent a manner of religiosity quite different from the monastic norm, but it is rare for them to explain such behavior as a conscious criticism of those institutions. None of the Tibetans I interviewed suggested that the holy madmen may

\footnotetext{
${ }^{43}$ Ibid., p 29.
} 
have been motivated by a wish to make such criticisms (presumably because it would be too mundane, too worldly a motivation for beings so well-respected and assumed by most to be fully enlightened). Nor would most Tibetans take as negative a view of the institutionalized aspect of Tibetan Buddhism as Dowman does. Dowman sees a deep bifurcation between what he considers authentic and inauthentic forms of Buddhism, and asserts Drukpa Künlé to be intent upon exposing the same. Although Tibetans certainly recognize that Drukpa Künlé embodied a critical attitude toward many things, they still think of him as a representative of the greater Buddhist tradition of which he was a part. By contrast, in Dowman's reading Drukpa Künlé and the Indian siddha Saraha “believed that total renunciation and detachment, including detachment from religion and its institutions, were necessary conditions for perfect happiness." ${ }^{44}$ Drukpa Künlé is, for Tibetans, a religious figure and a Buddhist. By no means do they see him as one intent on doing away with religion. The issue of Tibet's famous holy madmen and their relationships vis-à-vis religious institutions - as their critics and sometimes founderswill be a perpetual theme in the remainder of this dissertation. We take special note of Dowman's presentation of Drukpa Künlé as roundly anti-institutional because of the great influence it has had in shaping (and distorting) the Euro-American world's thinking on the subject.

We should also note that Dowman uses heavily psychologized language to explain holy madness and the Buddhist worldview (terms like "therapy," "shocktherapy," "psychological norm," "insane," "psychosis," "neurotic status quo"). This issue will be returned to in Chapter Seven.

\footnotetext{
${ }^{44}$ Ibid., p 26, emphasis added.
} 
Dowman makes comments about "holy madness" similar to those described above in some of his other books, including Masters of Mahämudrā: Songs and Histories of the Eighty-Four Buddhist Siddhas and Sky Dancer: The Secret Life and Songs of the Lady Yeshe Tsogyel, both of which have also achieved a degree of popularity. ${ }^{45}$ Dowman's words on the subject of holy madmen have thus played a major role in shaping the way non-Tibetans understand this topic.

\section{II.2 Georg Feuerstein}

Georg Feuerstein has also written provocatively about Tibet's holy madmen.

German-born, British-educated and now residing in Canada, Feuerstein is the author of more than thirty books, including The Shambhala Encyclopedia of Yoga (1997), Tantra: The Path of Ecstasy (1998), Yoga for Dummies (1999) and Green Yoga (2007). Through his website (traditionalyogastudies.com) he teaches distance-learning courses on the philosophy and history of yoga, based largely on his own writings. In 1991 Feuerstein published Holy Madness: The Shock Tactics and Radical Teachings of Crazy-Wise Adepts, Holy Fools, and Rascal Gurus, which was revised and expanded to more than 500 pages and published as Holy Madness: Spirituality, Crazy-Wise Teachers, and Enlightenment in 2006.

\footnotetext{
${ }^{45}$ In the introduction to Masters of Mahāhmudrā (Albany, NY: State University of New York Press, 1985), Dowman writes: "If the siddha's action is concomitant with Mahāmudrā, what then of his craziness, his flaunting of social convention and his uninhibited emotivity? To a large extent those very prejudices, preconceptions and other limitations of his critic's blinkered vision which the siddha rejoices to see eradicated, determine the perception of him as crazy. For instance, when the critic interprets the siddha's act, or gesture, as a crazy irrelevancy, as the non-sequitur of a madman, it is probable that he is failing to intuit the level of response upon which the siddha is operating.... Thus on the short-cut part of Tantra, disregard of social and moral discipline is the corollary of the compassionate skillful means employed by the adept to eradicate obstacles to liberation." $\mathrm{p} 23$.

Translated into German as Die Meister der Mahamudra, Munchen: Diederichs, 1991. Sky Dancer first printed in London: RKP, 1983; reprinted by Penguin 1991, and Snow Lion 1997.
} 
In his 2006 book Feuerstein provides a survey of eccentric saintly figures from many of the world's religions, including Christian mystics who acted like fools in their humility before Christ; Hindus intoxicated by their devotion to god; Zen masters of China and Japan whose teaching methods Feuerstein calls a form of "shock therapy" (a term Dowman had applied toward interpreting the behavior of Drukpa Künlé). Feuerstein also discusses the lives of some modern masters like Gurdjieff, Aleister Crowley, Osho, and Adi Da/Bubba Da Free John (Franklin Jones) who were all "crazy-wise" in some way. Feuerstein presents himself as an advocate of spirituality rather than a scholar of religion. ${ }^{46}$ Feuerstein casually alternates between the terms "crazy wisdom" and "holy madness" throughout the book.

Much of Feuerstein's chapter on the "Crazy Adepts of Tibet" is actually devoted to the eccentric Indian tantric siddhas he sees as their precursors, relating stories about Saraha, Kāṇha and Manibhadrā. Feuerstein also traces the lineage from Tilopa to Nāropa to the Tibetan Marpa, and from Marpa to his famous disciple Milarepa. (This lineage plays an important role in the self-understanding of the Kagyü sect, as we will see in Chapter Six.) Each master in this lineage taught his successor by using unpredictable, occasionally brutal lessons that Feuerstein assures us exemplified "crazy wisdom": Tilopa forced Nāropa to undergo twelve great physical trials_-including throwing himself off a rooftop and getting beaten to within an inch of his life by a group of guards - before he would grant him the tantric instructions he so desired. ${ }^{47}$ Marpa made

\footnotetext{
${ }^{46}$ As Feuerstein says in his preface, "I do not intend this book as an academic exercise. Rather, I understand it as a spiritually engaged account and critique of crazy wisdom." Prescott, Arizona: Hohm Press, p xxix.

${ }^{47}$ Ibid., pp 64-5.
} 
Milarepa commit sinful acts of black magic, and build a stone tower five times, alone and entirely by hand, before accepting him as a student. As Feuerstein explains:

Their unconventional behavior looks highly eccentric and at times even immoral to most people's sensibilities. But, as the Tibetan sources assure us, their crazywise actions originated not in egoic motives but in a desire to demonstrate and communicate the Tantric wisdom of the seamless juncture between the finite and the infinite. ${ }^{48}$

Feuerstein sees these trials not as a way for the teacher to test the dedication of his student or to purify his karma, as others sometimes suggest. Rather, Feuerstein assumes that its meaning lies in the master's need to communicate the ineffable. Feuerstein interprets holy madness in the Tibetan context as primarily a vehicle for teaching, stating that Tibetan holy madmen "teach by directly interfering with the disciple's life." ${ }^{, 49}$ The purpose of crazy wisdom is to communicate an abstract "Truth."

Feuerstein also spends some pages on Drukpa Künlé, for which his only source is Dowman's Divine Madman. After quoting Dowman on the meaning of Drukpa Künlé's madness, he then paraphrases a number of the episodes from Drukpa Künlé's life story. (Some popular stories from Drukpa Künlé Life will be told in Chapter Five.) Based on these stories Feuerstein reaches the same conclusion as Dowman, that Drukpa Künlé's behavior was essentially pedagogical; his "anarchism was a manifestation of his boundless compassion for his fellow beings whose spiritual awakening he had at heart."

\footnotetext{
${ }^{48}$ Ibid., p 57.

${ }^{49}$ Ibid., p 58.

${ }^{50}$ Ibid., p 77. Due to the popularity Feuerstein achieved in writing about holy madness, later printings of Dowman's Divine Madman include a foreword by Feuerstein in which he explains the meaning of Drukpa Künlé's holy madness through a discussion of the teachings of Bubba Da Free John, Nāropa, and some eccentric Hindu renunciants. Feuerstein has become something of an authority on "holy madness," with Dowman serving as one of his main sources of information on the topic.
} 
Drukpa Künlé's mad behavior is ultimately an outgrowth of his only real concern, which is help other beings achieve enlightenment.

Feuerstein also discusses the life of the controversial 20th-century Tibetan lama, Chögyam Trungpa Rinpoché. Trungpa was born in Tibet, then fled to India in 1959 at the age of 20. He spent some years studying in the United Kingdom, then relocated to America and started making a name for himself as a teacher of Buddhism. Trungpa had been a monk, recognized as the 11th incarnation in the Trungpa lineage, but disrobed when he came to the west. He married a 16 year old girl when he himself was about 30 . Many of Trungpa's early students were hippies, with whom he partied while gradually introducing them to the practice of meditation. By the mid-1970s Trungpa was leading retreats and teaching his students serious tantric practice. It is well known that Trungpa was a heavy drinker, and as Feuerstein notes, would even show up drunk to give lectures. ${ }^{51}$ Over the years Trungpa would have sexual relationships with many of his students, for which Feuerstein calls him "a modern Drukpa Kunley." led to charges of abuse.

What is most interesting about this for our purposes is that throughout his account of the life of Chögyam Trungpa, Feuerstein continually reminds the reader that his actions embodied crazy wisdom, offering no other light in which to view them. This does not prevent Feuerstein from mentioning some of the charges of moral laxity that have been made against Trungpa. In the end Feuerstein concludes that the situation is ambiguous, stating that

\footnotetext{
${ }^{51}$ Ibid., p 93.

${ }^{52}$ Ibid., p 94.
} 
Either our conventional understanding is too limited to comprehend all of this guru's behavior or he, as an embodied human being, was subject to error on at least some occasions, which would not, however, invalidate the merit of his work overall. Like other crazy-wise adepts of the past and present, Chögyam Trungpa's remains an enigma. ${ }^{53}$

In Feuerstein's view, if Chögyum Trungpa is in fact a highly realized being his eccentric behavior-like that of Drukpa Künlé and the figures in the Tilopa-Nāropa-MarpaMilarepa lineage before him—must be a profound and meaningful lesson. The only question is whether or not we are able to comprehend that lesson.

Chögyam Trungpa figures into this conversation as more than just another mad saint, however. Although Feuerstein addresses "holy madmen" in all the major religions, his basic definition of holy madness is based primarily on modern, popular ideas about the holy madness tradition in Tibet. ${ }^{54}$ And no one has been more influential in creating the modern notion of "crazy wisdom" than Trungpa, whom Feuerstein credits with having coined the very term. ${ }^{55}$ Feuerstein's label "holy madness," which he applies to many of the world's religious traditions, is based on his understanding of holy madness in the Tibetan context, which is derived from the writings of Chögyam Trungpa and Keith Dowman. Feuerstein then takes the label "crazy wisdom" and applies it to eccentric personalities in other religious contexts around the world, expecting these figures to in some way match the understanding he has grafted onto them. Thus his understanding of holy madness in the Tibetan context creates the lens through which he sees "holy madness" in other religious contexts. In Chapter Seven I will return to discuss the great

\footnotetext{
${ }^{53}$ Ibid., p 99.

${ }^{54}$ In the preface to the 2006 edition Feuerstein singles out Tibetan Buddhism as "highly relevant to the discussion of crazy wisdom," Ibid., p xiii.

${ }^{55}$ Ibid., p 344. In his book Wisdom Tales From Tibet, Surya Das has a section on "crazy wisdom" in Tibetan culture that is heavily influenced by Trungpa (Harper SanFrancisco, 1992), pp 251-2.
} 
circularity between the life of Chögyum Trungpa, the role he has played in popularizing the idea of "crazy wisdom," and the way that idea has influenced the way people have interpreted his personal conduct.

Feuerstein's book on Holy Madness is a fascinating document about what he sees as a universal phenomenon. At times he suggests we see a case of "holy madness" as a natural result of one's awakening, sometimes as an aspect of one's personal spiritual practice, but most often he characterizes it as something a guru engages in for the sake of teaching his students. This is very much in line with how Dowman presented the notion. It is also quite similar to the traditional Tibetan presentation, as described above, but with greater emphasis placed on the interpretation of its being a form of teaching.

Here we have considered the way two popular authors and teachers of Buddhism have presented the phenomenon of "holy madness" in Tibet. They represent an important and influential voice in the conversation on the subject, with a wider readership than most academics writing on Tibetan Buddhism could ever dream of achieving. Restrained neither by an indebtedness to traditional Tibetan ways of thinking nor to the mandates of modern scholarly standards, they are free to present these ideas in the way that seems most compelling to them. And it is their ability to give an account that is custom-tailored for a modern Euro-American audience that accounts for much of their popularity. They have had a great influence in shaping the way Tibetan holy madmen are understood by the Euro-American world, establishing what amounts to a baseline understanding of the phenomenon. 


\section{III. The Modern Academic Discussion of Holy Madmen}

We will now consider the ways modern scholarship has tended to explain the "madness" of Tibet's holy madmen. We will look in detail at two of the fuller descriptions of holy madness that have been offered by modern scholarship, then isolate the main modes of thinking that underlie them. The goal is to highlight the ofteninvisible ways of thinking that define and delimit the way scholars have tended to think about the subject, and the way one's basic assumptions about what holy madness is determine the shape and direction of one's inquiry.

In this section I will make three related arguments: that most modern academic discussions of Tibet's holy madmen portray them as naively pious; that recent Buddhology has failed to offer an explanation of holy madmen that is notably different from those traditionally offered by Tibetans; and that most scholarly attempts to explain the nature of the eccentric behavior of the "holy madmen" have been thoroughly unhistorical in their approach. The few exceptions to these norms will be mentioned below.

To date there have been three dissertations and one academic article on the life and literary production of one famous Tibetan holy madman, the Madman of Tsang (1452-1507, by Goss, Larsson, Quintman and E. Gene Smith); an article on the Madman of Ü (Ehrhard); a scholarly translation of the "autobiography” of Drukpa Künlé (Stein), and a dissertation and a master's thesis on his shorter biography (Kretschmar, Ardussi). To date, the only publication to address the question of holy madness in Tibet head-on is one relatively short article (Ardussi and Epstein). There are also a number of broader 
studies of Tibetan Buddhism that briefly address the holy madman phenomenon (Davidson, The Tibetan Renaissance; Samuel, Civilized Shamans).

Here we will look closely at places where scholars have tried to answer the question of "What is a Tibetan holy madman?" The first example we will look at is a larger work on Tibetan religion in which holy madness is but one topic among the many that are addressed. A document like this is no less significant for our purposes, for an off-hand comment or an easily-encapsulated discussion of holy madman when it is oblique to the greater concern of the work in question can reveal just as much about prevailing attitudes about them as an entire article devoted to the topic.

\section{III.1 Geoffrey Samuel}

Geoffrey Samuel's Civilized Shamans: Buddhism in Tibetan Society (1993) offers a significant discussion of Tibetan "crazy siddhas." Samuel writes about holy madmen from the 15 th through the 20th centuries in Tibet, building his discussion from a mix of modern scholarly literature and first-hand accounts by Tibetan lamas who have encountered holy madmen in their own lives. Samuel explains that the kind of “deliberate rejection of conventional behavior" exhibited by the holy madman would be for Tibetans "part of a recognizable form of spiritual path." suggests that the holy madman phenomenon can be understood as having to do with a set of yogic practices called ronyom ch'enpo tulshug chödpa (ro snyoms chen po brtul zhugs spyod pa), or "the practice of taking every experience in the great equal taste." $" 57$ In this kind of practice "obedience to conventional social dictates is rejected as an obstacle to the

\footnotetext{
${ }^{56}$ Washington, D.C.: Smithsonian Institution Press, p 306.

57 Ibid.
} 
yogin's spiritual practice." ${ }^{, 58}$ Samuel explains that the mad yogi's behavior pertains to two larger rubrics of tantric practice: ronyom ch'enpo and tulshug chödpa. In Samuel's understanding,

Ronyom ch'enpo, the "great equal taste," is recognized Buddhist terminology for regarding all phenomena as alike and rejecting conventional responses of like and dislike, good and bad. The term tulshug chödpa refers to various kinds of yogic practice, including the internal tsalung practices of Anuttarayoga Tantra, but it can also be used to refer specifically to the path of rejection of conventional behavior. The aim of tulshug chödpa is to go beyond the needs for ordinary social restraints, so that the practitioner acts out of the necessity of the situation itself. $^{59}$

Mahāyāna Buddhism maintains that all phenomena are empty of inherent existence and, in reality, lack the natures we commonly attribute to them. Our usual, conventional way of experiencing the world is ultimately constructed out of our considering things to be big or small, dirty or clean, hot or cold, right or wrong, and so on. A major component in the process of moving towards a truer experience of the world around us is, therefore, overcoming these sorts of conventional distinctions. The goal, instead of relying on these distinctions to order and create our world, is to experience all phenomena as empty and therefore as being of a single taste (ro snyoms). Practices specifically leveled towards helping an individual see the falsity of those conventional distinctions, and thereby overcome them, are often brought under the heading of tulshug chödpa (brtul zhugs spyod pa; these practices will be explained in much greater detail in Chapter Three). Samuel provides an example of this in the life one Kenpo Gangshar, a teacher of Chögyam Trungpa Rinpoché. Kenpo Gangshar, after having observed the dictates of monasticism earlier in his life, went through a dramatic change and "adopted the tulshug

\footnotetext{
${ }^{58}$ Ibid., pp 306-7.

${ }^{59}$ Ibid., p 307.
} 
chödpa style" - taking a female consort, giving back his monastic vows, and engaging in eccentric behavior. ${ }^{60}$

In this explanation offered by Geoffrey Samuel the madness of the Tibetan holy madmen is understood to be an aspect of their personal religious training: the mad behavior is for the sake of having certain experiences that will ultimately help them fully realize the fact that all phenomena are ultimately empty. As we saw earlier, this interpretation has at times been suggested by Tibetans.

A question that deserves to be asked about Samuel's account is what kind of explanation is he trying to express? Does he intend that his comments here represent the way he as a scholar understands holy madmen, or is he merely relating to the reader a traditional Tibetan understanding of the phenomenon? On the one hand, it seems that Samuel endeavors only to give voice to a traditional Tibetan understanding (as he writes: "The deliberate rejection of conventional behavior could..., for the Tibetans, be part of a recognizable form of spiritual path"). ${ }^{61}$ But on the other hand, as Samuel offers no alternative mode of understanding holy madmen, no interpretation of his own, his words constitute a silent consent and recommendation of the traditional view on the subject. The lack of a clear distinction between the way scholars, more popular commentators and traditional Tibetans have all spoken about the holy madman phenomenon is an important point and will be discussed further below.

\footnotetext{
${ }^{60}$ Ibid., p 307.

${ }^{61}$ Ibid., p 306, emphasis added.
} 


\section{III.2 Ardussi and Epstein}

To date the only academic piece dedicated in its entirety to exploring the holy madman phenomenon is an article by the Tibetologists Lawrence Epstein and John Ardussi, "The Saintly Madman in Tibet" (1978). ${ }^{62}$ Because of being the most comprehensive and the most cited academic treatment of the subject, this article has had great influence in shaping the way scholars think about the holy madman phenomenon and warrants some consideration here.

Ardussi and Epstein begin their article by summarizing the concept of the Two Truths (bden pa gnyis) and its importance in Madhyamika and tantric philosophies. According to the Madhyamika view, all phenomena are empty; the realization of this fact is what leads to salvation. One of the defining characteristics of tantra is that it encourages one to embrace relative, untrue phenomena as a means to moving towards that realization.

With this background in place, the authors then list the various causes to which madness has traditionally been attributed in Tibetan culture. These include attacks from witches and demons, mental aberrations related to the internal psycho-physical complex of the individual (often attributed to a problem with the "winds," rlung), pollution (grib) coming from outside the individual, and also mistakes made by meditators in the course of their practice. Finally, and separate from all of these, is the "saintly madman" (bla ma smyon $\mathrm{pa}$ ), whose madness is most often interpreted in a positive light.

${ }^{62}$ In Himalayan Anthropology: The Indo-Tibetan Interface, edited by James F. Fisher (The Hague: Mouton, 1978), pp 327-337. Ardussi and Epstein's comments in this article are based in large part on Ardussi's unpublished master's thesis, 'Brug-pa Kun-legs, The Saintly Tibetan Madman (University of Washington, 1972). 
The authors then describe six characteristics the saintly madmen often display. Briefly, these are:

1) "A generalized rejection of customary behavior which society-at-large, and the monastic establishment in particular, regard as appropriate for the religious man."

2) "An inclination towards bizarre modes of dress."

3) "A disregard for the niceties of interpersonal behavior, particularly with regard to social status, modes of address, deferential behavior, and so forth."

4) "A professed disdain for scholasticism, the study of religion through books alone."

5) "The use of popular poetical forms, mime, songs, epic tales, and so forth, during the course of their preaching."

6) "The use of obscenity and vulgar parlance."63

The authors dedicate a paragraph to each characteristic, drawing examples from the lives of famous saintly madmen for support. For example, regarding the holy madmen's proclivity for nonconventional attire, the authors note that the semi-legendary saint Tangtong Gyelpo, also known as the "Madman of the Empty Valley" (lung stong smyon $p a$ ), was once chastised by some monks for sitting on a circumambulation path under a seedy old blanket. In response, the saint proceeded to explain how each seam and patch of the blanket was rife with special meaning. They also cite Tangtong Gyelpo's (purported) invention of Tibetan opera ( lce lha mo) to show the saintly madman's special connection to more "popular" forms of art and entertainment.

${ }^{63}$ Ibid., pp 332-3. 
Having thus roughly defined the saintly madman based on the characteristics he generally displays, Ardussi and Epstein turn towards explaining the reasons that underlie his "madness." They offer what amounts to a few different basic explanations. First, they suggest that

His madness, in the popular mind, is the proof of his success, and his misconduct is beyond judgment; he serves the masses as living proof of the Mahayana thesis that the liberated man is outside the laws of karma. Having already achieved enlightenment, he is just an appearance, an embodied illusion like everything else in this world. ${ }^{64}$

In this explanation, the saint's madness serves as a sign of his enlightenedness. He is completely enlightened and thereby unaffected by the law of karma, and thus free to behave however he pleases. ${ }^{65}$ Note that here the authors are presenting this interpretation as a traditional Tibetan mode of understanding the phenomenon ("in the popular mind" here referring to the popular Tibetan mind).

Directly after this the authors offer a somewhat different explanation of the saint's madness, which is to say that "[b]y behaving in a manner contrary to social norms, the saintly madman attempts to reach a perfect understanding of the Madhyamika thesis that there is no distinction between good and bad, that everything has a 'uniformity of flavor' (ro-snyoms)."66 Whereas in the first explanation the yogi's "madness" was an indication of his fully liberated state, in this second explanation the madness is a means toward achieving that liberation. This is essentially the same as the explanation offered by Samuel that was reviewed above.

\footnotetext{
${ }^{64}$ Ibid., pp 335.

${ }^{65}$ Earlier in the article the authors expressed a similar sentiment: "When Tibetans are questioned about the motivation and meanings of these figures, they almost invariably say that they behave the way they do because they are really Buddhas," p 327.

${ }^{66}$ Ibid., p 335.
} 
On the following page Ardussi and Epstein suggest a third basic understanding of holy madness. They observe that from the Tibetan Buddhist perspective

the conventional rules of social behavior, which function to insure the smooth operation of the moral order, are also a moral illness. What the mad saint demonstrates is that these conventional rules not only bind us to the world, they also perpetuate our spiritual problems. He demonstrates this by using his naturalness and spontaneity to slash away at the rules of interaction and the hypocrisies which they engender - excessive, insincere deference, politeness, and humility. $^{67}$

As an example, the authors cite a story about Drukpa Künlé in which he sings an offensive song in the presence of the Second Dalai Lama and his retinue. The song points out the sins and hypocrisy of a variety of groups, including nuns, whom he condemns as "whores and murderers of their own illegitimate children." 68 In the end the saint goes a step further, informing the audience, "But this song does not at all comprehend the real truth, and I myself am an old bag of lies!" The authors conclude that the "real message of 'Brug-pa Kun-legs [Drukpa Künlé] is that from the point of view of the absolute truth, none of what he says is true. And that, from the relative point of view, makes him a liar. He has beguiled them to view reality from a point of view which they had become accustomed to ignore in practice." ${ }^{\prime 69}$ In this interpretation the yogi's madness is understood as essentially pedagogical in nature. This madness is for the purpose of teaching unenlightened beings to cut through the delusions that they, by dint of their participation in society, have necessarily built up around them-an explanation we have seen shades of before.

\footnotetext{
${ }^{67}$ Ibid., p 336, emphasis added.

${ }^{68}$ Ibid.

${ }^{69}$ Ibid., pp 336-7.
} 
Thus in the course of trying to explain the phenomenon of holy madmen in Tibetan religious culture, Ardussi and Epstein have offered three different interpretations of their characteristic mad behavior. These are the same as the basic explanations that Tibetans most often offer. These three basic explanations have been repeatedly appealed to by modern scholars, as the next few paragraphs will show. After this survey we will make some final points about Ardussi and Epstein's article, and about the modern academic study of Tibet's holy madmen in general.

In his chapter on tantric Buddhism in Paul Williams' Buddhist Thought (2000), Anthony Tribe suggests an understanding of Tibet's holy madmen that echoes the primary mode through which Tibetans today interpret the phenomenon. Tribe writes that accomplished practitioners of the Yoginī tantras were called siddhas or mahāsiddhas and often had "unconventional lives."70 They exemplified the tantric notion of sahaja, meaning "born-together," which, Tribe explains,

... was taken to denote the innate and spontaneous nature of the awakened mind. This idea underlies much of the unconventional behaviour of the siddhas. From the perspective of conventional society, they appeared to be crazy. From their point of view, however, they were delighting in the spontaneity of non-dual cognition. ${ }^{71}$

Tribe then cites the tradition of "crazy wisdom" in Tibet as an example of this. ${ }^{72}$ For Tribe, the crazy behavior of great siddhas like Tibet's holy madmen is best thought of as a symptom of their high level of spiritual attainment.

In the introduction to his French translation of the "Autobiography" of Drukpa Künlé (published in 1972), R. A. Stein explores “the 'madman' epithet” (l'épithète de

\footnotetext{
${ }^{70}$ A quotation from this serves as the epigraph to this chapter. p 216.

${ }^{71}$ Ibid.

${ }^{72}$ Ibid., p 273.
} 
'fou') through the expressed "doctrinal stance" (position doctrinale) of its three most famous exemplars. ${ }^{73}$ According to Stein, the essential element of their view is the "mystical union" (union mystique) found in the Mahāmudrā or Great Seal doctrine. ${ }^{74}$ Here the yogi's apparent madness is a result of his having achieved a highly-realized state.

The second primary interpretation of the madman's crazy behavior — that it is performed for the sake of teaching other beings — was suggested by Ardussi and Epstein, as well as by Kunchok Delek, Pelden Tashi, and Kevin Stuart, in their article "Tibetan Tricksters," published in Asian Folklore Studies (1999). This article summarizes the common understanding of trickster figures in Tibetan folklore, such as Aku Tönpa, Nyichö Zangpo and, in their reading, the Madman of the Drukpa, Drukpa Künlé. It is their understanding that Drukpa Künlé, “as an enlightened being, engages in profane (e.g., sexual, scatological) activities in order to awaken people from the dream-like reality that prevents them from understanding Truth." 75 As with many of the examples we have already reviewed, there is ambiguity here as to whether this is meant to represent a view the authors themselves endorse or if they are merely trying to restate the traditional Tibetan understanding of the holy madman's behavior. They do not posit any alternative

\footnotetext{
${ }^{73}$ R. A. Stein, translator, Vie et chants de 'brug-pa kun-legs le yogin (Paris: G.-P Maisonneuve et Larose, 1972), p 10.

${ }^{74}$ In an earlier, less influential publication ("Un saint poète tibétain" in Mercure de France, July-August, 1964, pp 485-501) Stein explains the phenomenon of holy madness in similar terms. Referring specifically to the Madman of Ü, the Madman of Tsang, and the Madman of the Drukpa, Stein writes that "L'épithète $[<<$ fou $>>]$ qu'on leur donne et qu'ils se donnent à eux-mêmes désigne le yogin illuminé qui a dépassé la dualité inhérente à la pensée normale, placé au-delà des conventions, au comportement paradoxal et ambivalent," p 485. Stein makes a similar statement on p 486.

${ }^{75}$ Kun Mchog Dge Legs, Dpal Ldan Bkra Shis, and Kevin Stuart, "Tibetan Tricksters" pp 5-30 in Asian Folklore Studies, Vol 58, No 1 (1999). This citation is from $\mathrm{p} 11$.
} 
understanding. In general the idea that the holy madman's crazy behavior should be understood as a form of teaching is pervasive in scholarly circles. ${ }^{76}$

The third of the three modes through which Tibetans explain holy madness - that it is engaged in for the purpose of furthering the yogi's religious training - has been suggested by Samuel and by Ardussi and Epstein, under the rubric of "one-taste" (ro snyoms). Hildegard Diemberger makes an off-hand comment that belies a similar understanding of holy madmen, seeing them as purposefully overturning "social and religious conceptions in order to achieve liberating awareness."77

This sampling from the modern academic attempt to understand and explain the behavior of Tibet's holy madmen shows how a few basic interpretations of holy madmen have been repeated time and time again. These three modes of thinking about holy madmen have become common knowledge, providing the standard interpretation of the madmen's behavior. These basic understandings of Tibet's holy madmen have become all but assumed, so that "holy madman" becomes a fixed category to which scholars like Tribe and Diemberger can refer in order to explain some phenomenon in the Buddhist world.

Holy madness, understood from the perspective of these three basic modes, has taken on a life of its own. It is appealed to more often than is justified and has distorted some commentators' understanding of the historical past. In 2006 the Rubin Museum of Art in New York, a world leader in the exhibition of trans-Himalayan art, put on an

\footnotetext{
${ }^{76}$ Anecdotally, I can say that when telling other American- and Europoan-educated Buddhologists that I was working on a dissertation on Tibet's holy madmen, on more than one occasion they have shot back with the response, "Skillful means." There is a strong urge to explain away the behavior of the holy madmen using this pre-existing category within Mahāyāna ideology.

${ }^{77}$ Diemberger, p 138.
} 
exhibition titled "Holy Madness: Portraits of Tantric Siddhas." The primary subjects of this exhibit were the Indian mahāsiddhas of the 7th to 11th centuries. The exhibit's catalogue includes ten essays by some of the leading scholars in the fields of Indian and Tibetan religion and art. ${ }^{78}$ A handful of the Tibetan and Indian mystics-Buddhist, Hindu, and Sufi-addressed in the exhibit and its catalogue were talked about with a rhetoric of madness in their respective cultural contexts. But the scope of the exhibit and catalogue extends well beyond them, so that the majority of figures brought together under the title of "Holy Madness" were never discussed using terms that had any connotation of "holy madness" or "crazy wisdom" or any other closely-related term by the indigenous traditions of which they were a part. The title of the exhibit is misleading, and the logic with which it was put together faulty.

This exhibition and catalogue exemplify a complex case of mimicry, selfrepresentation and misapplication, which is best understood as a feedback loop. The process that has lead to the misapplication of the "holy madman" idea in this exhibition is as follows: from the 11 th century to the present there have been a small subset of religious practitioners in Tibet who have to varying degrees emulated the famous eccentric siddhas of India who came before them; through their eccentric behavior, writings and self-proclamations they have come to be called "holy madmen" within their own culture. Modern-day scholars have seized upon this idea of "holy madness" to such an extent that it has become a commonly-referred-to category in their work. It has become so ubiquitous that scholars have come to apply the idea of holy madness back

\footnotetext{
${ }^{78}$ Rob Linrothe, editor, Holy Madness: Portraits of Tantric Siddhas (New York: Rubin Museum of Art, 2006), inside jacket.
} 
onto those original Indian siddhas. But we must ask: if only a small subset of all the yogis covered by this exhibition and catalogue were ever referred to as "madmen" by their respective religious and cultural traditions, is it not misleading to apply the term "holy madman" to the entire group? The idea of holy madness has taken on a life of its own. ${ }^{79}$

As further evidence of "holy madness" being taken out of context and re-applied to make sense of the Tibetan tradition, consider Glenn H. Mullin's translation of the Second Dalai Lama's poetry, titled Mystical Verses of a Mad Dalai Lama. ${ }^{80}$ The Second Dalai Lama (1475-1542, who served as a foil to the irreverent Drukpa Künlé in the story cited by Ardussi and Epstein and mentioned above) sometimes referred to himself as a "madman" (smyon pa), using the term as a pen name. The practice of using "madman" as a pen name has a long history, as will be described in Chapter Seven. But the publisher's blurb on the back of the book claims that this Dalai Lama was "was 'crazed' by the wisdom of the nature of reality"; the blurb by Richard Gere states that the Second Dalai Lama's signing his works "The Mad Beggar" "refer[s] to that state beyond all attachment and conventional modes of thought and behavior, the realization of emptiness." These commentators have casted the "madness" of the Second Dalai Lama in a light never before intended. ${ }^{81}$ Here the Second Dalai Lama's use of "madman" as a

\footnotetext{
${ }^{79}$ This applies in both scholarly and popular thinking about Buddhism. In The Dharma Bums Jack Kerouac, through the voice of Ray Smith, uses the term "Zen Lunatics" to describe his circle of friends, who were, in their free-spiritedness - in his eyes, at least - emulating the ways of past Buddhist sages. ${ }^{80}$ Wheaton, IL: Quest Books, the Theosophical Publishing House, 1994.

${ }^{81}$ In the Foreword to this book the 14th Dalai Lama writes, "The implication of 'Mad' here is that when a person gains experience of emptiness, the ultimate mode of existence of all phenomena, his perception is as different from that of ordinary people as a madman's. Due to his or her realization of emptiness, a practitioner completely transcends the conventional way of viewing the world." Ibid., xiv. I will discuss this passage again in Chapter Seven.
} 
pen name carries a connotation of playfully ironic humility, rather than an open declaration of enlightenment. This is another example of how the exaggerated popularity of the idea of holy madness has distorted the way some modern commentators understand and portray important savants of Tibet's past.

These cases show how the idea of holy madness has in recent times taken on a life of its own. It has come to be used in a cavalier manner that often neglects to seriously consider the realities of how the idea may have existed — or not existed - in its original cultural and religious context. This is a result of the compelling, romantic way in which “divine madness" and "crazy wisdom" have been presented by people like Keith Dowman, Georg Feuerstein and Chögyam Trungpa Rinpoché. A strong scholarly corrective has not been voiced.

We now return to Ardusi and Epstein's seminal article, to consider how it exemplifies the modes of thinking that define the academic discourse on the subject of Tibet's holy madmen.

As we saw, Ardussi and Epstein made three attempts at explaining the nature of holy madness: they suggest that it is either the result of a state of liberation, a method employed in order to teach and help other beings, or a training method for bringing oneself towards liberation. The authors make no attempt to integrate these possible explanations into an overarching theory; they are merely placed side-by-side on a single conceptual plane. Although the authors signal that the madness-as-a-sign-ofenlightenment explanation is the one most often relied on by Tibetans, they make no comment regarding whether or not they consider the latter two explanations to be their 
own formulations or whether they also represent a traditional way of thinking. We have seen this same ambiguity in all the scholarly discussions of holy madness we have examined so far. It seems that the critical distinction of whether scholars are speaking for the tradition or about the tradition all but disappears when addressing the topic of Tibetan holy madmen.

Even more significantly, a close reading of Ardussi and Epstein's article reveals that their fundamental strategy for understanding Tibet's holy madmen is to construct a portrait of Tibetan Buddhist philosophy and then place the holy madmen within it. Their concern is to identify the correct and pertinent notions from within their understanding of Tibetan Buddhist philosophy so that the madman's behavior can be accounted for. As was mentioned above, the article begins by summarizing the authors' basic understanding of Madhyamika and tantric philosophies. Then to the extent to which the madman appears to fit within the framework they have constructed, it comes to seem a fitting and reliable explanation. The basic approach of Ardussi and Epstein's article is thus to construct a vision of how one might explain the eccentric behavior of the Tibetan holy madman, rather than engaging with the admittedly more convoluted history of how their eccentric behavior actually was explained, during the holy madmen's lifetimes and the centuries after.

Although the authors' portrayals of the holy madmen and of Tibetan Buddhist philosophy are nuanced, multi-faceted and well-constructed, in the end their approach is fundamentally problematic in that their understanding of holy madmen is not derived, first and foremost, from a consideration of the details of their actual lives. Rather, they have developed an explanation which they project onto the holy madmen. Their rationale 
for connecting the holy madman with the vision of Tibetan Buddhist philosophy they have constructed is based on the assumption that the holy madmen's motivations must lie within the sphere of religion; Ardussi and Epstein assume that the dictates of Mahāyāna Buddhism—particularly the philosophical maxims of Madhyamika and tantra—are sufficient to comprehensively explain the motivations behind the behavior of Tibet's holy madmen.

This brings us to a more significant point, which is that the three explanations of holy madness offered by Ardussi and Epstein and so many other modern-day scholars all have one essential thing in common: they consider the holy madman to be an exclusively religious being. This is clear from the way the article is organized: the background we need in order to understand the holy madmen is Madhyamika and tantric theory. Even more explicitly, the authors repeatedly insist that the holy madmen must be understood within the context of Mahāyāna Buddhism. ${ }^{82}$ The last line of the article repeats the authors' assertion that the holy madman is driven by a "purposeful pursuit of salvation for all beings." 83 Ardussi and Epstein's entire presentation of Tibetan holy madmen is framed by an inescapable Buddhist piety. In fact, Ardussi and Epstein do not consider any reason or motivation behind holy madness other than those that are thoroughly Buddhist in nature. The holy madmen are either perfectly enlightened beings, or beings

\footnotetext{
82 "The aim of the mad saint is consistent with the ideals of Mahayana, i.e., to work for the salvation of all sentient beings," p 334. Ardussi and Epstein maintain that the saintly madmen voluntarily removed themselves from monastic living because of the possibility that their "contrary behavior" might prove a bad influence on the other monks, and "[a]s this could jeopardize their chances for salvation, the saintly madman would be hurting his stated purpose of working for the salvation of all sentient beings," $\mathrm{p} 332$, emphasis added. Ardussi and Epstein cite the life of the Madman of Tsang as an example of this. As we will see in Chapter Three, according to the written record of the life of the Madman of Tsang, when he makes the decision to leave his life in the monastery there is no suggestion whatsoever that he is doing so for fear that his madness might disturb his fellow monks - far from it.

${ }^{83}$ Ibid., p 337.
} 
(already enlightened or not) whose only real concern is to help others to move towards spiritual liberation, or beings whose primary interest is in working towards enlightenment. This same basic stance has been adopted by Geoffrey Samuel and all the other scholars whose work we have reviewed. A major trend in the scholarly attempt to make sense of the Tibetan holy madman phenomenon has been seeing the holy madmen as beings for whom the only possible motivation for their behavior worth considering must somehow be found within the dictates of Mahāyāna Buddhist philosophy (including tantra).

By repeatedly falling back onto the explanations that this mad behavior is a result of the yogi's enlightenedness, for the sake of teaching others, or for his own training, scholars have not explored ways to understand these figures in any way other than as beings whose only possible motivations must lie within religion. This points to a larger question about the way we as scholars tend to think about the representatives of religious traditions around the world: do we not in many cases project onto them our own expectations for how they should view and live in the world? By the mere fact that our consideration of these holy madmen takes place within the field of the study of Buddhism, we often assume that they will conform to expectations we have about them as religious beings. This light of holiness is especially difficult to deflect when we are investigating saints of the distant past. Perhaps a clear-eyed rereading of our sources might suggest that some of these "holy madmen" purposefully employed the notion of "holy madness" to some non-religious end? ${ }^{84}$ Or maybe it is best understood as an

\footnotetext{
${ }^{84}$ Ronald Davidson suggests that the "madness" of one Tibetan "crazy saint" was a means to justify his own immoral behavior ( $\mathrm{p} 329)$, but then undercuts this by suggesting interpretations more closely aligned
} 
attempt to gain attention? Or maybe it was just fun? None of these possibilities is ever seriously explored. That these "saints" can only be understood through the lens of religious motivations is an unstated and undefended assumption that defines the way our field thinks about this topic. The few scholars who defy this rule and take a different basic approach to understanding Tibet's holy madmen will be discussed below.

This brings us to a second important point: As we have seen in our survey of modern scholarly literature on Tibetan holy madmen, the types of explanation suggested again and again by scholars tend not to be significantly different from those most commonly offered by Tibetans. As we have seen, there has been no systematic distinction between how Tibetans have traditionally understood this phenomenon and how we as Buddhologists should understand the phenomenon. This represents a breakdown in the scholarly endeavor. As scholars, our job is to do research that allows us to come to new ways of understanding things. But it has become perfectly acceptable to simply repeat traditional Tibetan views on the subject without complicating them. This is an ongoing problem in the academic study of Tibetan Buddhism. ${ }^{85}$ The fact that scholars have not seriously explored the possibility that Tibetan holy madmen may be motivated by anything but pure religious ideals is in large part a result of this overreliance on traditional Tibetan understandings of the holy madman phenomenon. The dominant scholarly understanding has also failed to differentiate itself from the sort of “popular," practitioner-oriented understanding represented by the work of Dowman and

with the three most-commonly offered views (pp 330-1), in Tibetan Renaissance: Tantric Buddhism in the Rebirth of Tibetan Culture (New York: Columbia University Press, 2005).

${ }^{85}$ For a discussion of this, see two chapters by Donald Lopez: "The Field" in Prisoners of Shangri-La: Tibetan Buddhism and the West (Chicago: University of Chicago Press, 1998), pp 156-180; and "Foreigner at the Lama's Feet" in the volume edited by Lopez, Curators of The Buddha: The Study of Buddhism Under Colonialism (Chicago: University of Chicago Press, 1995), pp 251-95. 
Feuerstein. To some extent this happens because of the way some scholars have relied on sources like Dowman's in forming their basic understanding of holy madmen.

We have seen how the majority of scholarly descriptions of Tibetan holy madmen rely heavily on traditional Tibetan ways of explaining the phenomenon, and have insisted on seeing the holy madmen as idealized religious beings (the latter in large part a result of the former). A significant consequence of these two factors is that a concern for history is missing from most scholarly accounts of Tibet's holy madmen. Completely absent from all the scholarly discussions of Tibet's holy madmen that we have reviewed above is a systematic accounting of the details of the actual lives of these figures (limited, of course, by what data we have at our disposal) and the historical circumstances in which they lived. Further, there has been little interest in investigating what this "craziness" meant in context - neither the more narrow and concrete question of what living in society with the reputation of being a "holy madman" actually entailed, nor the way this "craziness" may have been a part of a yogi's purposeful self-presentation, nor the broader context of thinking about what normative sanity this "craziness" was defined against. Many scholars have been content to imagine possible meanings of the label "madman" without asking what it really meant to live under that name in a specific time and place.

In response to the question of what living as a holy madman may have entailed, Euro-American scholars have long held the notion that Tibetans are unlikely to write-off an individual with an odd outward appearance as being an unworthy adept. As David Snellgrove and Hugh Richardson once stated,

It is interesting to observe that Indian and Tibetan society have never abandoned those who reject their social norms. A place of honour and respect is accorded to 
the mendicant and the yogin, once it is judged that his intentions are sincere, and if he has teachings to impart, he will soon have disciples. ${ }^{86}$

(Coming from such respected authorities on things Tibetan, this statement would be quoted by other scholars commenting on the holy madman phenomenon. ${ }^{87}$ ) In support of this same notion Ardussi and Epstein cite a study by Beatrice Miller, an anthropologist working in Tibetan exile communities in India who showed Tibetans a series of drawings and took note of their reactions. One of these drawings was of an encounter between a monk and a hippie. As Ardussi and Epstein summarize,

The hippie, despite his disheveled and beggarly appearance, was treated in a manner not inconsistent with how a madman might be viewed. A typical response was that one should not judge a book by its cover, or that the hippie might have a good heart (mind) despite his appearance. ${ }^{88}$

There is no reason to question the veracity of the notion that Tibetans may have a different attitude towards those of odd appearance from that which prevails in our own culture, and I think it correct to assume that the holy madmen were likely among the eccentric saints who have contributed to this notion's being established. However, although it may be the case that in general Tibetans harbor a more welcoming attitude towards eccentric religious figures, we should not let this deter us from looking at the real-life ramifications that living as a holy madman at a given point in history would have

\footnotetext{
${ }^{86}$ A Cultural History of Tibet (Boston and London: Shambhala, 1995. First printed in 1968 by George Weidenfeld and Nicolson Ltd.), pp 117-8.

${ }^{87}$ Quoted by E. Gene Smith in his 1969 essay about the Madman of Tsang ("Introduction to The Life of Gtsang smyon Heruka," edited by Lokesh Chandra, New Delhi: IAIC, 1969; reprinted in Among Tibetan Texts: History and Literature of the Himalayan Plateau, Boston: Wisdom Publications, 2001; all citations of this text will be from the reprint), p 69; and by Robert Everett Goss, The hermeneutics of madness: A literary and hermeneutical analysis of the "Mi-la'i-rnam-thar" by Gtsang-smyon Heruka (Th.D. dissertation, Harvard University, 1993), p 60.

${ }^{88}$ Ardussi and Epstein, p 334. The study by Miller is printed in the same volume as Ardussi and Epstein's article, "Tibetan Culture and Personality: Refugee Responses to a Tibetan Culture-Bound TAT," pp 365-94 in Himalayan Anthropology: The Indo-Tibetan Interface, edited by James Fisher.
} 
had. The fact is that the holy madmen were not always accepted with open arms and open minds - a significant fact that should not be elided.

Many scholars have mentioned the obvious anti-monastic, anti-scholastic attitude embodied by the "holy madmen." In this context the tendency has been to see the holy madman's behavior as expressing timeless contradictions that have always existed within Tibetan Buddhist culture. This understanding is expressed throughout Ardussi and Epstein's article, alongside their other explanations. ${ }^{89}$ This line of thinking helps contribute to the continued lack of historical thinking about these figures, for it distracts one from looking at the specific lives and times of individual holy madmen to instead base one's interpretation on a more impressionistic understanding of his behavior. Implicit to this line of thinking is that the "madness" of all Tibet's holy madmen is essentially the same.

The holy madmen's reputations as bawds, jokers, freaks — as madmen — has had the effect of precluding many people from taking a serious interest in the more mundane and conventional aspects of their lives. ${ }^{90}$ As Ardussi and Epstein state, the holy madman

\footnotetext{
${ }^{89}$ In Ardussi and Epstein's words, "His actions resolve a central problem of meaning that involves the disjunct relationship between the ideals of Buddhist theology and the realities of everyday life," $p 327$.

Dowman also evocatively portrayed Drukpa Künlé as a staunch critic of religion, but did so in a non-historical manner.

${ }^{90}$ The topic of holy madmen has occasionally come up in discussions of tricksters and humor in Tibetan literature and culture. In these contexts the author is almost always basing his observations on popular iterations of Drukpa Künlé, then extending the observation to apply to all holy madmen. But even here the scholar's apparent need to cast the madman's behavior in a pious light wins out and we are assured that, in the end, there is a strong religious motivation behind his madness. (See, for example Kun Mchog Dge Legs, Dpal Ldan Bkra Shis and Kevin Stuart's article "Tibetan Tricksters".) R. A. Stein also writes about Drukpa Künlé as a trickster (in Tibetan Civilization, p 154; and in "Un saint poète tibétain," p 486). In this context it is often noted how this more popular, less historical version of Drukpa Künlé sometimes overlaps—or is conflated — with the figure of Aku Tönpa.

There is also a long-standing tradition of trying to understand Tibetan holy madmen in the context of Tibetan bards and shamans. (See Goss, pp 61-62, who cites Stein's early work on this subject.) I think this angle of understanding Tibetan holy madmen is inaccurate. It is mostly based on the author's understanding of the more popular version of Drukpa Künlé, creating an understanding that the author then
} 
"is a tricksterlike figure that is perpetually engaged in one sort of perverse activity or another-drinking to excess, fornicating, thieving, defying authority, playing magical tricks. In short, this character is a sociopath of the first order..." ${ }^{91}$ It is no surprise that their drunkenness, their smearing themselves with ashes, the moments of violence and sex, are what have captured the imaginations of many, in Tibet and beyond. But this antinomian behavior was only one of the holy madmen's various endeavors. In reality their lives were taken up with much more conventional activity. The Madman of Ü, despite his frequent brawls and his penchant for libertine urination, gathered a large following of students, founded a monastery and passed its leadership onto his nephew, an altogether conventional thing to do in 16th-century Tibet. The Madman of Tsang, despite having once tied the fingers he had cut from an exhumed corpse into his hair and draped himself with intestines, spent years of his life writing the twelve-volume compendium of the Aural Transmission, The Life of Marpa, and The Life of Milarepa, which has become one of the most beloved pieces of Tibetan literature ever written. Given their all-toocommon characterization as willing outcastes, one might be surprised to learn that some of these "holy madmen" landed in positions of political influence, as will be shown in Chapter Four. These basic facts signal that we should think of them as "madmen" in a less literal way than has become the norm. To understand the nature of their madness, we must look at it as one aspect of their lives, but not the only aspect of their lives. To arrive at a new understanding of their madness, we must see it in the context of their more conventional activity, which helps locate them in history.

applies to describe holy madmen in general. This is both quite far removed from what we know about Drukpa Künlé as an historical being, and is doubly-inaccurate when applied to other holy madmen. ${ }^{91}$ p 327. 
To a large extent this lack of interest in the holy madmen as historical individuals is an effect of the insistence upon seeing their behavior as having a purely religious meaning behind it — whether it be a selfless drive to instruct others in religious truths, or for one's own spiritual training, or the fact of being enlightened. If these are the ideals or spiritual states that motivate the madman's crazy behavior, what difference does it make when or where he lives, what books he writes, who his donors are or what challenges his sect is facing? If the holy madman is an exclusively religious being, historical context becomes all but irrelevant.

Another reason scholars have been reluctant to consider real historical factors in trying to understand holy madmen is the fact that Tibetans themselves have resisted historical understandings of the phenomenon. There is a lot of resistance on behalf of Tibetans to thinking about the holy madman phenomenon as having anything to do with historical, social, political or economic circumstances. For example, when I asked one Tibetan lama what significance there could be behind the fact that the three most famous of Tibet's holy madmen were born within a period of six years, knew one another personally, and had teachers and patrons in common, he suggested that it might be because they had made a prayer (smon lam) to be reborn together when they had met each other in some previous life. ${ }^{92}$ When I suggested we might look into what was happening in central Tibet in the 15 th century to find some clue as to why there were three famous holy madmen at that time, one lama vehemently rejected the possibility. He said that these three holy madmen all lived at the same time and in the same place because they had good instruction and good practice; it could have nothing to do with

\footnotetext{
${ }^{92}$ Kenpo Könchok Namdak interview.
} 
anything at all worldly or historically-specific. ${ }^{93}$ Tibetans show a strong resistance to alternative, non-traditional, not-entirely-religious understandings of a question like the behavior of holy madmen. Some monks and lamas with whom I talked were willing to think about holy madmen in a different way, but they were exceptions to the rule. That Tibetans would hold fast to the traditional understanding of the holy madman phenomenon is entirely understandable, as they are personally invested in a particular worldview and an understanding of their history and culture. Less defensible is EuroAmerican scholars' resistance to new ways of thinking on this subject.

The purpose of this discussion is not to criticize individual scholars who have commented on Tibet's holy madmen, but rather to bring to light some of the embedded tendencies in the field of the study of Tibetan Buddhism. The aversion to taking a historical look at Tibet's holy madmen is symptomatic of a larger trend within the field of the study of Tibetan Buddhism, in which a lack of real historical vigor has dominated for a long time. I would not suggest that the scholars whose work I have reviewed here have consciously precluded historical understanding of the crazy yogis, but their manner of approaching holy madmen has come by force of habit and is symptomatic of a greater lack of historical interest in our field, which has relied more on a vision of religions as being about beliefs and ideas than institutions and more real-world concerns.

\footnotetext{
${ }^{93}$ Choegyal Rinpoché interview. This attitude was also expressed by Kenpo Könchok Norbu. I was surprised by the resistance towards exploring an alternative understanding of holy madmen exhibited by even some very historically-minded, non-traditional Tibetan scholars.

In this I see a connection to an observation regarding the way Jesus is most often thought about, made by Marcus Borg: "Because he is more than human he is not fully human. As the South African scholar scholar Albert Nolan has remarked, we consistently underrate Jesus as a figure of history." Marcus Borg and N. T. Wright, The Meaning of Jesus (New York: HarperSanFrancisco, 1999), p 8, citing Albert Nolan, Jesus Before Christianity (Maryknoll: Orbis Books, 1978), p 117. When we emphasize the saint's divinity at the expense of his humanity, we often lose track of the utterly remarkable human being he or she may have been.
} 
This is not to say that historical issues have never been mentioned in academic treatments of Tibet's holy madmen. In his introduction to his French translation of the “Autobiography” of Drukpa Künlé, R. A. Stein describes some of the political and religious conflicts that took place in the 15 th century. But Stein does not connect these considerations with the "madness" of the saint in any way; these events serve only as the backdrop before which Drukpa Künlé's madness played out. Similarly, in Civilized Shamans, a full two hundred pages after his description of holy madmen summarized above, Geoffrey Samuel talks about the Madman of Tsang as a critic of certain trends in 15th-century Tibetan religious life. But Samuel does not go so far as to explore the possibility that the Madman of Tsang's "madness" may itself have been in some way a strategic response to the situation. ${ }^{94}$ In neither case is the author's explanation of the holy madman's behavior precipitated out of his understanding of the circumstances of the time in which the madman lived.

\section{III.3 The Historical Perspective}

Although the modes of thinking about Tibet's holy madmen I have just described apply to the majority of modern scholarly comments on the subject, they do not represent the entirety of the discourse. There has long been another voice in this conversation, but it has thus far been a quiet one. The 1969 Indian printing of a notoriously inscrutable biography the Madman of Tsang (quoted from at the outset of this chapter) included with it an essay by E. Gene Smith about the holy madman in question and the 15 th-century madman movement of which he was a part. This was written before all of the scholarly

\footnotetext{
${ }^{94}$ pp 518-24.
} 
accounts mentioned above and represents a very different way of thinking about the subject.

What differentiates Smith's comments on the Madman of Tsang from the scholarly works described above is that he takes a rigorously historical approach. Smith not only mentions some issues of historical concern, but allows them to inform his reading of the madman phenomenon. For example, Smith notes that the three most famous of Tibet's holy madmen all lived at the same time, which he takes as an indication that we should zero-in on what was happening during that moment in Tibet's history in search of clues that may help us understand what may have prompted the "holy madman" movement. Smith, like many of the commentators whose work we have reviewed here, notes that the holy madman "is the antithesis of the scholastic monk." 95 But unlike most other scholars, Smith endeavors to place this anti-clericalism in historical context, noting that this madman movement "flowered... during an age of fervent religious reform and doctrinal systematization," especially in the form of "monastic reforms and Dge lugs pa [Gelukpa] rationalism." 96 Smith goes on to say that the madman movement was not only a reaction to these reforms, but represented a positive force, "an attempt to re-dedicate the Bka' brgyud pa [Kagyüpa] sects to old truths and insights that were being forgotten." $" 97$ The holy madman phenomenon was also an attempt to mitigate against the increasing wealth and institutionalization of the Kagyü sect that had been taking place over the previous few centuries. Smith also takes into account the literature

\footnotetext{
${ }^{95}$ E. Gene Smith, "Introduction to The Life of Gtsang smyon Heruka," edited by Lokesh Chandra (New Delhi: IAIC, 1969). This article was reprinted in Among Tibetan Texts: History and Literature of the Himalayan Plateau, edited by Kurtis Schaeffer (Boston: Wisdom Publications, 2001). All citations are from the reprint. I refer to this article as Smith, 2001a. p 60.

${ }^{96}$ Ibid., pp 59-60.

${ }^{97}$ Ibid., p 60.
} 
that was produced by the Madman of Tsang and his close disciples. In these few pages Smith has looked beyond the madman's crazy behavior to try to see the man beneath it and imagine the way his performance of this mad behavior may have been a means of dealing with certain real-world and historically-specific circumstances. To do this one must look at what the saint did when not performing outrageous public displays, and consider what was happening during the time in which he lived. Smith is able to develop this alternative understanding of the holy madman's behavior because of his willingness to see the madman as motivated to some extent by something other than the otherworldly (in this case, concern for the standing and well-being of his sect).

Smith's discussion of the holy madman movement covers only a few pages and is not a full-blown historical study in itself, but it lays the groundwork for a particular way of thinking about Tibet's holy madmen. It represents a departure from the traditional Tibetan modes of thinking on the subject, seeing the mad saints as real, complex individuals, motivated by more than just idealistic religious concerns. Smith's account suggests a more complex understanding of this apparent madness, taking a more historical approach that seeks reasons for this "madness" not in timeless religious truths but in contextualized history. It is, above all else, historically grounded.

Compared to the article by Ardussi and Epstein or the comments made by Keith Dowman, Smith's article has had a relatively small influence on the current academic conversation about Tibet's holy madmen. Smith's basic understanding of the 15 thcentury holy madmen is cited and followed by Andy Quintman in his 2006 dissertation on the literary activity of the Madman of Tsang when he comments on the 15th-century madman movement, and by Robert Goss (1991) when he does the same in his own 
dissertation. ${ }^{98}$ Todd Lewis and Lozang Jamspal also draw heavily from Smith in their brief discussion of the activities of the Madman of Tsang. ${ }^{99}$ In effect, Smith's article has become the primary source relied upon by a handful of scholars who have chosen to take an historical look at the holy madman phenomenon (all of whom have focused on the Madman of Tsang). It is, in effect, the major pole in the limited attempts at a historical understanding of Tibet's holy madmen. But this has by all means been a less popular view. The fact that Smith's comments have had such limited influence (in comparison to the article by Ardussi and Epstein, and Dowman) is likely due to the fact that, by dint of the context in which they were published, they were much less widely-accessible than the many other accounts that would be written later. As the introduction to a little-read 16thcentury Tibetan biography printed in India, it was fore-determined that Smith's essay would have less of an influence than something like Dowman's highly-readable and entertaining English (and French and German and Spanish) translation of the life of Drukpa Künlé. The way mass printing can influence history (both in terms of creating a past and in changing the course of the past-yet-to-come) will be a major theme in this dissertation. It is worth pausing here to consider how our understanding of Tibet's holy madman (and many other topics) may have evolved differently if someone like Kurtis Schaeffer had come along and reprinted Smith's essays three decades sooner.

\section{IV Conclusion}

The attempts to explain Tibetan holy madmen by exploring how their behavior can be justified through Madhyamika and tantric philosophy or through decoding their

\footnotetext{
${ }^{98}$ Quintman 2006, pp 189-90; Goss, p 60.

99 Todd Lewis and Lozang Jamspal, "Newars and Tibetans in the Kathmandu Valley: Three New Translations from Tibetan Sources," pp 188-90 in The Journal of Asian and African Studies, No. 36, 1988.
} 
meaning as tricksters are useful in that they highlight certain aspects of what it meant to be a holy madman. What follows in the next six chapters is what I intend to be a thoroughly historical description of Tibet's holy madmen. Although not planned as such, the final product resembles what I believe would result from taking E. Gene Smith's basic approach and applying it to the entire breadth of the holy madman tradition. In the end, the conclusions I reach are very similar to those suggested by Smith in his short article, which is another testament to his great foresight.

The goal of this study is a re-evaluation of their "holy madness" by looking specifically at the role the performance of madness played in their lives, and the way their reputations as madmen positioned them in the greater social, religious and material economies they participated in. My goal is to develop an understanding of Tibet's holy madmen that is systematic rather than impressionistic. We will look at the process through which their reputations as holy madmen were created, how they were received, and the ongoing role they played in shaping the idea of holy madness. This can only be achieved through taking a multi-perspective but essentially historical look individual "holy madmen." Instead of trying to somehow plumb the inner, experiential dimension of this kind of practice, this book will explore the external dimensions of this "mad asceticism": the effects (or side effects) this kind of religious practice would have had for these individuals as historical and socially embedded beings. Instead of idealizing them as beings motivated only by religious concerns, I work with the assumption that their motivations are complex and multi-faceted: although they may have been trying to embody certain Buddhist ideals, they are just as likely to have been moved to act by real- 
world concerns. Towards this end, I will see the madman not as a divine, enlightened being, but as a human being taking on a public persona towards some specific end.

Our review of the Tibetan, popular Euro-American and scholarly ways of understanding Tibetan holy madmen provides an important point of departure for this inquiry, which, it will be seen, is circular in nature. After having taken this snapshot of the current life of the idea of holy madness has come to live, the shape and scope it has achieved, we now turn to tracing the history of the idea leading up to this point. It is, above all else, the story of the conscious, purposeful activity of some very wise "madmen." We begin by looking at the lives of two of the most famous of Tibet's holy madmen, who are the main subjects of the study that follows. 


\section{Chapter 2: The Lives of the Madmen of Ü and Tsang}

In this chapter we will look at the lives of the Madman of Ü and the Madman of Tsang through summarized retellings of their standard biographies. As two of the most famous "holy madmen," these figures will play major roles in the story that unfolds in the rest of this dissertation. These summaries give a basic idea of who the Madmen of Ü and Tsang were and what trajectories their lives took. Many aspects of their lives-including their religious practices, the nature of the eccentric behavior that got them labeled "madmen," the historical moment in which they lived, their lay patrons, what they were trying to achieve through their work, and so on-will be discussed in greater detail in the chapters that follow. Another question that will be addressed in later chapters is that of the nature of the biographies from which these summaries are derived and the degree to which they relate or distort the historical past. Here our purpose is to get a basic idea of who these men were.

\section{I. The Life of the Madman of $\ddot{U}$}

The man who would come to be known as the Madman of Ü was born in a village called Olka, in the $\ddot{U}$ region, in $1458 .{ }^{100}$ He was born into an ordinary family in the

\footnotetext{
${ }^{100}$ This summary is based on the biography of the Madman of $\ddot{U}$, written in two parts by his disciples. The first part was written in 1494 when the Madman of Ü was about 36 years old. It was written by Nyukla Penchen Ngawang Drakpa (smyug la paN chen ngag dbang grags pa). This first part runs 90 folios in the 1972 printing. It bears the title The life story of the venerable Künga Zangpo, glorious holy lama, foremost among the siddhas, whose activity is totally victorious in all directions, called, "that which without bias gives goosebumps ${ }^{100}$ of faith" (dpal ldan bla ma dam pa grub pa'i khyu mchog phyogs thams cad las rnam
} 
Nyang clan, the youngest of five sons. He was a pleasant child with religious inclinations. They called him Kyepo Dar (skyes po dar). ${ }^{101}$ At times he did not get along with the other children because of his dedication to religious ideals. When Kyepo Dar was five or six years old his mother would carry him on her back to Leu Monastery, where he listened to stories about the lives of past masters of the Kagyü sect. When he was eight or nine he began to learn reading and writing at that same monastery. Kyepo Dar's adolescence was a time marked by difficulties. His mother passed away when he was still young. His father and brothers struggled under the weight of the compulsory work that was imposed on them as a tax (khral ' $u$ lag). Instead of sharing just one wife among them (as was the norm), the five brothers took two. The two wives did not get along, which caused discord in the household. Once Kyepo Dar was beaten by a drunken servant of a minor government official. Because of these experiences Kyepo Dar decided to dedicate his life to the practice of Buddhism, rather than

par rgyal ba'i spyod pa can rje btsun kun dga' bzang po'i rnam par thar pa ris med dad pa'i pu long g.yo byed).

The second part was written in 1537, five years after the yogi's death. It was written by Lhatong Lotsawa Shényen Namgyel (lha mthong lo tsA ba bshes gnyen rnam rgyal) on the basis of records maintained by Künzang Nyida Pelbar (kun bzang nyi zla dpal 'bar), the Madman of Ü's nephew and successor. According to Franz-Karl Ehrhard (citation in the following paragraph, p 237), Karma Trinlepa (karma 'phrin las pa, 1456-1539) also had a hand in the composition of the narrative. This second part runs 50 folios. It bears the title "Ornamental Drumsound of Activity," the second part of the life story of the venerable Künga Zangpo, called "that which without bias gives goosebumps of faith" (rje btsun kun dga' bzang po'i rnam par thar pa ris med dad pa'i spu long g.yo byed ces bya ba las/ rim par phye ba gnyis pa phrin las rgyan gyi rnga sgra). There is a consistent chapter structure throughout the two parts of the Life.

For other summaries of the Madman of Ü's life based on this same biography, see "The Three Divine Madmen," in The Dragon Yogis: A Collection of Selected Biographies and Teachings of the Drukpa Lineage Masters; no editor or author listed (Gurgaon: Drukpa Publications, 2009), pp 44-7; and Franz-Karl Ehrhard, "The Holy Madman of dBus and His Relationships with Tibetan Rulers of the 15th and 16th Centuries," pp 219-46 in Geschichten und Geschichte: Historiographie und Hagiographie in der asiatischen Religionsgeschichte, edited by Peter Schalk (Uppsala: Uppsala University Library, 2010). Ehrhard's summary contains many historical details that I have left out of my account, for the sake of brevity. I made use of Ehrhard's version when making this summary, and make some specific reference to it below.

${ }^{101}$ Meaning, perhaps, "One Who Will Unfold [the Dharma]" or "Young Boy." 
participate in the self-perpetuating cycle of suffering that is village life. Despite his ardent wish to leave the home and become a monk, for two years his father and brothers prevented him from leaving.

When he was fifteen or sixteen Kyepo Dar ran off, joining some people on their way to Tsari, the nearby mountain that was perceived as the abode of the tantric deity Cakrasamvara. At this great locus of religious activity Kyepo Dar met Chuwo Ripa Künga Namgyel, whom he took as his master. Kyepo Dar took his preliminary monastic vows under Chuwo Ripa, dressing himself in the maroon robes of monkhood. He was given the name Künga Zangpo. He would follow Chowo Ripa for the next three years, as they stayed together in various monasteries and meditative centers in south-central Tibet. Chuwo Ripa transmitted to Künga Zangpo many tantric teachings and ritual empowerments. Künga Zangpo applied himself enthusiastically to meditation. His understanding of the emptiness of all phenomena blossomed. He had success in visualizing the workings of his internal, tantric body. Warmth blazed in his belly, giving him a feeling of bliss. He experienced waking life as if it were a dream.

In 1475 , at the age of eighteen, Künga Zangpo took full monastic ordination at the Forest of Glorious Samantabhadra (dpal kun tu bzang po'i nags khrod), a site for meditative retreat near Densa Til Monastery, not far from his home village. Künga Zangpo continued to receive transmissions and tantric teachings from his guru, getting ritually empowered to perform meditations on many different deities and tantric systems. He also traveled to other monasteries in the $\ddot{U}$ region to receive transmissions from other masters, including Drakchokpa Rinchen Zangpo, who would replace Chuwo Ripa as his primary guru from then onward. Künga Zangpo also received teachings from one called 
Bangrimpa (bang rim pa). Drakchokpa and Bangrimpa played an important role in passing on the teachings of chenga Sönam Gyeltsen (spyan snga bsod nams rgyal mtshan, 1386-1434), who had been the abbot of Densa Til Monastery and represented the religious arm of the Pakmodru regime, which was ruling central Tibet at the time.

Having received this thorough training, Künga Zanpo spent the next period of his life meditating in various sites in southwestern Tibet. For three years he stayed meditating in retreat in Lapchi and Chubar. ${ }^{102}$ His awareness of the true nature of phenomena progressed further, as did his control over his inner, tantric body. He is said to have gained clairvoyance and had visions of deities.

Künga Zangpo then returned to the Forest of Glorious Samantabhadra in central Tibet to be near his master, Drakchokpa, who transmitted to him some teachings he had not gotten before. After a year Drakchokpa told Künga Zangpo to go off and meditate in the holy places of Tsari, Mount Kailash, and Lapchi; the Six Fortresses where Milarepa had meditated; places in central Nepal, and so on.

Künga Zangpo went again to southwestern Tibet to meditate in the holy sites indicated by his master. He stayed for five years, during which he spent an entire year practicing at Mount Kailash. He undertook great austerities during this period, fearlessly submitting himself to extreme weather, eating and wearing very little. He took no worldly comforts. His meditative practice continued to improve and his understanding of Buddhist truths became firmer.

\footnotetext{
${ }^{102}$ There is some disagreement over how the name of this place should be spelled and pronounced. Although the spelling chu dbar (pronounced "Chuwar") is attested to, the spellings chu bar and chu 'bar (pronounced "Chubar") are more commonly encountered. The name of the other site is invariably spelled la phyi, and should be pronounced "Lachi," but seems to be more often pronounced "Lapchi."
} 
Künga Zangpo then underwent a transformation that would define the course of the rest of his life, and his historical legacy thereafter. Künga Zangpo went before a statue of the Buddha and took off his maroon monk's robes. He then adorned himself with bracelets, anklets, a necklace and a sash, all made of human bone. He smeared himself with ashes, blood and fat from a human body. He draped a human skin over his upper body as a cloak and wore a tiger skin as a skirt. He took up a hand drum made from two human skulls, a trumpet made from a thighbone, a cup made from a human skull and a trident. He based this mode of dress on passages from the Hevajra and Cakrasamvara tantras and other texts, as well as depictions of the wrathful deities Hevajra, Cakrasaṃvara and Mahākāa.

Shortly after making this dramatic change in his appearance, Künga Zangpo engaged for the first time in the sort of provocative behavior that would make him famous. Dressed in this garb that made him look like a tantric deity, Künga Zangpo went to the palace of the king of Ngari Gungtang, a small kingdom in western Tibet, with the intention of "overpowering him with his glory" (zil gyis gnan). Seeing Künga Zangpo dressed in such an unexpected manner, the guards were too shocked to stop him and so he walked directly into the presence of the king, surrounded by his ministers. They too were shocked. Soon the guards came to their senses and threw Künga Zangpo out into the courtyard. They beat him savagely. Künga Zangpo pronounced the divine syllables hüm and phat and danced like a wrathful deity. Seeing this, the king and his ministers and subjects became convinced that Künga Zangpo was a siddha, an awakened being. They gave him a lavish reception and asked forgiveness for having hurt him. From this time onward he was renowned by the name "the Madman from Ü." 
The Madman of Ü returned to meditating in the famous caves associated with Milarepa in southwestern Tibet. He went for the first time to Kathmandu, where he visited a number of holy sites. ${ }^{103}$ He meditated in the frightening, haunted places where corpses were burned and disposed of. We are also told that he desecrated and destroyed many statues of Hindu deities, even urinating on them, smearing them with filth and dancing on their heads. This outraged the locals, who beat and stoned him enough to kill any ordinary man. The king of Bhaktapur sent an army to attack the Madman of Ü, but he miraculously survived. According to the Madman of Ü's biography, those people were so impressed by his superhuman capacities that they started to honor and praise him. They even stopped performing animal sacrifices and began to revere images of Buddhist deities. The Madman of $\ddot{U}$ also forcibly reclaimed some sacred caves in the Kathmandu area that had been taken over by non-Buddhists.

The Madman of Ü returned to central Tibet, traveling from one monastery to the next, receiving some new teachings he had not gotten previously. He made his way back to his home area. He spent a year meditating and performing rituals at many holy places around Tsari, the sacred mountain where he had first begun his religious life. It is during this time that we are first told of the Madman of Ü's having disciples. He instructed them in the Six Dharmas of Nāropa, the Mahāmudrā, and other teachings central to the identity of the Kagyü sect. These are the teachings the Madman of Ü would teach most often for the rest of his career. The Madman of Ü traveled to Kongpo and continued to win people over by impressing them with his yogic feats, such as when he threw himself into some

\footnotetext{
${ }^{103}$ Earlier in the biography there is mention of Künga Zangpo's going to Nepal, but it is likely a reference to the trip described here.
} 
violent rapids and emerged unhurt. He drank impressive amounts of liquor without getting drunk.

The Madman of Ü visited the provincial regent of the area, Tashi Dargyé of Ja, who would become one of his first significant lay patrons. Tashi Dargyé and his underlings all received the yogi with reverence and generosity; in turn he gave them blessings and Buddhist teachings. This model would be repeated in his relationships with patrons for the rest of his life.

After this the Madman of Ü visited Lhasa (the first visit to that place we are told of, but not likely to have been his first). There he fought with the caretaker of the Jokang temple, who would not let him in to visit the precious Jowo Buddha statue. The yogi miraculously slipped through the gate and went before the statue. The people of Lhasa were very impressed by this feat.

From there the Madman of Ü traveled to Tsang, where he visited many monasteries and retreat sites, spending his time teaching the Dharma and meditating. In the autumn he went to Gyantsé, where people were harvesting. He danced on the grain they had laid out and slapped anyone who tried to oppose him. They gave him a savage beating, but as always, he survived. He spent a winter meditating in a cave. We are told for the first time that some of the Madman of Ü's disciples could make a show of wearing nothing but a simple cotton cloth, which was a testament to their ability to generate warmth in their bellies through tantric meditation. The Madman of Ü spent time at many of his old favorite places, like Mount Kailash, Chubar, and so on. He made his second and last trip to Kathmandu, where he attended to some corpses that had been left to rot. He cut off the thigh bones, presumably to make trumpets out of. Again the locals 
attacked him, but he survived. He punched and urinated on a local king, which shocked and frightened the people so much that they came to revere him.

The Madman of $\ddot{U}$ circled back to the Tsang region in central Tibet and established a meditation center (sgrub sde) called "Fortress of the Space of the Dharmarealm" (chos dbyings nam mkha'i rdzong) in Lower Nyang, made possible by financial support from the ruler of the nearby town of Gyantsé. ${ }^{104}$ At Fortress of the Space of the Dharma-realm the Madman of Ü gave teachings to many students. This place would serve as the Madman of Ü's base for the next few years, as he occasionally returned there to meditate and teach in between traveling around Tsang.

By this time the Madman of $\ddot{U}$ had gained a reputation for disruptive, combative behavior. When the Madman of $\ddot{U}$ found out that a religious festival was being held at Gyantsé to which he had not been invited, he sent an angry letter to his patron expressing his intention of coming anyway. Frightened, the ruler of Gyantsé sent the Madman of Ü a sheepish letter inviting him to the event but asking him to please not cause any problems. The Madman of Ü went, and religious practitioners and laypeople alike were impressed by him.

The Madman of Ü traveled to many places in the Tsang region. In Shigatsé he stole into the presence of Dorjé Tseten of the powerful Rinpungpa family, seated at court. The Madman of Ü scolded them all, drank Dorjé Tseten's tea, danced about, thrust his trident and stomped on the table. They were all shocked, and became faithful in him.

\footnotetext{
${ }^{104}$ Ehrhard, 2010, pp 230-1, reads this place to have been entrusted to the Madman of Ü by another lord, Dönyö Dorjé of the Rinpung regime.
} 
The Madman of Ü's relationship with the Rinpungpa family would be important for many years of his life.

In 1488, when the Madman of Ü was about thirty-one years old, he attended an enormous gathering of religious practitioners at Zabpulung (zab phu lung) in the Shang valley. There he gave teachings and "tamed" people with his fierce activity. It is said that, wearing his costume that made him look like the deity Heruka, he stood out from and outshined everyone gathered there. The Madman of Ü continued to spend time in Tsang, visiting people like the scholar-monk Sākya Chokden.

One time when he was in the midst of giving a Dharma teaching, a monk died of smallpox nearby. It was not convenient to cremate the body just then, so it was buried underground. The Madman of $\ddot{U}$ went to that place and dug up the body, which was swollen and rotten. He pulled the flesh off the corpse's head, cracked open the skull, and took out a handful of brains, which he then ate. Everyone present was nauseated.

The next period of the Madman of Ü's life was marked by his relationship with members of the powerful Rinpung family. He had met Dorjé Tseten and his nephew Dönyö Dorjé in Tsang. At that time their faction had, through timely power grabs, alliance-making and military engagements, taken control of most of that region. As the Rinpungpa faction made inroads to the Ü region, the Madman of Ü went with them, spending much time with Dönyö Dorjé — at this point, the most powerful person in all of Tibet—at the strategically-located Chushül Lhünpo fortress. The Madman of Ü gave Dönyö Dorjé teachings and received lavish offerings in return. Around this time the Madman of Ü endured a famously-savage beating at the hands of the people of Nyukla, who were skeptical of the man who arrived wearing the garb of a wrathful tantric deity. 
They were so impressed that he had survived the worst they could possibly have done to him that they became convinced of his holiness. The Madman of Ü stayed at Nyukla for some time, where he and his disciples well taken care of. There he gave teachings to Ngawang Drakpa, also known as the Penchen of Nyukla (1458-1515), who would become one of the Madman of Ü's closest disciples and wrote the first part of his biography.

The Madman of Ü visited some other places in the Ü region, making his way back to his home village, Olka. He gave teachings and visited with his father. He then embarked on a journey through Kongpo, where he meditated in holy sites, gave teachings, and impressed many skeptics with his special abilities. He circled back to the Lhasa area, meeting with another member of the Rinpung family and visiting the Jowo Buddha statue. He stayed for a long time the retreat site Yöl Rinchen Ling, where he taught extensively to his disciples. He spent five or six months between Nyukla and Karak fortresses. The secretary (nang pa drung chen) of Karak gave the Madman of Ü the gift of an estate (chos gzhis) called Liberation Park (thar pa gling), where the yogi established a new monastery—-his second—-dedicated specifically to the practice of meditation.

The Madman of Ü went to Nyemo in Tsang, where he acquired another faithful patron in the local official (nang so). In Tsang the Madman of Ü visited his old patron and friend Dönyö Dorjé, and some other monasteries in eastern Tsang. Everywhere he went he gave teachings and received offerings.

One time when the Madman of $\ddot{U}$ was staying at a hot spring he started to feel unwell and stayed inside for a few days. Word quickly spread that the master had passed 
away, so many people started to gather there, bearing offerings. The yogi came out dancing and singing, proving to everyone that he was still alive. This event made him more famous than ever before. He went to Shang, Nyang, and Serdok Chen Monastery, where he saw Śākya Chokden a second time. The Madman of Ü visited the monastery he had founded some years earlier, Liberation Park, where he paid great honor to all the teachers and worked to ensure the ongoing success of the center. He traveled south to the Yardrok area. At this point the Madman of Ü started to use the resources he had received as offerings to sponsor festivities at various monasteries. He sponsored tea and noodles for the monks of Densa Til, Tashi Lhünpo, and other monasteries. He sponsored a religious service to be held at the Forest of Glorious Samantabhadra in the presence of the skull of his old master, Drakchokpa, who must have died in the years since he saw him last.

It was now 1495 and the Madman of Ü was 38 years old. He received word that his father was nearing the end of his life, so he returned to his home village. It was clear that no medical treatment or religious ritual could prevent his father's death at this point, so the Madman of Ü and his disciples performed ceremonies to ensure a positive transference of consciousness in the dying process. The body was cremated.

From there the Madman of Ü went to Kongpo, stopping at monasteries along the way. In Dakpo a wealthy patron asked the Madman of Ü for a blessing to ensure that she would give birth to a son. So the Madman of Ü urinated in all the pots and pans in the house. It is said that after that the household became rich in offspring, possessions and livestock. 
The Madman of Ü visited many holy sites around Tsari, his third visit to that mountain. As by now had become the norm, the Madman of Ü met some people who were accepting of him, and others who physically attacked him. But he always survived and gained their reverence in the end. He returned to central Tibet, stopping along the way at Rechung Puk and the Yarlung Valley. He stayed for some time at Nedong, visiting the headquarters of the Pakmodru regime. He made offerings to the ascetics staying in the nearby retreats.

From this time onward the center of the Madman of Ü's activities would be the Penyül area, north of Lhasa. For the next few years the Madman of Ü would alternate between teaching and meditating in retreat. In winter of 1499, at the age of 42, he went into meditation in Kyaluk Cave (phug pa skya lhug) and gave advanced instructions to some of his more advanced, closest disciples. They held a special event during which those advanced practitioners, wearing only loincloths, wrapped themselves with wet sheets and sat in a very cold place. By generating yogic heat they were able to make the sheets completely dry. The following year the Madman of Ü went to the Boneyard of the Nāga Queen (dur khrod klu mo rgyal), where there was a gathering of advanced tantric practitioners.

In 1500 the Madman of Ü announced that he would reduce his distractions and only meditate for some years, as he would a handful of times in the latter part of his life. At one point the Madman of Ü became ill from the water he had been bathing in and decided to go to Lhasa for a change. He scandalously rode a horse right into the middle of the Barkor. During this visit he had the faces of the famous Buddha statues in the 
Jokang and Ramoché temples painted with gold and made offerings of butter lamps, silk scarves and the like.

Having returned to Penyül, north of Lhasa, the Madman of Ü set his sights on acquiring a monastery, perhaps defunct, situated on a beautiful, auspicious site. It was called Tsimar Pel. The Madman of Ü charged one of his close disciples with making the monastery come into their possession, presumably by gaining the permission and favor of the local lords. On the 15 th day of the 11 th month of 1502 the Madman of Ü took residence there. This would be his home until his death thirty years later.

The Madman of Ü spent the next ten years in meditative retreat, focusing on his own practice rather than teaching, showing himself publicly only a few times. It is said that he lived for some time consuming only flowers and berries. At one point there was a dispute over who should have control over Tsimar Pel. Some troops arrived at the monastery, but the situation was resolved without incident.

In 1509 one of the Madman of Ü's disciples came from Tsang to see him, accompanied by two hundred disciples of his own. They brought him offerings of gold, silver, coral, amber, clothing, cushions, and so on. As the Madman of Ü was staying in a sealed retreat, he spoke to them only through a small window, as he would with most of the visitors who came to him during these years. (It is unclear from his biography whether the Madman of Ü spent all of his time sealed in retreat, interacting with the world only through a small window, or just long periods of it.) Knowing that he would never see this disciple again, the Madman of Ü told him to compose some texts and gave him some gifts, including a deer hide and a cup. He was then visited by another disciple, Nyukla Penchen, whom he encouraged to pass on to his own disciples the teachings of 
the Great Seal, the Six Dharmas of Nāropa, the Dohās of Saraha, and a practice called the Secret Activity of the Indians (rgya gar gsang spyod). Around this time the Madman of $\ddot{U}$ received many visits from disciples and respected religious practitioners in the area. In 1511 one of his disciples returned from spending a long time in eastern Tibet. The Madman of Ü gave him permission to go visit his mother in Tsang. However, on his way he stopped in Lhasa, where he performed the sort of provocative behavior for which his master was famous. Some people attacked him and he was killed.

In 1512 at the age of 55, after having spent the last ten years in a strict retreat, the Madman of Ü decided he should teach more actively again. A few of his disciples had died young, so he was concerned about the continuation of his lineage. An announcement was spread far and wide that he would begin giving teachings again. Five hundred religious practicioners came from central Tibet and Kham to listen to the master. He gave more advanced and secret instructions to a smaller circle of disciples. When the teaching session was over, he instructed some of his close disciples to travel to the holy sites he himself had visited, including Mount Kailash, Lapchi, Chubar, the Swayambhūnāth stūpa, and the Six Fortresses of Milarepa, to make offerings, raise statues, and meditate. Some he sent to Kham and other regions. He encouraged them all to meditate diligently.

The next twenty years of the Madman of Ü's life would be characterized by a steady succession of visitors and gifts arriving at Tsimar Pel. Some of these visitors were local officials, who gave the madman offerings and received teachings in return. The Madman of $\ddot{U}$ also had correspondence with political figures who did not arrive in person, like when he received a letter accompanied by many gifts - five hundred large 
pearls, rugs, a deer hide, and so on-from the king of Lowo Möntang (also known as Mustang, inside the boundaries of present-day Nepal). He received letters from other Tibetan dignitaries as well, including the heads of the two political factions competing for control of central Tibet: Ngawang Namgyel, the son of Dönyö Dorjé and the head of the Rinpungpas, and the gongma Ngawang Tashi Drakpa, head of the Pakmodru regime. The Madman of Ü would also receive gifts from the king of Santika (san+ti ka'i rgyal po), the king of Mön (mon rgyal po sprang po dar), and the king of Jangsadam ( 'jang sa tham), in present-day Yunnan province. Later, the ruling family of Ngari Gungtang, whom Künga Zangpo had "overcome with his brilliance" in the process of becoming the Madman of Ü, sent a letter asking the yogi to give a name to their newborn son.

Others who came to visit the Madman of Ü at Tsimar Pel over the next twenty years were more-or-less-renowned religious practitioners. Drukpa Künlé, "the Madman of the Drukpa" (1455-1529?), came bearing gifts and some compositions he had written on behalf of the Madman of Ü. The Madman of Ü was also visited by the great Indian cotton-clad ascetic, Tilmarwa of Bodhgaya, who arrived with his retinue of students. He gave the Madman of Ü the gift of a conch shell. In 1521 the Madman of Ü was visited by a siddha from India named Jaharbhi (rgya gar nas grub thob dza harb+hi). He praised the Madman of Ü, saying that even in India there was no guru greater than him. When word was sent out that Tsimar Pel was in need of food, the nephews of one of the Madman of Ü's closest disciples, Nyukla Peṇchen, came from the Nyukla fortress bearing a hundred loads of tsampa (barley flour), and many other things. The Madman of Ü also received a very flattering letter from the Eighth Karmapa, asking him questions 
about difficult points in the practice of tantra. This letter was offered up as a testament to the greatness achieved by the Madman of Ü during his time.

The greatest number of those visiting the Madman of $\ddot{U}$ at Tsimar Pel during these years were his own students. Some he instructed to travel to remote places to meditate and spread the Dharma. Many would return, months and years later, having been successful in their endeavor and bearing gifts for their master.

In 1514 the Madman of Ü's nephew, who was thirteen years old, came to Tsimar Pel from Olka to become a monk and begin training to become his spiritual heir. The Madman of Ü gave him the name Künzang Nyida Pelbar. He was made to blow a conch shell in the four directions; it made a loud sound, which was said to be a good sign.

In 1516 serious problems arrived at the Madman of Ü's doorstep. It was a time of ongoing conflict between the regions of $\ddot{U}$ and Tsang. It is said that some people in Taktsé (stag rtse), east of Lhasa, were plotting some evil against the Madman. Those close to the yogi warned him of this, but he declared that he would not leave Tsimar Pel under any circumstances. He instructed his disciples to not fight back, no matter what might be done to them. In the autumn, just after the harvest, when most of the master's disciples were away from the monastery begging, a host of soldiers - made up of both monks and laypeople — surrounded the Madman of Ü's residence and began pummeling it with a great rain of stones and arrows. (It is unclear which faction these troops represented; they may have been troops based in the Lhasa area who were on their way out to a military engagement.) They began to attack the Madman of Ü's residence with bars and weapons. A few soldiers got onto the roof and were about to drop down to attack the yogi when they saw him wearing his wrathful deity costume of eight bone 
ornaments, with a fierce look in his eyes, staring into space. The soldiers immediately desisted and prostrated at his feet, unable to hit him. Nevertheless, overcome by their own craving, they took all of his belongings and left.

That night the guilty parties saw many bad signs portending punishment for what they had done, so the next morning they returned the Madman of Ü's possessions to him. The yogi said he did not care about getting his things back, except for his trident, which was of a special ritual significance.

In 1518, when the Madman of Ü was 61, he made an announcement that it was time to appoint replacements for the close disciples of his who had died, in order to ensure the continuation of his lineage. (In recent years he had lost the disciple who was killed in Lhasa, Nyukla Peṇchen, who died in 1515, and Chokro Peṇchen Rinchen Samtenpa, who died around 1518.) Many students flocked to him. He transmitted important tantric teachings. He expressed the highest truths by means of oral statements, bodily and hand gestures. To a hundred advanced ascetics he imparted the highest transmissions. He then gave them gifts and sent them out to holy places like Tsari to meditate. We are told that the Madman of Ü did all this from inside his sealed-up retreat, speaking only through a small window.

Throughout the 1520 s the Madman of Ü gave teachings regularly, holding teaching sessions in winter, spring and summer. In winter of 1524 there were five hundred ascetics in attendance. The teachings he imparted most often were the Mahāmudrā and the Six Dharmas of Nāropa. He would give more advanced teachings to a circle of a hundred or so more serious ascetics. Even more advanced and secret teachings would be reserved for a smaller group. At the end of these sessions the 
Madman of $\ddot{U}$ would often instruct his disciples (who in many cases had disciples of their own) to meditate and spread their brand Buddhism in different regions, in southwestern Tibet, eastern Tibet, or even China. Dzongkar Rechen returned from China bearing many exotic gifts. When Künga Nyishar returned from Kham, he brought a large piece of turquoise for the Madman of Ü, and treated the entire community of Tsimar Pel to a tea ceremony and gifts of cloth and silk.

One time the Madman of $\ddot{U}$ received a request to perform a consecration ritual for the Tashi Gomang stūpa that had been constructed at Drikung Til Monastery. Unwilling to travel there, the Madman of $\ddot{U}$ put on the garb of the Heruka and recited a prayer with a loud voice, accompanied by a dance.

One significant visitor to the Madman of Ü was Tsuklak Trengwa, the second in the Pawo incarnation lineage, who was considered a reincarnation of Gampopa. Their meeting is compared to Gampopa's meeting Milarepa. The boy's hair was cut, marking his entrance into monastic life, and the Madman of $\ddot{U}$ gave him extensive Dharma teachings, including that on inner-fire meditation. The Madman of Ü gave Tsuklak Trengwa a parting gift of a deerskin, a ladle made of mother-of-pearl, and so on.

A few years before the Madman of Ü's death he told his nephew, who was in his late 20 s, that he would have to take on greater responsibilities within the monastery, working as chantmaster and overseeing the operation of the institution. The following year Künzang Nyida Pelbar undertook work to prolong the life of the Madman of Ü: offerings were made and rituals performed before the skull of Drakchokpa, the Madman of Ü's master; at Drikung Til, Tsari, lake Manasarovar, mount Kailash, Lapchi, Chubar, the Six Fortresses of Milarea, Ramoché temple, the Jokang, the Yerpa caves, and many 
other places as well. A tea ceremony and a feast were held at Tsimar Pel; it is said that each of the five hundred practitioners in residence there was given a $z h o$ of gold.

In 1531 the Madman of Ü announced to his students, "If you want to meet father, come this year. I don't know if we'll be able to keep on meeting!" Then the number of people visiting the Madman of Ü was higher than ever. Tea ceremonies and feasts were sponsored. The Madman of $\ddot{U}$ gave teachings, along with prophecies about the future.

In this year renovations were made to two of the monastery's assembly halls. The Madman of Ü knew of his coming death, and made cryptic statements suggesting as much to his students.

In the middle of that year's summer teaching session the Madman of Ü announced that he was finished teaching the Dharma forever. He told many stories about the deaths of famous lamas of the past, a sure sign that his own time was coming soon. Later he hold his disciples that they knew all they needed to know, and that diligence in meditation was more important than relying on one's lama. Madman of Ü entered a very strict retreat and would not grant an audience to anyone.

In 1532, on the anniversary of the Buddha's descent from Trāyastrimsśha heaven, the Madman of $\ddot{U}$ called for his nephew and successor to come to him. He gave three proclamations: about the importance of maintaining the teachings and taking care of Tsimar Pel monastery; about what should be done with his blessed belongings; and that his disciples should not be sad when he passed away. He died at dusk, sitting in the meditation posture with his hands together, staring straight ahead.

The casket in which the Madman of Ü's corpse rested was adorned with the six bone ornaments that were the main part of his wrathful deity costume. The monks of 
Tsimar Pel surrounded the corpse, reciting prayers and making offerings. An unending stream of tears was shed. News that the Madman of Ü had died spread everywhere. An unfathomable array of offerings came rolling in. People flocked to Tsimar Pel. In the second week after his death, a great ritual was held and the corpse cremated. For two weeks his disciples continued to perform rituals. The Madman of Ü's nephew, Künzang Nyida Pelbar was officially installed as the head of the spiritual community there. Offerings of food, clothing, silk scarves, butter lamps, money and so on were made at Drikung Til, Taklung Monastery, before the skull of the Madman of Ü's master, and other places. Those performing the rituals at Tsimar Pel were compensated with trinkets, livestock and other gifts.

Four weeks after the master's passing the cremation chamber was opened and blessed objects found inside, including the yogi's skull, and multi-colored pearl-like relics.

Sometime after this patrons stepped in to sponsor the construction of a stüpa at Tsimar Pel, which would contain the yogi's relics, hair, fingernails, teeth and other blessed objects. It took a year and a half to construct and then consecrate the stüpa.

\section{II. The Life of the Madman of Tsang}

The man who would come to be known as the Madman of Tsang was born in 1452, in Karka in Upper Nyang in the Tsang region. ${ }^{105}$ Like the Madman of Ü, he was of

\footnotetext{
${ }^{105}$ This summary of the life of the Madman of Tsang is based on the latest and most extensive of his three biographies, that by Götsang Repa. I rely on only this one version for the sake of simplicity. Noting the differences between the three versions of the biography would be too distracting here, but the fact that the biographies differ is telling. This will be addressed in Chapter Six. I plan to write an article on the differences between the various versions of The Life of the Madman of Tsang in the future.
} 
the Nyang clan (gdung). The men in his family had been non-celibate tantric

practitioners for generations; his father was a village priest. After his birth he was given the name Chögyel Lhünpo (chos rgyal lhun po), meaning "Dharma-king Mountain." Chögyel Lhünpo was the second of three brothers, all of whom would go on to become well-known religious practitioners. From a young age Chögyel Lhünpo took an interest in religion; at the age of six when he played with his friends, he pretended to be a vajra master teaching the Dharma.

Chögyel Lhünpo developed a strong wish to renounce worldly activity and at the age of seven took preliminary monastic ordination (dge tshul). At this time he was given the name Sangyé Gyeltsen. He maintained strict adherence to the monastic discipline. At the age of thirteen he tied a knife around his neck, stating that if he ever broke his vows, he would kill himself. He learned reading and writing. He had great faith in the

The three main versions of The Life of the Madman of Tsang were all composed by his disciples:

1) Ngödrup Pelbar (dngos grub dpal 'bar) wrote rje btsun gtsang pa he ru ka'i thun mong gi rnam thar yon tan gyi gangs ril dad pa'i seng ge rnam par rtse ba, xylograph completed in 1508;

2) Lhatsün Rinchen Namgyel (lha btsun rin chen rnam rgyal, 1473-1557) wrote grub thob gtsang pa smyon pa'i rnam thar dad pa'i spu slong g.yo ba, xylograph completed in 1543;

and that summarized here, 3) Götsang Repa Natsok Rangdröl (rgod tshang ras pa sna tshogs rang grol, 1494-1570) wrote gtsang smyon he ru ka phyogs thams cad las rnam par rgyal ba'i rnam thar rdo rje theg pa'i gsal byed nyi ma'i snying po, xylograph completed 1547.

These dates for the completion of Lhatsün Rinchen Namgyel and Götsang Repa's versions of the biography are attested to in Franz-Karl Ehrhard, Early Buddhist Block Prints from Mang-yul Gung-thang (Lumbini: Lumbini International Research Institute, 2000), p 17.

Peter Alan Roberts has argued that Götsang Repa's version must have predated Lhatsün Rinchen Namgyel's, The Biographies of Rechungpa: The Evolution of a Tibetan Hagiography (Abingdon, New York: Routledge, 2007), p 41. I believe Roberts to be incorrect, for reasons I plan to address in a future article.

For brief summaries of the life of the Madman of Tsang based on this same text, see E. Gene Smith, "Introduction to The Life of Gtsang smyon Heruka," in Among Tibetan Texts: History and Literature of the Himalayan Plateau, edited by Kurtis Schaeffer (Boston: Wisdom Publications, 200; originally published by Lokesh Chandra, New Delhi: IAIC, 1969) and "The Three Divine Madmen," in The Dragon Yogis: A Collection of Selected Biographies and Teachings of the Drukpa Lineage Masters; no editor or author listed (Gurgaon: Drukpa Publications, 2009), pp 41-4; and Roberts, pp 60-65. For a very thorough account of the Madman of Tsang's life, see Stefan Larsson, The Birth of a Heruka: How Sangs rgyas rgyal mtshan became gTsang smyon Heruka: A Study of a Mad Yogin (Ph.D. dissertation, University of Stockholm. Institutionen för etnologi, religionshistoria och genusstudier, 2009). 
past masters of the Kagyü tradition, so that whatever pleasing thing came into his visual range, he mentally offered it to the Kagyü.

At the age of eighteen Sangyé Gyeltsen decided to travel from Tsang to Tsari, a famous pilgrimage site especially important to the Drukpa subsect of the Kagyü. At Tsari he met Shara Rabjampa, with whom he had an immediate connection. Sangyé Gyeltsen took Shara Rabjampa as his master and served as his attendant for a long time. Shara Rabjampa imparted many teachings to Sangyé Gyeltsen, including various transmissions of the Six Dharmas of Nāropa, the Mahāmudrā, Saraha's Dohā Trilogy and the Aural Transmission. Shara Rabjampa initiated Sangyé Gyeltsen into the practice of various tantric systems, including the 62-deity Cakrasamvara maṇdala and others.

Sangyé Gyeltsen soon manifested signs of success in his meditation. He achieved yogic warmth, enabling him to go about wearing nothing but a simple cotton cloth. He gained control over the workings of his internal, yogic body. He had realizations and strengthened the good qualities within himself. Before they parted, Shara Rabjampa told Sangyé Gyeltsen to seek out tantric transmissions from other masters, to dedicate himself to the study of the Hevajra tantra, to wear torn clothes and practice austerities, and to meditate in holy sites like Lapchi, Chubar and the Six Fortresses of Milarepa. They had a tearful farewell. This would be the last time Sangyé Gyeltsen ever saw his master.

Sangyé Gyeltsen traveled to Tsang to see his mother. He enrolled at the great monastic college in Gyantsé, the Pel Korlo Dechen or Pel Korlo Chödé. There he studied the Hevajra tantra intensively, memorizing the root text and a commentary. He studied and received empowerments for the practice of other tantric systems as well, like the Path and Fruit, which was especially important to the Sakya tradition. Sangyé Gyeltsen 
studied religious dance and singing, the proper creation of religious images, and the performance of rituals. He became fully accomplished in teaching, debating over, and writing about these topics. He showed great aptitude and sensitivity in everything he learned, knowing both the words and their inner meanings. In short, Sangyé Gyeltsen gained all the skills and qualities of a genuine tantric master (rdo rje slob dpon).

At one point while living and studying in this renowned monastic institution Sangyé Gyeltsen underwent a dramatic change. He began to act strangely, laughing and making odd noises. One day when the ruler of the town of Gyantsé came to the monastery with his ministers, a formal assembly was called. While all the monks were seated in rows, Sangyé Gyeltsen arrived carrying a skull cup and a trumpet made from a human thighbone. He was scolded by the monastery's disciplinarian for acting in such a disruptive manner. Sangyé Gyeltsen asked the disciplinarian, "Where in the sūtras and tantras does it say one cannot carry a skull cup and thighbone trumpet in the line of monks?" The disciplinarian told him to leave the assembly. Sangyé Gyeltsen announced that rather than studying all the time, he needed to dedicate himself to meditation; he said that living as a monk was a hindrance to the practice of austerities and tantra. So Sangyé Gyeltsen handed in his monk's robes and left the monastery, with the intention of going back to Tsari. For much of his life from this time onward Sangyé Gyeltsen would dress in a set of ornaments made from human bone, referred to as "the garb of the charnel ground" (dur khrod kyi chas) or "the garb of the Heruka" (he ru ka'i chas), just like the Madman of Ü.

Sangyé Gyeltsen stopped at his home village and met up with his younger brother, who set off with him. They stopped at Lhasa, where Sangyé Gyeltsen went into the 
middle of the marketplace, tore apart a thread cross (mdos) and ate a torma. People physically attacked Sangyé Gyeltsen for this obscene behavior, but miraculously he was not hurt. He started to gain a reputation.

Sangyé Gyeltsen arrived at Tsari, where he would stay for the next three years. He soon began to act in even more shocking ways. He told the wife of Tashi Dargyé, the provincial regent of the Ja area, that he wanted to "screw" her. He justified his impertinent behavior by saying that it was as instructed by the Hevajra tantra. Tashi Dargyé was won over by this, and promised to provide for Sangyé Gyeltsen's upkeep as long as he stayed at Tsari. After this a local lord asked Sangyé Gyeltsen to ritually prepare the ground at a site where he intended to build a temple. So Sangyé Gyeltsen adorned himself with intestines from a human corpse, worn like jewelry. He smeared his body with blood and danced around. Shortly after this Sangyé Gyeltsen went to a marketplace and ran about, holding molasses in his right hand and human feces in his left, eating them both. He urinated everywhere. The people were shocked by this unfathomable behavior. Some became faithful in Sangyé Gyeltsen and started to call him “the 'Hero' (ḍakka) of Tsari.”

One night Sangyé Gyeltsen had a vision of the wrathful tantric deity Hevajra, accompanied by his retinue. The deity gave Sangyé Gyeltsen four tantric initiations and the name "King of the Blood Drinkers" (khrag 'thung rgyal po). The next morning Sangyé Gyeltsen left his retreat and found the corpse of one who had died of smallpox ( 'brug nag). Sangyé Gyeltsen ate some of the flesh and the brains, and distributed bits to everyone there as a blessing. It is said that from this time onward Sangyé Gyeltsen was completely free from misunderstanding or grasping; saṃsāra and nirvāṇa became one 
and the same thing to him; he achieved the five types of wisdom; and the knots in his yogic channels came undone. Sangyé Gyeltsen continued to perform shocking behavior in the Tsari area. Once he went into a crowd of people naked, covered in ashes and blood, wearing intestines as a necklace, with the fingers and toes of a corpse tied into his hair. He did all manner of uncouth behavior. Around this time people started to call him "the Madman of Tsang." He meditated in frightening places, like charnel grounds and along the banks of rivers.

The Madman of Tsang traveled to Lhasa dressed in the gruesome garb of the Heruka, which frightened people. Some shouted, "A demon has arrived!" and ran from the streets. The next day some monks who had known Sangyé Gyeltsen from his days in the Pel Korlo Chödé recognized him. They invited him to an assembly at the palace of the local lord. There the Madman of Tsang argued with some scholar-monks from Sera and Drepung monasteries about the validity of his odd manner of dress and behavior. The Madman of Tsang argued that it was all based on the tantric scriptures, and the example of the great siddhas of the past.

From Lhasa the Madman of Tsang traveled to his home village in Tsang. His mother requested that he return to the monastic college in Gyantsé. If he would not do that, she begged him to at least change his clothes, reasoning that people might see him as a demon and try to kill him. The Madman of Tsang handed over to his mother his skull cup and the human skin he used as a cloak.

On his way to Chubar in southwestern Tibet, near the border with Nepal, the Madman of Tsang continued to perform his gruesome asceticism. He went amid a crowd of people, smeared with the ashes of a corpse, wearing intestines like bangles and a 
necklace. He leapt about, sang and danced, chased the men and the women with inappropriate gestures and remarks. He consumed human feces and urine and threw them at people. They were shocked and horrified.

The next period of the Madman of Tsang's life would be spent in southwestern Tibet. He meditated at sites that were considered holy because of their past associations with the yogi Milarepa, like Lapchi, Chubar and Kangtsuk Puk. He was received by many local lords, who gave him offerings and faithfully honored him. Throughout his stay in the area the Madman of Tsang had ongoing contacts with the rulers of Ngari Gungtang and Tsamda (tsha ' $\left.d a^{\prime}\right)$.

During this period the Madman of Tsang went to Mount Kailash, and made his first of three visits to Kathmandu in central Nepal, where he visited the Swayambhūnāth stüpa as a simple pilgrim and meditator. (As we will see below, the Madman of Tsang would return to this monument two more times, sponsoring the stüpa's being whitewashed, and then renovated. The increasing means at the Madman of Tsang's disposal on these three occasions serve as an index of his rise to prominence.)

The Madman of Tsang and his disciples traveled to Lowo Möntang. It was a time of fighting, and the heads of many people from Gugé who had been killed by the Lowo faction were being displayed on stakes. The Madman of Tsang took some of the brains that were dripping out of one of those heads and ate them. He promised the many people gathered there that if they ate some of the brains they would gain magical favors (siddhi). Those who ate the brains are said to have become prosperous.

While traveling to the kingdom of Ngari Gungtang the Madman of Tsang met up with a yogi who was known as "the Lama from [Densa] Tel" (bla ma thel pa), who would 
later come to be known as the Madman of Ü. Having arrived at the capital, the Madman of Tsang stole into the king of Gungtang's chambers and woke him in his sleep. The king, queen and princess were all terrified, but soon saw the Madman of Tsang's spiritual worth. The Madman of Tsang stayed there for some time as a guest of the king. When the Lama from Densa Tel arrived at the gate to his home, the king refused to let him in and had him beaten. The Madman of Tsang interceded, telling the king that it was not appropriate to treat a renunciant in such a way. The king finally received the Lama from Densa Tel as well. Soon thereafter that yogi would become renowned as the Madman of Ü. The Madmen of $\ddot{U}$ and Tsang would have a tenuous relationship for some years. Their relationship would dissolve completely after their disciples got into a fight and people on both sides were killed.

While traveling through the area of Milarepa's birth the Madman of Tsang visited a small temple housing a relic of the great yogi. The temple keeper asked the Madman of Tsang to compose a supplicatory biography (rnam thar gsol 'debs) to Milarepa, which he did. A little later he had a footprint left in solid rock by Milarepa at Rechen Puk covered with gold. During this period the Madman of Tsang began writing texts about the Aural Transmission (snyan rgyud).

One time the Madman of Tsang arrived in a place where many people had died from an epidemic, so he and two of his disciples performed rituals to subdue the evil spirits who were responsible for the calamity.

Throughout this period the Madman of Tsang meditated and instructed his disciples. He was constantly acquiring new followers as people heard of him and were moved by faith to come to into his presence. For example, a very learned scholar-monk 
from Shalu Monastery at one point heard about the Madman of Tsang's miraculous abilities, went before him and became one of his realized disciples. Among the Madman of Tsang's disciples, at least twenty-eight of them regularly wore the same gruesome Heruka garb as their master. He sent some of his more advanced disciples to meditate on their own in other important sites in the region, like Mount Kailash and Lapchi.

After spending some years in southwestern Tibet, the Madman of Tsang set off on a trip to Tsari in south central Tibet, where his religious life had started in earnest years earlier. He stopped to visit his mother in Karka along the way (this was his third of at least six such visits). He went by way of Rong, Chushül, and Lhasa. Lhasa at the time was experiencing a drought. Some pleaded with the Madman of Tsang to make it rain. He asked one woman what her name was. She told him it was "Sky," which was a good sign. Some people doubted he could make rain fall from a cloudless sky and called him a fake yogi. That very night it rained. The people of Lhasa were relieved of their suffering and became faithful in the Madman of Tsang. He stopped to practice at some caves near Nedong, capital of the Pakmodru regime. He was invited by the queen of the gongma, head of the Pakmodru regime and the titular ruler of central Tibet. He gave the queen a blessing and some prophecies about the future of her family.

From there the Madman of Tsang visited his old patron, Tashi Dargyé, the provincial regent of Ja. Tashi Dargyé again offered to provide for the Madman of Tsang's upkeep, this time having to take into account his disciples as well. Laborers were conscripted into carrying these goods. There was a heated exchange as some of the laborers refused to carry the Madman of Tsang's things. Tempers escalated. They threw 
rocks at the Madman of Tsang, but neither he nor his distinctive bone ornaments were harmed.

After arriving at Tsari, the Madman of Tsang stayed at various holy sites, meditating and instructing his disciples in the highest forms of tantric practice. He continued to work on texts explicating the Aural Transmission.

The Madman of Tsang then went back to southwestern Tibet, stopping to visit his mother along the way. The Madman of Tsang also visited various patrons, and monasteries where he gave teachings and sometimes acquired new disciples. Many of the Madman of Tsang's exchanges with lay patrons throughout his career are recorded in versified poems, as he addressed their questions and concerns.

In southern Latö the Madman of Tsang visited Shriri Samten Ling monastery (shri ri bsam gtan gling). The abbot (mkhan po) held a great feast, and invited the Madman of Tsang to take over the monastery. The abbot had grown old and he felt there to be no greater upholder of the Kagyü teachings than the Madman of Tsang. The Madman of Tsang demurred, saying that he intended to continue living as a wandering ascetic, as he had been instructed to do by his guru, Shara Rabjampa.

The Madman of Tsang and his disciples spent the winter staying in various caves near Lapchi. It was around this that the Madman of Tsang got the idea to compile or compose versions of the Life and Collected Songs of Milarepa, and then have them massprinted. The first step was to send his disciples to various places in search of existing songs by and narratives about Milarepa, as well as assembling carvers to make the woodblocks for printing. When they all returned the Madman of Tsang got to work creating his versions of the texts. When the woodblocks bearing the imprint of the text 
were finally finished and copies of the text made, copies were sent all over Tibet. The printing project was completed in 1488; the Madman of Tsang was about thirty-six years old.

During this time the Madman of Tsang met Küntu Zangmo, the woman who would become his consort. Küntu Zangmo was the daughter of a minor lord. She had been married to a tantric ritualist. When he died Küntu Zangmo ran off to become a nun. She heard that the Madman of Tsang was in the region and went to see him. She gave him some offerings and he readily accepted her as a disciple. He gave her high-level tantric empowerments. It is difficult to say exactly what their relationship was like, but she would be mentioned from time to time in the events of the rest of the Madman of Tsang's life. After the Madman of Tsang's death Küntu Zangmo would attend the three month prayer ceremony held at Chubar. She would also sponsor the compiling of his Collected Songs, and the printing of the first version of his biography.

The Madman of Tsang and his disciples then traveled to Lowo Möntang. They were immediately invited to the palace of the king. There the Madman of Tsang engaged representatives of other religious groups in debate about the nature of worldly phenomena. During a great reception the Madman of Tsang was given more than a dozen cups of chang as a test, but he did not become intoxicated. Before leaving Lowo Möntang the Madman of Tsang was given extensive gifts of gold, copper and so on from the king, his ministers and subjects.

The Madman of Tsang set off for central Tibet. Along the way he was given some bad food, which, it turned out, had been offered by a lord of Nyanang (gnya' nang). There were suspicions of poisoning. The Madman of Tsang stopped off to again visit his 
mother. He was invited to Rinpung by Dönyö Dorjé, the warlord of the Rinpung family who was at this time consolidating his control over central Tibet. Dönyö Dorjé was impressed by the Madman of Tsang's having created his versions of the Life and Songs of Milarepa. This would develop into an important patron-priest relationship lasting until the end of the Madman of Tsang's life.

The Madman of Tsang went to Lapchi in southwestern Tibet to spend three years meditating. During this time the Madman of Tsang composed or compiled a number of texts relating to the Aural Transmission teachings that explicated the practices of the Cakrasamvara tantra. Around this time the Madman of Tsang heard that the abbot of Dingri Langkor Monastery was regularly denouncing him as a fake and a deluder of beings. Some of the Madman of Tsang's disciples wanted to retaliate, but the Madman of Tsang convinced them that there was no need. It is said that that evil abbot died a horrific death shortly after this.

The Madman of Tsang returned to central Tibet and visited his mother, then saw the warlord Dönyö Dorjé, who gave him gifts of gold, silver and silk. In return the Madman of Tsang gave Dharma teachings to the lord, his ministers and some citizens.

The Madman of Tsang then set out on his second journey to the Kathmandu valley, this time with the intention of whitewashing the Swayambhūnāth stūpa. On the way the Madman of Tsang stopped at the capital of Ngari Gungtang, where he stayed for a month and a half. He gave the royal family tantric empowerments and Dharma teachings, while continuing to write texts about the Aural Transmission.

After descending into Nepal the Madman of Tsang met some people who had taken possession of a woman and her three children with the intention of selling them off 
as slaves. It is said that although the Madman of Tsang regarded all phenomena in nondual manner, he was overcome with compassion for these people. So he purchased them from their captors with gold. He clothed and fed the family, then set them free.

While staying at the Swayambhūnāth stūpa the Madman of Tsang was visited in the middle of the night by Ganesh and other divine figures, who asked him to renovate the stūpa. The Madman of Tsang would return to Nepal to undertake this project some years later. This time the Madman of Tsang paid to have the stūpa whitewashed. Before leaving Kathmandu a great reception was held in his honor by the local kings and their ministers. He returned to Tibet via Gungtang, where he again taught the Dharma to the royal family.

After this the Madman of Tsang and his disciples set out on pilgrimage to Mount Kailash, stopping at Lowo Möntang along the way. The Madman of Tsang was received at a formal assembly of about four hundred people, including the king and his retinue, secretaries, scholar-monks, artisans, and so on. Some learned ones questioned the Madman of Tsang on points of philosophy, the tantric view and art. He won everyone over with his brilliance.

When the Madman of Tsang arrived at the Mount Kailash area he was welcomed with a big reception by some of his students who were there meditating. He visited many of the caves is the region. In the process he gave many displays of his clairvoyance, knowing other peoples' thoughts before they even voiced them. The Madman of Tsang distributed payments to his disciples so they could support themselves in meditative retreats. In the winter he gave extensive tantric initiations and instructions. The Madman of Tsang was visited by faithful nomads, who gave him yaks, goats and sheep. 
This was a time of fighting in western Tibet, between the minor kingdoms of Purang and Lowo Möntang. Much blood had been shed on both sides. Both factions requested that the Madman of Tsang try to mediate in the conflict. The Madman of Tsang, filled with compassion, took up this challenge. It was a difficult task, as both sides continued to wrong one another. The Madman of Tsang became frustrated by their refusal to listen to him. When he left to go into meditative retreat, open fighting broke out again. He spent more than a year trying to find a solution to the problem. Eventually Purang defeated Lowo and order was restored. Mount Kailash once again became a protected site for religious activity. Each year provisions were sent from Purang to the Madman of Tsang and his followers.

During this time one of the Madman of Tsang's disciples asked for permission to go to Tsari to meditate. The Madman of Tsang composed a letter of safe passage (lam yig), that would ensure he was protected and cared for by the various lords with whom he had connections. It seems other disciples of the Madman of Tsang were also given copies of this letter, as it became quite well known.

The Madman of Tsang again visited Lowo Möntang, where he attended another formal reception. The Madman of Tsang was given the secondary position in terms of respect, seated on a cushion slightly lower than that of a Nyingma lama. The Madman of Tsang challenged this lama on questions of the proper proportions for drawing an image of Vajradhāra (they were in the process of constructing a new temple at the time), and tantric doctrine. The Nyingma lama could not respond to the challenge and the Madman of Tsang said it was ridiculous that he should be given a position lower than that of one who knows so little. The Madman of Tsang gave a long excurses on various matters, 
which amazed everyone. He was seen off by the king, ministers and subjects of Lowo, who made offerings and paid their respects.

The Madman of Tsang and his disciples traveled in the southern Latö area, gathering from the faithful offerings of gold, turquoise, copper, meat, butter, barley and felt. Then the Madman of Tsang made a vow to stay for three years in meditation at Chubar, one of his favored haunts.

During this time the Madman of Tsang thought about establishing a stronger presence for his tradition at Mount Kailash. In order to establish a more formal meditation center there, the Madman of Tsang petitioned the rulers of Lowo, Gugé and so on for materials and provisions, and the Rinpung regime for official permission. The center was established and became a node for the spread of the teachings. The Madman of Tsang continued to write texts that would go into his compendium of the Aural Transmission.

Lhatsün Rinchen Namgyel, the son of the king of Gungtang, who had finished his studies in the Geluk system at Tashi Lhünpo, came to the Madman of Tsang to practice his particular form of Buddhism. In time Lhatsün Rinchen Namgyel would become a prolific writer and publisher of Kagyü texts.

Two years into his retreat at Chubar, the Madman of Tsang received word that his mother had died. He vowed to do three years of practice on her behalf.

One winter during this time the Madman of Tsang sent some of his disciples on pilgrimage to the Swayambhūnāth stūpa in Nepal while he stayed in retreat. When they returned he found out that there had been some unpleasantness between them and some of the Madman of Ü's disciples. Harsh words were exchanged and, fueled by alcohol, 
there was a fight, with members of both sides getting killed. This was followed by more retaliatory killings. The Madman of Tsang was very saddened by this.

Around this time the Madman of Tsang decided to take on the task of overseeing the renovation of the Swayambhūnāth stūpa. He had been receiving requests to do so for some time. He sent his disciples to various patrons with letters asking for support. When enough funding and materials had been gathered, the Madman of Tsang departed for Nepal. The Madman of Tsang oversaw the artisans and conscripted laborers working on the project, and performed the important ritual function of making sure everything went smoothly. The project took two months. When everything was finished, the Madman of Tsang returned to Tibet, more famous than ever.

For the next three years the Madman of Tsang would alternate, spending summers in Onjung ('o 'byung) and winters in Chubar. He used some of his resources to put finishing touches on the Swayambhūnāth stūpa and to make woodblocks for the printing of Marpa's Life Story and Collected Songs. He tried to have his compendium of the Aural Transmission written in gold, but the circumstances did not come together to make this possible, so a less ornate version was made.

It started to become clear that the Madman of Tsang's time of death was approaching. He began a journey to central Tibet, being honored at many places along the way. He stopped briefly at Rechung Puk, then circled into Tsang, making stops at Rinpung and Shang, where he visited with the warlord and his long-time patron, Dönyö Dorjé of the Rinpung family. He spent more time with Dönyö Dorjé at Shigatsé. The Madman of Tsang visited his natal village of Karka, where he visited his mother's remains. After this he visited Dönyö Dorjé in Lhasa and Chushül. 
The Madman of Tsang's health worsened. He stayed at Zalmo cave (zal mo brag), where five hundred religious practitioners came to receive teachings from him. Some of the Madman of Tsang's followers suggest he go into meditative retreat instead of teaching, in order to prolong his life. But the Madman of Tsang was resigned to the inevitability of his death and chose to continue teaching. His disciples and patrons continued to gather there and pray for his life; day and night they circumambulated and prostrated to the place where he stayed, making prayers to come into his presence again in some future lifetime. During this time the Madman of Tsang received an invitation from the emperor of the Pakmodru regime but declined it.

The Madman of Tsang then went to Rechung Puk, where he had visited once before. He entered into meditative retreat, not meeting with anyone for ten days. Then he instructed all of his students to come there. He instructed one of his disciples to take responsibility for the well-being of his community of followers after his death. He made proclamations about the future of that community and encouraged his disciples to practice in the manner of Milarepa. He passed away on the 15 th day of the 5 th month of 1507. In the Tibetan manner of counting, he was 56 years old.

Forty of the Madman of Tsang's disciples carried out the cremation rites. The whole are around Rechung Puk is said to have been filled with butter lamps that people had piously offered; it was like the stars had fallen to earth. 2,500 were people on hand when the cremation chamber was opened a week later. Bits of the Madman of Tsang's bone, hair, ash, and pearl-like relics, along with his various possessions, were distributed to his disciples. 
Tea ceremonies were sponsored at many different monastic assemblies. At Rechung Puk there was a feast for 824 religious practitioners. Some of the Madman of Tsang's close disciples went to Tsari and held a feast there for 1,500 people. Offerings rolled in from the Madman of Tsang's many patrons. A statue of the Madman of Tsang was constructed at Rechung Puk. At a mountain retreat near Chubar a three-month memorial prayer service was held, attended by Dönyö Dorjé, other government ministers, and commoners. Services were also held at Lapchi. Relics of the Madman of Tsang were installed at these places. Statues of the Madman of Tsang were made, along with those depicting other famous members of the Kagyü sect, like Vajradhāra, Marpa and Milarepa. Virtuous offerings were made in many places in honor of the Madman of Tsang. Some made vows to go into retreat for one or three or six years, perhaps the most fitting way of honoring the memory of the great saint. 


\section{Chapter 3: Mad Behavior, Tantric Fundamentalism}

In that way [Künga Zangpo] had made himself destitute of food and clothing. He had expelled from his mind all concern for his future livelihood in this world of appearances, casting such thoughts to the wind by submitting himself to inconceivable hardships. And so-like the king of noble lords, Mila Laughing Vajra - he composed himself single-pointedly in meditative absorptions and yogas of the [Generation and Perfection] Stages, and thereby attained mastery in all the good qualities of direct realization.

At that time when he had become a great supreme siddha, never to return to this world after death, the Great One gradually received prophetic assurances (lung bstan dbugs dbyung) from his guru and the dākinis s, and so thought, "My mental continuum is ripened and liberated, and so whatever I do is just as well. However, in accordance with the assurances given by my guru and the $d \bar{a} k i n \bar{i} \mathrm{~s}, \mathrm{I}$ should give up the indicators and dress of monkhood ( $r a b$ tu byung ba) and take on the emblems of a Heruka (he ru ka'i chas). Having made myself embody (mtshams sbyar) the Activity (spyod pa) of the yogas of the [Generation and Perfection] Stages, which are derived from the short path of the Vajrayāna, the swift path of the definitive secret of the $d \bar{a} k i n \bar{\imath}$, I will show the enhancement practice that utilizes other peoples' perceptions (? gzhan snang thabs kyi cha' $i$ bogs dbyung $b a$ ), and the manner of traversing the stages of the Grounds and Paths as easily as if they were mere illusions. In one life and one body I should make manifest the Body of the all-pervading lord Vajradhāra."

Then, for the sake of overpowering all of phenomenal existence with his glory; for the sake of taming spirit beings and all the enemies and obstacles to the Teachings; for the sake of assisting all worthy beings without exception and setting them on the ground of accomplishment; for the sake of pronouncing the greatness of the Vajrayāna, and drawing out the profound distinguishing features of its essential meaning; for the sake of fulfilling the intentions of the dākas and dākinis of the three realms; for the sake of emanating Samantabhadra heaps of offerings for the Lord and his Sons; for the sake of spreading and increasing the presence of the Teachings of the Lord in general, but especially for the sake of initiating a tradition dedicated to the definitive meaning of the precious Kagyü[all] by means of Activity (spyod pa) - [Künga Zangpo] laid down the indicators and dress of monkhood before an image of the Lord of Sages and took on the emblems of glorious Blood Drinking Heruka.

Upon his naked body he was adorned with a crown of matted hair, as well as hoops, earrings, a necklace, bangles and a girdle, all made of bone- the Six Bone Ornaments. He was adorned with clumps of ash, drops of blood, and smears of grease from a human corpse. As an upper garment he wore a human 
skin, with hair and nails attached; for a lower garment he wore a tiger's hide. He wore a brahmin's string made of human hair. He took up a damaru made of sengdeng wood, or a hand drum made from the tops of skulls; a trumpet made of bone; a kapāla [skull cup] that bore special qualities, fissured and yellowed. He had a vajra, a bell, a "sky-staff" or khatvāinga that was decorated with bells, strips of silk, and so on-all of which were associated with special oaths. Thus he was adorned with the Six Emblems of Heruka or the Eight Emblems of the Great Glorious One.

For these commitments [Künga Zangpo] relied on such volumes as the root text of the Hevajra Tantra, the condensed Cakrasamvara tantra, the Dohā Trilogy, and the like. For his appearance he relied on the forms of Hevajra, Cakrasamvara, the glorious four-faced vitality-sapping Mahākāla, and so on. ..... ${ }^{106}$ Additionally, he held a sword that symbolized wisdom, a bow and arrow that symbolized wisdom and means, and so on. In that way, he took on all the emblems of the charnel ground... 107

\section{I. Introduction}

This passage from the biography of Künga Zangpo describes a key moment in the yogi's life, when he exchanged his monk's robes for the fearsome dress of a Heruka. This signaled his transition into a lifestyle defined by the more eccentric forms of behavior that would earn him the title "the Madman of Ü."

The purpose of this chapter is to describe the odd behavior of the Madman of $\ddot{U}$ and the Madman of Tsang based on what we know about their lives, drawn primarily

\footnotetext{
${ }^{106}$ The Life of the Madman of $\ddot{U}$, published in Vol. 2 of bka' brgyud pa hagiographies: a collection of rnam thar of the eminent masters of Tibetan Buddhism, compiled and edited by khams sprul don brgyud nyi ma (Palampur, Himachal Pradesh, India: Sungrab Nyamso Gyunphel Parkhang, Tibetan Craft Community, 1972). All references to The Life of the Madman of $\ddot{U}$ are from the 1972 printing, unless otherwise noted. I will make only a few references to the manuscript and 1973 printing. As for The Life of the Madman of Tsang, I will make reference to all three versions, and will therefore specify which one I am citing: that by Ngödrup Pelbar, Lhatsün Rinchen Namgyel, or Götsang Repa.

In this quotation I have omitted a short line that neither I nor any of the Tibetans I consulted were able to make definitive sense of: dam tshig gi rdzas gza' bsrungs la sogs pa bsten par mdzad..., pp 439.6440.1. The manuscript reads: dam tshig gi bza' bsrungs la sogs pa bsten par mdzad..., p 19b5. The 1973 version reads: dam tshig gi rdzas bza' bsrung la sogs pa rten pa mdzad..., p 490.2-.3. The passage describes some aspect of the behavior taken on by the yogi and what it was based on. Does it say that his adoption of samāya-bound belongings were in some way connected to a protector deity, such as Rāhula? What the yogi would eat and drink (substituting bza' btung for bza' bsrungs)?

${ }^{107}$ This passage runs pp 436.6-440.2.
} 
from their biographies. What was their crazy behavior like? How did it fit into their lives? What was the motivation behind it? How might it have been an aspect of Buddhist praxis? In this chapter we will address only the Madmen of Ü and Tsang, whose lives and distinctive behavior followed a very similar pattern. Some other ascetics who followed a similar lifestyle will be discussed in Chapters Four and Seven; Drukpa Künlé, the Madman of the Drukpa, will be discussed in Chapter Five, as the trajectory of his life and his eccentric behavior are quite different from those of his two peers.

\section{II. Eccentric Behavior, Engaged Asceticism}

An important first step towards understanding what was unique about the behavior of the Madmen of $\ddot{U}$ and Tsang is to take note of the fact that many of the supernatural and eccentric things they are portrayed as having done were relatively conventional as far as biographies of Tibetan saints go. At times in their life stories the Madmen of Ü and Tsang are said to have done such miraculous things as walk across rivers, fly through the air, carry heavy things (like a rock the size of a yak), go fearlessly among wild beasts of prey, make water miraculously appear, as well as emanate multiple bodies at the same time or make their bodies disappear. ${ }^{108}$ The Madmen of Ü and Tsang are both attributed with having been able to generate such great yogic heat with their

\footnotetext{
${ }^{108}$ Crossing rivers: Götsang Repa, p 43.1-.2, when the Madman of Tsang crossed a river while seated in a lotus posture, using his khatvāmga staff as an oar; The Life of the Madman of $\ddot{U}$, pp 402.6, 474.6-475.3, 484.3-.4, 485.6-486.4, 502.6-503.2.

Flying: Götsang Repa, pp 71.6, 72.3-.4, 132.7-133.1; The Life of the Madman of Ü, p 427.1-.6. 589.3. Carrying heavy things: Götsang Repa, pp 118.6-119.1; The Life of the Madman of $\ddot{U}$, pp 431.4,

Going among wild animals: Lhatsün Rinchen Namgyel, pp 27.5-28.3; The Life of the Madman of $\ddot{U}$, pp 402.6, 496.1-.5.

Making water appear: Götsang Repa, pp 99.4-100.1, and 134.2-.3, when the Madman of Tsang makes it rain in a place that was facing a drought; The Life of the Madman of Ü, p 501.2-.4.

Emanating multiple bodies: Lhatsün Rinchen Namgyel, p 124; The Life of the Madman of Ü, pp 426.2-.427.6, 486.4-487.1, 579.2-.4.

Disappearing: Götsang Repa, p 109.1-.2; The Life of the Madman of $\ddot{U}$, pp 426.2-.4, 551.2-552.1.
} 
bodies that the snow around them would melt. ${ }^{109}$ The biographies of the Madmen of $\ddot{U}$ and Tsang are filled with depictions of violence and both yogis are said to have withstood ferocious attacks from skeptics: there were kings' guardsmen and angry villagers wielding swords, axes and poison arrows, and the ubiquitous "rain of stones." But no matter how severe these attacks were — at times so severe that everyone who had witnessed them was certain the yogi had died — the Madmen of $\ddot{U}$ and Tsang are always said to quickly reappear without bearing even a scratch. These abilities — being able to withstand physical peril thanks to the strength of one's meditation ${ }^{110}$; to heal one's gross body by exercising the subtle, yogic body; the ability to fly; and to generate enough bodily warmth to easily endure Tibetan winters wearing nothing more than a loin clothare intended to be indicators of the saint's realization and meditative prowess. These displays of the siddhis or worldly superpowers achieved by the yogi while on the path to liberation serve as milestones indicating his level of accomplishment, but they are not the final goal. These supernatural abilities are commonly attributed to Indian and Tibetan yogis and therefore do not lead us to an understanding of what was unique about these "holy madmen." In order to identify what was unique about the Madmen of Ü and Tsang we must focus on the more distinctive forms of behavior that led to their becoming famous as grub thob smyon pa, "mad siddhas," holy madmen.

As for their more distinctive behavior, the Madmen of $\ddot{U}$ and Tsang are many times said to have walked directly into the presence of a powerful lord, taken the drink from his hand and done the unthinkable thing of slapping him in the face. At times they

\footnotetext{
${ }^{109}$ Götsang Repa, p 109.3-.4; The Life of the Madman of $\ddot{U}$, p 579.1-.2.

${ }^{110}$ Götsang Repa, pp 39.4-40.5, when people are attacking the Madman of Tsang with swords and weapons, but cannot hurt him because of the meditative state (ting nge ' $d z$ in) he is in; also on pp 30.6-31.4, 42.3-43.1, 63.4-64.1; The Life of the Madman of $\ddot{U}$, pp 568.1-569.1, 588.6-589.2.
} 
did obscene things among crowds of people, like when the Madman of Tsang went into the marketplace and climbed on all the women and chased the men, saying "Screw me!", while throwing urine and excrement at everyone, and even eating it himself. ${ }^{111}$ Most significant of all, the Madmen of Ü and Tsang both spent much of their lives traveling around Tibet smeared with ashes and blood, wearing ornaments made of bone, carrying a bowl made from a human skull and an ornate staff. Their appearance was so gruesome and unexpected that people sometimes exclaimed that they were demons. But despite the immediate strangeness of this behavior it was neither random nor meaningless; it is all consistently explained as part of a directed religious regimen, as we will shortly see.

Before discussing the sorts of Buddhist practice that impelled the Künga Zangpo and Sangyé Gyeltsen to act in this way, we should address the notion that perhaps they were genuinely mentally unstable individuals. Early in his biography there is some suggestion that Künga Zangpo (later to become the Madman of Ü), was by nature somewhat eccentric. From a young age he did not get along with the other children. ${ }^{112}$ As a teenager he performed magical feats, like walking across rivers and flying from treetop to treetop, which caused his teacher to scold him for running about so wildly, saying, "You are like a madman (smyon pa), not practicing religion, going about wherever!" "113 A similar thing is said about the future Madman of Tsang. When Sangyé Gyeltsen was in his late teens and before he had taken on a decidedly eccentric lifestyle, we are told that his meditative realization gave him the ability to magically travel to the twenty-four holy sites and famous charnel grounds of India, which were so important in

\footnotetext{
${ }^{111}$ Götsang Repa, p 48.3-.7. This passage will be given in full later in the chapter.

${ }_{112}^{112}$ The Life of the Madman of $\ddot{U}$, pp 390.6-.391.4.

${ }^{113}$ khyod dge sbyor mi byed par smyon pa bzhin gang du 'gro yin yod pa yin/, The Life of the Madman of $\ddot{U}, \mathrm{p}$ 403.2.
} 
the mythology of his lineage. Because of his going on these magical journeys, on some occasions when his guru was giving teachings Sangyé Gyeltsen was nowhere to be found. Later when his dharma brothers asked where he had been, he told them he had been at the holy lands of Oḍḍiyāṇa, Jālandara, and so on. Because of this his dharma brothers said, "He seems crazy!"

Considered in the fuller context of their biographies, these occasions do not read like indications that Künga Zangpo or Sangyé Gyeltsen were by nature mentally unwell individuals. On the contrary the authors of these biographies are foreshadowing the fact that these youngsters will later become famous as "holy madmen," and establishing an interpretive framework for how that "madness" should be understood. When madness is explicitly mentioned before Künga Zangpo and Sangyé Gyeltsen would begin to regularly engage in the eccentric behavior that would make them famous as "madmen," the authors are trying to express that it is their deep connection with religion that puts them at odds with the world. As teenagers, it is their having obtained the ability to perform miracles that gets Künga Zangpo and Sangyé Gyeltsen called "mad” by others. When the other children made fun of the adolescent Künga Zangpo, literally saying, "He doesn't get along with anyone, so let's call him, 'Nobody Likes Him!”, what this shows - the author is sure to tell us - is that the boy had developed such strong renunciation that his was to be a life dedicated to practicing the Dharma, rather than participating in the self-perpetuating social and familial cycles of samsāra, and for this

${ }^{114}$ la las ni smyo yong ba 'dra zer ba byung/, Götsang Repa, p 24.4. 
reason he did not get along with ordinary people. ${ }^{115}$ In this way Künga Zangpo and Sangyé Gyeltsen's early eccentricity is established as being a byproduct of their dedication to and accomplishment in religion — not some mundane form of mental unwellness.

The notion that the yogi's "madness" is a byproduct of his success in the practice of Buddhism is virtually always present in discussions of the eccentricity of the Madmen of Ü and Tsang, throughout their biographies and elsewhere. As we saw in Chapter One, this is the primary mode through which Tibetans interpret the holy madmen's eccentric behavior. It has also played a large role in shaping how non-Tibetan commentators have sought to explain the tradition. But in direct tension with this is the fact that in the course of their biographies the eccentric behavior of the Madmen of $\ddot{U}$ and Tsang is consistently portrayed as part of a purposeful, ordered spiritual regimen, as will be clear in the ensuing pages. We will return to discuss the tension between portraying the Madmen of Ü and Tsang's eccentric behavior as practice or as a post facto indication of their enlightenment at the end of this chapter.

\section{II.1 Engaged Asceticism in the Lives of the Madmen of Ü and Tsang}

Contrary to the suggestion that the "holy madmen" may have been mentally unbalanced individuals, according to his biography, the name "the Madman from Ü" "became renowned (grags) in and pervaded every direction" not because of quirks in the yogi's personality or his performing feats of magic, but because of his taking up a brand of tantric practice that, although uncommon, was ultimately based on prescriptions given

\footnotetext{
115 'di ni su dang yang mi mthun pas/ su mi 'dod du thogs zer ro/, The Life of the Madman of Ü, p 391.1-
} 4 . 
by canonical Buddhist texts. ${ }^{116}$ The Madman of Ü's seeming eccentricity was an outcome of his consistently and purposefully engaging in a specific form of tantric practice - a form of tantric practice that happened to dictate that the yogi should be defiant in the face of authority, behave in ways that provoked people to beat him, dress like a blood-drinking deity and literally embrace the cult of the macabre. The same holds for the Madman of Tsang. Let us now explore this defining aspect of the Madmen of $\ddot{U}$ and Tsang's identities.

The eccentric and sometimes shocking behavior engaged in by the Madmen of $\ddot{U}$ and Tsang was part of a constellation of advanced tantric practices most often described under the rubric of brtul zhugs spyod pa. ${ }^{117}$ Literally, the term means "the performance of taming-engagement" and has been variously translated into English as "deliberate behavior"118 and "practice of spiritual discipline."119 Tibetans gloss the essential part of the term, brtul zhugs, in a few slightly varying ways. Broken into its parts, it means "taming" (brtul) and "entering" (zhugs). The 4th Red Hat Karmapa, Chödrak Yeshé

\footnotetext{
${ }^{116}$ The Life of the Madman of $\ddot{U}, \mathrm{p}$ 443.3-.4.

${ }^{117}$ Also rendered as brtul zhugs kyi spyod pa. This term is sometimes written as brtul shugs. This is the case in Sangyé Darpo's History of the Kagyü: Accumulation of the Brilliant Light of a Heap of Jewels (bka' brgyud chos 'byung rin po che spungs pa' $i$ 'od stong 'khyil or bde gshegs bstan pa'i gsal byed bka' rgyud chos kyi 'byung gnas rin po che spungs pa'i 'od stong 'khyil ba), more commonly referred to as Sangyé Darpo's History (sangs rgyas dar po chos 'byung) (unpublished block print; available from NGMPP; hard copy lent to me by Tashi Tsering of Dharamsala), pp 120 (60b), 158 (79b), 171 (86a). In this same text the term is occasionally spelled rtul shugs, pp 146 (73b), 159 (75b). The term is also spelled brtul shugs in Mardo's translation of The Cakrasamvara Tantra, cited on p 281 in David B. Gray, The Cakrasamvara Tantra (The Discourse of Śrī Heruka) (Śrīherukäbhidhāna): A Study and Annotated Translation (New York: The American Institute of Buddhist Studies, Columbia University Press, 2007).

${ }^{118}$ Cyrus Stearns, translator, King of the Empty Plain: The Tibetan Iron-Bridge Builder Tangtong Gyalpo (Ithaca: Snow Lion, 2007), p 59.

${ }^{119}$ Christian K. Wedemeyer, Äryadeva's Lamp that Integrates the Practices (Caryāmelāpakapradīpa): The Gradual Path of Vajrayāna Buddhism According to the Esoteric Community Noble Tradition (New York: The American Institute of Buddhist Studies, Columbia University Press, 2007), p 742; R. A. Stein translates it into French as "conduite exceptionnelle" in Vie et chants de "brug-pa kun-legs le yogin, p 320; Geoffrey Samuel discusses brtul zhugs spyod pa in Civilized Shamans, pp 306-307, but does not offer a translation of the term, instead giving only a phoneticization of the Tibetan, tulshug chödpa.
} 
(1453-1524), glosses brtul zhugs as meaning that one intends to tame afflictive emotions and conceptual formations and enter into the potency of the wisdom that is their antidote. ${ }^{120}$ The term can be interpreted as "taming worldly activity and entering into the activity of the buddhas" or the less specific "taming bad activity and entering into perfect activity." 21 Or, less specific yet, "taming or ending ordinary purposeless activity of doing whatever one wants, and entering into a state of doing distinctive activity." ${ }^{122}$ Brtul zhugs is frequently used to translate the Sanskrit term vrata, which means vow or observance; brtul zhugs spyod pa is used to translate vratacary $\bar{a}$. Much more will be said about the earlier Indian usages of these terms below, as they figure into this conversation in an important way. Throughout this dissertation I will translate brtul zhugs spyod pa as "engaged asceticism."

Brtul zhugs is a difficult term to define because it can be used to refer to asceticism in a general way or to a very specific form of asceticism. For example, in the text of The Life of the Madman of $\ddot{U}$, brtul zhugs is sometimes used in its more general sense to mean a basic form of asceticism or a directed way of life: when Künga Zangpo took his formal monastic ordination it is said that he "properly took up the lifestyle (brtul

\footnotetext{
${ }^{120}$ dam chos dgongs pa gcig pa'i gsal byed: A detailed explanation of the 'Bri-gun Bka'-brgyud Dgonis gcig teaching, reproduced from a copy of ancient manuscripts from the Library of Yudra Rinpoche (Bir: pubilished by D. Tsondu Senghe, the Bir Tibetan Society, 1992). spang bya nyon mongs dang rnam rtog brtul nas/ gnyen po ye shes kyi stobs la zhugs pa..., p 64.

${ }^{121}$ This is from Stearns 2007, citing an explanation given to him by Dezhung Rinpoché, p 60; the actual Tibetan for this reads: 'jig rten gyi spyod pa brtul/ sangs rgyas kyi spyod pa la zhugs/ yang na spyod pa ma rung ba brtul/ spyod pa yang dag pa la zhugs, $\mathrm{p} 486$.

${ }^{122}$ In Dungkar Rinpoché's dictionary (the dung dkar tshig mdzod chen mo, full title: mkhas dbang dung dkar blo bzang 'phrin las mchog gis mdzad pa'i bod rig pa'i tshig mdzod chen mo shes bya rab gsal, Beijing: krung go'i bod rigs dpe skrun khang, 2002), brtul zhugs is defined as: tha mal rang ga ba ci 'dod du byed pa'i spyod pa brtul ba'am mjug sgril te thun mong ma yin pa'i spyod pa'i gnas la zhugs pa'o/, $\mathrm{p}$ 1019.
} 
zhugs) of a novice monk."123 In another passage brtul zhugs is used to refer not to the Madman of Ü but to an assembly of ascetics "who had taken on the lifestyle of a yogi," displaying various forms of dress and conduct, clearly differentiated from the "ordinary monks" who were also present. ${ }^{124}$ The Kagyü-centric history of Tibet, The Scholar's Feast, written in 1545, mentions individuals doing an "engaged asceticism of total renunciation" (kun spangs kyi brtul zhugs) $)^{125}$ or the less specific "engaged asceticism of a renunciant" (bya bral gyi brtul zhugs). ${ }^{126}$ As a further example of its referring to ascetic observances in a general way, brtul zhugs (here a direct translation of the Sanskrit vrata) is used to refer to the additional rules the Buddha's cousin Devadatta tried to impose on the monastic community in the 5th century BCE, including not eating meat, not living in monasteries, and so on. ${ }^{127}$

When applied towards explaining the distinctive behavior of the holy madmen, brtul zhugs carries a more specific meaning. When this specific meaning is meant, it is usually stated as brtul zhugs kyi spyod pa, "the performance of engaged asceticism," but in some cases, especially in conversation, the term spyod pa is left out, and we are left

\footnotetext{
${ }^{123}$ dge tshul gyi brtul zhugs yang dag par blangs, The Life of the Madman of Ü, $\mathrm{p} 405.3$.

${ }^{124}$ The Life of the Madman of $\ddot{U}$, "Although there were assembled there around 20,000 who were taking up the lifestyle (brtul zhugs) of a yogi, with various modes of dress and activity - not to mention the 'virtuous friends,' ordinary monks, governors and householders-... dge ba'i bshes gnyen dang / rab tu byung ba tha mal pa rnams dang / sde dpon khyim bdag rnams mi the ba'i rnal 'byor pa'i brtul zhugs 'chang ba cha lugs dang kun spyod mi 'dra ba du ma 'dzin pa khri phrag gnyis tsam tshogs 'dug na'ang/, p 505.1-.4. ${ }^{125}$ dpa' bo gtsug lag phreng ba, chos 'byung mkhas pa'i dga' ston (Beijing: mi rigs dpe skrun khang, 2006), p 615. See also $\mathrm{p} 590$, in which someone is said to have done kun spangs bya btang gi brtul zhugs. ${ }_{127}^{126}$ p 612 .

${ }^{127}$ In the "autobiography" of Drukpa Künlé, he recounts one occasion in which he had a conversation with someone about whether or not it was wrong (nyes pa) to eat fish, pork and eggs. Drukpa Künlé quotes a text stating that, according to the early Buddhism of the "hearers" (nyan thos), it was permissible to eat meat as long as it was not killed specifically for you; if one still abstained, one would be adhering to "the asceticism (brtul zhugs) of Devadatta" (lhas byin gyis [sic] ni brtul zhugs 'gyur) in 'brug pa kun legs kyi rnam thar (this is actually the four-volume collected works of Drukpa Künlé) (Beijing: bod ljongs mi dmangs dpe skrun khang, 2005), p 48; Stein, 1972, p 99. See Reginald A. Ray, Buddhist Saints in India: A Study in Buddhist Values and Orientations (New York: Oxford University Press, 1994), pp 162-173, on Devadatta's additional austerities.
} 
only with brtul zhugs, "engaged asceticism," it being clear from context that this more

specific meaning is what is meant. In other cases, referring to basically the same kind of activity, brtul zhugs is left out and only the word spyod pa, "activity," is used. ${ }^{128}$ These various permutations of the term all refer to a phase of advanced practice reserved for serious practitioners of the Mahāyoga and Yogin̄ tantra classes (both of which fall under the category of Highest Yoga Tantra). ${ }^{129}$ Brtul zhugs kyi spyod pa is engaged in for the sake of bogs 'don, which means "further improvement."130 (Bogs dbyug and bogs dbyung, or even simply just bogs, are also used to express the same meaning. ${ }^{131}$ ) When a practitioner has begun to show signs of success in meditation, he is to engage in these practices for the sake of having "further improvement" in his realization. Note that brtul zhugs kyi spyod pa is explicitly not for beginners, but for those already well along the path. The degree of success in meditation one should have achieved before beginning

\footnotetext{
${ }^{128}$ For example, Book I, Chapter 6 of the Hevajra Tantra, the chapter on spyod pa, which many commentaries make clear is dedicated to explicating brtul zhugs kyi spyod pa. These commentaries will be cited below.

${ }^{129}$ There may be reference to brtul zhugs kyi spyod pa carrying this sort of meaning in discussions of other classes of tantric texts, but I have yet to come across any.

${ }^{130}$ See, for example, the commentary on the Hevajra Tantra by the Third Karmapa, Rangjung Dorjé (12841339), titled The Stainless Light Explaining the Two-Chaptered (brtag gnyis rnam bshad dri med 'od) (Seattle: Nitartha International, 2006), p 139. (This is one of Rangjung Dorjé's "Eight Great Texts on Sūtra and Tantra," mdo sngags gzhung chen brgyad). Rangjung Dorjé even goes so far as to put the two together in a single term as "the performance of engaged asceticism-that-is-a-further-improvement-practice on the Perfection stage" (rdzogs rims kyi bogs 'don brtul zhugs kyi spyod pa), p 156.

The Fourth Red Hat, Chödrak Yeshé (1453-1524), in his commentary on the Six Dharmas of Nāropa, states that brtul zhugs is performed for the sake of bogs 'don, in addition to ridding oneself of the residual nyon mongs that have been there from the beginning (thog ma med pa' $i$ nyon mongs pa'i bags chags), pp 368-9 in dpal nA ro chos drug gi khrid kyi rim pa sbas pa'i don mtha' dag gsal bar byed pa brgyud sde'i snying po kun las btus pa: A detailed intsructional manual for the practice of the six doctrines of Nāropa according to the system of the Kam-tshan Bka'-brgyud-pa, reproduced from a rare manuscript which had once belonged to 'Jam-mgon Kon-sprul recently found by Lama Nor-bla (Delhi: published by Karlo, Tibetan Camp, Majnukatilla, 1985).

${ }^{131}$ See Karma Trinlepa, "reply to queries put by a monk from Riwoché, called 'answers that clarify the darkness of doubt"' (dri lan the tshom mun sel zhes pa khams ri bo che'i dge slong gi zhu lan) in The Songs of Esoteric Practice (mgur) and Replies to Doctrinal Questions (dris lan) of karma-'phrin-las-pa, reproduced from prints of the 1539 Rin-chen-ri-bo blocks (New Delhi: printed by Ngawang Topgay, 1975), p 212; and Marpa's Sun of the Little Collection ('bum chung nyi ma) (Dehradun: srong btsan dpe mdzod khang, 2005), p 96, for an instance of each. Götsang Repa, p 24.5, uses just just bogs.
} 
these less conventional practices is most often quantified in terms of "achieving [yogic] heat" (drod thob), indicating success in the practice of the inner-fire visualization of tummo. In this context no hard distinction is made between mental and physical aspects of the self. ${ }^{132}$ As will be shown in a dialogue from The Life of the Madman of Tsang below, the prerequisites for the performance of engaged asceticism can also be articulated in terms of experiential realization (nyams rtogs) or (supernatural) abilities (nus pa). ${ }^{133}$

But the question still remains: what does the performance of engaged asceticism entail? The essence of the performance of engaged asceticism is engaging in specific activities outside of the formal confines of seated meditation or ordered ritual practice, for the sake of cultivating feelings and experiences that challenge one's habitual modes of thinking, and thereby contribute to one's having deeper and more transformative realizations. ${ }^{134}$ Indicative of this meaning is the fact that many Kagyüpas use the term rig

\footnotetext{
${ }^{132}$ Stearns 2007, p 60. Rangjung Dorjé, p 144, says that the indicators of having achieved a little yogic heat (cung zad drod ... thob pa) include not being distracted by lesser conceptual formations, having destroyed the greater afflictive emotions, and being prepared to make offerings of whatever benefit might arise from the practice. It is interesting that Rangjung Dorjé posits these accomplishments as "signs" of having achieved warmth, since the warmth is most often said to be a sign of these less tangible accomplishments. We can perhaps take this circularity as indicative of the absence of a strong mind-body distinction in this system.

Karma Trinlepa, in his "reply to queries put by a monk from Riwoché, called 'answers that clarify the darkness of doubt"" in The Songs of Esoteric Practice (mgur) and Replies to Doctrinal Questions (dris lan) of karma-'phrin-las-pa, $\mathrm{p} 211$, uses the term drod thob.

In his commentary on the Hevajra Tantra, Marpa gives a more thorough description, stating that one should engage in these practices once one has achieved the abilities of generating yogic heat and making the unfaithful faithful, and when one no longer harbors the least bit of attachment, pp 99-100.

${ }^{133}$ This passage will be translated below, in section 3.II.1. See also the commentary on the Hevajra Tantra, by Dakpo Penchen Tashi Namgyel (also known as sgam po bkra shis rnam rgyal) (1512/13-1587), The Commentary on the King of Tantras Known as the 'Glorious Hevajra' (dpal kye'i rdo rje zhes bya ba' $i$ rgyud kyi rgyal po'i 'grel pa) (si khron mi rigs dpe skrun khang, 2002), p 192.

${ }^{134}$ The Fourth Red Hat's commentary on the "single intention" (dgongs gcig) doctrine (dam chos dgongs pa gcig pa'i gsal byed, cited above) provides another perspective on the topic of the performance of engaged asceticism. Chödrak Yeshé (1453-1524) maintains that all of the dharma combats afflictive emotions, but tantric practices are for the purpose of combatting subtle afflictive emotions (nyon mongs phra ba). The performance of engaged asceticism of awareness is one tantric method. Basically, it
} 
pa brtul zhugs kyi spyod pa (or rig pa’i brtul zhugs kyi spyod pa, Sanskrit:

vidyāvratacaryā) as synonymous with brtul zhugs kyi spyod pa (vratacaryāa). In these cases rig pa often gets glossed as "awareness," so that the term comes to mean "the performance of engaged asceticism [to train] one's awareness" or "the performance of entering [activity] that tames one's awareness." This suggests that the purpose of brtul zhugs kyi spyod pa is to deal directly with the way one experiences the world. ${ }^{135}$ Other commentators understand rig pa brtul zhugs kyi spyod pa differently, taking rig pa to refer to a sexual consort. (The same ambiguity exists in the Sanskrit term of which this is a translation, vidyāvratacary $\bar{a}$, in which vidya can be taken to bear the literal meaning of "awareness" or its related but more figurative meaning of sexual consort.) Complicating the matter further, in some instances brtul zhugs kyi spyod pa (without the term rig pa) is itself treated as synonymous with practice with a consort. ${ }^{136}$ In the context of the Lives of the Madmen of Ü and Tsang, the former meaning is operative, as rig pa brtul zhugs kyi spyod pa is used as synonymous with brtul zhugs kyi spyod pa to refer to a variety of practices that are not necessarily sexual in nature. Further, there is no mention in The Life of the Madman of $\ddot{U}$ of his having a sexual consort. ${ }^{137}$ The Madman of Tsang had a

\footnotetext{
involves abandoning the clothing and implements of a monk and taking on the garb of a yogi (so thar gyi dge slong gis kyang rtags dang yo byad dor nas rnal 'byor pa'i chas kyi spyod pa/), p 64. Chödrak Yeshé's comments here are informed by Āryadeva's Lamp that Integrates the Practices (caryāmelāpakapradīpa), which was cited above and will be discussed further below.

${ }^{135}$ Choegyal Rinpoché stated that it is called rig pa'i brtul zhugs because it concerns one's experiential practice (nyams len). Interview at Changchub Jong, H.P., India, 15 August 2009.

${ }^{136}$ This is the case in the Book II, Chapter 2 of the Hevajra Tantra: Rangjung Dorjé, pp 257-286; David Snellgrove, translator, The Hevajra Tantra: A Critical Study (London, New York, Toronto: Oxford University Press, 1959), translated in Vol. I, pp 89-94; Tibetan provided in Vol. II, pp 45-53.

${ }^{137}$ For example, in The Life of the Madman of Tsang, rig pa brtul zhugs kyi spyod pa is used in a few instances in a way suggesting that it is synonymous with brtul zhugs kyi spyod pa (Götsang Repa, p 147.5). In his commentary on the Hevajra Tantra, the Third Karmapa, Rangjung Dorjé, seems to use brtul zhugs kyi spyod pa and rig pa brtul zhugs kyi spyod pa as interchangeable (see pp 139, 157). In the commentary on the Hevajra Tantra attributed to Marpa, it is suggested that the rig pa in this term, when applied to
} 
long relationship with a woman named Küntu Zangmo, who was his patron, his disciple

and his sexual consort. She is most often referred to as "the Mother" (yum). Their

relationship is an interesting one. For our purposes here let us note that in the instances

in the Madman of Tsang's Life when she is mentioned, it is never in connection with his

practicing the performance of engaged asceticism or "secret activity" (another potentially

sexual practice to be described below). ${ }^{138}$ Some commentators assume the term brtul

Generation Phase practice, refers to deity yoga; and when applied to Perfection Phase practice, it refers to the experience of sahaja (p 99). Here in Marpa's commentary it does not seem that rig pa brtul zhugs kyi spyod pa is meant to mean anything substantially different from brtul zhugs kyi spyod pa.

${ }^{138}$ However, in one instance the Madman of Tsang is said to have instructed Küntu Zangmo (kun tu bzang mo) in a specific practice text called "The Secret Activity," which will be described later in this chapter. The Madman of Tsang is said to have instructed her in gsang gcod (sic, corrected as gsang spyod), along with the Six Dharmas of Nāropa, the Hevajra Tantra, the Dohās, and so on, Götsang Repa, p 142.3.

Regarding their relationship, their first meeting occured while Sangyé Gyeltsen was struggling to gather resources to complete his printing of The Life of Milarepa. Their meeting was preceeded by his having a vision in which five female deities assured him that his printing project was beneficial to the Kagyü, and that they would help him in his endeavor. Küntu Zangmo was a patron for this first printing project and would continue to support him in others. After the Madman of Tsang's death, the sponsored printings of his own biography.

The section in which their meeting is described runs Götsang Repa, pp 137.7-142.6 and bears the title yum kun tu bzang mo dang mjal tshul lo rgyud 'dor bsdus la sogs tel bar du spyod pa las rgyal zhing spar bzhengs pa la 'jug pa'i skor tsho de dang po'o/, p 142.6. Küntu Zangmo was of a noble family and had the name Gönmo Kyi (mgon mo skyid). She had reluctantly married a Nyingma practitioner named Tashi Kar (bkra shis mkhar) against her will. She would have preferred to practice religion rather than get married. When Küntu Zangmo was going off to live with her new husband, she made a prayer to the deities that they might make her a widow within three years. Surely enough, her husband died after just a few months. But as those around Küntu Zangmo would still not let her dedicate her life to religion, she had to flee by night, and entered the nunhood at Pelmo Chöding (dpal mo chos sdings). When she heard that the Madman of Tsang was working on printing the Life and Songs of Milarepa, staying at Shelpuk (shel phug), her residual tendency (bag chags) was awakened. She gained irrepressible faith in the Madman of Tsang and quickly went to see him. (Her backstory up to her meeting the Madman of Tsang is described pp 140.1-141.4) The night before she arrived, the Madman of Tsang had a dream in which he was visited by a woman adorned with bone ornaments, who came offering him jewels (pp 141.5-.6). The next day Küntu Zangmo arrived, bearing offerings. The Madman of Tsang soon began giving her empowerments and instructions. After this there was a disagreement between Küntu Zangmo's people at Takla (stag la ba) and her late husband's people (bkra shis mkhar ba). It is said that any trouble that might have come to the Madman of Tsang's community as a result of this situation was eradicated by the yogi through his performance of austerities.

The other instances in Götsang Repa's version of The Life of the Madman of Tsang in which Küntu Zangmo is mentioned are as follows: 145.1, where she is praised as a wisdom dākini $\bar{i}$ 159.7-161.1, where she requests instructions from the Madman of Tsang and he responds in song; 172.2-172.5, in which their respective travels are mentioned; 172.5-173.1, during a gaṇacakra Küntu Zangmo was holding a rosary and the yogi told her to give it to him, which she did; he said this was a good sign (rten 'brel legs), then jokingly quoted from the Hevajra Tantra, "If one shows a rosary in one's hand, it says 'we should get 
zhugs spyod pa or rig pa brtul zhugs spyod pa (and their various permutations) to refer to

practicing with a sexual consort, and this specific reading may be justified in certain

contexts, but not in reference to the lives of the Madmen of $\ddot{U}$ and Tsang. ${ }^{139}$

A survey of the types of activity referred to as the performance of engaged

asceticism in the biographies of the Madmen of Ü and Tsang will give us a better idea of

what this practice entailed. The performance of engaged asceticism in many cases refers

to moments of violent confrontation with other people, with the madman disrespecting or

together'; if one gives the rosary forth, one has good engaged asceticism with respect to the samāyas (?)"), which made everyone laugh (Book I, Chapter 7, verses 8-9; Snellgrove, The Hevajra Tantra, translated in Vol. I, p 68; Tibetan provided in Vol. II, p 23; Rangjung Dorjé, pp 160-161); 176.1, when Küntu Zangmo and some others served as the Madman of Tsang's attendants while he was practicing at Chuwar; 189.3, when Küntu Zangmo circumambulated mount Kailash (gangs skor la phebs) with the yogi and his students; 198.4-.5, when the Madman of Tsang finished some compositions at Küntu Zangmo's request; in a passage beginning at 238.2, while staying at the forest retreat of Onjung Pel ('o 'byung dpal gyi nags khrod) Küntu Zangmo requested that the Madman of Tsang give a teaching on whether the ground was mistaken or the path was mistaken (gzhi 'khrul lam 'khrul); 249.2, when Küntu Zangmo sponsored a ganacakra (tshogs 'khor); 259.3-.4, in the chapter about the Madman of Tsang's many students, Küntu Zangmo is listed first, and treated to four lines of praise (mkha' spyod gtso mo sprul pa'i yum/ rgyal ba skyed (skyong?) mdzad rnal 'byor ma/ rje btsun gsung gi gsang mdzod dzin/ kun tu bzang mo la phyag 'tshal/); 281.1-.4, after the Madman of Tsang's funeral, Küntu Zangmo is mentioned as having attended a three month gathering at the forest retreat of Onjung Pel, at Chuwar, along with the Rinpungpa Dönyö Dorjé, other lords, ministers, and disciples of the yogi (this is mentioned by Kurtis Schaeffer, "Dying Like Milarépa: Death Accounts in a Tibetan Hagiographic Tradition," pp 208-233 in The Buddhist Dead: Practices, Discourses,

Representations, edited by Bryan Cuevas and Jacqueline Stone (Honolulu: University of Hawai'i Press, 2007), p 232); 282.2-.3, after the Madman of Tsang's death, Küntu Zangmo had his students compile his teachings and songs (gsung $m g u r$ ), and sponsored the biography written by Ngödrup Pelbar to be carved into woodblocks (spar du gzhengs) (in the Ngödrup Pelbar version of The Life of the Madman of Tsang, her patronage is mentioned in the colophon, p 30b; this is mentioned in Schaeffer, "Dying Like Milarépa," p 232); 284.1-.3, Küntu Zangmo is mentioned in Götsang Repa's author's colophon as one of the people who impelled him to undertake writing his version of the life story; lastly, Küntu Zangmo is mentioned in the printer's colophon ( $\mathrm{p}$ 286.4) as the "great mother" (yum chen), described in beautiful poetic terms as a full moon, her words compared to the moon's cool pure light, which helps open the lotus of the author's mind and thus compose the life story.

${ }^{139}$ For example, see Gray, p 275, where he cites an Indian commentary on the Cakrasamvara tantra that was translated into Tibetan, using the terms vidyāvrata, rig pa'i brtul zhugs, which he translates as "consort observance," which from context clearly means the practitioner's having sexual intercourse with a woman. In Āryadeva's Lamp that Integrates the Practices, which outlines one system of practicing the Guhyasamāja Tantra, in chapters 9 and 10 (which will be discussed further below) rig pa'i brtul zhugs (vidyāvrata) clearly refers to sexual practice, in Wedemeyer, pp 68, 118, 313-15.

On one occasion the Madman of Tsang sang a song in which he stated that if one performs brtul zhugs for the wrong reasons, one's consort will get angry (this passage will be translated in the conclusion to this chapter; Götsang Repa, p 103.3-.4). Elsewhere in The Life of the Madman of Tsang there is mention of his giving an initiation using a real consort, Götsang Repa, p 130.6. The fact that this specific fact is mentioned here may suggest that they did not always use consorts for these practices. 
assaulting a powerful lord or doing things to provoke the ire of a gathering of people. In The Life of the Madman of $\ddot{U}$ the term the performance of engaged asceticism most often comes as part of the phrase "the performance of fierce engaged asceticism" (drag po brtul zhugs kyi spyod pa). For example, the Madman of Ü uses the performance of fierce engaged asceticism to cast out the heretics who had come to occupy a few Buddhist holy sites near Kathmandu. He also does the performance of fierce engaged asceticism to bring a curmudgeonly lord in Tsang to heel. ${ }^{140}$ This kind of violent confrontation is a recurring theme in The Life of the Madman of $\ddot{U}$. On one very typical occasion, the Madman of Ü is said to have walked directly into the Shigatsé fortress where a powerful lord of the Rinpungpa family was sitting with his ministers. The yogi scolded them, danced and stomped about, and committed the ultimate disrespect by seizing the lord's cup of tea. ${ }^{141}$ Everyone was frightened by this behavior, and showed the yogi great reverence. To some extent these episodes are employed by the author to make the reader wonder at the amazing punishments the yogi was able to endure when people physically attacked him for behaving so inappropriately. ${ }^{142}$ But more important for our purposes, these many episodes indicate the fact that the Madman of Ü purposefully provoked these

\footnotetext{
${ }^{140}$ The Life of the Madman of $\ddot{U}$, pp 452.4-453.1 and pp 506.6-507.6. The Madman of $\ddot{U}$ is said to perform drag po brtul zhugs kyi spyod pa on at least eight different occasions, constituting the majority of the instances of the use of the term brtul zhugs kyi spyod pa. There are a handful of other occasions in which slightly different terminology is used, but it is clear that drag po brtul zhugs kyi spyod pa is meant. For example, p 570.4-.6, in which the Madman of Ü disrupts an altar and threatens a local lord, provoking a violent reaction; here his actions are referred to as brtul zhugs kyi spyod pa. Clearly this is violent (drag po) activity.

${ }^{141}$ The Life of the Madman of $\ddot{U}, \mathrm{p}$ 503.2-.6.

${ }^{142}$ For example, The Life of the Madman of $\ddot{U}$, pp 565-6, when the Madman of Ü visited Samten Ling Monastery, somewhere near Dakpo, and "engaged in the performance of fierce engaged asceticism" (drag po brtul zhugs kyi spyod pa la zhugs pa). The monks of the monastery then attacked him with stones, swords, daggers, arrows, spears, and so on, but his body did not bear the list bit of harm, as when the demon Māra tried to inflict harm on the soon-to-be Śākyamuni Buddha.
} 
violent confrontations as part of his practice, and they were often described using the language of "the performance of fierce engaged asceticism."

The Madman of Tsang engaged in similar forms of engaged asceticism. For example, in Chushül he went before three lords (dpon po) who were set up in a house drinking chang with thirty soldiers. Then, "by means of the performance of engaged asceticism" (brtul zhugs spyod pas) he took the chang from a lord's hand and drank it. Before the soldiers could attack him with their swords and spears, he dissuaded them with his ritual scepter (khațvāiga) and "overwhelmed them with his brilliance." Then one of the lords expressed his reverence and offered prostrations. ${ }^{143}$ In time the Madman of Tsang gained a reputation for violence, as in one episode it is related how the famous Pawo Chöwang Lündrup (also known as Chöjé Pawo, the first in the Pawo incarnation lineage) had a younger brother who had entered into the religious life, but was of a wild disposition (thugs shin tu rgod). So Chojé Pawo instructed him to go to the Madman of Tsang, who was staying at Tsari, and who, he said, "maintained the Teachings of the secret mantra through his mastery of fierce activity and his performance of engaged asceticism." Shortly thereafter the younger brother is said to have returned. When Chojé Pawo asked him why, he said that he "didn't get" (blo la ma song) the Madman of Tsang's way of dressing and practicing tantra! ${ }^{144}$ More will be said about the First Pawo in Chapter Four.

The Madman of Tsang, like the Madman of Ü, had a propensity for angry confrontations. Whereas in The Life of the Madman of $\ddot{U}$ these confrontations were

\footnotetext{
${ }^{143}$ Götsang Repa, p 46.2-.5.

${ }^{144}$ Götsang Repa, pp 126.6-127.3. drag po'i 'phrin las la mnga' snyen shing brtul zhugs kyi spyod pas gsang sngags kyi bstan pa 'dzin pa.
} 
consistently referred to as "the performance of fierce engaged asceticism" (drag po brtul zhugs kyi spyod pa), in various versions of The Life of the Madman of Tsang this wrathful activity is described with less consistent terminology. ${ }^{145}$

The Madman of Tsang performed a variety of other activities that were referred to as the performance of engaged asceticism. Beyond the sort of direct violent confrontation described above, the two main types of engaged asceticism performed by the Madman of Tsang were either deliberately private or deliberately public. As one passage in The Life of the Madman of Tsang reads, "In charnel grounds, [under] trees, and on the banks of rivers; in open spaces; in temples and abandoned buildings; in alleyways and in marketplaces; in frightening and horrific places inhabited by spirits, he roamed, performing engaged asceticism..." significance, defined either by the presence of people or their absence. The performance of engaged asceticism is often used to refer to something performed in liminal spaces like charnel grounds (dur khrod) and places thought to be inhabited by malicious spirits, where sensible people do not tread.

\footnotetext{
${ }^{145}$ For more examples of the Madman of Tsang's having violent confrontations with authority figures, in which terminology related to brtul zhugs kyi spyod pa is used, see: when a lord whom the Madman of Tsang had attacked and subsequently won over referrs to the Madman of Tsang as "one who enters the 'practice' of a yogi" (rnal 'byor pa spyod pa la zhugs pa), Götsang Repa, p 43.5-.6; or "a yogi with an engaged ascetic observance" (rnal 'byor pa brtul zhugs can zhig 'dug), Götsang Repa, $\mathrm{p} 47$.

See also Lhatsün Rinchen Namgyel's version of the Life, in which this same confrontational activity is described with related yet slightly different terminologiy: spyod pa, spyod pa la zhugs pa, and so on.

${ }^{146}$ dur khrod dang shing gcig chu 'gram dang / thang chen dang / khang stong dang lha khang / lam srang dang tshong 'dus/ 'jigs shing kyi g.ya' ba'i snyan sa rnams/ brtul zhugs kyis spyod pas nyul zhing phebs pa... Götsang Repa, p 40.5-6. In a similar passage it is said that the Madman of Tsang's students practiced: "In haunted places and mountain retreats near and far (? phyogs rigs); in charnel grounds and divine abodes; in places and districts; in villages and marketplaces, and so on, his students roamed, performing 'secret practice' and engaged asceticism..." (bu slob phyogs rigs kyi ri khrod dang snyan sa/ dur khrod dang gnas chen/ yul dang ljongs/ grong yul dang tshong 'dus la sogs pa rnams su/ gsang ba' $i$ spyod pa dang / brtul zhugs kyi spyod pas nyul ...), Götsang Repa, p 192.5-.6.
} 
It is normative for a Tibetan Buddhist yogi to meditate in mountain retreats, or in charnel grounds and other liminal spaces believed to be inhabited by spirits. One meditates in mountains in order to get away from the distractions inherent to being around other people. One meditates in charnel grounds in order to challenge pernicious spirit beings where they dwell. What adds a unique dimension to the holy madmen's performance of engaged asceticism is that at times it was performed in the most public of spaces. The Madman of Tsang's distinctive activity was often said to have been performed in marketplaces (in a rural society like Tibet in the 15th century, no place is more public than the marketplace), or even simply amidst a crowd of people (khrom). ${ }^{147}$ This aspect of the performance of engaged asceticism may provide us with a window into its meaning, and what differentiates it from other types of ascetic practice.

One instance of the Madman of Tsang's "performance of engaged asceticism" is described as follows:

He went to a big assembly at Tsari, his naked body rubbed with corpse ash, dabbed with blood and smeared with fat; he wore the intestines from a dead body as a necklace, and ornamenting his wrists and ankles; he cut off the fingers and toes, and having strung them together as a garland, tied up his hair with it. $\mathrm{He}$ wore on his body fine ornaments made of bone, which someone had offered to him. Sometimes laughing, sometimes crying, he did all sorts of nonsensical things (? gyam tho? gya mtho?) ${ }^{148}$, especially in the marketplace. Because of this, although the people of Tsari were untrained and very rough, he subdued them with his abilities and conquered them with his compassion. Thus they became faithful, and as they unanimously praised him as "the Madman of Tsang," in every direction that name became as renowned as the sun and the moon. ${ }^{149}$

\footnotetext{
${ }^{147}$ khrom kyi dkyil..., Götsang Repa, p 30.6; tshogs pa'i khrom rnams kyi khrod la..., p 34.7; khrom chen po, $\mathrm{p}$ 65.3.

${ }_{148}$ This term will be discussed further below.

${ }^{149}$ rtsa ri'i tshogs gral shin tu che ba gcig la sku gcer bur ro thal kyis byugs shing / khrag gi thig le/ zhag gi zo ris/ mi gcig shi ba'i ro yi rgyu ma rnams do shal dang / phyag zhabs kyi rgyan du mdzad/ rkang lag gi sor mo rnams gcad nas srad bu la rgyus pa'i 'phreng bas dbus skra bcings/ gcig gis rus pa'i rgyan ka rags med pa gcig phul ba sku la gsol/ res rgod res ngu/ khyad par khrom gseb du gyam tho (synonymous with tho co?) sna tshogs mdzad pas/ rtsa ri ba mi sbyong shin tu rtsub kyang nus pas zil byi [sic] mnan
} 
Not long after this the Madman of Tsang exhibits even more shocking engaged asceticism:

The next morning he rubbed his body with ashes from a corpse that had been burned and thrown to the birds. He made a necklace, bracelets and anklets out of the intestines. He went amidst a crowd of people doing a full moon offering, ate the tormas and threw them at the people. He danced and sang, then he cried and beat his chest. Letting his "vajra" hang out, he chased and climbed on all the women, kissed and hugged them, and grunted; then he pulled his "vajra" inside, so there was only a hole with hair around it, and chased the men, saying "screw me!", and grabbed and hugged them; he threw and ate feces and urine- no matter what kind of engaged asceticism he performed, out of their fear and shock, no one could contest him. [But] as they were beings of the lower vehicle, they did not have any faith... ${ }^{150}$

Thus a major part of the performance of engaged asceticism for the Madman of Tsang

was going amidst crowds of people and doing the most unimaginably shocking things.

The Madman of Ü is also described as having performed engaged asceticism among

crowds of people and in towns, although not with the same degree of vivid detail. ${ }^{151}$

When one of the Madman of Ü's close disciples performed engaged asceticism in Lhasa, it provoked such a violent reaction from the people that he was killed. ${ }^{152}$ Performing this

\footnotetext{
zhing thugs rjes dbang du'dus pas shin tu mos shing kun kha 'cham par mtshan gtsang pa smyon pa gsol nas phyogs kun du nyi zla ltar grags so/, Götsang Repa, pp 37.6-38.1; this passage is translated in Quintman 2006, p 193.

${ }^{150}$ de nas sang de ro cig sreg cing cig bya la 'thor ba las ro thal rnams sku la byugs/ sgyu ma rnams mgul dang phyag zhabs kyi gdub bu mdzad de nya mchod byed pa'i khrom rnams kyi khrod du byon nas/ gtor ma rnams zhal du gsol ba dang khrom rnams kyi seb du 'phyong ba dang res bro brdung zhing glu gar dang / res ngu zhing brang rdung pa dang / rdo rje lasu (abbrevition for las su? or should it be read as la su rung?) rung par mdzad nas bud med thams cad 'ded cing zhon pa dang / 'o dang khyud pa dang / 'khud pa (read as 'khung, mistaken for 'khun?) dang / res rdo rje sbubsu drangs nas bug pa hu re ba'i mtha' ma la spu sung tsam las med par mdzad nas/ khyo ga thams cad 'ded cing nga la rgyor shog gsung zhing bzung nas 'khyud pa dang / dri chen dang dri chu mi la 'thor zhing zhal du gsol ba sogs brtul zhugs kyi spyod pa ci mdzad kyang kun 'jigs zhing bkrag pa las sgol [read as rgol] ba yang ma nus/ gang zag theg dman gyi rigs mang bas mos pa cam [read as tsam] yang ma byung/, Götsang Repa, p 48.3-.7.

There is another mention of Sangyé Gyeltsen's running back and forth in a marketplace near Tsari: in one hand he held some molasses (bu ram) and in the other feces (dri chen) which he took turns eating from, while urinating everywhere - uncouth activity (mi 'tsham pa'i spyod pa) through which he overcame appearances (snang ba zil gyis mnan) and made the people faithful. They gave him the name "the Hero of Tsari" (rtsa ri dpa' bo), p 34.7-35.1. The term engaged asceticism is not used to describe Sangyé Gyeltsen's activity on this occasion.

${ }^{151}$ See, for example, The Life of the Madman of $\ddot{U}$, pp 522.4-524.3.

${ }^{152}$ The Life of the Madman of $\ddot{U}$, pp 595.1-596.4.
} 
kind of shocking and anti-social behavior was a dangerous enterprise.

Thus we see that for the Madmen of Ü and Tsang, the performance of engaged asceticism entailed three different times of activity: brazenly confronting authority figures and overturning the norms of respect and decorum; meditating in haunted places; and making very public displays of shocking behavior. This conforms to the pattern for how Tibetan commentators explain the performance of engaged asceticism in other sources. A useful outline of these practices and the ways they are understood by various tantric traditions is provided by Dakpo Penchen Tashi Namgyel (1512/13-1587) in his commentary on the Hevajra tantra, The Commentary on the King of Tantras Known as the 'Glorious Hevajra'. He explains that in the Cakrasamvara and Drubnying (grub snying) systems, there is discussion of four phases of practice: 1) "all-good activity" (kun tu bzang po ’i spyod pa); 2) “secret activity” (gsang spyod dam sbas pa'i spyod pa);3) "the performance of engaged asceticism of awareness" (rig pa brtul zhugs kyi spyod pa); and lastly 4) "activity that is victorious in all respects" (phyogs las rnam rgyal gyi spyod $p a$, often rendered as phyogs thams cad las rnam par rgyal ba'i spyod pa). "All-good activity" refers to living in accordance with one's vows and commitments (dam tshig dang sdom pa), while living at home (most often a monk's home monastery), without doing anything amiss. "Secret activity" refers to a period in which one "does tantric activity" (sngags kyi kun spyod bya) without indicating to others that one is doing religious practice; one should use a consort and consume tantric substances (dam rdzas) secretly. ${ }^{153}$ "The performance of engaged asceticism" denotes a phase in which the

\footnotetext{
${ }^{153}$ The 10th and 12th abbots of the Taklung Kagyü lineage practiced "secret activity," stag lung chos byung, pp 405, 429.
} 
practitioner "puts on the accoutrements of a yogi" (rnal 'byor pa'i chas su zhugs), and should, along with his consort, perform tantric activity in public (tshogs su). Lastly, "activity that is victorious in all respects" means that one has subdued all adverse circumstances and overpowers existence with his brilliance. ${ }^{154}$

Here Dakpo Penchen uses the term "the performance of engaged asceticism" to refer to a period in which one performs tantric practices publicly. In other descriptions of these practices, this phase is referred to as "public activity" (tshogs spyod), while the performance of engaged asceticism is used as an umbrella term for all these practices. For example, Karma Trinlepa (1456-1539) — an almost exact contemporary of the famous 15th-century holy madmen and a well-respected scholar active in central Tibet, who may have had a hand in writing part of the Madman of Ü's biography—states that the practice of the performance of engaged asceticism of awareness (rig pa brtul zhugs kyi spyod pa) can include, depending on the practitioner's mental capacity, specific practices called “public activity" (tshogs spyod), "secret activity" (gsang spyod), "all-good activity" (kun tu bzang po'i spyod pa), and so on. ${ }^{155}$

Alternatively, Sangyé Darpo, a grand-disciple of the Madman of Tsang, wrote in his History of the Kagyü: Accumulation of the Brilliant Light of a Heap of Jewels that the Madman of Tsang performed "secret activity, public activity, the engaged asceticism of

\footnotetext{
${ }_{155}^{154} \mathrm{pp} 193-4$.

155 drod thob pa'i dus nil rig pa brtul zhugs kyi spyod pa la spyod par bzhed del de yang rnal 'byor pa rang rang gi rgyud tshod dang bstun nas/ tshogs spyod dang / gsang spyod dang / kun tu bzang po' $i$ spyod pa la sogs pa sngon gyi rnal 'byor gyi dbang phyug chen po rnams kyis ji ltar spyad pa spyod par mdzad pa ji lta ba bzhin du... Karma Trinlepa, "reply to queries put by a monk from Riwoché, called 'answers that clarify the darkness of doubt"' in The Songs of Esoteric Practice (mgur) and Replies to Doctrinal Questions (dris lan) of karma-’phrin-las-pa, pp 211.7-212.1.
} 
awareness, and activity that is victorious in all respects." 156 Sangyé Darpo uses "public activity" and "the engaged asceticism of awareness" to refer to two distinct phases of practice, whereas Dakpo Penchen combines these two phases and refers to them by the latter term.

There is thus a lot of diversity in the way Tibetan commentators have described this set of practices: whether they should be considered as three or four or five stages of practice, whether the performance of engaged asceticism is an umbrella term or whether it refers to a specific phase of practice, and so on. This is complicated further by the fact that in some cases "secret activity" is used as synonymous with the performance of engaged asceticism, while in other cases it is said to be a prerequisite for it. ${ }^{157}$ "Secret Activity" also designates a more specific cycle of tantric practices, which will be discussed in the next section.

To expand on these categories, "all-good activity" refers to living a conventionally virtuous lifestyle so successfully that it becomes second nature and one

\footnotetext{
${ }^{156}$ p 158 (79b). Geshé Tubten Samdrup (sgom sde lha rams pa dge bshes thub bstan bsam grub), Dictionary of the Great Sütras and Tantras: Words of the Boundless Learned Ones (mdo sngags kyi gzhung chen chen mo'i tshig mdzod ris med mkhas pa'i zhal lung, Delhi: Sherig Parkhang, 2005), also uses "the engaged asceticism of awareness" to refer to a specific phase of practice, listing a set of five such practices under the heading "the five types of activity" (spyod pa lnga), as they pertain to the Kagyü sect. In order they are "all-good activity," "secret activity," "the engaged asceticism of awareness" (rig pa brtul zhugs), "public activity," and "activity that is victorious in all respects" (phyogs las rnam rgyal gyi spyod pa), $\mathrm{p}$ 432.

${ }^{157}$ Stearns 2007, p 60; see also pp 159, 512. In this passage from The Life of the Madman of $\ddot{U}$, gsang spyod seems to be used as synonymous with brtul zhugs kyi spyod pa: "While staying there [performing] inconceivable external, internal and secret wonders (ngo mtshar) like these, having seen signs indicating that if he went to the area of Kongpo Gyela (kong po rgyal la) it would benefit transmigrating beings, he intended to continue his secret activity (gsang spyod skyong ba) and assist transmigrating beings - human and non-human - in that area," pp 471.6-472.2.

In his commentary on the Hevajra tantra, Rangjung Dorjé says gsang ba'i spyod pa is a prerequisite (sngon du 'gro ba) for brtul zhugs kyi spyod pa, 143.
} 
remains at all times in accord with the Dharma. ${ }^{158}$ This would usually be performed at one's home monastery. Then one would progress to the phase of "secret activity," in order to have more profound realizations. "Secret activity" entails living in an out of the way place like a charnel ground or under a tree, and is often said to require cohabiting with a female consort. ${ }^{159}$ Then one would enter into "public activity," during which the practitioner goes among crowds of people and sings and dances and does odd things in order to provoke people to scold and even beat him; the practitioner then turns this abuse into an aide for his practice and meditation. ${ }^{160}$ This is usually listed after "secret activity," meaning that one would engage in "public activity" after having had some success in meditating in out-of-the-way places. "Activity that is victorious in all respects" refers to living in such a way that all conceptual formations of good and bad have been transformed from delusory impediments into aides for virtuous practice and meditation. ${ }^{161}$ In some cases "activity that is victorious in all respects" refers to an

\footnotetext{
${ }^{158}$ In his Dictionary of the Great Sütras and Tantras, Geshé Tubten Samdrup bases his discussion of these terms on the Ocean of Definitive Meaning of the Mahämudrā, written by the 9th Karmapa, Wangchuk Dorjé. He defines kun tu bzang po'i spyod pa as: lhag mthong gi nyams dang ma bral ba spyod lam rnam bzhir rnam rtog thams cad rdo tshan la kha ba bab pa ltar gnyen po bsten mi dgos par chos nyid kyi ngang du lhan gyis zhi zhing rang yul du 'gro ba'i spyod pa zhig gol, p 21. Kenpo Tsülnam Rinpoché stated that kun tu bzang po'i spyod pa is like the practice of a monk with good ethics (tshul khrims), and that the term does not have any connection to the Buddha Samantabhadra (kun tu bzang po), interview 28 August 2009. ${ }^{159}$ Geshé Tubten Samdrup defines gsang spyod as: spyod pa lnga'i nang gses/ kun bzang gi spyod pa la bogs 'don pa'i slad du dur khrod dam/ shing gcig la sogs pa'i gnas su phyag rgya mo dang lhan cig gnas pa'o/, p 736.

${ }^{160}$ Geshé Tubten Samdrup defines tshogs spyod as: spyod pa lnga'i nang gses/ khrom chen po'am tshong 'dus sam rigs ngan gyi khyim sogs su phyin te glu gar la sogs pas bstod rgod gshe rdeg 'tshog sogs byung na nags la me mched pa ltar dge sbyor dang ting nge 'dzin gyi grogs su 'gro ba'i spyod pa la zer/, p 585.

${ }^{161}$ Geshé Tubten Samdrup defines phyogs las rnam rgyal gyi spyod pa as: spyod pa lnga'i ya gyal/ bzang ngan gyi rtog pa gang shar thams cad dge sbyor dang ting nge 'dzin gyi grogs su song na/ de la phyogs las rnam rgyal gyi spyod pa zhes bya/ sgra bshad nil 'khor 'das thams cad la phyogs ris med pas phyogs las rnam par rgyal ba zhes bya'o/, p 457.
} 
exalted state one can achieve as a culmination of the earlier phases of practice just described. ${ }^{162}$

In the course of their lives the Madmen of $\ddot{U}$ and Tsang progressed through phrases of practice that match quite well with these different aspects of the performance of engaged asceticism, putting aside the inconsistencies in how these phases of practice are presented by different commentators. After a period of living in accordance with conventional discipline as a monk ("all-good activity"), each spent much time practicing in out of the way places ("secret activity"), which was followed by a period in which they performed outrageous things among crowds of people ("public activity"). Moreover, these specific categories of engaged asceticism are used in the biographies of the Madmen of Ü and Tsang: in a passage in which the author of The Life of the Madman of $\ddot{U}$ summarizes the practices his master has performed and the accomplishments he has displayed, he states that the yogi had completed the practices of "secret activity," "public activity," "activity that is victorious in all respects," and lastly "all-good activity," which are instructed by the Mother (Yoginī) tantras. ${ }^{163}$

In one instance the Madman of Tsang is said to have relied on these categories to explain the vision of the religious path he was living and passing onto his students. The story maintains that someone questioned the Madman of Tsang thus:

As for the dress and implements (cha lugs dang phyag mtshan) of a Heruka-the dredded hair of the Secret Mantra Vajrayāna and so on - although there are many yogis literally (dngos su) taking them up in India, before the arrival of the master

\footnotetext{
${ }^{162}$ Kenpo Tsülnam Rinpoché states that phyogs las rnam rgyal gyi spyod pa is a manner of activity (spyod $p a$ ) in which one is victorious over afflictive emotions (nyon mongs pa) and conceptual formations (rnam rtog); this is the sort of activity a siddha performs, interview 22 August 2009.

163 gzhan yang ma rgyu kyi gdams pa gsang spyod tshogs gcod (read as spyod) nas phyogs las rnam rgyal dang / kun tu bzang po'i spyod pa zhes pa rnams kyi mtshan nyid gang yin pa'ang/ rje 'di la phal cher tshang ba... p 522.1-.2.
} 
[i.e., the Madman of Tsang] there were none in Tibet wearing the complete garb of the Heruka, beyond some individuals with dredlocks or plaited hair. These days there are many who do not have good qualities (yon tan) or experiential realization (nyams rtogs) who nevertheless take on an external manner of dress like this. If your disciples do not have your authorization, they are not allowed to wear the emblems of the Heruka: regarding this, how much experiential realization and good qualities must one have on the inside before one is allowed to take on the emblems of the Heruka?

The Madman of Tsang replied,

Regarding that, once a person has developed nausea with samsāra and bad rebirths; once one has entered the door of the Teachings, unattached to life or the eight worldly concerns; after one has faultlessly upheld the instructions of individual liberation and bodhisattvahood, just as they promised; after having gotten the ripening and liberating empowerments from an authentic lama of the Vajrayāna, along with the instructions, tantras, and practices; and having become learned in the words and meanings; and then thanks to practice (nyams su blangs pas), experiential realization is born in one's continuum-one such as this has arrived at the time for Performance (spyod pa'i dus la bab pa, here "Performance" is synonymous with "the performance of engaged asceticism") and takes on the emblems of a Heruka.

So when is the time for Performance? At the time of the Path of Accumulations, one does "all-good activity" (kun tu bzang po'i spyod pa). At the time of the Path of Application (sbyor lam), one does "secret activity" (gsang ba' $i$ spyod pa). At the time of the Path of Seeing, when one has directed the consciousness-bearing wind (rlung sems) into the central channel, and externally can by means of one's clairvoyance (mngon shes) and abilities (nus pa) convert the unfaithful and bear difficulties as part of the path (rkyen lam du slongs), then one enters into the performance of engaged asceticism of awareness (rig pa brtul zhugs tshogs kyi spyod pa la 'jug). At that time one adorns oneself with the emblems of a Heruka.

But even if one does not have abilities (nus pa) like those, if one's secret mantra samāyas and vows are unbroken (gsang sngags kyi dam tshig dang sdom pa ma nyams la), and internally one has the antidote to the afflictive emotions, and externally one is benefitting the Teachings, then it is suitable (rung ba) [to enter into the performance of engaged asceticism]. ${ }^{164}$

The Madman of Tsang goes on to explain the symbolic meanings of various aspects of the garb of the Heruka, such as the khațānga, the tiger skin one wears as a lower garment, and so on. The most significant part of this passage is that it shows the

${ }^{164}$ Götsang Repa, pp 230.3-231.3. 
Madman of Tsang conceived of his distinctive form of practice in terms of these

categories: one progresses from "all-good activity," to "secret activity," to the performance of engaged asceticism. Here the defining feature of the performance of engaged asceticism is wearing the garb of a Heruka, which will be discussed below. It is likely that in this case the performance of engaged asceticism also refers to the kinds of practices included under the rubric of "public activity" mentioned above, as suggested by the way Dakpo Peṇchen Tashi Namgyel described these practices.

In some of the lists of these practices mentioned here, "all-good activity" is given last, and thereby given the position of honor in the graduated succession of practices that is implied; in other accountings "all-good activity" is given first. ${ }^{165}$ The difference stems

\footnotetext{
${ }^{165}$ An alternative list is given by Cyrus Stearns, 2006, based on Jamgön Kongtrül's Encompassment of all Knowledge (shes bya kun khyab). Sterans maintains that the three main categoies of "deliberate behavior" are 1) avadhüti (in Tibetan this can be called "sinful behavior," sdig pa spyod pa; "nondual behavior," gnyis spangs; or "behavior that makes everyone tremble," kun 'dar); 2) totally good (kun tu bzang po); and 3) completely victorious (phyogs las rnam rgyal). As Stearns summarizes, the meaning of the first is that it "purifies sins, destroys dualistic thinking, and destabilizes and expels conceptual notions and clinging to things as true. The second behavior is called totally good because the essence of the behavior is always good, whether it appears externally to be good or bad. The third is known as completely victorious because the person has actually achieved victory over the afflictions, the four māras have been subdued, he or she has the power to benefit sentient beings, and the obscuration of knowledge has also been destroyed."

Stearns states that the first phase of deliberate behavior involves practicing at night in charnel grounds and cemeteries, with either a real or imagined consort, and "engaging in various kinds of socially unacceptable behavior," for the sake of determining whether or not one's "awareness [rig pa?] is stable." If it is not, the yogi should not proceed further with this kind of practice until he is ready; if it is stable, he should practice in this way for a month in order to become accustomed to it. This stage of the yogi's practice is not represented in Stearns's list of three categories, unless it is taken as part of the avadhüti practice. The practice here described probably corresponds with what most commentators mean by "secret activity."

Then, "with a prophesied consort, and after requesting permission from his or her teacher," the yogi begins the avadhüti behavior, "which is to publicly pretend to be a crazy person, a fool, or another type of despised individual. Together with the consort or dākinīs, the practitioner does various kinds of unpredictable acts, such as singing, dancing, babbling, scolding, playing, laughing, running and leaping about it public, and engaging in prohibited sexual activities. The mind is kept focused in meditation at all times while doing these things that actually serve to further meditative concentration. Overt religious acts that might be recognized by other practitioners and reveal the nature of what is really going on are not done at this time."

Then one progresses to totally good behavior, in which the yogi reveals that he is practicing a yogic discipline. "Various miraculous deeds are performed to change the minds of those who lack faith,
} 
from whether the commentator sees pure monastic conduct as the highest ideal for one living a Buddhist life or only a stepping stone to higher tantric practices. ${ }^{166}$ In cases where "all-good activity" is placed first, the highest ideal is usually represented by "activity that is victorious in all respects," a term that gets much use in the biographies of the Madmen of Ü and Tsang, often to express the great state these yogis have achieved as a result of their distinctive behavior. For example, "activity that is victorious in all respects" is used in the title to the first part of the biography of the Madman of Ü and to the third version of the biography of the Madman of Tsang, expressive of the total

and techniques such as the charismatic gazes and so forth that are taught in the tantras are used to benefit sentient beings in different ways. Numerous ḍākinīs are effortlessly attracted."

When performing completely victorious behavior, according to Stearns, "[w]hile some conditions may have been slightly harmful before, nothing is harmful anymore. The same consort as before may still be relied on here, but since vast ability has been gained, various female spirits and ḍākinīs are also attracted."

Stearns maintains that these three types of practice correspond to people who are 1) "on the level of lesser warmth on the Path of Application"; 2) on the "level of middling warmth," "when the ordinary conceptual process has ceased"; and lastly 3 ) when a person "reaches the level of greater warmth," and by which he attains the Path of Seeing.

Summarizing, Stearns states that "The behavior of a madman and other unusual styles of action can be deliberately chosen according to the formulas described in the tantric treatises, or can also arise in a spontaneous and ecstacic way. A vision of a deity or some similar experience can serve as the catalyst for an ecstatic outburst of apparent madness or the assumption of a specific deliberate behavior," pp 60-62.

Some of the possibilites mentioned in Stearns' account will be discussed further below.

${ }^{166}$ Kenpo Nyima Gyeltsen cited the Dalai Lama as one who lives with perfect monastic conduct (tshul khrims) and thereby embodies "all-good behavior"; this is the highest ideal (interview, 4 October 2009, Dehradun). Kenpo Tsülnam Rinpoché also cited the Dalai Lama as the embodiment of "all-good behavior" on numerous occasions. 
freedom and boundless capacities the yogis are asserted to have achieved. ${ }^{167}$ In other

cases the term is used to describe the nature of their distinctive behavior itself. ${ }^{168}$

${ }^{167}$ Götsang Repa's version of The Life of the Madman of Tsang bears the title: The Life Story of the Madman of Tsang, the Heruka, Who is Victorious in All Directions: the Essence of the Sun that Elucidates the Vajrayāna (gtsang smyon he ru ka phyogs thams cad las rnam par rgyal ba'i rnam thar rdo rje theg pa'i gsal byed nyi ma'i snying po, $\mathrm{p} 1$ ). The first part of The Life of the Madman of Ü bears the title: The Life Story of the Venerable Künga Zangpo, Glorious Holy Lama, Foremost among the Siddhas, whose Activity is Totally Victorious in All Directions, Called, "That Which Without Bias Gives Goosebumps of Faith" (dpal ldan bla ma dam pa grub pa'i khyu mchog phyogs thams cad las rnam par rgyal ba'i spyod pa can rje btsun kun dga' bzang po'i rnam par thar pa ris med dad pa'i pu long g.yo byed), $\mathrm{p} 383$. This title is repeated, in slightly varying formulations, at the end of each of the five chapters that comprise part I of the Life.

${ }^{168}$ Traditional commentators and present-day informants often assert that the term phyogs thams cad las rnam par rgyal ba' $i$ spyod $p a$ as having one specific meaning: either it is distinctive activity engaged in to destroy one's conceptual formations, or distinctive activity engaged in to tame other beings; or it is a state of utter freedom that one may hope to achieve. (There are similarities between the way this term is understood and the way holy madness in general tends to get explained.) But if we look closely at the way the term is used in even just two texts, we see that the term can bear multiple meanings.

For example, in a section best understood as a sort of overture, giving a summary of the fuller description of The Life of the Madman of Tsang that is to follow, it is said that the yogi "was a great hero who achieved the four types of activity without difficulty, and by means of his performance of engaged asceticism that was victorious in all respects completely annihilated all the demons and negative forces, and set them on the path of goodness ("phrin las rnam bzhi thogs med du grub cing brtul zhugs kyi spyod pa phyogs thams cad las rnam par rgyal bas bdud dang log 'dren ma rungs pa thams cad tshar gcad nas yang dag pa'i sa la 'god pa'i dpa'o [sic] chen po), Götsang Repa, p 9.5-.6. Note that in this instance the desciptor "victorious in all respects" modifies "the performance of engaged ascetisim." Later the term is used slightly different manner, describing the contents of a chapter: "this was the chapter describing the way [the Madman of Tsang], like the king of the wild beasts among small deer, was victorious in all directions by means of his performance of engaged asceticism" (ri dags phra mo'i nang na can zan gyi rgyal po ltar brtul zhugs kyis spyod pas phyogs thams cad las rnam par rgyal ba'i bskor tsho de le'u brgyad pa'o/), Götsang Repa, p 49.4. Here it is implied that the Madman of Tsang was "victorious in all respects" because of his performance of engaged asceticism, which posits them as two separate things, the former achieved by means of the latter. This same chapter was described earlier (p 11.3-.4), with the terms having the same causal relationship: "by means of his performance of engaged asceticism [the Madman of Tsang] roamed in the great abodes, charnel grounds and frightening places and was victorious in all directions" (btul zhugs kyi spyod pas gnas chen dang dur khrod gnyan sa rnams nyul zhing phyogs thams cad las rnam par rgyal ba'i le'u). Thus in The Life of the Madman of Tsang, the term is used both to refer to a form of engaged asceticism and the sort of state one might hope to achieve as a result of such behavior.

In The Life of the Madman of $\ddot{U}$ the term is used in a consistent but still ambiguous manner. On a number of occasions the term appears as "activity that is victorious in all respects" (phyogs thams cad las rnam par rgyal ba'i spyod pa). In these cases the meaning of the term - whether it is meant to imply a means of accomplishment or a state of accomplishment - is ambiguous. It seems that both meanings apply to some extent (see pp 443, 453, 496, 556-7). However, in many cases it is stated that by means of the Madman of Ü's activity that is victorious in all directions he "outshined with his brilliance" (zil gyis mnan) other beings. This suggests that the term carries the meaning of a state of accomplishment.

In The Life of the Madman of $\ddot{U}$ the term is also used in a more generic sense: on two occasions it is used as a form of praise to a warlord, the Madman of Ü's patron Rinpungpa Dönyö Dorjé (pp 510, 518). This shows that the term held meaning in a way completely removed from the kind of distinctive tantric activity we have been discussing here. However, there are enough instances in which the two ("activity that is victorious in all respects" and distinctive "activity" (spyod pa or brtul zhugs) are used together that 
The performance of engaged asceticism has been described in many different ways by various Tibetan commentators and in the life stories of the Madmen of $\ddot{U}$ and Tsang. There is no way to sort out all of these inconsistencies; there is a high degree of disagreement in the way people describe these practices, and no single understanding to be arrived at. (Complicating the picture further, these practices and the categorization of them are presented in additional varying ways by commentaries on the Highest Yoga Tantras, as will be discussed later in this chapter.) These inconsistencies and ambiguities aside, these terms give an accurate rendering of the behavior exhibited by the Madmen of $\ddot{U}$ and Tsang. ${ }^{169}$ Their lives exhibit phases of living in accordance with the dictates of monasticism, practicing in frightening and out of the way places, doing unimaginable things in public places, and exhibiting "activity that is victorious in all respects." In a meaningful sense, through consistently using these terms and continually relating the yogis' activity with the performance of engaged asceticism, the biographies of the Madmen of Ü and Tsang portray them in such a way that the entire trajectory of their lives reflects this course of spiritual development. As we will now see, the performance

\footnotetext{
we can assume that in most cases, a more specific meaning is implied (including when the author clearly mentions "activity that is victorious in all directions" directly alongside "secret activity," "public activity" and "all-good activity," as on $\mathrm{p}$ 522.1).

${ }^{169}$ Adding to the diversity with which commentators describe practices associated with brtul zhugs kyi spyod pa, Dungkar Rinpoché states that brtul zhugs kyi spyod pa involves three types of activity, which are "activity with elaborations" (spros bcas kyi spyod pa), "activity without elaborations" (spros med kyi spyod $p a$ ), and "activity that is thoroughly without elaborations" (shin tu spros med kyi spyod pa), Dungkar Rinpoché dictionary, p1019.

The Third Karmapa uses a similar three-fold classification when explaining brtul zhugs kyi spyod $p a$ in his commentary on the Hevajra Tantra: "activity with elaborations" (spros pa dang bcas pa' $i$ spyod $p a$ ), "activity without elaborations" (spros pa med pa'i spyod pa), and "activity that is not beyond vows and commitments" (dam tshig dang sdom pa la mi 'da' ba'i spyod pa), pp 142-156. The rubric described by Dungkar Rinpoché will be described further below, as it pertain's to Āryadeva's Lamp that Integrates the Practices and the Guhyasamāja tantra.
} 
of engaged asceticism is not just something the Madmen of Ü and Tsang practiced, but was absolutely central to the nature of their distinctive behavior and their public personas.

\section{II.2 "...there is no rivaling the Madman of Tsang or the Madman of Ü in engaged asceticism..."}

The close association between the Madmen of Ü and Tsang and the performance

of engaged asceticism is evinced by the fact that when their biographers refer to them in a general sense, they often use the language of the performance of engaged asceticism to describe them. Götsang Repa describes the Madman of Tsang in the opening verse of his biography as "the supreme glorious protector, the Heruka fully perfected in engaged asceticism. ${ }^{, 170}$ In another verse of praise, Götsang Repa describes him as

Great Vajrasattva, in the form of a man, possessed of the power of performing engaged asceticism, the master from Tsang, unequalled in the three realmsto that glorious Heruka I prostrate! ${ }^{171}$

Other of the 15th-century holy madmen's peers perceived them through the idea of the performance of engaged asceticism as well. In the "Autobiography" of Drukpa Künlé, during a somewhat rambling monologue, the yogi states: "There is no rivaling Sakya Paṇ̣ita in intellect; .... there is no rivaling Atîśa and his students in terms of bodhicitta; there is no rivaling the Dakpo Kagyü in terms of realization; there is no rivaling the Madman of Tsang or the Madman of Ü in engaged asceticism (brtul

\footnotetext{
${ }^{170}$ Götsang Repa, p 4.6, brtul zhugs mthar phyin he ru ka dpal mgon po mchog. In his version of The Life of the Madman of Tsang, Lhatsün Rinchen Namgyel addresses a verse of praise to the mad yogi directly, saying "you who are perfected in the performance of engaged asceticism..." (brtul zhugs spyod pa mthar phyin khyod), p 53.3-.4.

${ }^{171}$ rdo rje 'chang chen mi yi gzugs/ brtul zhugs spyod pa'i mthu stobs can/ sa gsum mtshungs med gtsang pa rje/ he ru ka dpal la phyag 'tshal/, Götsang Repa, p 259.3-.4.
} 
zhugs)..." ${ }^{172}$ In a verse of praise to the Madman of Ü the great Kagyü scholar Karma Trinlepa refers to him as a "master of engaged asceticism." 173 The 16th-century history The Scholar's Feast by Pawo Tsuklak Trengwa includes a brief account of the life of Nyukla Penchen Ngawang Drakpa (1458-1515), a disciple of the Madman of Ü and the author of the first part of his biography. After having become accomplished as a scholar (mkhas) and a monk (btsun), Nyukla Peṇchen met the Madman of Ü "while performing the engaged asceticism of awareness," during which the young monk was impressed by the yogi's doing miraculous feats, arising unharmed after being attacked and pinned under a large heap of rocks. ${ }^{174}$

As the traditional history would have it, the Madman of Tsang's special association with the performance of engaged asceticism extended even beyond the bounds of his lifetime. At the beginning of his version of The Life of the Madman of Tsang, Götsang Repa quotes a verse of praise prophesying the future coming of the Madman of Tsang, derived from a treasure revealed at Samyé by the treasure revealer Changchub Lingpa. It is stated that in a snake year one will be born into the Nyang clan

\footnotetext{
${ }^{172}$ sa skya paN+Di ta la rig pa ma 'gran/.... jo bo rje yab sras dang byang chub kyi sems ma 'gran/ dwags po bka' brgyud dang rtogs pa ma 'gran/ gtsang smyon dbus smyon dang brtul zhugs ma 'gran/ ,'brug pa kun legs kyi rnam thar (Beijing, 2005), p 202. Stein, Vie et chants... translates this passage as “... avec le Seigneur (Atiśa) et ses fils (spirituels) il ne faut pas se mesurer en Pensée-de-Bodhi, avec les bKa'brgyud de Dvags-po (lha-rJe, alias sGam-po-pa) il ne faut pas se mesurer en illumination, avec le Fou de gCan et le Fou de dBus il ne faut pas se mesurer en conduite exceptionnelle...”, p 320.

${ }_{173}$ brtul zhugs kyi dbang po..., p 78.5. This verse of praise to the Madman of Ü (dbus smyon pa la bstod pa) runs pp 78.4-79.3 in The Songs of Esoteric Practice (mgur) and Replies to Doctrinal Questions (dris lan) of karma-'phrin-las-pa.

${ }^{174}$ rje dbus smyon pa rig pa brtul zhugs kyi spyod pa mdzad skabs smyug lar mi gcod mdzad dbu thod rag rug tu chag rdo phung chen pos mi mthong bar mnan yang har gyis bzhengs te rlung ro gcig bsal bas sku lus skyon med du gyur te mgur len zhing mgyogs par byon pa la thugs dad cher 'khrungs te chos mang du gsan zhing rigs drug 'khor lo'i khyab bdag rdo rje 'chang / zhes pa'i bstod dang rnam thar yang mdzad/in the Scholar's Feast (mkhas pa'i dga' ston, mi rigs dpe skrun khang, 2006), p 592. This passage is reused word for word in Situ Penchen and Belo Tsewang's history of the Karma Kagyü sect, when relating the life of Nyukla Penchen, bsgrub brgyud karma kaM tshang brgyud pa rin po che'i rnam par thar pa rab 'byams nor bu zla ba chu shel gyi phreng ba (New Delhi: published by D. Gyaltshan and Kesang Legshay, 1972; TBRC W23435), p 648.3-.9.
} 
who "does the performance of engaged asceticism, bearing the name 'Madman"" (btul [sic] zhugs spyod pa smyon pa'i ming /). ${ }^{175}$

The idea of the performance of engaged asceticism thus played a vital role in shaping how the Madmen of Ü and Tsang's activities were interpreted by their peers. The performance of engaged asceticism runs throughout the entirety of their biographies, explaining individual aspects of their behavior, and informing how their biographers present the entire course of their lives. It was also a central part of their public legacies, as reflected in the way other contemporaries wrote about them.

Given the centrality of the performance of engaged asceticism in creating the Madmen of Ü and Tsang's public personas in 15th- and 16th-century Tibet and the consistency with which these terms are used to describe their distinctive behavior in their biographies, it is surprising — and very telling - how little mention the performance of engaged asceticism has received in Tibetan and non-Tibetan scholarly and popular commentators' explanations of their "mad" behavior. The only modern sources that give the term serious treatment are those by Stefan Larsson and Cyrus Stearns. ${ }^{176}$ In the course of my many interviews with Tibetans about the nature of the behavior of the holy madmen, none readily used the language of the performance of engaged asceticism or any related terms, like "secret activity" or "public activity." Instead, they most often

\footnotetext{
${ }^{175}$ Götsang Repa, pp 6.7-7.1.

${ }^{176}$ Stearns' discussion of brtul zhugs kyi spyod pa (which he translates as "deliberate behavior") (2006, pp 58-80) desipte being the most comprehensive I have seen, makes no mention of the sort of distinctive form of dress that was a central part of the Madmen of Ü and Tsang's performance of engaged asceticsm. On the other hand, Stearns makes numerous mentions of "feigned madness" and the fact that the "mad yogin has gained freedom from the limitations and bonds of saṃsāra, while worldly people are trapped by the stringent ties of their narrow viewpoints," pp 74-5.

Stefan Larsson, The Birth of a Heruka: How Sangs rgyas rgyal mtshan became gTsang smyon Heruka: A Study of a Mad Yogin (Ph.D. dissertation, University of Stockholm, Institutionen för etnologi, religionshistoria och genusstudier, 2009).
} 
relied on the traditional explanation that the eccentric behavior of the Madmen of $\ddot{U}$ and Tsang was a byproduct of their enlightenment, and thus were not inclined to see it as an aspect of the yogi's spiritual training. Once I suggested that their distinctive behavior be understood as an example of these practices, some lamas accepted that it was a possibility; others maintained that it certainly was not. One could argue that the general explanation sometimes offered by Tibetans - that the holy madmen's eccentric behavior was a form of training for overcoming conceptual thinking (rnam rtog) — may cover the meaning expressed by the performance of engaged asceticism. However, I believe that most of these commentators are suggesting a form of religious practice that is more freewheeling than the specific regimen the Madmen of $\ddot{U}$ and Tsang are described as following by their biographies. To this end, it is significant that none of the lamas I interviewed mentioned the fact that the holy madmen had spent much of their lives wearing the fearsome garb of a wrathful deity, which, as we will see below, was an absolutely central part of their performance of engaged asceticism and their public identities.

In this section we have discussed the way the Madmen of Ü and Tsang's biographers chose to portray their eccentric behavior as part of a directed set of yogic practices, known as the performance of engaged asceticism. Here we have developed a general framework for how the practice is written about and how it applies to the lives of the Madmen of Ü and Tsang. A few key issues remain to be addressed. One is the distinctive mode of dress the Madmen of $\ddot{U}$ and Tsang featured, which played such an essential role in forming their public personas. Another important question is where this performance of engaged asceticism was derived from. As we follow this trajectory and 
flesh out what the performance of engaged asceticism meant for the Madmen of Ü and Tsang we will arrive at a new understanding of their distinctive behavior.

\section{III. Macabre Herukas and Tantric Fundamentalists: Engaged Asceticism continued}

As was mentioned above, in addition to denoting a phase of tantric practice

(posited as a part of the performance of engaged asceticism, synonymous with it, or a prerequisite for it), "secret activity" (gsang spyod) also refers to a specific cycle of texts and ritual practices. The Madman of Tsang on numerous occasions received and gave teachings on a text or practice called The Secret Activity of Nāro[pa], and even wrote about it. ${ }^{177}$ The Madman of $\ddot{U}$ also received and taught texts or practices called Secret Activity, sometimes as part of "the Eight Great Instructions of the Drukpa" ('brug pa' $i$ khrid chen brgyad). ${ }^{178}$ The "Secret Activity" texts the Madman of Ü received and taught were referred to by a variety of related names, including The Secret Activity of Nāro ( $n A$ ro gsang spyod), The Secret Activity of India (rgya gar gsang spyod) or often just Secret Activity. Whether these are distinct texts and practices or different ways of referring to the same thing can be determined only if we find separate texts that bear these titles. ${ }^{179}$

\footnotetext{
${ }^{177}$ Götsang Repa, pp 24.4; 142.3: de nas na ro chos drug dang gsang gcod [sic] dang snyan rgyud sogs zab khrid rnams dang / rtag gnyis mdo [sic] ha sogs rgyud dang bstan chos 'dor na zab chos thams cad yongs su rdzogs par snang /. Interestingly, this passage suggests that the Secret Activity of Näro would have been taught alongside the much better known Six Dharmas of Näro; 190.6: gzhan yang $n A$ ro gsang spyod/ sngo ba rgyas sdus rnams gsung rtsom mdzad do/. The shad in the text here may well be a mistake, in which we would read the line as saying that he composed, "the expansive and abbreviated dedications of the Secret Activity of Nāro." The Madman of Tsang's practicing the Secret Activity of Nāro is also mentioned in Ngödrup Pelbar's version of his life story, p 9a6.

${ }^{178}$ The yogi receives gsang spyod sogs khrid chen brgyad, The Life of the Madman of Ü, p 404. Dungkar Rinpoché lists gsang spyod ldog sgom gyi khrid as one of the khrid chen brgyad of Tsangpa Gyaré, Dungkar Rinpoché dictionary, $\mathrm{p} 406$.

${ }^{179} \mathrm{On}$ one occasion the Madman of $\ddot{U}$ is said to have received gsang spyod (p 404); on other occasions he is said to have received or taught na ro pa'i gsang spyod (pp 410-1), rgya gar gsang spyod (pp 458, 573, 580), mai tri rgya gar gsang spyod che chung ( $\mathrm{p} 410)$, rgya gar gsang spyod che chung ( $\mathrm{p} 598)$. Based on the way they are used in the life story, I would hazard a guess that rgya gar gsang spyod and nA ro gsang
} 
Our purpose here is to establish the role these texts and practices played in motivating the distinctive behavior of the holy madmen. It is telling that on one occasion the Madman of Ü stated that The Secret Activity of India was one of the distinctive teachings (gdams $p a)$ of the Kagyü sect, along with the Mahāmudra, the Six Dharmas of Nāropa, and the Dohās. He then instructed one of his students (Nyukla Penchen, author of the first part of the yogi's biography) to have a copy of The Secret Practice of India printed (along with the Dohās, and the Life and Songs of Milarepa). ${ }^{180}$ More telling still, late in his life when the Madman of Ü was giving a teaching to followers gathered at Tsimar Pel, the Madman of Ü said, "The essence of all the Teachings [of the Buddha] and all the treatises is this...", then proceeded to give oral instructions on the Secret Activity of India. ${ }^{181}$

These practices clearly held a special significance for the Madmen of $\ddot{U}$ and Tsang. But what were they about? There are a handful of texts surviving in various collections of Kagyü texts that bear the titles Secret Activity and The Secret Activity of Nāro. Based on the texts I have reviewed, The Secret Activity of Nāro refers to a meditation practice very similar to "Cutting" ( $g c o d)$. (In fact, there seems to be much overlap between the two, as the homophonous spyod and gcod are often used (mistakenly?) as interchangeable. ${ }^{182}$ ) In the practice described by a text titled The Manner of Performing the Recitation and Visualization for the Secret Activity of Nāro

\footnotetext{
spyod are used interchangably. As yet I have not been able to find any other reference to the Secret Activity of Maitri. I have asked a number of learned Kagyüpas if they were familiar with any of these texts or practices, but none were able to offer any clarification.

${ }^{180}$ The Life of the Madman of $\ddot{U}, \mathrm{p} 592$.

${ }^{181}$ lo de'i dbyar chos 'dzugs pa gnang ba na tshogs pa'ang shin tu che ba byung ba la/ skyes bu chen po'i zhal nas bka' bstan bcos thams cad kyi snying po 'di yin gsung nas/ rgya gar gsang spyod kyi gdam ngag gnang /, The Life of the Madman of $\ddot{U}, \mathrm{p} 642$.

${ }^{182}$ For examples, see Götsang Repa, p 142.3 (gsang gcod), and pp 520-2 in The Life of the Madman of $\ddot{U}$, where gcod and spyod are used interchangeably without much care.
} 
( $n$ A ro gsang spyod kyi 'don dmigs bya tshul), included in a collection of Drukpa Kagyü texts compiled by Pema Karpo, one begins by visualizing oneself as a gruesome Vajrayoginī holding a curved knife and a skull cup filled with blood, smeared with ash, wearing human skulls — of both dried and dripping varieties — with the wrathful deity Heruka standing before one. The meditator then makes supplications to some deities and the masters of the lineage-Nāropa, Rechungpa, Lingrepa, Tsangpa Gyaré, and many others. Then one visualizes Vajrayoginī in front of oneself, holding a sword. The practitioner visualizes her cutting him with it, then makes makes an offering of his body — to the lama and the deities, and satisfying the desires of all the inhabitants of cyclic existence. The practice ends with making a wish that all sentient beings may become free from suffering. ${ }^{183}$

We have no reason to doubt that the "secret activity" practices learned and taught by the Madmen of Ü and Tsang were similar to the one described in this sädhana included in the collected works of Pema Karpo, a later bearer of their lineage. And it is likely that these texts represent some of the practices that would have been performed during the "secret activity" phase of the yogi's practice (as part of the typically four-fold

\footnotetext{
${ }^{183}$ This is the meditation described in $n A$ ro gsang spyod kyi 'don dmigs bya tshul, in Rtsib-ri spar-ma: the collected instructional material on the practice of the teachings of the Dkar-brgyud-pa and Rdzogs-chen traditions (collected and arranged into a coherent structure and carved on to xylographic blocks at La-stod Rtsib-ri from 1934 through about 1958 by La-dwags Khrid-dpon 'Khrul-zhig Padma-chos-rgyal) (Darjeeling: Kargyud Sungram Nyamso khang, 1978-1985), Vol. 7, pp 485-99; also included in the collected works (gsung 'bum) of the 8th 'brug chen, 'kun gzigs chos kyi snang ba (1768-1822) (Rewalsar, Distt. Mandi: Zigar Drukpa Kargyud Institute, 1985), vol 3, pp 745-53.

Another text on the visualization of the Secret Activity of Nāro in included in the collected works of Pema Karpo, Vol. 17, pp 1-19, in Collected works (gsui 'bum) of Kun-mkhyen Padma-dkar-po, Reproduced photographically from prints from the 1920-1928 Gnam 'Brug Se-ba Byan-chub-glin blocks (Darjeeling: Kargyud Sungrab Nyamso Khang, 1973-1974, 24 volumes); also included in pp 501-27 in Vol. 7 of the Rtsib-ri spar-ma collection cited above. In this latter printing the practice is said to be a "reversing meditation" (zlog sgom, p 502), a term that is often used to describe these Secret Activity practices.
} 
progression of practices described above), although we should not assume that these practices represent the entirety of that phase of practice. ${ }^{184}$

These Secret Activity practices constitute one part of the macabre activity performed by the Madmen of Ü and Tsang. Much of their macabre activity can be understood as their doing Cutting-style meditative practices, to which Secret Activity was clearly related (and as we will see in Chapter Seven, the connection between the Cutting tradition and Tibetan "holy madmen" is a longstanding one, dating to well before the 15th century). The Madmen of Ü and Tsang are both said to have ended epidemics, an ability often attributed to practitioners of "Cutting."185 But the Madmen of Ü and Tsang went a few steps beyond this: not only did they perform these meditative practices and teach them to their students, but they made themselves walking embodiments of the cult of the macabre. Their very literal embracing of the the macabre is best understood through a consideration of the distinctive clothing they wore, which played a key role in the formation of their public personas and holds the key for our understanding of the nature of their seemingly eccentric activity, and thus their "madness."

\footnotetext{
${ }^{184}$ The practice described in this and another Secret Activity of Nāro text bears a close relation to the "secret activity" practiced by the Madmen of Ü and Tsang. As one passage in The Life of the Madman of Tsang describes, "... during the day he received teachings on the Secret Activity of Glorious Nāro as the critical aspect of (?) the Spoken Red Instructions (?), and at night he wandered in haunted places, practicing the 'secret activity,' whereby most of the non-human spirits offered their lives to him, and he bound them with oaths. In particular, he practiced Cutting (gcod; should this perhaps be spyod pa, short for brtul zhugs kyi spyod pa?) beneath a tree, and thereby had much improvement." de nas dpal na ro pa'i gsang spyod bka' ma dmar khrid du gnad che nyin mo gsung chos gsan mtshan mo snyan sa gang 'dug 'grim zhing gsang spyod skyangs pas/ mi ma yin phal che bas srog snying phul zhing dam la thogs/ khyad par shing sdong rkang cig gcig yod pa'i 'og du gcod mdzad pas bogs shin tu che ba byung ..., Götsang Repa, p 24.4.5 .

${ }^{185}$ The Life of the Madman of $\ddot{U}, \mathrm{p}$ 495.4-.6; Götsang Repa, pp 71.6-72.1, 83.5-84.3.
} 


\section{III.1 The Garb of the Heruka}

In their article on Tibetan "holy madmen," summarized in Chapter One, John Ardussi and Lawrence Epstein mention that the holy madmen were known for an "inclination toward bizarre modes of dress." 186 In the cases of the Madmen of $\ddot{U}$ and Tsang, although the mode of dress may have been striking, it was consistent, purposeful, and not the least bit random. Close attention to their distinctive mode of dress will bring us to a deeper understanding of what these "holy madmen" were trying to embody through their behavior.

The trajectories of the lives of the Madmen of Ü and Tsang are defined by a dramatic turn in which the future saints left their lives as monks in favor of one defined by the kind of eccentric activity we have been discussing here. This turn is marked by a change in dress that would come to exemplify what the holy madmen strived to represent. In the biographies of Künga Zangpo and Sangyé Gyeltsen it is described how each, in his $20 \mathrm{~s}$, in a defining moment took off his monastic robes and started to dress in a much more macabre fashion. In The Life of the Madman of Tsang this change is portrayed as having been prompted by Sangyé Gyeltsen's feeling of disillusionment with monastic life and his wish to practice a different form of Buddhism. At the time of his definitive break with monasticism, it is said that Sangyé Gyeltsen had begun to behave in a nonsensical way and act disrespectfully towards other members of the assembly. Then one day when the monks were gathered to receive a visit from the rulers of the town of Gyantsé, Sangyé Gyeltsen arrived carrying a skull cup and a thigh-bone trumpet. He drank tea and soup from the skull, and then mixed a paste of tsampa and cheese (mar thud) in it using the

\footnotetext{
186 “The Saintly Madman in Tibet,” p 332.
} 
thigh bone. All the monks laughed. When the disciplinarian (chos khrims pa) scolded him, Sangyé Gyeltsen asked, "Where in the sütras and tantras does it say one cannot carry a skull cup and thighbone trumpet in the line of monks? Answer me!" "187 The disciplinarian was unable to make a response. Then Sangyé Gyeltsen began to think seriously about leaving the monastery. He reasoned that the monk's robes did not accord with performing austerities and practicing tantra, and thus decided to give his robes back to the monastic assembly. He then spent a night on the roof of the monks' dormitory reciting the Hevajra tantra. Then he left, headed for Tsari. ${ }^{188}$ Shortly thereafter he began to perform shocking behavior in public, dressing strangely and impressing people with his engaged asceticism. ${ }^{189}$

As we saw in the passage with which this chapter began, the Madman of Ü's transformation was quite similar: he made the conscious decision to give up his monk's robes and take on a very different form of dress, "the emblems of the Heruka." As evinced by the trajectories of the lives of the Madmen of $\ddot{U}$ and Tsang, wearing the emblems of the Heruka and performing engaged asceticism go hand in hand. Above we saw the Madman of Tsang make this connection explicitly, when he stated that at the time when one enters into the performance of engaged asceticism of awareness (rig pa brtul zhugs tshogs kyi spyod pa la 'jug), one should adorn oneself with the emblems of a Heruka. ${ }^{190}$ Marpa also makes this association, when in his commentary on the Hevajra tantra, titled The Sun of the Little Collection (? 'bum chung nyi ma), he glosses the

\footnotetext{
${ }^{187}$ thod pa dang rkang gling dge 'dun gyi gral du khur mi chog pa mdo rgyud ga nas bshad/ khyod kyi [sic] bsgrubs dang /, Götsang Repa, p 28.5.

${ }_{188}$ This story is related in Götsang Repa, pp 27.7-29.4; E. Gene Smith, "Introduction to The Life of Gtsang smyon Heruka," 2001 reprint, p 64.

${ }_{189}$ Götsang Repa, pp 30.6-.7 and 33.4.

${ }^{190}$ Götsang Repa, p 231.1-.2.
} 
meaning of brtul zhugs kyi spyod pa in the following manner: "As for the meaning of the taming and entering, having tamed one's activity with one's ordinary body, one enters into the way of wearing the ornaments of the Heruka."191 For many Tibetan commentators, the performance of engaged asceticism is all but synonymous with the odd manner of dress that was iconic for the Madmen of Ü and Tsang.

The distinctive dress adopted by the Madmen of $\ddot{U}$ and Tsang is described throughout their biographies as "the emblems of the Heruka" (he ru ka'i chas) ${ }^{192}$ (sometimes said to be eight-fold, he ru ka'i chas brgyad ${ }^{193}$ ), "the mode of dress of the Heruka" (he ru ka'i cha lugs), 194 "the emblems of the charnel ground" (dur khrod kyi chas $)^{195}$ or "the bone ornaments" (rus pa'i rgyan) ${ }^{196}$ (often said to be six-fold). ${ }^{197}$

There remains some question as to what individual emblems constitute these various overlapping sets. According to Dungkar Rinpoché, the "six bone ornaments" should be 1) a diadem; 2) earrings; 3) throat ornament or choker; 4) a girdle or sash (mchod phyir thogs); 5) bangles [worn on the wrists]; and 6) anklets. ${ }^{198}$

\footnotetext{
${ }^{191}$ brtul zhugs ni tha mal lus kyi spyod pa brtul nas/ he ru ka'i rgyan cha lugs su zhugs pa'o/, p 99.

${ }^{192}$ he ru ka'i chas, The Life of the Madman of Ü, pp 441.2, 505.6.

${ }^{193}$ he ru ka'i chas brgyad, The Life of the Madman of Ü, pp 613.4, 630.5.

${ }^{194}$ Götsang Repa, pp 230.3-231.3. This passage was quoted above, in which an interlocutor tells the Madman of Tsang that he knew of yogis wearing the manner of dress of a Heruka in India but considered it to be unprecedented in Tibet.

${ }_{195}$ dur khrod kyi chas, The Life of the Madman of $\ddot{U}, \mathrm{p} 449.5$.

${ }^{196}$ rus pa'i rgyan, Götsang Repa, p 124.1.

${ }^{197}$ rus pa'i rgyan drug, The Life of the Madman of $\ddot{U}, \mathrm{p} 439.1$.

${ }^{198}$ Dungkar Rinpoché dictionary, p 1920: rus pa'i rgyan drug: 1) rus pa'i dbu rgyan, 2) rna rgyan, 3) mgul rgyan, 4) mchod phyir thogs, 5) lag gdub, 6) rkang gdub. Dungkar Rinpoché's definition of the he ru ka'i rgyan drug (p 2135) imlplies that they are the same as the "six bone ornaments." The Cakrasamvara tantra and its commentaries make occasional reference to this same set of six ornaments (Gray, p 165), as well as to a set of five ornaments, which are the same save for the absence of the ashes. Gray translates these five as "necklace, crest jewel, earring, choker and the sacred thread" (p 278; also p 304). The Cakrasamvara tantra (Gray, p 377), fleshed out by a commentary, provides a list quite similar to the set of fourteen ornaments described by Dungkar Rinpoché. It includes: the upper elephant skin, lower tiger skin, the five insignia (which are the six "bone ornaments," minus the ash), a vajra and bell, plus six additional implements.
} 
The "eight ornaments of the charnel ground" include: 1) a necklace with five dry skulls and 50 wet skulls; 2) a snake (Geshé Tubten Sampel clarifies this as sbrul rgyan, a "snake ornament"199) ; 3) an elephant hide, worn on the upper part of one's body; 4) a human skin, worn around the middle of the body; 5) a tiger skin, worn as a skirt; 6) ashes from a human corpse, smeared on one's forehead; 7) blood dabbed between one's eyebrows $^{200}$; and 8) fat smeared on one's throat. ${ }^{201}$

Lastly, Dungkar Rinpoché lists "the fourteen emblems of the Heruka," which include: 1) the six bone ornaments; 2) fat; 3) clumps of human corpse ash; 4) drops of blood; 5) a skull cup; 6) a khațvànga staff; 7) a curved knife; 8) a damaru; 9) a small drum; 10) a thigh bone trumpet; 11) a human corpse used as a cushion; 12) a tiger skin used as a cushion; 13) a human skin as a garment; and 14) a tiger skin worn as a skirt. ${ }^{202}$ These lists represent an ideal mode of dress drawn from canonical sources. The second chapter of the Cakrasamvara tantra states that the yogi should be smeared with ash, wear a crown, [the six bone] ornaments (which the commentator Jayabhadra identifies as a necklace, diadem, earrings, choker, sacred thread and ash), a bone garland, and have his hair formed into a plait. ${ }^{203}$ The 27 th chapter of the tantra provides an expanded list of the yogi's ideal dress, including: an animal hide, a choker, armlet, earring, sacred thread, a garland of heads around his neck, a girdle, anklets, and dredlocks adorned with strips of cloth. The practitioner should bear a "vajra and lotus" (which may

\footnotetext{
${ }^{199}$ p 315.

200 Geshé Tubten Sampel says the blood should be dabbed on one's cheeks, p 315.

${ }^{201}$ Dungkar Rinpoché dictionary, p 1082: dur khrod chas brgyad. An almost identical list is given by Geshé Tubten Sampel, p 315.

${ }^{202}$ Dungkar Rinpoché dictionary, p 2135: he ru ka'i chas bcu bzhi.

${ }^{203}$ Gray, pp 164-5.
} 
refer to a skull marked with a vajra), a skull-staff (khațvāiga), and a damaru drum. ${ }^{204}$ As is often the case in the world of the Highest Yoga Tantras, complete agreement across different texts and commentators is hard to find.

We cannot be certain that the dress taken up by the Madmen of $\ddot{U}$ and Tsang matched any of these idealized lists completely. The only instance in the course of their biographies when the yogi's dress is described in its entirety is the passage from The Life of the Madman of $\ddot{U}$ with which this chapter began. There the yogi's dress is said to include the "six bone ornaments," here consisting of 1) a crown (made of his own hair); 2) earrings; 3) a throat ornament; 4) bangles; 5) girdle or sash; 6) anklet (rus pa'i 'khor lo; perhaps meaning some other kind of ornament?). These six match quite well with what Dungkar Rinpoché suggests is the normative list of the "six bone ornaments." In addition, the future Madman of Ü adorned himself with corpse ash, blood, and fat; he wore a human skin and a tiger's hide; he had a skull cup, khațvāiga staff, damaru, small drum, thighbone trumpet, and also a vajra and bell, sword and bow and arrow. In this list the yogi's dress nearly matches the "fourteen emblems of the Heruka" as listed by Dungkar Rinpoché; the only thing missing is an elephant skin. The Madman of Ü also bears some additional items (vajra and bell, sword and bow and arrow) that are relatively conventional for a yogi to carry. In this passage the Madman of Ü's dress is most broadly referred to as "the emblems of the charnel ground."

Towards addressing how closely the garb worn by the Madmen of Ü and Tsang corresponded to the ideal forms of these items, let us consider the khațvaniga staff, which

\footnotetext{
${ }^{204}$ Gray, pp 277-8. Complicating matters further, it seems that most of this list is missing from most Tibetan recensions of the tantra.
} 
was a central part of their distinctive garb. There is some diversity in how the ideal khațvāinga staff is described and defined by various commentators. Some say it is a staff with a skull on it; some say it bears three skulls; some say it should be a trident, and so on. ${ }^{205}$ Geshé Tubten Samdrup offers a detailed description of the ideal staff, stating that the actual meaning of the word khațāinga (kha TwAMga) is "six-limbed," meaning that it bears six distinctive features. Ideally the staff should include be central shaft adorned with: 1) a five-pronged vajra; 2, 3, 4) three human heads (mi mgo); 5) a crossed vajra (sna tshogs rdo rje); 6) and a pot (bum pa). Geshé Tubten Samdrup goes into greater detail, explaining various details of this staff and the symbolic significance they bear. For example, the shaft should be octagonal, its eight corners referring to the eight great charnel grounds of India; the lowest of the three heads should be wet (rlon pa) and black; the head on top of that should be old and red; the head on top of that should be dessicated and white; each head refers to a set of sixteen $d \bar{a} k a$ s and $d \bar{a} k i n \bar{\imath} \mathrm{s}$. (Geshé Tubten Samdrup also notes that according to one source, the three skulls refer to (mtshon pa) the body, speech and mind of the Buddha. ${ }^{206}$ )

\footnotetext{
${ }^{205}$ M. Monier-Williams, in his Sanksrit-English Dictionary (Delhi: Motilal Banarsidass, 2005) says the term khațāniga is related to the word khațā, which means "a bedstead, couch, cot"; khațāniga means "“a club shaped like the foot of a bedstead,' i.e. a club or staff with a skull at the top (considered as the weapon of Śiva and carried by ascetics and Yogins)." Śiva is sometimes referred to by the name khațvängadhara, "staff-bearer," p 335

Sarat Chandra Das, A Tibetan-English Dictionary (Delhi: Motilal Banarsidass, 1970-2000) follows Monier-Williams' definition, but also suggests that it may be in the form of a trident, or a staff with three skulls, stacked vertically, with the lowest one resting on a pot. Das maintains tha this version of the staff was introduced to Tibet by Padmasambhava. (Das notes the alternative Tibetan spellings kha tam ga and kha Twam ga, and so on), p 127.

The bod rgya tshig mdzod chen mo (mi rigs dpe skrun khang, 1996) (spelling the term kha TwAM $\mathrm{ga}$ ) defines it as a (wooden) staff with three dried skulls (thod skam) stacked towards one end, and on top of which there is a three pointed [trident-like] shape (Vol. I, p 194).

${ }^{206}$ pp 60-1.
} 
The khațāinga staffs possessed by the Madmen of Ü and Tsang are mentioned numerous times in their biographies, but they are never described in full detail, so we cannot be certain how closely they resembled the ideal khatvānga staff described in these other sources. However, on one occasion the Madman of Tsang was asked by one of his students to explain the various aspects of the khațāinga staff and their significance. The Madman of Tsang states that the staff should be straight and about the length of the yogi who is to carry it. The staff should be ornamented with a five-pronged vajra, a lotus, a "sun and moon 'seat"' (nyi zla'i gdan), a crossed vajra, and small bells (dril bu g.yer $k h a$ ), as well as various other ornaments, including hair from different kinds of people (both living and dead). The Madman of Tsang maintains that the staff should also be festooned with a pot, a wet head, a dry head, and another head, as well as three trident points. The Madman of Tsang explains the symbolic meaning of each of these aspects of the richly-ornamented staff. ${ }^{207}$ Although we cannot be certain whether this teaching was actually given by the Madman of Tsang or if it was put into his mouth by his disciple writing the biography, this does suggest that the Madman of Tsang carried an elaborate (and perhaps extremely heavy) staff that bears close resemblance to the idealized vision of a khațāinga. The only details we are given about the khațāinga staff carried by the Madman of $\ddot{U}$ is that it was adorned with "bells, strips of silk, and so on.",208 The Madman of Ü's staff may have been adorned with bells, silk and the like in addition to the other expected ornamentations like trident points, a pot and skulls. Thus we cannot be certain that the khațānga or other aspects of the macabre garb worn by the Madmen

\footnotetext{
${ }^{207}$ Götsang Repa, pp 231.4-233.6.

${ }^{208}$ The Life of the Madman of $\ddot{U}, \mathrm{p}$ 439.4.
} 
of $\ddot{U}$ and Tsang matched their idealized versions according to tantric discourse, but they may have. One may remain skeptical as to whether or not the holy madmen actually wore human skins and elephant hides, but we have no reason to rule this out entirely. As we will see in Chapter Five, there were sources other than the Madmen of Ü and Tsang's biographies that mention the wearing this sort of garb.

Another question we remain uncertain about is whether the Madmen of $\ddot{U}$ and Tsang wore these costumes at all times after initially putting them on, or only intermittently. There are enough explicit mentions of their wearing these costumes to suggest that they wore them at times throughout the rest of their lives, if not at every moment. For example, sometime after taking on the garb of a Heruka, the Madman of Tsang visited his mother in their home village, and before he left she begged him to stop wearing such gruesome things, arguing that people would say he was a demon and try to kill him. ${ }^{209}$ Her concern was not unwarranted. One of the strongest indications that Madmen of Ü and Tsang continued to wear the garb of the Heruka throughout much of their lives is the numerous instances when people attacked them and tried to destroy their bone ornaments. On one occasion some people beat the Madman of Ü, trying to break his bracelets, earrings and girdle, hitting him so savagely that the ornaments even sunk into the wood of the weapons they were beating him with. ${ }^{210}$ On this same occasion we also see that the yogi was not above using his khațāniga to ward off angry dogs. There

\footnotetext{
${ }^{209}$ yum gyis gsung gis/ [sic] o lo shes da dung dpal 'khor sde chen du sdod la dang po'i chos dga' mo de byed rogs bgyis dang gsung ma gnang ba las/ yum la zhu ba nan gyis phul bas/ cis kyang 'gro na chas 'di rnams nga la zhog byon de min srin pho yin pa 'dug zer/ mi yis gsod pa 'dug gsung ma gsan bar g.yang bzhi dang thod pa lcang lo can gcig yod pa yum gyi phyag du bzhag/, Götsang Repa, p 46.5-.7.

${ }^{210}$ The Life of the Madman of $\ddot{U}$, pp 512.6-513.6. In Götsang Repa's version of The Life of the Madman of Tsang there is a similar story in which people attack the Madman of Tsang and try to break his ornaments (sku chas), pp 119.3-.4.
} 
was also an instance when some drunk youngsters stole the Madman of Ü's bracelet, and when some brigands tore the earring from his ear. ${ }^{211}$

This suggests that the Madmen of Ü and Tsang continued to wear the garb of the Heruka throughout much of the remainder of their lives, if not at every moment. This uncertainty stems from ambiguity in the way these instances are described. For example, when the Madman of $\ddot{U}$ had nearly reached the age of 60 and was quite settled at Tsimar Pel, he received a request from Drikung Til Monastery to perform a consecration ritual (rab gnas) for the Tashi Gomang [stūpa?]. Unwilling to travel to Drikung, the Madman of $\ddot{U}$ "covered his body with the eight accessories of the Heruka" (he ru ka'i chas brgyad po legs par sku la bsgos) and recited a prayer accompanied by a dance. ${ }^{212}$ The language is ambiguous and can be read as, "wearing the garb of the Heruka..." or "having put on the garb of the Heruka..." In this instance and many like it the question is whether the author is trying to indicate that at this moment the yogi changed his clothing and put on the Heruka garb, or if the author is merely reminding the reader that the yogi was wearing the garb all the time. It is significant that there is never any mention of the holy madmen's wearing anything else — no mention of reassuming monk's robes or the chuba of a layman. We will never know whether the Madmen of $\ddot{U}$ and Tsang wore this odd and uncomfortable attire for the rest of their lives, from their 20s onward, or whether they did so only intermittently.

Regardless of whether or not the Madmen of Ü and Tsang wore the garb of the charnel ground at every moment, and regardless of how closely their garb replicated the

${ }^{211}$ The Life of the Madman of $\ddot{U}, \mathrm{pp} 472.3-473.4,498.5-499.1$.

212 The Life of the Madman of $\ddot{U}, \mathrm{p}$ 630.3-.6. 
idealized forms of these items according to tantric texts, the fact is that they integrated wearing the garb of the Heruka into their religious practice and made it a distinctive part of their public personas. As an indication of the extent to which the Madman of Tsang wished to be identified with this mode of dress, in the colophon to The Life of Milarepa he styles himself "the yogi who wanders in charnel grounds, wearer of the bone ornaments." 213 Similarly, in perhaps the ultimate expression of his identification with the cult of the macabre, he signs The Life of Marpa "the yogi who wanders in charnel grounds, the King of Blood Drinkers.” (According to his biography, this name was given to him by the deity Hevajra, who came to him in a vision. ${ }^{214}$ ) "Blood-drinker" (khrag 'thung $b a$ ) is a Tibetan translation of the Sanskrit "Heruka." 215 The Heruka garb became part of the Madman of Tsang's public persona. According to his biography, after his death it is told that a woman, who had never actually seen the Madman of Tsang before but had great faith in him, had a vision of the yogi, astride a lion and bedecked with bone ornaments and the emblems of the charnel ground. ${ }^{216}$ What these examples show us is that these yogis made wearing the garb of the Heruka one of the main ways in which they defined themselves, and it became central to others' perceptions and descriptions of them.

Among the Madman of Tsang's disciples there were various sub-groups. These included "the twenty heartsons upholding the way of individual liberation," "the eighteen secret great siddhas," and "the eight realized ones shared [with other gurus]." There was

\footnotetext{
${ }^{213}$ E. Gene Smith, 2001 reprint, p 286, note 155. The Madman of Tsang signs The Life of Milarepa as dur khrod nyul ba'i rnal 'byor pa rus pa'i rgyan can (rnal 'byor gyi dbang phyug chen po mi la ras pa'i rnam mgur, mtsho sngon mi rigs dpe skrun khang, 2005, p846); he signs The Life of Marpa as, dur khrod nyul ba'i rnal 'byor pa khrag 'thung rgyal po (sgra bsgyur mar pa lo tsA'i rnam par thar pa mthong ba don yod; Varanasi: printed by E. Kalsang, 1970; TBRC text number W21718), p 252.

${ }^{214}$ Götsang Repa, p 36.2-.3.

${ }_{216}^{215}$ Gray, p 40.

${ }^{216}$... rus pa dang dur khrod kyi chas kyi rgyan pa mngon gsum du mthong ba..., Götsang Repa, p 280.3-.5.
} 
also a group called "the twenty-eight realized heartsons who wore the garb of the Heruka." ${ }^{217}$ Thus among the Madman of Tsang's students there were some who wore the garb of the Heruka, either occasionally or all the time. Further, one of the Madman of Tsang's students is casually referred to in his biography as "Chöchok Pelzang who performs engaged asceticism" (brtul zhugs spyod pa chos mchog dpal bzangs), which indicates that he must have specialized in this practice. Later this same student is said to be "without rival in the performance of engaged asceticism" (brtul zhugs spyod pa 'dran zla med). ${ }^{218}$ It is likely that one of the things this is meant to express is that he wore the garb of the Heruka. This would also hold for when contemporaries of the Madmen of $\ddot{U}$ and Tsang like Karma Trinlepa and Drukpa Künlé praised them as masters of the performance of engaged asceticism.

The Madmen of Ü and Tsang emulated the fearsome and macabre deity Heruka through means other than their dress. They also imitated the deity through their singing, ceremonious dancing (expressed in The Life of the Madman of $\ddot{U}$ as gar bsgyur, sku gar

\footnotetext{
217 "The twenty-eight realized heartsons who wore the garb of the Heruka" (he ru ka'i cha lugs can gyi thugs sras rtogs ldan nyer brgyad) are mentioned in Götsang Repa, pp 83.4, 110.5, 164.2, 170.7, 190.7, 207.7, and 259.5-262.1, where the individuals of the group are all listed; "the twenty heartsons upholding the way of individual liberation" (so so thar pa'i cha lugs can gyi thugs sras ston sgom bcu phrag gnyis) are mentioned pp 137.5, 190.6, 207.6, 246.4, and 262.1-263.7, where the group is listed in its entirety; they are referred to by similar titles on pp 90.1 and 164.1; "the eighteen secret great siddhas" (sbas pa'i sgrub chen bco brgyad) are mentioned pp 164.3-.4, 190.7-191.1, 207.4, and 263.7-264.6; "the eight realized ones shared [with other gurus]" (thun mong gi rtogs ldan brgyad) are mentioned pp 164.4, 191.1, 207.6, 256.4 and are listed in their entirety at 266.5-.7. It is this last instance in which the other gurus with whom the disciples are shared are mentioned; interestingly, one of these eight disciples, named rtogs ldan chos 'phel, is said to have been "shared" with the Madman of Ü. Some other groupings of the Madman of Tsang's students are listed a chapter in The Life of the Madman of Tsang dedicated entirely to his students, which runs pp 259.1-268.5.

${ }^{218}$ Götsang Repa, pp 213.5 and 260.1. See also p 259.4, where it says that one of the Madman of Tsang's students "worked for the benefit of beings by means of his performance of engaged asceticism" (brtul zhugs spyod pas 'gro don mdzad); see also pp 260.2 and 260.4, where some of the Madman of Tsang's other students are praised for their performance of engaged asceticism.
} 
stabs, rol gar, and so on ${ }^{219}$ ) and especially the "fierce" confrontational behavior that was described above. The Heruka is the epitome of wrathful deities, and we have reason to believe that the madmen's engaging in “fierce” behavior (drag po'i spyod pa or drag po' $i$ brtul zhugs) was attendant to their larger purpose of emulating the deity. At the end of the chapter in which the Madman of Ü exchanged his monk's robes for the garb of the Heruka, the author summarizes that he had thus "embraced the engaged asceticism of a wrathful Heruka" (drag po he ru ka'i brtul zhugs bzung). ${ }^{220}$ Drag po can be a translation of the Sanskrit word raudra, which is connected with Rudra, who is the wrathful form of Siva upon whom the Buddhist deity Heruka is modeled. ${ }^{221}$ (More will be said about this connection below.) It is no great stretch to read the many instances of the Madmen of $\ddot{U}$ and Tsang's engaging in drag po brtul zhugs as meaning not just "fierce engaged asceticism" but "engaged asceticism in the manner of a [Heruka-like] wrathful deity." After all, it was not by coincidence that the Madmen of Ü and Tsang (and occasionally the Madman of the Drukpa) had "Heruka" appended to their names; to this day Tibetans most often mention the Madman of Tsang under the name "Tsangnyön Heruka."222 From

\footnotetext{
${ }^{219}$ These forms are used on pp 445.5, 449.6, 486.1; 446.4; and 494.3 respectively, as well as many other places in the course of the text.

${ }_{220}$ The Life of the Madman of $\ddot{U}, \mathrm{p} 532.1-.5$.

${ }^{221}$ Gray, p 228, in a footnote mentions drag as Tibetan translation of the Sanskrit "Rudra."

${ }^{222}$ The association between the Madman of Tsang a the term Heruka is ubiquitious. The lesser-known Madman of Ü's association with the term is attested to in a number of sources. For example, Johan van Manen, "A Contribution to the Bibliography of Tibet," pp 445-525 in Journal and Proceedings of the Asiatic Society of Bengal, Vol XVIII, New Series, 1922 (Calcutta). This article is a list of 219 works that were at the being printed in various printing houses in Tibet. Included among them is a work referred to as the Life Story of the Madman of Ü, the Heruka (dbus smyon he ru ka 'i rnam thar) (the Life Stories of the Madman of Tsang and the Madman of the Drukpa are also mentioned). Regarding this text, van Manen writes: "The biography of the frantic Heruka from (the province of) Ü. Heruka is a god, but the name is also given to an ascetic or yogi who dresses as a Heruka and is Heruka-inspired. It is said that here a member of the latter class is meant. There are two of them known as the Ü Heruka (in Lhasa) and the Tsang Heruka (is Shigatse). They are regular 'incarnations,' and their method or manifestation is that of frenzy or madness. Bhutanese Kagyüpa.” p 513. See also pp 481, 485 and 514.
} 
all of this we can conclude that these yogis were actively and purposefully attempting to embody the identity of the Heruka, and were successful in doing so, as indicated by the fact that "Heruka" became such a key part of their public identities.

\section{III.2 Tantric Fundamentalism}

The Madmen of Ü and Tsang made their very lives synonymous with the performance of engaged asceticism. A key part in their doing so was their dressing up and acting like the deity Heruka. We will now begin to consider what practical ramifications this had in late 15th- and early 16th-century Tibet. Pursuing this question will give us some important answers for why Künga Zangpo and Sangyé Gyeltsen decided to engage in this sort of behavior.

Readers familiar with the religious traditions of South Asia might not feel the full impact of the Tibetan holy madmen's adopting this mode of dress. In India there is a great diversity of ascetic traditions featuring remarkably divergent forms of dress, some of which have been practiced for thousands of years. To this day the sight of a $b a b a$ or a $s \bar{a} d h u$ dressed in a loincloth is not an uncommon sight. They might be Vaiśnava or Śaivite, sometimes smeared with ashes, with dredlocks or head shaved, carrying ritual implements like skull cups and staffs. There is also the long-standing tradition for the most serious practitioners of Jainism to go completely naked. (As the Chinese pilgrim Hsüan Tsang famously observed during his visit to India in the first part of the 7th century, "The dress and ornaments worn by [non-Buddhists] are varied and mixed. Some wear peacocks' feathers; some wear as ornaments necklaces made of skull bones...; some

The Madman of Ü is also referred to as dbus smyon he ru ka in a verse of praise by Drukpa Künlé in the latter's Collected Works (Beijing, 2005, p 418). Lastly, in the popular version of The Life of the Madman of the Drukpa translated by Dowman, the Madman of Ü, the Madman of Tsang and the Madman of the Drukpa are referred to as "three Herukas," p 110; p 184 notes 13 and 14. 
have no clothing, but go naked...; some wear leaf or bark garments; some pull out their hair and cut off their moustaches; others have bushy whiskers and their hair braided on the top of their heads." ${ }^{223}$ ) The South Asian ascetics whose outward appearance the Madmen of Ü and Tsang resembled most were the kāpālikas, a tantric Śaiva movement (if not a formal sect) that existed in India from the 8 th to the 14 th centuries. ${ }^{224}$ The nature and significance of this connection will be discussed below.

Although in Tibet there have always been religious specialists who did not conform to the dictates of formal monasticism - letting their hair grow long and dressing in a variety of ways - the shaved head and red robes of the monk constitute the norm for how many Tibetans would expect those living a life fully dedicated to the practice of Buddhism to look. For a handful of yogis and perhaps a few dozen of their disciples to walk around central Tibet in the late 15 th and early 16 th centuries dressed in this wayin loin cloths, smeared with ashes and filth, wearing bangles and earrings, carrying a skull cup and a skull-topped staff — must by all means have been a remarkable sight. (As we saw in the passage from The Life of the Madman of Tsang quoted above, some would have considered these holy madmen's manner of dress to be unprecedented on Tibetan soil.) One can imagine the effect that was produced when the Madman of Tsang and two dozen of his students, all dressed in the garb of the Heruka, burst into the formal assembly of a powerful lord like Rinpungpa Dönyö Dorjé, surrounded by his ministers. They also would have created quite a stir when they went into the Lhasa Barkor, singing and dancing about. The holy madmen's outward appearance would have been the most

\footnotetext{
${ }^{223}$ Samuel Beal, trans., Chinese Accounts of India (Calcutta: Susil Gupta (India) Ltd, 1957-8, 4 volumes; first printed in 1883), Vol. II, p 134; quoted in David Lorenzen, The Kāpālikas and Kālāmukhas (Berkeley and Los Angeles: University of California Press, 1972), pp 15-6.

${ }^{224}$ David Lorenzen, The Käpālikas and Kälāmukhas, p 51.
} 
immediate factor in shaping how people perceived them. Let us now consider how their mode of dress was received by others, and how it contributed to their becoming known as "madmen."

The appearance of the 15th-century holy madmen dressed in the garb of the Heruka would have been surprising to all, threatening to some, and despicable to others. The Madman of Tsang's mother's concern that people would mistake him for a ghoul ( $\sin$ pho) was realized, providing us with an anecdote that lends some insight into how his manner of dressing and behaving would have been received. On one occasion when the Madman of Tsang arrived in Lhasa, the people said, "A demon has arrived!" (srin po byung) and everyone fled. That night whenever anyone approached him, the Madman of Tsang played his hand drum and blew his thighbone trumpet, frightening them off. The next day some people said he was a ghoul; others wondered if he was a siddha (grub thob). ${ }^{225}$ Finally some monks who had known him from his days at the monastic center in Gyantsé recognized him. He was then invited to the Neudzong fortress by the local lord, Depa Paljor Gyelpo. There some scholar-monks (geshés) from Sera and Drepung monasteries began to argue with him. The geshés said, "We have not heard of this way of dressing (cha lugs) and behaving ( $\operatorname{spyod} p a)$ among the Teachings of the Buddhathere is no precedent for it. From whose system (su'i lugs) is your manner of dressing and behaving derived?" The Madman of Tsang responded, "If there is no precedent for

\footnotetext{
${ }^{225}$ Götsang Repa, p 44.5-.7; see also p 70.1. As narrated in The Life of the Madman of $\ddot{U}$, when some people were savagely beating the yogi and trying to break his bone ornaments, "they thought he was not human, that he might be a demon ('dre) or a ghoul (srin po); they reckoned that if they were not sure to kill him, he might later rise and eat or kill them. So they beat him beyond what was necessery, so that there was no way he could have survived," pp 513.6-514.2. There is another instance in Götsang Repa's version of The Life of the Madman of Tsang, when he sneaks into the chamber of a sleeping king and startles him in the night; the king gropes at the yogi's body in the dark and concludes, "It feels like a demon's body!" (srin po'i gzugs bzhin 'dug), pp 69.1-70.1.
} 
this way of dress, then the tantric deities and the Eighty Mahāsiddhas of India have never existed! Haven't you seen it drawn in pictures? My manner of dressing and behaving is explained in the Highest Yoga Tantras of Vajradhāra, especially in the Hevajra Tantra.",226

The Madman of Ü also received criticism by those who had doubts about his eccentric appearance and behavior. As his biographer states, “Although some people do not know what to make of this kind of yogi and say that his manner of behaving (spyod pa'i byed lugs) does harm to the Teachings," it is only the prattle of the uninformed and the sinful, so what would be the point of responding to their criticisms? ${ }^{227}$ From these anecdotes we get some sense of how the Madmen of Ü and Tsang's ways of acting and behaving would have gotten them received: ordinary people may have had no idea what to make of them, while better informed monks sometimes took issue with their appearance because it did not conform to their understanding of Buddhism. And yet as we saw in the episode related above, the Madman of Tsang maintained that directives for his ways of dressing and acting were to be found in canonical Buddhist sources. How could this be? How is it that their appearance could resemble that of the non-Buddhist kāpālikas, invoke the ire of monks, and yet be derived from texts that most Buddhists in 15th-century Tibet would have accepted as canonical? This question is essential to our entire understanding of the distinctive activities of the Madmen of $\ddot{U}$ and Tsang.

\footnotetext{
${ }^{226}$ For the sake of brevity, I have omitted the colorful verse with which the Madman of Tsang began his response to the geshés. This description of these events, from his being called a ghoul in Lhasa to his defending his mode of dress, runs from pp 44.5 to 45.6 in Götsang Repa.

${ }^{227}$ The Life of the Madman of $\ddot{U}$, p 525.1-.4. See also pp 473.4-474.6, relating an incident in which the yogi met a monk who told him his behavior was crude and did harm to the Teachings - especially his consuption of alcohol. So he used his yogic magic to make the monk vomit a long stream of alcohol, while he himself vomited a small amount of milk, at which everyone was amazed and became filled with faith.
} 
In the biographies of the Madmen of Ü and Tsang, when individuals (most often monks or "scholar-monks," dge bshes, dge ba'i bshes gnyen, in this dissertation this will be rendered with the phoneticization, geshé) criticize the behavior of the holy madmen on the grounds that it is problematic and un-Buddhist, the yogis' responses to this charge provide us with an important insight into what motivated their behavior. Their basic defense, repeated time and time again, is that their behavior is derived from the dictates of the tantric scriptures themselves. For example, while staying in caves near Mount Kailash, the Madman of Tsang got into an argument with a learned one from the Ganden tradition (which would would later be called the Geluk) (dga' ldan pa bka' bcu pa). The argument proceeded as follows: first the Madman of Tsang asked the monk if he had received tantric empowerments, and whether or not he had studied the tantras. The monk responded by saying that he became a monk at a young age, studied the Ten Great Philosophical Treatises (mtshan nyid kyi bka' pod bcu), then received empowerment in the Gandenpa systems of the Guhyasamāja, Vajrabhairava and Cakrasamvara tantras; and studied the root text and commentaries for the Guhyasamāja, and practiced in accordance with them. The Madman of Tsang then asked the monk why he did not partake of the "samāya substances" (dam rdzas la mi spyod pa ci yin) (referring to alcohol and other substances consumed in the course of tantric rituals, perhaps including sexual fluids ${ }^{228}$ ), and doesn't his avoiding them constitute the downfall of contradicting the Word of the Buddha, or of not upholding the samāya vows. By not consuming the substances, doesn't the monk contradict the very tantras themselves? The monk's response was to

\footnotetext{
${ }^{228}$ See Wedemeyer, p 118, where he states that in the context of Āryadeva's Lamp that Integrates the Practices, "samāya substances" can refer to sexual fluids, but a wider array of tantric substances as well.
} 
say that the current age they lived in was not the time to practice tantra literally ( $d a$ lta gsangs sngags dngos su nyams su len pa'i dus min), and that in Tibet there were no legitimate tantric gatherings (ganacakra; bod na tshogs 'khor mtshan nyid pa yod yang med). The Madman of Tsang responded by asking, "If now is not the time to practice tantra [literally], when is?" (da lta gsang sngags nyams su ma lan na nam nyams su len). The Gandenpa answered by saying that he was a monk practicing the Vinaya and one who took after lord Tsongkhapa and his disciples, and would not, therefore, be drinking any alcohol. ${ }^{229}$

We saw the same set of issues brought to the table during the Madman of Tsang's debate with the geshés from Drepung and Sera monasteries (both of the Geluk/Gandenpa sect), which was described above: faced with the charge that his behavior and appearance were not authentically Buddhist, the Madman of Tsang justified his lifestyle as being based on tantric scriptures like the Hevajra tantra, and his manner of dress as being based on the appearance of deities and Indian saints. This prompted the monks to say that our current age is not the time to be practicing tantra in such a literal manner (da lta de ltar gsang sngags spyod pa'i dus ma yin). To this the yogi asked where it is stated that now is not the time to practice tantra (da lta gsang sngags nyamsu len pa'i dus ma yin pa gang nas bshad). ${ }^{230}$ (This is reminiscent of Sangyé Gyeltsen's break with monastic life, when he asks the disciplinarian, "Where in the sūtras or tantras does it say that one cannot have a skull cup and a thigh-bone trumpet in the line of monks?")

\footnotetext{
${ }^{229}$ Götsang Repa, pp 178.7-180.2.

${ }^{230}$ Götsang Repa, pp 45.6-46.1.
} 
We see in these and other episodes that the Madman of Tsang believed his behavior to be based on the tantric scriptures, while recognizing that it contradicted the way more conventional monks (in these cases, representatives of the Geluk sect) understood the practice of Buddhism. ${ }^{231}$ Unable to pursue the argument that the yogi's behavior had no textual backing, the monks were left to argue that his manner of taking the texts so literally was not appropriate for the age in which they lived. This debate over how literally the tantric texts should be taken - and the starkness of the contrast between how the Madmen of Ü and Tsang took those texts and how more conventional monks did so- shows us very clearly that the Madmen of Ü and Tsang were promoting a distinctive form of Buddhist life, and doing so very publicly through their eccentric behavior. It is not that the behavior of the holy madmen was unjustified or unprecedented, but that it was based on a very literal interpretation of late Indian tantric texts that was highly anachronistic in light of the hundreds of years of reinterpretation that had gone into creating the much tamer form of tantra that had become the norm in Tibet, the sort of tantra that would have been practiced by these Gelukpa monks. ${ }^{232}$ We will now explore the issue of these greatly varying attitudes towards how to interpret the Yogini tantra texts, to better understand what was so unique about the approach taken by the Madmen of Ü and Tsang.

\footnotetext{
${ }^{231}$ For other instances of the Madman of Tsang explicitly justifying his actions as being based on the Hevajra tantra, see Götsang Repa, pp 55.2-.3 and 61.7-62.3.

${ }^{232}$ After one instance of justifying his insulting behavior-in this case, taking for himself a cup that had been placed in front of a queen and telling her he wanted to screw her ( rgyo ... 'dod) - as being based on the Hevajra tantra, and in particular the "Activity" chapters (spyod pa'i le'u) of the tantras, a noblewoman comments that a yogi with such realization and engaged asceticism (brtul zhugs) that are in accordance with the tantras, is, in our degenerate age, "as rare as stars during daylight" (snyigs ma'i dus 'dir nyin mo' $i$ kar ma lta bur 'dug). Götsang Repa, pp 32.4-33.6.
} 
The Yoginī tantras (often called the "mother tantras," ma rgyud) were a subset of the Highest Yoga tantras (*anuttarayogatantra; rnal 'byor bla na med pa'i rgyud; more literally rendered as the Unexcelled Yoga tantras) ${ }^{233}$, written in the 8th to 10th centuries in India. From the time of their creation up to the present, they have been subject to a continual process of reinterpretation and remapping. ${ }^{234}$ The Yoginī tantras represent the latest stage of the development of Buddhist tantra in India and it is in these texts that the themes of sex, violence and things macabre became most prominent. These texts promoted ritualized sex, as well as the consumption of alcohol, sexual fluids, meat, and so on. These tantras instructed the practitioner to consume all manner of disgusting and transgressive substances, as will be described below. The central deities upon whom these tantras are focused are usually wrathful in appearance, adorned with skulls and weapons, drinking from cups of blood. Given the Yoginī tantras' antinomian nature, it might come as a surprise that in Tibet, which featured a form of Buddhism that was so centered around institutionalized monasticism, most sects of Tibetan Buddhism would uphold the Yoginī tantras as representing the highest form of Buddhist practice. This became possible thanks to the creative hermeneutical efforts of various commentators who established a unique mode of understanding the tantras, through a centuries-long

\footnotetext{
${ }^{233}$ The term *anuttarayogatantra is not attested to in Indian sources. Rather, this category is one most often used by Tibetans scholars attempting to organize Indian tantric texts. See Gray, pp 5-8, for a concise description of this class of tantras. See also Anthony Tribe's chapter "Mantranaya/Vajrayāna - tantric Buddhism in India" in Paul Williams' Buddhist Thought: A Complete Introduction to the Indian Tradition, pp 213-7.

${ }^{234}$ Gray concludes that the Cakrasamvara Tantra would have been written between the early- 8 th century and the mid-9th century, although it likely existed in some form before this time, pp 11-3. See also Ronald Davidson, Tibetan Renaissance: Tantric Buddhism in the Rebirth of Tibetan Culture (New York: Columbia University Press, 2005), p 40 on the dating of the Cakrasamvara Tantra. Davidson states that the Hevajra tantra would probably have been written in the late 9th or early 10th century, later than the Guhyasamāja and Cakrasamvara tantras, p 41. A few decades earlier, David Snellgrove stated that the Hevajra Tantra would have been written by the late 8th century, The Hevajra Tantra, Vol. I, p 14.
} 
process of creative intellectual work. The history of this process has been addressed by scholars like David Snellgrove, David Gray and Ronald Davidson; here I will tell only a small part of the story. ${ }^{235}$

The question of how to reconcile the transgressive aspects of the Yoginī tantras with the demands of the monastic code has been a perennial question in the intellectual history of Tibetan Buddhism. It was famously addressed by Atīsa in the 11th century in his Lamp for the Path to Enlightenment. Atīśa argued that monks should practice tantra without taking the "higher" consecrations which, if practiced literally, would have involved breaking their vows of celibacy. ${ }^{236}$ Two centuries later this question was addressed by Sakya Pạdita in his Clear Differentiation of the Three Codes, wherein he argues that one must practice tantra in a careful manner, so as not to contravene the monastic vows. ${ }^{237}$ The monk's and bodhisattva's vows are integrated into tantric practice, and tantra is practiced so as to not contradict the lower sets of vows. (The same basic approach would be taken by the Kagyü scholar, Jamgön Kongtrül Lodrö Tayé in the 19 th century. ${ }^{238}$ ) In the early 15 th century, Tsongkhapa, initiator of the Geluk sect, would address this issue by promoting a system in which the aspects of tantric practice that contravened the monastic vows would be practiced only through visualization, and

\footnotetext{
${ }^{235}$ David Snellgrove, Indo-Tibetan Buddhism (Boston: Shambhala, 2002) on the taming of tantra for Tibet, pp 508-516. See Gray, p 11, on the "creative hermeneutics" involved in this process.

${ }^{236}$ Snellgrove, Indo-Tibetan Buddhism, pp 481-4 on Atîśa's Lamp for the Path (byang chub lam gyi sgron $m a)$.

${ }^{237}$ sdom gsum rab dbye. Jared Douglas Rhoton, trans., Sakya Pandita Kunga Gyaltshen's A Clear Differentiation of the Three Codes: Essential Distinctions among the Individual Liberation, Great Vehicle, and Tantric Systems (State University of New York Press, 2002), pp 23-5.

${ }^{238}$ See book five of his Encompassment of All Knowledge (shes bya kun khyab), translated with its commentary as Buddhist Ethics (Ithaca: Snow Lion Publications, 1998), pp 301-6, where he discusses the ways in which different Indian and Tibetan commentators have dealt with the issue of the relationship between the different sets of vows.
} 
not literally. ${ }^{239}$ (It is even said that Tsongkhapa, in order to avoid breaking monastic vows, waited until he entered the dream-like intermediate state (bar do) after death to practice the sexual yoga needed to achieve ultimate liberation.) Others, like the 11th- to 12th-century Kagyü systematizer Gampopa, maintained that the practice of tantra superseded the dictates of monasticism, and therefore any transgression of the monastic code undertaken for the purpose of practicing tantra was justified. ${ }^{240}$

Over a period of centuries many of the most important Tibetan Buddhist intellectuals would address the issue of how to reconcile the opposing demands of monasticism and later forms of tantric practice. This is an index of how Tibetan Buddhism's unique makeup as being fully dedicated to monasticism and tantra simultaneously was a perpetual cause of friction requiring creative responses. Whereas the scholars mentioned in the previous paragraph were dealing with this fundamental contradiction on a theoretical level, we can also see how scholars dealt more directly with this problem in their commentaries on these tantras. In these commentaries we can see very vividly the sort of intellectual work needed to resolve the inherent contradictions between monasticism and transgressive forms of tantra. It is a process of reinterpreting the tantric texts by making the literal figurative, the embodied imagined, and the external internalized. ${ }^{241}$ Let us look at the chapter from the Hevajra that played the most central

\footnotetext{
${ }^{239}$ Donald Lopez, "Introduction" to Religions of Tibet in Practice (Princeton: Princeton University Press, 1997), p 15.

${ }^{240}$ Summarized in Jamgon Kongtrül's Buddhist Ethics, pp 303-4. Lopez, "Introduction” to Religions of Tibet in Practice, mentions this issue: "Whether this intercourse [called for by the Highest Yoga Tantras] is to be performed only in imagination or in fact, and at what point on the path it is to take place, has been a point of considerable discussion in Tibetan tantric exegesis," $p 15$.

${ }^{241}$ As David Gray summarizes, "Buddhists... advocated internalized meditative practices that bracketed and neutralized the transgressive exercises that are actually prescribed by the text," p xv. On pp 124-31 Gray describes this trend, by which the tantric empowerments "came to be performed in a symbolic fashion," $p$ 127. Gray notes that during a tantric empowerment performed in New York recently, the menstrual blood
} 
role in motivating the eccentric behavior of the Madmen of Ü and Tsang, with an eye towards the ways the root text was reinterpreted by later thinkers. We will consider the commentary on the Hevajra tantra by the Third Karmapa, Rangjung Dorjé (1284-1339), titled The Stainless Light Explaining the Two-Chaptered.

The chapter on "Activity" (spyod pa'i le'u), the sixth chapter of the first book of the Hevajra tantra, is taken by commentators as describing "the performance of engaged asceticism" (or "the performance of engaged asceticism of awareness") which some commentators describe as a "further enhancement" practice (bogs 'don or bogs dbyung). ${ }^{242}$ (Here as in many other places, spyod pa is understood as meaning brtul zhugs kyi spyod pa, the performance of engaged asceticism.) As we will see below, this chapter provides the source for many aspects of the Madmen of Ü and Tsang's distinctive behavior, which they state explicitly. ${ }^{243}$ Towards the beginning of the chapter, when

and semen called for by the root texts of the Yogini tantras had been replaced by yogurt mixed with red Gatorade ( $\mathrm{p} 127$ ) - perhaps a full pendulum swing away from a literal reading of the text.

${ }^{242}$ Rangjung Dorjé, p 139. See also Marpa, 'bum chung nyi ma, pp 96, 99.

${ }^{243}$ Götsang Repa, pp 32.2-33.6. In this version of the story, there is mention of the "Activity Chapter" (spyod pa'i le'u), without explicitly stating which tantra this is from. This same story is told in an earlier version of The Life of the Madman of Tsang, but it is explicitly stated to be the "Activity Chapter" from the Hevajra tantra (Lhatsün Rinchen Namgyel, pp 18.6-19.4). The same story is told in the earliest version of The Life of the Madman of Tsang (Ngodrup Pelbar, pp 8b5-9a3), but, as in the Götsang Repa version, the Hevajra tantra is not explicitly mentioned. Later in the Lhatsün version, the Madman of Tsang again cites the Activity Chapter of the Hevajra tantra as the source of his eccentric behavior (Lhatsün Rinchen Namgyel, pp 57.7-58.2). We can be fairly certain that mention of the spyod pa'i le'u refers to that chapter from the "Two-Chaptered," i.e., Hevajra tantra.

The practice of literally taking on the garb of a Heruka is also prescribed by the Cakrasamvara Tantra, in Chapter 2 ("The Procedure of Wheel Worship," Gray, pp 164-70), although with less detail than in the Activity chapter of the Hevajra tantra. Chapter 27 of the Cakrasamvara ("The Procedures of the Conduct, Observances, Worship and Sacrificial Cakes") seems to bear the closest resemblance to the "Activity" chapter of the Hevajra tantra. It is, however, extremely terse and uses much "enigmatic language." It is nevertheless clear that the yogi is instructed to dress in the garb of a Heruka, and perform brtul zhugs (Gray, pp 271-81).

The second chapter of the second book of the Hevajra Tantra also describes the performance of engaged asceticism, but is less important than the sixth chapter of the first book, which is the locus classicus for the discussion of these practices in this tradition, extending beyond the 15th-century holy madmen. 
stating that the performance of engaged asceticism requires meditation in out of the way places, the root text reads:

Herein will be explained good meditation, which is practiced [under] a tree, at a charnel ground, in a house of female spirits ( $m a$ mo), at night, or in an empty place, or in solitude. ${ }^{244}$

After glossing what is meant by each of these terms, Rangjung Dorjé provides the reader with the "inner meaning" of the passage (nang don), which belies a radically different understanding of what is expressed by this verse. Rangjung Dorjé's commentary maintains that the word "tree" refers to the central channel in one's internal, yogic body (rtsa dbu ma); "charnel ground" means the doors to one's senses (dbang po'i sgo); while "night" refers to the thirty-two channels of the yogic body. The practitioner's aim is to make the yogic winds and bodhicitta (an important substance that is controlled and moved for great psycho-physical effect in the process of subtle body meditation) enter the “empty place," which refers again to the central channel. Finally we are told that "in solitude" refers to stopping the yogic winds from escaping through the doors to the senses. All of this is what is meant by "excellent meditation." In this way we see that the root text's directives that the yogi should meditate in these various places has been completely reinterpreted so that he is no longer required to perform the practice anywhere in particular. The verse in question has not been thrown out of consideration, but completely reinterpreted so that it refers to an internalized meditation process. Rangjung

\footnotetext{
${ }^{244}$ Book I, Chapter 6, verse 6; the Tibetan reads: shing gcig dang ni dur khrod dang / ma mo'i khyim dang mtshan mo dang / yang na dben pa'am bas mtha' rul bsgom pa bzang bar brjod par bya/. Snellgrove translates this passage as: "Meditation is good if performed at night beneath a lonely tree or in a cemetery, or in the mother's house, or in some unfrequented spot," Vol. I, p 63; Tibetan provided in Vol. II, p 19; Nitartha International printing of Rangjung Dorjé's commentary, p 143.
} 
Dorjé explicitly states that this interpretation is not idiomatic, but based on precedent established in commentaries on other tantras. ${ }^{245}$

This same kind of internalization occurs a number of times in Rangjung Dorjé's commentary on this chapter. When the root text states that the yogi should practice with a beautiful woman, Rangjung Dorjé informs us that in the "definitive meaning" (nges $p a$ 'i don) of this passage, "consort" actually refers to the letter $A$ one visualizes in one's belly during subtle body meditation. ${ }^{246}$ Thus an overt statement of the necessity of sexual intercourse has been completely sanitized for a celibate practitioner through reinterpretation. Another case of this kind of internalization is the way the external holy sites of the Indian subcontinent — the twenty four divine abodes, the eight charnel grounds, and so on - are said to correspond to the thirty-two major channels of the subtle yogic body, and are thereby mapped onto the yogi's own body. ${ }^{247}$ The holy site of Jālandara corresponds to the top of the head; Oḍdịāṇa corresponds to the right ear, and so on. It was not possible for Tibetan meditators to visit these sacred sites, and yet they were listed in the tantras as essential for their practice. By mapping the sacred sites onto the body, they became completely transportable and no less meaningful. This remapping and internalization was key to the process of making more extreme aspects of the tantras amenable to institutionalized monastic life, and to making them transportable to a new, distant place like Tibet. $^{248}$

\footnotetext{
${ }^{245} \mathrm{p} 143$.

${ }^{246}$ pp 144-5.

247 Rangjung Dorjé, p 65, and pp 162-6.

${ }^{248}$ Gray, pp 68-71. Gray mentions the "interpretive trend in the Cakrasamvara and related traditions ... , which involved increasing emphasis on the internalized yogic anatomy highlighted in the perfecting stage practices," p 71. In many ways Gray's entire translation and study of the Cakrasamvara tantra is a testament to the trajectory of the process of Indians and Tibetans reinterpreting the Cakrasamvara tantra.
} 
Describing the dress a meditator performing these practices should wear, the Hevajra tantra's chapter on "Activity” reads:

Akșhobya is symbolized by the form of the circlet, Amithāba by the identity of the earrings, Ratneśha by the necklace, and Vairocana [by the bangles] upon the wrists. Amogha[siddhi] is symbolized by the girdle, Wisdom by the khatvaninga and Means by the drum; the yogi represents the Wrathful One himself. ${ }^{249}$

The most straightforward reading of this passage would suggest that the practitioner should take on these various accouterments, and that each has symbolic value, invoking the special qualities these various deities represent. However, Rangjung Dorjé reads the passage in a way that renders the actual emblems irrelevant. "Akṣhobya ('immovable') is symbolized by the form of the circlet" is reinterpreted as meaning that the bodhicitta originating from the "cakra of great bliss" at the crown of one's head is "unwavering." "Amithāba ('boundless light') is symbolized by the earrings" is reinterpreted as meaning the white bodhicitta is restrained and the inner fire burns. Saying "the necklace symbolizes Ratneśha” actually means the bodhicitta is bound up at the subtle body's node at the throat. Saying "the bangles on the wrists symbolize Vairocana" means that the body's ancillary winds are bound up. Saying "Amogha[siddhi] ('meaningful accomplishment') is symbolized by the girdle" actually means the downward-voiding wind (thur sel) is restrained, whereby one is "accomplished" in "meaningfulness" (don yod par 'grub pa). Thus statements in the root text referring to ornaments the practitioner is supposed to wear on the outside of his body are refashioned as referring to various

\footnotetext{
${ }^{249}$ Book I, Chapter 6, verses 11-2; translated by Snellgrove, Vol. I, p 64; Tibetan provided in Vol. II, p 19; Rangjung Dorjé, pp 146-7.
} 
elements of subtle body meditation. This refashioning is in part accomplished by making playful use of the names of the deities the various ornaments were once said to represent. Instead of indicating that the practitioner should actually carry a khatvāinga staff and a drum, which represent wisdom and means, the passage is said to indicate that the yogi himself should embody these special qualities, rendering an actual staff and drum unnecessary. ${ }^{250}$ The Madmen of $\ddot{U}$ and Tsang's taking the root text literally and actually dressing up in this garb is a long way from the "definitive meaning" asserted by Rangjung Dorjé.

Let us consider one final passage, following shortly after the one just quoted, which reads:

One certainly eats "medicine," one always drinks "water"; one is not afflicted by old age or death, and will always be protected. ${ }^{251}$

The commentary indicates that here "medicine" and "water" refer to feces and urine, an example of the "enigmatic," coded language described by David Snellgrove. ${ }^{252}$ Since the very creation of the text, these terms were code words. The use of such coded language even in the earliest reading of the text establishes a precedent for reinterpretation. Rangjung Dorjé states that the definitive meaning (nges pa'i don) of this passage is that if one can stop the yogic winds from entering the left and right channels in one's body, one

\footnotetext{
${ }^{250}$ Rangjung Dorjé, pp 146-7. My translation here draws heavily from Snellgrove's, Vol. I, p 64. For a similar passage in the same chapter, in which "the Six Bone Ornaments" are listed, see Rangjung Dorjé, pp 140-141; Snellgrove, Vol. I, p 63. The same proccess of reinterpretation seems to be employed.

${ }^{251}$ Book I, Chapter 6, verse 14; translated by Snellgrove, Vol. I, p 64; Tibetan provided in Vol. II, p 21; Rangjung Dorjé, p 148.

${ }^{252}$ Snellgrove, Indo-Tibetan Buddhism, pp 158, 161, 169, etc.; Ronald Davidson, Indian Esoteric Buddhism: A Social History of the Tantric Movement (New York: Columbia University Press, 2002), pp 262-9.
} 
can prevent aging and death. ${ }^{253}$ An earlier commentary attributed to Marpa goes into the realm of the transgressive, saying that "medicine" refers to the "five meats" (sha lnga) and "water" refers to the "five nectars" (bdud rtsi lnga), which are revolting substances a practitioner is supposed to eat and drink in the course of his norm-overturning practice. ${ }^{254}$ The "five meats" are the meat of a bull, dog, elephant, horse and human; the "five nectars" are feces, blood, semen, bone marrow and urine. ${ }^{255}$ As this example shows, there are many divergent paths that can be taken in the ongoing process of reinterpreting the text. This latitude is enabled by the fact that the original texts were so laconic and utilized coded language. ${ }^{256}$ Because of this the Yoginī tantras were an extremely malleable material in the hands of late Indian and then Tibetan interpreters, who had a vested interested in discovering ways of practicing these tantras so that they could be reconciled with the dictates of monasticism.

By comparing these passages in the root text of the Hevajra tantra with the ways they were interpreted by some later commentators we get an idea of how the text underwent a radical process of reinterpretation in the years after its composition. As David Gray has shown in his close study of the Cakrasamvara tantra (which was, like the Hevajra tantra, a major source of inspiration for the Madmen of Ü and Tsang) the process of domesticating and sanitizing the Yoginī tantras through reinterpretation was well under way in India, just centuries after the texts were composed. Each person who wrote a commentary on the text added to its history and furthered the process of

\footnotetext{
253 Rangjung Dorjé, p 148.

${ }_{254}^{254}$ Marpa, 'bum chung nyi ma, p 100.

255 These two sets are listed by Geshé Tubten Samdrup, pp 686 and 343, respectively.

${ }^{256}$ Gray observes that the Cakrasamvara tantra is "very cryptic" and "written so as to require commentary," p 15.
} 
reinterpretation. Rangjung Dorjé's interpretation of the Hevajra tantra presented here represents a very typical Tibetan reading of the text, continuing a trajectory initiated by Indian commentators centuries earlier.

As was mentioned above, the tension between the practices enjoined by Yoginī tantras and the dictates of institutionalized monasticism necessitated that the tantras be interpreted anew. The alacrity with which Indian and Tibetan commentators did so was a remarkable intellectual feat. One aspect of these tantras that made this process of reinterpretation a smoother one is the fact that the tantras often employed what Snellgrove calls "enigmatic language," in which the true meaning of a term is hidden beneath a different external referent. ${ }^{257}$ We saw this above when it is maintained that eating "medicine" actually referred much less invigorating substances. Thus a kind of hermeneutical uncertainty was written into the original tantric texts, inviting a nevercomplete process of reinterpretation.

The behavior and dress of the Madmen of Ü and Tsang shows that they insisted on following a literal reading of the Yogini tantras, not mediated by commentaries, sādhanas or other associated ritual texts. In so doing the Madmen of Ü and Tsang were undoing centuries of sanitization and domestication through reinterpretation that had been such an important intellectual task for the tradition. The very starkness of the contrast between the appearance and behavior of the Madman of Tsang and the Geluk monks with whom he argued about the proper practice of tantra is the clearest testament to how far the process of reinterpreting the tantras had gone, and just how radical Sangyé Gyeltsen's insistence on a literal reading of them was. By enacting a literal reading of the late

${ }^{257}$ Indo-Tibetan Buddhism, pp 158, 161, 169, etc. 
tantras, the holy madmen highlighted just how dramatic this process of reinterpretation

had been, and how differently the original text had come to be construed. In light of this

context, the distinctive behavior of the Madmen of Ü and Tsang can be best understood

as a form of tantric fundamentalism.

Here I understand "fundamentalism" to indicate a religious movement promoting

a specific lifestyle that claims to be derived from a more literal reading of canonical texts.

This is in line with the definition of fundamentalism articulated by Henry Munson, who

states that religious movements can be considered fundamentalist "insofar as they insist

on strict conformity to holy writ and to a moral code ostensibly based on it." ${ }^{, 258}$ There is

${ }^{258}$ My basic definition is similar to that articulated by Henry Munson in his entry on "Fundamantalism" in The Routledge Companion to the Study of Religion (edited by John R. Hinnells, New York: Routledge, 2005, pp 337-354), here quoting from p 351. Earlier Munson writes that "In this essay, we shall speak of movements having a fundamentalist dimension only if they insist on strict conformity to sacred scripture and a moral code ostensibly based on it," although I am not convinced that fundamentalist movements must include a degree of "moral outrage" (p 340). See also Lionel Caplan, pp 14, 17 ("Introduction" (pp 1-24) to Studies in Religious Fundamentalism, edited by Lionel Caplan, Albany: State University of New York Press, 1987). Munson's chapter provides a very useful look at religious fundamentalism, summarizing the debates surrounding the term, a few well-balanced case studies, and an attempt to see the phenomenon from a more removed, scholarly perspective.

There has been much debate about the propriety of using the term "fundamentalism," with some scholars maintaining that it should be used only with respect to the conservative Protestant movement that coined the term; others maintain that the term is too loaded and should not be used at all. Most of the scholarship on "fundamentalism" makes the curious claim that it is a uniquely 20th-century phenomenon, a response to changes in the "modern" world (see Peter Herriot, Religious Fundamentalism and Social Identity, New York: Routledge, 2007, p 2; see also Malise Ruthven, Fundamentalism: The Search for Meaning, New York: Oxford University Press, 2004, p v).

Here I am suggesting a more generic understanding of the term, seeing it as a religious movement in response to perceived threats (at any time in human history) which bases itself on a more literal reading of canonical texts. To this end I mean "fundamentalism" in the sense meant by Marty and Appleby, who define it as follows, in their massive The Fundamentalism Project: "In these pages, then, fundamentalism has appeared as a tendency, a habit of mind, found within religious communities and movements, which manifests itself as a strategy, or set of strategies, by which beleaguered believers attempt to preserve their distinctive identity as a people or group. Feeling this identity to be at risk in the contemporary era, they fortify it by a selective retrieval of doctrines, beliefs, and practices from a sacred past. These retrieved 'fundamentals' are refined, modified, and sanctioned in a spirit of shrowd pragmatism: they are to serve as a bulwark against the encroachment of outsiders who threaten to draw the believers into a syncretistic, areligious, or irreligious cultural milieu..."

I would add that "fundamentalists" may not only be "preserv[ing]" their "distinctive identity," but creating one, and the perceived threat in the face of which the fundamentalism is formulated may not be secularizing forces coming from outside the religion, but could be trends within the religion itself, as in the 
also an historical element to the way fundamentalist movements are understood. The scholarship on religious fundamentalism readily recognizes that fundamentalist movements are best understood as formulated in response to specific historical circumstances (usually in the manner of a "perceived threat"). The historical circumstances surrounding the 15 th-century holy madmen and the threat against which they aligned themselves will be described in the following chapter.

Here I do not intend to suggest that the more transgressive aspects of the late Buddhist tantras were never practiced in Tibet by anyone other than the Madmen of Ü and Tsang. Surely some lamas had tantric consorts, used sexual fluids in the course of initiations and held gatherings in which transgressive substances were consumed. But those Tibetans who were practicing the late tantras in this way were more the exception than the rule; this manner of practicing was not the form an outside observer would have encountered more immediately. What was so remarkable about the behavior embodied by the Madmen of Ü and Tsang is that they were taking aspects of this more transgressive, less-seen form of tantric practice and making them completely central to their practice and — more importantly—-their public identities. There certainly were some who were doing these practices, but few made it their public face. Nor was it the public face of Buddhism in general. What the Madmen of Ü and Tsang did was turn this

case of the 15th-century holy madmen. (M. E. Marty and R. S. Appleby, "The Fundamentalism Project: A User's Guide," in Fundamentalisms Observed, edited by Marty and Appleby, Chicago: University of Chicago Press, 1991, p 835. This is the first volume of their enormous "Fundamentalism Project," which spans five volumes and brings together the work of dozens of scholars addressing different instances of fundamentalism in the world's religions). 
precedent inside-out. They took what was practiced rarely and in secret and put it front and center. This is what their eccentric behavior was most fundamentally about. ${ }^{259}$

The fact that the Madmen of Ü and Tsang could justify their behavior as being based on the tantras did not make it seem any less unconventional to their contemporaries. On one occasion the Madman of Tsang went before a large monastic assembly and was asked what his training was in (slabs sbyangs gang la mdzad), to which he responded that he trained in accordance with the Hevajra [tantra] (slab sbyangs dpal dgyes pa rdo rje la byas). Then, after conversing about the tantras with the religious dignitary presiding over the assembly, Chöjé Rabjampa Sangyé Chöpel, that dharmalord expressed his wonderment that the yogi's explanation of tantra and his mode of practicing it (including his engaged asceticism) were all consistent (don mthun). ${ }^{260}$ One gets the sense that the fact that the yogi could explain his odd-looking dress and behavior as being in accordance with the tantras was very surprising to some of his more conventional contemporaries.

\section{III.3 In the Image of the Siddhas?}

As was shown in Chapter One, one of the primary modes through which Tibetans, Euro-American popular commentators and scholars have sought to explain the eccentric behavior of Tibetan holy madmen is to understand them in light of the example provided

\footnotetext{
${ }^{259}$ The Madman of Tsang had so assimilated the Yoginī tantras that he even cracked jokes by quoting the Hevajra tantra. During a ganacakra the lady Küntu Zangmo was holding a rosary, which the yogi told her to give to him. When she did he said it was a good sign (rten 'brel legs), then jokingly quoted from the Hevajra Tantra (Book I, Chapter 7, verses 8-9; translated in Snellgrove Vol. I, p 68; Tibetan provided in Vol. II, p 23; Rangjung Dorjé, pp 160-161; "If one shows a rosary in one's hand, it says 'we should get together'; if one gives the rosary forth, one has good engaged asceticism with respect to the samäyas (?)"), which made everyone laugh, Götsang Repa, pp 172.5-173.1.

${ }^{260}$ Götsang Repa, pp 54.2-55.1.
} 
by the Buddhist mahāsiddhas (the "great saints") of India. ${ }^{261}$ It seems almost inevitable that the holy madmen should be compared to the mahäsiddhas, considering how (to some) they all represent the highest ideal of achievement in meditation. The more important question for our purposes here is whether or not it is valid to say that the distinctive behavior of the Madmen of Ü and Tsang was based on their emulating the great tantric saints of India. To this end, we will now explore the relationship the Madmen of Ü and Tsang saw between themselves and the mahäsiddhas, and the extent to which the mahāsiddhas provided motivation for the distinctive behavior of the Madmen of $\ddot{U}$ and Tsang.

There were many points of connection between the Madman of Ü and the famous siddhas of India: he received and gave teachings derived from the mahäsiddhas (especially the Dohās of Saraha, and the yogic practices of Nāropa), had visions of them, and visited holy sites associated with them in Nepal. ${ }^{262}$ The Madman of Tsang also

\footnotetext{
${ }^{261}$ To cite just a few examples among many: Kenpo Könchok Namdak and Kenpo Nyima Gyeltsen mentioned Saraha, Virūpa, Nāropā or some other Indian mahāsiddha in the process of explaining the nature of holy madness, as ones who appeared strange to the world but secretly harbored great wisdom. When asked about Tibetan holy madmen, Wangdül Rinpoché oriented his entire discussion of the topic in terms of famous Indian siddhas.

As for more popular commentators, Keith Dowman compares the Madman of the Drukpa with the mahāsiddha Saraha (The Divine Madman, p 26). In his chapter on the "Crazy Adepts of Tibet" Georg Feuerstein writes about Nāropa, Kāṇha, Saraha and other Indian saints as exemplifying "crazy wisdom" in their lives (Holy Madness, pp 64-70).

As for more scholarly sources that describe Tibetan holy madmen using the framework provided by the Indian mahāsiddhas, consider Holy Madness: Portraits of Tantric Siddhas, the catalogue for an exhibit at the Rubin Museum of Art. The exhibit is about South Asian and Himalayan art portraying siddhas, but the notion of "holy madness" (derived mainly from popular conceptions of Tibetan "holy madmen") runs throughout the entire collection of essays (not to mention being the heading under which these pieces of art and scholarship are all brought together). Here the Tibetan "holy madmen" are constantly compared to the mahäsiddhas of India, both explicitly and implicitly. Lastly, in his chapter on Tantric Buddhism within Paul Williams' Buddhist Thought (2000), Anthony Tribe cites the Tibetan holy madmen as exemplifying the spiritual ideals of which the Indian mahäsiddhas were the utmost embodiment (p 216, footnote on $\mathrm{p} 273$ ).

${ }^{262}$ The Madman of Ü receives transmissions of dohās (tantric songs) by Saraha, Tilopa, Nāropa, Birwapa (birba pa), Lohipa (lo hi pa) and Shawaripa (sha ba ri), Maitripa, as well as "vajra songs of the eighty mahāsiddhas along with their commentaries," p 410; the Madman of Ü gives teachings on the dohās and
} 
received and gave teachings derived from the mahāsiddhas on many occasions. All of this is relatively conventional and not particularly revealing, for most meditators of the Kagyü sect would have had the same sorts of connections with the Indian saints from whom they believed their lineage to have derived.

However, there are a number of instances in which a more significant connection between the holy madmen and the mahāsiddhas of India is articulated. As related in the story above, on an occasion when some Geluk monks questioned the Madman of Tsang where his manner of dressing and his behavior were derived from, he cited the tantric deities and the Eighty Mahāsiddhas of India as constituting a precedent for his ways. ${ }^{263}$ In another episode the Madman of Tsang decided to perform a meditation by which he raised a bloated, stinking corpse as a zombie (ro slongs kyi dmigs pa) because of the fact that the "siddhas of the past" (sngon gyi grub thob rnams) used to perform a "corpse practice" (ro spyod). This probably refers to the Indian mahāsiddhas. (After raising the corpse and having a somewhat harrowing encounter with it, the Madman of Tsang was finally able to subdue it again. This tale is included in the second version of The Life of the Madman of Tsang, but omitted from the third. ${ }^{264}$ )

For his part, towards the end of his life the Madman of $\ddot{U}$ is purported to have proclaimed, "I am the granddaddy of the Eighty [mahā] siddhas [of India!]” (kho bo grub

\footnotetext{
other instructions composed by Virupa, Tilopa, Shawaripa (? sha bar pa), Nāropa, and other siddhas, p 598; he meets the eighty mahāsiddhas in a vision, pp 457, 538; he visits holy sites associated with the eighty mahāsiddhas, p 451.

The Madman of Tsang teaches the dohās, Götsang Repa, p 142; the Madman of Tsang's teacher, Shara Rabjampa is said to be an emanation of Saraha, p 20.6.

${ }^{263}$ This description of these events, from his being called a ghoul in Lhasa to his defending his mode of dress, runs from pp 44.5 to 45.6 in Götsang Repa.

${ }^{264}$ This story is told in Lhatsün Rinchen Namgyel, pp 34-5. I hope to address this story in a future article on the Lives of the Madman of Tsang.
} 
thob brgyad bcu'i spyi mes chen po cig yin). ${ }^{265}$ Later, on an occasion when the Madman of $\ddot{U}$ was giving teachings to some of his closest disciples, he entered a state in which he had magnificent visions (gzigs snang sogs phun sum tshogs pa'i ngang nas) and is said to have given many pronouncements, including saying, "I am the granddaddy (spyi mes) of the Eighty [mahā]siddhas, and thus I remain surrounded by those siddhas" (kho bo grub thob brgyad cu'i spyi mes yin pas kho bo la grub thob de dag gis bskor nas yod) and so on. ${ }^{266}$ Both of these episodes occur in part II of the yogi's biography; the author of part I of the biography was also interested in connecting the Madman of $\ddot{U}$ with the famous siddhas of India. In stating his case for why readers should have faith in the yogi, Nyukla Peṇchen describes how the Madman of Ü had had meditative experience or achieved stability in his realizations and then submitted himself to austerities (rkyen thog tu 'gro zhing rkyen dang bsre thub $p a$ ), in a manner that was truly amazing. Nyukla Penchen then instructs the reader: "Do not think that the amazing stories (or "total liberation"; rnam par thar pa) of all the mahāsiddhas of India differ from this [story about the Madman of Ü] except in terms of distance (rgyang ring thung ma gtogs)"-as in, the Madman of $\ddot{U}$ is equal to them in all things, save for geographic location. ${ }^{267}$

\footnotetext{
${ }^{265}$ The Life of the Madman of $\ddot{U}, \mathrm{p}$ 581.1. This is a difficult section. It is not clear who is speaking, but based on the context and the fact that he says something very similar 20 folios later, it seems that the speaker is the Madman of Ü. The key term is spyi mes, which means the forefather or ancestor. Kenpo Tsülnam Rinpoché (interview, 12 September 2009) glossed spyi mes in this case as meaning the "byung gnas, rtsa lag or gtso bo. This I have translated the term as "granddaddy," meaning forefather, but also carrying the sense of its more colloquial meaning of "the best of all..." This reading was confirmed by Sangyé Tandar Naga. ${ }_{267}^{266}$ p 622.5-.6.

${ }^{267} \mathrm{p}$ 525.4-.6. The Madman of Ü also actively associated his lineage with the most famous of Indian siddhas: on one occasion when giving a teaching on a text about the Great Seal, in the context of telling the history of the transmission (rgyud pa'i lo rgyus kyi skabs su), the Madman of Ü said, "My lama, the Noble Lord Ratnabhadra [Drokchak Chöjé] — he was Cakrasaṃvara. Chuworipa was Telopa. Sönam Zangpo was Nāropa. Tsachungwa Yönten Peljung was Dampa Künga [Padampa Sangyé]. All the lineage holders
} 
This last example is interesting because of the specific criteria it isolates as the basis for the comparison between the activities of the Madman of $\ddot{U}$ and those of the Indian mahassiddhas. Most commentators who explain the behavior of the holy madmen by making reference to the stories of the Indian siddhas make the connection based on the perception that they all embody a natural eccentricity that comes as a result of having transcended worldly concerns and limitations. And yet for Nyukla Penchen the basis for comparing the Madman of Ü with the Indian mahāsiddhas is the fact that they all submitted themselves to austerities in the course of their yogic training. In the same vein, earlier in his life, when the young Künga Zangpo was developing revulsion to worldly life and generating the conviction to become a monk and dedicate his time to the practice of religion, his thought process is depicted in the following manner:

The food and possessions that one needs to amass [in a householder's life] are like the honey of bees, not [truly] under one's own control, so what is the use of amassing what you do not need? These temporary joys and pleasures are like seeing a show in a dream - recognizing this uncertainty, where should one stay? The superior siddhas of the past (sngon gyi grub thob gong ma rnams), having subjected themselves to severe austerities (rkyen drag po re dang bsres), practiced the Dharma, and when the thought crossed their minds, they did not give up (lit: flee, 'khyus pa). The Dharma is not practiced in pleasant and peaceful settings. Now, even if sky and earth were to be flipped (gnam sa bla 'og 'gyur kyang), I would fearlessly practice the holy and authentic Dharma! ${ }^{268}$

In these two examples the stated reason for why the mahāsiddhas of India are so commendable is not because of their having performed behavior that exemplified their transcendence of worldly limitations, but rather because they endured great hardships in

before me have been siddhas: I did not have one lama who was an ordinary being!" (kho bo yan chad la grub thob brgyud pa ma gtogs so so skye bo'i bla ma med), $\mathrm{p} 620$.

${ }^{268} \mathrm{pp}$ 394.5-395.3. Based on the example given above when the author compared the Madman of Ü's asceticism to that of the "great siddhas of India," we can assume that in this instance when he uses almost precisely the same language to describe their practices, by the "superior siddhas of the past" he intends the mahāsiddhas of India to be understood. 
the course of their training. In these cases the mahāsiddhas are more important as models of those who performed extreme austerities than as models of enlightened eccentricity.

The distinctive behavior of the Madmen of $\ddot{U}$ and Tsang was certainly based on the model provided by the Buddhist mahāsiddhas of India to some degree. ${ }^{269}$ The strongest indication of this is the instance in which the Madman of Tsang explicitly states that the Indian mahāsiddhas provide a precedent for his manners of dressing and behaving. There are also these multiple suggestions in The Life of the Madman of $\ddot{U}$ that they provided a model of asceticism and dedication to practice. This suggests a basis of comparison quite different than that most often assumed by modern commentator-both Tibetan and non-Tibetan — drawing a connection between the holy madmen and their Indian forbears, this disjunct ultimately resulting from modern commentators' misreading of the distinctive behavior of 15 th-century holy madmen. But we should not overstate the significance of the Indian mahāsiddhas in providing a model that Künga Zangpo and Sangyé Gyeltsen may have been following in the course of performing the eccentric behavior that would earn them fame as madmen. Their distinctive behavior is derived first and foremost from their enacting a literal reading of the Highest Yoga Tantras, especially the Hevajra Tantra. Perhaps the the mahāsiddhas of India were seen by the 15 th-century holy madmen as providing a precedent for what they were doing, rather than as a direct inspiration. And as we will see in Chapter Six, the relationship between the holy madmen and the earlier saints of their tradition is not one of mere imitation, but a more complex one, in which the holy madmen had a direct hand in creating the identities of these earlier saints as we now know them.

\footnotetext{
${ }^{269}$ See a footnote about the mahāsiddha Kāṇha below, in section 3.V.3.
} 


\section{III.4 "You, the hero, glorious Heruka himself..."}

One of the defining features of tantra is the degree to which it emphasizes the practitioner's identifying himself with a deity. That deity is a representation of enlightenment and likewise the practitioner's own true nature. One of the goals of tantric practice is to, by various means, help the practitioner learn to identify with the deity, see his own true, enlightened nature, and thereby achieve liberation. ${ }^{270}$ Many of the features of tantra can be seen as directed towards this end: the use of mantras, which effect the immediate presencing of the deity; mandalas, used in initiatory rituals and subsequent visualizations, which serve as an indexical reference points, mediating between microand macrocosm, for the purpose of making the practitioner recognize his true status as the enlightened divinity ${ }^{271}$; and perhaps most important of all, deity yoga, in which the practitioner visualizes himself as the deity, bearing the deity's outward physical form and all of his or her sublime qualities. The ultimate goal is to become the deity, to achieve "union" with a deity such as Heruka. ${ }^{272}$ The goal of tantra is often articulated as "achieving the state of a Vajradhāra," the Buddha as primordially liberated and allpervading. $^{273}$

\footnotetext{
${ }^{270}$ Gray, summarizing the sentiment expressed by an Indian commentator on the Cakrasamvara Tantra states, "to realize Śrī Heruka is to realize the nature of the universe which is one's own nature," pp 54-5. Union with the deity - realization that the deity represents one's own nature-is aided by the mandala ( $p$ 55).

${ }^{271}$ Gray, pp 55-64.

${ }^{272}$ Snellgrove understands the tenth stanza of the Hevajra tantra as proclaiming that the tantra is "the one means of producing Heruka, and it is by such production that men are released..." Vol. I, p 48. The Tibetan reads: he ru ka ni bskyed pa'i rgyu/ dang por gcig ni bsgom par bya/. Snellgrove, Vol. II, p 3; Rangjung Dorjé, p 56.

Similarly, one of the first lines of the Cakrasamvara tantra reads, "Union with Śrī Heruka is the means of achieving all desired aims," Gray, p 155. Gray, p 36, mentions how the practitioner achieves union with Heruka by means of "creative visualization."

${ }^{273}$ Tribe, in Williams, p 221. This is not a direct quotation.
} 
One of the things motivating the distinctive behavior of the Madmen of $\ddot{U}$ and Tsang was enacting this ideal more literally than most practitioners of tantric Buddhism (in India, Tibet and elsewhere), who would tend to take the idea in an abstract way. At the moment the Madman of Ü gave up his monk's robes before an image of the Buddha he is said to have thought, "In one life and one body I should make manifest the Body of the all-pervading lord Vajradhāra. ${ }^{, 274}$ He then proceeded to take on the emblems of a Heruka. Both he and the Madman of Tsang would spend much of their lives dressing like a Heruka and emulating his divine activity (through fierce engaged asceticism, through singing and striking dancing poses); they would encourage others to identify them with the deity, through referring to themselves as Herukas. Just as the Madmen of $\ddot{U}$ and Tsang endeavored to follow a literal reading of the root texts of the Yoginī tantras, their activity was also an attempt to literally embody the divine being. We have already seen that the Madmen of Ü and Tsang were unafraid of defying norms of interpretation.

Our sources enables us to gauge the extent to which the Madmen of $\ddot{U}$ and Tsang were successful in their attempt to embody the divine being in a more literal way. The phrasing used by Karma Trinlepa in a verse of praise to the Madman of Ü that he composed is instructive. He addresses his verse of praise thus:

The essence of glorious Cakrasamvara, whose name is everywhere renowned as "the Madman of Ü," lord of siddhas, who is an emanation of Father Tilopa, master of engaged asceticism, please lend an ear! ${ }^{275}$

\footnotetext{
${ }^{274}$ tshe gcig lus gcig la khyab bdag rdo rje 'chang gi sku mngon du bya'o snyam du dgongs shing /, The Life of the Madman of $\ddot{U}, \mathrm{p} 438.1$.

${ }^{275}$ dpal bde mchog 'khor lo'i ngo bo nyid/ mtshan yongs su grags pa'i dbus smyon pa/ yab te lo'i rnam 'phrul grub pa'i dbang / brtul zhugs kyi dbang po snyan gson cig. This verse of praise to the Madman of Ü (dbus smyon pa la bstod pa) runs pp 78.4-79.3 in The Songs of Esoteric Practice (mgur) and Replies to Doctrinal Questions (dris lan) of karma-'phrin-las-pa; here I cite p 78.4-.5.
} 
It is quite normative for Tibetan Buddhist authors to compare masters with yidam deities. However, this kind of statement takes on added significance when applied to someone like the Madman of Ü, who spent so much of his life trying to literally embody the deity. In another verse of praise, Karma Trinlepa equates the Madman of Ü with the other main deity his lifestyle invoked:

You, the hero, glorious Heruka himself, for the purpose of performing engaged asceticism for the sake of others, in public activity, these days you act with the ability of having achieved warmth in the manner of the Madman of $\ddot{U} . .{ }^{276}$

Here Karma Trinlepa states explicitly that the Madman of Ü is the deity Heruka, manifest in the here and now (deng 'dir). The yogi's performance of engaged asceticism, including "public activity," is the vehicle through which the deity becomes manifest. Thus these lines express the sentiment that through his performance of engaged asceticism, the Madman of Ü tangibly brought the deity Heruka into being. It seems that Karma Trinlepa had an understanding of what the Madman of Ü was trying to achieve through his distinctive behavior, which was, in part, to embody higher tantric deities through his performance of engaged asceticism.

This point remains somewhat speculative. In Tibetan writings - so heavily influenced by tantric ideals - it is not uncommon to see a human described as an embodiment of a divine being, especially in a verse of praise or a supplication to one's guru. But it remains likely that the Madmen of Ü and Tsang fostered this identification in a way that was less figurative than usual, making the deity manifest through various

${ }^{276}$ he ru ka dpal dpa' bo nyid/ deng 'dir dbus pa smyon pa'i tshul/ rig pa brtul zhugs kyis [sic] spyod phyir/ gzhan don tshogs kyi spyod pa la/ drod thob dbang gis spyod pa khyod/. This verse of praise to the Madman of Ü runs pp 18.7-20.1 in The Songs of Esoteric Practice (mgur) and Replies to Doctrinal Questions (dris lan) of karma-'phrin-las-pa; here I cite pp 18.7-19.1. 
means — not least of which was literally dressing like the deity - throughout their lives. This point will be returned to below.

In this section we have explored the possibility that the activities of the Madmen of Ü and Tsang can be understood as a form of "tantric fundamentalism" in that they promoted and based their behavior on a very literal reading of the Yoginī tantras. In the process they were effectively rolling back hundreds of years of reinterpretation and compromise, as the original tantras had been thoroughly reinterpreted and reformulated to match the needs and ideals of institutionalized Buddhism in India and Tibet. The Madmen of Ü and Tsang's literal enactment of the tantras put them well out of place visà-vis the norms of Buddhist practice in 15th- and 16th-century Tibet. Dressing as Herukas, draped with ornaments made of bone and smeared with filth, cracking open the skulls of corpses and eating the brains, they were walking freak shows- "madmen," whose behavior many had trouble making sense of. They were criticized and attacked for their appearance and behavior, but still they persisted.

The possibility that the Madmen of Ü and Tsang, who were thought of by many as severely deluded (if not freakish or even heretical), may actually have been enacting a form of fundamentalism is, I believe, ironic, considering the modes of interpreting their behavior that have become so dominant, as described in Chapter One. The holy madmen are so often thought of as ultimate free spirits, their behavior the spontaneous play of beings who have transcended all mundane concerns. This is a long way from the understanding of their behavior that I have presented here. Most peoples' first thought about the crazy yogis is that they are iconoclasts. But as we see in the cases of the 
Madmen of Ü and Tsang, they actually fashioned themselves as living, breathing icons.

The difference between these two very different views is a matter of perspective, and how broadly one is able to envision the religious marketplace.

Another ironic aspect to this is the degree to which the Madmen of $\ddot{U}$ and Tsang's fundamentalist behavior made them resemble certain non-Buddhists. A consideration of this fact contributes an interesting albeit unlikely case study in the origins of Buddhist tantra, to be returned to in section 5 of this chapter, after a brief detour.

\section{IV. Crazy Behavior}

Then, unafraid of anything, like a lion; without any doubts, like an elephant in pursuit of water; without any concern (zhen med), [the Madman of Tsang] roamed unpredictably (nges pa med pa) in every direction, like leaves blown by the wind; without concern for anything, with nothing to eat or drink, he went about in the manner of a madman (smyon pa lta bu'i tshul gyis gshegs pa). He went to Yarlung Tsadru (yar lungs tsha bgru), where he went directly into the home of the lord (dpon po)...277

All that we have said thus far about the eccentric behavior of the Madmen of $\ddot{U}$ and Tsang has been well supported in their biographies and other sources. We know that they performed many types of engaged asceticism, which involved seeking out violent confrontations, meditating in out of the way places, performing outrageous acts in the most public places, and wearing the garb of a Heruka. Some interpreted their behavior as enlightened activity, while others saw it as shocking, despicable, even harmful towards Buddhism. In their biographies this behavior is directly attributed with the spread of their fame as "madmen.",278

\footnotetext{
${ }^{277}$ Götsang Repa, pp 41.7-42.2.

${ }^{278}$ In a passage cited and translated above, when the Madman of Tsang performed the most shocking sorts of behavior amidst an assembly of people at Tsari, having draped himself with body parts cut from a
} 
In addition, it remains a possibility that at times they may have acted like madmen specifically. If so, their behaving in this manner would have been drawing from a long tradition stretching back through the histories of South Asian religious traditions to the time of the Buddha and even earlier, which will be addressed in the next section. In this section we will first weigh the evidence for and against the perception that famous "holy madmen" like the Madman of Ü and the Madman of Tsang actually acted like crazy people, then consider the precedent such a practice would have had. Let us make this distinction entirely clear: what we are considering here is the possibility that the Madmen of Ü and Tsang may have pretended to be insane as one aspect of their ascetic practice. This is slightly different from other aspects of their eccentric behavior, that were transgressive or surprising to others.

In the life stories of the Madman of Ü and the Madman of Tsang there are a handful of passages suggesting that behaving like an insane person may have been a part of their lives. For example, the passage from The Life of the Madman of Tsang cited at the outset of this section can be read in two ways: the first is to read "in the manner of a madman" as a general description of the ascetic lifestyle the Madman of Tsang was following: he wandered aimlessly from place to place as a mad person might. The second possible reading is to see this line as suggesting that Sangyé Gyeltsen actually imitated the ways of an insane person in the course of his wanderings.

corpse, it explicitly states that as a result of his doing this behavior the people "unanimously praised him as 'the Madman of Tsang,' [and] in every direction that name became as renowned as the sun and the moon," Götsang Repa, pp 37.6-38.1. Similarly, in The Life of the Madman of $\ddot{U}$ a direct connection is made between his "activity that is completely triumphant in every direction" and the spread of the name "the Madman of Ü," p 443. 
In The Life of the Madman of $\ddot{U}$ there is only instance of the word "mad" (smyon $p a$ ) being used to directly describe the yogi's behavior. In this lone instance, his behavior is described as "the performance of mad engaged asceticism" (smyon pa brtul zhugs kyi spyod pa). The author of part I of the biography sets out to summarize the master's practices and accomplishments:

Having mastered those [magical feats], he would go into the market or the middle of a town and submit himself (bsre; lit: to mix) to small hardships (rkyen chung $n g u$ ) and assimilate them as part of the Path (lam du btang). He had no fear of them, and while going along the path he would perform the engaged asceticism of a madman (smyon pa brtul zhugs kyi spyod pa): keeping his status (rigs), clan (rus), family (cho 'brang) and so on secret (gsangs), he roamed ('khyam) in various places where he did not know anyone ('dris med; or, "places he did not know"). Without any concern ('jigs) for causes or appearances, high or low, good or bad, upper or lower, melodious or annoying, pleasurable or painful, hope or fear, things to be adopted or rejected, and so on; nor for hot or cold, hunger or thirst, exhaustion and so on - all of these; nor for fear of avalanches or roofs collapsing and so on; nor for fire, water, wind and the like - without any fear or apprehension, with confidence in his realization of the nature of things (gnas lugs; the nature of the mind?) and his meditation (ting nge 'dzin) in the Great Illusion (sgyu ma chen po), he overpowered with his glory. ${ }^{279}$

This passage carries the same ambiguity as the one from The Life of the Madman of Tsang. It may be read as suggesting that the Madman of Ü actually behaved in the manner of a madman in the course of his religious practice, or it may be read as a more general description of his lifestyle, saying that he performed his asceticism, roaming around with no possessions, similar to the way in which a mad person lives. In this instance I am inclined towards taking the passage in the first way, based on the context. Thus these two passages remain somewhat ambiguous: they might indicate that the Madmen of Ü and Tsang literally imitated the actions of insane people, but they can also easily be read in a different manner. However, the significance of this passage from The

${ }^{279}$ The Life of the Madman of $\ddot{U}$, pp 522.4-523.4. 
Life of the Madman of $\ddot{U}$ suggesting that performing truly crazy behavior may have been a part of the Madman of Ü's life is tempered by the fact that "the performance of mad engaged asceticism" is mentioned only once in the course of his biography, whereas "the performance of wrathful engaged asceticism" (or something very similar) is mentioned at least eight times.

Another significant term that is sometimes used to refer to the kind of nonsensical, mad behavior we are looking for evidence of is tho co (or tho cho), which means "senseless," "babbling," “crude," "coarse." ${ }^{280}$ In most cases this term simply means nonsensical chatterings, and is used in The Life of the Madman of $\ddot{U}$ in this way. ${ }^{281}$ However, the term can carry a more positive meaning when used to denote the behavior of a practitioner who is purposefully behaving in a senseless manner, as part of one's religious practice, which is how it is used in a number of occasions in The Life of the Madman of Tsang. ${ }^{282}$ For example, in a long versified letter in which the Madman of

\footnotetext{
${ }^{280}$ bod rgya tshig mdzod chen mo, p 1188; Das, p 589; dag yig gsar bsgrigs (Zining: mtsho sngon mi rigs dpe skrun khang, 2003), p 338.

${ }^{281} \mathrm{p} 502.4$.

${ }^{282}$ For an example of the two-fold meaning of this term, consider the chapter (which is a transcript of a teaching) called "rje mi la'i lta sgom spyod 'bras kyi rnam gzhag mdor bstan gyi 'grel pa/," pp 75-81 in nges don phyag rgya chen po'i rnam gzhag bstan pa'i sgron me by mkhan chen tshul khrims rin po che (mi rigs dpe skrun khang, 2006). On pp 77-8 Kenchen Tsültrim Rinpoché provides commentary on a verse from a song of Milarepa's, which runs: "spyod pa chags med rgyun zhig del tho co rkyang par 'chor nyen gda'/ lta sgom grogs su ma shar na/ brtul zhugs spyod pa chos brgyad grogs/ des na zhen med sgrib med gces/" Here "tho co spyod pa" is explained as carrying the more negative meaning of behavior without profound view or good meditation. The author states that the same term can also refer to ascetic practices, such as going naked and acting dumb (? gcer rgug) amidst crowds of people. On the following page (p 78) he suggests that tho co'i spyod pa may be synonymous with brtul zhugs kyi spyod pa. The point to emphasize here is that what differentiates good tho co spyod pa from bad is the motivation behind it, and the state of mind of the practitioner: it is either purely senseless activity, or meaningful practice disguised as senselessness.

Here gcer rgug may be a mistake for gcer rgyug, meaning to "run naked." In The Life of Drakpa Tayé, the yogi is instructed by his master to "run naked in empty, unpeopled valleys" (mi med kyi lung stong du gcer rgyugs gyis), p 54.1.

In support of reading the term as meaning senseless or wild behavior rather than chattering or babbling, when I went hiking with Kenpo Tsülnam Rinpoché (with whom I had had many conversations
} 
Tsang advises a follower regarding his question about whether he should stay at home to care for his aging parents or go to pursue the Dharma at Lapchi, the Madman of Tsang refers to himself as "the mad yogi who does nonsensical things" (tho cho byed pa'i rnal 'byor smyon pa, or perhaps "the babbling mad yogi"); later in the verse he again refers to himself as "the mad yogi" (rnal 'byor smyon pa) and "the mad yogi of the realm, from Tsang" (rgyal khams rnal 'byor gtsang pa smyon pa). ${ }^{283}$

In the passage translated earlier in this chapter, when the Madman of Tsang was performing some truly shocking behavior near Tsari, including wearing intestines like a necklace, there is a line that reads, "Sometimes laughing, sometimes crying, he did all sorts of nonsensical things (? gyam tho? gya mtho?), especially in the marketplace."284 This seems to be a reference to some specifically crazy behavior. I have never encountered this term before, and cannot find it in any dictionary. Based on the context it would seem to have a similar meaning to tho co. There is no other mention of the

about the Madmen of Ü and Tsang) and some other monks in 2009, he joked with me, "Hey siddha-do something crazy!" (grub thob lags/ tho co spyod pa cig byed a).

${ }^{283}$ The Madman of Tsang uses the term rgyal khams rnal 'byor smyon pa quite often to refer to himself in the course of his songs and writings.

The entire letter runs Götsang Repa, pp 105.6-107.7. The most pertinent portion is pp 105.7106.1: tho cho byed pa'i rnal 'byor smyon pa ni/. The text is unclear and actually looks more like tho cho byed pa'i rnal 'byor skyon pa ni/. This same passage is given in the earlier biography of the Madman of Tsang, that by Lhatsün Rinchen Namgyel. In that version it is clear that the line reads tho co byed pa'i rnal 'byor smyon pa ni (Lhatsün Rinchen Namgyel, p 94.3). Interestingly, although the passage is the same in both texts, each describes the context in a quite different manner: in the Götsang Repa version, it is said to be the text of a letter the yogi sent to an adherent in response to a letter asking about whether to stay with his parents or go to Lapchi; in the Lhatsün Rinchen Namgyel version, it is a song sung in response to the student's request for instructions ( $\mathrm{gdam} n \mathrm{gag}$ ). These issues of textuality will be discussed in detail in Chapter Five.

${ }^{284}$ res rgod res ngu/ khyad par khrom gseb du gyam tho (synonymous with tho co?) sna tshogs mdzad pas... Götsang Repa, pp 37.7-38.1. Quintman 2006, p 193, reads the key term as gyam tho, and translates it as "outrageous behavior (?)". To my eyes it looks more like gya mtho. However, I have been unable able to find either possible spelling in any dictionary. 
Madman of Ü's doing this kind of "nonsensical" behavior, neither under these terms nor any similar vocabulary. ${ }^{285}$

We should note that the term "secret yogi" (sbas pa'i rnal 'byor) may to some extent indicate the sort of mad behavior we are in search of here. When the Madman of Ü was practicing and converting people in in Nepal, it is said that he "assisted many sentient beings in the manner of a secret yogi' (sbas pa'i rnal 'byor gyis 'gro ba du ma rjes su 'dzin par mdzad). ${ }^{286}$ Much later, when the Madman of the Drukpa came to visit the Madman of Ü at his monastery, the Madman of the Drukpa is referred to as a "secret yogi” (sbas pa'i rnal 'byor 'brug smyon kun dga' legs pa). ${ }^{287}$

It is difficult to speculate about what it meant to be a "secret yogi" from these brief mentions. It seems to mean one who conceals one's accomplishments - a realized yogi who pretends to be an ordinary being. ${ }^{288}$ A passage from The Life of the Madman of

\footnotetext{
${ }^{285}$ Expressing a similar meaning to all this, when I asked Kenpo Nyima Gyeltsen in an interview what the performance of engaged asceticism entailed, he said there were four parts (dbye ba bzhi): 1) aimless activity (dmigs yul med pa'i spyod pa), which he glossed as "activity like that of a madman" (smyon pa nang bzhin gyi spyod pa), doing whatever for no reason (I suggested this might be synonymous with tho co' $i$ spyod pa, to which he agreed); 2) activity without concern for cleanliness or dirtiness (gtsang tsog med pa'i spyod pa), which is acting like a dog or a pig (khyi phag nang bzhin gyi spyod pa), eating whatever, going wherever; 3 ) activity without hopes or doubts (re dogs med pa'i spyod pa), glossed as acting like a child (phru gu lta bu'i spyod pa); and lastly 4) acting without concern for virtue or $\sin$ (dge sdig med pa'i spyod pa), which he glossed as "acting lika a butcher" (shan pa lta bu'i spyod pa). Kenpo Nyima Gyeltsen stated that these should only be practiced by a person with his individual liberation and bodhisattva's vows (dam tshig) intact. This is not for ordinary people, but for a special person (dmigs bsal gyi gang zag) —one with good practice (nyams len) and realization (rtogs pa). A similar list related in the teachings of Jikten Sugmön will be given below.

${ }_{287}^{286}$ p 431.2.

${ }^{287} \mathrm{p}$ 601.2-.3. There are many other examples in the course of Tibetan Buddhism of individuals living in the manner of "secret yogis." In the History of the Taklung Kagyü (stag lung chos 'byung) there is mention of ascetics living in the manner of "secret yogis" long before the time of the Madmen of Ü and Tsang (p 244); it is also maintained that the mother of the 12th abbot of Taklung Monastery was a "secret yogin $\vec{\imath}$ " (sbas pa'i rnal 'byor ma, $\mathrm{p}$ 422). stag lung chos 'byung (brgyud pa yid bzhin nor bu'i rtogs pa brjod pa ngo mtshar rgya mtsho), by stag lung ngag dbang rnam rgyal (bod ljongs bod yig dpe rnying dpe skrun khang, 1992). On the sbas pa'i rnal 'byor ma, see Rase Dawa Konchog Gyatso's 'bri gung chos 'byung, $\mathrm{p}$ 409.

${ }^{288}$ Dungkar Rinpoché includes in his dictionary the term "maintaining secret engaged asceticism" (sbas pa'i brtul zhugs 'dzin pa), which he says is characterized by "internally practicing secret mantra, but
} 
Tsang is more instructive. After leaving the monastic life and just before beginning the outrageous behavior he famously performed at Tsari that was described above, it is said that Sangyé Gyeltsen thought to himself, "Now than I have become fully accomplished for my own benefit, now it is time to work for the benefit of others." So he entered a meditative stabilization called "the Great Clear, Unobscured Knowing of the Three Times," and saw with the eye of great wisdom that in the degenerate time in which we live, sentient beings have ample afflictive emotions, short lives, many illnesses, and intractable false views. Therefore, he should engage in behavior that is directly beneficial for others: he would "wander in every direction performing engaged asceticism and - keeping his excellent qualities very secret (sbas pa)—align himself with the manner of ordinary people, establish pure connections with people of lesser faculties, and achieve great benefit for the Teachings and for sentient beings." Having thought in this way, he smeared himself with ashes and blood, donned a necklace of intestines, and paid a disruptive visit to a religious gathering at Tsari. ${ }^{289}$

Whether this passage represents the actual thoughts of the Madman of Tsang or a more idealized presentation created by his disciple who composed this account, it does provide a window into what likely motivated the Madman of Tsang's behavior. Interestingly, here the Madman of Tsang is presented as an already perfected being,

maintaining a manner of behaving so that it is not made manifest externally" (nang du gsang sngags nyams su blangs kyang phyi la mi mngon par byed pa'i spyod tshul 'dzin pa'i rgyu mtshan gyis yin/), p 1577.

${ }^{289}$ nga ni rang don mthar phyin par grub pas/ da gzhan don bya ba'i dus la bab dgongs tel dus gsum sgrib pa med par gsal ba mkhyen pa chen po zhes bya ba'i ting nge 'dzin la gzhugs nas/ ye shes chen po' $i$ spyan gyi gzigs tshel snyings ma lnga sngo ba'i sems can rnams nyon mongs pa rags pa/ tshe thung ba nad mang zhing log lta che bas/ rang don du phyogs thams cad las rnam par rgyal yang / phal gyi blor mi shong bas da dung gzhan don du lam zhugs kyi rnal byor ba rang rgyud pa'i [should this read rang rgyud sbas tshul?] tshul bzung nas/ brtul zhugs kyi spyod pas phyogs kun du rgyu zhing mchog gi yon tan rnams shin tu sbas pas/ phal pa rnams dang tshul stun na gdul bya rman pa rnams la rnam dkar gyi 'brel pa 'jog cing / bstan pa dang sems can gyi don rgya che bar dgongs nas rtsa ri'i tshogs gral shin tu che ba gcig la sku gcer bur ro thal kyis byugs shing..., Götsang Repa, p 37.3-.6. 
meaning that his eccentric behavior was performed not for his own training, but for the benefit of others. (As we have seen, this is not the way their eccentric behavior is always portrayed.) This passage also shows that concealing his good qualities (assuming the manner of a "secret yogi") is closely associated with his performance of engaged asceticism.

Further suggesting the importance of the notion of the "secret yogi" for these famous holy madmen, one of the main sub-groups of the Madman of Tsang's students was "the eighteen secret mahāsiddhas" (sbas pa'i sgrub chen bco brgyad). ${ }^{290}$ Like wearing the garb of the Heruka, acting in the manner of a secret yogi was evidently not something only the Madman of Tsang himself was doing, but he was also passing it on to some of his students.

It may also be the case that living like a "secret yogi" was connected to the period of practice called "secret activity" (gsang spyod) that was discussed previously. ${ }^{291}$

We can speculate that the notion of hiding one's meditative accomplishments and pretending to be an ordinary being may have provided a framework for their acting like actual madmen at times, as part of their religious practice. The two are certainly on the same conceptual spectrum. In fact, there seems to have been much overlap or interrelation between these various aspects of the holy madmen's distinctive behavior. Consider the following verse, given within The Life of the Madman of Tsang, in which one of the Madman of Tsang's students, Jikmé Drakpa, is praised:

\footnotetext{
${ }^{290}$ The "eighteen secret great siddhas" (sbas pa'i sgrub chen bco brgyad) are mentioned on Götsang Repa, pp 164.3-.4, 190.7-191.1, 207.4, and 263.7-264.6.

${ }^{291}$ Dakpo Penchen Tashi Namgyel's commentary on the Hevajra tantra suggests that gsang spyod and sbas pa'i spyod pa are synonymous, $\mathrm{p} 193$, although it is impossible to tell exactly what the author has in mind here.
} 
A Heruka in the secret manner who demonstrates all possible playful dance of illusion who with his unpredictable activity works for the benefit of othersprostration to Jikmé Drakpa! $!^{292}$

This verse of praise shows how many of the elements that inform the distinctive behavior of the holy madmen and their students are closely related to one another. It is suggested that Jikmé Drakpa, like his master, models himself on the form of a Heruka; we can perhaps read the phrase "in the secret manner" (sbas pa'i tshul) as "in the manner of a secret yogi"; he also performs "unpredictable" or "irregular" activity (nges med spyod pa), probably similar to the "senseless" (tho co) activity described above. This verse of praise exemplifies how the practice of fashioning oneself after a fierce Heruka, the practice of concealing one's true identity, and also behaving in an unpredictable, perhaps nonsensical manner can all come together in one individual, as they did in the Madmen of Ü and Tsang.

The line between acting like a madman and the sort of outrageous behavior the Madman of Tsang is said to have performed in the marketplace is certainly blurry, but there remains a significant distinction between the two. To say that the mad yogis did provocative things in the marketplace and elsewhere in order to generate a reaction from others is similar to but nevertheless significantly different from saying that they behaved in a manner imitating the insane.

Based on these scant references it seems that one aspect of the distinctive behavior of Künga Zangpo and Sangyé Gyeltsen would have been doing truly nonsensical things, and may have involved imitating the behavior of an insane person-

\footnotetext{
${ }^{292}$ sbas pa'i tshul gyi he ru ka rgyu [sic] ma'i rol gar spyir [sic] yang ston/ nges med spyod pas gzhan don mdzad/ 'jigs med grags pa la phyag 'tshal/, Götsang Repa, p 261.1.
} 
“feign[ing] madness," as Cyrus Stearns has put it. ${ }^{293}$ We also have every indication that if this was an element of their lives, it would have been performed within the context of a specific course of tantric practice, as part of their performance of engaged asceticism. Feigning madness (if in fact they did feign madness) was a much less important than the performance of engaged asceticism in the process by which Künga Zangpo and Sangyé Gyeltsen transformed themselves into holy madmen.

If the Madmen of Ü and Tsang were behaving in a nonsensical manner as part of their asceticism, this would not be the only case of such a practice in the Tibetan Buddhist tradition. In his article "The Elements, Madness, and Lettered Subjectivity," David Germano describes a Great Perfection practice in the Nyingma tradition in which monks are instructed to run about, shouting and acting crazily. This has been practiced in Tibet into modern times. ${ }^{294}$ (The possibility that other Tibetans bearing the title "madman" may have done similar practices will be discussed in Chapter Seven.)

As for more specific references to "crazy behavior," there is a text contained in the collected works of Jikten Sumgön, the founder of the Drikung Kagyü tradition, bearing the title "The Essential Meaning of the Eight Great Activities of the Great Master Saraha," which is purported to relate a teaching given by Saraha to Nāgārjuna. After explaining the proper view and meditation, Saraha describes "activity that is free from all acceptance and rejection" (blang dor thams cad dang bral ba), of which there are eight aspects: behaving in the manner of a great lion, elephant, madman (smyon pa), bee, carnivore, ga pa (a deer?), rainbow and bubble (chu bur). Each exemplifies an aspect of

\footnotetext{
${ }^{293}$ King of the Empty Plain, p 60.

${ }^{294}$ pp 313-34 in Religions of Tibet in Practice.
} 
liberation from menial concerns that the practitioner should come to embody, just as Saraha had. The aspect of being like a madman indicates one's living without conceptions (gza'gtad med), without thinking what one should and should not do, and thereby not accumulating mental propensities (bag chags). ${ }^{295}$ Here "madman" is representative of qualities an ideal Buddhist practitioner will embody.

The more common way in which madness appears in the context of Tibetan Buddhist practice, and more directly related to the behavior of the Madmen of Ü and Tsang, is the long-standing tradition of including behaving in the manner of a madman as one aspect of higher tantric practices, as described in the Tibetan tantric commentarial tradition. In his Great Jeweled Tree of Tantric Practice, a commentary on the Hevajra tantra, the Sakya scholar Drakpa Gyeltsen (1147-1216) describes a phase of practice for those who have achieved some degree of yogic warmth. ${ }^{296}$ Drawing directly from Book I, Chapter 6 and Book II, Chapter 2 of the Hevajra tantra, and supported by references to various songs and other tantras, Drakpa Gyeltsen describes how the practitioner should prostrate to his lama, make an offering of everything he owns, and fully dedicate his body to benefiting other beings, and then go to perform "activity" (spyod pa, caryā) (here most likely meant to express the performance of engaged discipline, or something very similar to it). During this phase of practice the adept should adorn himself with corpse ash, animal hides, and eat whatever he finds, no matter how disgusting. He should

\footnotetext{
${ }^{295}$ The text is called slob dpon chen po sa ra ha'i spyod chen brgyad kyi don gnad/, pp 650-7 in Vol. II of khams gsum chos kyi rgyal po mnyam med 'bri gung skyob pa 'jig rten gsum mgon gyi bka' 'bum nor bu'i bang mdzod bzhugs so/ (The Collected Works of Jikten Sumgön) (edited by 'bri gung skyabs mgon che tshang 'phrin las lhun grub, Dehradun: srong btsan dpe mdzod khang, 2008). The section about "mad behavior" runs pp 653.17 to 654.8 .

${ }^{296}$ Drakpa Gyeltsen was a son of Sachen Künga Nyingpo, grandson of the founder of Sakya Monastery and an important hierarch of the Sakya sect in his own right. For more information about his life and works, see Ronald Davidson's Tibetan Renaissance.
} 
wander about at night, stay in charnel grounds, on the shores of large bodies of water, under trees or in caves. He should associate with whomever and go wherever. Freed from his commitments regarding his speech and bodily conduct, he should do and say anything (without, of course, ever giving up his reverence to his lama).

Drakpa Gyeltsen then describes the specific practices that are to be performed during this time, under the headings of "all-trembling activity" (kun 'dar gyi spyod pa; Sanskrit: avadhūtacaryā) and "all-good activity" (kun tu bzang po’i spyod pa; Sanskrit: samantabhadracaryā). ${ }^{297}$ He states that the former category (called "all-trembling" because of the fact that one is to terrify the inhabitants of the world with one's behavior) includes such practices as "the activity of a prince" (rgyal bu gzhun nu'i spyod pa), "secret activity" (gsang spyod), or "the performance of mad engaged asceticism" (smyon pa'i brtul zhugs kyi spyod pa). ${ }^{298}$ Regarding the last, Drakpa Gyeltsen writes: “As for why it is called 'mad engaged asceticism' (smyon pa'i brtul zhugs), one behaves by imitating a madman, keeping hidden one's class (rigs) and so on." ${ }^{299}$ Regarding how this fits into the greater scheme of the practitioner's development, when one has achieved a little warmth, one should continue to live a normal life, but perform the "all-trembling" practices secretly at night. When one has achieved middling warmth, one should perform "all-trembling" activity for the world to see. The purpose of performing the different

\footnotetext{
${ }^{297}$ The Sanskrit for these two terms is provided by Davidson, Tibetan Renaissance, $\mathrm{p} 201$.

${ }^{298}$ rgyud kyi mngon par rtogs pa rin po che'i ljon shing (according to TBRC, this text is also referred to by the title kye rdor rgyud kyi mngon rtogs rin po che'i ljon shing, thus identifying the text as a commentary on the Hevajra tantra specifically), pp 1-1.1 to 70-1.6 (1a-139a) in Vol. 3 of the sa skya bka' 'bum, (Tokyo: The Toyo Bunko, 1968), hereafter referred to as the SKB. Drakpa Gyeltsen provides his gloss of kun 'dar gyi spyod pa on $\mathrm{p} 48-4.4$ to .5 .

Monier-Williams' definition of avadhüta suggests a slightly different meaning of the term: "shaking" off worldly concern, p 100.

${ }^{299} \mathrm{p}$ 49-1.2-.3. This reference came to my attention thanks to references made by Ronald Davidson in his Indian Esoteric Buddhism, pp 223, 327, 392n187, 415n67. The section I am discussing here runs four folios, pp 48-1.2 to 49-4.5.
} 
aspects of "all-trembling activity" is "to examine the stability and wavering of the mind" (sems kyi brtan g.yo brtag pa) and for "exercising dominion over the practitioner's territory and associates" (grub pa thob pa'i yul dang grogs dbang du bya). ${ }^{300}$

We know that the Madman of Tsang was familiar with Drakpa Gyeltsen's written works. In an episode described above, when the Madman of Tsang was said to have given a teaching on the specifications and meaning of the khațvāinga staff, he mentions a text titled "The Six Ornaments of Heruka," by "the Sakyapa Noble Lord, Drak Gyel” as a source. This text is included in the collected works of the Sakya master, documenting the construction, symbolism and use of the various accoutrements of the Heruka, making many citations from the Hevajra, Cakrasamvara and Buddhasamayoga tantras. ${ }^{301}$ Sangyé Gyeltsen may have studied his works during his time at the Pelkor Chödé in Gyantsé.

In his commentary on the Hevajra tantra, Dakpo Peṇchen Tashi Namgyel (1512 or 1513-1587), mentioned already above, surveys the variety of ways in which these practices are discussed by various tantric and commentarial traditions. Tashi Namgyel shows that in addition to the tradition associated with the Cakrasamvara tantra in which the advanced yogic practices are divided into "all good activity," "secret activity," "the performance of engaged asceticism of awareness," and "activity that is victorious in all

\footnotetext{
${ }_{300}^{300}$ 49-4.1-.2.

301 The Madman of Tsang mentions Drak Gyel and his text in Götsang Repa, p 231.5. The text bears the title "he ru ka'i chas drug" and is 8.5 folios long, running pp 265-4.1 to 271-2.4 in Vol. 3 of the SKB. The section in which he discusses the khatvaninga runs pp 268-4.6 to 269-4.3. In answering the question of why one might need these ornaments Drakpa Gyeltsen states that there are six possible reasons: 1) for performing dances that are an offering to all the buddhas during a ganacakra;2) occasions when one must subdue demons by means of having divine pride, such as during an earth-breaknig ritual (sa chog); 3) to generate an experience (nyams bskyang) of putting on the ornaments during an introduction to the nature of the basis of purification and the purifier; 4) to serve as a reminder when one is entranced in the experience of emptiness; 5) to examine whether or not one's meditative stabilization is actually stable, one puts on the ornaments and performs engaged asceticism; 6) when one has achieved stability in one's meditation, one wears the six ornaments while performing "all-good activity," pp 268-1.4 to 2.1.
} 
respects," there are the commentarial traditions associated with the Father Tantras ( $p h a$ rgyud) such as the Guhyasamāja tantra that divide these types of practices using the rubric of practices with elaborations (spros bcas), without elaborations (spros med) and thoroughly without elaborations (shin tu spros med). ${ }^{302}$ There are alternative schemes suggested by the Buddhasamayoga tantra and the Sambuti. Tashi Namgyel then describes a few more alternative schemes based on dividing these practices into "alltrembling” and “all-good," just as Drakpa Gyeltsen's had done, and including “the activity of a madman" (smyon pa'i spyod pa). ${ }^{303}$

Dakpo Penchen Tashi Namgyel's comments about the performance of mad engaged asceticism (smyon pa'i brtul zhugs; Sanskrit: unmattavrata) is likely derived from the tradition based on Ārydeva's Lamp that Integrates the Practices (caryāmelāpakapradīpa, spyod bsdus sgron ma; written between 850 and 1000), which draws primarily from the Father Tantra tradition of the Guhyasamāja. ${ }^{304}$ This discipline

302 They are summarized on Wedemeyer, pp 74-6 and 112-20; the pertinent chapters are translated pp 277332. In this tradition, the performance of engaged asceticism "with elaborations" includes sex with many consorts; "without elaborations" includes sex with a single consort; and at the highest stage, "thoroughly without elaborations," a visualized encounter is substituted for intercourse. It is in the final of these three stages that the yogi would perform "mad spiritual discipline" (unmattavrata).

In his commentary on the "single intention" doctrine (dam chos dgongs pa gcig pa'i gsal byed, cited above), the 4th Red Hat Karmapa, Chödrak Yeshé mentions rig pa brtul zhugs kyi spyod pa as it pertains to the three categories of activity "with elaborations" (spros bcas), "without elaborations" (spros med), and "thoroughly without elaborations" (shin tu spros med). The third of these is equated with the state of "the activity of a bhüsuku with great naturalness" (mnyam bzhag chen po bhU su ku'i spyod pa) - a state in which one has no concerns (rnam rtog) beyond eating (bhu), sleeping $(s u)$ and defecating $(k u)$. Here rig pa brtul zhugs kyi spyod pa is considered to be a practice "without elaborations" and which serves as a stepping-stone to this simpler, more exalted state, $\mathrm{p} 66$.

Marpa, in his commentary on the Hevajra tantra, the 'bum chung nyi ma, also uses these same three categories (pp 96-97). Therefore their usage does extend beyond the Guhyasamāja cycle, although it is in the context of the Guhyasamajja that they are most often appealed.

In his commentary on the Hevajra tantra, Dakpo Penchen Tashi Namgyel summarizes these practices of the Guhyasamāja and Buddhasamayoga tantras, as they compare to the "Activity" chapter of the Hevajra tantra (Book I, Chapter 6), p 193.

${ }^{303}$ pp 194-5.

${ }^{304}$ The Tibetan is attested to on Wedemeyer, p 650; the Sanskrit is on $\mathrm{p} 492$. This date for the text comes from Wedemeyer, p 14. 
is to be practiced by a yogi in the very final stage of meditative practice, the phase "thoroughly without elaborations" (shin tu spros med). This refers to a state similar to that of the $b h u-s u-k u$, a highly realized practitioner who displays no concern for sensory activity other than to eat $(b h u)$, sleep $(s u)$ and defecate $(k u){ }^{305}$

In the chapter on the grounds and paths a Buddhist practitioner is to traverse in the course of his training included in Jamgön Kongtrül Lodro Tayé's (1813-1899) famous Encompassment of All Knowledge (shes bya kun khyab mdzod) there is a section called "an aspect of the path: further improvement activity" (? lam gyi yan lag bogs 'don spyod $p a)$. Kongtrül's vision of the special "activity" taught by the Highest Yoga Tantras is, like that of Dakpo Peṇchen Tashi Namgyel, essentially based on Āryadeva's Lamp that Integrates the Practices, a commentary most closely aligned with the Guhyasamāja tantra. Kongtrül's goal, however, is to present these practices as drawn from and pertaining to a broader range of tantric systems. To this end Kongtrül draws from many of the other descriptions of these practices that have been discussed in this chapter, including the Buddhasamayoga tantra, the 27th chapter of the Cakrasamvara tantra, the sixth chapter of the first book of the Hevajra tantra, as well as the second chapter of the second book, and so on. In the course of his presentation Kongtrül discusses many of the practices that we have seen played an important role in the lives of the Madmen of $\ddot{U}$ and Tsang, including dressing like a deity, wandering in charnel grounds, eating revolting substances like the "five meats" and the "five nectars" and so on. The categories of the performance of engaged asceticism (brtul zhugs kyi spyod pa), "all-good activity" (kun tu bzang po’i spyod pa), "secret activity” (gsang spyod), "public activity” (tshogs spyod),

\footnotetext{
${ }^{305}$ Described in Wedemeyer, pp 119, 323-8.
} 
and "activity that is victorious in all respects" (phyogs las rnam rgyal gyi spyod pa) are used consistently throughout.

Most pertinent to our purpose here, Kongtrül describes the phase of practice known as "secret activity." Its purpose is to determine whether or not the practitioner's state of realization is stable. While training with a worthy consort, one should wander at night in charnel grounds; one should do "various activities that contradict worldly ways" ('jig rten dang 'gal ba'i spyod pa sna tshogs pa byas), and if one's wisdom (ye shes) is the least bit unstable, one should meditate further. Once it has become stable, one asks permission from one's lama to perform avadhüti ( $a$ ba $d+h U$ ti) behavior in full view of the world ('jig rten pa'i mngon du). ${ }^{306}$ At this time one disguises one's true identity by acting like a madman (smyon pa ... brdzus), a degenerate ( $n a l b u$ ) or a low class person (rigs ngan). One should perform various uncertain activities (ma nges pa'i spyod pa), including singing and dancing (glu gar) and babbling ( $c a c o$ ); one should joke and laugh, run and jump. In time the practitioner reveals himself as a yogi, performs miracles for the purpose of changing the minds of the unfaithful, and progresses on to the next phase of practice. $^{307}$

The fact that Tibetan treatises on tantric practice written in the 12th, 16th and 19th centuries, as well as a Sanskrit text that was translated into Tibetan, all mention "mad activity" as an aspect of advanced tantric practice is significant for showing that in

\footnotetext{
${ }^{306}$ In the History of the Taklung Kagyü (stag lung chos 'byung), there is mention of one Driblungpa Tokden Sönam Wangchuk (grib lung pa rtogs ldan bsod nams dbang phyug) who received his monastic vows from the 12th abbot of Taklung Monastery. He is described as one who "externally performed the avadhuti behavior..." (phyi rol du a wa d+hu ti'i kun spyod...), pp 453-4.

${ }^{307}$ The entire section runs pp 935-52 in the 2002 printing (Beijing: mi rigs dpe skrun khang); the section cited here is on $\mathrm{p} 944$. Behaving in the manner of a madman is also mentioned on $\mathrm{p} 945$. Stearns' discussion of "deliberate behavior" (pp 58-80) draws heavily from Jamgön Kongtrül's presentation.
} 
Tibetan Buddhist discourse there has long been a sustained awareness of this practice. (The extent to which the behavior of other "holy madmen" throughout Tibetan history may or may not be related to such a commentarial tradition will be addressed in Chapter Seven.) This sheds some light on "crazy behavior" of the Madmen of Ü and Tsang, and increases the likelihood that part of their ascetic practice included publicly imitating the behavior of madmen, despite scant evidence to this effect in the documents describing their lives.

In the tantric commentaries by Drakpa Gyeltsen, Dakpo Penchen Tashi Namgyel and the much later Jamgön Kongtrül, this practice of acting like a madman is discussed in relation to a series of practices described using the overlapping and variously-defined of the performance of engaged asceticism, "secret activity," "public activity," "all-good activity" and "activity that is victorious in all respects." This is significant in that it indicates to us that the Madmen of Ü and Tsang's performing this behavior would have been conceived of as part of their graded tantric regimen. The fact that the practice is fully embedded in the schematization of different phases of practice gives us strong hints about its origins, which is the subject of the following section. As we will see, this was not a unique Tibetan phenomenon: the roots for this kind of practice can be seen in nonBuddhist ascetic practices in South Asia, stretching all the way back to the time of the Buddha.

Based on the evidence presented in their respective life stories, this practice of literally acting like madmen seems to have accounted for a relatively small portion of their eccentric behavior. Pretending to be mad should not be thought of as the main reason why the Madmen of Ü and Tsang had the term "madmen" applied to them. The 
meaning of the term smyon pa as applied to the Madmen of Ü and Tsang was much more complex and much less literal than that. The Madmen of Ü and Tsang performed the different aspects of engaged asceticism described above, and were as a result labeled "madmen" in a way that was, depending on whose mouth it issued from, either pejorative or full of praise. This distinction between whether they were called "madmen" because they acted like madman (which the evidence suggests they did, although it was a relatively minor aspect of their actual practices and public legacies) or for a broader complex of reasons may seem a minor one, but it ought to be recognized if we are to properly understand the proper place of the Madmen of $\ddot{U}$ and Tsang in the history of Asian religions. The more complex way in which we should think of them as "madmen" will be expressed more fully in the chapters that follow.

\section{V. South Asian Precedent: Pāśupatas, Kāpālikas and the Origins of Buddhist Tantra}

In the course of this chapter dedicated to exploring the distinctive behavior of the Madmen of Ü and Tsang as an aspect of religious practice I have on a few occasions mentioned some non-Buddhist South Asian religious traditions whose practices seem to have much in common with that of the 15 th-century holy madmen. In this section I will describe those non-Buddhist traditions, then the nature of the holy madmen's connection to them.

\section{V.1 The Pāśupatas}

One religious group whose practices constitute a precedent for some key aspects of the Madmen of Ü and Tsang's eccentric behavior is the Pāśupatas, who practiced a 
non-tantric form of Śaivism. ${ }^{308}$ The Pāśupatas are considered to have been the first Śaivite sect. ${ }^{309}$ We have evidence of their existing from the early centuries of the Common Era into the 12th century; the peak of their influence would have been the 6th to 10th centuries. ${ }^{310}$ Pāśupatism was only for serious ascetics and not householders. ${ }^{311}$ The Pāśupatas took their name from Paśupati, a form of Rudra, who was an early form of Śiva. (Throughout Pāśupata literature and scholarship on the Pāśupatas, the names Rudra, Maheśvara, Paśupati and Śiva are used almost interchangeably). Our main source of information about the Pāśupatas is the Pāśupata Sūtra, which was taught by Lākulīśa at some point before the 10th century (although believers considered the text to be of much earlier provenance). ${ }^{312}$ There is a widely-used commentary on the sütra by Kauṇịinya called the Pañcārthabhāṣa.

\footnotetext{
${ }^{308}$ However, some scholars have suggested that Pāśupatism laid the groundwork for what would later become tantric thought. Toward this end, in Śaivism: a Religio-Philosophical History (Delhi: The Theological Research and Communication Institute, 1987) Moti Lal Pandit cites the Pāśupatas' emphasis on asceticism as a means of achieving a greater, more powerful autonomous self; their inclusion of practices that cause one to transcend the limits of the bodily organism; and also their emphasis on the gurudisciple relationship, pp 56-7.

${ }^{309}$ Moti Lal Pandit, p 48; Gavin Flood, An Introduction to Hinduism (Cambridge: Cambridge University Press, 1996), p 155.

${ }^{310}$ On the early side, there is evidence of their receiving royal patronage in northwestern India in the early centuries of the Common Era, Flood, pp 155-6; Moti Lal Pandit, pp 54, 55. For other early evidence of the sect see Haripada Chakraborti (trans.) Pāśspata Sūtram, with Pañchārtha-bhyāṣa of Kaundinya (Calcutta: Academic Publishers, 1970), p 10. On the late end, Ronald Davidson lists 101 sites that can probably be associated with the Pâśupatas, ranging from the 5th century through the 12th, in locations all over India (Indian Esoteric Buddhism, appendix, pp 341-3). Davidson considers the Pāśupatas to have been "the most widespread and important development in early medieval ascetic orders," especially from the 6th to 10th centuries, p 183. Chakraborti, p 15, mentions that the Chinese Buddhist pilgrim Hsüan Tsang described their presence in India and present day Afghanistan. This is also mentioned on Lorenzen, The Käpälikas and Kālāmukhas, pp 15, 182. Geoffrey Samuel, The Origins of Yoga and Tantra (New York: Cambridge University Press, 2008), offers a history of the Pāśupatas, pp 240-3.

${ }^{311}$ Alexis Sanderson, "Śaiva and Tantric traditions" in S. Sutherland et. al. (eds.), The World's Religions (Routledge, 1988) also in Hardy F. (ed.) Religions of Asia (Routledge, 1990), p 644. Sanderson's article is the primary source for this and the following paragraph.

${ }^{312}$ Flood, p 156.
} 
Entrance into the Pāśupata order was restricted to brahmin males with full life-rite initiation (upanayana). ${ }^{313}$ Pāśupata adherents were to remain celibate, and were- $-\mathrm{a}$ period of norm-overturning behavior aside — to avoid contact with women and low castes. ${ }^{314}$ The Pāśupatas thus represented an interesting position vis-à-vis Vedic values.

Becoming a Pāśupata was defined by the taking of a vow of observance (vrata, in Tibetan: brtul zhugs, engaged asceticism), which provides the basis for a set of practices for which the Pāśupatas are famous. Their spiritual regimen was characterized by four distinct stages $^{315}$ (vidhi) of practice, which I will describe individually here, as these signal us to some interesting comparisons with the behavior of the Madmen of $\ddot{U}$ and Tsang.

The first stage of Pāśupata practice (called vyaktāvasthā, "the stage of manifest marks") focused on cultivating reverence for god and beginning to overcome one's attachment to the self. In the first stage of practice, the practitioner was to live near a Śiva temple, wear a single cloth or go naked, smear his body with ashes, ${ }^{316}$ worship Śiva through dancing, chanting, laughter, circumambulating the temple and silent meditation

\footnotetext{
${ }^{313}$ Flood, p 156.

${ }^{314}$ Flood, $p$ 156; Chakraborti, pp 78-9. Sanderson's brief but factually dense description of the Pāśupatas, pp 664-5, in "Śaiva and Tantric traditions" is the primary source for this summary.

${ }^{315}$ Some scholars (for example, Lorenzen, The Kāpālikas and Kālāmukhas, p 185; Davidson, Indian Esoteric Buddhism, p 183) speak of five stages, the fifth being the state of bliss a practitioner achieves after death. Flood (pp 156-7) writes of only three stages (collapsing the third and fourth stages described below). The last three stages (in Lorenzen or Davidson's reckoning) become quite difficult to distinguish from one another and neither the Pāśupata Sütra nor its commentary are much help in clearing up the distinctions between them. This is likely the reason behind Flood's more simplified presentation. As Lorenzen describes, "The most important of the five Stages are the first two; the Marked and the Unmarked. The other three seem to denote mental states as much as courses of behaviour."

${ }^{316}$ Chakraborti, pp 4-5; pp 55-7, sleeping on and "bathing" in ashes is described by the root text and the commentary; it is said that the practitioner should bathe in ashes three times a day.
} 
on five mantras connected to Śiva. During this period he would wear the marks that distinguish members of the sect (linga). ${ }^{317}$

It is the second phase that interests us most in our consideration of the connection to the practices of the holy madmen. During the second stage of practice the ascetic would shed all marks and symbols (it is thus called avyaktāvastha, "the stage of nonmanifest marks"). ${ }^{318}$ The practitioner would leave the temple for a more populated place. While there he would do such things as pretending to be asleep, shaking his limbs to simulate being afflicted with a nervous disorder, walking with a limp and making lewd suggestions to women. The ascetic would behave in these ways in order to incite people to verbally and physically attack him; David Lorenzen calls it "courting dishonour by disreputable behavior.",319 As the commentator Kaundinya explains, "Having seen his marks, customs, knowledge and inclinations contrary to injunctions and by their standard judging this man to be defective for all defects, (the people) insult him." ${ }^{.320}$ Kauṇ̣inya states that, "He should have his body smeared with ashes and soiled with dirt like that of a poor man and that of a lunatic." ${ }^{321}$ Because he bears no signs of being an ascetic, others have no idea that he is play acting, and their improperly censuring him, according to the Pāśupata Sūtra, causes what can be best described as an exchange of merit. The moment

\footnotetext{
${ }^{317}$ Minoru Hara, Pāśupata Studies, Jun Takashima, ed. (Vienna: De Nobili Research Library, 2002), p 127. Some scholars consider this stage to consist of normative Śaivite practice, while others maintain that in even these early practices the ascetic is beginning to act as a madman. Davidson, Indian Esoteric Buddhism, p 183; Hara, pp 64-6. The first vidhi of practice is described in the first chapter of the Pāśupata Sütra, mainly on Chakraborti, pp 55-97; Lorenzen, The Kāpālikas and Kälāmukhas, p 185-7; Flood, p 156; Davidson, Indian Esoteric Buddhism, p 183.

${ }^{318}$ Chakraborti, $p$ 122. The second stage of practice is described mostly in the third chapter of the Pāśupata Sütra (Chakraborti, pp 122-35), but is also mentioned in the second (Chakraborti, pp 109-10). It is summarized by Flood, pp 156-7; and Davidson, Indian Esoteric Buddhism, p 183.

${ }^{319}$ Lorenzen's description of this stage of practice runs pp 185-8 in The Kāpālikas and Kälämukhas.

${ }^{320}$ Chakraborti, p 123.

${ }^{321}$ Chakraborti, pp 127-8.
} 
a person attacks the yogi, the yogi's sins and bad karma are transferred to his abuser, while whatever good merit the abuser may have is transferred to the yogi. ${ }^{322}$ This is how the purpose of the practice is described by the Pāsupata Sütra and its commentary; some scholars have gone a step beyond this, speculating about what psychological effect these practices would have had on the one performing them. ${ }^{323}$

In the third stage, the "stage of victory" (jay $\bar{a} v a s t h \bar{a})$ — meaning victory over the senses - the practitioner would reside in a remote cave or other secluded place and practice meditation by means of the constant repetition of five mantras. During this stage the yogi would conceal the fact that he was a religious practitioner by keeping his observances (vrata), such as laughing and bathing in ashes, hidden. The Pāśupata Sütra dictates that during this phase the practitioner was to "wander like a lunatic among the people" (unmattavad eko vichareta loke), imitating different types of madness. ${ }^{324}$ People

\footnotetext{
${ }^{322}$ Kaundinya says, "Then the people recognize him to be sleeping, mentally or verbally, and insult him. By the false practice of this man whatever merit they have comes to him; and whatever sin this man has, goes to them. Thus the false pretension of sleeping is the performance" (Chakraborti, p 128). Also: "Thus the aspirant gives sin to them or contaminates them who unite him with insult etc," $p$ 126. Minoru Hara considers the Pāśupata idea of the transference of merit to be an instance of a more universal phenomenon within Hinduism, p 108. Other scholars discuss the notion of a transfer of merit: Flood, p 157; Sanderson, $\mathrm{p} 665$.

323 Of all the scholars considered in making this study, Ronald Davidson comes closest to a well-rounded explanation of the Pāśupatas. He notes the concept of a transference of merit as well as the anti-social aspects of the Pāśupatas' practices, but pushes this last issue further by emphasizing the importance of ritual (both religious and secular) in the culture in which the Pāśupatas lived. Davidson's explanation of Indian society of this period is sensitive to the great importance of ritual in a society that is founded on segregation and hierarchy. For a Pāśupata ascetic it was ritual observances of all types that created the self he once knew. It was ritual observances that told him everything about what he ought to believe and how to behave. Davidson says that one who took up the Pāśupata renunciatory vows was like a ghost, in that he was neither human (because of his not following the restrictions and rituals that create a person) nor dead (because he still lived, breathed and depended on food). As Davidson says, "He is thus a contradiction in terms, a living paradox" (Indian Esoteric Buddhism, p 221). The Pāśupata ascetic consciously puts himself in this unanswerable position. See also G. V. Tagare, Śaivism: Some Glimpses (New Delhi: D. K.

Printworld, Ltd., 1996), p 37.

${ }^{324}$ Chakraborti, pp 140-1.
} 
will think the practitioner "insane or foolish" (unmatto mū dho ityevam manyante itare janāh). ${ }^{325}$

In the fourth stage, the "stage of severing" (chedāvasthā) the ascetic was to leave his secluded abode for a cremation ground, where he would wait for death, living off whatever sustenance he could find (previously he abided by begging). The practitioner is to strive to live as a cow or a deer, non-dual with respect to all physical or mental sensations. ${ }^{326} \mathrm{He}$ would "cut off" attention to all sense objects, and thereby concentrate fully on lord Śiva. ${ }^{327}$ This fourth stage would end at death, after which through the grace of Rudra the ascetic entered the stage of completion (nișthā) (which some commentators enumerate as a fifth stage). In this state all suffering and bodily existence has been transcended and the practitioner has attained the perfected qualities of Rudra. ${ }^{328}$ Liberation is described as the achievement of union $(\operatorname{yog} a)$ with the deity, at which point the ultimate qualities of the deity are attained. In this system the Lord's grace descends only after the practitioner has had the realization of his oneness with the deity.

The similarities between the distinctive practices of the Pāśupatas and those of the Madmen of Ü and Tsang are more than passing. Most obviously, their practices of going into the most public and populated places and acting in such a way as to invoke the censure of others are remarkably similar. One aspect of the second phase of Pāśupata practice involved making amorous advances towards women, strongly reminiscent of the Madman of Tsang chasing women (and men) through the marketplace yelling, "Screw

\footnotetext{
${ }^{325}$ This phase of practice is described in the fourth chapter of the Pāśupata Sütra: Chakraborti pp 136-52; Lorenzen, The Kāpālikas and Kālāmukhas, p 185; Flood, p 157; Davidson, p 183.

${ }^{326}$ Chakraborti, p 165.

${ }^{327}$ Chakraborti, $\mathrm{p} 177$. This phase of practice is described in Lorenzen, The Käpālikas and Kälämukhas, $\mathrm{p}$ 185. Flood ( $\mathrm{p}$ 157) collapses it with the previous stage.

${ }^{328}$ See Minoru Hara, pp 127-9 for a similar but more detailed account.
} 
me!"329 Both the Pāśupata and the holy madmen had phases during which they smeared themselves with ashes, and also periods of practice during which they bore no external distinctions, completely concealing their being religious practitioners (the Madmen of $\ddot{U}$ and Tsang's following the way of the "secret yogi," sbas pa'i rnal 'byor).

What's more, the four stages of Pāśupata practice (vidhi)—living in a temple while engaging in traditional forms of worship; performing erratic behavior in the marketplace; wandering like a madman; solitary meditation in charnel grounds-are quite similar to the phases of practice through which the holy madmen's various life phases were at times described: "all-good activity," "secret activity," "public activity," and "activity that is victorious in all respects." In fact, the third phase of Pāśupata practice, the "stage of victory" (jayāvasthā), is remarkably similar to the phase of practice exhibited by the Madmen of Ü and Tsang called "activity that is victorious over all distinctions" (phyogs thams cad las rnam par rgyal ba'i spyod pa). In both cases the meaning expressed is having achieved a state of victory over the senses. The terms describing the first two stages of Pāśupata practice, vyaktāvasthā and avyaktāvasthā, are very similar to two terms often used by Tibetans to describe phases of tantric practice in the Father Tantra tradition of Highest Yoga Tantra (spros bcas and spros med respectively). ${ }^{330}$ In these two traditions these phases of practice are discussed using the terminology of vrata or its Tibetan equivalent, brtul zhugs.

\footnotetext{
${ }^{329}$ Chakraborti, pp 130-1; Lorenzen, The Kāpālikas and Kälāmukhas, pp 139, 185.

${ }^{330}$ Wedemeyer states that spros bcas, spros med and shin tu spros med are translations of the Sanskrit terms prapañcatā, niṣprapañcatā and atyanta-nișprapañcatā, p 68. However, in this context prapañca does not carry its usual meaning of "mental fabrications," but rather refers to "ritual accoutrements used in the rites" (or lackthereof), p 74. These three terms are all discussed in Āryadeva's Lamp that Integrates the Practices in the context of the performance of engaged asceticism.
} 
In Tibetan descriptions of the performance of engaged asceticism there is often a somewhat curious mention that the yogi would keep his "class" (rigs) secret when going forth to imitate the manner of a madman. We saw this in The Life of the Madman of $\ddot{U}$ (“... while going along the path he would perform the engaged asceticism of a madman (smyon pa brtul zhugs kyi spyod pa): keeping his status (rigs), clan (rus), family (cho 'brang) and so on secret (gsangs), he roamed ('khyam) in various places where he did not know anyone"). ${ }^{331}$ The commentary on the Hevajra tantra by Drakpa Gyeltsen mentions that performing "mad engaged asceticism" (smyon pa'i brtul zhugs) involved "imitating a madman, keeping hidden one's class (rigs) and so on." The somewhat awkward presence of the term rigs here may be understood as a carry-over from the Pāśupata tradition. In a traditional Indian context, one's caste or varna (in Tibetan, rigs) played an integral role in determining one's public identity. Although in traditional Tibetan culture one's status would be defined by some extent by birth, it was not as persistent a social concern.

Lastly, the ultimate goal of the Pāśupatas was to achieve identification with Śiva in his Rudra form. The Madmen of Ü and Tsang endeavored to embody the same deity, except rebranded as Buddhist. In this respect their behavior was even more closely related to that of the Śaivite movement to be described next, the kāpālikas.

\section{V.2 Kāpālika-style practice}

Beyond proceeding through a series of ascetic lifestyles resembling that adhered to by the Pāśupatas, the other most defining feature of the Madmen of Ü and Tsang was their wearing the ornaments of a Heruka. The garb they wore corresponds exactly to the distinctive garb worn by kāpālika-style ascetics of India. The kāpālika garb included a

${ }^{331}$ The Life of the Madman of $\ddot{U}, \mathrm{p} 522.5-.6$. 
set of six "bone ornaments" (mudrikā-șața or mudrā-śatka ${ }^{332}$ ), which one 11th-century

Indian commentator identifies as including a necklace, neck ornament, earring, crestjewel, ashes and sacred thread. Other Indian ascetics (especially Śaivite ones) would wear some of these same ornaments. But what was most definitive of the kāpālikas were two secondary insignia: the skull cup and khatvāinga staff. ${ }^{333}$ According to David Lorenzen, the kāpa $\bar{a}$ ikas seem to have existed from the 5th or 6th century, and to have died out as a distinct sect by the 14th century. They were likely absorbed into the Aghorīs or the Kānphațās. ${ }^{334}$ However, David Gordon White has argued that we should not think of the kāpālikas as having constituted a distinct sect. ${ }^{335}$ For this reason I have chosen to use the looser term "kāpālika-style," as has Geoffrey Samuel in his recent research, or simply refer to the kāpālikas without capitalizing the term. ${ }^{336}$

Käpālika-style practitioners followed a set of texts called the Bhairava tantras and worshiped ferocious forms of Śiva, like Bhairava and the goddess Kālin. ${ }^{337}$ The kāpālikastyle practitioner's practice was defined by the adhering to the "great observance" (mahāvrata), through which he imitated lord Śiva by carrying around a cup made from a

\footnotetext{
${ }^{332}$ Lorenzen, The Kāpālikas and Kālāmukhas, pp 2 and 3 respectively.

${ }^{333}$ Lorenzen, The Kāpālikas and Kälāmukhas, p 2. This same list is cited Davidson, Indian Esoteric Buddhism, p 178. See also Lorenzen, "A Parody of the Kāpālikas in the Mattavilāsa," pp 81-96 in David Gordon White, ed., Tantra in Practice (Princeton: Princeton University Press, 2000), p 83, where he offers a slightly different list based on the same source: two kinds of earrings, a necklace, a jeweled crest, ashes, sacred thread, plus the khațāinga staff and skull.

${ }_{334}^{334}$ Flood, p 166; Lorenzen, The Kāpālikas and Kālāmukhas, pp 51-3.

335 "Review of Indian Esoteric Buddhism, by R. M. Davidson," Journal of the International Association of Tibetan Studies 1, 2005: pp 1-11. White states that there are "no Hindu Tantric scriptures that contain the term kāpālika in their title, or whose authors call themselves Kāpālikas, and there is not a single inscription in all of South Asia that names the Kāpālikas in a way that would indicate an actual sectarian order," p 9. Cited in Samuel, The Origins of Yoga and Tantra, $\mathrm{p} 243$.

${ }^{336}$ Samuel, The Origins of Yoga and Tantra, gives an overview of kāpālika-style asceticism, pp 243-6.

${ }^{337}$ Flood, p 165; Lorenzen, The Kāpālikas and the Kãlāmukhas, pp 4, 20.
} 
human skull. ${ }^{338}$ This observance was based on the legend in which Śiva had a skull stuck to his hand as punishment for cutting off one of the god Brahma's heads. Also adding meaning to the kāpa $l i k a$ 's practice was the fact that the standard punishment for killing a member of the brahmin varna included carrying a skull, wandering, and begging for one's food for a period of twelve years. ${ }^{339}$ For this reason, maintaining the great observance was like imitating the punishment for the most heinous of all crimes, structurally positioning oneself as the most debased and socially unwelcome of all beings. ${ }^{340}$ Ultimately the purpose of the kāpālika-style observances was to achieve union—in Lorenzen's words, "mystical identification or communion"—with Śiva: "Through their imitative repetition of Śiva's performance of the Mahāvrata, the ascetics became ritually 'homologised' with the god and partook of, or were granted, some of his divine attributes, especially the eight magical powers (siddhis). ${ }^{341}$ In addition to imitating the deity through dressing in his image and maintaining the "great observance," the practitioner sought to appease Śiva through human sacrifice, making offerings of human flesh, performing püjas with corpses, and making offerings of bloody heads and liquor. ${ }^{342}$ These were highly polluting activities, placing the kāpālika practitioner (unlike the Pāśupatas) on the opposite end of the spectrum from brahmin orthodoxy. Lorenzen

\footnotetext{
${ }^{338}$ Lorenzen, The Kāpālikas and the Kālāmukhas, p xiii: "Of greatest importance is the identification and description of the peculiar vow of the Kāpālikas called the Mahāvrata. It is this vow, I believe, that provides the key to a proper understanding of many of their unorthodox ascetic practices." See also Lorenzen, "A Parody of the Kāpālikas in the Mattavilāsa," p 81. An overview of the kāpālikas is given pp 81-3. The play that follows is a rich and hilarious observation of the relations between religious sects in medieval India.

${ }^{339}$ Lorenzen, The Kāpālikas and the Kālāmukhas, pp 73-81.

${ }^{340}$ Lorenzen, The Kāpālikas and the Kālāmukhas, pp 70, 77.

${ }^{341}$ Lorenzen, The Kāpāilikas and the Kālāmukhas, p 80; Flood, p 165. Gray talks of their practice as a "pursuit of power... that often involved the transgression of social mores and rules of purity," $p 8$.

${ }^{342}$ Lorenzen, The Kāpālikas and the Kālāmukhas, pp 85-6. As summarized by Flood, "the Kāpālika ascetic lived in the cremation grounds, imitating his fierce deities and appeasing these deities with offerings of blood, meat, alcohol and sexual fluids from ritual intercourse unconstrained by caste restrictions," $\mathrm{p} 165$.
} 
states that the relationship between the kāpälika-style practitioner and Śiva (in his

Bhairava form) was one of personal devotion (bhakti), the rituals of which took forms that were "either propitiatory, imitative or a combination of both." 343 Maintaining the mahāvrata was a core part of this imitation

There were in India a few ascetic orders that combined Pāśupata practice with the distinctive observances of the kāpālikas (dressing like a wrathful form of Śiva, carrying a skull cup and staff, engaging in more transgressive practices and embracing impurity), such as the Lākulas and the Kālāmukhas (the latter perhaps being a subdivision of the former). Gavin Flood has described the Lākulas in this way:

These were ascetics who accepted the doctrines of the Pāśupata Sütra, though they were more extreme in their ascetic practices and rejection or transcendence of vedic injunctions than the other Pāśupatas. [Alexis] Sanderson quotes one surviving manuscript of the sect which describes them as wandering, carrying a skull-topped staff (khatvainga), with a skull begging bowl, a garland of human bone, and covered in ashes, with matted hair or shaven head in imitation of their Lord Rudra. ${ }^{344}$

The Kālāmukhas ("black-faced ones") flourished from the ninth to thirteenth centuries. ${ }^{345}$ They had many temples in southern India. Lorenzen considers the Pāśupatas to have been the "spiritual parent" of the Kālāmukhas, although they were distinct sects. ${ }^{346}$ The practices of the Kālāmukhas (and Lākulas) can be best understood as the Pāśupata practice merged with that of the kappālikas. ${ }^{347}$

\footnotetext{
${ }^{343}$ Lorenzen, The Kāpālikas and the Kālāmukhas, p 83.

${ }^{344}$ Flood, p 157.

${ }^{345}$ Flood, pp 157-8. Lorenzen provides a detailed history of the sect based on the copious epigraphic evidence, The Käpālikas and the Kälämukhas, pp 97-172.

${ }^{346}$ Lorenzen, The Kāpālikas and the Kãlāmukhas, p 173.

${ }^{347}$ Lorenzen, The Kāpālikas and the Kălāmukhas, $\mathrm{p} 183$. Here Lorenzen does not say this literally, but maintains that "we must assume that the Kālāmukhas maintained the Pāśupata regimen and theology more or less intact." Chakraborti states that the "kāpālikas and Kālāmukhas formed the most extreme sect of the Pāśupatas," p 18. We cannot hope to definitively sort out the distinctions between these various sects, as it is likely that even in the time in which they lived there would have been much overlap. For our purposes
} 
It is in the Lākula and Kālāmukhas movements that we find the closest comparison to the distinctive behavior of the Madmen of $\ddot{U}$ and Tsang: the trajectories of the practices of the Madmen of Ü and Tsang followed quite closely with the phases of practice engaged in by the Pāśupatas, but also included dressing in the image of Bhairava or Rudra (as the Buddhist deity Heruka), carrying a skull cup and khațvänga, and making offerings with alcohol and flesh. These two streams - the Pāśupata stream and the $k \bar{a} p \bar{a} l i k a$-style stream—were brought together by the Lākulas and/or the Kālāmukhas, who were so fully devoted to achieving identification or union with a wrathful form of Śiva, through offerings, meditation and imitation.

Here we should address the question of the relationship between the deities praised and imitated by the Pāśupatas and kāpālika-style practitioners and the Heruka that was emulated by the Madmen of $\ddot{U}$ and Tsang. There are a few related Indian and Tibetan myths regarding the origin of Heruka, which explain why he so closely resembles a non-Buddhist deity. According to one Tibetan version of the story, on the continent of Jambudvīpa, Śiva (as Maheśvara) had achieved dominion, and was seated in state surrounded by his consort and many dark minions. They ate human flesh and drank blood, wore bone ornaments and were smeared with ashes. In order to subdue these terrible beings Heruka along with an entire retinue was emanated from the Buddhist deity Vajradhāra. ${ }^{348}$ First the Buddhist deities imitated the ghastly Śaivite ones, eating flesh and drinking blood, and thereby earning the epithet "the Glorious Bunch of Blood-

let us just conclude that they shared much and there was a good deal of cross-over between them. See Flood, p 154, on the way some different South Asian texts classified these various groups.

${ }^{348}$ Ronald Davidson, "Reflections on the Maheśvara Subjugation Myth: Indic Materials, Sa-skya-pa Apologetics, and the Birth of Heruka," Journal of the International Association of Buddhist Studies, 14.2: pp 197-235; here I cite the reprint, pp 1-31 in Buddhism: Critical Concepts in Religious Studies, edited by Paul Williams, Vol. 6 (New York: Routledge, 2005), p 9. 
drinking Divinities." ${ }^{349}$ They then stole (phrog) the ornaments of Maheśvara and his retinue and put them on themselves. They then subdued Śiva and his hordes "by causing their consciousness to be absorbed into the clear light," ensuring that in the future Siva would become an enlightened being. This is the version presented by the Sakya thinker Drakpa Gyeltsen; it is mostly derived from older mythologies about the Cakrasamvara tantra and the origins of its teacher and central deity, Heruka. This myth bears a close relationship to the older legend of the subjugation of Śiva by the bodhisattva Vajrapāṇi. ${ }^{350}$

This story makes the unsurprising assertion that Buddhist deities (and thus Buddhism) are more powerful (and closer to the truth) than Śaivite ones, and also provides a justification for why the Buddhist deity Heruka looks so similar to a form of Siva, in appearance and activity: it was all a part of his subjugation of them. ${ }^{351}$ Thus when the Madmen of Ü and Tsang emulate Heruka, it is basically the same deity as that worshipped by the Pāśupatas and the kāpālika-style practitioners, albeit in a Buddhist form (the conversion accomplished via name-changing and the composition of mythology). This adds to the many similarities between the practices and appearances of the Madmen of Ü and Tsang and their Indian predecessors. It was suggested above that

\footnotetext{
${ }^{349}$ dpal khrag 'thung gi lha tshogs. Davidson, "Subjugation," p 9.

${ }^{350}$ On the various versions of the two myths mentioned here (Vajrapāni's subjugation of Śiva, and then the later story of Heruka's subjugation of Śiva), see Gray, pp 35-54, which includes some other myths about the macabre origins of the deity Heruka; Snellgrove, Indo-Tibetan Buddhism, pp 134-41; Davidson, "Subjugation"; Davidson, Indian Esoteric Buddhism, pp 211-7. The version of the myth of the origin of Heruka related here is based on Davidson's synopsis of Drakpa Gyeltsen's short text, "The Origination of Heruka" (dpal he ru ka'i byung tshul) (in SKB, Vol. 3, pp 298-4.2 to 300-2.6; 3.5 folios long) in his "Reflections on the Maheśvara Subjugation Myth."

${ }^{351}$ As Gray concludes, "This myth represents the adoption of non-Buddhist elements while at the same time representing the subordination of these elements within a Buddhist cosmic hierarchy, graphically represented by the placement of the Śaiva deities under the feet of their Buddhist vanquisher," $p 53$. According to Gray, Heruka resembles Rudra and/or Bhairava iconographically, pp 43, 52.
} 
the holy madmen's performing "fierce engaged asceticism" (drag po brtul zhugs) may

bear some meaning of performing behavior recognized as similar to that of the deity

Rudra (drag po), a wrathful form of Śiva. The fact that Heruka is a Buddhist

appropriation of this same deity strengthens the possibility.

\section{V.3 The Question of Influence}

The important question here is how the Madmen of Ü and Tsang came to behave

in a way that so closely resembled the ascetic observances of these non-Buddhists in

India. Is there a connection between these two phenomena, or are their similarities the

product of coincidence?

For one, we have no indication that the Madmen of Ü and Tsang had any inkling that their behavior was so similar to that of any group by the name of Pāśupata, kāpālika, Kālāmukha, Lākula or any other non-Buddhist sect. There is no discussion of any of these groups in the life stories or writings of the 15th-century holy madmen, nor in any contemporary discussion of their practices which I have come across. (In fact, I been unable to find any reference as to how the terms Pāśupata, kāpālika, Kālāmukha or Lākula would even be translated into the Tibetan language. ${ }^{352}$ ) And we have no reason to

\footnotetext{
352 Tibetans have long known and used the word "kapāla" ( $k a$ pA la), meaning skull cup (see, for example, The Life of Drakpa Tayé, p 61.3, 131.1, etc.), which in conversation is pronounced "ka pa li." The question here is whether or not Tibetans were at any point aware of a specific group called Kāpālikas, or something similar.

One instance that might indicate how Tibetans may have dealt with the notion of a kappālika is in the Old Bengali songs of the Caryāgitti, which includes three songs by a mahāsiddha named Kānha who calls himself a "kāpālin." See Lorenzen, The Käpālikas and the Kälāmukhas, pp 52, 69-71, 77. It would be interesting to see how this term is dealt with in the Tibetan translation and commentaries on the collection. Interestingly, the commentator Munidatta's gloss of the term kāpālika is transliterated into Tibetan rather than translated, suggesting that Tibetans did not know what to make of the term. See Per Kvaerne, An Anthology of Buddhist Tantric Songs (Oslo: 1977), pp 150-4. (This instance of Kāṇha's songs and how they were received by the Tibetan tradition was suggested to me by David Gray in an email (22 April 2010), for which I am very thinkful.) Despite this potential connection, I argued above that the mahāsiddhas provided only slight influence on the Madmen of Ü and Tsang and I see no evidence that they
} 
believe the holy madmen would have drawn inspiration from any non-Buddhist source.

On the contrary, they presented themselves as the upholders of true Buddhist tantra.

Some of their contemporaries charged them with enacting a non-Buddhist way of life, but there is no discussion of which non-Buddhists they may have been influenced by.

But there is evidence that in 15th-century Tibet some were aware of the nonBuddhist practices that would evolve into the asceticism of the Pāśupatas. These are the South Asian ascetic practices of imitating the behavior of animals, usually a cow or a dog or a bird, which go back to the time of the Buddha and even earlier. In the Kukkuravatika Sutta, the Buddha tells an ascetic pursuing the ox observance (vrata) and one pursuing the dog observance that the best they could hope for as a result of their practice was to be reborn among oxen and dogs, and nothing better. ${ }^{353}$ Those doing these practices are occasionally mentioned in Tibetan works on philosophical systems ( $g r u b$ mtha') as exemplifying the wrong-headed practices of heretics. For example, a contemporary of the 15th-century holy madmen, the 4th Red Hat, Chödrak Yeshé, mentions in his enormous commentary on the Six Dharmas of Nāropa:

As for the heretics who intend to achieve liberation by the observances of going about naked or [acting like] an animal, because this has degenerated from the correct view and practice, it is to engage in a perverse path. And as this is removed from the true path of liberation, it is mistaken... ${ }^{354}$

\footnotetext{
were in any way inspired by Kāṇha specifically, although they may well have received his songs along with the other dohās at some point. But even if they did receive his songs, it remains a possibility that they would not have known what "kāpālin" meant, depending on how it had been rendered into Tibetan and passed onto them.

${ }_{353}^{353}$ Samuel, The Origins of Yoga and Tantra, p 162.

${ }^{354}$ gcer bu dang dud 'gro'i brtul zhugs kyis grol bar 'dod pa'i mu stegs can rnams ni yang dag pa'i lta spyod las nyams pas log pa'i lam du zhugs pa da (de?) rnams la thar pa'i lam dang bral bas phyin ci log pa yin yang... in dpal nA ro chos drug gi khrid kyi rim pa sbas pa'i don mtha' dag gsal bar byed pa brgyud sde'i snying po kun las btus pa: A detailed intsructional manual for the practice of the six doctrines of Näropa according to the system of the Kam-tshan Bka'-brgyud-pa, p 650.1-.2.
} 
The term here used to express these "observances" is brtul zhugs, engaged asceticism, which translates the Sanskrit vrata. (Elsewhere in the same text the 4th Red Hat discusses brtul zhugs in the more specific tantric sense as an "enhancement" (bogs 'don) practice that describes the behavior of the Madman of Ü and the Madman of Tsang.) Thus we know that in 15th-century Tibet there was some awareness of the older Indian practice of imitating the behavior of animals. Some scholars consider these practices to constitute a "proto-Paśupatism," while others are more resistant to the notion that these practices actively contributed to the development of the distinctive asceticism of the Pāśupatas. ${ }^{355}$

Although some 15th-century Tibetans had some familiarity with this kind of practice, we have no reason to believe the Madmen of Ü and Tsang were emulating them. On the contrary, their primary source of inspiration was - as is made clear time and time again in their life stories - the Yoginī tantras, especially the Hevajra and Cakrasaṃvara tantras. And based on directives given in these tantras, they did the performance of engaged asceticism (brtul zhugs kyi spyod pa, vratacayrā). And what the performance of engaged asceticism entails according to the Hevajra tantra is the performance of "observances" (brtul zhugs, vrata), here bearing two different yet related meanings. As the life stories of the Madmen of Ü and Tsang clearly show, one aspect of the

\footnotetext{
${ }^{355}$ In, "Cynics and Pāśupatas: The Seeking of Dishonor" (in Harvard Theological Review 55: pp 281-98, 1962) David H. H. Ingalls argues that the various "beast-vows" attested to in Sanskrit literature (including the bull-vow, the cock-vow and the sparrow-vow) likely contributed to the Paśsupata practices of behaving improperly in public, $\mathrm{p} 295$. Samuel, The Origins of Yoga and Tantra (pp 162, 241-2) follows Ingalls' suggestion that the Pāśupatas bore an influence from this tradition. Lorenzen, The Kāpālikas and Kälämukhas, is not convinced, instead seeing the Pāśupatas' "courting of dishonour mainly as an extension, ableit a highly original one, of the search for worldly detachment through ascetic penance," and therefore a product of "the dominant asceticism complex of Indian religion itself," rather than being derived from the "beast-vows," pp 187-8.
} 
"observances" called for by the Yoginī tantras is a series of ascetic practices through which the trainee assumes a few different lifestyles in stages, from relatively conventional religious practice at a temple or monastery, to doing shocking behavior in the midst of a marketplace, to wandering like a madman. The other main meaning carried by the term "observances" in the Yogini tantras, as exemplified by the Madmen of $\ddot{U}$ and Tsang, is wearing ashes and a set of bone ornaments, carrying a khațāinga staff and a skull cup-i.e., dressing up in the garb of a Heruka. As we saw above, for the Madmen of Ü and Tsang and some of their contemporaries, the performance of engaged asceticism is synonymous with wearing this garb. Thus the activities of the Madmen of Ü and Tsang that fell under the category of the performance of engaged asceticism (of which they made themselves the authority par excellence) clearly brought together two streams of South Asian, non-Buddhist ascetic practices, most strongly exemplified by the Pāśupatas and the kāpālikas, and in this way were most similar to the practices of the Lākulas and/or the Kālāmukhas, who practiced a fusion of those two streams.

Since the behavior of the Madmen of Ü and Tsang is in large part inspired by the Yoginī tantras, which draw from the form of asceticism exemplified by the Lākulas and the Kālāmukhas, who themselves bore much influence from the Pāśupatas, it is possible that the eccentric behavior that got Künga Zangpo and Sangyé Gyeltsen called "madmen" may be genetically related to the tradition of the "holy fool" in the Christian tradition, via some similar intermediaries. In his article, "Cynics and Pāśupatas: The Seeking of Dishonor,” David H. H. Ingalls describes the many similarities between the Pāśupatas and the Greek cult of the Cynics (active in Athens from the 4th century BCE), who also performed shocking public acts for the purpose of attracting abuse. Ingalls is clear that 
we do not have enough information to suggest that one tradition was drawn from the other, but that the two were parallel movements, with some perhaps significant interconnections. For example, the founding of the Pāśupata order is often attributed to one named Lakulīśa ("bearer of the club"), who is usually depicted bearing a club. Linguistically, this is very similar to the name of the man considered to be the founder of the Cynics, Hercules (or Heracles in Greek), who is also depicted as holding a club. ${ }^{356}$ If it were proven that the practices of the Pāsupatas were derived from those of the Cynics, or vice-versa, or if they were both derived from some even older tradition, it would seem that the Tibetan "holy madman" tradition as exemplified by the Madmen of $\ddot{U}$ and Tsang was genetically related to the tradition of the "holy fool" in the Christian tradition, as they are known to have derived from a strong Cynic influence. ${ }^{357}$ This genealogy remains a fascinating possibility; much more information is needed before a definitive statement about the matter can be made.

It is worth dwelling for a moment on the significance the Madmen of $\ddot{U}$ and Tsang put on imitating tantric deities. I believe this aspect of Tibetan Buddhist tantric practice is often overlooked. One of the few arenas in which scholars often talk about Tibetan Buddhists imitating deities is in cham dancing, during which monks wear special costumes and masks resembling the appearance of Buddhist deities, and perform

\footnotetext{
${ }^{356}$ One interesting difference between the two cults is the fact that the purpose of the dishonor-courting asceticism of the Pāśupatas is traditionally articulated in terms of an exchange of merit with one's attackers. In the case of the Cynics, it was performed more for the sake of benefiting the public, according to Ingalls: "He is really shaming them more than they shame him. He is showing them the truth and thus effects an ethical cure of those whom he visits much as a physician effects a physical cure," p 293. This seems more similar to the explanation sometimes given for the erratic behavior of the Tibetan holy madmen: it is for the purpose of teaching observers a lesson, although this would be articulated in terms of the faults of conceptuality (rnam rtog) rather than a question of ethics.

${ }^{357}$ See Derek Krueger's Symeon the Holy Fool: Leontius's Life and the Late Antique City (University of California Press, 1996).
} 
ceremonious dances that imitate the deities' divine activity. This same kind of ceremonious dancing (coupled with singing) was one of the characteristic activities of the Madmen of $\ddot{U}$ and Tsang, and best understood as one of the ways in which they attempted to imitate the deities. In the course of my interviews with Tibetan lamas a number of them mentioned that these days the practice performed by Tibetans that most closely resembles the holy madmen's dressing in the garb of and imitating a Heruka is cham dancing. This suggests that the kernel of what the Madmen of Ü and Tsang were performing has lived on, although in a heavily domesticated form.

In recent years there has been some scholarly debate about the origins of the Buddhist Highest Yoga Tantras. Alexis Sanderson and Robert Mayer have argued that they were basically Śaivite texts, with some vocabulary changed to make them nominally Buddhist. ${ }^{358}$ Based on his detailed study of the Cakrasamvara tantra, David Gray arrives at the same conclusion, saying that the tantra "was composed via the active appropriation of elements of both text and practice belonging to non-Buddhist groups, most notably the Kāpālikas..." The process through which this was achieved included "active erasure of Śaiva elements and the addition and overlay of standard Buddhist terms and concepts.” This also included the formulation of new mythology and the internalization of meditative practices, which "bracketed and neutralized the transgressive exercises that are actually prescribed by the text." ${ }^{359}$ In a similar vein, David Snellgrove's position on

\footnotetext{
${ }^{358}$ David Gordon White, "Introduction" to the volume Tantra in Practice, $\mathrm{p}$ 22-3, quotes Sanderson, pp 678-9 on how late Indian Buddhist tantra resembles Kāpālika Śaivism; White quotes Robert Mayer, $A$ Scripture of the Ancient Tantra Collection, The Phur-pa bcu-gnyis (Oxford: Kiscadale Publications, 1996), pp 102-32, as one who expanded this argument.

${ }^{359}$ Gray, p xv. Gray continues to address these issues throughout the introduction to the translation.
} 
the matter (as summarized Gavin Flood) is that the "religious culture of the Tantras is essentially Hindu and the Buddhist tantric materials can be shown to have been derived from Śaiva sources," although Snellgrove suggests that much of the source material cannot be identified as either "Hindu" or "Buddhist.",360

Ronald Davidson has argued that although there was certainly much Śaivite influence on the Buddhist tantras, they seem to have drawn from other sources as well, most notably "tribal" culture of India. ${ }^{361}$

Surely this is a large question with much at stake, and I cannot offer an answer to it here. But I do believe that the Madmen of Ü and Tsang themselves represent a fascinating case study with something to add to the ongoing research into this question of the origins of the Buddhist Highest Yoga Tantras. We have little information about what the lifestyles of actual practitioners of the Buddhist Highest Yoga Tantras in India would have looked like. But perhaps based on the lives of the 15 th-century holy madmen we can imagine how it may have been. The 15th-century holy madmen show us what enacting a literal reading of the Hevajra tantra looks like, and may provide some clue as to how its practice would have appeared around the time when it was written. As we have seen, their practices bore a close resemblance to the practices of the Läkulas and/or Kālāmukhas, who practiced a fusion of Pāśupata- and kāpālika-style ascetic traditions, all of which are thoroughly non-Buddhist (and about whom the 15th-century holy madmen most likely had no specific knowledge). The influence on the Lākulas and/or Kālāmukhas by the kāpālikas and the Pāśupatas is indicated by the fact that they wore the

\footnotetext{
${ }^{360}$ Flood, p 158; Snellgrove, Indo-Tibetan Buddhism, pp 152-60.

${ }^{361}$ Davidson, Indian Esoteric Buddhism, pp 211-8.
} 
garb of the kāpālikas, which was based on the appearance of a wrathful form of Siva and that they performed "mad behavior" very similar to that of the Pāśupatas. Here the similarities are in the actual practices followed by the holy madmen, and in the multistaged scheme in which they were structured. The phases of practice that oriented the odd-seeming behavior of the Madmen of Ü and Tsang_ “all good," "secret activity," "public activity," "activity that is victorious in all respects"-closely resemble the stages of practice performed by a Pāśupata. This is not to say that the Madmen of Ü and Tsang were imitating non-Buddhists of India, but rather that trough their performance of engaged asceticism, based on a literal reading of the Hevajra and other Yogini tantras, they exemplify how much of these non-Buddhist practices went directly into late Indian Buddhist tantra.

It is worth noting that in the life stories of the Madmen of $\ddot{U}$ and Tsang and the commentaries on the Yoginī tantras, there is no rhetoric of mahāvrata ${ }^{*}$ brtul zhugs chen $p o ?)$, the "great observance" that defined the asceticism of kāpalika-style practitioners. It may well be that the Indian Buddhists who adopted elements of practice distinctive of the Pāśupatas and the kāpālikas were fully aware that the mahāvrata was too closely associated with devotion and imitation of Śiva, definitively non-Buddhist, and could not be brought into the Buddhist fold.

In this section we have explored some Buddhist and non-Buddhist ascetic traditions that constituted a precedent for the kind of eccentric behavior performed by the Madmen of Ü and Tsang. As we have seen, Madmen of Ü and Tsang drew from a tradition that stretches all the way back to the time of the Buddha and beyond. The fact that such a precedent exists in no way detracts from the innovativeness in what the 
Madmen of Ü and Tsang were doing. The decision to buck the norm and enact such a literal reading of the Yoginī tantras was entirely their own (the reasons behind this decision will be developed in the following chapter). The behavior of the Madmen of $\ddot{U}$ and Tsang constitutes a late Tibetan adaptation of religious practices and cultural memes that were once thoroughly Indian in nature: the Madmen of Ü and Tsang's iconic skull cup was based on a form deeply embedded in Indian religious culture, as the penance for killing a brahmin; the deities whose manner they dressed in were thinly-veiled Buddhist adaptations of Hindu deities, and so on. The 15th-century holy madmen thus represent a daring Tibetan usage of some quintessentially Indian cultural forms.

\section{V.4 The Rhetoric of "Madness" in the Śaivite Tradition}

Although the Madmen of Ü and Tsang imitated the behavior of madmen at times as part of their performance of engaged asceticism, the importance of this as a contributing factor to their being renowned as "madmen" is tempered by the fact that there is a much older rhetoric of madness in the Buddhist and non-Buddhist traditions the Madmen of Ü and Tsang were drawing from — a rhetoric that extends well beyond describing individuals actually performing "crazy" behavior.

For example, there is a legend about the Hindu sage Śankara having an encounter with a kāpālika of the Śndra caste by the name of Unmatta-Bhairava, "the Mad Bhairava."362 (In Tibetan this would be rendered something like *he ru ka smyon pa.) According to some kāpālika-style practitioners, the deity Bhairava has eight forms, one of which is "the Mad One" (unmatta). ${ }^{363}$

\footnotetext{
${ }^{362}$ Lorenzen, The Kāpālikas and Kālāmukhas, pp 46-8, 88, 91.

${ }^{363}$ Lorenzen, The Kāpālikas and Kālāmukhas, pp 84-5.
} 
In these cases the use of the term "mad" may have some connection to the trope of intoxication. Very close to the Sanskrit term unmatta is the word matta, meaning "intoxicated" or "drunk." These two terms are linguistically very close and there is much semantic overlap between them - the difference between them is much less than the difference between the English "crazed" and "drunk," for example. The same linguistic closeness and semantic overlap carries over into the Tibetan terms with which these Sanskrit terms were translated. ${ }^{364}$ Another kāpālika-style practitioner with whom Śankara is storied to have had an encounter is described as having arrived in the sage's presence "with his eyes inflamed and rolling about through intoxication."365 This conforms to the commonly held stereotype that the kāpālikas were hedonists. This stereotype is portrayed in the 7th century one-act play The Mattavilāsa ("Drunken Games"), in which the kāpālika yogi and his consort spend their days in the grog shop, "worshipping" Siva with offerings of alcohol. In fact, there is a precedent for the association of intoxication and religious ecstasy or devotion going all the way back to the Vedas. ${ }^{366}$ The use of alcohol and other intoxicants in the kāpālika tradition probably helped foster a rhetoric of "madness" (closely related to drunkenness). This in turn likely

\footnotetext{
${ }^{364}$ In most cases in Tibetan when the meaning of "intoxicated" is expressed, the term is spelled myos, but the two are semantically very close, and smyon can be used to express the meaning of "intoxicated." ${ }^{365}$ Lorenzen, The Kāpālikas and Kālämukhas, p 34.

366 Wendy Doniger O'Flaherty, The Rig Veda: An Anthology. One Hundred and Eight Hymns, Selected, Translated and Annotated (London: Penguin Books, 1981), pp 137-8, translates Rg Veda verse 10.136, "crazy with asceticism [unmaditā mauneyena], we have mounted the wind." Cited in Samuel, The Origins of Yoga and Tantra, p 158. Marcy Braverman's dissertation Possession, Immersion, and the Intoxicated Madness of Devotion in Hindu Traditions (Ph.D. dissertation submitted to the University of California, Santa Barbara, June 2003) says that in this verse the long-haired ascetic, Keśin, has ingested a plant essence or drug (visa), probably soma, that causes the gods to enter him, whereupon he flies through the air in a maddened (unmaditā) state of consciousness, $\mathrm{p} 17$. Braverman's entire dissertation is filled with examples of the intersection of intoxication, madness, devotion and asceticism in the Hindu tradition.
} 
fed into the culture of the Highest Yoga Tantras from which the Madmen of Ü and Tsang took their cues.

We have evidence that some awareness of this mythology surrounding "madness" and the cult of Siva made its way into Tibetan cultural knowledge. The 5th Dalai Lama's history of Tibet, The Song of the Queen of Spring (dpyid kyi rgyal mo'i glu dbyangs), written in the 17 th century, includes an odd verse in the midst of his relating the ongoing conflict between Changchub Gyeltsen (1302-1364) and the territory of Yabzang ( $g \cdot y a$, bzang) during the former's rise to power in central Tibet (which will be described briefly in the following chapter). The verse is quoted from Sakya Pạ̣dita’s (1182-1251) Treasury of Good Sayings (legs par bshad pa rin po che'i gter) (from the chapter on "unseemly tendencies," mi rigs pa'i tshul) and reads:

Compelled by the force of karma, the wise embark upon the wrong path; the supreme teacher of the heretics embraces the engaged asceticism of mad Śiva.

The verse makes reference to the story of how the god Brahma once held a big gathering to which all of the gods were invited. When Siva arrived the other gods sneered at him. Brahma then told the story of how Siva had once cut off Brahma's heads with his fingernail. It is suggested that Siva had been compelled to do this heinous because he was actually a zombie (ro langs), which made him an outsider and brought with it unfortunate circumstances; thus the crime was not really Siva's fault. Then as a penance Śiva took on the bone ornaments, the skin of an elephant, a skull cup, a staff, and so on, wandered all over the place, and danced in front of people. The 5th Dalai Lama quotes this verse to remind the reader of one brought low by unfortunate tendencies, ultimately 
to describe the Yabzangpas' foolish persistence in opposing Changchub Gyeltsen. ${ }^{367}$ It is not suggested in the story that Śiva was actually insane or pretended to be insane; he represents a force of wildness and "mad one" is simply one of his epithets. Also note that his engaged asceticism is basically synonymous with his eccentric mode of dress.

What this instance shows us is that there was a strong association between Śiva, engaged asceticism and a rhetoric of "madness" in the Tibetan cultural consciousness, derived directly from Indian mythology. This awareness was enshrined by Sakya Paṇdita in his Treasury of Good Sayings, which has remained hugely influential in Tibetan literary culture ever since it was written. We will look at more of the complexity of the rhetoric of "madness" employed by Tibetan holy madmen in Chapter Seven; here I refer only to the broader rhetoric of madness in the pre-Tibetan traditions from which the 15thcentury holy madmen's behavior was inspired. As we will see later, there are more streams feeding into this river, more meaning given to the term, including poet-saints like Milarepa and Kodrakpa who used "madness" as a metaphor for enlightenedness, and other Tibetans using "madman" as a pen name.

I mention this wider rhetoric of "madness" here as a cautionary note. We should not get the notion that the use of the rhetoric of "madness" in reference to the Madmen of $\ddot{U}$ and Tsang was primarily a result of their feigning madness in the course of their ascetic practices. Although literally acting in the manner of madmen was probably something

\footnotetext{
${ }^{367}$ See Nordrang Orgyen's (nor brang o rgyan) dpyid kyi rgyal mo'i glu dbyangs kyi 'grel pa yid kyi dga' ston (Beijing: mi rigs dpe skrun khang, 1993), pp 343-4, in which the verse is quoted, explained, and identified as being originally penned by Sakya Pandita. The Tibetan runs, las kyi shugs kyis bdas pa na/ blo chen log pa'i lam la 'gro/ mu stegs byed kyi ston pa mchog dbang phyug smyon pa'i brtul zhugs 'dzin/. For an English translation of this verse along with a commentary, see Ordinary Wisdom: Sakya Pandita's Treasury of Good Advice, translated by John T. Davenport (Boston: Wisdom Publications, 2000), pp 186-7.
} 
they did at times, this is not the primary contributing factor to their being called "madmen." Instead, we should consider that in these contexts the term "madman" carries with it a long history and rich connotations, with many shades of meaning and significance. ${ }^{368}$ As I will argue, when used in reference to people like Künga Zangpo and Sangyé Gyeltsen — and when they proudly use it in reference to themselves — the usage of the term is best understood as tongue-in-cheek, if not overtly ironic. This will be discussed in greater detail in Chapter Seven.

\section{VI. Conclusion: The Inherent Ambiguity of Sainthood}

In this chapter we have considered the distinctive behavior performed by the Madmen of Ü and Tsang, how it fit into the trajectories of their lives, and how it drew from a tradition stretching back centuries. Based on a close reading of the biographies of the Madmen of Ü and Tsang and some other contemporaneous sources we can conclude that their reputations as madmen did not result from their actually being mentally unstable individuals. There is overwhelming evidence showing that what led them to be called "madmen" was their performance of engaged asceticism, a form of advanced tantric practice that involved meditation in out of the way places, performing shocking behavior in public spaces, and—most importantly—dressing like a fierce Heruka deity. It is possible that as part of their performance of engaged asceticism they may have at

\footnotetext{
${ }^{368}$ David Kinsley's article, “'Through the Looking Glass': Divine Madness in the Hindu Religious Tradition," in History of Religions, Vol. 13, No. 4, May, 1974, pp 270-305, provides an excellent overview of the theme of holy madness in many strands of the Hindu tradition, some of which may be argued to have directly or indirectly fed into the religious identity embodied by the Madmen of Ü and Tsang. Kinsley's survey covers myths in which Hindu deities embody madness as well as the many flavors of madness embodied by famous Hindu saints, from the Pāśupatas to the Bauls, some of whom bear the honorific title $k h e p \bar{a}$, "mad one." Kinsley covers the wide variety of connotations this "madness" can carry, from being intoxicated with devotion to the deity to detachment from worldly concerns to feigning madness as part of one's ascetic practice. See also June McDaniel's The Madness of the Saints: Ecstatic Religion in Bengal (Chicago: The University of Chicago Press, 1989).
} 
times behaved like madmen (in the fashion of the Pāśupatas), but there is relatively little evidence suggesting that their behavior should be understood in this way. The more likely possibility is that the rhetoric of madness accompanied the Heruka discipline, as it had since the early Śaivite traditions on which the behavior of the Madmen of $\ddot{U}$ and Tsang was ultimately based.

Most importantly, the seemingly eccentric behavior that made the Madmen of $\ddot{U}$ and Tsang famous was not spontaneous or nonsensical. On the contrary, it was part of an ordered - though uncommon — regimen. As such, their distinctive behavior was part of their adopting a fundamentalist attitude with respect to tantra in that it was first and foremost a result of their insisting on taking the Yogini tantras quite literally, which made them highly anachronistic in the religious culture of 15 th-century Tibet.

Let us briefly consider how the authors of these life stories portray the reasons behind the Madmen of Ü and Tsang's respective decisions to take on the unique lifestyle that made them famous. The gaps between the contradictory ways in which these saints are portrayed by their biographers can give us a more complex idea of the nature of sainthood, which will provide a conceptual framework for the remaining chapters of this study.

In many ways the Madmen of Ü and Tsang are portrayed as highly realized beings even from the earliest part of their lives. Sangyé Gyeltsen flew to the sacred sites of India on a whim while Künga Zangpo walked across rivers and leapt from treetop to treetop — all of these feats are indicators that the young monks had, by force of their understanding of the true nature of appearances, taken control over apparent phenomena. Moreover, when Künga Zangpo was on the verge of giving up his monkhood and taking 
on the garb of the Heruka, it is said that he had "attained mastery in all the good qualities of direct realization," and was a "great supreme siddha, never to return to this world after death." Similarly, it is said of Sangyé Gyeltsen that even before beginning to perform engaged asceticism "he had already been completely victorious in pursuit of his own benefit" and was possessed of "supreme good qualities" (mchog gi yon tan rnams). ${ }^{369}$ Because Künga Zangpo and Sangyé Gyeltsen were both so highly realized before taking on the distinctive behavior that would make them famous, their performing that behavior is consistently said to have been done for the sake of other beings. Before embarking upon his shocking behavior, Sangyé Gyeltsen reasoned in this way: "By now I have become fully accomplished for my own sake; now it is time to work for the benefit of others." And so he reflected on the plight of beings living in the world:

Having entered into the meditation called the "Great Clear, Unobscured Knowing of the Three Times," he saw with the eye of great wisdom and thought that sentient beings endangered by the five types of degeneration had an excess of afflictive emotions, had short lives and many illnesses; they are poor and filled with doubts and have many wrong views. Therefore, although he had already been completely victorious in pursuit of his own benefit, since [his true state] was inconceivable to the minds of common folks, for the sake of other beings he assumed the manner of an ordinary yogi entering the path, and performing engaged asceticism he roamed in all directions, completely concealing his supreme good qualities, and having thereby made himself in accordance with the manners of common people, would enter into a virtuous connection with the most ordinary of disciples, which would be of great benefit to the Teachings and to sentient beings... 370

\footnotetext{
${ }^{369}$ Götsang Repa, p 37.4-.5.

${ }^{370}$ da ni rang don mthar phyin par grub pas/ da gzhan don bya ba'i dus la bab dgongs tel dus gsum sgrib pa med par gsal ba mkhyen pa chen po zhes bya ba'i ting nge 'dzin la gzhugs nas/ ye shes chen po'i spyan gyi gzigs tshel snyings ma lnga sdo (sngo?) ba'i sems can rnams nyon mongs pa rags pal tshe thung ba nad mang zhing dbul ba the tshom za zhing log lta che bas/ rang don du phyogs thams cad las rnam par rgyal yang / phal gyi blor mi shong bas da dung gzhan don du lam zhugs kyi rnal 'byor ba rang rgyud pa' $i$ tshul bzung nas/ brtul zhugs kyi spyod pas phyogs kun tdu rgyu zhing mchog gi yon tan rnams shin tu sbas pas/ phal ba rnams dang tshul stun na gdul bya rman pa rnams la rnam dkar gyi 'brel ba 'jog cing / bstan pa dang sems can gyi don rgya che bar dgongs nas..., Götsang Repa, p 37.3-.6.
} 
After this Sangyé Gyeltsen went amidst the ritual assembly at Tsari, did some outrageous things, and made a name for himself as the Madman of Tsang. As we saw above, Künga Zangpo's decision to take on the garb of a Heruka was described as being for the sake of a number of things, such as "taming all the enemies and obstacles to the Teachings," "assisting all worthy beings without exception, and setting them on the ground of accomplishment."

Thus Sangyé Gyeltsen and Künga Zangpo are both portrayed in their biographies as fully realized beings who performed their distinctive behavior for the benefit of others, in order to form expedient connections with beings of different capacities and of different stations in their lives. This is in full contradiction to the way in which the performance of engaged asceticism and related practices are always described by the tantras from which the Madmen of $\ddot{U}$ and Tsang drew their inspiration, or the tantric commentaries that give us an insight into the ongoing Tibetan discourse about these practices. In those sources these practices are always described as being done by those who were part of the way down the path towards enlightenment — those who have achieved some yogic warmth and realizations but still need to increase them or make them more stable. (The Madman of Tsang himself said that "secret activity" should be practiced by one on the Path of Application (sbyor lam), and the performance of engaged asceticism of awareness should be practiced by one on the Path of Seeing; these are the second and third of the five paths to liberation, respectively. ${ }^{371}$ ) Clearly what motivates the authors of these biographies to give an altogether different portrayal of the distinctive practices of the Madmen of Ü and Tsang is their desire to portray their masters as effortlessly enlightened beings, long since

${ }^{371}$ Götsang Repa, p 231.1-.3. 
supremely accomplished in meditation and realization. Although the Madmen of $\ddot{U}$ and Tsang's biographies describe their engaging in meditative practice, this is all for show. The yogi himself does not need to meditate further, we are told: he does these things for the sake of benefitting other beings. ${ }^{372}$

What this contradiction highlights is the dilemma inherent to trying to understand the behavior of the holy madmen. The question is whether the yogi's performance of engaged asceticism is for the sake of his own training, or for the purpose of teaching and thereby benefitting others. Because of the author's prevailing attitude of respect and deference to the yogi, he makes sure to state that the master is already a perfected being who no longer needs to perform this kind of practice for his own development. The yogi conceals his perfected nature and takes on the mode of an ordinary practitioner engaging in these feats — whether it be by performing miracles, acting like a madman, or even meditating - so as to be able to form a connection with ordinary people. Such is the depth of the yogi's compassion.

This brings us back to a question raised earlier in this chapter: did Künga Zangpo and Sangyé Gyeltsen perform engaged asceticism for the sake of achieving holiness, or because they already were holy? The above-reviewed commentaries that discuss these practices and the very trajectories of the lives of the Madmen of $\ddot{U}$ and Tsang clearly suggest that they would take on these practices for the sake of achieving something. But the way the authors of the biographies would have it, the Madmen of Ü and Tsang were already highly realized beings, and performed this engaged asceticism because they were enlightened. This latter view is in line with the way contemporary Tibetans most often

\footnotetext{
${ }^{372}$ Wedemeyer, p 120, discusses this notion as expressed in Āryadeva's Lamp that Integrates the Practices.
} 
explain the behavior of the holy madmen. As described in Chapter One, by far the most commonly offered explanation is that they are enlightened beings and their eccentric behavior is an expression of their enlightenedness. ${ }^{373}$ The second most offered explanation is that it is for the purpose of teaching others. The possibility that it may be for the sake of the yogi's own spiritual development is a distant and rarely-considered third possibility. It seems that the perception that these are enlightened beings holds so much sway that the great mass of evidence to the contrary (i.e., the many indications that this eccentric behavior was performed for the sake of the yogi's own practice) does not get considered. Despite the fact that almost every aspect of the eccentric behavior of the Madmen of Ü and Tsang is explained in the course of their life stories as part of the performance of engaged asceticism, and despite the fact that this is how they were known by many of their peers, not one lama whom I interviewed offered this as an explanation.

The case of the holy madmen's eating human brains provides a clear example. When asked about why the Madman of Ü or the Madman of Tsang would have eaten brains out of a corpse, most present-day Tibetans will say that it is an indication of the yogi's thorough realization of emptiness, so that he experiences all phenomena as the same. Some others might say that the yogi would do such a thing for the sake of teaching other beings the nature of phenomena as empty. But if we actually look closely at the life

\footnotetext{
${ }^{373}$ In conversation Kenpo Tsülnam Rinpoché said that a practitioner like the Madman of Ü would spend a long time meditating, become a siddha (grub thob), and then would start to perform the more eccentric forms of practice, such as wearing the garb of the Heruka and so on, for the sake of further increasing his realizations. Although highly realized, this person is not a buddha and still requires further realizations. Kenpo Tsülnam Rinpoché emphasized that one should not perform this kind of eccentric behavior before becoming a siddha. If so, it would be just senseless activity (tho co'i spyod pa); the person would be a fake. In Kenpo's words, it would be like if I were to start acting like a professor before finishing my doctorate. Interview, 9 September 2009.
} 
stories of the Madmen of $\ddot{U}$ and Tsang, this practice is almost always directly equated with the pursuit of siddhis, superpowers.

There is clearly a disjunct between so many of the details of the lives of the Madmen of Ü and Tsang and the way in which they are remembered in popular Tibetan discourse. The reason for this disjunct is the attitude of extreme reverence most Tibetans hold towards these famous saints of the distant past — they must be treated as fully enlightened beings.

In this chapter we have explored the Madmen of Ü and Tsang's behavior as a form of engaged asceticism. Along the way we have considered the notions that they may have performed their eccentric behavior for the purpose of teaching other beings, or because they were in fact enlightened beings. Thus to this point we have viewed the distinctive behavior of the Madmen of Ü and Tsang from a limited perspective, as an entirely religious concern.

There remains the possibility that their performing this kind of behavior may have been for the sake of very different ends. As it was related in The Life of the Madman of $\ddot{U}$, when Künga Zangpo gave up his monk's robes and took on the garb of a Heruka, he did so for the sake of helping beings achieve their spiritual goals. But it was also related how he did this "for the sake of pronouncing the greatness of the Vajrayāna and drawing out the profound distinguishing feature of its essential meaning." This belies a recognition that the Madman of Ü was dedicated to what he perceived as the essence of tantric Buddhism, making him, as I term it, a "tantric fundamentalist." What's more, there is recognition that the soon-to-be Madman of Ü's distinctive behavior would be 
performed "for the sake of initiating a tradition dedicated to the definitive meaning of the precious Kagyü," suggesting that an element of sectarian concern may have played a part in motivating his eccentric behavior. To understand how this could have been so requires that we imagine the situation in which the Madmen of $\ddot{U}$ and Tsang lived, and how their behavior affected their position within that situation. It is moving in this direction, towards developing a more historically contextualized understanding of the 15 th-century holy madmen, that we move in the next chapter.

In so doing we will be entering into new territory for how we understand the behavior of the 15 th-century holy madmen and Tibetan holy madmen in general. For many, the thought that certain individuals might take on the identities of "holy madmen" for some sort of worldly concern is deeply counterintuitive. But the fact of the matter is that even the renunciants performing the most world-rejecting antinomian behavior are still acting within the matrix of worldly concerns. It is naturally surprising to consider that the Pāśupatas — who distinguished themselves by going into the marketplace and imitating the manners of insane people and completely defiled themselves vis-à-vis societal expectations - were in fact one of the best funded religious orders of their day. The impurity-embracing kāpālika-style ascetics also received official patronage. ${ }^{374}$ As we will see in the following chapters, the Madmen of Ü and Tsang were also quite successful in the same way. Becoming a holy madman was, in some instances, a lucrative enterprise, in addition to any possible soteriological benefits it may have

\footnotetext{
${ }^{374}$ Davidson, Indian Esoteric Buddhism, p 184: “There can be little doubt that the Pāśupatas were extraordinarily successful in associating themselves with powerful patrons"; see also pp 183 and 186. Lorenzen, pp 27-8, talks about kāpālikas getting official patronage. Much of Lorenzen's book is about the partonage received by the Kālāmukhas, who were the late Pāśupata- and kāpālika-style practitioners whose behavior that of the Madmen of Ü and Tsang resembled most.
} 
brought. Awareness of this fact should have an effect on how we understand the nature of their behavior.

It is not the case that this mode of thinking about the behavior of saints like the Madmen of Ü and Tsang represents some entirely modern, cynical understanding being imposed upon naive religious practitioners of centuries past, as some might object. On the contrary, the holy madmen themselves were well aware of the real-world dynamics of sainthood. The Madman of Ü's student who wrote his biography recognized an element of sectarian concern as motivating his master's behavior. It is also explicitly stated that it was because of performing truly shocking behavior in marketplaces that the name " "the Madman of Tsang' in every direction ... became as renowned as the sun and the moon," indicating that the author was not naive to the true workings of fame and sainthood in the social sphere. ${ }^{375}$ Further, the Madman of Tsang sang in a song of instruction to one of his students,

If you perform engaged asceticism for the sake of fame, the jealousy of your 'karmic $d \bar{a} k i n \vec{\imath}$ [i.e. consort] will cause various adverse circumstances in this life and you will be reborn in a vajra hell in the next. Do not perform engaged asceticism for any reason other than obtaining buddhahood. ${ }^{376}$

What this passage amounts to is an explicit recognition by a man who became very famous because of his performance of engaged asceticism that some might wrongly use the performance of engaged asceticism to become famous. Although he is admonishing his disciple not to do engaged asceticism for any worldly reason, we should not miss the

\footnotetext{
375 This passage was translated in full above, in section 3.II.1.

376 brtul zhugs snyan grags phyir spyod na/ las kyi mkha' 'gro'i phrag dog gi [sic, read as gis]/ tshe 'dir 'gal rkyen sna tshogs 'byung/ phyi ma rdo rje dmyal bar skyel sangs rgyas thob phyir ma lags pa'il brtul zhugs kyi spyod pa ma byed cig/, Götsang Repa, p 103.3-.4.
} 
fact that this constitutes the Madman of Tsang's admission that people do the very thing he is warning against. If it was not a real possibility and a concern, the Madman of Tsang would not have had to warn his student about it. Here the Madman of Tsang expresses recognition of the fact that one might perform engaged asceticism because of the way it positions one in the religious marketplace. We will develop this idea more fully in the following chapter.

In this chapter I have described the distinctive behavior of the Madmen of Ü and Tsang in terms of the history of Indo-Tibetan ascetic traditions, both Buddhist and nonBuddhist. In the following chapter I will turn towards understanding them in the more specific context of 15 th-century Tibet. In this chapter we have explored the way the Madmen of Ü and Tsang's choosing this odd lifestyle may have been a part of their religious practice; in the following chapter we will focus more on how their eccentric behavior was received and how it positioned them in the overlapping religious, cultural, political and economic marketplaces of life in 15th- and 16th-century Tibet. In many ways this will involve turning the religious perspective inside-out, by attending to the real-world ramifications of their eccentric yogic practice and examining what, other than enlightenment, they may have been trying to achieve by it.

It should be noted that the discussions of the lives and eccentric behavior of the Madmen of $\ddot{U}$ and Tsang presented in this chapter were based on a relatively naive reading of their biographies. This is justified to the extent that understanding the subject matter of this chapter does not necessitate that every detail related be historically verifiable fact. What we have been drawing from here are accounts of the holy madmen's lives as presented by their disciples, which enables us to develop a coherent 
explanation for their behavior. The messier details of the histories of these texts themselves, and how they may distort our understanding of the saints whose lives they tell, will be addressed in Chapter Six. 


\section{Chapter 4: Madmen in the Marketplace: Fame, Patronage and Civil War in 15th-Century Tibet}

A tea-merchant that had been to Lhasa said, "There was a yogi who wore a human skin, named the Madman of Tsang." As soon as I heard that my body-hair stood up and tears came to my eyes.

- from the autobiography of Götsang Repa; the event occurred when he was seven years old ${ }^{377}$

In front of the silver reliquary (dngul gdung) at Drikung Til offerings of butter lamps, silk scarves and pleasant smelling things were made... In front of the Dharmalord there were offerings the foremost part of which were inner and outer clothing (gos phyi nang). The general assembly of monks (dge 'dun spyi la) were furnished ('gyed) with armor, helmets, and the like (khrab rmog sogs). ${ }^{378}$

- from The Life of the Madman of Ü, describing some of the offerings made to various monasteries upon the death of the famous yogi

In this chapter we will refine our understanding of the eccentric behavior of the

Madmen of Ü and Tsang by considering the effects that behavior had on their actual

lives. What, tangibly, did it mean to be a holy madman? What effect did it have on one's

life? By looking into these issues we can work towards answering one of the most

important questions about Tibet's holy madmen: why is it that there were so many of

them at this particular moment in Tibetan history?

\footnotetext{
${ }^{377}$ Quoted from Roberts, $\mathrm{p} 43$. The text bears the title rnal 'byor gyi dbang phyug rgod tshang ras chen pa'i rnam thar tshigs gcad ma dngos grub kyi rgya mtsho zhes bya ba dad ldan spro ba bskyed byed; the only known copy is an incomplete transcription of the text kept among the personal notes of E. Gene Smith, mentioned in Central Tibetan Prints, Vol. 2 (unpublished).

${ }^{378}$ The Life of the Madman of $\ddot{U}, \mathrm{p} 652$.
} 
We assume that it was not by mere coincidence that the three most famous of Tibet's holy madmen and many lesser-known ones all lived at the same time in the same geographical area. Our interest is to reconstruct the historical situation of this period and determine why it would have led to there being so many "holy madmen" at one time and place. What we uncover is a complex world of competing political factions, ascetics, patrons, military conflicts, intersectarian competition, personal grudges and murderwith the famous holy madmen caught up in all of it. By focusing on the actual lives of the holy madmen many interesting and significant details will be brought to light, many of which have previously been left unnoticed by Tibetan and Euro-American scholars commenting on the holy madman tradition. This shift is brought about by thinking differently about the basic nature of the holy madmen's distinctive activity. Here we treat the Madmen of $\ddot{U}$ and Tsang as ordinary men who have risen to sainthood in the social sphere, rather than as holy beings somehow existing without any worldly concerns. What we see when we cast a light on the 15 th- and 16th-century historical situation is a complicated web of interconnections between events and individuals. Understanding the significant connections between a famous yogi and his public, between lamas and patrons, fathers and sons, ascetics and their lineages, provides us with a way to understand the real situation the holy madmen inhabited, and what the true nature of their "madness" may have been.

\section{I. The Drumsound of their Fame: "Holy Madmen" in the Religious Marketplace}

Before we can understand how the activities of the famous holy madmen of the 15th century relate to historical circumstances much larger than their individual lives we 
must develop a working idea of the lived dynamics of fame and sainthood. This is a key step in our developing a thoroughly historical understanding of the holy madmen. We begin by imagining the dynamics of the religious marketplace in which the holy madmen operated, towards coming to understand the tangible real-world effects their eccentric activity would have had. In a sense, we will be exploring the lives of the holy madmen as public beings.

As was shown in the previous chapter, Künga Zangpo and Sangyé Gyeltsen both made the conscious decision to take on a life of eccentric asceticism. Their persistence in this and their consistent use of a rhetoric of madness made them famous as "holy madmen." While some of their contemporaries were convinced of their holiness and worth as Buddhist exemplars, many were not. Considering the nearly universal admiration with which the Madmen of Ü and Tsang are remembered by Tibetans today, it may come as a surprise that during their lifetimes they were often met with indifference, open criticism, or worse. Let us look at a few of these instances in order to better understand the perpetually-contested status of the holy madmen during the time in which they lived.

One time the Madman of Ü arrived at Nyukla (snyug la, smyug la or sometimes gnyug la) fortress dressed in the garb of a Heruka. His biographer Nyukla Peṇchen, himself a renowned monk and scholar from that same place, relates the story as follows: "At that time no one knew that [Künga Zangpo] was an excellent yogi or that it was the Lord of Siddhas himself, so they certainly thought he was an absolute fake (zog po) intent upon mad behavior (smyon spyod)." Fifteen soldiers were sent out from the fortress to 
give the yogi a truly epic beating, which, fortunately, he survived. ${ }^{379}$ On another occasion a petty king was so skeptical of Künga Zangpo's worth as a yogi that he wanted to submit him to an immediate test: if Künga Zangpo proved to be impervious to weapons and fire, then the king would receive him with the honor and respect deserving of a yogi. If he failed those tests, he would be turned away. We will never know how Künga Zangpo would have fared under such an examination, because the Madman of Tsang, who was also present at the time, intervened and shamed the king into withdrawing his demand. This fascinating story will be told in greater detail below. In the colophon to Part I of The Life of the Madman of $\ddot{U}$, Nyukla Penchen directly addresses the issue of the Madman of Ü's (perhaps numerous) detractors. He states that there were certain individuals unable to believe some of the stories about the Madman of Ü, but these were "unfortunate people who have fallen under the strong influence of false views (log lta'i phul tshabs che ba), counterfeit logic (? tshig rigs ltar snang) and sectarian hatred (phyogs 'dzin sdang zhen gyi dbang du song ba)."380 Elsewhere in the Life Nyukla Penchen makes the argument that there is ample scriptural backing for the various aspects of the Madman of Ü's seemingly eccentric activitystaying in uninhabited places, smearing his body with corpse ash, wearing the bone ornaments, dancing, and so on — and those who maintain that the yogi's lifestyle does harm to the Teachings of the Buddha are "fools who do not have the wealth of great learning; very unfortunate beings whose eyes of their intellects are obscured by partisan

\footnotetext{
379 The Life of the Madman of $\ddot{U}$, pp 510.6-518.4.

${ }^{380}$ The Life of the Madman of $\ddot{U}, \mathrm{p}$ 559.4-.5.
} 
jealousy (phyogs lhung phrag dog); whose mouths have been poisoned by demons." ${ }^{381}$ This very defensive language suggests that criticisms had been made of the Madman of Ü during his lifetime. Considering the eccentricity of his behavior, this should not come as a surprise.

We have evidence that the Madman of Tsang was also treated with great skepticism at times. At one point after Sangyé Gyeltsen had become famous as the Madman of Tsang it is said that an artist staying at Dingri Langkor Monastery (ding ri glang 'khor) was moved by his faith to begin making a hundred and eight statues of the great yogi. One day the abbot of the monastery, who had no faith in the Madman of Tsang, saw the statues and said that "making a statue of the Madman of Tsang is even more sinful than destroying a stūpa!" (mchod rten bshig pa las gtsang smyon gyi sku gzhengs pa sdig che). He took one of the completed statues and for some time purposefully treated it with disrespect, putting it underneath his own seat. Each day when the monks were assembled for tea the abbot would tie a string around the statue's neck and drag it across the floor while hurling invectives at it: "False one (zog po)! Destroyer of the Teachings of the Buddha (sangs rgyas kyi bstan gshig)! It is wrong that you should delude living beings (khyod kyi sems can kyi mgo skor ba 'os su ma 'gro)!" Clearly this abbot had no love or respect for the the Madman of Tsang, and even charged him with the lowliest of sins: teaching a false dharma. The biographer informs us that shortly after this the abbot died a horrific death, surely to be understood by the reader as due punishment for his lack of faith. ${ }^{382}$

\footnotetext{
${ }^{381}$ The Life of the Madman of $\ddot{U}$, pp 524.6-525.1.

${ }^{382}$ Götsang Repa, pp 165.2-166.3.
} 
From these accounts we can gather that during their lives the Madmen of $\ddot{U}$ and Tsang were not universally treated with devotion and respect, even at the peak of their fame. They surely had some serious critics. Beyond this there would have been a larger population who simply remained unconvinced of their holiness, not to mention others who never even heard of them. Although the biographies of the Madmen of Ü and Tsang tell us that most of the individuals who harbored doubts about the worth of the yogis were in time convinced to reverse their feelings about them (or, as in the case of the evil abbot from Dingri, receive their just deserts for their sinful ways), what all of these stories indicate to us is the important fact that their holiness - their status as ones highly accomplished in meditation, as siddhas — was not always immediately obvious to others. Although the sort of attitudes about the Madmen of $\ddot{U}$ and Tsang that prevail today might suggest otherwise, it is not the case that the crazy yogis were unanimously praised and accepted during their lifetimes, that their holiness was anything but contested. It is not the case that they achieved a highly realized state, became siddhas, and from that point forward for the rest of their lives everyone recognized them as such, even though Buddhist narratives so often tell us it occurred in just that very way. Quite to the contrary, we see that during the lives of the Madmen of $\ddot{U}$ and Tsang there was a constant struggle to win people over, to convince people of their enlightenedness. This struggle would continue even after their deaths, as their disciples and spiritual descendents would fight to have their greatness recognized.

The Madmen of $\ddot{U}$ and Tsang also had their supporters, who provided a counterbalance to their critics in the ongoing struggle for broader acceptance. Two Karmapas (from the perspective of most Kagyüpas, each the highest spiritual authority of 
his time) personally recognized the accomplishments of the two holy madmen. The 7 th Karmapa, Chödrak Gyatso (1454-1506), sent a brief letter to the Madman of Tsang late in his life, praising him as "the holy Madman of Tsang, Lord of Yogis" (rnal 'byor gyi dbang phyug dam pa gtsang smyon pa), expressing his personal joy upon hearing of the yogi's many accomplishments, including printing the Life and Songs of Milarepa and establishing meditation centers at the three holy mountains (gnas gsum; Kailash, Tsari and Lapchi) — all of this being "activity that spreads and increases the Teachings of the Kagyü" (bka' rgyud kyi bstan pa dar rgyas). ${ }^{383}$ A few decades later the Madman of Ü received a personal letter from the Karmapa's next incarnation, the 8th Karmapa, Mikyö Dorjé (1507-1554), in which the highest-ranking figure in the Kagyü sect asked the yogi some questions about tantra and praised him for his accomplishments in meditation and exhorting him to continue "setting beings on the path of the Vajrayāna during this degenerate age." 384 Receiving these letters from the 7th and 8th Karmapas was a real honor. The fact that the Madmen of Ü and Tsang's disciples felt moved to quote these letters in their respective biographies is a testament to their significance. These letters were very symbolic: to the supporters of the holy madmen these letters served as proof of the yogi's worth, a rejoinder to the doubters and critics. The later parts of The Life of the Madman of $\ddot{U}$ make constant mention of the many letters and offerings the yogi received from important individuals all across the Himalayas, from western Tibet to modern-day Yunnan Province, all of which contribute to the argument for the yogi's greatness.

\footnotetext{
${ }^{383}$ Götsang Repa, p 214.5-.7.

${ }^{384}$ The Life of the Madman of $\ddot{U}$, pp 632.2-633.2.
} 
The author of Part I of The Life of the Madman of $\ddot{U}$ further sought to bolster the status of the yogi by banking on the reputations of other important figures of their day. In his colophon, after mentioning those "unfortunate people who have fallen under the strong influence of false views (log lta'i phul tshabs che ba), counterfeit logic (? tshig rigs ltar snang) and sectarian hatred (phyogs 'dzin sdang zhen gyi dbang du song ba)" who would not believe some of the stories about the Madman of Ü, Nyukla Penchen goes on to list the important Kagyü luminaries who would vouch (khas len pa po) that the text had been written with pure intentions and should not be treated as the basis for any doubts. These figures include the 7th Karmapa, the 4th Red Hat, and a handful of others - in short, "the entire dharma circle of the precious Kagyü" (bka' rgyud rin po che'i chos skor ma lus pa). ${ }^{385}$ The author has gone out of his way to say that these important and respected figures have faith in the Madman of Ü—and, by extension, so should everyone else.

Through this brief consideration of a few aspects of the life stories of the Madmen of $\ddot{U}$ and Tsang we get an idea of the sort of contentiousness that surrounded them throughout their lives. They would always be faced with skeptics, certainly made even more numerous by the very unconventional nature of the lifestyle they chose to adopt (as we saw in Chapter Three, it was the fundamentalist nature of their activity that made them seem, ironically, unconventional in 15 th-century Tibet). There were surely even those who had never even heard of these crazy yogis. Their biographies were written to have maximal effect in changing these types of people into faithful followers. The

${ }^{385}$ The Life of the Madman of $\ddot{U}$, pp 559.3-560.3. Much earlier in the biography it is also mentioned how, when Künga Zangpo visited Tsurpu Monastery on the occasion of the 7th Karmapa's giving a public teaching, the Karmapa continually looked directly at the yogi and "regarded him as something amazing" (ngo mtshar du'dzin pa mdzad pa), p 420.3-.6. 
purpose of specifically mentioning the Karmapas and other important individuals whose reputations lend symbolic weight to the achievements of the holy madmen—just like the the descriptions of the many miracles performed by the holy madmen - is to engender in the reader a recognition of the yogi's greatness. That the texts are clearly written with the purpose of convincing people of the greatness of the yogis is an indicator of just how vulnerable they actually were. What all of this points to is that the yogi's status as a saint, a fully liberated siddha, a great being worthy of our awe and respect, is never an obvious fact. During his lifetime the yogi is never universally accepted, never beyond reproach. On the contrary, his enlightened status is something perpetually attested to, something someone always needs to be convinced of. It is with this end in mind-to convince people of the yogis' greatness - that the biographies of the Madmen of Ü and Tsang were written and printed in the first place. From all this we can get a sense of how during their lifetimes whatever holiness they achieved was a product of an ongoing and inherently social process, a process of convincing people. They remained, as all saints during their own lifetimes, incomplete. Their holiness was fragile, with no more solidity to it than the mercurial opinions of their contemporaries.

We can further refine our understanding of the nature of the sainthood of the Madmen of Ü and Tsang if we consider the very public component to their rise to prominence. In the course of their lives the Madmen of Ü and Tsang went from being ordinary monks from average families to being highly realized masters who were believed to have gained control over the play of appearances and were surrounded by many faithful disciples and influential patrons. A key aspect of their development along this trajectory was their ever-widening fame, of which the authors of their biographies 
make consistent mention. For example, The Life of the Madman of $\ddot{U}$ states that Künga Zangpo made the decision to overpower the king of Ngari Gungtang with his glory (zil gyis gnan), which would result in "great benefit for the Teachings of the Buddha and for sentient beings" (sangs rgyas kyi bstan pa dang sems can la phan pa rgya chen po). So he put on the garb of the Heruka, stole into the king's palace and endured the savage beating that followed. We are told that after this the name "'the Madman of Ü' was renowned in and pervaded every direction. ${ }^{\$ 366}$ Later, after the Madman of Ü survived another fierce attack from some soldiers it was said that the "white banner of his fame became visible as far as the ends of the earth." ${ }^{387}$ Another occasion, when the Madman of Ü theatrically showed himself to be alive and well after many of his followers thought he had died from sickness, the biographer states that "the banner of his fame was renowned all around," to cite but a few examples. ${ }^{388}$ In each of these cases the Madman of Ü did something miraculous, which had the direct result of increasing his fame.

The same awareness of the workings of renown and sainthood is displayed by the author of the most extensive version of The Life of the Madman of Tsang. Throughout the Life Götsang Repa makes numerous mentions of the spread of the yogi's fame, which in nearly every case is attributed as a direct result of the yogi's own actions. According to the quotation with which Chapter One began, it was on account of Sangyé Gyeltsen's smearing himself with ashes and blood and doing nonsensical things before the eyes of

\footnotetext{
${ }^{386}$ dbus pa smyon pa zhes bya ba'i mtshan kyang de nyid kyi dus nas phyogs thams cad du grags shing khyab par gyur..., The Life of the Madman of $\ddot{U}, \mathrm{pp}$ 440.5-443.3.

${ }^{387}$ thams cad dad cing snyan pa'i ba dan dkar po'ang phyogs mtha' kun tu gsal bar gyur..., The Life of the Madman of $\ddot{U}, \mathrm{p} 484.2$.

${ }^{388}$ snyan pa'i ba dan kyang 'khor yug tu grags par gyur..., pp 548.2-549.2. For more mentions of events that furthered the spread of the Madman of Ü's fame, consider the following: shin tu dad cing kun la snyan pa'i grags pas khyab par gyur..., pp 475.6-476.3; ... thams cad ngo mtshar bar 'dzin la/ snyan pa'i grags pa'ang kun la gsal bar gyur..., pp 546.6-547.3.
} 
the people of Tsari that "he was unanimously praised as "the Madman of Tsang,", a name which then became "as renowned in every direction as the sun and the moon." ${ }^{, 389}$ Not only is the spread of the Madman of Tsang's fame said to have been a direct result of certain of his own actions, but the biographer even goes so far as to state that the yogi purposefully endeavored to become more famous. One chapter describing the Madman of Tsang's activities ends thus:

This was the chapter about how by his performance of that kind of engaged asceticism he overpowered all evil people and non-human spirits and set them on the path of heroes, and gave immense happiness to good people and non-human spirits; and how on account of his diligence in sounding the drumsound of his fame in every direction, he became renowned in the three realms as a mahassiddha without rival. ${ }^{390}$

What is interesting about this passage is that Götsang Repa has explicitly stated that an aspect of the Madman of Tsang's rise to prominence was his taking steps to increase his own fame. This is something that most biographers do not readily admit, instead positing the fame of the saint in question as a mere side-effect of his holiness. It is surprising how blunt the authors of the Lives of the Madmen of Ü and Tsang are about how social a process the rise to saintliness is, making a direct link between the yogis' actions and the spread of their fame, and even suggesting that the holy madmen were themselves aware of the workings of this process (as opposed to portraying them as piously aloof or blissfully unaware). Here we see some recognition that in reality the relationship between the two is that sainthood comes as a result of fame, and not the other way around. The Madman of Tsang himself basically admits as much, as we saw in Chapter

\footnotetext{
${ }^{389}$ Götsang Repa, pp 37.6-38.1. For other examples of the spread of his "fame" (snyan pa or grags pa), see pp 9.6-.7, 33.5-.6, 171.4, 229.1-.2.

390 snyan pa'i rnga sgra phyogs kun du sgrog pa la brtson pas/ srid pa gsum na 'gran zla med pa'i grub thob chen por grags pa'i bskor tshe... Götsang Repa, p 67.1-.2. Emphasis added.
} 
Three, when he warns in a song against performing engaged asceticism for the sake of becoming famous. ${ }^{391}$ For one who has been propelled into fame and holiness by his own very public performance of engaged asceticism to admonish others not to use engaged asceticism to become famous belies recognition on behalf of the mad yogi just how social the process of his own rise to sainthood truly was.

We are beginning to understand the dynamics of the real circumstances in which the Madmen of $\ddot{U}$ and Tsang lived and made names for themselves. It was not the case that the Madmen of $\ddot{U}$ and Tsang at one point in their lives achieved a certain ontological state through their religious practice and then became universally accepted as saints. On the contrary, whatever holiness they achieved came about through the never-ending work of managing peoples' perceptions of them. The Madmen of Ü and Tsang were holy beings only to the extent that they and their followers were able to convince others of this. Their receiving official letters of praise from the 7th and 8th Karmapas served as certification that they had achieved some success in this endeavor; the fact that these letters are so proudly quoted in their life stories shows that the process was still an unfinished one, as there still remained minds that needed convincing, opinions to be shored up. And it was not the case that the Madmen of Ü and Tsang were naïve to the workings of this process: their biographers articulate a direct causal relationship between their activities and their ever-widening fame. We must assume the holy madmen themselves to have been aware of this basic social reality.

${ }^{391}$ Götsang Repa, p 103.3-.4. 
In light of these factors we can begin to reconsider the nature of the Madmen of $\ddot{U}$ and Tsang's eccentric activity, which was often very public. In the previous chapter we discussed some aspects of the eccentric asceticism of the Madmen of $\ddot{U}$ and Tsang that were highly attention-grabbing by nature: their striking mode of dress (smearing themselves with ashes, adorning themselves with bone ornaments), having fierce confrontations with authority figures, eating flesh from corpses, performing normoverturning feats in public spaces (at times this activity was specifically referred to as "public activity," tshogs spyod). It should come as no surprise that their reputations, good or bad, would have spread far and wide.

It is clear that one important motivation for the Madmen of Ü and Tsang's adopting this kind of lifestyle was the fact that it was so attention-grabbing and would thereby be an effective vehicle for spreading their renown, which would carry them towards sainthood. Their activity was so public and the spread of their fame so essential to their achieving the status of holy men that this is impossible to deny. It is no coincidence that many of the things they did that would make them famous (imagine the Madman of Tsang adorned with ashes and intestines, running crazily through the marketplace, throwing and eating feces, chasing the men, shouting "Screw me!") were performed in the most public of spaces. Doing such things in the marketplaces of central Tibet or the Barkor at the hub of Lhasa, it would not have taken long for one to gain a large degree of notoriety, as people witnessing such a thing at a centralized location would tell others of it elsewhere. Word of mouth would have spread quickly. And we should not for one moment think that the holy madmen would have been unaware of these basic social dynamics. By performing these kinds of public activity and actively 
working to spread the "drumsound of their fame" the Madmen of Ü and Tsang were participating in the ongoing competitive game that defined the religious field in which they operated. Seen from this perspective, we understand the genius of their decision to promote the use of the term "madman" in reference to themselves. This gave their eccentricity something tangible to adhere to - it was a one-word framework on which to hang a distinctive and memorable persona.

The Madmen of Ü and Tsang were not the only ones in search of fame, respect and standing in the religious field in 15th- and 16th-century Tibet. Other religious figures would have been renowned for their cunning as debaters; for the strength of their meditation; for the purity of their monastic conduct; for the profundity of the treasure texts they revealed; or for their status as reincarnations of past masters. The decision made by Künga Zangpo and Sangyé Gyeltsen to publicly perform often-neglected chapters of the Highest Yoga Tantras was a calculated strategy for positioning themselves more advantageously in an environment saturated with Buddhist practitioners of various stripes.

We can imagine the situation at any moment of the history of Buddhism in Tibet as a marketplace, in the sense that it is a site of competition and exchange. That marketplace is filled with a variety of Buddhist practitioners (we can think of them as Buddhist types) selling a variety of wares: some have protective pills to sell; others offer their services as ritual specialists. But what they all have is some amount of symbolic capital. This capital is something they have earned through their years of religious activity: years and months of meditation, texts memorized, pilgrimages undertaken. Some pursuing a more institutionalized education will have titles that signify a certain 
amount of educational capital. In the 15 th-century there was the "master of four texts" (bka' bzhi pa), the "master of ten texts" (bka'bcu pa), the "master of numerous [texts]" (rab 'byams pa), or the "virtuous friend" (dge bshes, which will be discussed further below). ${ }^{392}$ For those who chose to spend their time in meditation there were fewer such formal indicators. But nevertheless they all have some amount of this amorphous, (usually) invisible capital. Their relative amounts of this capital is what distinguished them from one another in this competitive forum. It is their symbolic capital that attracts them students, followers and patrons - individuals with an excess of material capital looking to purchase symbolic capital. Ultimately what the religious figures are competing for is renown, respect, recognition as bearers of enlightenment. (And as we will see in the following section, attempting to define and redefine what enlightenment is is an important maneuver in this game.) But this competition taking place in the cultural sphere has direct fiscal ramifications as well. It is through the magic of this marketplace that renunciants - Buddhist practitioners explicitly dedicated to a life of simplicity and poverty - became the recipients of at times great wealth, through a process modern scholars have come to call the "economy of merit." We will get a better idea of the workings of this economy as this chapter moves forward.

We can think of the Madmen of Ü and Tsang's shocking, attention-grabbing behavior in the marketplaces of Central Tibet as also being actions that register in this larger, more figurative marketplace as well. It was on both levels a calculated move, a

\footnotetext{
${ }^{392}$ On the nature of these degrees, see Yaroslav Komarovski, Echoes of Empty Luminosity: Reevaluation and Unique Interpretation of Yogācāra and Nihsvabhāvavāda Madhyamaka by the Fifteenth Century Tibetan Thinker Śākya mchog ldan (Ph.D. dissertation, University of Virginia, 2007), p 104. This topic will be returned to below.
} 
declaration of what Künga Zangpo and Sangyé Gyeltsen wanted others to see them as representing.

And we have every indication that the decision paid off handsomely. Although they may have fallen short of universal acceptance (which is never actually achieved, because nearly every religious figure in Tibet has his detractors, at least during the years in which he lives) the Madmen of $\ddot{U}$ and Tsang did become quite famous and were very successful in the religious marketplace. They attracted large followings of students and lay devotees. They also attracted a lot of attention from various patrons, some of whom played a huge role in the political affairs of central Tibet during this time. It was through achieving a high degree of standing in the religious marketplace that Künga Zangpo and Sangyé Gyeltsen went from being ordinary monks from average families to being widelyrenowned exemplars of enlightenment, with finances at their disposal that allowed them to found monasteries and retreat centers, undertake costly book printing projects, and even restore an enormous religious monument in Nepal.

For readers who expect all Tibetan Buddhists to be dedicated only to some universalistic cause or the promotion of peace and harmony, some of the events of 15thand 16th-century Tibet that will be described later in this chapter may come as a surprise. Monks angrily destroying the monastery of a rival sect is not the picture of Buddhist life we most often get. But these things did happen. And although throughout the life stories of the Madmen of $\ddot{U}$ and Tsang there is much talk of their actions being undertaken for the benefit of all sentient beings or for the Teachings of the Buddha in general, there are also plenty of indications that the holy madmen felt partial to their own sect and had a 
special interest in protecting its integrity and securing its future. When the Madman of $\ddot{U}$ laid down his monk's robes and took on the garb of the Heruka, it is said that he did so for the sake of (among other things) benefitting the Kagyü sect; he instructed one of his students to undertake the printing of some texts (the Life and Songs of Milarepa, the Dohās of Saraha, and a text on the "secret activity of India," rgya gar gsang spyod), and thereby "faultlessly protect (rma med du skyongs) the Teachings of the Buddha in general, and in particular (bye brag tu) the Teachings of the Peerless Dakpo Kagyü." The Madman of Ü sent his students to different places in Tibet to "spread and increase the Teachings of the Kagyü” (bka' rgyud kyi bstan pa dar rgyas). ${ }^{393}$ The same kind of concern is displayed in The Life of the Madman of Tsang. In the earliest version of the Life, by Ngödrup Pelbar, there is mention on a few occasions of the Madman of Tsang and his disciples taking on activity that would make the teachings of the Kagyü sect “shine like the sun." 394 In the latest version, Götsang Repa relates a dream in which the Madman of Tsang was visited by the five long life sisters (tshe rings mched lnga), who assured him that his undertaking the compiling and printing of the Life and Songs of Milarepa would directly benefit the Kagyü Teachings. ${ }^{395}$ As was mentioned above, he also received a letter from the 7th Karmapa in which he was thanked for his various activities that helped spread and increase the Teachings of the Kagyü sect. A special

\footnotetext{
${ }^{393}$ The Life of the Madman of $\ddot{U}$, pp 438, 592, 606. On another occasion the yogi expresses a special indebtedness to the Kagyü (p 527); he is also called "the unchanging the spine (lit: life tree) ( $m i$ ' $g y u r ~ b a$ ' $i$ srog shing) of the Teachings of the precious Kagyü" (p 555); and in a letter received from Drikung he is called "the spine of the Kagyü Teachings, the Precious Dharmalord of Ü" (bka' rgyud bstan pa'i srog shing chos rje rin po che dbus pa), p 630.

${ }^{394}$ Ngödrup Pelbar, bka' rgyud kyi bstan pa nyin mor mdzad pa..., p 17a7; spyir sangs rgyas kyi bstan pa/ dgos bka' rgyud kyi bstan pa 'di nyin mor mdzad pa yin..., p 30a1.

${ }^{395}$ Götsang Repa, p 139. The phrase is spelled tshe rings consistently in Götsang Repa's version of the Life.
} 
concern to protect and promote the sect of which they were a part was clearly a part of the lives of the Madmen of $\ddot{U}$ and Tsang.

Here we are beginning to see the eccentric activity of the Madmen of Ü and Tsang in a way that is quite different from that suggested in Chapter Three. In Chapter Three we considered Künga Zangpo and Sangyé Gyeltsen activity only as it pertained to their personal religious practice, as something propelling them towards enlightenment. In this chapter we are considering the social and this-worldly effects of their activity. This leads to a radically different way of thinking about the holy madmen — one that considers the real lived dynamics of sainthood as well as the specific historical situation in which their lives played out. Here I have suggested that we consider the eccentric activity of the Madmen of Ü and Tsang as, on one level, a calculated move for the purpose of helping them gain renown, respect, and eventually material wealth. All of this would have been for the purpose of benefitting their sect, the lineages with which they felt personally connected, as well as for their own aggrandizement. Some may charge that the suggestion that the holy madmen may have been acting for anything but purely spiritual, other-worldly motives is necessarily an improper one. The fact is that the interpretation of the crazy yogi's behavior I am suggesting here goes squarely against the way the vast majority of Tibetans today or at any point in their history would have thought about these figures. But if we look at the larger pattern of their activity, as well as the explicit mentions throughout their lifestories that part of what motivated their activity was a wish to benefit the Kagyü sect, this position will come to be seen as entirely grounded. To insist on seeing the Madmen of Ü and Tsang as purely spiritual beings concerned only with the practice of religion is to pay them a great disservice. It makes us blind to the 
great ingenuity that drove their actions, and to the historical moment in which those actions must be understood.

\section{II. Tantric Fundamentalism in Context: Competing Models of Buddhist Life}

It was argued in Chapter Three that the distinctive behavior of the Madmen of $\ddot{U}$ and Tsang that led them to be called "holy madmen" is best understood as an attempt to embody a literal reading of certain chapters of the Highest Yoga Tantras, in particular the chapter on Activity (spyod pa) from the Hevajra tantra. To this end, Künga Zangpo and Sangyé Gyeltsen took literally the instructions about dressing in the garb of a wrathful deity (including smearing oneself with ashes, wearing a set of ornaments made of bone, carrying a khațvāinga staff and a skull cup), wandering in out of the way places, eating human flesh and other repulsive substances, imitating the deity through song and dance, and so on. For these reasons it is fit to think of them as "tantric fundamentalists." Although none of these aspects of their activity was unprecedented in Tibet, the Madmen of $\ddot{U}$ and Tsang were unique in the extent to which they made these activities define their public identities.

An important question that was not addressed in Chapter Three is how the trajectories of the lives of Künga Zangpo and Sangyé Gyeltsen were affected by their decisions to follow this kind of lifestyle. This question needs to be answered by considering how their decisions to make themselves the foremost representatives of the tantric tradition affected their position in the religious world of 15th-century Tibet, which we are here thinking of as a competitive marketplace. We know that their adoption of this seemingly bizarre lifestyle gave them an added aura of holiness — symbolic capital— 
that made them stronger competitors in the marketplace. But where, more specifically, did it position them within that marketplace? Among the different ways Künga Zangpo and Sangyé Gyeltsen could have created fame for themselves as renunciants, why did they choose this one particular route? We can get the clearest idea of where the Madmen of $\ddot{U}$ and Tsang were trying to position themselves in the religious marketplace by looking at who they distinguished themselves from. They defined themselves by making clear who they were not. By fashioning themselves as the foremost representatives of adherence to the Highest Yoga Tantras, what model of religious life were they moving away from? This will prove important for our understanding of the patrons of the holy Madmen of $\ddot{U}$ and Tsang, and how they fit into the larger events of their day.

To begin with, it is significant that in taking on a life fully dedicated to practicing and embodying tantra, Künga Zangpo and Sangyé Gyeltsen both made the decision to leave behind the life of ordained monasticism. For the remainder of their lives as they encountered individuals who doubted the validity of the form of Buddhism they had chosen to embody, those individuals were in almost every case representatives of ordained monasticism, according to their respective biographies. And in most of these cases, those portrayed as doubters of the holy madmen were not simple monks, but rather representatives of higher monastic learning, in most cases referred to as dge ba 'i bshes gnyen or the shorter dge bshes (phonetically rendered as geshé). For example, on one occasion when the Madman of Ü was traveling in Kongpo he encountered a geshé who harbored doubts about the Master (rje la the tshom zos). With his real intentions concealed, he made a profession of faith and invited [the madman] in. [The geshé] called for a tantric feast. He invited [the Madman of Ü] to stay there that night. The Great One, as if he knew [the geshé's secret intentions], said, "I will not stay." He went to a side of that building where there were no doors and 
passed unobstructed through the wall. [The geshé] was filled with faith and [the Madman of Ü's] fame spread everywhere (kun la snyan pa'i grags pas khyab par gyur). ${ }^{396}$

This episode is presented as a simple case of the Madman of Ü's meeting a scholar-monk who was doubtful about his spiritual worth, whose admiration the yogi then won by performing a magical feat that served as witness to the special abilities he had gained through his practice. But as there are numerous encounters following this same basic pattern throughout the biographies of the Madmen of Ü and Tsang, they come to seem less like random encounters and more like indicators of what the holy madmen were meant to represent, and what they were decidedly opposed to.

What did the term dge ba'i bshes gnyen or dge bshes (geshé) mean in 15th- and early 16th-century Tibet? The term did not have the specific meaning of one who had completed a certain number of years of study of a circumscribed body of texts and then passed a series of formalized exams on those texts, as the Gelukpas would later give it. But in the 15 th and 16 th centuries it did indicate a more learned monk. The Tibetan term dge ba'i bshes gnyen is a translation of the Sanskrit kalyānamitra, which is often rendered as "virtuous friend." In earlier Tibetan usage it meant a good exemplar of Buddhist values upon whom one relied as a guide. By the late 15th century the term was used to refer to one with a high degree of institutionalized, textual learning. It was not fully formalized, but would be used with respect to monks from the Sakya and Ganden (i.e., Geluk) traditions with a high level of learning. ${ }^{397}$

\footnotetext{
${ }^{396}$ The Life of the Madman of $\ddot{U}$, pp 475.6-476.3.

${ }^{397}$ As Komarovski explains, "This title should not be confused with the contemporary title of dge bshes that can be granted after years of study in Dge lugs or Bon monastic universities. It seems that back in the 15 th century it did not necessarily indicate a sectarian affiliation, and could be applied to learned scholars as it had been previously in the Bka' gdams tradition earlier as well," p 81. After describing the formalized
} 
Künga Zangpo did not have had an extensive formalized education before becoming the Madman of $\ddot{U}$, and as such there are no stories about his debating with learned monks. Rather, as we saw above, he was more likely to respond to their criticism or questions by performing a miracle, as a sign of his meditative accomplishment and a de facto indication of the value of the tradition he represented. Sangyé Gyeltsen, on the other hand, did have an extensive monastic education at the Pelkor Chödé Monastery in Gyantsé before becoming the Madman of Tsang and later showed himself to be fully capable of engaging learned monks from various traditions on their own terms in formalized debate. The Madman of Tsang's adversarial encounters with representatives of monastic learning give us a great deal of insight into how his tantric fundamentalism positioned him in the religious marketplace, and what model of Buddhistness he was rejecting in the process.

On one occasion the Madman of Tsang found himself arguing with four geshés "arrogant about their learning" (yon tan kyi [sic] dregs pa) regarding his views, meditation, conduct and tenet system (Ita sgom spyod pa grub $m$ tha'), as they pertained to scripture and reasoning (lung rigs). Although the Madman of Tsang gave faultless answers, and although the geshés could not challenge him any further, they still had no faith in him and said that he was wrong. In his frustration the Madman of Tsang exclaimed how the geshés paid no recognition to the valid means of cognition (tshad ma) constituted by the Word of the Buddha, direct awareness of an object, or the direct experience of a yogi, and in so doing refused to play by the rules of the game they

study undertaken by Śākya Chokden towards becoming a dge ba'i bshes gnyen, Komarovski concludes that “... the term 'Sa skya virtuous spiritual friend [dge ba'i bshes gnyen]' ... [does not] seem to be a particular title, although it does convey an exalted status," p 104. 
themselves initiated. So the Madman of Tsang took up some sharp spears and gave them to the geshés, saying, "Stab me with these until you get tired. Otherwise, I'll stab you each once." The geshés were terrified of the prospect and threw down the spears. They cried and prostrated to the yogi, requested his blessing and became entirely faithful. These geshés are portrayed as haughty, stubborn, cowardly, and hypocritical in that they refused to play by the rules of their own game. The reader cannot but form a very negative opinion of these entirely unsympathetic characters, in direct contrast to the brilliant, just, and ultimately victorious Madman of Tsang. ${ }^{398}$

In the Madman of Tsang's biographies there are two encounters with certain geshés that are described in greater detail. These are very significant for understanding how the Madman of Tsang's choice of lifestyle positioned him in the religious field. The encounters with geshés that led to more direct attacks on his personal conduct, and his most revealing and vociferous defense of his ways, all involve representatives of the Ganden, soon-to-be-Geluk, tradition, the history of which will be told below. Both encounters were mentioned in Chapter Three but must be revisited briefly here.

In the first of these encounters the Madman of Tsang traveled from Lhasa to the nearby fortress at Neudzong, into the presence of a local lord, Depa Peljor Gyelpo. He argued with some geshés from Sera and Drepung monasteries, who charged that they had never before heard of the Madman of Tsang's manner of dressing (cha lugs) or behaving

\footnotetext{
${ }^{398}$ khyed rang rnams'di ngal thang ma chad bar du thebs tshad rgyob/ yang na ngas khyed tsho la thebs tshad cig rgyab gi..., Götsang Repa, pp 100.5-101.4. These geshés are from rdzong dkar chos sde, which may have been a Geluk institution. For more examples of the Madman of Tsang debating with geshés, see pp 132.5-133.5, when he debates with a about four hundred of them; pp 155.5-156.6, when he debated with "geshés who were learned, monkish, and good" (dge bshes mkhas btsun bzang gsum rnams), arguing about a number of topics connected to his Kagyü system, which he explained from the perspective of of the Three Vows literature of the Sakya (dpal ldan sa skya ba'i sdom gsum ram dbye).
} 
(spyod pa) among the Teachings of the Buddha. They must therefore be the way of some other religious system. The Madman of Tsang responded that his manners were in line with the Highest Yoga Tantras, the tantric deities and the Eighty Mahāsiddhas of India. He stated that the questions of who should practice this kind of activity (spyod $p a$ ), where, when, with whom, for what purpose, and how are all clearly taught in the tantras. Therefore, what reason did these monks have for expressing such doubts? The geshés challenged him by saying that the age we live in is not the time to be practicing tantra in so literal a manner (da lta de ltar gsang sngags spyod pa'i dus ma yin). To this the Madman of Tsang asked where it is stated that now is not the time to practice tantra ( $d a$ lta gsang sngags nyamsu len pa'i dus ma yin pa gang nas bshad). ${ }^{399}$ The geshés were unable to make a response, so the Madman of Tsang got up from the assembly and left. We are told that the local lord (sde pa) gained new faith in the yogi and offered him reverence and gifts. ${ }^{400}$

The other encounter with a representative of the Geluk system is only more revealing of the dynamics of the religious field at the time. While staying near Mount Kailash the Madman of Tsang was holding a gathering at which a representative of the Ganden (Geluk) system holding the degree of "Master of Ten Texts" (dga' ldan bka' bcu $p a)$ arrived along with fifteen of his students. The Gandenpa scholar-monk did not partake of the chang (a weak alcohol) that was being served at the gathering, which compelled the Madman of Tsang to ask him, "Have you received tantric initiation? Have you studied and contemplated the ways of the tantras?" (gsang sngags kyi dbang e thob/

\footnotetext{
${ }^{399}$ Götsang Repa, pp 45.6-46.1.

${ }^{400}$ Götsang Repa, pp 44.7-46.2.
} 
rgyud bzhin la thos bsam e byas). The Gandenpa related how he had become a monk (rab tu byung) at a young age, how he studied the "ten texts of philosophy" (mtshan nyid kyi bka' pod bcu); how he studied a number of tantras and commentaries in the tradition of the Gandenpa, and had some success in his practice. The Madman of Tsang then asked the monk,

Then why is it that, when sitting here in a profound tantric assembly at a holy place described in many of the sütras and tantras, you do not partake of the samāya substances? (dam rdzas la mi spyod pa ci yin) (referring to alcohol and other substances consumed in the course of tantric rituals, perhaps including sexual fluids ${ }^{401}$ ). Does this not constitute the second downfall of contradicting the Word of the Sugata, and the thirteenth downfall of not upholding one's samaya vows? If one commits a root downfall, one will fall into a vajra hell—isn't that taught in the tantras that you studied, like the Guhyasamäja and so on?

The scholar-monk's response was to say that the current age they lived in was not the time to practice tantra literally (da lta gsangs sngags dngos su nyams su len pa 'i dus $\mathrm{min}$ ), and that in Tibet there were no legitimate tantric gatherings (ganacakra; bod na tshogs 'khor mtshan nyid pa yod yang med). The Madman of Tsang pushed him further, asking, "In what authentic tantra or treatise does it say that? If now is not the time to practice tantra [literally], when is?" (da lta gsang sngags nyams su ma lan na nam nyams su len). The Gandenpa reiterated that he was a monk practicing the Vinaya and one who took after lord Tsongkhapa and his disciples, and would not, therefore, be drinking any alcohol. Their exchange ended on the worst possible terms. Three days after this the Gandenpa scholar-monk vomited blood and died. ${ }^{402}$

\footnotetext{
${ }^{401}$ See Wedemeyer, $\mathrm{p} 118$, where he states that in the context of Āryadeva's Lamp that Integrates the Practices, "samāya substances" can refer to sexual fluids or a wider array of tantric substances.

${ }^{402}$ Götsang Repa, pp 179.2-180.3. There is also an encounter in the version of The Life of the Madman of Tsang by Lhatsün Rinchen Namgyel in which the Madman of Tsang has an argument with monks from Sera and Ganden monasteries in the marketplace in Lhasa, which escalates into a swordfight, pp 38-9.
} 
These stories probably do not represent the veridical truth of historical events as they really happened. But they are by all means indicative of the position of the Madmen of $\ddot{U}$ and Tsang in the religious marketplace vis-à-vis the representatives of a more scholarly, sedate form of Buddhism.

It is no coincidence that the confrontations with scholar monks described in the greatest detail in The Life of the Madman of Tsang involve representatives of the Ganden/Geluk tradition. On these occasions the Madman of Tsang's relationship with the Gelukpas is portrayed as entirely adversarial. And the issues about which they argue give us great insight into the nature of the Madman of Tsang's seemingly eccentric activity. The two encounters described here bring to light the fundamentally different ways of thinking that motivate the madmen's and the Geluk scholar-monks' ways of life. They have entirely different attitudes about texts, about tantra, and ultimately about Buddhism itself. In the course of these conversations it becomes clear that the way of the holy madman and the way of the Gelukpa are mutually exclusive: whereas the Madman of Tsang aims, above all, to obey the letter of the tantras, with no compromise, the Gelukpa scholar-monks are dedicated to following Tsongkhapa's system, in which the dictates of Vinaya-based monasticism supersede a literal reading of the tantras. The Gelukpa monks justify their position on this matter by resorting to the often-used maneuver of stating that different phases in the history of the world require different types of Buddhist practice. Although it may once have been appropriate to follow the tantras in a literal manner, when people and the age they lived in were more pure, that time has now passed. What the current age calls for is a return to the unifying dictates of the Vinaya, which ensure moral behavior at all times. Thus the fundamental approaches 
of the Gelukpas and of the holy madmen could not be more different. The author of these accounts, Götsang Repa, has made no attempt to make these two ways somehow compatible with one another: they are mutually exclusive, and, according to these accounts, the Madman of Tsang's system is by all means superior. The geshés, on the other hand, are portrayed as narrow-minded and even hypocritical.

In the biographies of the Madmen of $\ddot{U}$ and Tsang there is a persistent theme of their having adversarial encounters with scholar-monks, most often called geshés. (As we will see in the next chapter, this is an even bigger and more obvious theme in the more popular version of The Life of Drukpa Künlé. Keith Dowman's claim that Drukpa Künlé's behavior constituted "attacks upon monasticism and organized religion" is accurate, although perhaps not in the sense that he meant it. ${ }^{403}$ ) The Madmen of $\ddot{U}$ and Tsang are not so consistently portrayed as having this kind of adversarial relationship with any other group of religious practitioners - not other meditators, nor Nyingmapas, nor Bönpos or other non-Buddhists (although there are so stories about the Madmen of $\ddot{U}$ and Tsang converting Hindus during their visits to Nepal). The yogi upholding a form of tantric fundamentalism stands as a direct foil to the Vinaya-following monk. The Madmen of $\ddot{U}$ and Tsang are the antithesis of Geluk values. It could be said that the model of the pious, Vinaya-following monk that was the cornerstone of the Geluk system was the norm, the "sanity" against which the insanity of the Madmen of Ü and Tsang was defined. They represent two very different — and competing — models of Buddhist life. The nature of the Madmen of Ü and Tsang's religiosity is best understood as standing in direct contrast to that of the scholar monk in general, and in particular the Gelukpas, who

${ }^{403}$ The Divine Madman, p 26. 
in the 15th and 16th centuries were fast becoming Tibet's scholar-monks par excellence, as will be described further below. The holy madmen stood in contrast to all scholarmonks to some extent, but their contrast vis-à-vis the Gelukpas was the starkest, because of the latter's unwavering insistence on the sanctity of the Vinaya and their attitudes regarding the practice of tantra.

These adversarial interactions between the holy madmen and the representatives of monastic learning are a dramatic expression of a deep and longstanding tension within Tibetan Buddhism. Throughout The Life of the Madman of $\ddot{U}$ and The Life of the Madman of Tsang, scholar-monks and renunciants more dedicated to the practice of meditation are often listed as being of two different categories. When the Madman of Tsang gave teachings to a crowd of over five hundred people it is said that this group included "scholar-monks [dge ba'i bshes gnyen], male and female yogis, and so on" (dge ba'i bshes gnyen dang / rnal 'byor pho mo sogs...). ${ }^{404}$ This basic pattern is repeated throughout their life stories, suggesting that these meditators and scholar-monks should be thought of as belonging to distinct categories of religious practitioners. In The Life of the Madman of Tsang these different groups are often mentioned as "lamas and geshés" 405 ; in The Life of the Madman of $\ddot{U}$ they are often mentioned as "geshés and ascetics" (dge bshes bya bral). ${ }^{406}$

All of this indicates a recognition on behalf of the authors of the biographies of the Madmen of Ü and Tsang that within their religious world there were Buddhists who

\footnotetext{
${ }^{404}$ Götsang Repa, p 256.2-.3.

${ }^{405}$ The assembly includes bla ma dge ba'i bshes gnyen/ nang so dpon blon bzo' rigs pa sogs..., Götsang Repa, p 54.2; bla ma dge ba'i bshes gnyen rtogs ldan gyi rnal 'byor pho mo rnams..., p 171.6.

${ }^{406}$ The Life of the Madman of $\ddot{U}$, p 550; see also when the order is reversed as bya bral dge bshes, p 543; phyogs kyi bu slob dge ba'i bshes gnyen/ bya bral la sogs ..., p 548; dge ba'i bshes gnyen bya bral skye bo'i tshogs..., p 554.
} 
were dedicated to different lifestyles, the most fundamental distinction often coming down to those dedicated to institutionalized learning and those more dedicated to meditation and itinerant forms of asceticism. We can see this basic distinction written into the Tibetan Buddhist ideals of being learned (mkhas) and accomplished [in meditation] (grub). That one person could embody both of these ideals and consequently be referred to as a mkhas grub does not lessen the fact that they are often thought of as essentially different from one another. These dual ideals are representative of the fact that within Tibetan Buddhism there are two very basic approaches that are at odds with one another: is liberation ultimately arrived at through meditation or through formalized study? There are various institutions built up within Tibetan Buddhism that are based on and dedicated to propagating each of these basic orientations. These two ideals have always existed within Indian and Tibetan Buddhism. The tension between them is never fully resolved. The basic tension I am describing here has many similarities with the "shamanic/clerical" divide argued for by Geoffrey Samuel in Civilized Shamans, or the contrast between "exegetes" and "visionaries" proposed by Janet Gyatso. ${ }^{407}$ It has also been observed by R. A. Stein. ${ }^{408}$ As Carl Yamamoto is surely correct in pointing out, this "issue is one of emphasis, and this is all the more reason to speak in terms of a conflict of style, not doctrine." 409 I would suggest that adopting Foucault's notion of these as

\footnotetext{
${ }^{407}$ Janet Gyatso, The Literary Transmission of the Traditions of Thang-stong rGyal-po: A Study of Visionary Buddhism in Tibet (Ph.D. dissertation, University of California at Berkeley, 1981), pp iii-iv. ${ }^{408}$ Tibetan Civilization, pp 156-7. See also Rupert Gethin, The Foundations of Buddhism (New York: Oxford University Press, 1998), p 38, where he observes, "Throughout the history of Buddhism there has existed a certain tension between the monk who is a great scholar and theoretician and the monk who is a realized practitioner."

${ }^{409}$ Carl Shigeo Yamamoto, Vision and Violence: Lama Zhang and the Dialectics of Political Authority and Religious Charisma in Twelfth-Century Central Tibet (Ph.D. dissertation, University of Virginia, 2009), $\mathrm{p}$ 132. Yamamoto writes of how in the 12th century, during the time of Lama Zhang, Tsöndrü Drakpa (brtson 'grus grags pa), "there must have been considerable tension between the hermit-meditative groups
} 
competing "regimes of truth" or "truth regimes" may lead to a more accurate and nuanced understanding of these competing ideologies within Buddhism.

Thus the highly dramatized conflicts between the Madmen of Ü and Tsang and learned scholar-monks were an expression of a long-standing tension within the history of Buddhism. Ultimately it is about two competing models of liberating truth-what that truth is, how it is established, and how an individual can arrive at it. As we saw in the debates between the Madman of Tsang and the Gelukpa scholar-monks, in the 15th and 16th centuries some saw no common ground between these two approaches. The scholar-monk (in particular one of the Gelukpa persuasion) represented one distinct way, and the holy madman represented another, and the two alternatives were fundamentally, antagonistically different. The scholar-monks of the time, and especially the Gelukpas, were the epitome of one truth regime, fully invested in the didactic value of philosophical texts and reasoning, and the immutable need to follow the dictates of the Vinaya. The Madmen of Ü and Tsang made themselves the epitome of an alternative, diametrically opposed truth regime: they insisted that the dictates of the Highest Yoga tantras superseded those of the Vinaya, and saw little use in the scholarly practices of memorizing texts, debating, and so on. Instead they emphasized the need for meditation. As miracle workers and "madmen" they became walking embodiments of the very efficacy of meditation itself. The larger tension between these two competing truth

led by figures like Zhang and the growing contingent of scholarly monks...," p 123. Yamamoto continues: "... [I]t seems clear that at this time, when the future of Buddhism in Central Tibet was still very much up for grabs, two different camps were gradually being separated out, and two very different visions of the Buddhist path and the role therein of intellect, reasoning, and scholarship were being offered up for consideration, and in increasingly polarized terms. Lama Zhang represented — or came to represent in subsequent debates - one pole of this opposition, the one that emphasizes direct experience and downplays intellect and reasoning," p 124. As we will see in Chapter 7, Lama Zhang is also sometimes (perhaps erroneously) referred to as a holy madman. 
regimes extends well beyond the holy madmen and their geshé foils, but they represent the apex of each of these ways, with its basic characteristics amplified and exaggerated.

It is not only in the biographies of the Madmen of Ü and Tsang that we find evidence of this tension in 15th- and 16th-century Tibetan religious culture. In the biography of the 7th Karmapa included in the 1545 history The Scholar's Feast (chos 'byung mkhas pa'i dga' ston) the list of his many disciples divides them into different categories, based on their fundamental orientation. There were various scholars, the most famous among them being Peṇchen Shākya Chokden, Nyukla Peṇchen, Karma Trinlepa, and the like, who were all referred to as "great geshés who in an entirely perfected manner [upheld] the Teachings" (bstan pa yongs rdzogs kyi dge ba'i bshes gnyen chen po). The other various sub-groups of the Karmapa's disciples include "secret yogis" (sbas pa'i rnal 'byor ba), "masters of yoga" (rnal 'byor gyi dbang phyug) — including the Madman of Ü, the Madman of Tsang and the Madman of the Drukpa, Drukpa Künlé, all of whom are mentioned specifically.

One of the terms used in this list from the Karmapa's biography to describe these various yogis and upholders of an orientation far removed from that of the geshés is "upholder of the Practice Tradition" (sgrub rgyud kyi bstan 'dzin). ${ }^{410}$ The term Practice Tradition basically refers to the tradition within the Kagyü that is more vociferously dedicated to the practice of meditation and less concerned with scholasticism. ${ }^{411}$ In many

\footnotetext{
${ }^{410} \mathrm{dpa}$ ' bo gtsug lag phreng ba, chos 'byung mkhas pa'i dga' ston (Beijing: mi rigs dpe skrun khang, 2006), pp 567-8.

${ }^{411}$ Dan Martin explains the term thus: “'Practice transmission' (sgrub-brgyud) is a term still in fairly common use among the Bka'-brgyud-pa schools, where it is sometimes contrasted to 'meaning transmission' (don-brgyud), although both are equally esteemed. 'Practice transmission' emphasizes sādhana practice, while 'meaning transmission' emphases [sic] the kind of learning transmitted through the oral precepts," "The Star King and the Four Children of Pehar: Popular Religious Movements of the 11th-
} 
ways its foremost exemplar is Milarepa, who is sometimes said to have been the initiator of this tradition. (Sumpa Kenpo's dpag bsam ljon bzang states that the Practice Tradition was propagated (spel) by Marpa, Milarepa's guru, and involved the Cakrasamvara, Hevajra and Mahāmaya tantras. ${ }^{412}$ ) This term goes a long way towards explaining what the Madmen of Ü and Tsang stood for during the time in which they lived.

"Practice Tradition" is used consistently throughout the biographies of the Madmen of $\ddot{U}$ and Tsang to describe the focus of their distinctive activities. In The Life of the Madman of $\ddot{U}$ the term Practice Tradition is often used to describe the nature of his activities, in most cases attached to the idea that his activities are performed for the sake of propagating (spel) the Practice Tradition. The Madman of Ü's guru, Drakchokpa Rinchen Zangpo (brag lcog pa rin chen bzang po) told him that he had become a master (bdag po) of the Teachings of the Practice Tradition, and thus should stay in a monasteries high above villages, away from those sunken in the concerns for worldly life; he should go to the three famous pilgrimage and meditation sites (gnas chen gsum), the Six Fortresses (rdzong drug) where Milarepa meditated, and down into Nepal. Much later, when the Madman of $\ddot{U}$ was establishing his monastery Tsimar Pel, one of his students opposed him, saying that instead of settling in one spot they should continue to move from place to place, meditating in the mountains as they had before. The Madman of $\ddot{U}$ assured him that they would use this new base to work for the benefit of sentient beings, but in particular they would establish the monastery as a "special resource for the

to 12th-Century Tibet" in Acta orientalia academiae scientiarum hungarica 49, nos. 1-2, 1996, p 187.

${ }^{412}$ lho brag mar pa chos kyi blo gros kyis bod du 'dus pa bde mchog kye rdor ma hA ma ya gdan bzhi sogs la brten nas sgrub rgyud spel/ In the dpag bsam ljon bzang, by sum pa mkhan po ye shes dpal 'byor (Sarnath: Mongolian Lama Guru Deva, 1965), p 344. 
Teachings of the Practice Tradition" (sgrub rgyud kyi bstan pa mig rkyen bzang po cig jog $p a \ldots . . ., 413$

The "Collected Works" of the Madman of the Drukpa contain a text praising the transmission of Saraha's Dohās that he wrote at the request of the Madman of Ü. Drukpa Künlé describes the Madman of Ü in the midst of that lineage in the following way:

I supplicate the Madman of Ü, the Heruka, Resting at the peak of the lofty snows of the Practice Tradition, Descending in the ten directions as the unending streams of the Aural Transmission, Who fills the whole sky as the crops of virtue. ${ }^{414}$

Thus a contemporary of Künga Zangpo and a fellow "madman" felt compelled to associate him with both the Practice Tradition and the Aural Transmission, which will be discussed in Chapter Six.

This same term is used Lhatsün Rinchen Namgyel's version of The Life of the Madman of Tsang on a handful of occasions in describing the activity of the famous yogi and his disciples. Early in his life Sangyé Gyeltsen reflected on the diligence (snying rus) displayed by Śākyamuni Buddha and by latter-day greats:

On the bank of the Niranjana river [Śākyamuni] practiced the water austerity for six years (chu'i dka' thub mdzad). In like manner, Peṇchen Nāropa, even though he had become learned (mkhas pa) in the five sciences, pleased his guru by performing difficult tasks $\left(d k a^{\prime} b c a d d u m a\right)$ for twelve years. Like that, by performing difficult tasks $\left(d k a^{\prime} b c a d\right)$, noble Mila accomplished whatever his guru said; by means of difficult tasks, he fulfilled his pledge of equating his very life with his practice (tshe dang sgrub pa snyom), and spread the Teachings of the Practice Tradition. I, too, should accomplish supreme siddhis in this lifetime by performing difficult tasks $\left(d k a^{\prime} b c a d\right)$ with fierce diligence.

\footnotetext{
${ }^{413}$ See pp 419-20; p 586 (the manuscript has the exact same reading, Part II, 10b4). See also pp 497, 552. ${ }^{414}$ sgrub brgyud gangs rim thon po'i rtse la gnas/ snyan brgyud chu bran mtha' yas phyogs bcur 'bab/ dge legs lo tog nam mkha'i mthar khyab pa'il dbus smyon he ru ka la gsol ba 'debs/, 'brug pa kun legs kyi rnam thar (Beijing: bod ljongs mi dmangs dpe skrun khang, 2005), Vol. ga, p 411.14-411.17.
} 
This passage portrays the asceticism of the Madman of Tsang as conforming to the tradition established by the spiritual grandfathers of his lineage. The specific formulation of the Kagyü purported to have been articulated by Milarepa — and which the Madman of Tsang himself was maintaining - was in some ways known as the Practice Tradition. Later in Lhatsün Rinchen Namgyel's version of the Madman of Tsang's Life, the mad saint is praised for having "made the Teachings of the Practice Tradition shine like the sun during the degenerate age. ${ }^{\not 15}$ Perhaps most telling of all, in his opening homage Rinchen Namgyel describes the yogi as "the sun of the Teachings, who primarily teaches the Practice Tradition from among the expository (bshad) and practice [traditions]" (...bshad sgrub gnyis kyi nang nas sgrub rgyud gtso bor ston pa bstan pa'i nyin byed/). ${ }^{416}$ Clearly to Rinchen Namgyel's mind there are two distinct ways within Buddhism: one more dedicated to the teaching and study (bshad) and one more dedicated to meditation (sgrub). The Madman of Tsang is representative of the latter.

The term "Practice Tradition" is also used in similar ways on a handful of occasions in Götsang Repa's version of The Life of the Madman of Tsang. For example, when the yogi spends three years meditating at Lapchi, that holy site is described as the "foundation stone for the excellent house of the Teachings of the Practice Tradition" (sgrub rgyud bstan pa'i khangs [sic] bzangs rmang rdo). ${ }^{417}$

Based on all this we can conclude that the Madmen of Ü and Tsang were strongly dedicated to the idea of the Practice Tradition. This was the vision of the Kagyü to which they felt a special allegiance and wanted to serve and to protect. Their tantric

\footnotetext{
${ }^{415}$ These two quotations are from Lhatsün Rinchen Namgyel, pp 19 and 111; see also pp 38, 40.

${ }^{416}$ Lhatsün Rinchen Namgyel, p 3.1.

${ }^{417}$ Götsang Repa, p 164; see also pp 11, 194, 198.
} 
fundamentalism can likely be understood as part of this larger concern for maintaining the distinctive ways of the Practice Tradition. And as we will see in Chapter Six, the Practice Tradition was one among a handful of traditions or lineages the Madmen of $\ddot{U}$ and Tsang saw themselves as representing.

It was not only the Madmen of Ü and Tsang who expressed a special concern for the Practice Tradition in late 15th- and early 16th-century Tibet. Other Kagyüpas perceived the greater shifts in the Tibetan religious culture taking place during this time as consisting of a decline in the Practice Tradition in favor of other models of Buddhistness. The History of the Drikung Kagyü (written in 1803) shows that during the 15th century the Drikung Kagyü order came under threat and entered a period of decline, and then was set aright some years later. ${ }^{418}$ The drama of this story sheds light on the dynamics of the time period, as perceived by a slightly later generation.

The Drikung Kagyü teachings were set on this negative trajectory during the time of the 11th abbot, Shényen Döndrup Gyelpo (bshes gnyen don grub rgyal po; lived 13691427; ascended to the throne in 1395). ${ }^{419}$ There was at this time some other bshes gnyen (perhaps short for dge ba'i bshes gnyen, or geshés; or just meaning "teachers") who held false views and were leading some people astray with incorrect teachings. They deceived the close retinue of the dharmalord and discouraged teaching and practicing the essential

\footnotetext{
${ }^{418}$ The date for the composition of the text comes from 'bri gung gdan rabs gser phreng (nges don bstan pa'i snying po mgon po 'bri gung pa chen po'i gdan rabs chos kyi byung tshul gser gyi phreng ba) by 'bri gung bstan 'dzin pad ma'i rgyal mtshan (bod ljongs bod yig dpe rnying dpe skrun khang, 1989), p 3. Rasé Dawa Könchok Gyatso's 'bri gung chos 'byung (Beijing: mi rigs dpe skrun khang, 2003) is based on this much earlier text, with some comments added. In the following pages I will draw from both of these texts. ${ }^{419}$ Rasé Dawa says this is the 12th abbot, p 392. See also Per K. Sørensen and Guntram Hazod, with Tsering Gyalbo, Rulers on the Celestial Plain: Ecclesiastic and Secular Hegemony in Medieval Tibet: A Study of Tshal Gung-thang (Wien: Österreichische Akademie der Wissenschaften and the Tibetan Academy of Social Sciences of the Autonomous Region Tibet, 2007), p 724, where he is said to be the 11th abbot. Rasé Dawa discusses the discrepencies in these dates, p 393. For most of these dates I am relying on the element-animal dates given by Rasé Dawa.
} 
teachings (snying po'i bstan pa'i bshad sgrub kyi bya ba rnams bshol) and clouding the light of enlightened activities. ${ }^{420}$ It is said that during this time, thanks to the influence of these teachers, "the Practice Tradition of meditating by means of the profound yogas was cast off..." (zab mo’i rnal 'byor gyis nyams lens grub brgyud kyi ring lugs rnams dor...). ${ }^{421}$

Then during the abbacy of the 13th hierarch of Drikung Til Monastery, Rinchen Pelzang (1421-1469; on the throne 1435-69 422 , there is again discussion of the decline of the true Dharma because of the influence of bad teachers. On account of these teachers of false views, people were losing faith in the true Dharma, a fact the abbot himself lamented vocally. In his later retelling of this story, the modern historian Rasé Dawa Könchok Gyatso inserts a comment that during this time at many of the important seats of the Kagyü—Tsurpu, Drikung Til, Densa Til, Dakla Gampo, and so on—the "current of the Dharma" (chos rgyun) was turning into that of the Geluk and the excellent Dharma of the Kagyü was on the verge of dying out. ${ }^{423}$

During the time of the 13th hierarch it is said that a realized lord of yogis (rtogs ldan rnal 'byor gyi dbang phyug) named Jamo Gedün Gönpo ( 'ja' mo dge 'dun mgon po) arrived. This yogi was a disciple of a "mahāsiddha of the Kagyü called 'Heruka"' (bka' brgyud gyi grub chen he ru ka bya ba'i slob ma). He spoke about the need to revive (gsos dgos) the Teachings of the Practice Tradition (sgrub brgyud kyi bstan pa).

However, demonic forces interfered and prevented him from meeting the abbot himself.

\footnotetext{
${ }^{420}$ History of the Drikung Kagyü, p 141.

${ }^{421}$ History of the Drikung Kagyü, p 143. Rasé Dawa mentions the negative influence of the wrong-headed teachers on $\mathrm{p} 394$.

${ }_{422}$ Rasé Dawa Könchok Gyatso considers him to be the 14th dharmalord. See also Sørensen and Hazod, p 725 .

${ }^{423}$ Rasé Dawa, p 402.
} 
Because this meeting did not take place and the disciple of the Heruka yogi did not have the opportunity to express to the abbot the importance of the Practice Tradition, many teachings of the Practice Tradition and related rituals and meditations (cho ga sgrub $m c h o d$ ) declined (nub) for a long time. ${ }^{424}$ Rasé Dawe Könchok Gyatso specifies that this would have included their seasonal teaching seminars (dus chos), and practices associated with the Cakrasamvvara, Vajravarāhi and Guhyasamāja tantras. ${ }^{425}$

The 14th abbot, Rinchen Chöki Gyeltsen Pelzangpo (rin chen chos kyi rgyal mtshan dpal bzang po, 1449-1484) $)^{426}$, studied under the erroneous teacher $\left(\log p^{\prime}{ }^{\prime} i\right.$ slob dpon) who had been so influential during the time of the 13th abbot. (According to Rasé Dawa, he was also influenced by some better teachers, and had the wish to revive the Practice Tradition, but was unable to do so. Rasé Dawa also adds that during this time many Drikung monasteries and mountain retreat centers in Amdo, Kham, Ü, Tsang and western Tibet were converted to the Sakya and Geluk sects; it was a period of great decline for the Drikung. ${ }^{427}$ )

Some years later this unfortunate trajectory was finally reversed by the 16th hierarch, named Rinchen Chögyel (rin chen chos kyi rgyal po; 1448-1504 428 ), who was born just a few years before the Madmen of Ü and Tsang. He was adamantly dedicated to revitalizing the Teachings of the Kagyü. At the age of 13 he is said to have fixated on practicing the teachings of the Practice Tradition and subsequently had a lot of exposure

\footnotetext{
${ }^{424}$ History of the Drikung Kagyü, p 152.

${ }^{425}$ Rasé Dawa, p 402.

${ }^{426}$ According to Rasé Dawa, this is the 15th abbot. See also Sørensen and Hazod, p 725.

${ }^{427}$ Rasé Dawa, pp 407-8.

${ }^{428}$ According to Rasé Dawa, this is the 16th abbot; his life is told on pp 411-5. According to The History of the Drikung Kagyü, he was not actually an abbot, pp 157-162. According to Sørensen and Hazod, he was the 14th abbot, pp 725-6.
} 
to the Highest Yoga Tantras in his early education. It is said that at the age of twenty he set about working to undo the negative trajectory that had started during the time of the 11th abbot, Döndrup Gyelpo. Rinchen Namgyel recognized that the life-force of the Kagyü was in its essential teachings and sent messengers all over looking for an accomplished teacher. From Taklungpa Ngawang Drakpa he received the Fivefold Mahāmudra (phyag rgya chen po lnga ldan), the Six Dharmas of Nāropa, as well as other teachings associated with the Drikung Kagyü and the Dakpo Kagyü. He returned to Drikung and took two consorts, with whom he practiced the "secret activity of secret engaged asceticism" (sbas pa'i brtul zhugs kyi gsang spyod thugs nyams su bzhes). He thus began the work of revitalizing the essential teaching of the Kagyü. ${ }^{429}$

Rasé Dawa is more explicit about what this revitalization entailed. In his telling of these events, during Rinchen Chögyel's time some Drikungpas studied under a teacher of didactic philosophy (mtshan nyid pa). Some of them developed false views and became arrogant as logicians, and even went so far as to poison Rinchen Chögyel. Rinchen Chögyel survived, however, which was taken as a sign of his accomplishments (sgrub rtags). His work of revitalizing the essential teachings (snying po'i bstan pa) succeeded. Among other things, he revitalized the traditions of the summer and winter dharma sessions (dbyar chos dgun chos). ${ }^{430}$ Not long after, the Drikungpas are shown having more than a hundred renunciants performing the wet-cloth offering inside a tent during a winter dharma session at which the Six Dharmas of Nāropa was taught—a clear

\footnotetext{
${ }^{429}$ History of the Drikung Kagyü, pp 157-62. See also Sørensen and Hazod, pp 725-6.

${ }^{430}$ Rasé Dawa, pp 411-5. In Rasé Dawa's version, he practiced the "secret activity of secret engaged asceticism" with his two consorts before receiving this great cache of teachings.
} 
sign that they had once again embraced the distinctive teachings and practices of the Kagyü. ${ }^{431}$

By tracing this trajectory over the careers of a few of the abbots of Drikung Til Monastery, we get a sense of the kind of crisis they are perceived to have faced in the 15 th and early 16th centuries. Changes were taking place within their tradition, with their being drawn away from their original emphases, including certain Highest Yoga Tantra practices. According to Rasé Dawa, these changes can in large part be attributed to changes forced upon the religious culture of Tibet by the rapid spread of the Geluk sect. Ultimately what saved the Drikung Dharma was one abbot who was adamant about reviving the Practice Tradition that had fallen into neglect. It is clear that this Practice Tradition represented the opposite of the scholastic ways represented by the logicians, who are ultimately seen as accountable for the unfortunate changes that had been taking place. The identity of the "yogi who was known as a Heruka" whose student had arrived some years earlier and tried to set the situation aright by reemphasizing the teachings of the Practice Tradition is a tantalizing possibility about which we can only speculate. It was too early to have been either the Madman of Ü or the Madman of Tsang, but suggests there may have been others taking on a similar tantric fundamentalist lifestyle a few decades before them.

This detour into the history of the Drikung Kagyü has shown that the emphasis on the Practice Tradition was not unique to the Madmen of Ü and Tsang during the period

${ }^{431}$ Rasé Dawa, p 417. 
in which they lived. There were certainly many others who felt this same concern. ${ }^{432}$ Talking about a return to or a revitalization of the Practice Tradition was one way to emphasize certain aspects of Kagyü religious culture that distinguished them from other groups, including the trend epitomized by the rise of the Geluk, which is the subject of the next section.

We now have a better idea of what it was the 15 th-century holy madmen endeavored to make themselves represent, and where this would have positioned them in the religious marketplace. As we will see in the following section, by the late 15 th century the Geluk sect had become a powerful force in the religious culture of Tibet. When Sangyé Gyeltsen and Künga Zangpo made the decision to take on their very demonstrative tantric fundamentalist lifestyle and dedicate themselves to the promotion of the Practice Tradition, it can be seen as an attempt to represent the very opposite of the ideals from which the Gelukpas drew their charisma. The Madmen of $\ddot{U}$ and Tsang sought to establish themselves at the opposite end of the spectrum from the Gelukpas within the competitive religious marketplace. On one level this might be seen as the result of a disagreement, differing intellectual notions about the nature of Buddhism and its proper practice. But as we consider this disagreement in light of the historical situation in which it played out, we will see that the decision made by Künga Zangpo and Sangyé Gyeltsen to make themselves tantric fundamentalists (which made them the foils of scholar-monkhood most fully epitomized by the Gelukpas) was not simply a matter of

${ }^{432}$ For example, see The Scholar's Feast, in which a serious Kagyü ascetic living around this time is said to have been so dedicated to the upholding the Teachings of the practice tradition, which he protected "as if they were his very eyes" ( $\mathrm{p} 588,2006$ version). There is another person said to have been dedicated to the practice tradition on $\mathrm{p} 589$. 
theoretical disagreement. Rather, this decision represents a creative response to a very real historical situation, which involved not just a difference of opinions, but economic, political, sectarian and personal issues as well.

\section{III. Tantric Fundamentalism: A Creative Response to 15th-Century Circumstances}

The eighty year span in which the three most famous of Tibet's "holy madmen" lived, from 1452 to 1532 , was marked by a protracted struggle between two factions vying for political control over central Tibet. The rebel Rinpungpas, based in Tsang, were in ascendency while the Pakmodru regime based in Ü saw their position as rulers of Central Tibet slip away. The battle between these two factions was fought through political maneuverings, shifting alliances and military campaigns. Just as importantly, this battle was also fought in the cultural sphere, as the competition between these factions had direct ramifications for the Buddhist institutions and individuals they respectively supported. A consideration of the events and the key players of this period will add much to our understanding of the nature of the distinctive behavior of the Madmen of $\ddot{U}$ and Tsang, including what may have prompted them to take on this eccentric lifestyle and what they may have been trying to gain by it.

\section{III.1 The Geluk-Pakmodru Partnership}

The political regime in control of central Tibet at the beginning of the 15 th century was that of the Pakmodrupas, who had risen to power thanks to a willful monk, Changchub Gyeltsen (1302-1364), who headed a rebellion against the Sakya regime 
(which had been supported by the Mongolian Yüan dynasty). ${ }^{433}$ From his position as governor (literally, myriarch, khri dpon) of the Nedong (sne gdong or Neudong, sne'u gdong) district, Changchub Gyeltsen rose to power in the 1350s through forming strategic alliances and open fighting. In 1354 Changchub Gyeltsen received recognition of his status by being awarded the title of Tai Situ ("chief minister") from the Mongol emperor of China, Toghon Temür. The regime established by Changchub Gyeltsen was closely associated with the Lang (rlangs) clan. The seat of their secular power was at Nedong, near modern-day Tsetang (rtsed thang) in the district of Lhoka (lho kha). They also held the abbacy, generation after generation, of nearby Densa Til Monastery, the seat of the Pakmodru subsect of the Kagyü. Their regime was most often referred to by the name of the subsect of the Kagyü they were all but synonymous with: the Pakmodrupas. $^{434}$

After his rise to power Changchub Gyeltsen instituted a number of reforms in law and government. One overarching goal of his was to connect his rule with the mystique of Imperial Tibet and its enduring association with greatness. He undid changes that had been made under the Sakya-Yüan rule and adopted aspects of Songtsen Gampo's law code and a bureaucratic structure that imitated those of the old empire. He also held New Year ceremonies that were modeled on the ceremonies of the early kings. During this celebration high officials wore costumes and performed rituals that were meant to mimic

\footnotetext{
${ }^{433}$ Changchub Gyeltsen's rise to power and the formation of the Pakmodru Regime has been descrbed in Tsepon W. D. Shakabpa, Tibet: A Political History (New Haven, Conn.: Yale Üniversity Press, 1967), pp 73-82; and in Matthew Kapstein, The Tibetans (Malden, MA; Oxford: Blackwell Publishing, 2006), pp 116-8. This latter account is largely based on the former.

${ }^{434}$ On the Pakmodrupas see Olaf Czaja, Medieval Rule in Tibet: The Rlangs Clan and the Political and Religious History of the Ruling house of Phag mo gru pa (Ph.D. dissertation, Üniversity of Leipzig, Wein, 2009). I have not yet had the opportunity to read this work.
} 
the dress and activities of the early Tibetan kings. ${ }^{435}$ The early rule of the Pakmodrupas is remembered by Tibetans as a golden age of peace and prosperity. ${ }^{436}$ The secular ruler would use the title gongma (gong ma), meaning "superior one." ${ }^{437}$ The gongmas would remain the titular rulers of Tibet until the establishment of the Depa Tsangpa in Shigatsé in the 1560 s, although as we will see below, by the 1430 s their authority was being severely undercut by their former vassals, the Rinpungpa family. The struggle between the Pakmodrupas and the Rinpungpas would go on for nearly a hundred years.

At the height of their power the Pakmodru regime was instrumental to the establishment of the Buddhist sect that would in time come to be known as the Geluk. ${ }^{438}$ The brilliant monk whose example and writings were the cornerstone of this tradition, Tsongkhapa Lozang Drakpa (1357-1419), came to central Tibet from Amdo in 1372. He studied the Kadam, Sakya, Kagyü, Zhalu and Jonang systems under some of the most learned masters of the time. ${ }^{439}$ Personally, Tsongkhapa's foremost allegiance was to the older Kadam tradition and as his own system started to take root it was often called the "New Kadam" ( $b k a$ ' dam gsar ma). Tsongkhapa was committed to a vision of Buddhist practice based on the gradualist path of the bodhisattva as well as the study of the finer

${ }^{435}$ Georges Dreyfus, "Cherished Memories, Cherished Communities: Proto-nationalism in Tibet," pp $492-$ 522, in McKay, Alex, ed., The History of Tibet: Volume II, The Medieval Period: c.850-1895, The Development of Buddhist Paramountcy (New York: RoutledgeCurzon, 2003), p 504.

${ }^{436}$ It is often called "the time when an old woman could carry a load of gold" (rgan mo gser khur gyi dus) from one place to the next without fear of being robbed.

${ }^{437}$ They are often referred to as lha btsun meaning "divine lord," Dreyfus, p 504; Turrell Wylie, "Monastic Patronage in 15th-century Tibet," in Acta Orientalia Academiae Scientiarum Hung., XXXIV (103) (1980) ( pp 319-28), p 319. Those who achieved official recognition from the Chinese emperor was referred to as dbang; in some modern accounts published in China (such as deb ther kun gsal me long, by phun tshogs tshe ring, bod ljongs mi dmangs dpe skrun khang, 1987), this is rendered in Tibetan as wang, highlighting that this was in fact a title given to these Tibetan rulers by the Chinese.

${ }^{438}$ Kapstein, p 119, calls the rise of the Gandenpa, "the most important" development in Tibetan religious culture during the 15th century. On the partnership between the Pakmodru and the Geluk, see hor gtsang 'jigs med, mdo smad lo rgyus chen mo las lo rgyus spyi'i gzhung shing gi skor (Vol. 1 of six) (Dharamsala: LTWA, 2009), pp 508-9. Hereafter this text will be referred to as Hortsang Jikmé.

${ }^{439}$ For an excellent history of the life and studies of Tsongkhapa, see Hortsang Jikmé, pp 468-73. 
points of Madhyamaka philosophy. He also took great pains to revive the practice of the monastic code, the Vinaya, which had fallen to the wayside over the preceding few centuries, with many fully-ordained monks still drinking alcohol and coupling with women. ${ }^{440}$ (The efforts of Tsongkhapa and the Geluk sect's rise to superiority in the Tibetan Buddhist world can be credited with the high behavioral expectations that are applied to Tibetan monks today. Tsongkhapa's model of monasticism has become so prevalent that we often forget that this was not always the norm in Tibetan Buddhist monastic culture.) Matthew Kapstein describes how "by drawing on earlier tradition, Tsongkhapa formulated a novel synthesis of the Indian Buddhist legacy, strongly emphasizing careful textual study and the demands of logic, as well as close adherence to the ethical precepts governing the life of a Buddhist monk." ${ }^{441}$ Tsongkhapa sought to revive what he considered an orthodox version of Buddhism. This included what Kapstein characterizes as a "markedly scholastic approach to tantrism."

The Pakmodru regime took a particular shining to the young monk and played a very active role in helping foster the spread of his sect. ${ }^{443}$ The New Red Annals, written

\footnotetext{
${ }^{440}$ Giuseppe Tucci, Tibetan Painted Scrolls, Volume I (Roma, La Libreria della Stato, 1949), pp 42-3. This is described vividly in the deb ther kun gsal me long, pp 230-1.

${ }^{441}$ Kapstein, p 120. On the nature of Tsongkhapa's system, see Elizabeth Napper, "Ethics as the Basis of a Tantric Tradition: Tsong kha pa and the Founding of the dGe lugs order in Tibet," pp 107-31 in Changing Minds: Contributions to the Study of Buddhism and Tibet in Honor of Jeffrey Hopkins, edited by Guy Newland (Ithaca: Snow Lion Publications, 2001); Rachel M. McCleary and Leonard W. J. van der Kuijp, "The Market Approach to the Rise of the Geluk School, 1419-1642," pp 149-80 in The Journal of Asian Studies (Vol. 60, Number 1, February 2010), p 162; Hortsang Jikmé, pp 473-9; Samuel, pp 506-12.

${ }^{442}$ Kapstein, $\mathrm{p} 120$. As Donald Lopez sees it, there is a "concern to uphold the validity of the conventional - understood primarily as the cause and effect of actions - in the face of the ultimate emptiness of all phenomena that seems to motivate much of Tsong kha pa's work. It is a concern with strong ethical implications, serving as a check against the antinomianism that the doctrine of emptiness might inspire...," The Madman's Middle Way: Reflections on Reality of the Tibetan Monk Gedun Chopel (Chicago: University of Chicago Press, 2006), p 245. It was this form of sanity that Gedün Chöpel struggled against, and in the process became a "madman" (smyon pa) in the eyes of some (see Chapter 7). ${ }^{443}$ In the words of Snellgrove and Richardson, the Pakmodrupas "gave a friendly welcome to the teachings of Tsong-kha-pa and his disciples," p 181.
} 
by Peṇchen Sönam Drakpa in 1538, records how a lord of the Gongkar district (gong

dkar) arranged the printing of the works of Tsongkhapa "as gongma Drakpa Gyeltsen had instructed." ${ }^{444}$ We will also see later how members of other sects, like the Sakyapa Śākya Chokden, were forced by the Pakmodru government to study Geluk materials.

But perhaps even more important to the rise of the Geluk was the Pakmodru government's financial support. Official patronage from the Pakmodrupas began in earnest in 1409 when Tsongkhapa instituted the annual Great Prayer Festival (smon lam chen mo) in Lhasa. ${ }^{445}$ Drakpa Gyeltsen (d. 1432), the gongma (secular head of the Pakmodru regime and nominally the ruler of central Tibet) served as a patron for this undertaking $^{446}$ along with Namka Zangpo, the local administrator (rdzong dpon) of Neudzong (sne'u rdzong). ${ }^{447}$ His headquarters were next to the Kyichu River, near Lhasa, with that town falling under his domain. Namka Zangpo had been appointed to the position of local administrator by the Pakmodru gongma Drakpa Gyeltsen. ${ }^{448}$ Later

\footnotetext{
${ }^{444}$ gong ma grags pa rgyal mtshan pa 'i gsung bzhin..., Giuseppe Tucci, trans., [The New Red Annals:] Deb Ther Dmar Po Gsar Ma: Tibetan Chronicles, Volume I (Serie Orientale Roma XXIV. Roma, ISMEO, 1971). The English translation is on $\mathrm{p} 237$.

${ }^{445}$ McCleary and van der Kuijp, p 160, say that this may not have been altogether new: the Kadampas and perhaps other religious hierarchs also held a festival known by the same name in the 15 th century. The question of the relationship between Tsongkhapa's Great Prayer Festival, earlier great prayer festivals performed by other religious groups, and the New Year's festivities put on by the Pakmodru government is a topic deserving of further research.

Regarding prayer festivals distinct from the one in Lhasa, we know that the 7th Karmapa held an annual prayer festival (smon lam) in his big roving encampment just after the new year. See The Scholar's Feast, 2006 version, pp 558, 559, 562, 563, 566, 580, etc.

On the founding of the Great Prayer Festival and Ganden, Drepung and Sera monasteries, see Shakabpa, p 85.

${ }^{446}$ dung dkar tshig mdzod chen mo, p 1524.

${ }^{447}$ Namka Zangpo of Neudzong's great reverence for Tsongkhpa and the Geluk system, as well as his patronage of Drepung Monastery and the Great Prayer Festival in Lhasa, are mentioned in The New Red Annals, Tucci translation, pp 240-1. deb ther kun gsal me long gives a fuller description, pp 227-9. On the support from Lhasa-area Pakmodru administrators, such as the sne'u pa, the brag dkar ba (brag khar ba), and so on, see Sørensen and Hazod, pp 49-51.

${ }^{448}$ Wylie, "Monastic Patronage in 15th-century Tibet," pp 319-20; McCleary and van der Kuijp, p 160; Kapstein, p 120; The New Red Annals, pp 240-1.
} 
that same year Tsongkhapa founded what would become the seat of the Geluk sect, Ganden Monastery, approximately 35 miles from Lhasa. The primary patron for this was Drakarwa Rinchen Pel (brag dkar ba rin chen dpal), who was the local administrator (rdzong dpon) of the Olka Taktsé district ('ol kha stag rtse) where the monastery was located. ${ }^{449}$ Gongma Drakpa Gyeltsen also patronized this project. ${ }^{450}$ Ganden quickly grew into an important center of religious activity, with five hundred monks in residence there within the first year. ${ }^{451}$

This same basic pattern would hold over the next few decades for the founding of what would become the most important institutions for the Geluk sect in central Tibet. Drepung Monastery, just outside of Lhasa — which would go on to become the largest monastery in Tibet—-was founded in 1416 by a disciple of Tsongkhapa's, thanks to patronage from Namka Zangpo, the local administrator who had also helped establish the Great Prayer Festival. ${ }^{452}$ In 1418 the Pelkor Chödé monastic complex (dpal khor chos sde) was founded in Gyantsé (then known as Gyelkartsé, rgyal mkhar rtse), a large town in Tsang, by another close disciple of Tsongkhapa's. The primary patron for this was the local ruler of Gyantsé, Rabten Künzang Pakpa (rab brtan kun bzang 'phags pa), who had

\footnotetext{
${ }^{449}$ On the founding of Ganden Monastery, with varying accounts of which patrons were involved, see The Song of the Queen of Spring by the 5th Dalai Lama, translated in Tibetan Painted Scrolls, Vol. II, p 645; deb ther kun gsal me long, p 229-30; bod kyi chos srid zung 'brel skor bshad pa, by dung dkar blo bzang 'phrin las (Dharamsala: Library of Tibetan Works and Archives, 1982), p 79; Wylie, "Monastic Patronage in 15th-century Tibet," pp 320-1; McCleary and van der Kuijp, p 160-1; Kapstein, p 120; Iha sa'i dgon tho rin chen spungs rgyan, by bshes gnyen tshul khrims (Lhasa: bod ljongs mi dmangs dpe skrun khang, 2001), pp 38-40.

${ }_{450}$ dung dkar tshig mdzod chen mo, p 1524. On the families of Neudzong and the Drakarwas, see Per K. Sørensen, "Lhasa Diluvium: Sacred Environment at Stake: The Birth of Flood Control Politics, the Question of Natural Disaster Management and their Importance for the Hegemony over a National Monument in Tibet," pp 85-134 in Lungta (16) Spring 2003, "Cosmogony and the Origins," pp 112-3. ${ }^{451}$ lha sa'i dgon tho rin chen spungs rgyan, $\mathrm{p} 40$.

${ }^{452}$ The New Red Annals, Tucci's translation, pp 240-1; Wylie, "Monastic Patronage in 15th-century Tibet," p 321; McCleary and van der Kuijp, p 161; lha sa'i dgon tho rin chen spungs rgyan, pp 47-51; Dungkar Rinpoché, chos srid zung 'brel, p 79-80.
} 
served as chamberlain (gzims dpon) under gongma Drakpa Gyeltsen and seemed to still hold some official position in the Pakmodru administration. ${ }^{453}$ (The Pelkor Chödé would be a somewhat diverse institution, containing within it schools for the study of the Geluk, Sakya, Kālacakra and other systems. This was where Sangyé Gyeltsen was studying and living as a monk before leaving to become renowned as the Madman of Tsang.)

In 1419 another disciple of Tsongkhapa, Jamchen Chöjé Śākya Yeshé (byams chen chos rje shAkya ye shes) founded Sera Monastery, which was, like Drepung, just outside the town of Lhasa. The available records are not clear on who the primary patrons for the founding of this monastery were, although it is likely that the sponsor was the local administrator from Neudzong, Namka Zangpo, probably further supported by riches Jamchen Chöjé had received during his visit to the Ming emperor in Beijing, having been sent there in lieu of his guru. ${ }^{454}$

There are a few important observations to be made about the establishment of these monastic institutions. First, we see the key role played by officials of the Pakmodru government as financial backers for these monasteries. In the cases of Ganden, Drepung, Sera and Pelkor Chödé, the primary patrons were all closely associated with the Pakmodru government - either its direct representative in the form of a local

\footnotetext{
${ }^{453}$ Rabten Künzang Pakpa is mentioned in The New Red Annals, p 190, as a patron of Kedrup Jé and for the building of the Pelkor Chödé. See also The Song of the Queen of Spring, Nordrang Orgyen's commentary, dpyid kyi rgyal mo'i glu dbyangs kyi 'grel pa yid kyi dga' ston (Beijing: mi rigs dpe skrun khang, 1993), p 434; Tibetan Painted Scrolls, Vol. II, p 646; Shakabpa, p 83. Rabten Künzang Pakpa is mentioned in The Annals of Gyantsé as having expanded the monastic complex in 1440, TPS, Vol. II, p $665-8$; in this source Künzang Pakpa is not mentioned as the primary patron of the Pelkor Chödé, but is responsible for its being greatly expanded and improved in 1440. There is a biography covering the first part of Künzang Pak's life, written in 1421. rab brtan kun bzang 'phags kyi rnam thar (rgyal rtse chos rgyal gyi rnam par thar pa dad pa'i lo thog dngos grub kyi char 'bebs), by 'jig med grags pa (bo dong paN chen phyogs las rnam rgyal) (bod ljongs mi dmangs dpe skrun khang, 1987).

${ }^{454}$ Wylie, "Monastic Patronage in 15th-century Tibet," pp 321-2; McCleary and van der Kuijp, p 161; dgon tho rin chen spungs rgyan, pp 52-7; Dungkar Rinpoché, chos srid zung 'brel, p 80.
} 
administrator or even the gongma himself. ${ }^{455}$ Second, we see how, by building what would come to be three enormous monasteries all in close proximity to the town, the Gelukpas made Lhasa the central hub of their sect, which would remain the case all the way into modern times. ${ }^{456}$ We must also note that in the cases of Ganden, Drepung, Sera and probably Pelkor Chödé monasteries, they were built within the area controlled by the primary patron. Lastly, all of these monasteries were founded so that a master could have a seat of his own; none of the masters for whom these monasteries were built had had a monastery of his own beforehand. ${ }^{457}$ These last two points will contribute to an important comparison to be made below.

It is telling of the dynamics of Tibetan politics and religion that the Pakmodru regime, who themselves had long been the very core of the Pakmodru branch of the Kagyü, would become the foremost patrons of Tsongkhapa and his disciples. Rather than seeing seeing Tsongkhapa as one determined to start a distinct new sect, the Pakmodrupas most likely perceived him as monk from the Sakya sect with an affection for the Kadampa tradition and some new ideas about what Buddhist monasticism should be. $^{458}$ The model of Buddhist life Tsongkhapa espoused was dedicated to formalized clerical education, conventional Mahāyāna morality and the monastic code. As many

\footnotetext{
${ }^{455}$ Tucci, The New Red Annals, p 227, mentions Namka Zangpo of Neudzong, Rinchen Pel of Drakar (of Olka Taktsé), and Rabten Künzang Pakpa of Gyantsé as among the "principal ministers" (blon chen) of gongma Drakpa Gyeltsen. Later in the same text it is mentioned that at a time when the chiefs of other districts in Ü had turned against the gongma Künga Lekpa in the midst of some conflict, the chiefs of Neudzong and Olka remained on the gongma's side. They thus seem to have been highly loyal to the Pakmodru regime. They were also connected through intermarriage (Sørensen, "Lhasa Diluvium," p 112). On the importance of the gongma Drakpa Gyeltsen, the governors of Neudzong and the Drakarwas, see Sørensen, p 113, where he calls them "zestful and liberal patrons" of the Geluk.

${ }^{456}$ Sørensen, "Lhasa Diluvium," p 113, comments on the significance of the early rise of the Gelukpa in Lhasa.

${ }^{457}$ Wylie, "Monastic Patronage in 15th-century Tibet," p 324.

${ }^{458}$ McCleary and van der Kuijp, p 162.
} 
scholars have observed, Tsongkhapa's system was a natural fit for the ruling

Pakmodrupas, who were interested to promote the rule of law based on Buddhist

morality. ${ }^{459}$ As Kapstein states, "The emphasis in Tsongkhapa's teaching on strict

adherence to monastic regulations and to the ethical guidelines of the Mahayana

comported well with [the Pakmodrupas'] desire to reinforce clerical and public mores. In

short, Tsongkhapa was a living exemplar of the very values the Pakmodrupa regime

sought to uphold." 460

There were less ideological aspects of Tsongkhapa's burgeoning tradition that were attractive to the Pakmodrupas. For one, the annual Great Prayer Festival, which brought Tibetans from all over central Tibet to Lhasa for a shared experience of ritual, teachings and celebration, would have been an effective vehicle for the Pakmodru administration to make an annual symbolic reassertion of its hegemony. ${ }^{461}$ We are short on details, but the Great Prayer Festival initiated by Tsongkhapa may have been combined with the New Year rituals initiated by the first Pakmodru lord Changchub Gyeltsen — which were an important vehicle for the articulation of his hegemony- to make an even grander affair. The Great Prayer Festival was closely related to the yearround administration of the Jokang temple housing the Jowo Śākyamuni statue, of great symbolic importance and at the very heart of Lhasa. ${ }^{462}$

\footnotetext{
${ }^{459}$ Kapstein, p 120-1. Snellgrove, p 479. See TPS, Vol. I, pp 85-6; Stein, Tibetan Civilization, pp 80-1; Samuel, Civilized Shamans, p 511.

${ }_{460}$ Kapstein, p 121.

${ }^{461}$ In Kapstein's words, the festival "was so contrived as to disclose and to reinscribe in awareness the perennial order governing the Tibetan world," p 121. I am suggesting that the annual Great Prayer Festival functioned in a manner similar to the tsa ri rong skor pilgrimage and its attendant rituals, described by Toni Huber in his article "Ritual and Politics in the Eastern Himalaya: The Staging of Precessions at Tsa-ri," pp 221-60 in Les Habitants de Toit Du Monde: Études Recueillies en Hommage à Alexander W. MacDonald, edited by Samten Karmay and Phillipe Sagant (Nanterre: Société d'ethnologie, 1997).

462 This is suggested in Sørensen's article, "Lhasa Diluvium," pp 113-4.
} 
In the same vein, the monastic tradition initiated by Tsongkhapa and his disciples offered the Pakmodru administration an unparalleled opportunity to increase the range of its symbolic presence across Tibet. Tsongkhapa's religious system was institutional by nature. Its cornerstone was formalized education based on a relatively standardized curriculum based on the writings of Tsongkhapa and his close disciples. And its unwavering commitment to Vinaya-based monasticism ensured a large degree of homogeneity across all of its institutions. This made the soon-to-be Geluk sect markedly different from the other sects operating in 15 th-century Tibet. It was less dependent on the charisma of a certain place or individual (living or dead) and bore no special longstanding relationship with any one noble family. In comparison to the Kagyü, which was fragmented into many subsects and separate lineages, Tsongkhapa's system offered the possibility of a much more unified religious tradition. For these reasons the system initiated by Tsongkhapa presented an unparalleled growth opportunity and seemed to the Pakmodru administration an ideal means through which to increase their symbolic presence in central Tibet and beyond.

And grow is precisely what the soon-to-be Geluk sect did. In Lhasa itself the institutes for the study of tantra Gyümé and Gyütö were founded in 1433 and 1474 respectively ${ }^{463}$; the Tsé Namgyel Tratsang (rtse rnam rgyal grwa tshang) was founded in Lhasa in 1468 by the Third Dalai Lama. ${ }^{464}$ There was also the Nelchung Ritrö (nel chung

\footnotetext{
463 dgon tho rin chen spungs rgyan, pp 59, 61.

464 dgon tho rin chen spungs rgyan, $\mathrm{p} 60$.
} 
ri khrod), a nunnery near Lhasa, founded sometime around the 15 th century by Rabjam Chöjé (ram 'byams chos rje). ${ }^{465}$

In the nearby district of Taktsé, where Ganden Monastery is located, there were at least six Geluk monasteries founded in the 15 th century or soon thereafter ${ }^{466}$, as well as two nunneries ${ }^{467}$, not counting Lepu Monastery (lhas phu dgon), a Kadampa monastery in Taktsé that Tsongkhapa himself converted to his system. ${ }^{468}$ In the nearby district of Medro Gungkar (mal gro gung dkar) there was at least two new Geluk monasteries ${ }^{469}$, as well a number of monasteries of other traditions that were converted to the Geluk in the 15th century. Examples of this include Tangkya Monastery (thang skya dgon), which was converted to Geluk from the Jonang system in $1460^{470}$, and at least four monasteries converted to Geluk from the Kadam tradition around this time. ${ }^{471}$

In Penbo district, there was perhaps only one new Geluk monastery founded in the 15 th century ${ }^{472}$ but at least six monasteries that were converted to the Geluk, most of them formerly Kadampa, as was the case with Reting Monastery (rwa sgreng dgon),

\footnotetext{
${ }^{465}$ dgon tho rin chen spungs rgyan, pp 62-3.

${ }^{466}$ There was Dechen Sangngak Kar (bde chen gsang sngags mkhar) in 1419, founded by Tsongkhapa, dgon tho rin chen spungs rgyan, pp 120-1, TBRC G2362; Nyiding Monastery (nyi sding dgon) founded in 1460, pp 121-2, TBRC G3043; Demo Tang Monastery (bde mo thang dgon) founded in 1460, p 122, TBRC G3461; Lomda Pakmo Monastery (lo mda' phag mo dgon) sometime in the 15th century, p 123, TBRC G3460; Chumda Gyükang (chums mda' rgyud khang) in the 15th century, p 123; Batsak Monastery ( ' $b a$ ' tshags dgon), founded in the 15th century, p 125.

${ }^{467}$ Langra Gönsar Nunnery (glang ra dgon gsar), dgon tho rin chen spungs rgyan, $\mathrm{p} 124$; Tsünmo Tsel Nunnery (btsun mo tsal dgon), founded in 1420, p 121, TBRC G330.

${ }^{468}$ dgon tho rin chen spungs rgyan, $\mathrm{p} 124$

${ }^{469}$ New Geluk monasteries in Medro Gungkar: Rinchen Ling Monastery (rin chen gling dgon), dgon tho rin chen spungs rgyan, pp 160-1; Öna Chödé ('od sna chos sde), pp 165-6.

${ }^{470}$ In Medro Gungkar, dgon tho rin chen spungs rgyan, $\mathrm{p} 138$.

${ }^{471}$ Jayül Mangra Monastery (bya yul mang rwa dgon), no specific date is given, although it is safe to assume that the monastery's conversion from Kadam to Geluk took place in the 15th century or shortly thereafter, dgon tho rin chen spungs rgyan, pp 140-1; Nönkyi Dumburi (snon gyi dum bu ri), was also converted from Kadam, with no date given, p 139; Ütö Takpu Chödé (dbus stod stag phu chos sde), p 139; and Cheka Monastery ( 'chad kha dgon), p 163.

${ }^{472}$ Serkang Monastery (ser khang dgon), dgon tho rin chen spungs rgyan, $\mathrm{p} 207$.
} 
which was converted to the Geluk after Tsongkhapa spent some time there. ${ }^{473}$ There

were also at least three nunneries in Penbo converted to the Geluk around this time. ${ }^{474}$ In

Tölung there were at least two new Geluk monasteries, including Tölung Chuzang

Monastery (stod lung chu bzang dgon), which was founded by one of Tsongkhapa's

disciples. ${ }^{475}$ Another of Tsongkhapa's students founded two monasteries in Chushur (chu

shur) in the 15th century: Nyima Tang Monastery (nyi ma thang) and Beser (sbe ser). ${ }^{476}$

In even so brief a survey as this we can count at least thirty-seven Geluk

institutions in the Lhasa area by the early 16 th century, about a hundred years since the

birth of the Geluk sect with the founding of Ganden monastery. This only accounts for

new Geluk institutions in a few districts, perhaps no more than 50 miles from the town of

Lhasa. The Geluk was also actively spreading in Tsang, with Tashi Lhünpo Monastery

founded in Shigatsé in $1447 .^{477}$ The Gelukpas were also founding monasteries in other

places in Ü, Tsang, Kham (such as Chamdo Jampa Ling, chab mdo byams pa gling),

${ }^{473}$ dgon tho rin chen spungs rgyan, pp 185-6. The other five are: Penpo Gyel Lhakang ('phan po rgyal lha khang), p 183; Rakma Jamkang (rag ma byams khang), pp 183-4; Tré Rinchen Drak (spras rin chen brag), p 189; Chöding Monastery (chos sdings gdon), pp 190-1; Ganden Chökor Monastery (dga' ldan chos 'khor dgon), $\mathrm{p} 203$.

${ }_{474}$ Drongteng Monastery ( 'brong steng dgon), dgon tho rin chen spungs rgyan, p 189; Poto Monastery (po to dgon), p 190; Penpo Shawa Bumpa ('phan pos ha ba 'bum pa), pp 200-3.

475 dgon tho rin chen spungs rgyan, $\mathrm{p} 288$; there was also Mang Tashi Chöding (rmang bkra shis chos sding), p 288-9.

476 dgon tho rin chen spungs rgyan, pp 303, 304.

${ }^{477}$ Founded (btab) by Gedün Drubpa (dge 'dun grub pa) in 1447 (re'u mig, p 48; TZCM, p 3248). According to The New Red Annals, at this time the dharmalord of Ngor approached Rinpungpa Norbu Zangpo and requested that he prevent the building of the monastery and convert the area's existing Geluk monasteries to Sakya. Norbu Zangpo said that doing so would be inappropriate (Tucci translation, pp 23940).

However, in The Song of the Queen of Spring (TPS, Vol. II, p 642; Nordrang, $\mathrm{p} 405$ ) the 5th Dalai Lama states that this story has no basis, maintaining that at the time Tashi Lhünpo was built, Peljor Zangpo of Chonggyé (dpal 'byor bzang po, 'phyongs rgyas) was the local administrator (rdzong dpon) of Shigatsé. He cites another historical work in support of his position which he holds to be reliable. Whether or not the original story about the dharmalord of Ngor is true, it certainly does seem that the Rinpungpas would have been in control of Shigatsé in 1447 when the monastery was built, unless construction had started years earlier. Even if it had been started during the time when the lords of Chonggyé were in control of Shigatsé, much of its construction and its opening would have happened under the Rinpungpas' watch. For a discussion of this, see Wylie, "Monastic Patronage in 15th-century Tibet," in McKay, Vol. 2, pp 484-5. 
Amdo and even the distant Chinese capital of Beijing: the Huang-ssu or "Yellow Temple" was founded by Jamchen Chöjé (byams chen chos rje), one of Tsongkhapa's main disciples. ${ }^{478}$ Hortsang Jikmé has counted 58 monasteries founded or converted by Tsongkhapa and his direct disciples in $\ddot{U}$, Tsang and far western Tibet; 26 by Tsongkhapa's direct disciples in Kham; and three in Amdo, although there are certainly many more. ${ }^{479}$ This only includes monasteries founded or converted by Tsongkhapa and his direct disciples. If we were to include monasteries founded or converted by Tsongkhapa's grand-disciples or other close associates, the number would be even greater. At the time of writing his Baidurya Serpo in the late 17th century, Desi Sangyé Gyatso counted 173 Geluk monasteries in Kham alone. ${ }^{480}$

From even so rough a list as this we get an idea of the fervor with which the Geluk sect spread. Within a hundred years of the founding of Ganden there were well more than a hundred Geluk monasteries and nunneries across Tibet. The Geluk sect had a truly remarkable period of growth, from its inception with a single monastery to occupying a huge part of the marketshare of the Tibetan Buddhist world. In the words of one Tibetan historian, "Thanks to those reasons [i.e., the profundity and originality of Tsongkhapa's teachings], although before that time the Nyingma, Sakya, Kagyü, Jonang [jo mo nang $b a]$ and $\mathrm{Bu}[$ tön] systems, along with other religious traditions and tenet systems, had pervaded the very ground and stones of Tibet, the system of this master

\footnotetext{
${ }^{478}$ On Chamdo Jampa Ling, see Hortsang Jikmé, p 492, TZCM, p 3248. On the Yellow Temple, see Shakabpa, p 84.

${ }_{479}^{4}$ Hortsang Jikmé, pp 483-94.

${ }^{480}$ Hortsang Jikmé, p 493. On the early spread of the Geluk, see Tucci, TPS, Vol. I, pp 39-40.
} 
[Tsongkhapa] came to pervade Amdo, Ü, Kham and even Mongolia [sog yul] like a wave of fire hitting a store of gasoline."

A major contributing factor to the rapid spread of the Geluk sect was its active missionary zeal. Tsongkhapa's students were encouraged to return to their native areas and found monasteries after having finished their educations in the Lhasa-are institutions. ${ }^{482}$ Because of this, the new monasteries of the Geluk were organized into a network. We can imagine the reach of the Geluk spreading like a web across Tibet. Smaller monasteries were considered "branch" (yan lag) institutions of the three seats in Lhasa. More capable monks would travel to regional centers and then to Lhasa for study. Because of the relatively standardized curriculum and uniform monastic regulations, there was a lot of continuity across these monasteries and exchange between them was relatively fluid, in comparison to the other sects that were inherently more fractured. ${ }^{483}$ The fact that these monasteries had within them regional houses, similar to dormitories, made exchange and unity much easier. ${ }^{484}$ The strongest concentration of the Geluk sect was in the area surrounding Lhasa, then literally radiating outward from there to cover all of Tibet.

\footnotetext{
${ }^{481}$ Hortsang Jikmé, pp 478-9. Hortsang Jikmé quotes the 8th Karmapa, Mikyö Dorjé (mi bskyod rdo rje) who in a verse of praise wondered at how in only a few years Tsongkhapa was able to establish a tradition that stretched from China in the east all the way to Kashmir in the west, p 497. Dungkar Rinpoché, chos srid zung 'brel, p 80, comments on how since the founding of the major Geluk monasteries early in the 15 th century their sect was very competitive with the Karma Kagyü and other Kagyü sects. Sørensen comments on the growing influence of Tsongkhapa's tradition in the Lhasa area and their project of "turning Lhasa into the spiritual center of the country," "Lhasa Diluvium," p 114.

${ }^{482}$ Dungkar Rinpoché, chos srid zung 'brel, p 79.

${ }^{483}$ Sørensen, "Lhasa Diluvium," p 113 writes about the Gelukpas' "strategic network of dependencies and colleges" and their "successful implementation of the grva skor programme..."

${ }^{484}$ Hortsang Jikmé, pp 501-2.
} 
Scholars like Hortsang Jikmé have suggested that improvements in publishing technology may have played a role in the rapid spread of the Geluk. ${ }^{485}$ During the time of Tsongkhapa the practice of printing by means of woodblocks became widespread, which greatly facilitated the spread of their text-based, standardized curriculum.

Lhasa was not the center of the Pakmodru government but was relatively close to their hub near modern day Tsetang. Lhasa and its surrounding districts were all ruled by ministers close to the Pakmodru gongma. There had been a general trend towards Lhasacentrism prior to the 15 th century, and the establishment of the Geluk helped further the process. This trajectory would take a huge step forward when the 5th Dalai Lama moved the seat of his government to the Potala palace. Part of what made it possible for the 5th Dalai Lama to take control of so much of Tibet is the fact that the Geluk monastic network was so effective. The Geluk monastic network provided the 5th Dalai Lama with a ready-made administrative network. Moreover, by positioning himself spatially at the hub of that network, the symbolic expression of his hegemony was made all the easier. (By comparison, the Karmapas also had control of Lhasa for some years, but were unable to exercise far-reaching hegemony on a remotely comparable scale.) At the time of the Pakmodrupas and the early spread of the Geluk, Lhasa was already well on its way to achieving this kind of importance as both the symbolic and the real center of the Tibetan cultural world. Per Sørensen and Guntram Hazod talk of Lhasa as the "geopolitical axis of orientation" for Tibetans. ${ }^{486}$

\footnotetext{
${ }^{485}$ Hortsang Jikmé, pp 500-1; Padmarāga (bod kyi lo rgyus spyi don pad+ma rA ga'i lde mig) by thub bstan phun tshogs (si khron mi rigs dpe skrun khang, 1996, 2 vols), Vol. II, pp 709-12.

${ }^{486}$ Sørensen and Hazod, p 20.
} 
The meteoric rise of the Geluk sect around Lhasa and beyond upset the balance of the Tibetan religious marketplace. The construction of so many monasteries and the upkeep of these legions of monks was possible only through a huge influx of resources, including currency, building materials, food and labor. In an economy like Tibet's in which there was always very little surplus, this rapid pooling of resources in the service of one sect would have had a palpable negative effect on the fortunes of the other sects. This would have been felt by the Kagyüpas, especially the Karmapas themselves, to whom the swift rise of this new sect was surely felt to be a threat. ${ }^{487}$ This is not to mention the sting that would have been felt when Kagyü monasteries were converted to Geluk during the latter sect's exponential growth; we know of at least six such cases in the districts surrounding Lhasa, but surely there were many more. ${ }^{488}$

We thus get the sense that the aggressive spread of the Geluk sect, radiating outward from Lhasa, had a profound effect on the dynamics of the Tibetan religious marketplace. The Kagyüpas felt this acutely. All of this created a tense, competitive environment. We will get a better idea of the intensity of the competition between the Kagyüpas and the Gelukpas_- which at times manifested itself as open antagonism and even violence - as we proceed further into this period of history. This conflict would

\footnotetext{
${ }^{487}$ Tucci states that the Geluk sect's “expansion and its rapid spiritual conquests aroused the rival sects' suspicions..." TPS, Vol. I, p 40.

488 dgon tho rin chen spungs rgyan, pp 28, 113,117, 154, 159, 161. Regarding the effect the rise of the Geluk had on the Kagyüpas, the modern historian Rasé Dawa Könchok Gyatso has stated that during the reign of the 14th abbot of Drikung Til Monastery (the years 1435-69), at many of the important seats of the Kagyü-Tsurpu, Drikung Til, Densa Til, Dakla Gampo, and so on - the "current of the dharma" (chos rgyun) was turning into that of the Geluk and the excellent dharma of the Kagyü was on the verge of dying out, 'bri gung chos 'byung (Beijing: mi rigs dpe skrun khang, 2003), p 402. Rasé Dawa again mentions this period of difficulty during the reign of the 15th abbot (lived 1449-84), saying that, in addition to the Kagyü dharma declining at Drikung Til itself, among the Drikung Kagyü monasteries and mountain retreats ( $r i$ khrod) in Kham, Amdo, Ü, Tsang, and far western Tibet, many were converted to the Geluk sect (and some to the Sakya), p 408. This theme is repeated, pp 411, 412-4.
} 
become inseparable from the political struggles that would define central Tibet during this period.

\section{III.2 The Rinpungpa Revolt and anti-Gelukpa Antagonism}

The Pakmodru gongma Drakpa Gyeltsen, who had played such an important role in supporting the Geluk movement at its moment of inception, died in 1432. The dispute over who would succeed him spelled the beginning of the end of the Pakmodru regime's political dominance in central Tibet. Their struggle against the Rinpungpa faction based in Tsang would drag on for the next hundred years. As we will see, this political struggle was played out through a cultural one in the domain of religion as well. ${ }^{489}$

The family that would come to be known as the Rinpungpas was of the Ger (sger) clan, which traced its history as civil administrators back to the time of earliest kings of Tibet. ${ }^{490}$ Around the turn of the 15th century, gongma Drakpa Gyeltsen appointed one of

\footnotetext{
${ }^{489}$ For a brief overview of the events and conflicts to be described below, see Komarovski, pp 46-9. See also TPS, Vol. I, pp 27-31, 39-41. Komarovski and Tucci both characterize the relationship between the religious struggle and the political struggle in a way very similar to the way I do.

${ }^{490}$ See Nordrang Orgyen's commentary on The Song of the Queen of Spring, p 402; and Tucci's translation in TPS, Vol. II, p 641; Yarlung Ambum (yar lung pa a 'bum), dpal ldan rin chen spungs pa sger gyi gdung rabs che long tsam zhig, pp 125-34 in bod kyi rgyal rabs phyogs bsdebs kyi nang gses (Dharamsala: Library of Tibetan Works and Archives, 1985; title on coverboard reads mi rje 'ba' nyag a thing mchog nas phyogs bsdus gces gsog gnang ba'i bod dpe'i khongs rim pa bdun pa'o: sngon gyi gtam me tog gi phreng $b a), \mathrm{p} 125$.

Unfortunately our historical sources on the Rinpungpas are very limited. Our primary historical sources are Penchen Sönam Drakpa's The New Red Annals (written 1538) and the 5th Dalai Lama's Song of the Queen of Spring (written 1643). There is a history of the Rinpungpas by Yarlung Ambum (no date; perhaps written in the 20th century?). It is in large part drawn from The Song of the Queen of Spring, but adds more details and dates, some of which are derived from The Scholar's Feast. There were two copies of this text available to me at the time of my research: that published by the LTWA, and a scan of a handwritten manuscript made available by TBRC. Unfortunately, both abruptly end mid-sentence while relating the events of the Rinpungpas after the time of Dönyö Dorjé, followed by a note stating that the original source manuscript was cut off. All citations are from the LTWA printing.

We find mentions of Dönyö Dorjé and the other Rinpungpas in other 15th- and 16th-century historical texts, such as the The Scholar's Feast, the life stories of the holy madmen, the Life of Śäya Chokden, the biographies of the 4th Red Hat, the 7th Karmapa, the Life of Drakpa Tayé, and so on. These sources can give us insight into the Rinpungpas' activities as patrons. There are a many later histories by Tibetan authors, but all are based on these original sources.
} 
his faithful administrators, Namka Gyeltsen, to be local administrator (rdzong dpon) of the Rinpung district in Tsang. ${ }^{491}$ He and his descendents took Rinpung as a family name. Some sources maintain that at this time Namka Gyeltsen was also appointed governor (lit: myriarch, khri dpon) of Chumik (chu mig) and also overseer of the great temple at Sakya Monastery (sa skya'i lha khang chen mo' $i$ dpon chen). ${ }^{492}$ In time, the position of local administrator of the Rinpung district (rdzong dpon) would also be given to Namka Gyeltsen's son, Namka Gyelpo, ${ }^{493}$ and then his son, Norbu Zangpo, and his son Künzang. ${ }^{494}$

In 1434 the Pakmodru regime faced some difficulties due to an internal dispute over who would assume the position of gongma after the passing of Drakpa Gyeltsen. ${ }^{495}$ Because of this 1434 would be called in later histories "the year of the collapse of the house of the Pakmodru" (phag mo gru pa nang zhig gi lo). ${ }^{496}$ And as various factions like the Rinpungpas seized this opportunity to increase their own holdings, it is also

In the Collected Works (gsung 'bum) of Śākya Chokden there are three texts that pertain the Rinpungpas: 1) gtsang rong byams chen chos sde'i par gsar pa rnams kyi dkar chag tu gnang ba, pp 22938, in Vol. 17 (tsa); 2) gzhis ka rin spung kyi phyag mdzod du bsdu ba'i deb gter chen mo'i shis brjod, pp 238-9; and 3) rje btsun byams pa mgon po'i sku brnyan bzhengs pa 'i dkar chag lo rgyus, pp 243-76. Unfortunately, none of these gives much insight into this family's activities.

Shakabpa's Political History is based mainly on The New Red Annals and The Song of the Queen of Spring, but he makes some mistakes in describing the relationships between the members of the Rinpung family (for example, stating Dönyö Dorjé to be the son of Norbu Zangpo, rather than his grandson, and Tsokyé Dorjé as being the brother of Norbu Zangpo instead of his son), p 87. Shakabpa's is a highlyreadable account, but should be used with caution in light of these mistakes.

${ }^{491}$ The Song of the Queen of Spring, Nordrang Orgyen, p 403; Tucci, TPS, Vol. II, p 642; Shakabpa, p 86. A brief biography of Namka Gyeltsen is given in the gang can mkhas grub rim byon ming mdzod by ko zhul grags pa 'byung gnas and rgyal ba blo bzang mkhas grub (kan su'i mi rigs dpe skrun khang, 1992) (hereafter referred to as the ming mdzod), $\mathrm{p} 1615$.

${ }^{492}$ Nordrang Orgyen, p 403; Tucci, TPS, Vol. II, p 642.

${ }^{493}$ According to the deb ther kun gsal me long, this was in 1416, p 240.

${ }^{494}$ Nordrang Orgyen, pp 403-4, 406; Tucci, TPS, Vol. II, p 642. A biography of Namka Gyelpo is given in the ming mdzod, pp 1614-5. Biographies of Norbu Zangpo are given in the ming mdzod, pp 1615-16 and Dungkar Rinpoché dictionary, p 1915.

${ }^{495}$ See Tucci, TPS, Vol. I, pp 28-9; Shakabpa, p 86.

${ }^{496}$ Tucci, The New Red Annals, p 219; Dungkar Rinpoché, chos srid zung 'brel, p 81; Padmarāga, Vol. II, pp 644, 767; Shakabpa, p 86; Nordrang Orgyen, p 384. 
known as "the Great Revolt of the Tiger Year" (stag lo'i sde gzar chen mo). Norbu Zangpo (grandson of the Namka Gyeltsen, who had been first appointed local administrator of Rinpung) led the Rinpungpa family in seizing control of a few minor districts near their home territory, and most importantly the town of Shigatsé. ${ }^{497}$ Norbu Zangpo's son, Döndrup Dorjé, had been serving as local administrator (rdzong dpon) of Shigatse at the direction of the Pakmodrupas, but from 1434 onward they defied the authority of the Pakmodrupas and claimed the territory as their own. The Rinpungpas shifted their seat from provincial Rinpung to the much larger town of Shigatsé, which would be key to their expanding influence. Other powerful families in Tsang aligned themselves with the Rinpungpas. As the historical chronicle the Re'u mig laconically states, in the year 1435 "the $\operatorname{Pak[mo]drupas~lost~the~Tsang~region~to~the~Rinpungpas."~} 498$ From this time onward the Rinpungpas would continue to rise while the power of the Pakmodrupas steadily declined. ${ }^{499}$ The initiatives of the Rinpungpa faction were led by three of Norbu Zangpo's sons in turn: Küntu Zangpo, Döndrup Dorjé and Tsokyé Dorjé. Leadership would then be passed onto Norbu Zangpo's grandson, the younger son of Küntu Zangpo, Dönyö Dorjé. Dönyö Dorjé would be a major player in the tumultuous events of these decades and provides an important reference point for our understanding of the careers of the Madmen of Ü and Tsang. ${ }^{500}$

\footnotetext{
${ }^{497}$ Nordrang Orgyen, p 384; Dungkar, chos srid zung 'brel, p 81, also attributes the seizure of Shigatsé to Norbu Zangpo; Dungkar Rinpoché dictionary, p 1915; Shakabpa attributes the conquering of Shigatsé to Norbu Zangpo's son, Döndrup Dorjé (p 86); Hortsang Jikmé, p 509. It is most likely that they were all working together, although historical documents are likely to fixate on one individual. Some scholars say this happened in 1434, while others (like Kapstein, The Tibetans, p 122) say it was 1435.

${ }^{498}$ re'u mig, $\mathrm{p}$ 47: phag gru bas gtsang phyogs rin spung ba la shorl

${ }^{499}$ Dungkar Rinpoché, chos srid zung 'brel, pp 81-2; Hortsang Jikmé, p 509.

${ }^{500}$ bod kyi lo rgyus dris lan brgya ba, by cha ris skal bzang thogs med (kan su'i mi rigs dpe skrun khang, 1997) lists the major players in the Rinpung family at this time, pp 136-7.
} 
Before exploring the life and activities of Dönyö Dorjé let us consider the nature of the conflict during this time. The relationship between the Rinpungpas and the Pakmodru regime during these years was a complex one. Historians writing about the time period all recognize that from the mid-1430s onward, most of the real political power in central Tibet was held by the Rinpungpas. And yet the Pakmodru administration continued to function, perhaps as a ceremonial body struggling to regain its former strength. And despite the Rinpungpas' openly engaging the Pakmodrupas in armed conflict, the Rinpungpas still continued to serve in the Pakmodru government and at times offered outward signs of respect to the position of the gongma, as we will see below. The Rinpungpas themselves never received official recognition from the Chinese of their own status as rulers and never supplanted the Pakmodrupas as titular rulers of Tibet.

In addition to occasional armed confrontations with the Pakmodrupas and their allies, the Rinpungpas also took diplomatic action. Some members of the Rinpung family spent much of their careers working within the Pakmodru government as ministers, as they had for many years prior to their rise to power. For example, Norbu Zangpo, even after forcibly seizing Shigatsé and expanding the realm controlled by the Rinpungpas in Tsang, continued to serve in an official capacity in the Pakmodru government. ${ }^{501}$ Further, Tsokyé Dorjé (1462-1510), son of Norbu Zangpo and uncle to Dönyö Dorjé, worked within the Pakmodru government for years. He became a chief

\footnotetext{
${ }^{501}$ From The Song of the Queen of Spring, Nordrang Orgyen, p 385; TPS, Vol. II, p 640. Tucci translates Norbu Zangpo's position as "Minister of Justice" (khrims kyi kha lo bsgyur ba'i blon po mdzad). This statement perhaps might also read as saying not that Norbu Zangpo occupied a specific post called "Minister of Justice" but rather that he was holding the reigns of power in the government. This passage is not in The New Red Annals; if so, it would fall at Tucci, p 221. Shakabpa, p 87, states that Norbu Zangpo, along with his deputy, "looked after the civil administration."
} 
minister (blon chen) in $1481^{502}$, and then took full control of the reigns of that

government as a sort of regent (dpon tshab) or "user of the [state] seal" (thel gtong), a

position he would hold for about nine years, starting around $1491 .^{503}$ He came into this

position because the next gongma had not yet reached an age at which he could govern

and the Rinpungpas had become too powerful to be ignored. From this position, and

supported by the great influence wielded by his militant nephew Dönyö Dorjé, Tsokyé

Dorjé was able to have Ngawang Tashi Drakpa Gyeltsen put on the throne as gongma in

about 1499; as the boy was only 12 years old, Tsokyé Dorjé would continue to control

the government for some time. ${ }^{504}$ The Rinpungpas also managed to have the 4th Red Hat

appointed as the spiritual head of Densa Til Monastery for some years, beginning in 1491

or $1493^{505}$, despite his (by some accounts) having been openly antagonistic towards the

Gelukpas and representing a political force highly threatening to the Pakmodrupas. ${ }^{506}$

Some of the most important historical sources about this period pause to mention who the

${ }^{502}$ Tucci, The New Red Annals, p 226.

${ }^{503}$ Tucci, The New Red Annals, p 227; Tucci, TPS, Vol. I, p 30. The 5th Dalai Lama's Song of the Queen of Spring states that Tsokyé Dorjé first seized the Kartog fortress (mkhar thog gi rdzong bzung) (Nordrang Orgyen, p 387, 406; Tucci, TPS, Vol. II, pp 640, 642), then became something like the "regent, user of the official seal" (dpon tshab thel gtong byed pa) (Nordrang Orgyen, pp 390, 406; Tucci, TPS, Vol. II, pp 640, 642). According to The Song of the Queen of Spring, he was something of a tyrant, doing what he pleased without consulting with the other ministers of the Pakmodru government, which caused them to rise up against him numerous times; but as the Rinpungpas were too powerful, no one could contest them (explained in Nordrang Orgyen's commentary, pp 390, 406-7).

Dungkar Rinpoché, chos srid zung 'brel, p 83; entry for Tsokyé Dorjé, in Dunkar Rinpoché dictionary, pp 1916-7.

${ }^{504}$ Tucci, The New Red Annals, p 228; The Song of the Queen of Spring, Tucci, TPS, Vol. II, p 640; Nordrang Orgyen, p 391. Dungkar Rinpoché dictionary, pp 1524-5, on Ngawang Tashi Drakpa himself (b 1488 , lived about 80 years).

${ }^{505}$ Nordrang Orgyen, p 389 puts this at 1491; Tucci, The New Red Annals, p 227, says 1493; this is not mentioned in Sumpa Kenpo's re'u mig or dpag bsam ljon bzang. According to The Scholar's Feast, he took this responsibility in 1493 (2006 version, p 579) (sde srid phag mo gru pa'i lugs gnyis kyi dbu 'don $m d z a d)$.

Tucci, The New Red Annals, p 232, makes it look like he held this position until he died in 1524; the ming mdzod, p 1493, says he was sde srid spyan snga for about 20 years. The Scholar's Feast makes it seem that he held the position until he resigned, shortly before his death in 1524, p 586.

${ }_{506}$ bod kyi lo rgyun dris lan brgya ba, p 137, talks about the open warfare but also more diplomatic wresting of power from the Pakmodrupas. 
most important ministers were during the reign of each gongma; members of the Rinpungpa family are always prominent among them. ${ }^{507}$ They are described in the 5th Dalai Lama's Song of the Queen of Spring as "those who guided the great chariot of the gongma desi's [the Pakmodru gongmas'] government." ${ }^{\text {508 }}$ Much of the Rinpungpas' maneuvering over the years involved their capitalizing on the internal dissension between the Pakmodrupas themselves. The Rinpungpas also seized opportunities to spread their power during the years when there was no strong Pakmodru ruler, usually following the death of one gongma and before the next rightful claimant to the throne came of age.

Throughout the 15th century the Rinpungpas also formed various marriage ties with the Pakmodrupas, which was part of their becoming closer to the Pakmodrupas while still pursuing their own agenda. The Rinpungpa Namka Gyeltsen married a daughter of a Pakmodru gongma (Śākya Rinchen). ${ }^{509}$ Their daughter, Künga Peldzom, would be given in marriage to a Pakmodru official and produce two future gongmas: the two brothers who would come to serve as the 6th and 7th gongmas, Drakpa Jungné (1414- c. 1446, grags pa 'byung gnas) and Künga Lekpa (1433-1483 ${ }^{510}$, kun dga' legs $p a){ }^{511}$ There was a dispute within the Pakmodru regime regarding whether the first of these two brothers, Drakpa Jungné, or his father (brother of the previous gongma) should

\footnotetext{
${ }^{507}$ Tucci, The New Red Annals, pp 217, 221, 225, 233.

${ }^{508}$ gong ma sde srid kyi bka' khrims kyi shing rta chen po'i kha lo pa rnams..., Nordrang Orgyen, p 402; my translation is from Tucci, TPS, Vol. II, p 641.

${ }^{509}$ Yarlung Ambum, p 128.

${ }^{510}$ In the Dungkar Rinpoché dictionary, the gongma Künga Lekpa is said to have been the 7th abbot and to have lived 1433-1483; he held the throne 1448-1457, then was reinstated in 1481, pp 1521-2.

${ }^{511}$ Yarlung Ambum, p 128; Padmarāga, Vol. II, p 643; Nordrang Orgyen, p 383; Shakabpa, p 86. Tucci’s rendering of The New Red Annals suggests that the two sons were born to two different Rinpungpa women, p 218.
}

By some accounts Künga Lekpa and Drakpa Jungné are the 7th and 8th holders of the throne of the Pakmodrupa, with the first being Changchub Gyeltsen (Dungkar Rinpoché dictionary, p 1180); according to the TZCM, p 1699, they are the 6th and 8th. By the account given by the Padmaragga, they are the 6th and 7th, Vol. II, pp 643-5. 
take the throne. It was at this moment that the Rinpungpas started to aggressively expand their domain in 1434 . The second brother, Künga Lekpa, would go on to marry a woman of the Rinpung family. ${ }^{512}$ Not long after, another gongma Ngawang Tashi Drakpa Gyeltsen (who was put on the throne by the Rinpungpas Tsokyé Dorjé and Dönyö Dorjé) married a Rinpungpa woman. ${ }^{513}$ (This may have been a daughter of Dönyö Dorjé, for according to The Life of the Madman of Tsang, the gongma was married to one of the great warlord's daughters. ${ }^{514}$ ) When the gongma had children with a second, nonRinpungpa wife, this was cause for some friction within the family. The Rinpungpa woman and her children were sent away from the Pakmodru capital, but because of the strength of the Rinpungpas and their supporters, the gongma experienced some fallout over this. ${ }^{515}$ In most cases we see Rinpungpa women being given to Pakmodrupas as wives; I have found only one case of a Pakmodru woman being given to a Rinpungpa. During these years the Rinpungpas took wives from various powerful families of central Tibet, creating strategic alliances in the process.

It is difficult to judge how meaningful the marriage ties between the Rinpungpas and the Pakmodrupas were. They may not have accounted for much, for when the

\footnotetext{
512 Tucci, The New Red Annals, p 222; Dungkar Rinpoché dictionary, pp 1521-2. Nordrang Orgyen, p 386, identifies this woman as chos dpal bzang mo.

Tucci, TPS, Vol. I, p 29 states that between this husband and wife there was a "violent quarrel," which he suggests Tsokyé Dorjé and Dönyö Dorjé used as a justification to cause further trouble.

${ }^{513}$ Tucci, The New Red Annals, p 228; The Song of the Queen of Spring, Tucci, TPS, Vol. II, p 641; Nordrang Orgyen, $\mathrm{p}$ 394. According to Nordrang Orgyen's commentary, this was in 1504. According to the TZCM, p 1699 and Dungkar Rinpoché dictionary, p 1180, he was the 10th abbot.

${ }^{514}$ Neither The New Red Annals, The Song of the Queen of Spring, nor Nordrang Orgyen's commentary mentions the name of this woman, nor that she was a daughter of Dönyö Dorjé specifically—only that she was from the Rinpungpa family. Götsang Repa, p 258.6, states that one of the gongma's wives was a daughter of Dönyö Dorjé, named Lektso Gyelmo (legs mtsho rgyal mo). Yarlung Ambum mentions two daughters had by Dönyö Dorjé, but neither is said to have been given to the gongma, or to have had this name, $\mathrm{p} 133$.

${ }^{515}$ Shakabpa, pp 88-9.
} 
gongma Künga Lekpa paid visits to the territories of his domain, the Rinpungpa Norzang, who would have been his cousin, treated him so poorly that it was cause for some displeasure. $^{516}$ Then around 1481, after a military campaign by Dönyö Dorjé into central Tibet, Künga Lekpa was removed from his position as gongma and replaced by chengga Ngaki Wangpo (spyan snga ngag gi dbang po) by the acting government ministers (Dönyö Dorjé and Tsokyé Dorjé among them). At the very least, these marriages gave the Rinpungpas at times semi-legitimate claims for more powerful positions within the Pakmodru government; when denied their wishes, they used this as an excuse to agitate more openly. In the end these marriages were just another vehicle through which alliances and appeasements could be made in this ever-shifting political landscape. ${ }^{517}$

The political dynamics of central Tibet in the 15 th and 16 th centuries were made more complicated by the fact that there were other important political families acting as independent agents in these events. There were the Nelpas (snel pa), the Chonggyepas ('phyong rgyas pa), the Yargyabpas (yar rgyab pa), Samdepas (bsam sde pa), and so on. They were party to constantly shifting divisions and alliances; at times they fell on the side of the Rinpungpas, at times against them. A reading of The New Red Annals or The Song of the Queen of Spring gives an idea of how complicated these events were.

It seems that the basic strategy of the Rinpungpas was to maintain a shell of the Pakmodru government in Nedong, staffed mainly with their own supporters, while

\footnotetext{
${ }^{516}$ Tucci, The New Red Annals, p 222; The Song of the Queen of Spring, Nordrang Orgyen, p 386; this passage is omitted from Tucci's translation in TPS, Vol. II (it would fall on p 640); Shakabpa, p 87. Based on Yarlung Ambum's history of the Rinpungpas, Künga Lekpa's mother was Künga Peldzom, who was a sister of Namka Gyelpo, Norbu Zangpo's father - thus making them cousins, pp 128-9.

${ }^{517}$ It is worth noting that two of the groups who were the most stalwart supporters of the Geluk during this period - the family ruling Neudzong, near Lhasa, and the Drakarwas, whose domain was where Ganden Monastery was established - had been intermarrying, likely making them further invested in banding together in their support of the Geluk and the Pakmodru regime. Sørensen, "Lhasa Diluvium," pp 112-3.
} 
exercising real political power from their base in Tsang. From the 1430s onward, the Pakmodru regime was not powerful enough to punish or marginalize the Rinpungpas for their defiance (the Rinpungpas' rebellious seizure of Shigatsé, a major turning point in these events, would have been the appropriate moment to strike back), and thus had to continue to work with them, biding their time until they themselves would be able to close ranks and check the increasing power of the usurpers.

The Rinpungpas' rise to power was a gradual one. It began around the turn of the 15 th century when they got control of Rinpung, which led to their slowly gaining some other small districts, and then seizing Shigatsé in 1434. After that began a long period in which they increased their strength by working within the Pakmodru government, forming alliances, intermarrying and getting their own supporters appointed to positions of power, until Tsokyé Dorjé reached the peak of his power in the 1480s and 90s, which coincided with Dönyö Dorjé's most active period of military adventurism. ${ }^{518}$ Having reviewed how the Rinpungpas increased their influence through diplomatic means, let us now consider the more overt struggle that accompanied this. We can best understand this aspect of the Rinpungpas' rise to power by looking at the life of Dönyö Dorjé, one of the most important players in 15 th-century central Tibetan affairs.

\footnotetext{
${ }^{518}$ As the All-Illuminating Mirror of Histories (deb ther kun gsal me long) summarizes, the Pakmodrupas "were able to gradually usurp power from the Pakmodrupas using both peaceful and violent methods..." (zhi drag gnyis ka'i thabs la brten nas phag gru'i srid dbang khad kyis 'phrog thub pa byung...), p 241 (printed in 1987). The Hundred Questions and Answers about Tibetan History (bod kyi lo rgyus dris lan brgya ba), 137 (printed in 1997) uses the same exact line. The deb ther kun gsal me long gives a good description of the Rinpungpas' rise to power, serving for ministers as they had for generations, then betraying the Pakmodrupas openly when the opportunity came to them, as in 1435 when they seized Shigatsé.
} 


\section{III.2.i Rinpungpa Military Campaigns Under Dönyö Dorjé}

Dönyö Dorjé (1462/63-1512 $\left.2^{519}\right)$ was born into the Rinpungpa family in the midst

of their rise to power. In his youth Dönyö Dorjé received a good education, showing an aptitude for military, political and religious matters; he also served as a sort of apprentice, working in various administrative centers ( $r d z o n g)$ controlled by his family. ${ }^{520}$ As an adult Dönyö Dorjé led the Rinpung regime during its most aggressive expansion in central Tibet. The role of leading the Rinpungpa regime had earlier been held by Dönyö Dorjé's grandfather, his father, and then his uncles.

The received histories show much disagreement regarding the details of the military campaigns of the Rinpungpa faction with Dönyö Dorjé at the helm. It was by all means a chaotic time in central Tibet. To simplify matters, here we will review these events based on only one historical source, Peṇchen Sönam Drakpa's New Red Annals, leaving discussions of the variations in the way these events are related to the footnotes.

According to The New Red Annals, in 1480, at the age of 17 or 18, Dönyö Dorjé led an army deep into Nedong territory and forcibly removed some officials from their positions within the Pakmodru government. They then seized some districts near Lhasa, such as Chushül Lhünpo Tsé and some estates belonging the lord of Neudzong. ${ }^{521}$

\footnotetext{
${ }^{519}$ Dungkar Rinpoché dictionary, p 1915, has the dates as 1462-1512; in the ming $\operatorname{mdzod}$ his years are given as 1463-1512, p 1613; TBRC.org admits 1462 or 63.

520 ming mdzod, p 1614; Dungkar Rinpoché dictionary, 1915.

${ }^{521}$ Tucci, The New Red Annals, pp 224-5. There is a lot of disagreement among our various sources about this campaign. In large part the difficulty is that these historical chronicles compact events together. The New Red Annals makes it seem that this was all part of a single campaign for Dönyö Dorjé, but The Song of the Queen of Spring indicates that there were years between these events.

After The New Red Annals, a second key source is The Song of the Queen of Spring (written in the 17th century), which gives two different accounts of these events: the first account states only that Dönyö Dorjé led an army into Ü and seized some estates from the Neupas (Nordrang Orgyen, p 388; Tucci, TPS, Vol. II, p 640). The second account specifies that those estates were Drakar (brag dkar) and Chushül Lhünpo Tsé and so on (chu shus lhun po rtse), which belonged to the Nelpa (snel pa) (Nordrang Orgyen, p 407; Tucci, TPS, Vol. II, p 642); then Dönyö Dorjé seems to have gone to Nedong, at which time he and
} 
Shortly after this Dönyö Dorjé was in Nedong with other ministers appointing the next

gongma. (Some sources state that during this campaign Dönyö Dorjé's troops also

others had the chengga Ngaki Wangpo put on the throne, then had a few other military campaigns, then led troops to Kyishö (the Lhasa area) and Ganden Monastery (his attack on the monastery itself was foiled twice, however, by the rituals performed by the abbot Mönlam Pelwa). Upon news of Mönlam Pelwa's death, Dönyö Dorjé again started a military conflict, but as some local lords caused some trouble, he agreed to accept tribute from Neu[dzong], and relented.

A third influential source is the re'u mig, the historical chronicle based on the dpag bsam ljon bzang, which was written in 1748. It states: "lcags glang [1481]: zhwa dmar pas gtsang dmag dbus su drangs...." ([re'u mig], dpag bsam ljon bzang, by sum pa mkhan po ye shes dpal 'byor; edited by Lokesh Chandra. New Delhi: International Academy of Indian Culture, 1959, Vol. III, "containing a history of Buddhism in China and Mongolia, preceded by the rehu-mig or chronological tables," pp 51-2). The text of the dpag bsam ljon bzang itself states that the 1481 campaign involved an army of 10,000, which the 4th Red Hat himself led; their primary target was the lord of Neudzong, patron of the Gelukpas; the Rinpungpas' efforts were twice turned back by the rituals performed by the abbot of Ganden, Mönlam Pelwa. Tucci, TPS, Vol. II, p 654; dpag bsam ljon bzang (by sum pa mkhan po ye shes dpal 'byor. Sarnath: Mongolian Lama Guru Deva, 1965), p 24. I have not been able to determine what additional sources Sumpa Kenpo may have been working with when he wrote this account, but it has become one of the most influential sources on these events.

Dungkar Rinpoché, chos srid zung 'brel, pp 82-3, basically follows the account given by the dpag bsam ljon bzang, saying that this attack was prompted by the 4th Red Hat and was led by Dönyö Dorjé and his father, Künzangpa; it involved an army of 10,000 troops; the lord of Neudzong, Ngawang Sönam Lhünpo, and his son, Ngawang Sönam Namgyel, both fled.

Dungkar Rinpoché, in his entry on Dönyö Dorjé in his dictionary, p 1915, basically follows the account given in The New Red Annals.

The deb ther kun gsal me long is sort of a hybrid, saying that Dönyö Dorjé defeated Neudzong, but also saying that he had more than 10,000 troops, p 236.bod kyi lo rgyus dris lan brgya ba says the Rinpungaps captured some estates from Neudzong and others, then attacked Nedong itself, $\mathrm{p} 137$.

Wylie, "Monastic Patronage in 15th-century Tibet," p 324, simply states that in 1481 Rinpung forces "attacked the Lhasa region, but they were defeated." He is drawing from The Song of the Queen of Spring and the dpag bsam ljon bzang.

Shakabpa gives a very different account. He says that the campaign against $U ̈$ in 1480 was led by Dönyö Dorjé; first they seized some "small districts under the jurisdiction of the Lhasa administrator" (i.e., the lord of Neudzong), then marched on Nedong proper, where they removed the deputy minister, Könchok Rinchen, from office. Then in 1481 Dönyö Dorjé led an attack on Lhasa itself, which was unsuccessful. Shakabpa also states that this 1480 campaign was undertaken in retaliation for the fact that Gelukpa monks had razed a Karma Kagyü monastery Dönyö Dorjé had had built just outside of Lhasa, p 87.

In "Lhasa Diluvium" Sørensen states that on this first compaign Dönyö Dorjé and the Rinpungpas conquered Penyül ( phan yul), which was under the control of the Drakarwas, and did damage to the governors of Neudzong, $\mathrm{p} 115$. Sørensen thus sees the object of this campaign to be the Lhasa area, rather than the Pakmodru capital of Nedong.

The History of the Taklung Kagyü (written in 1609) corroborates these events to some extent, although it may be based in part on The New Red Annals. This text mentions how nang so Dönyö Dorjé and Yungpa Tsewang led troops to Ü and put $d b o n ~ s a$ Ngaki Wangpo on the throne (of Nedong), describing the 1480 or 1481 campaign, p 438. We also see Tsokyé Dorjé and Dönyö Dorjé as ministers working within the Nedong/Pakmodru government and having many contacts with religious emissaries, including the 12th abbot of Taklung Monastery, Ngawang Drakpa, who sees Tsokyé Dorjé and Dönyö Dorjé on numerous occasions in the 1480s and 90s in the Nedong/Yarlung area, Chushül Lhünpo Tsé, and so on. stag lung chos 'byung (brgyud pa yid bzhin nor bu'i rtogs pa brjod pa ngo mtshar rgyo mtsho), by stag lung ngag dbang rnam rgyal (bod ljongs bod yig dpe rnying dpe skrun khang, 1992), pp 438-45, 455. 
attacked the Ganden Monastery, home of the Geluk sect, but they were turned back because of rituals performed by the abbot, Mönlam Pelwa, smon lam dpal ba, 1414$1491 .^{522}$ ) After this campaign most of the Rinpungpa forces returned to Tsang. In 1485 the Rinpungpas attacked the town of Gyantsé in Tsang. It is not stated whether or not Dönyö Dorjé was involved. The text is unclear, referring to the agent only as rin spungs pa. ${ }^{523}$ Elsewhere in The New Red Annals it is stated that Gyantsé had provoked the Rinpungpas into attacking them by raising and army and boasting of their strength. $^{524}$

In 1492 the sde pa sgar pa (the "encamped leader," i.e., Dönyö Dorjé), launched an attack on districts in Ü, seizing a handful of territories. The campaign ended with a peace agreement. ${ }^{525}$

In 1498, seizing upon internal problems in the family ruling the Kyishö district (skyid shod; basically, Lhasa), the Rinpungpas (again, probably referring to Dönyö Dorjé) attacked that area, and the ruling brothers (nang so sku mched) were forced to flee. The Rinpungpas would maintain control of the Lhasa area for the next twenty years. During

\footnotetext{
522 Tucci, TPS, Vol. I, p 30. The efforts of Mönlam Pelwa are mentioned in The Song of the Queen of Spring (Nordrang Orgyen, p 408, TPS, Vol. II, p 642) and the re'u mig (re'u mig, p 51; TPS, Vol. II, p 654). The dpag bsam ljon bzang by Sumpa Kenpo, on which the re'u mig is based, states specifically that this attack by Dönyö Dorjé was motivated out of sectarian hatred (rje'i lta grub la ldang ba...), p 200.

${ }^{523}$ Tucci, The New Red Annals, 226.

${ }^{524}$ Tucci, The New Red Annals, p 189. Among the alternative presentations offered by other sources, some say that there were in fact two separate campaigns against Gyantsé: one in 1485, which was unsuccessful, and one in 1488, in which they achieved their aim (Shakabpa, p 88). Wylie, p 325, citing The New Red Annals and the unabridged version of Shakabpa's history, does not say that Dönyö Dorjé was involved in the first attack on Gyantsé, but does say that he was in the second; once they took Gyantsé, the Rinpungpas dominated the southern road between $\ddot{U}$ and Tsang.

The Padmaräga (Vol. II, p 646) states that because of the misfortune caused by the Rinpungpas' leading an army to Gyantsé (in 1485), this year was called "gyang ro spe rgya'i jus nyes kyi lo."

${ }^{525}$ Tucci, The New Red Annals, p 227.
} 
this time monks of the Geluk sect were barred from participating in the annual Great Prayer Festival, which had been founded by Tsongkhapa.

In 1499 the head Rinpungpa (again most likely referring to Dönyö Dorjé) led a gathering of many officials (sde dpon) at Nedong, at which time they invited Ngawang Tashi Drakpa, at the age of twelve, to become the next gongma. On this occasion the Rinpungpas sponsored a big party, with lavish gifts of tea, cloth, silk, gold, and silver that were almost unimaginable in scale. ${ }^{526}$ During these years Dönyö Dorjé and his people stayed in a encampment (sgar) near Lhasa. For this reason, he is sometimes referred to as the sde pa sgar pa. Sørensen notes that at times during the twenty years the Rinpungpas controlled the Lhasa area they assumed responsibility for the public good at such a trying times as 1500 , when the area was hit with drought, famine and epidemics. The 4th Red Hat also performed a ritual consecrating the local water-dikes, a symbolic expression that the Karma Kagyü sect had become "legitimate heirs and local rulers" of Lhasa under Dönyö Dorjé’s watch. ${ }^{527}$

Starting in 1509 there was some strife between Dönyö Dorjé and the Pakmodru gongma, Ngawang Tashi Drakpa Gyeltsen. ${ }^{528}$ It seems that Dönyö Dorjé was somehow at fault for the situation and he was advised by the 4th Red Hat, holding the position as Chennga Rinpoché (spyan snga rin po che), the abbot of Densa Til, to make restitution. So in 1510 Dönyö Dorjé arranged a formal meeting, during which he made displays of

\footnotetext{
${ }^{526}$ Tucci, The New Red Annals, p 228. The entry in the re'u mig for the year 1498 (sa rta) reads: "the Rinpungpas of Tsang kick out the Neudzongpa.... For the Great Prayer Festival the ones from gsang phu and Karma and so on gathered; Sera and Drepung forbidden," p 53.

${ }^{527}$ Sørensen, "Lhasa Diluvium," pp 115-6.

${ }^{528}$ According to The Song of the Queen of Spring, this was in about 1510, just after the death of Tsokyé Dorjé. The problem started when Ngawang Namgyel (cousin of Dönyö Dorjé and son of Tsokyé Dorjé), attacked E and Nyel (e gnyal); Tucci, TPS, Vol. II, p 640; Nordrang Orgyen, pp 391-2. According to The New Red Annals, Tucci, p 229, the army was sent against g.ye bla 'bring.
} 
homage and devotion to the gongma and his old friend the Red Hat. Dönyö Dorjé

offered the gongma a minor estate as a gift. This was an obvious slight, which impelled the gongma to further the exacerbate the situation. With the conflict still unresolved, Dönyö Dorjé died in 1512. To die in the midst of conflict seems the only fitting end for such a man. ${ }^{529}$ At his peak, Dönyö Dorjé was called by a variety of names: nang so, drung, sgar pa, sde pa, sde pa sgar pa, sde srid, sa skyong, chos rgyal, chos skyong ba' $i$ rgyal po, sa skyong chos kyi rgyal po, stobs kyi rgyal po, mi'i dbang po, sa skyong mi’i dbang po, and so on. As an indicator of what he had achieved, The Scholar's Feast called him "the lord of the four horns of U-Tsang" (dbus gtsang ru bzhi'i bdag po don yod $r$ do rje). ${ }^{530}$ He had no official status, but these titles suggest that he was widely recognized as the de facto ruler of central Tibet. The biography of the 7th Karmapa given in The Scholar's Feast (written in 1545) shows us a glimpse of Dönyö Dorjé at the height of his glory. When Dönyö Dorjé invited the Karmapa for tea in what was likely 1501 (bya lo), it is said how the worldly protector (sa skyong) Dönyö Dorjé had seized the lands of the administrators of Neudzong (gzhis ka snel pa), controlled Ü and Tsang for some years, and had become like a cakravartin, a king setting in motion the wheel of the Buddhist teachings. ${ }^{531}$

\footnotetext{
${ }^{529}$ Tucci, The New Red Annals, pp 229-30.

${ }^{530}$ The Scholar's Feast, 2006 version, p 556; the Karma Kamtsang history, bsgrub brgyud karma kaM tshang brgyud pa rin po che'i rnam par thar pa rab 'byams nor bu zla ba chu shel gyi phreng ba, by si tu paN chen chos kyi 'byung gnas and 'be lo tshe dbang kun khyab (New Delhi: D. Gyaltshan and Kesang Legshay, 1972; TBRC W23435), p 569. All future references to the Karma Kamtsang history are to this text.

Shakabpa, p 89: "Officially, the people of the three regions of Tibet still addressed the Nedong ruler as Gongma, but the Rinpung faction really held the reins of the government."

${ }^{531}$ The Scholar's Feast, 2006 version, p 561.
} 
After the death of Dönyö Dorjé the Rinpungpas entered a period of decline. The Rinpungpa faction would be led in succession by Dönyö Dorjé's cousin, Ngawang Namgyel (ngag dbang rnam rgyal) ${ }^{532}$; Zilnön Dorjé, who was probably Dönyö Dorjé's son (zil gnon rdo rje, who was called up to become zhal ngo, "leader," at the time of Dönyö Dorjé's death) ${ }^{533}$; and then Ngawang Namgyel's sons, Döndrup Tseten Dorjé and Ngawang Jikdrak, the latter a famous man of letters. ${ }^{534}$ The New Red Annals are not entirely clear on the chronology of events in the years after Dönyö Dorjé's death, but it is clear that the Rinpungpas continued their belligerent ways. The larger tide had turned against them, however. The Red Hat no longer supported the Rinpungpas fully, seeming to have grown tired of their unending aggressions. Their territories started to slip away from them. The Rinpungpas withdrew from Lhasa around 1518 and lost Gyantsé around the same time. The Gelukpas returned to the celebration of the Great Prayer Festival in full force. ${ }^{535}$ The Song of the Queen of Spring describes the fall of the Rinpungpas in the most ignoble terms, portraying their last military acts in 1516 or so as open rebellion of the worst type (whereas their earlier seizing of Shigatsé and attacks on Ü are described in a less judgmental manner). Troops were sent from Ü to Tsang, and the leader of the Rinpung faction was reduced to the position of local administrator (rdzong dpon) of

\footnotetext{
${ }^{532}$ Tucci, The New Red Annals, pp 233, 240; The Song of the Queen of Spring, TPS, Vol. II, p 642; Nordrang Orgyen, $\mathrm{p} 408$.

${ }^{533}$ Tucci, The New Red Annals, pp 230, 232, 233. This is not mentioned in The Song of the Queen of Spring. According to Yarlung Ambum, p 133, this is Dönyö Dorjé's son.

${ }^{534}$ According to one later history, rgya bod du bstan pa'i sbyin bdag rgyal blon ji ltar byung tshul gyi mtshan tho by Longdöl Ngawang Lozang (klong rdol ngag dbang blo bzang) (pp 419-60, text ' $a$ in his Collected Works; Vol. II, 756 pages, printed by bod ljongs bod yig dpe rnying dpe skrun khang, 1991; also printed in Delhi, Lokesh Chandra, 1973), over the years there were seven heads (sde pa) of the Rinpung faction: Namka Gyeltsen, Namka Gyelpo, Norbu Zangpo, Künzang, Dönyö Dorjé, Ngawang Namgyel and Nawang Jikdrak, p 449.

${ }_{535}$ In the re'u mig the entry for the year 1518 (sa stag) states that "since 1516 (me byi) the power of the Tsangpa had been waning and Sera and Drepung could again participate in great prayer festival...", p 55.
} 
Rinpung, the position from which their rise to power all began. Not ones to give up, they tried one last time to start a revolt in 1522 , but it was unsuccessful. ${ }^{536}$ Thus within about a decade of the passing of Dönyö Dorjé, the domain of the Rinpungpas had shrunk back to their original holding of the Rinpung district. The Pakmodrupas experienced a reciprocal resurgence. ${ }^{537}$

The goal of Dönyö Dorjé was to expand the territory under the control of the Rinpungpa regime by military means. At his command the Rinpungpa army seized many smaller districts, but the primary goal was to conquer the biggest towns of central Tibet, which in time they were able to achieve. After Shigatsé they seized Gyantsé, then Lhasa, the crown jewel of all of Tibet and an important center of the Pakmodrupas' influence. Some versions of this history maintain that it took Dönyö Dorjé and the Rinpungpas at least two attempts to conquer Gyantsé, and two to conquer Lhasa as well. This shows how indispensable the Rinpungpas saw these towns as being for the expansion of their domain.

\section{III.2.ii Sectarian Aggression Under the Rinpungpas}

The version of these events given by Penchen Sönam Drakpa's New Red Annals

tells of Dönyö Dorjé's military antagonism and the diplomacy engaged in by other

\footnotetext{
${ }^{536}$ Nordrang Orgyen, pp 391-3; Tucci, TPS, Vol. II, pp 640-1. The account given in The Song of the Queen of Spring does not identify Dönyö Dorjé as being involved in these events; it is most likely his cousin Ngawang Namgyel and his son, Ngawang Jikdrak (ngag dbang 'jig grags).

${ }^{537}$ Tucci, The New Red Annals, pp 230-3. See Tucci, TPS, Vol. I, p 40. On the fall of the Rinpungpas and the Pakmodrupas' resurgence, see Dungkar Rinpoché, chos srid zung 'brel, p 84. For a very brief summary of the rise and fall of the Rinpungpas, see $\mathrm{p} 449$ of the rgya bod du bstan pa'i sbyin bdag rgyal blon ji ltar byung tshul gyi mtshan tho. For a very useful short description of the Rinpungpas and their activities, well organized and extracted from a larger text called rgyal rabs deb ther dwangs gsal shel gyi me long (which is based almost word for word on The Song of the Queen of Spring), see "bstan pa'i sbyin bdag chen po sa skyong rin spungs pa'i skor" by sa skya'i spyi 'thus ga zi tshe rings po, pp 39-41 in chos kyi blo gros, No. 2, 2009, printed by chos kyi blo gros rtsom sgrig khang (Choekyi Lodoe Editorial Section) Dzongsar Institute, Distt. Mandi (H.P.), India.
} 
members of the Rinpungpa family, like his uncle, Tsokyé Dorjé. But the ambitions of Dönyö Dorjé and his family were not achieved only through diplomatic maneuvering and military force. On the contrary, there was a large religious component to their ongoing struggle to improve their status relative to the Pakmodrupas. The Rinpungpas fostered and supported a cultural battle that took place alongside the more overt military and political struggles. ${ }^{538}$ As we will see below, because of the role played by the Madmen of Ü and Tsang in this cultural battle they were participants in the bigger political events that defined the time in which they lived. Most basically, this broader cultural battle involved the Rinpungpas' using various means to cut off the influence of the Gelukpas, and supporting certain Sakyapas and Kagyüpas who represented an alternative to the Gelukpas in the broader religious marketplace.

First let us consider the overtly sectarian aspects of Dönyö Dorjé's ambitions visà-vis the Pakmodrupas and their allies the Gelukpas. As was mentioned above, on Dönyö Dorjé's first military campaign into central Tibet he seized territory belonging to influential patrons of the Gelukpas (depending on which historian's account we are considering, either the Neudzongpas, the Drakarwas, or both) and may even have attacked or threatened to attack Ganden or the other Lhasa-area Geluk monasteries themselves. Later, during the approximately twenty years when the Rinpungpas controlled Lhasa, participation in the annual Great Prayer festival was open only to

\footnotetext{
${ }^{538}$ Stein, Tibetan Civilization, $\mathrm{p} 80$, talks about this time period as having two "wars" taking place: that between the Pakmodrupas based in Nedong and the Rinpungpas based in Shigatsé, and the war between the Karmapas (based in Tsang) and the Gulukpas (based in Ü). Stein portrays these as two separate wars; I hope that by focusing on the activities of Dönyö Dorjé we will see that the political and religious conflicts are so interconnected that they cannot be thought of as separate from one another. Stein (p 81) discusses the fact that the Pakmodrupas were naturally allied with the Gelukpas because they were both based in Ü, but I would go further, suggesting that this sharing of territory was not the result of mere coincidence, but that the two actually had a deeply symbiotic relationship.
} 
representatives of the Kagyü and Sakya sects; Geluk monks were barred from

participating. During this period the administration of the Jokang temple, the most

important religious site in all of Tibet, was also taken out of the hands of the local

Gelukpas. $^{539}$ (When the Madman of Ü was denied entry to the Jokang on a visit to Lhasa

in the late 1480 s by the acting dkon gnyer, the temple would have been in the hands of

the Gelukpas; no such trouble is mentioned on his later visits. ${ }^{540}$ )

Many historical accounts state that during this period the Rinpungpas made life

difficult for Geluk monks living near Lhasa. ${ }^{541}$ In the 1520 s the situation between the

Drikung Kagyüpas and Gelukpas got so bad that they were openly fighting one another,

and forcibly converting each other's monasteries. Some historical accounts relate how

Geluk monks whose monasteries were in areas that came under the control of the

Drikungpas had to keep two different hats, one red and one yellow, which they would

\footnotetext{
${ }^{539}$ Sørensen, "Lhasa Diluvium," p 114.

${ }^{540}$ The Life of the Madman of $\ddot{U}, \mathrm{p} 481$. On the Jokang temple being in the hands of the Gelukpas or their supporters, see Sørensen, "Lhasa Diluvium," p 113.

${ }^{541}$ Hortsang Jikmé, p 509.

By some accounts during this time there also was an attempt by the Pakmodru government at Nedong to force the monks of Tsetang Monastery to change their hats from yellow to red (an important symbol of sectarian affiliation), but they were not fully successful in making this happen; it seems most monks continued to wear a yellow hat, but with a small patch (lhan pa) of red on it. (According to The New Red Annals, this was around 1466, which would have been during the reign of gongma Künga Lekpa, when Tsokyé Dorjé was in a very strong position within the government, Tucci, p 223. This is not mentioned in The Song of the Queen of Spring; if so, it would be in Nordrang Orgyen, p 387 and Tucci, TPS, Vol. II, p 640. It is, however, mentioned in Nordrang Orgyen's interlinear commentary on The Song of the Queen of Spring, pp 390 and 407, although put much later, in the 1490s when the 4th Red Hat had assumed the position of spyan snga and Tsokyé Dorjé was acting as regeant.) There is some disagreement over when this happened, although we can surely attribute it to Rinpungpa-backed activities. That Tsetang Monastery - of such symbolic importance to the Pakmodru government as it was so close to the seat of the official government at Nedong - was Geluk seems to have been an ongoing issue during the years that the Rinpungpas were a powerful force within the Pakmodru government. In addition to this question of forcing them to wear red hats, there are continual mentions in our historical sources of conflicts between Tsetang Monastery and various government figures.
} 
wear when they were outside and inside the monasteries, so as to appear to be conforming to conversion forced upon them. ${ }^{542}$

Many Tibetan historians perceive Dönyö Dorjé's overt actions against the Gelukpas as being attributable to his close relationships with the 7th Black Hat Karmapa, Chödrak Gyatso, and the 4th Red Hat, Chödrak Yeshé. Some Tibetan historians maintain that Dönyö Dorjé's first major attack on Ü in 1480 or 81 was “commanded” (bka' bkod gnang) ${ }^{543}$, "encouraged" (bskul) ${ }^{544}$ or even “incited" (ngan skul byas) ${ }^{545}$ by the 4th Red Hat. In his influential historical chronicle the Re'u mig, Sumpa Kenpo portrays the 4th Red Hat as having had an even more central role in these events. He describes this campaign as follows: “1481: The Red Hat led ${ }^{546}$ the army of Tsang to Ü” (zhwa dmar pas gtsang dmag dbus su drangs). ${ }^{547}$ (However, in the longer version of Sumpa Kenpo's history, the dpag bsam ljon bzang, it is stated more clearly that the Red Hat along with

\footnotetext{
${ }^{542}$ Dungkar Rinpoché, chos srid zung 'brel, p 85; Nordrang Orgyen, p 306; Rasé Dawa Könchok Gyatso, 'bri gung chos 'byung, p 427. The New Red Annals mentions this moment (Tucci, p 199; Tucci's dates in the English translation are wrong, inserting 1406 for the me khyi year instead of 1526) but there is no mention of the issue of the hats. Nor are they mentioned in The Song of the Queen of Spring (if so, it would fall on Nordrang Orgyen, p 306).

Shakabpa, pp 89-90, states that around this time (the 1510s), Geluk monks (in all of Ü?) had special hats, which were red on the outside and yellow on the inside; when they came in from being outside, they would turn their hats inside-out. This story is likely the product of an oral tradition and may not represent historical fact.

${ }^{543}$ According to bod kyi lo rgyus dris lan brgya ba, when Dönyö Dorjé and his father led an army of 10,000 against $\ddot{U}$ in 1481, it was at the advice or command (bka' bkod gnang) of the 4th Red Hat, p 138. ${ }^{544}$ Hortsang Jikmé, p 509, says that the 4th Red Hat in 1481 encouraged (bskul) Künzangpa (Norzang's son; Dönyö Dorjé's father), and others, to attack Ü. This is likely following the dpag bsam ljon bzang, $\mathrm{p}$ 24 , in which the same word is used.

${ }^{545}$ Dungkar, chos srid zung 'brel, p 83, says that the 1481 attack on Ü by Dönyö Dorjé and his father was "incited" (ngan skul byas) by the 4th Red Hat.

${ }^{546}$ Drangs could also potentially be read as meaning "invited," but elsewhere in his histories Sumpa Kenpo uses drangs unanbiguously in the sense of leading troops and we have no reason to think he intends any other reading here.

${ }^{547}$ re'u mig, pp 51-2. This is quoted word-for-word in the TZCM's chronicle of Tibetan history, which is based on the re'u mig, p 3252
} 
the Karmapa merely encouraged (bskul) Dönyö Dorjé, who then led an army of 10,000 into $\ddot{U}{ }^{548}$ )

In the same vein, some historians maintain that the idea to disallow Gelukpa monks from participating in the annual Great Prayer Festival during the twenty years the Rinpungpas controlled Lhasa was actually suggested to Dönyö Dorjé by the 7th Black Hat Karmapa. ${ }^{549}$ We cannot be certain that these stories represent historical fact, but regardless of whether or not they are literally true, they are certainly indicative of the dynamics of the time. It is clear that the Rinpungpas, the 7th Karmapa and the 4th Red Hat of the Karma Kagyü all felt seriously threatened by the Geluk-Pakmodru partnership and were willing to resort to almost any means to counter them. Although it may be a bit of an overstatement, Dungkar Rinpoché writes that during the time of the 7th Black Hat, "In $\ddot{U}$ and Tsang there was a great struggle (or competition, 'gal zla che ba) between the Karma Kagyü and the Gelukpas; the Japa myriarch Tashi Dargyé and Dönyö Dorjé of Rinpung instigated a great disturbance to destroy the Geluk so that its very name would not even exist. At that time, ... there were military conflicts based on sectarianism...,

\footnotetext{
${ }^{548}$ dpag bsam ljon bzang, p 24. Tucci, TPS, Vol. II, p 564, translates the passage as follows: "Then Kun bzang's son Don yod rdo rje of sGar, sDe pa of Rin spungs, was solicited by Zhva dmar, Kar ma Chos grags rgya mtsho, and beginning from the year earth-ox, (1481) he led about 10,000 soldiers against dBus; having driven out the dGa' ldan's patron, who was in charge of the effort of sNeu, although he had conquered dBus, nevertheless he was twice beaten back by Khri sMon lam pa, by means of great liturgical offerings."

${ }^{549}$ Dungkar Rinpoché, chos srid zung 'brel, p 83, says that when Geluk monks were disallowed from participation in the Great Prayer Festival for 20 years, it was incited (ngan skul byas) by the 7th Karmapa; according to bod kyi lo rgyus dris lan brgya ba, this was at the advice or command (bka' bkod gnang) of the Karmapa, p 138.

${ }^{550}$ Dungkar Rinpoché dictionary, p 36. lhag par du dbus gtsang gnyis su karma bka' brgyud dang / dge lugs pa'i bar gyi 'gal zla che ba dang / bya pa khri dpon bkra shis dar rgyas dang / rin spungs don yod rdo rje gnyis kyis dge lugs ming med du gtor ba'i 'khrugs pa chen po bslang skabs grub mtha'i phyogs lhung phyogs 'gal la brten pa'i dmag 'khrug byas na... 441.

On Tashi Dargyé of Ja, see The Song of the Queen of Spring, TPS, Vol. II, pp 647-8; Nordrang, p
} 
But the Rinpungpas' and Karma Kagyüpas' aim of disrupting the stability of the Geluk-Pakmodru venture was not to be achieved through destructive means alone. One way to check the influence of the Gelukpas in the Tibetan cultural sphere was to foster the vitality of the Kagyüpas. We know that in addition to the Karmapas and the Red Hat, the Rinpungpas were financial supporters of the Drikungpas, Taklungpas ${ }^{551}$, the Madmen of Ü and Tsang and many others associated with the Kagyü sect. (As we will see in the next chapter, Drukpa Künlé resisted Dönyö Dorjé’s overtures.) Below we will see that the Rinpungpas also supported the Sakyapas, who offered a strong alternative to the Geluk sect in Tsang. The Rinpungpas were interested to support those who offered an alternative to the Geluk. But the Rinpungpas were also interested to strengthen the Kagyü and the Sakya monastic networks, which increased their symbolic presence in a given area, and gave the the Rinpnugpas an enduring, physical network through which to enforce their hegemony. ${ }^{552}$

\footnotetext{
${ }^{551}$ The 12th abbot of Taklung Monastery, Taklung Ngawang Drakpa (thams cad mkhyen pa ngag dbang grags pa dpal bzang), is said to have had a patron-priest relationship with the Rinpungpas ever since his meeting Norbu Zangpo (stag lung chos 'byung, pp 428, 438-9), which carried over into his having a similar connection with Tsokyé Dorjé and Dönyö Dorjé. Ngawang Drakpa sees the two of them on numerous occasions in the 1480s and 90s between the Nedong area and Chushül Lhünpo Tsé. At one point Tsokyé Dorjé welcomes Ngawang Drakpa to Yarlung with 500 horsemen. He gives teachings and initiations to Dönyö Dorjé, who claims to have great faith in him. These meetings give an idea of the activities of Dönyö Dorjé during this time, officially working as a representative of the Pakmodru government, circulating among various strategic locations in $\ddot{U}$, and meeting with religious figures in the midst of their political careers. See the stag lung chos 'byung, p 440-55. Within just a few pages of this text, Dönyö Dorjé is referred to as nang so (p 438), drung (p 440), sgar pa (p 440), sa skyong (p 443), mi'i dbang po (p 481). See also Sørensen, "Lhasa Diluvium," p 116.

${ }^{552}$ Regarding the greater political significance of monasteries, The New Red Annals relates how Dönyö Dorjé's famous grandfather, Norbu Zangpo, then serving as administrator of Shigatsé, was asked by the dharmalord (chos rje) of Ngor Monastery (ngor) to prevent the building of Tashi Lhünpo monastery in Shigatsé and convert all of the Geluk monasteries in his district to Sakya. The Rinpungpa lord refused, saying it was not right for an adimnistrator to make his subjects change their sect (Tucci, pp 239-40). The very fact that this story is told in The New Red Annals shows that it was a somewhat remarkable occurance: given the politics of the time, it might have been expected that the Rinpungpas would stop the construction of this new Geluk institution. It seems something of an anomaly that they did not-an historical quirk requiring explanation. The 5th Dalai Lama says that this story is false, although his own account seems suspect (Tucci, TPS, Vol. II, p 642; Nordrang Orgyen, p 405).
} 
During the years of the Rinpungpas' military expansion, drawing ever-nearer to taking control of Lhasa, the center of the Geluk world, one of their agendas was to establish a stronger Kagyü presence in the Lhasa-area. The 7th Karmapa and other Kagyüpas recognized the significance of Lhasa and felt some urgency to increase the presence of their sect there. A very colorful and revealing passage in the biography of the 7th Karmapa included in The Scholar's Feast (and later in the History of the Karma Kagyü) relates the following story. In the late 1470 s the Karmapa had on three occasions heard a prophecy from the Buddha Maitreya about how the Jowo Sākyamuni statue in the Jokang temple should be surrounded by a pure monastic community (dge 'dun gtsang seng ba'i sde zhig), which would revive the state of the Buddha's Teachings in Tibet. (This is clearly an implicit criticism of the Gelukpas who had been in control of the Jokang for some years.) So the Karmapa approached the governor of Neudzong (the gzhis ka snel pa) with his request to establish a new monastic community in Lhasa, but permission was not granted. The Karmapa did not give up, as he felt that a command of Maitreya's should not be treated so lightly and was confident that his undertaking would benefit the Teachings. He lamented how in this degenerate age those responsible for the site (i.e., the local Gelukpas) pretended to practice religion, but were only concerned with amassing wealth in the manner of householders; although externally they wore the garb of monks, they were perpetually making preparations for war. It seems that at this time the Karmapa and his followers were in a position to try to forcibly take control of the site, but decided not to do so because of their Buddhist principles. Meanwhile an army of five hundred (Geluk) monks ${ }^{553}$ assembled and descended upon the Kagyüpas’ camp.

${ }^{553}$ The Scholar's Feast, 2006 version, p 550 and Karma Kamtsang history, p 559.6, simply say ser dmag, 
According to the text they wore their begging bowls as helmets and using their cushions as lance banners. Fortunately all those in the Karmapa's camp obeyed his order not to fight back, and nobody was harmed. ${ }^{554}$

This story suggests that the Kagyüpas had been expressing an interest in establishing a stronger presence in Lhasa for some time before Dönyö Dorjé took control of that territory and made their doing so a real possibility (even if it would only be shortlived, with the the hold of the Gelukpas proving too strong in the end). ${ }^{55}$

Dönyö Dorjé sponsored the construction of a few monasteries in or near Lhasa for the 7th Karmapa and the 4th Red Hat, although the records at our disposal are unclear as to their names, locations and dates when they were founded. None of them lasted long as a stable monastic institution. What we know about them is as follows:

1) During the twenty years the Rinpungpas controlled Lhasa it seems that the Karmapa wanted to establish a monastery on top of Marpori (dmar po ri), the large hill in the center of town that would later become the site of the grand Potala palace, home of the Dalai Lamas. Dönyö Dorjé was skeptical about the prospects of building a full monastery there, citing strong opposition by the local Gelukpas, so only a more modest residence (the khang gsar) was built. The site had been in the possession of the Karmapas since the time of the Third Karmapa, Rangjung Dorjé (1284 - 1339). We see

which usually means "monk army." Sørensen, "Lhasa Diluvium," p 115, translates ser dmag as "monks from Sera."

${ }^{554}$ The Scholar's Feast, 2006 version, pp 549-50; Karma Kamtsang history, pp 558.7-559.7. This passage is translated in Sørensen, pp 114-5. Sørensen notes how the governors of Neudzong during much of this time were patrons of the Karmapas, in addition to being financial supporters of the Gelukpas.

${ }^{555}$ In the words of Per Sørensen and Guntram Hazod, "Among the main instigators of the Rin-spungs military and political activity in Central Tibetan territories were the Karma-pa hierarchs, who never ceased coveting the lHa-sa area and its prestigious national legacy," p 51. 
this mentioned in the biography of the 4th Red Hat, when he consecrates the structure, then visits it again later with Dönyö Dorjé. ${ }^{556}$

2) There was also a monastery built on behalf of the Karmapa, which popular history maintains was razed by monks of the nearby Geluk monasteries not long after it was established. ${ }^{57}$ The 5th Dalai Lama in his Song of the Queen of Spring chooses to give only a very veiled description of this event, stating that "because no one could

${ }^{556}$ The Scholar's Feast, 2006 version: he performs the consecration (rab gnas) ceremony at the po ta la' $i$ khang gsar, p 582; he goes to the Potala with the sa skyong chen po, i.e., Dönyö Dorjé, p 585. In the Karma Kamtsang History, these are pp 617 and 621 respectively. Sørensen, "Lhasa Diluvium,” p 116

The Scholar's Feast states that because their Kagyü dharma center around the Jokang temple was destroyed, the sde pa wanted to build one at the Potala, but he did not get permission. So they laid the foundation for the thub chen chos 'khor on the east side of Lhasa... But the rten 'brel were not very good, pp 563-4.

${ }_{557}$ The histories of these two monasteries deserve further research in their own right.

There is no mention of the founding of any of these monasteries in The New Red Annals.

The Song of the Queen of Spring mentions two monasteries: Yangpachen, built for the Red Hat, and "a monastery near Lhasa" built for the Karmapa. Hovewer, because no one could stop the karmic forces, this latter monastery did not last long (Nordrang, p 408; Tucci, TPS, Vol. II, p 642). Nordrang Orgyen in his commentary states that this monastery was called karma dgon gsar thub bstan chos "khor, was built in 1503, and that it was destroyed by monks from Sera and Drepung; he observes that "As the Rinpungpas led troops to Ü because of [?] sectarianism between the Ka[gyüpas] and Ge[lukpas], there were many unpleasant times" (kar dge grub mtha'i phyogs zhen dang bcas rin spungs pas dbus su dpung 'jug sogs dus mi bde ba mang po byung).

The Scholar's Feast, p 587, mentions that a disciple of the 4th Red Hat or the 7th Karmapa wanted to build something at thub bstan chos "khor (in Lhasa) but "the merit of Tibet was not enough."

According to Richardson, "The Karma-pa Sect: A Historical Note," p 347, two Karmapa monasteries were built near Lhasa "in order to overawe" Drepung and Sera during the 20 years the Rinpungpas controlled Lhasa: one he does not name; the other was near Drepung and called Yamdapur Tubwang Lekshé Ling (ya mda' phur thub dbang legs bshad gling). This is the only reference I have seen to a monastery by this name.

The TZCM, p 3253, mentions the founding of thub bstan chos 'khor in 1503. The re'u mig does not mention the founding of any of the Lhasa-area Kagyü monasteries

According to the Dungkar Rinpoché dictionary, p 26, the Red Hat monastery was called Karma Gönsar (karma dgon gsar) or Gönsar Tubten Chökor (dgon gsar thub bstan chos 'khor), and was built in 1503 on the east side of Lhasa.

Tucci mentions these two monasteries, TPS, Vol. I, p 40, saying that they were built near Sera and Drepung.

Shakabpa, pp 87-8, presents the construction and descruction of the Karmapa's monastery as having happened relatively early, so that Dönyö Dorjé's campaign into Central Tibet in 1480 was in retaliation to this attack from representatives of the Geluk sect. This is not supported by any other sources.

See also Wylie, "Monastic Patronage in 15th-century Tibet," p 326; Dungkar Rinpoché, chos srid zung 'brel, $\mathrm{p} 83$. 
prevent certain karmic forces, [the monastery] did not last long." Sørensen, this monastery was called Tubten Chökor Ling (thub bstan chos 'khor gling), and was built in the eastern part of Lhasa, not far from the Barkor. ${ }^{559}$ It was commonly known as the "New Karma Monastery" (karma dgon gsar). The 7th Karmapa evidently lived there for some time towards the end of his life.

Hugh Richardson and Giuseppe Tucci both suggest that there was another Karma Kagyü monastery built during this time, closer to Drepung monastery. They may be referring to the institution established on top of Marpori.

More research needs to be done into the precise historical timeline of these events, as well as the location and names of these Kagyü institutions, how long they were in operation, and so on. What is clear is that Dönyö Dorjé was involved in their establishment. Tibetan historians are also in agreement that these monasteries were built with direct competition with the Gelukpas in mind. Many of the received histories explicitly state that these monasteries were built to counteract or suppress ( $k h a g n o n d u$ ) the three Geluk monasteries. ${ }^{560}$ Sumpa Kenpo goes so far as to say that they built two Karma Kagyü monasteries on the east side of Lhasa, "with the intention that they would naturally destroy Sera and Drepung” monasteries (rang shugs kyis med par byas 'dod). Sumpa Kenpo states that the Karma and Drukpa Kagyüpas together led some troops, converted some small Geluk monasteries, and stole some estates from Sera and

\footnotetext{
${ }^{558}$ las 'bras kyi shugs 'di gang gis kyang dgag par ma nus pas/ yun du ma gnas pa... The Tibetan is from Nordrang Orgyen, p 408.

${ }^{559}$ Its founding is mentioned in the biography of the 7th Karmapa given in the history of the Karma Kamtsang, p 586. Dungkar Rinpoché, chos srid zung 'brel, p 83, notes the common name for this monastery.

${ }^{560}$ This terminology is first used in Sumpa Kenpo's dpag bsam ljon bzang, p 24. This terminology is taken up by Dungkar Rinpoché, chos srid zung 'brel, p 83; and by bod kyi lo rgyus dris lan brgya ba, p 139. Also Richardson, "The Karma-pa Sect: A Historical Note," p 347.
} 
Drepung_because of all this, "the Karma [Kagyü] and the Geluk were [at odds], like a

bat and the light of day." ${ }^{, 561}$ We can take these statements as indicators of the seriousness of sectarian competition during this time.

Dönyö Dorjé sponsored the building of another monastery that, not falling under the sway of "certain karmic forces," did last and about which more is known. This is Yangpachen Monastery (yangs pa can), which would become the new seat of the 4th Red Hat. Many sources state that this monastery was built around 1490, while others say 1503. The biography of the 4th Red Hat given in the History of the Karma Kagyü makes it clear that it was this latter date. ${ }^{562}$ Historians who maintain that Yangpachen was built in 1490 may be confusing it with the Red Hat monastery built in Lhasa, described above. $^{563}$

Here I will make a few comments about the founding of these (probably) three Kagyü monasteries, inspired by the argument made by Turrell Wylie in his 1980 article, "Monastic Patronage in 15th-century Tibet." ${ }^{564}$ When we compare the circumstances

${ }_{561}^{562}$ dpag bsam ljon bzang, p 24. kar dge gnyis pha wang dang nyi 'od ltar gyur...

${ }^{562}$ In the Karma Kamtsang history, pp 618-21.

${ }^{563}$ Richardson, “The Karma-pa Sect: A Historical Note," p 339, says this monastery was founded in 1489. However, Dungkar Rinpoché dictionary, p 1846 says this monastery was not established (btab) until 1503. According to the most reliable accounts of the 4th Red Hat's life, presented in The Scholar's Feast (and repeated in the Karma Kamtsang history), he had visions regarding Yangpachen monastery starting in 1501 (lcags bya) (p 583); he drew the foundation (rmang bting) for the future monastery in 1503 (chu phag) (p 584); the construction is described thereafter, continuing through 1504 (shing byi). The pages for these events in the Karma Kamtsang history are pp 617 and 619.

The re'u mig, p 54, says that the 4th Red Hat "took" (bzung) the monastery in 1503; it may have been under construction for some time before then.

The source of the confusion regarding when the monastery was founded may be the fact that in 1490 (lcags khyi) a monastery called thub bstan yangs pa can was founded by a Sakyapa named Mü Rabjampa Tukjé Pel (mus rab 'byams pa thugs rje dpal), re'u mig, p 52. The Red Hat monastery was formally called byang yangs pa can, "the Northern Yangpachen." Sørensen, "Lhasa Diluvium," p 116 says that there was also a Geluk monastery called Yangpachen, adding to the potential for confusion.

${ }^{564}$ Wylie's article is mainly about the founding of Yangpachen Monastery and how it fit into the Rinpungpas' ambitions towards conquering Lhasa. Wylie was working under the assumption that Yangpachen was built in 1489, before the Rinpungpas took over the Lhasa area. Although this date is 
surrounding the creation of Yangpachen and the two Kagyü monasteries in Lhasa with the pattern established with the founding of Ganden, Drepung and Sera monasteries, the specific aim of Dönyö Dorjé in founding these Kagyü monasteries comes clearly into relief.

Whereas Ganden, Drepung and most likely Sera were all sponsored by administrators whose seats were quite close to the monastery in question, Yangpachen and the two Kagyü monasteries in or near Lhasa were all nowhere near the seat of Dönyö Dorjé's power in Tsang. ${ }^{565}$ Second, Ganden, Drepung and Sera were all bestowed to masters who did did not have home monasteries of their own; Yangpachen Monastery and the two other Kagyü monasteries, on the other hand, were built for the Red Hats and the Karmapas, who already monasteries of their own in the Tölung valley. These three Kagyü monasteries were thus in a sense redundant. These points of comparison lay bare the role these monasteries played in Dönyö Dorjé's ambitions towards gaining a permanent foothold in the Lhasa area.

For the foundation of the Kagyü monasteries in or near Lhasa the strategic significance is quite obvious: the Kagyüpas wanted to increase their presence in the largest and holiest town in all of Tibet, both to increase their own presence there and to counter the Gelukpas' dominance in that place. The strategic significance of Yangpachen Monastery is less immediately obvious. To understand its significance we must consider the geography of central Tibet. In the 15th and 16th centuries there were three main travel routes between Lhasa and Shigatsé (the capitals of the Ü and Tsang regions

attested to in some historical sources, I think the biography of the 4th Red Hat, in which it is clearly stated that the monastery was built in 1502 and 1503, must be taken as the correct dating. This does not render Wylie's article irrelevant, however, as the kind of thinking Wylie is suggesting is still valid and very useful. ${ }^{565}$ Wylie, p 325. 
respectively and the two largest towns in Tibet): there was the central route that followed the Tsangpo river; the southern route through Nakartsé and Gyantsé; and the northern route through the Uyuk ( ' $u y u g$ ) valley. The central route had long been under the control of the Rinpungpas, as it passed directly through their original power base. The southern route came under the control of the Rinpungpas when they conquered Gyantsé in 1485 or 88 (our sources are unclear as to when the Rinpungpas took this town). This left only the northern route through the Uyuk valley, which Wylie maintains was the "shortest natural route" between Lhasa and Shigatsé. ${ }^{566}$ Yangpachen Monastery was built directly on this northern route, at the crossroads with the route going to Damshung. It thus seems that Yangpachen Monastery was built for tactical reasons: the monastery would have given the Rinpungpas control over the third and final route between Lhasa and Shigatsé, and would have constituted a base of operations within striking distance of Lhasa. ${ }^{567}$

We can think of the founding of Yangpachen Monastery as an attempt by Dönyö Dorjé's to expand the reach of his domain. In a sense, the monastery constituted an outpost of Rinpungpa influence. ${ }^{568}$ It would be inhabited by a Red Hat who was very much in their debt. ${ }^{569}$

\footnotetext{
${ }_{566}^{567}$ Wylie, p 328.

${ }^{567}$ The strategic importance of this monastery is suggested by the fact that it also played a role in the struggle between the depa of Tsang and the 5th Dalai Lama's regime in the 17th century: Dungkar Rinpoché states that after the Tsangpa desi and the 6th Red Hat led an army to Ü and damaged Sera and Drepung monasteries in 1618, when Gushri Khan went to destroy the Tsangpa desi in 1642, he attacked Yangpachen Monastery along the way. Dungkar Rinpoché dictionary, p 1846.

${ }^{568}$ Charles Ramble has discussed bits of this history from a similar perspective. He sees the construction of Tashi Lhünpo Monastery in Shigatsé in 1445 an "act of provocation" (un acte de provocation) against the Karmapas and the Rinpungpas, pp 170-1 in his "Chronologie" in Tibétains: 1959-1999: 40 ans de colonization, edited by Katia Buffetrille and Charles Ramble (Paris: les Éditions Autrement, 1998).

${ }^{569}$ Wylie has made the argument that the establishment of this monastery was integral to the Rinpungpas' eventually being able to seize the Lhasa area, when earlier attempts had failed. But as it seems
} 
The haziness of the histories of these monasteries show that the Kagyüpas had only limited success in establishing institutions in direct proximity to Lhasa. But they also moved into areas surrounding Lhasa, especially the hilly areas to the northeast. The Madman of Ü was himself a participant in the Kagyüpas' zeroing-in on Lhasa. After spending many of his adult years in Tsang and western Tibet, it was in Penyül ( 'phan $y u l$ ), northeast of Lhasa (less than 50 miles from Lhasa proper) that he established a monastery and settled later in his life. Ehrhard sees the fact that the Madman of Ü ended up settling there, of all places, as part of this larger concern by the Kagyüpas to increase their presence in the Lhasa area. ${ }^{570}$ We can also see the Kagyüpas' concern to establish a presence in Lhasa expressed in the call by Karma Trinlepa (1456-1539) to Dakpo Rabjampa Chögyel Tenpa (dwags po ram 'byams pa chos rgyal bstan pa, 1449-1524) to take control of the Yerpa retreat caves ( $\operatorname{rag}$ yer $\mathrm{pa}$ ) just outside of Lhasa, as recorded in The Scholar's Feast. ${ }^{571}$

Here we are exercising a way of thinking about Tibetan Buddhist monasteries that is not always considered. We are looking at how in addition to their importance as dwellings for monks and sites of religious practice, on another level monasteries may be significant as strategic institutions of more worldly affairs. In this case we can imagine

\footnotetext{
Yangpachen was established in 1503 instead of 1490, as Wylie had thought, this argument no longer holds, as we know the Rinpungpas had control of Lhasa by 1498. Yangpachen was certainly important to expanding the influence of the Rinpungpas, but the specific argument about its contributing to their capture of Lhasa cannot be made.

${ }^{570}$ In Franz-Karl Ehrhard's assessment, "In the period under consideration these sites were coming under the administrative and religious influence of the Karma bKa'-brgyud-pa school, and this may have contributed to Kun-dga' bzang-po's choice of rTsi-dmar dpal as a residence after the years of pilgrimage to regions in the south-west and south-east of Tibet," "The Holy Madman of dBus and His Relationships with Tibetan Rulers of the 15th and 16th Centuries," in Geschichten und Geschichte: Historiographie und Hagiographie in der asiatischen Religionsgeschichte, edited by Peter Schalk (Uppsala: Uppsala University Library, 2010), p 243.

${ }^{571}$ In the 2006 version, p 595.16-17; in the 1986 version, p 1166.11-12. Ehrhard, "The Holy Madman of dBus...", p 243.
} 
the Rinpungpas and the Pakmodrupas as engaged in a multi-faceted chess match being played out in a variety of spheres: military, political, cultural and religious. From this perspective these monasteries can be seen as like chess pieces, strategically placed for maximal effect in the larger struggle between two factions.

The Rinpungpas were not the only political agents in 15th-century Tibet who saw defying the authority of the Pakmodrupas and acting against the Gelukpas as going hand in hand. In Peṇchen Sönam Drakpa's New Red Annals (written 1538) it is recorded how in the territory of Gyama (rgya ma), one lord (dpon) "opposed the Pakmodrupa desi and drove away (mthar 'ded) the Gendenpas [i.e., Gelukpas] and destroyed a statue of the Precious Lord, [Tsongkhapa]." 572 To the inhabitants of central Tibet in the 15 th century, the symbiotic relationship between the Pakmodrupas and the Geluk sect was apparent; it was equally apparent that one way to hurt the Pakmodrupas was to attack the Geluk monks and monasteries that were close at hand, as they were in a very real sense proxies, agents of the Pakmodru regime.

Some readers may be surprised to see the extent to which militaristic and religious affairs came together in 15 th- and 16th-century Tibet. Here we have only seen the tip of the iceberg. Indicative of the seriousness of the situation, in 1494 the Second Dalai Lama was forced to leave Tashi Lhünpo in Shigatsé—stronghold of the Rinpungpas — and go to Drepung to ensure his safety. Then after 1498 when the Rinpungpas took Lhasa, the Second Dalai Lama was forced to leave Drepung and spend a period traveling to different places in eastern Ü, away from the reaches of Dönyö Dorjé and his supporters. (It was during this time the Second Dalai Lama founded Chökor Gyel Monastery, chos 'khor

\footnotetext{
${ }^{572}$ My translation, based on Tucci, p 195; the Tibetan is on 60a.
} 
rgyal, near Dakpo in $1509 .{ }^{573}$ ) From even this brief consideration of 15 th-century

Tibetan history we clearly see the interrelatedness and in fact inseparability of religious and secular affairs. ${ }^{574}$ Here we are getting a sense of the roles played by important Tibetan religious figures as more than just men of religion. When we look at the historical circumstances of their lives we see that they are always connected in some way to worldly affairs, which are not always peaceful.

Our understanding of these figures is heavily influenced by the vicissitudes of the texts that tell us about them. The historian Sumpa Kenpo created a very unfavorable presentation of the 4th Red Hat. In his historical chronicle of Tibet, the re'u mig, the 18th-century Gelukpa author states that the Red Hat himself led Dönyö Dorjé's troops in their attack on Ü. In his history the dpag bsam ljon bzang, he asserts that the Red Hat worked with the Drikungpas in seizing territories belonging to the Geluk and forcibly converting monasteries. ${ }^{575}$

Sources composed by Kagyü authors give a markedly different portrayal of the activities and motivations of the 4th Red Hat. In the Second Pawo, Tsuklak Trengwa's (dpa' bo gtsug lag 'phreng ba) biography of him, the Red Hat is actually said to have

\footnotetext{
${ }^{573}$ Wylie, "Monastic Patronage in 15th-century Tibet," pp 326-7; Tucci, TPS, Vol. I, p 41, describes the Second Dalai Lama's significance and movements during this time. Sørensen and Hazod, p 52, describe how the Second Dalai Lama spent these years in exile networking - building allies, founding monasteries, and strengthening his position in preparation for his eventual return to Lhasa and to a position of power. ${ }^{574}$ After the decline of the Rinpungpas there would be serious fighting between the Drikungpas and the Pakmodru-Geluk regime. In the 1520 s and 30 s there were a number of military campaigns, with estates being stolen back and forth, and the Drikungpas' seizure of eighteen Geluk monasteries, which they converted to the Kagyü. See Hortsang Jikmé, p 511; Dungkar Rinpoché, chos srid zung 'brel, pp 84-5; Tucci, TPS, Vol. I, p 43; Tucci, The New Red Annals, pp 200-1; Sørensen, "Lhasa Diluvium," p 118. This was surely not the beginning of the conflict between the Drikungpas and the Pakmodrupas, as these two factions (here the Pakmodrupas are referred to as those from gdan sa thel) had a conflict over retreat sites at la phyi and chu bar during the lifetime of the Madman of Tsang, Götsang Repa, p 210.1-.7. On this conflict, see Toni Huber, "A Guide to the La-Phyi Mandala: History, Landscape and Ritual in SouthWestern Tibet," in Mandala and Landscape (Emerging Perceptions in Buddhist Studies, No. 6), edited by A. W. Macdonald (Delhi: D. K. Printworld, 1997b), pp 242-3.

${ }^{575}$ dpag bsam ljon bzang, 202.
} 
tried to dissuade Dönyö Dorjé away from fighting on a handful of occasions. In around

1497 (the me sprul year, after the Rinpungpas' successful invasion of the Lhasa area, which would result in 20 years of occupation) it is reported that a great army of troops from Tsang (i.e., the Rinpung regime) and Ja (bya, i.e., Japa Tashi Dargyé's troops) had arrived in the Lhasa area (skyid shod) and were on the verge of destroying the Neudzong (gzhis ka snel pa) estate. So the governors of Neudzong, along with those of Taklung and Olka (i.e., Olka Taktsé, the seat of the Drakarwas, where Ganden monastery is located) asked the Red Hat and the 7th Karmapa for protection. The Red Hat and the Karmapa managed to ensure that Sera and Ganden monasteries would not be destroyed and their estates remained intact. ${ }^{576}$ (Some sources indicate that during the years the Rinpungpas controlled Lhasa, the Drakarwas and Neudzongpas became patrons of the Kagyüpas. ${ }^{577}$ It is likely that it would have started around this time, as they bowed under the pressure

${ }^{576}$ The Scholar's Feast, 2006 version, p 581; Karma Kamtsang history, p 615. See also The Scholar's Feast, p 579 (Karma Kamtsang history, p 620), when the Red Hat protects someone from intimidation from Dönyö Dorjé's army when they were in Yarlung in 1492; and The Scholar's Feast, p 585, when the Red Hat convinces the Rinpungpas not to send troops to lho stod.

In his dictionary, Dungkar Rinpoché states that the 7th Karmapa tried to prevent Dönyö Dorjé and Japa Tashi Dargyé from creating so much strife against the Gelukpas, but his words fell on deaf ears; he is probably referring to this occasion, $\mathrm{p} 36$.

Richardson, $p$ 347, summarizes the career of the 4th Red Hat, stating that he "turned with energy to politics and worldly interests. He acted as a sort of 'cardinal-counsellor' to the princes of Rin-spungs, who in 1481 effectively usurped in central Tibet the authority of the Phag-mo-gru-pa rulers which they had been undermining since about 1435. He joined in the struggle against the rivals of Rin-spungs, including the rising power of the Dge-lugs-pa sect and its lay supporters. From 1498 to 1518 the Karma-pas excluded the monks of 'Bras-spungs and Se-ra from the Great Prayer ceremony which had been initiated by Tsong-kha-pa; they also founded monasteries of the Zhwa-nag and Zhwa-dmar schools near Lhasa in order to overawe 'Bras-spungs and Se-ra- that near 'Bras-spungs was called yam mda' phur thub dbang legs bshad gling; and they exacted respectful salutes from any Dge-lugs-pa who met a Karma-pa. Chos-grags ye-shes [the 4th Red Hat] took the lead in these matters and the same militant spirit was shown by his successors..."

${ }^{577}$ Sørensen, "Lhasa Diluvium," pp 113, 115. See the biography of the 4th Red Hat in the Karma Kamtsang history, when he meets with ministers of sne'u gdong (should perhaps be sne'u rdzong) and brag khar (brag dkar) as patron and priest, p 618.

In the History of the Taklung Kagyü it is mentioned that after the Rinpungpas' initial campaign into the Lhasa area around 1480, the gzhis ka snel pa (i.e., the ministers of Neudzong) become faithful patrons of the Taklung Kagyü (stag lung chos 'byung, pp 440, 442, 445). 
of the Rinpungpas' military presence in the area and as repayment for the Red Hat and the Karmapa's interceding on their behalf against Dönyö Dorjé.) Pawo Tsuklak Trengwa concludes that, because of his efforts at preserving peace, the 4th Red Hat was a refuge for all the inhabitants of central and western Tibet, protecting them from fear. ${ }^{578}$ That the 4th Red Hat can be portrayed in two such contrasted ways - as a foe intent upon destruction, and a great protector-is an indication of the seriousness of the sectarian conflict during the time in which he lived. Dönyö Dorjé may perhaps have the same kind of dual legacy: as a dharmaking, a benevolent protector and patron, but also a warlord.

The 4th Red Hat Chödrak Yeshé and Dönyö Dorjé had a complex partnership. The ever-present threat of Dönyö Dorjé's army is what propelled the 4th Red Hat into his position of great power, as he was appointed spyan snga, head of Densa Til Monastery, by the Rinpungpas. Dönyö Dorjé was the strong arm that propped up the Red Hat. At the same time, Dönyö Dorjé's rule was granted legitimacy through his association with the Red Hat. Supporting the Red Had earned Dönyö Dorjé the reputation as—or at least, the ability to claim himself to be - a righteous Buddhist ruler dedicated to the spiritual prosperity of Tibet. Hugh Richardson states that the 4th Red Hat "acted as a sort of 'cardinal-counsellor"' to the Rinpungpas. ${ }^{579}$ They represented two arms of a single organization, secular and religious. What brought them into this partnership was a shared interest in increasing their own influence and power, which could not be achieved without antagonizing the Pakmodrupas and the Gelukpas. As we saw above, the Pakmodrupas and the Gelukpas were in a mutually beneficial alliance in which the

\footnotetext{
5782006 version, p 587.

579 “The Karma-pa Sect: A Historical Note," p 347.
} 
Gelukpas received patronage and official backing, while the Pakmodrupas used the Gelukpa organization for symbolic legitimization and to have their own interests and influence spread. The Rinpungpas and the 4th Red Hat and the 7th Karmapa had the same sort of relationship. ${ }^{580}$

And these two factions of mutually-beneficially-aligned priests and patrons came into direct conflict with one another. As the Rinpungpas endeavored to undermine the Pakmodrupas and expand their own power, they also had to attack the Gelukpas. This was achieved through direct means, such as attacking Geluk monasteries and their patrons in the Lhasa area. This was also achieved through indirect means by supporting the Karma Kagyü sect. ${ }^{51}$ The Karmapa and the Red Hat wanted to preserve the status of their own sect, and to do so had to do what they could to check the expansion of the Gelukpas. Thus they shared a very basic aim with the Rinpungpas, which made their formation of an alliance and a patron-priest relationship a natural conclusion. (Although it seems that in the end the Red Hat grew weary of Dönyö Dorjé's ambitions. The Red Hat took umbrage with Dönyö Dorjé for his constantly stirring up conflict, as this was causing life in central Tibet to deteriorate, and thus moved away from Dönyö Dorjé towards the end of Dönyö Dorjé's life.)

\footnotetext{
${ }^{580}$ As for symbolic legitimization, we get a glimpse of this in The Scholar's Feast where it is stated that the 7th Karmapa was on his way to Rinpung "which in the past was renowned in the prophecies of lord Marpa" (sngon rje mar pas lung bstan par grags pa'i gzhis ka rin spungs...) (2006 version, $\mathrm{p}$ 562). What this suggests is that the rule of the Rinpungpas was, in a sense, divine, and that their close association with the Kagyüpas - the heirs of Marpa's tradition - was a natural, predestined one. Until we are able to track down the origin of this "prophecy" we must keep in mind that the ones responsible for the gathering and composition of the Life and many of the works attributed to Marpa were the Madman of Tsang and his disciples; and the printing of these works was in many cases sponsored by the Rinpungpas themselves. ${ }_{581}$ Tucci, TPS, Vol. I, p 30: "By adhering to the [Red Hat], the [Rinpung] princes cut themselves off from the $[$ Pakmodru] also from a religious point of view..."
} 
15th-century Tibet was thus the site of a complex, multi-faceted battle. There

were two conflicts taking place at the same time, between the Kagyüpas and the

Gelukpas and between the Rinpungpas and the Pakmodrupas, with the former members

trying to supplant the influence of their better established rivals. The political struggle

made the competition between the Gelukpas and the Kagyüpas grow more intense,

turning into something of a proxy war. ${ }^{582}$ These were, in fact, different aspects of the

same conflict, taking place on different registers, religious and political. But because of

their interrelatedness, they were actually inseparable, ultimately all part of the same

greater conflict.

\section{III.2.iii Rinpungpas and Sakyapas}

The Rinpungpas had been, since their rise to power, steadfast supporters of the

Sakya sect through their patronage activities in their home region of Tsang. Dönyö

Dorjé's grandfather, Norbu Zangpo, who made the bold move of seizing Shigatsé and

launching the Rinpungpas' rise to power, also sponsored the founding of the Rong

Jamchen Chödé (rong byams chen chos sde). ${ }^{583}$ (Later, the abbot of this monastery,

\footnotetext{
${ }^{582}$ Tucci, TPS, Vol. I, p 30, summarizes his understanding of the situation as follows: "Tibet was full of wars and military movements. Jealousy between sects and contrasting religious currents, more and more hostile, began to centre round the noble families' rivalries and to foster their quarrels; on one side the Kar ma pa, who had become chaplains of the Rin spungs princes, put their prestige and their exorcisms at the service of their patrons, hoping that in the hour of need they would prove their secular arm, the defenders of the sect's interests; on the other hand the rising church of the dGe lugs pa, founded by Tsong k'a pa, gathered around itself the dBus aristocracy, threatened by the Rin spungs's expansion and the religious sects who did not side with the Kar ma pa's corrupt formalism." Tucci further writes of how the Rinpungpas, "from the new court of bSam 'grub rtse [Shigatsé], which they had conquered since 1435, some of their ministers issued with a brave self-confidence, to take up, with greater daring, the dream of their masters. They intended to lead gTsang in a victorious offensive against dBus, now represented not by the Sneu gdong chiefs, reduced to a feeble appearance of power, but by the great monasteries of the Yellow Sect," $p$ 30. This suggests that the Geluk monasteries are where the real power in Ü resided, and therefore the Rinpungpas had to attack them.

${ }^{583}$ According to Nordrang Orgyen's interlinear commentary on The Song of the Queen of Spring, p 404, this was 1427. The text of The Song of the Queen of Spring mentions how he had built the monastery of rong byams chen (Tucci, TPS, Vol. II, p 642; Nordrang Orgyen, pp 404-5). Some sources say he founded
} 
Natsok Rangdröl, dharmalord of Jamchen Chödé, byams chen chos rje sna tshogs rang grol, would be said to be a reincarnation of a Rinpungpa lord (zhal ngo). This is a potent example of the symbiotic and ever-tightening relationship between the Sakyapas and their lay Rinpungpa backers. ${ }^{584}$ ) A giant Maitreya statue would be built there with Rinpungpa support. ${ }^{585}$ Norbu Zangpo also sponsored the founding of what would come to be known as the Dreyül Kyemö Tselkyi Chödé ('bras yul skyed mos tshal gyi chos sde). All of these were essentially Sakya institutions near the Rinpungpas' home district. ${ }^{586}$ Dönyö Dorjé's father, Künzang, had patron-priest relationships with the Sakyapas Künkyen Sangyé Pel (kun mkhyen sangs rgyas 'phel) and Gorampa Sönam Sengé (go ram pa bsod nams seng ge). He supported the founding of Tanak Tubten Monastery (rta nag thub bstan dgon), as well as the monastic college (bshad grwa) at Dreyül Kyemo Tsel. ${ }^{587}$ Through supporting these institutions and individuals, the Rinpungpas created religious merit, shored up the legitimacy of their rule, and supported a religious tradition that was in many ways synonymous with the greatness of Tsang itself.

Dreyül Kyemo Tsel Monastery ( 'bras yul skyed [mo] tshal dgon) in 1449 (re'u mig, p 48; Dungkar Rinpoché dictionary, p 1482); perhaps these two are synonymous? According to Nordrang Orgyen, a large Maitreya statue was completed in 1469. It may be that the monastery was called Dreyül Kyemo Tsel until the completion of the giant statue (Nordrang says it was nine stories tall) at which time it was called "Big Maitreya Dharma Center of Rong."

${ }^{584}$ The Scholar's Feast, 2006 version, p 587.

${ }^{585}$ According to Nordrang Orgyen, this was finished in 1469, p 404. According to The New Red Annals, Norbu Zangpo's father, Namka Gyelpo, made the pledge to have a giant Maitreya statue built in Tsang Rong; Norbu Zangpo brought that project to completion, Tucci, pp 238-9.

${ }^{586}$ According to Nordrang Orgyen's interlinear commentary to The Song of the Queen of Spring, p 405, this was 1437.

${ }^{587}$ This is from The Song of the Queen of Spring (Tucci, TPS, Vol. II, p 642; Nordrang Orgyen, p 406). Dungkar Rinpoché dictionary, p 1916. According to the re'u mig, p 51, this was 1478. Ngawang Namgyel, Dönyö Dorjé's cousin, who would become the next leader of the Rinpungpas after the former's death, is also mentioned as sponsoring activities at byams chen Monastery and elsewhere (Nordrang Orgyen, p 409; omitted from Tucci, TPS, Vol. II). 
This raises the important issue of the conflict between the Rinpungpas and the Pakmodrupas as being one of the Tsang region versus Ü. Giuseppi Tucci saw the issue of regional competition as an important motivating factor in the struggle that defined this time period. After a stretch of time in which Tsang dominated central Tibetan affairs during the reign of the Sakyapas (supported by the Mongolian Yüan dynasty), they chafed at being under the control of a regime based in $\ddot{U}$, the Pakmodrupas. A degree of regional pride may well have encouraged the Rinpungpa revolt, and may have motivated other chiefs in Tsang to join the Rinpungpa cause. ${ }^{588}$ A degree of competition between $\ddot{U}$ and Tsang is a factor in much of central Tibetan affairs even after this period, as seen in the struggle between the 5th Dalai Lama and the Tsangpa Desi in the early 17th century $^{589}$, and in the struggle between the 13th Dalai Lama and the 9th Penchen Lama in the early 20th century. ${ }^{590}$ Importantly, we have evidence that Tibetans living in the 15th century perceived the conflict between the Pakmodrupas and the Rinpungpas as a battle between $\ddot{U}$ and Tsang. Regarding the fighting that occurred around 1518, which resulted in the Rinpungpas' withdrawal from the Lhasa area, the author of Part II of The Life of the Madman of $\ddot{U}$ relates how upset the yogi was due to this "civil war that arose between $\ddot{U}$ and Tsang" (dbus gtsang gi sde 'khrug langs pa na...). ${ }^{591}$ Thus in addition to playing

\footnotetext{
${ }^{588}$ Tucci, TPS, Vol. I, p 27, suggests that this was in large part a battle of Tsang versus Ü. After having been in control of Tibet while the Sakyapas ruled, the Tsangpas did not like being under the rule of Ü. This helped bring together support the Rinpung revolt. See also pp 29, 30.

${ }_{589}^{5}$ Sørensen and Hazod, pp 55-6.

${ }^{590}$ These events are described in Melvyn C. Goldstein, A History of Modern Tibet, 1913-1951: The Demise of the Lamaist State (University of California Press, 1989).

${ }^{591} \mathrm{p} 608$. We cannot be sure that this actually represents the thought of the Madman of Ü, but at the very least the notion of the conflict being one of Ü versus Tsang was present in the mind of the Madman of Ü's disciple who composed this part of the text.

Ehrhard says this fighting broke out in 1516, "The Holy Madman of dBus...," p 220. Rasé Dawa Könchok Gyatso's 'bri gung chos 'byung also mentions the fighting between $\ddot{U}$ and Tsang that broke out in 1516 , during the reign of the 17 th abbot of Drikung, $\mathrm{p} 420$.
} 
out on political and religious registers, the great conflict that defined the 15 th and early 16th centuries in central Tibet was also tinged with an element of not nationalism but regionalism.

Dönyö Dorjé's patronage of the Kagyü was a part of his adventurism into Ü. The Karmapas and the Red Hats were already well established in Ü, with home monasteries in the Tölung valley, although they did not have much of a presence Lhasa. The Kagyüpas were already players in the struggle for influence in Ü before the rise of the Rinpungpas, and therefore were willing allies to the Rinpungpas in their wish to expand their influence into this new territory. The Sakyapas were less of a force in Ü. They had some monasteries in the region, but were not as important players as the Karmapas and the Red Hats. Yet Dönyö Dorjé's venture into Ü did not necessitate that he break with the tradition of supporting the Sakyapas established by his forefathers. Dönyö Dorjé continued to financially support representatives of the Sakya sect, who in many ways found themselves thrown into a partnership with the Kagyüpas. There is evidence suggesting that their shared interest in countering the Gelukpas played an important role in bringing them together.

We get a good idea of the religious and political dynamics of the time by looking at the career of one important Sakyapa scholar, Śākya Chokden (1428-1507). Sāàkya Chokden had close relations with the Rinpungpas, who gave him financial support. ${ }^{592}$ Śākya Chokden also had good relations with the Karmapas, especially the 7th Karmapa,

${ }^{592}$ Komarovski, pp 48, 99.

The Kyorlung Dharma History (skyor lung chos 'byung), written 1830-1, mentions the connection between Dönyö Dorjé and Śākya Chokden (C41a, p 161), in Per Sørensen and Sonam Dolma, Rare Texts From Tibet: Seven Sources for the Ecclesiastic History of Medieval Tibet (Lumbini International Research Institute, 2007). 
Chödrak Gyatso. ${ }^{593}$ It is reported in his biography that Śākya Chokden had very positive visions of the Karmapas. ${ }^{594} \mathrm{He}$ also received extensive teachings from the 12th abbot of the Taklung Kagyü. ${ }^{595}$ The Madman of Ü met Śākya Chokden on a few occasions at his monastery in Tsang, called Serdok Chen. (These meetings will be described in Chapter Six.) The Madman of Ü received teachings from the great Sakya scholar, and had him compose some texts on his behalf. ${ }^{596}$ Indicative of the good relations between Śākya Chokden and the Karmapa is the fact that a very favorable biography of Śākya Chokden was included in the famous history of the Karma Kagyü sect by Situ Penchen and Belo Tsewang Künkyab ( 'be lo tshe dbang kun khyab), written in the 18th century. ${ }^{597}$ Perhaps to some Śākya Chokden was something like an honorary Kagyüpa.

As for Śākya Chokden's position vis-à-vis the Geluk, we know that he was one of Tsongkhapa's most ardent critics, disagreeing with the great founder of the Geluk on a number of philosophical points. The differences between Śākya Chokden’s views and those of Tsongkhapa were systemic, having different fundamental views on the importance of logical reasoning and its relationship to the most important Buddhist realizations. Śākya Chokden admitted more room for alternative means for realizing

${ }^{593}$ p 40; see p 94, where Komarovski concludes, “It is important to notice that beside Śākya mchog ldan’s primary involvement in his own Sa skya tradition, he maintained connection with Bka' brgyud traditions throughout his life, and would receive teachings of Karma, Shang pa, Stag lung, and other Bka' brgyud lineages. There is no doubt that this connection extended beyond a mere intellectual understanding of different Bka' brgyud systems, and greatly contributed to his sympathetic attitude to the various practice lineages..."

${ }^{594} \mathrm{pp} 108-9$. Komarovski states that "from the age of forty Śākya mchog ldan saw the Karma pa—and possibly Karma Bka' brgyud views as well—as being 'on his own side."”

${ }_{595}$ stag lung chos 'byung, p 449.

${ }^{596}$ Komarovski, pp 111-2. These were the Garlands of Wondrous Ornaments of the Union of Calm Abiding and Special Insight: Guiding Instructions on the View of the Middle (dbu ma'i lta khrid / zhi gnas dang lhag mthong zung du 'jug pa ngo mtshar rgyan gyi phreng ba, Vol. 13, pp 190-202 in the Collected Works of Sākya Chokden); according to The Life of the Madman of $\ddot{U}$, the other text was about the Hevajra Tantra, p 509.

${ }^{597}$ Karma Kamtsang history, p 646. 
ultimate reality, including the experiences of meditators not schooled in Madhyamaka syllogisms, than Tsongkhapa was willing to. ${ }^{598}$ Another important point of disagreement was over the role tantra should play in one's religious system. ${ }^{599}$ As Slava Komarovski has characterized it, Śākya Chokden was "dismayed” at the lack of seriousness with which tantra was dealt in the Geluk (or soon-to-be-Geluk) system. The differences between the twe great exegetes were not purely academic in nature, however. Komarovski concludes that Śākya Chokden voiced his differences with Tsongkhapa not only because of disagreements over intellectual matters, but because the views held by the Sakya system were being "endangered" by the swiftly-rising Gelukpas, who were redefining the mainstream of Tibet's Buddhist discourse. ${ }^{600}$

Thus in addition to there being disagreements over theoretical matters, Śākya Chokden and his peers resented the growing power of the up-and-coming Geluk sect. Śākya Chokden's biography states that he was forced to study the teachings of Tsongkhapa by an official decree issued by the Pakmodru gongma. Śākya Chokden is later shown expressing great displeasure over this abuse of political power. ${ }^{601}$ Śākya Chokden was concerned about protecting teachings and lineages that he perceived as coming under threat because of the spread of the Geluk, and the particular ways in which they were re-forming Buddhism. (In this way Śākya Chokden has been compared to the later Rimé, ris med, or Ecumenical Movement. ${ }^{602}$ ) Komarovski states that Śākya

\footnotetext{
${ }^{598}$ Komarovski, pp 15-6.

${ }^{599}$ Komarovski, p 58.

${ }^{600} \mathrm{p} 17$.

${ }^{601}$ Komarovski, pp 89-90. See also pp 48, 106.

${ }^{602}$ Komarovski, p 14.
} 
Chokden was "bitter... about the rise of the Gelukpas..." "603 It may also be the case that the Sakyapas still harbored some resentment against the Pakmodrupas, who rebellion against them in the 14th century spelled the end of their supremacy in Tibetan political affairs. This might account for some of the ire Sākya Chokden held against the Gelukpas.

Śākya Chokden became an outspoken critic of the Geluk system because of both intellectual disagreements with points of the Geluk system and his resentment over the way the Geluk-Pakmodrupa partnership enforced their agenda. Śākya Chokden's critiques of the Geluk were so bold and incisive that the Gelukpas outlawed his writings after their rise to near-absolute power in central Tibet in the 17 th century. ${ }^{604}$

It was to some extent because of his stance contra the Gelukpas and the Pakmodrupas that Śākya Chokden had such good relations with the Karmapas and the Rinpungpas. ${ }^{605}$ They all had a shared interest in dealing with the threat posed by the aggressively spreading sect that was being promoted by the official rulers of central Tibet. It is significant that during the nearly twenty years the Rinpungpas controlled Lhasa, from 1498 to about 1518, during which time the Gelukpas were excluded from participating in the annual Great Prayer festival, it was the Kagyüpas and the Sakyapas together who took over this important ceremony.

\section{III.3 The Holy Madmen and their Patrons}

There was a complex host of reasons for a patron and a representative of religion to enter into a relationship of exchange in 15th- and 16th-century Tibet. These reasons

\footnotetext{
${ }_{604}^{603}$ p 88

604 Komarovski, p 3.

${ }^{605}$ This is my formulation. Something similar is suggested by Komarovski, p 95.
} 
were all essentially strategic, but registered in a wide variety of visible and invisible domains. For one, by becoming a patron of a religious figure, a layperson like Dönyö Dorjé would, according to traditional Buddhist thinking, accrue merit (basically, good karma). He would also gain access to some religious instructions, which he might (if he had the time and interest) put into use personally. He would also receive blessings through tantric empowerment. Or he may be employing the lama to perform salvific or life-protecting rituals on his or his family's behalf. For his part, the religious figure would receive material support—for himself, his students, his monastery and perhaps his lineage or sect in general. He would also gain an ally, a protector, an advocate.

We can also see that entering into such a relationship with a respected religious figure would bring a degree of standing and renown to the layperson. By being associated with an eminent monk or lama, the layperson's status would be elevated. On this level we can say that the lay patron uses his material capital to purchase a religious type of symbolic capital. We get a glimpse of the workings of patronage on this level when in The Life of the Madman of Tsang, at the conclusion of the yogi's restoration of the Swayambhūnāth stūpa in Nepal, there is a long list of all the significant patrons who supported the project and what each of them offered - exactly how much gold, silver, etc. This indicates that when a patron made significant offerings to a religious figure in 15 thcentury Tibet, it was as much a public act as a private one; it was something that people were meant to know about. ${ }^{606}$ The patrons would have wanted people to know about the offerings they made because of the symbolic capital it thereby accrued them. For someone like Dönyö Dorjé, having people perceive him as a liberal supporter of

\footnotetext{
${ }^{606}$ Götsang Repa, pp 220.6-226.3.
} 
Buddhism earned him some good will which helped solidify his rule in a shifting, uncertain political world. This would have been especially important for a faction like the Rinpungpas, who were usurping power without any official legitimacy of their own.

Looking at the other side of the equation from the same perspective, we can see that the monk or lama in question would receive some legitimization of his own worth by receiving something like official recognition from an important political figure.

Lastly, as we have seen throughout this chapter, a patron's relationship with an eminent monk or a yogi can have more direct political ramifications. One of the stated reasons a lay patron might support a religious figure is because of the merit (good karma) this would accrue him. But as the pattern of Dönyö Dorjé and the Rinpungpas' patronage activities belie, there was often political motivations determining who they would enter this kind of symbolic exchange with. In a sense, the patron is purchasing allies with the skillful use of his religious offerings. As we look at the relationships between the Madmen of Ü and Tsang and their main patrons, especially Dönyö Dorjé, we will see all of these factors at play. In the end what we are coming to see is that patronage and perhaps the holy madmen's efforts to earn that patronage were more strategic that many might assume.

\section{III.3.i The Patrons of the Madman of $\ddot{U}$}

The Rinpungpa family constituted the most important source of patronage for the Madman of Ü. The Madman of Ü met Dönyö Dorjé's older brother twice ${ }^{607}$; his father

\footnotetext{
${ }^{607}$ The Madman of Ü had a savage encounter with a sa skyong chos kyi rgyal po at Shigatsé; following Ehrhard (2010) p 231, I take this to be Dorjé Tseten (rdo rje tshe brtan, b. 1462), older brother of Dönyö Dorjé; The Life of the Madman of Ü, pp 503.2-503.6. Just a few pages later the Madman of Ü has an encounter with sa skyong chos kyi rgyal po rdo rje tshe brtan at Rinpung, p 506.4-.5.
} 
once $^{608}$; and his famous uncle, Tsokyé Dorjé, once. ${ }^{609}$ The Madman of Ü also received a letter of praise along with some offerings from Tsokyé Dorjé's son (Dönyö Dorjé's cousin). ${ }^{610}$ A woman of the Rinpung family, who was probably Dönyö Dorjé's aunt, also played an important role as a patron. She is the only donor listed by name for the construction of a jeweled reliquary built to hold the Madman of Ü's remains after he was cremated. Her son, Nyukla Penchen, a close disciple of the Madman of Ü's and author of Part I of his Life, was probably Dönyö Dorjé's cousin, making the web of interconnections between the holy madmen and the realities of their historical moment even more closely bound. ${ }^{611}$

${ }^{608}$ pp 506.6 - 507.6, when he meets mi yi dbang po dpal ldan kun tu bzang po at Rinpung. ${ }^{609} \mathrm{p}$ 540.2-.4. Near 'phan yul; the two developed "a mutual understanding between the donor and the preceptor" (yon mchod thugs mthun).

${ }^{610} \mathrm{p}$ 609.4-.5. This is dharmalord Ngawang Namgyel (chos rgyal ngag dbang rnam rgyal ba). According to Ehrhard, Ngawang Namgyel was the son of Dönyö Dorjé and the next head of the Rinpungpas after him (2010, p 241). I believe this to be a mistake, as Ngawang Namgyel was instead the son of Tsokyé Dorjé, and thus Dönyö Dorjé's cousin.

${ }^{611}$ On the construction of the jeweled reliquary, see The Life of the Madman of $\ddot{U}$, pp 653.6-654.3; this woman is mentioned as cho 'brang gi do shal chen po bsod nams kyi srad bu la 'chang ba'i bdag mo, residing at gser khang. This is most likely the woman of the Rinpung family who had been given as a wife to a lord of Nyemo, named gser khang ma. Earlier the Madman of Ü had receieved patronage from representatives (nang so) at snye mo, probably this woman's husband, pp 546.3-546.6. She was also a patron of Minyak Rabjampa, who was a student of the Madman of Ü's (The Scholar's Feast, 2006 version, pp 591-2; 1986 version, pp 1158.10-1159.23). On the association of Minyak Rabjampa with the Madman of Ü, see the latter's biography, pp 628, 632. She is mentioned in The Scholar's Feast, 2006 version, pp 656, 657 when she met the 8th Karmapa (pp 1285.15-16 and 1287.10-11 in the 1986 version). According to this latter mention, she was a daughter of the sde pa sgar pa. The question then becomes who is referred to by this term sde pa sgar pa.

The head of the Rinpung at the time of these events was Ngawang Namgyel, son of Tsokyé Dorjé and cousin to Dönyö Dorjé. Ehrhard assumes sde pa sgar pa to refer to Norbu Zangpo (Dönyö Dorjé's grandfather). According to Yarlung Ambum, p 133, Dönyö Dorjé had a daughter named dpon sa gser khang rgyal mo, who was given to snye mo rin chen rtse as a wife.

Unfortunately, Yarlung Ambum's statement must be incorrect, as Nyukla Penchen lived 14581515 and Dönyö Dorjé lived 1462/1463-1512, making the notion that the former would have been the latter's grandson an impossibility. Given how close Nyukla Peṇchen and Dönyö Dorjé's dates are, it seems reasonable to assume that they were of the same generation — cousins-and that the sde pa sgar pa whose daughter the ser khang ma was was Norbu Zangpo, as concluded by Ehrhard.

On Serkangma's being the mother of Nyukla Penchen, see The Scholar's Feast, 2006 version, p 592; 1986 version, $\mathrm{p} 1160.8$.

We have further evidence of this in the "Collected Works" of Drukpa Kunle, when he meets Nyukla Penchen (snyug la rje) at Serkang (gser khang) (Beijing 2005 version, Vol. nga), p 456.6. 
As for Dönyö Dorjé himself, the Madman of Ü met him at least five separate points in his life. In The Life of the Madman of $\ddot{U}$, Dönyö Dorjé is often referred to as "the protector of the earth, great lord among men" (sa skyong mi dbang chen po), or some variant thereof. By mapping their meetings we can actually trace the career of Dönyö Dorjé as he worked to expand the area under the control of the Rinpungpas and gain a foothold in Lhasa.

The Madman of Ü's first meeting with Dönyö Dorjé took place in the Shang (shangs) valley, not far from the family's original home base at Rinpung. The Madman of Ü went fearlessly into where Dönyö Dorjé was staying, tied the two ferocious guard dogs to one another, and urinated over all the barley that had been set out to dry. It is said that everyone was frightened and amazed. ${ }^{612}$

The Madman of Ü had some other early encounters with Dönyö Dorjé in eastern Tsang. First, during a big gathereing at Zambulung (zam bu lung) in $1488^{613}$; and shortly thereafter at nearby Reda ( $r a s ~ m d a$ '), on which occasion it is said that there existed "a mutual understanding between the donor and the preceptor" (yon [bdag] mchod [gnas] thugs mthun). ${ }^{614}$

The Madman of Ü's later meetings with Dönyö Dorjé took place when the latter was staying at Chushül Lhünpo Tsé (chu shul lhun po’i rtse), at the confluence of the Tsangpo (gtsang po) and the Kyichu (skyid chu) rivers east of Lhasa. This fortress was

\footnotetext{
${ }^{612}$ Shortly after this the Madman of Ü was given his own mountain hermitage (ri khrod) in Pelnam (dpal nam), south of Shigatsé on the way to Gyantsé. There he set up a meditation center (sgrub sde), which he named "Fortress of the Space of the Dharma-realm" (chos dbyings nam mkha'i rdzong). As was mentioned in Chapter Two, Ehrhard assumes the patron for this to have been Dönyö Dorjé. But it might have been the lord of Gyantsé instead.

${ }^{613}$ The great gathering at Zambulung is described pp 504.1-506.2; the fact that Dönyö Dorjé and the yogi had met there is mentioned $\mathrm{p} 510.1-.2$.

${ }^{614}$ p 510.1-.4.
} 
strategically located at the crossroads of a few important travel routes, including the main path that would be taken between Lhasa and the Pakmodru capital of Nedong. The Rinpungpas had taken control of this fortress during their first major military campaign into central Tibet in around 1480. When the two met there a few decades later, Dönyö Dorjé sent a messenger with a horse to bring the Madman of Ü to Chushül Lhünpo Tsé fortress; while staying there Dönyö Dorjé would come see the yogi every day and receive teachings from him. ${ }^{615}$ Their final meeting occured not long thereafter, at Dreyül Dzongkar ('bras yul rdzong dkar), back near their hereditary fief of Rinpung. ${ }^{616}$

Little is said about the kind of relationship that formed between the Madman of $\ddot{U}$ and Dönyö Dorjé and his relatives. The only comment we have about their relationship (used once with respect to the Madman of Ü and Dönyö Dorjé, and once between the yogi and Tsokyé Dorjé) is that they were "of like mind as donor and preceptor" (yon mchod thugs mthun). Whether they found themselves to be in agreement regarding religious affairs or worldly, or some combination of the two, we can only imagine. The Madman of Ü formed his relationships with the Rinpungpas at the peak of their power, in the midst of their struggle against the Pakmodrupas. They supported him financially, allowing him to set up his first semi-permanent meditation center. In return Dönyö Dorjé received teachings from the yogi. And the Rinpungpas were concerned to do honor to the yogi's memory after his death.

The Madman of Ü also had a significant relationship with Tashi Dargyé of Ja, who was long a steadfast patron. A handful of their meetings are described, including

\footnotetext{
${ }^{615}$ pp 510.5-.6; 518.6-519.2.

${ }^{616} \mathrm{p} 547.3$.
} 
one occasion on which "the dharmalord, Tashi Dargyé" is referred to as "the lone sentinel for the Teachings and the holy ones who upheld them." For some time Tashi Dargyé is said to have been the yogi's primary benefactor (rtsa ba'i sbyin bdag). ${ }^{617}$ Tashi Dargyé was an important governor during this time and played a significant role in central Tibetan affairs as a major antagonist in the ongoing sectarian conflict. Dungkar Rinpoché mentions that he, along with Dönyö Dorjé, wanted to destroy the Gelukpas. We should not be surprised that Tashi Dargyé’s son, Jamyang Chöki Drakpa ('jam dbyangs chos kyi grags pa, 1478-1523), was chosen as the Third Drukchen incarnation, tightening the bond between the Drukpa Kagyüpas and a powerful family of supporters. ${ }^{618}$ Tashi Dargyé was also an important patron for the printing of the Kagyücentric history, The Blue Annals, completed in $1478 .{ }^{619}$

As was noted in Chapter Two, the Madman of Ü also received gifts from many other patrons, both within central Tibet and outside of it. But it was the Rinpungpas and Tashi Dargyé with whom he had the most enduring and significant relationships.

\section{III.3.ii The Patrons of the Madman of Tsang}

The Madman of Tsang's main patrons can be divided into three main groups.

They were the petty kings of western Tibet; Tashi Dargyé, the "myriarch" of Ja; and the Rinpungpas, Dönyö Dorjé being the most important among them.

${ }^{617}$ Their various meetings are described pp 479-80, 570, 582. The Rinpungpa Tsokyé Dorjé and Tashi Dargyé of Ja are listed among those making offerings after the death of Tangtong Gyelpo, the famous saint sometimes counted among the "holy madmen," according to his biography. See Stearns, King of the Empty Plain, $\mathrm{p} 431$.

${ }^{618}$ Toni Huber, The Cult of Pure Crystal Mountain: Popular Pilgrimage and Visionary Landscape in Southeast Tibet (New York: Oxford University Press, 1999), p 245.

${ }^{619}$ Leonard W. K. van der Kuijp, "On the Composition and Printings of the Deb gter sngon po by 'Gos lo tsā ba gzhon nu dpal (1392-1481)" in Journal of the International Association of Tibetan Studies 2 (August 2006), p 9. John Ardussi, 'Brug-pa Kun-legs, The Saintly Tibetan Madman (Master's thesis, University of Washington, 1972), p 11. See also p 57 for a comment on Tashi Dargyé's son. 
As for this first group, the Madman of Tsang had close relationships over the years with the kings of Gungtang. The Madman of Tsang spent much of his career in western and south-western Tibet, at sites like Lapchi, Chuwar and many other sites along the modern Tibet-Nepal border that had a special significance for Kagyüpas. The Madman of Tsang would visit Gungtang periodically throughout these many years, including before and after most of his trips to Nepal. The kings of Gungtang helped sponsor some of the Madman of Tsang's printing projects, as well as the restoration of the Swayambhūnāth stūpa in Nepal. One of the Madman of Tsang's most important students, Lhatsün Rinchen Namgyel — author of the second of the three versions of his Life and a prolific publisher of texts — was the son of one of these kings. ${ }^{620}$ The Madman of Tsang had a similarly close relationship with the kings of Lowo Möntang, whom he visited on a number of occasions, mostly while traveling to and from Mount Kailash and Chuwar. The kings of Lowo Möntang supported the reconstruction of the Swayambhūnāth stūpa. ${ }^{621}$ For some years Lowo Möntang and Gugé Purang were mired

\footnotetext{
${ }^{620}$ The Madman of Tsang goes the capital (rgyal sa) of Gungtang after a stay at Drakar Taso (p 93.7); visits Gungtang on his way to Nepal ( $\mathrm{p} 172.3-.5$ ); and again on his way back from that very same trip to Nepal (p 176.2-.3); Lhatsün Rinchen Namgyel, one of the sons of the king of Gungtang (gung thang rgyal pa'i sras), after having finished his studies in the Gandenpa system at Tashi Lhünpo Monastery in Shigatsé, became one of the Madman of Tsang's students ( $p$ 198.5-.6). The madman is received at Gungtang on his way back to Tibet after renovating the Swayambhūnāth stūpa in Nepal (p 229.6); he also received paper from Gungtang in order to make a copy of the snyan rgyud yin bzhin nor bu (p 244.7-245.2). The "three brother kings of Gungtang" (lha sras gung thang rgyal po mched gsum) are also recorded as patrons for the construction of the Swayambhūnāth stüpa, having offered gold, salt and so on (p 221.3-.4). The madman also sent Gungtang a copy of The Life of Milarepa along with a set of tangkas (p 161.6).

${ }^{621}$ The Madman of Tsang was first received at the capital of Lowo Möntang with his retinue of students by "the king of Lowo, Aseng" (klo bo rgyal po a seng) (p 153.6, all page numbers in this footnote from Götsang Repa); during this visit he was received personally by King Aseng on a second occasion (p 155.3); later, on his way to Mount Kailash he was received at the capital of Möntang by klo bo rgyal po bde legs rgya mtsho (p 177.7); he has major contacts with Lowo Möntang and Purang when he tries to mediate between them; this was a tough job, and neither side was entirely happy with how he handled the situation (pp 184.4-188.7); he was received at Lowo Möntang on his way to Chubar (chu 'bar) (p 195.2). He also sent Lowo Möntang a copy of The Life of Milarepa along with a set of tangkas (p 161.6). The sde pa of Möntang was also among the patrons of the reconstruction of the Swayambhūnāth stūpa, offering gold
} 
in a bloody conflict, in which the Madman of Tsang tried (without complete success) to mediate. The Madman of Tsang also had less significant contacts with the lords of Gugé Purang $^{622}$ and Tsanda. ${ }^{623}$

The Madman of Tsang's contacts with these various lords of western Tibet spanned years. They were a major source of support for his many years of meditating and maintaining important Kagyü retreat centers like Drakar Taso. They are not directly involved in the main central Tibetan conflict that is our concern in this chapter, however, so we will make only this brief mention of them here.

Another patron of the Madman of Tsang who was involved in the conflict between the Rinpungpas and the Pakmodrupas was the governor or myriarch (khri dpon; also referred to as the nang so and even gong ma) of Ja (bya), Tashi Dargyé (bkra shis dar rgyas). The Madman of Tsang came into contact with this powerful lord during an early visit to the area around the holy mountain of Tsari in southern Tibet. Having heard that some Ja lords would be traveling down a particular road, the Madman of Tsang laid down in the middle of it. As the lords and their retinue arrived and walked past the yogi, they wondered if he had really passed out or if he was faking. The yogi got up and went to where the lords had assembled. He shocked them all by telling the lady Künga Zangmo (who would in time become a significant patron having a heartfelt connection with the yogi) that he wanted to screw her $(r g y o)$. An official asked him what was the

other precious materials ( $\mathrm{pp}$ 221.7-222.2). The madman also sent a request to Lowo when he was trying to gather resources to establish practice centers at Mount Kailash (p 198.2).

${ }_{622}$ Götsang Repa, pp 198.2, 221.5.

${ }^{623}$ The Madman of Tsang was reverently served by a tsha ' $d a$ ' $b a$ (p 52.2) while staying near Lapchi; According to E. Gene Smith ("Introduction to The Life of Gtsang smyon Heruka," p 65) this is the sde pa of Tsanda (tsha ' $d a^{\prime}$ '). A tsha mda' nang so offered provisions to maintain the Madman of Tsang during meditation ( $\mathrm{p}$ 57.6). 
value of such behavior, which led into a discussion of the Hevajra tantra (and in particular the "activity" chapter, spyod pa'i le'u) and his engaged asceticism. Based on this discussion one official remarked that, because of the way the Madman of Tsang's eccentric activity matched the engaged asceticism taught by the tantras, he was a very special yogi, "as rare in this degenerate age as a star in the daytime sky" (snyigs ma'i dus 'dir nyin mo'i dkar ma lta bu). So began the yogi's relationship with Tashi Dargyé and some other important members of the Ja ruling class. The Madman of Tsang would meet Tashi Dargyé a few more times over the years, with Tashi Dargyé supporting the yogi and his disciples with provisions when they stayed near Tsari. ${ }^{624}$

Dönyö Dorjé first invited the Madman of Tsang to Rinpung, where he received him respectfully and made offerings. Upon the Madman of Tsang's leaving the lord requested that the yogi send him a copy of The Life of Milarepa when it was finished, along with the accompanying paintings. They were sent to Dönyö Dorjé a while later. ${ }^{625}$ Dönyö Dorjé would remain a supporter of the yogi for the rest of his life, giving him offerings of gold, silver and silk. Perhaps more importantly, Dönyö Dorjé supported the Madman of Tsang in his restoration of the Swayambhūnāth stūpa, and imparted to him one of Milarepa's former hermitages (called 'om chung or 'o 'byung), where the yogi established a retreat center that would remain active even after his death. ${ }^{626}$ Dönyö Dorjé

\footnotetext{
${ }^{624}$ Their first few meetings are described pp 32.1-34. In a slightly later meeting the yogi and Tashi Dargyé both drink from a skull cup filled with human brains and chang, as a result of which the official experiences some very pleasant effects and their connection ( $r$ ten 'brel) is cemented, p 39.1-.4. On a later visit to the Tsari area the yogi met with Tashi Dargyé "as patron and priest" (yon mchod gnyis), pp 120.4121.6. Tashi Dargyé sent loads of barley for the upkeep of the yogi and his disciples. In the record of patrons for the restoration of the Swayambhūnāth Stüpa there is mention of a "depa of the Ja area" (bya yul sde pa), who offered one zho of gold; this likely refers to Tashi Dargyé (p 223.2).

${ }^{625}$ Götsang Repa, pp 158.2-.4, 161.7.

${ }^{626}$ Götsang Repa, pp 171.6-.7; 213.7, 222.7. On 'o 'byung/'om chung, see Quintman, 2006, p 237; Götsang Repa, pp 213.7-214.1. This site had also once been inhabited by Lord Kodrakpa (rje ko brag pa)
} 
spent a lot of time with the Madman of Tsang near the end of the yogi's life. ${ }^{627}$ On one of these late meetings, in the Shang (shangs) valley, Dönyö Dorjé said to the Madman of Tsang,

It has been a long time since I have seen the lord of yogis (rnal 'byor dbang phyug) - because people have been saying that you have become stooped over with age, I thought your hair and spots ( $r m a r a$ ) would have turned white and you would be weakened by old age. But it is clear that you have not aged at all since we first met as patron and priest (yon mchod) at Shangdrön Gang (shangs 'gron khang, sic; should perhaps be shangs 'gron po sgang).

The Madman of Tsang responded,

It is just so. And I thought that because of the king's consuming the enjoyments of all of Ü and Tsang (rgyal pas [sic] dbus gtsang thams cad kyi longs spyod zos pas) you would have become an old man who has lost his teeth. And it is clear that you certainly have grown old!

-at which everyone gathered there had a great laugh. ${ }^{628}$ From there they went to Shigatsé and stayed together for some time. ${ }^{629}$ Dönyö Dorjé left for Ü, but furnished the Madman of Tsang and a hundred and fifty of his students with excellent hospitality for ten days. Shortly after this the Madman of Tsang went to Lhasa and saw Dönyö Dorjé there. This was shortly before the Madman of Tsang died in 1507, and thus during the twenty or so years the Rinpungpas controlled the town of Lhasa. They stayed for some time together, with the yogi giving this most powerful lord in Tibet teachings, until one morning the Madman of Tsang mentioned having had a dream suggesting that they would not meet again in this lifetime as patron and priest. ${ }^{630}$ The Madman of Tsang left the place where they had been staying together and died shortly thereafter. After the

(see Chapter Seven), then later was fought over by the Drikungpas and the Pakmodrupas, Götsang Repa, $\mathrm{p}$ 210.

${ }^{627}$ Götsang Repa, p 247.6.

${ }^{628}$ Götsang Repa, pp 251.4-252.1.

${ }^{629}$ bsam grub rtse. Götsang Repa, p 252.5.

${ }^{630}$ Götsang Repa, pp 254.1-256.1. 
Madman of Tsang's passing there were remarkable gatherings of his former students, patrons, and other relations at many sites with which the yogi had been associated, to recite prayers and perform rituals on behalf of the deceased master. The earth-protecting lord of men, Dönyö Dorjé, is mentioned as foremost among the high ranking officials who traveled all the way to Chuwar, near the border with Nepal, to participate in rites honoring the deceased yogi. ${ }^{631}$

As for what sort of influence the Madman of Tsang had on the man often referred to in Götsang Repa's version of his Life as the "dharmaking" (chos kyi rgyal po), it is recorded that the yogi persuaded him on at least a few occasions to not follow through with some planned military measure. ${ }^{632}$ It is said that one time the Madman of Tsang heard that the Rinpungpas had amassed 80,000 troops and were preparing to take a military action against the lho pa dgo dgos rgyal (?). Out of his compassion for living beings, the yogi sent a few of his students to deliver a letter asking Dönyö Dorjé to not cast $\ddot{U}$ and Tsang into such disorder and instead work more constructively towards the cause of well-being throughout the realm; this kind of military activity is one of the ten sins ( $m i$ dge bcu) and a cause for bad rebirth, in addition to causing harm to many living beings. The ruler took the yogi's advice and dispersed his troops. ${ }^{633}$ Later, the Madman of Tsang interceded again and prevented Dönyö Dorjé from sending troops on a punitive mission to Ngarik Dzongkar (mnga' rigs rdzong dkar; should this be mnga' ris?). ${ }^{634}$ It is

\footnotetext{
${ }^{631}$ Götsang Repa, p 281.1-.2; Schaeffer, "Dying Like Milarépa: Death Accounts in a Tibetan Hagiographic Tradition," p 221.

632 He is variously called: stobs kyi rgyal po, p 222.7; sa skyong chos kyi rgyal po, p 213.7; chos skyong ba 'i rgyal po, p 247.6; rgyal po don yod rdo rje, p 251.5; sa skyong mi'i dbang po, p 281.2; on a number of occasions he is referred to simply as sde pa.

${ }^{633}$ Götsang Repa, pp 234.4-235.3.

${ }^{634}$ Götsang Repa, pp 254.1-256.1.
} 
difficult to judge the significance of these excursions that the yogi advised the depa against. In reality, none of these campaigns could have possibly involved 80,000 troops. Even if the Madman of Tsang persuaded Dönyö Dorjé against a few military actions late in his career, the fact is that his take-over of $\ddot{U}$ and Tsang was already complete by this time. We should not get the idea that the Madman of Tsang somehow convinced his patron to fully abandon his war-like ways. The yogi even joked with Dönyö Dorjé about how he had taken control over all of Ü and Tsang.

The Madman of Tsang also had contacts with other members of the Rinpungpa family at various points in his career. ${ }^{635}$ Götsang Repa's Life of the Madman of Tsang expresses a sense of gratitude to the Rinpungpas for all they had done for the yogi. It is said that when the Madman of Tsang's activities came to the attention of the 7th Karmapa, it is because of the kind things that were being said about the yogi at Rinpung. The Karmapa was so moved that he wrote a letter praising the yogi for his various accomplishments in his career. This letter will be quoted at the opening of Chapter Six. ${ }^{636}$ The Rinpungpas also helped sponsor the printing of Götsang Repa's version of the Life and the Madman of Tsang's establishing meditation centers at holy places like Mount Kailash. ${ }^{637}$

\section{III.3.iii The Significance of these Patronage Relationships}

The Madmen of Ü and Tsang were both on excellent terms with Japa Tashi

Dargyé and various members of the Rinpungpa family, especially the one who would rise

\footnotetext{
${ }^{635}$ Götsang Repa, $\mathrm{p}$ 222.7. rin dpungs blon chen nam mkha' dbang rgyal (is this Ngawang Namgyel?) is mentioned as one of the patrons of the restoration of the Swayambhūnāth Stüpa. Throughout the biography there are various mentions of patronage coming from Rinpung without specifying who precisely it is coming from.

${ }^{636}$ Götsang Repa, p 214.5-.7.

${ }^{637}$ Götsang Repa, pp 288.5, 198.2-.3.
} 
to hold de facto but unofficial dominion over Ü and Tsang, Dönyö Dorjé. The holy madmen had long-standing relationships of exchange with these lords. The patrons would support the endeavors of the madmen, and the yogis in turn would give teachings and blessings to their more worldly counterparts. The patrons also no doubt derived a certain amount of standing and renown — indexes of symbolic capital—from these relationships.

It was also the case that Rinpungpa Dönyö Dorjé and Japa Tashi Dargyé were intent upon undoing the recent rise of the Geluk sect. By charting the patterns of the Madmen of Ü and Tsang's relationships with their patrons (also considering whose patronage they chose not to accept), we can better understand the role they played in the conflict that defined their time.

To round out our consideration of this matter, we should consider the significant political figures with whom the Madmen of Ü and Tsang did not maintain amiable relations. For example, early on in his career of eccentric behavior, the Madman of Tsang was traveling near Lhasa when the depa of Neudzong, Peljor Gyelpo, was passing by with his attendants. The yogi mixed urine and barley flour in his skull cup and sat eating it as they passed. Some of them exclaimed, "It's Tangtong Gyelpo!", another eccentric Buddhist sometimes called a crazy yogi, who will be discussed in Chapter Seven. The Madman of Tsang's appearance was upsetting to the horses. One rider asked him, "Yogi, where did you come from? And what are you doing here? Where are you going?" To which he answered, "What difference does it make where I came from?" (ga nas yongs na ci byed). At which time the rider urged him, "The depa is coming closemake a salutation!" (legs pos gsungs dang). The Madman of Tsang responded impertinently, "I have no depa" (nga la sde pa su yang med). A few days later the 
Madman of Tsang found himself in this very same depa's palace, arguing with geshés from the nearby Geluk monasteries of Sera and Drepung who charged him with enacting a lifestyle that was not even Buddhist. ${ }^{638}$ At the conclusion of this meeting it is said that the lord of Neudzong was very impressed by the Madman of Tsang, but he never became a significant patron. This depa of Neudzong was a major patron of the Gelukpas; his territory was one of Dönyö Dorjé's primary targets during his military forays into the Lhasa area.

Near the end of his life the Madman of Tsang received an invitation from the Pakmodru gongma Ngaki Wangchuk Tashi Drakpa Gyeltsen Pelzang to visit him at Nedong, the Pakmodru capital. By this time most of Ü and Tsang was under the control of Dönyö Dorjé and the Rinpungpas, but the Pakmodru gongma remained the titular ruler of Tibet. This gongma had been selected and put on the throne by Dönyö Dorjé and his uncle Tsokyé Dorjé, but according to The New Red Annals, by this time the relationship between Dönyö Dorjé and the gongma had soured. The Madman of Tsang refused the gongma's invitation. Götsang Repa couches the Madman of Tsang's decision in a delicate manner, saying "The dependent connections for his going were not there" (phebs pa'i rten 'brel ma 'grig). (As we will see in Chapter Six, this same turn of phrase was used to explain Śākya Chokden's initial refusal to meet with Madman of Ü.) Immediately after this it says that the Madman of Tsang did, however, meet with the gongma's wife, who was a daughter of Dönyö Dorjé (de'i btsun mo chos kyi rgyal po don yod rdo rje'i sras mo legs mtsho rgyal mo), along with some other patrons, at which time

${ }^{638}$ Götsang Repa, pp 43.7-46.2. 
he "satisfied them with the nectar of his speech."639 On another occasion the Madman of Tsang was received at Nedong by another wife of gongma Ngawang Drakpa; she was said to have been 'lady Döndrup Gyelmo, daughter of the emperor-king (monga' [sic] bdag rgyal po'i sras mo lha lcam don grub rgyal mo), i.e. a daughter of the yogi's good friend the king of Gungtang. ${ }^{640}$

To sum up the greater pattern of the Madman of Tsang's relationships with patrons, he had close relationships with figures who were the foremost antagonists of the Pakmodru-Geluk partnership, while at times being perhaps deliberately disrespectful towards some of the Pakmodru regime's most important representatives.

The Madman of Ü's feelings about the Pakmodru regime are more ambiguous. The religious side of the Pakmodru regime based at Densa Til Monastery and the nearby forest retreats would always be an important part of the Madman of Ü's life. The Madman of Ü was born nearby and underwent much of his early training in this area. We also know that the religious branch of the traditional Pakmodru regime (not counting the Gelukpas, who were just as much a part of the Pakmodru regime as anyone else) had grown quite separate from the political branch. During this time the 4th Red Hat, whom some historians consider a sworn enemy of the Geluk, held the throne of Densa Til as the chengga (spyan snga). The Madman of Ü visited Nedong itself, but is not said to have met with the gongma or any other representative of the Pakmodru regime. ${ }^{641}$ Late in his life the Madman of Ü received some offerings from the gongma Ngawang Tashi Drakpa (the one snubbed by the Madman of Tsang), including three bricks of tea and some sort

\footnotetext{
${ }^{639}$ Götsang Repa, pp 258.6-259.1.

${ }^{640}$ Götsang Repa, pp 119.5-120.4.

${ }^{641}$ The Life of the Madman of $\ddot{U}$, pp 571-2.
} 
of certificate (li khi ta). ${ }^{642}$ This was after the resurgence of the Pakmodrupas and the concomitant decline of the Rinpungpas around 1518.

It would be a mistake to read too far into any of these individual relationships or apparent snubs, but taken together they form a relatively consistent and predictable pattern. The Madmen of Ü and Tsang had close relationships with certain individuals on the Rinpungpas' side of the conflict, and were less well-connected with lords on the other. This suggests that Künga Zangpo and Sangyé Gyeltsen's decisions to take on their distinctive lifestyle - their distinctive identities as holy madmen being what brought them into the ken of their patrons - may to some extent have been a response to the contours carved out by the sectarian and political conflicts of their day, as will be described in the following section.

More will be added to this discussion in the following chapter, when we see how Drukpa Künlé positioned himself differently from the Madmen of Ü and Tsang vis-à-vis the Pakmodrupas and the Rinpungpas. Drukpa Künlé remained a strong supporter of the Pakmodru regime and criticized the Rinpungpas, even snubbing Dönyö Dorjé when he requested a meeting with the yogi. The reasons for Drukpa Künlé's feelings about these political matters were complex, including some very personal, familial issues.

\section{III.4 The Madmen of Ü and Tsang in their Time}

Having reviewed the dynamics of the larger political and religious conflicts that characterized central Tibet in the 15 th and early 16 th centuries, we can now answer the question of how this larger historical situation may have contributed to the Madmen of Ü

\footnotetext{
${ }^{642}$ The Life of the Madman of $\ddot{U}, \mathrm{p}$ 624; this is in 1522 and the gongma would have been Ngawang Tashi Drakpa.
} 
and Tsang's respective decisions to take on the lifestyle of tantric fundamentalists. We have seen how this period was marked by a few overlapping and interrelated conflicts. There was the struggle between the Rinpungpas and the Pakmodrupas, which was played out in political and military spheres. Meanwhile in the religious realm there was an ongoing struggle between the Gelukpas on one side and the Kagyüpas and Sakyapas on the other. We have seen that these two struggles were interrelated in so many ways that we cannot reasonably treat them as being separate from one another. The religious battle was to some extent a proxy war for the political one, but no less real for the individuals involved. What's more, the political factions were highly dependent upon the religious sects they supported, with whom they had relationships of mutual dependence. ${ }^{643}$

It was in the midst of these ongoing struggles in the 1470s and 80s that Künga Zangpo and Sangyé Gyeltsen made their decisions to enact the tantric fundamentalism that would earn them reputations as the Madmen of Ü and Tsang. On one level this was a decision to embody something that was the very opposite of what the Gelukpas stood for. During a time when the ideal of a scholarly, Vinaya-based monkhood was in the process of becoming the norm — and carrying the Geluk sect to prominence along with it— Künga Zangpo and Sangyé Gyeltsen made the decision to articulate a distinctive

\footnotetext{
${ }^{643}$ Komarovski describes the situation well: "Weakening of a centralized state power structure, constant conflicts among rival political groups, and struggle for centralization during the course of the 15th century provided a fertile ground for the flourishing of sects and religious figures whose legitimization and support were sought by political leaders. It comes as no surprise, then, that in tandem with political clashes, the 15 th century also witnessed an explosion of intra- and inter-sectarian polemics on questions of perception, scriptural authority, and other issues - topics concerning authority, validity, and reality with clear parallels to political affairs and disputes. Rivalry in the political arena was thus accompanied by and accompanying the rivalry in the religious sphere, and inter- and intra-sectarian polemics became a distinguishing feature of the intellectual landscape of 15th-century Tibet," p 49.
} 
alternative for what a Buddhist renunciant might look like. ${ }^{644}$ The contrast in what they represented is expressed in the holy madmen's adversarial confrontations with scholarmonks, as recorded in their biographies. As E. Gene Smith wrote of the 15th-century holy madmen,

The smyon $p a$ is the antithesis of the scholastic monk; yet to view the phenomenon simply as a reaction against monastic reforms and Dge lugs pa rationalism misses much of the point. The smyon pa, too, represented a force for reform. Just as the movement of Tsong kha pa attempted to reorient the Bka' gdams pa tradition toward the fundamental contribution of Atiśa - the Graduated Path (Lam rim), with its emphasis on the exoteric as an indispensable foundation for the esoteric - so the smyon pa represents an attempt to re-dedicate the Bka' brgyud pa sects to old truths and insights that were being forgotten. ${ }^{645}$

The Madmen of Ü and Tsang represented something that was the very opposite of the Gelukpa monk. But in the real circumstances of the 15th-century religious marketplace, they were not only a foil to the Gelukpas but a positive force, an attempt to shift the Kagyü sect in a particular direction. They posited a new alternative, a new model on which the Kagyü sect might define itself—and one that was strongly contrasted with the ideals from which their rivals the Gelukpas drew their charisma. But as I will show in Chapter Six the role the famous 15 th-century holy madmen played was actually even more active than that suggested by Smith, in that they were not simply "re-dedicating" the Kagyü sect to a static set of truths and insights, but through their writing and publishing activities they actively created a particular vision of the Kagyü, of which their activity as madmen then became an expression.

\footnotetext{
${ }^{644}$ Here we are thinking of the Madmen of Ü and Tsang in a way similar to how Komarovski understands Śākya Chokden's specific doctrinal formations, which were highly critical of Tsongkhapa and Geluk views: in both cases, these religious figures have formulated a creative response in the face of the serious threat posed by the ever-strengthening Geluk.

645 "Introduction to The Life of Gtsang smyon Heruka," p 60.
} 
The greater point I have been arguing in this chapter is that we should not think of the decision by Künga Zangpo and Sangyé Gyeltsen to embody tantric fundamentalism as being one that registered only in the religious sphere. Their decision to take on this shocking and eccentric lifestyle had direct political and material ramifications. And their decision to take on this lifestyle would have been informed by their understanding of what various effects it would have. Their decision to represent something anti-Geluk and distinctly Kagyü made them natural allies with the Rinpungpas and Japa Tashi Dargyé, who were openly fighting against the Geluk-Pakmodru partnership. Many scholars have noted that the specific characteristics of the Geluk system as formulated by Tsongkhapa made supporting them an almost obvious decision for the Gelukpas, for they ultimately shared very similar aspirations. In the words of Matthew Kapstein, “Tsongkhapa was a living exemplar of the very values the Pakmodrupa regime sought to uphold."646 I would argue that we can see a parallel partnership of a similar nature between the Madmen of $\ddot{U}$ and Tsang and their biggest central Tibetan supporters, the Rinpungpas and Japa Tashi Dargyé. The order, monasticism, conventional ethics and learning promoted by the Gelukpas provided a vehicle for the Pakmodrupas to expand the strength of their rule. Likewise, the holy madmen, as upholders of tantra over monasticism, meditation over learning, as foils to the Gelukpas and quintessentially Kagyü, made them natural partners with the Rinpungpas and Tashi Dargyé, who were looking to undermine the Gelukpa sect as part of their larger political ambitions against the Pakmodrupas.

The holy madmen were not the only religious endeavor the Rinpungpas chose to support. In addition to the holy madmen there were the Karmapa and the Red Hat, the

\footnotetext{
${ }^{646}$ Kapstein, The Tibetans, p 121.
} 
Drikungpas, some Sakyapas, and others as well. But each in some way represents a counter-move against the Gelukpas, an attempt to chip away at the dominance of the Geluk-Pakmodru partnership.

It would be a mistake to work under the assumption that Künga Zangpo and Sangyé Gyeltsen were somehow unaware of the larger dynamics of the time in which they lived, or of how their highly attention-grabbing activity would have positioned them relative to those dynamics, politically and financially speaking. The decision by Künga Zangpo and Sangyé Gyeltsen to make themselves the public embodiments of tantric fundamentalism was likely motivated by a variety of overlapping concerns. It may have been to support what they believed was true Buddhism. Or it may have been to support their own sect, by differentiating themselves from the Gelukpas, offering an alternative Buddhist model, and thereby helping their fortunes against the increasingly powerful Geluk. There likely was some concern for their own enrichment and advancement. Their understanding that they were doing something that made them direct foils to the Geluk (and would have propelled them into the good graces of the wealthy Rinpungpas) may have been conscious or unconscious. Most likely it was some mixture of these concerns. Perhaps the most important thing in trying to reconstruct their decision process is that we treat the holy madmen as complex, multifaceted beings. What we should not do is treat them as if they somehow would have been ignorant of the real-world ramifications their living this lifestyle would have had.

We can thus see how Künga Zangpo and Sangyé Gyeltsen's decisions to leave conventional monasticism, put on the garb of a Heruka, and travel around Tibet enacting the dictates of the Highest Yoga Tantras represented an informed decision, a creative 
response to the circumstances in which they lived. It achieved multiple aims and had a variety of ramifications. In the next section we will address questions of how coordinated Künga Zangpo and Sangyé Gyeltsen were in this effort, and what larger holy madman trend they may have been a part of.

\section{IV. A Madman Movement?}

As we saw in Chapter Three, the distinctive behavior of Künga Zangpo and Sangyé Gyeltsen that earned them reputations as the Madmen of Ü and Tsang was almost the same. They dressed like gruesome Herukas, emulated the Highest Yoga tantras, performed shocking behavior in public places, provoked violent confrontations from authority figures, antagonized the representatives of scholastic Buddhism, and so on. Was the decision to enact this form of tantric fundamentalism made jointly, or independently of one another? Were the Madmen of Ü and Tsang in some way working together? Or was it merely a coincidence that the two yogis both decided to take on this same eccentric lifestyle at around the same time?

Towards answering this question we will look at the personal relationship between the Madmen of Ü and Tsang to see what may be gleaned. We will then seek to gauge the extent to which we can speak of a "madman movement." We know that the Madmen of Ü and Tsang as well as the Madman of the Drukpa all operated at basically the same time (born within six years of one another). And as will be listed at the end of this section, there were a number of other "holy madmen" operating within this same time period. To what extent were these other holy madmen influenced by the Madmen of $\ddot{U}$ and Tsang? Or were the Madmen of Ü and Tsang drawing inspiration from their madman peers? Were they all part of some larger trend taking place within Tibetan 
religious culture at this time? To this end we will look at the biographies of two other Kagyüpa ascetics who lived around the same time—Chöwang Lhündrup and Drakpa Tayé - to gauge what kind of impact the Madmen of Ü and Tsang had on the religious culture of their time, and the extent to which they may have been participating in a larger trend.

Towards trying to understand where the motivation to take on this eccentric lifestyle came from, we should try to determine what role the Madmen of Ü and Tsang's gurus played in the process. Did Künga Zangpo and Sangyé Gyeltsen take on this lifestyle of their own initiative, or were they to some extent following the orders of the lamas guiding them in their spiritual development?

The biographies of the Madmen of $\ddot{U}$ and Tsang suggest that they were encouraged to take on this lifestyle by their gurus, although the evidence is not strong enough to conclude that their masters played a major role in this process. Shara Rabjampa encouraged his young disciple, Sangyé Gyeltsen, here referred to by another of his names, in the following way:

Boy, Chöki Drakpa from Tsang, your tutelary deity is glorious Hevajra, so meditate on him. Become fully learned in the Two-Chaptered [Hevajra Tantra] and the other classes of tantras - in the future there will be a great need for that. Look at my life story and my activities. Don't look back over your shoulder at this life. Take on a humble state (sman pa'i sa zung). Wear torn clothes. Make yourself destitute of food, clothing and conversation. Become a son of the mountains and wear mist as your clothing. Through the practice of engaged asceticism [gtul zhugs kyi spyod pas] take apparent objects as the path (yul snang lam du khyer) and stamp on despair (? nyams nga la thog rdzis gyis). Cast from your mind the eight worldly concerns; at Tsari, Tsagong (? rtsa gong), Lapchi, Chubar, Mount Kailash, the Six Fortresses, and the other great abodes of the Kagyü (bka' rgyud kyi gnas chen) raise the victory banner of practice (bsgrub 
pa'i rgyal mtshan tshugs); and establish worthy disciples who are servants of the Teachings on the path to ripening and liberation. ${ }^{647}$

This was the master's heartfelt advice to his student shortly before their tearful last farewell. (As we will see in Chapter Six, certain of the words used in this passage echo throughout the history of the Kagyü. Marpa told Milarepa to do without food, clothing and fame; Milarepa said the same to his disciples; Shara Rabjampa tells it to Sangyé Gyeltsen, then later the Madman of Tsang would say the same to his disciples shortly before his death.) Later at the decisive moment when Sangyé Gyeltsen left the monastic life to take on one of wandering asceticism, all three versions of his biography use precisely the same words in relating the yogis thought that doing so would fulfill the wishes of his master. ${ }^{648}$

Künga Zangpo's master, Drakchokpa Rinchen Zangpo, is said to have addressed him in a similar manner, telling him to stay in the mountains away from villages, practice in the famous meditation sites, and so on, as was mentioned earlier in this chapter. Although on this occasion Drakchokpa is not said to have said anything too specific about what kind of lifestyle the future Madman of Ü should take on, when the yogi gave back his monastic robes to take on the garb of a Heruka, according to his biography he thought to himself that his doing so was "in accordance with the prophetic assurances of his guru and the dākinis's" ('on kyang bla ma dang DA ki'i lung bstan bzhin du/ rab tu byung ba'i rtags dang cha lugs bzhag la/ he ru ka'i chas su zhugs...). ${ }^{649}$ The key word here, lung bstan, can mean a whole range of things, from "command" to "prophecy."

\footnotetext{
${ }^{647}$ Götsang Repa, pp 25.5-26.1. This same story is related in the two earlier versions of The Life of the Madman of Tsang, although with less detailed instructions and worded slightly differently. See Ngödrup Pelbar, pp 6a5-6b1 and Lhatsün Rinchen Namgyel, p 13.4-.6.

${ }^{648}$ Götsang Repa, pp 28.7-29.2; Lhatsün Rinchen Namgyel, p 16.5-.6; Ngödrup Pelbar, p 7b6-7b7.

${ }^{649}$ The Life of the Madman of $\ddot{U}, \mathrm{p} 437$.
} 
Here it may well carry the former meaning. Regardless of how precisely the word is best understood, this line clearly suggests that we are not to think of Künga Zangpo's decision to take on his eccentric lifestyle as his going rogue, but rather that he was conforming to what he was meant to do.

The biographies of the Madmen of Ü and Tsang suggest that each yogi was to some extent encouraged by his guru to take on the eccentric lifestyle that would in time make him famous, but not strong enough to suggest that their being encouraged by their gurus was the most important factor in their making this decision. These passages may be read as indicating that the Madmen of Ü and Tsang were encouraged into this lifestyle by their masters. They may also be read as an attempt on behalf of the holy madmen's biographers to lend an air of orthodoxy to their eccentric behavior.

It seems most accurate to locate the decision to take on tantric fundamentalist lifestyles in the minds of Künga Zangpo and Sangyé Gyeltsen themselves. We get even more insight into the holy madmen's motivations and the extent to which they may have been participating in a larger, more coherent movement when we look at the complex, uneven relationship between the Madmen of Ü and Tsang.

\section{IV.1 The Relationship Between the Madmen of $\ddot{U}$ and Tsang}

The third version of The Life of the Madman of Tsang tells of his having a series

of interactions with the Madman of Ü. Tracing their relationship tells a mysterious story that offers a revealing look at the circumstances of their lives.

The first meeting between the two yogis occurred when the Madman of Tsang and some of his students were traveling in western Tibet, headed towards Mount Kailash. It is said that he met up with 'one 'dharmalord of Ü,' at that time not yet famous as 'the 
Madman of Ü'; some called him 'the Lama of [Densa] Til,' while others called him 'the Mountain Dwelling Lama." ${ }^{650}$ Meanwhile the fame of the Madman of Tsang had already become quite widespread; the king of Gungtang had heard of him as "a mad yogi who could not be harmed by [any] weapon." ${ }^{\circ 51}$ After a visit to Mount Kailash the Madman of Tsang went to Gungtang. ${ }^{652}$ When he arrived at the gate to the king's residence the guards took up their weapons and began to hit him. But he did not waver from his profound meditative state. He generated the divine pride of seeing himself as Hevajra with eight faces and sixteen arms, trampling the four demons with his four feet. He held his right hand in the air; with his left hand he took up his khațāinga. He lept and danced. With his eyes open wide, he said, "Ha ha!" All became frozen like wood and were unable to move. Then the Madman of Tsang passed unimpeded into the palace of the king (rgyal po yab) and found him asleep with his head on the lap of his queen with his sixteen year old daughter seated nearby. The yogi stalked up to them unnoticed and slapped the king, which woke him with a start. The queen, cowering in a corner, informed the king that a siddha (grub thob) had arrived. Unable to see very well, the king felt the yogi's body with his hands, and stated that it felt like the body of a ghoul ( $\sin$ po). The king offered the Madman of Tsang two ivory earrings (ba so'i snyan long [sic]); he and his entire retinue became devoted to the yogi.

\footnotetext{
${ }^{650}$ chos rje dbus pa yang de dus dbus smyon du ma grags par/ la las bla ma thel pa zer la las bla ma ri pa zer ba gcig yod pa dang sdebs nas lam dpal gud nas byang 'grims mdzad phebs tshe/, Götsang Repa, $\mathrm{p}$ 67.3-.4.

${ }_{651}^{65}$ mtshon gyis mi tshugs pa'i rnal 'byor pa smyon pa, $\mathrm{p} 67.4$.

${ }^{652}$ Along the way he had stopped in Lowo Möntang where the heads of some people from Gugé were on stakes (sgo snya; reading as snyi, meaning "trap" or "snare"; or as snyu, for "bamboo" or "staff" or "reed"), with rotting flesh and brains oozing to the ground. The Madman of Tsang took some of this filth in hand and ate it. People gathered around. He told them that if they wanted to attain siddhis (dngos grub) they should eat some; he gave each of them a spoonful, and the ones who ate it became wealthy, p 67.5-.7.
} 
While the Madman of Tsang was staying there in Gungtang, Künga Zangpo, "the Lama of [Densa] Til" (bla ma thel pa) arrived. In an excited state (thugs 'ur) he came to the royal palace where the Madman of Tsang was staying with the king and his son (or sons; mnga' bdag rgyal po yab sras). The gate was locked from the inside and Künga Zangpo was refused entrance. The guards kicked him and he began bleeding from his nose. Hearing that "there is one called the Madman of $\ddot{U}$ and he is practicing selfsacrifice" (mi spyod stong, read as gtong), many people gathered. Another appeal was made to the king. The king said that if this other yogi was equal to the Madman of Tsang, he should be impervious to weapons and fire. Therefore the yogi should be hit with swords and staffs, and burned with fire, and if he went unharmed the king would offer him reverence.

At this point the Madman of Tsang intervened, saying, "In general, regardless of whether or not [this yogi] can endure hardships, it is inappropriate for you-a dharmaking - to act in this way. And in particular, if an ascetic (bya bral ba) is killed outside while I am staying inside, nothing could be more shameful (ngo tsha ba) than that, so I will not stay here," and got up to leave. ${ }^{653}$ The king dropped his demand. Citing the Madman of Tsang's displeasure, he said that the "Madman of Ü" should be let in and offered chang. The Life of the Madman of Tsang states that from then on the name “the Madman of Ü, Künga Zangpo, was renowned in every direction” (phyogs kun du grags so). ${ }^{654}$

\footnotetext{
${ }^{653}$ spyir rkyen theg mi theg gang yin kyang khyod chos kyi rgyal po yin pas de 'dra byas pas mi yong / khyad par nga nang du gdad nas phyir bya bral ba gsad na/ de las ngo tsha ba mi yong bas nga 'dir mi gdod, p 71.1.

${ }^{654}$ This entire story as related here runs Götsang Repa, pp 67.3-71.3. In relating this story The Life of the Madman of Tsang states that Künga Zangpo was at first not yet known as the Madman of Ü. It then says
} 
This same moment is described very differently in The Life of the Madman of $\ddot{U}$. In this version, after Künga Zangpo exchanged his monk's robes for the garb of the Heruka he spent some time meditating in some important sites along the Tibet-Nepal border, such as Lapchi, Chuwar and so on. Then he decided to "overpower with his glory" (zil gyis gnan) the King of Ngari Gungtang, reasoning that if he subdued this one lord, all the gods, demons and people of Tibet would also come under his sway. So, wearing the garb of the Heruka, Künga Zangpo went directly into the king's palace, with no fear of the guards, eunuchs (nyug rum pa) or dogs. He was absorbed in a samädhi called "overpowering samsāra and nirvāna, all of phenomenal existence, with glory," (snang srid 'khor 'das thams cad zil gyis gnon pa). Everyone was shocked and terrified of him, and no one was able to touch him. Howling, he went directly into the king's presence. All were stupefied. In time some guards rushed in and threw him out into the courtyard. They sent down on him various sharp weapons and a rain of stones. They beat him fiercely, but he did not suffer any harm. Künga Zangpo meditated throughout the attack, and while uttering "hūm" and "phat" he performed a dance (bro 'khrabs pa). Seeing this, the king and all his ministers and subjects gained faith in the yogi's signs of meditative accomplishment (grub pa'i rtags), and reverently invited him in and served him. They confessed their sins for having attacked him. He was received in turn in the homes of all the ministers and subjects. It is said that from that time onward he was renowned in all places as "the Madman of Ü."655

that people were referring to him as the Madman of Ü. Then it states that he became widely renowned by that name. This was clearly a transitional moment in Künga Zangpo's assuming the identity of the Madman of Ü.

${ }^{655}$ The Life of the Madman of $\ddot{U}, \mathrm{pp}$ 440.2-443.4. 
The two accounts of this event describe the same basic circumstances of Künga Zangpo's coming to be accepted by the kings and subjects of Gungtang, as well as the fact that this is what launched his reputation as the Madman of $\ddot{U}$. But these two accounts are in disagreement as to how these events actually played out. In the version presented in The Life of the Madman of $\ddot{U}$, the Madman of Ü passes almost magically into the presence of the king, then miraculously endures a savage beating, which convinces everyone of his status as a siddha. There is no mention of the Madman of Tsang. In the account by Götsang Repa, it is the Madman of Tsang who passes into the presence of the king, while the Madman of Ü is a low-level outsider who gains acceptance by the king of Gungtang thanks only to the kind support of the Madman of Tsang. The biographies of the Madman of $\ddot{U}$ and the Madman of Tsang agree in some key ways while disagreeing in some equally important ones.

The next point of interaction between the Madmen of Ü and Tsang bears the first suggestion that their relationship may not have always been a positive one (and as we will see below, later it would degenerate entirely). Not long after the story just described, the Madman of Tsang was staying at Kangtsuk Cave (rkang tshug phug), which was said to have had an historical association with Milarepa. Götsang Repa's version of The Life of the Madman of Tsang maintains that while staying at Drakar Taso (brag dkar rta so) the Madman of Ü had heard from one of the Madman of Tsang's students how learned and accomplished in meditation (mkhas shing grub pa gnyis) he was regarding the Hevajra tantra. And so the Madman of Ü generated the intention of studying that tantra under him. When the Madman of $\ddot{U}$ arrived at Kangtsuk Cave and requested an audience with the Madman of Tsang, the latter was already engaged with teaching another student. 
In the meantime the Madman of Ü was invited by some locals who offered him some humble food (zan $\mathrm{ra}$ ) while other guests were given meat and beer. This perceived slight angered the yogi, who knocked the food and dishes to the floor, snapped his fingers, give his thighbone trumpet a fierce toot, and left. The Life of the Madman of Tsang states that after this it was renowned that the relationship between the Madmen of Tsang and the Madman of $\ddot{U}$ as teacher and student was disrupted because of this event (dpon slob gi [sic] rten 'brel ma 'grig ces grago). ${ }^{656}$ Perhaps the Madman of Ü should have exercised more patience on the eve of receiving teachings from the Madman of Tsang, six years his senior.

Evidently the relationship between the two eccentric yogis was not entirely unredeemable. Not long after this unpleasantness the Madman of Tsang held a special teaching session in order to heal a student of his who had become ill due to a blockage in the movement of the drops circulating in his subtle, yogic body (thig le'i gags byung). The Madman of Tsang's bestowal of teachings and empowerments had the desired effect and the student was cured. But during this gathering a pernicious spirit being entered into one of the people camped there. All attempts to exorcise the spirit through ritual were unsuccessful. So the lama Menlungpa (man lungs pa) was asked to perform a fierce fire ritual (homa; drag po'i sbyin sreg), and the Madman of Ü was asked to give a blessing (byin rlabs). The Madman of Ü's blessing consisted of beating everyone (mi kun brdungs), tossing about the provisions stored in the lower part of the house, and breaking all the pottery. He beat the sick person almost to death (nad pa 'chi ba tsam brdungs), but it did not help. So the Madman of Tsang himself was asked to give a verbal blessing.

\footnotetext{
${ }^{656}$ Götsang Repa, p 84.3-.6.
} 
He recited some mantras mixed with some lurid phrases, and the ill man got better. It was said that the fire ritual was unsuccessful because at that time the pernicious spirit had hid in the riverbank, and the Madman of Ü's violent blessing was unsuccessful because it was hiding behind a door. But in the end there was no escaping the powerful mantra pronounced by the Madman of Tsang. ${ }^{657}$

We know that the Madmen of $\ddot{U}$ and Tsang spent time in many of the same sites. This episode offers a glimpse of what the dynamic between them might have been. This passage also corroborates that the Madman of $\ddot{U}$ performed the kind of eccentric behavior described in his biography. The blessing the Madman of Ü gave to the man possessed by the malevolent spirit is highly reminiscent of an episode from The Life of the Madman of $\ddot{U}$ when a female patron asked the yogi for a blessing, to ensure that sons and wealth would come to her household. The Madman of Ü then proceeded to urinate in all the pots and pans in the whole house. In time good fortune came to them as a result of this blessing. ${ }^{658}$ The story from The Life of the Madman of Tsang seems to corroborate the fact that the Madman of $\ddot{U}$ at times engaged in this kind of odd and violent ceremony. We should also note that this account, written by a student of the Madman of Tsang, maintains that yogi had superior power in dealing with malevolent forces.

There is one last significant event that occurred between the Madmen of Ü and Tsang, although it involved their students rather than the madmen themselves. One time the Madman of Tsang sent some of his disciples on pilgrimage to the Swayambhūnāth stüpa in Nepal (which he would renovate not long after) while he stayed in meditative

\footnotetext{
${ }_{657}^{657}$ Götsang Repa, p 98.2-.6.

${ }^{658}$ The Life of the Madman of $\ddot{U}$, pp 556.3-567.2.
} 
retreat with some others. When they returned from their pilgrimage those students reported that they had had a fight ('khrugs pa) with some of the Madman of Ü's monks. They said some things back and forth and got angry with one another. The friction between them escalated until on one occasion when they were gathered for an assembly and, drunk off chang, got into a physical altercation. One from their side was killed, while a few of the Madman of Ü's students were also killed.

Hearing this, the Madman of Tsang began to cry. He lamented how in the degenerate age in which they lived, even the representatives of the Dharma had no restraint and killed people. The Madman of Tsang was very upset for many days, crying, unable to sleep. Then news arrived that six of the Madman of Ü's monks had harassed about fifty of their monks for many days; and although they practiced restraint and did nothing in retaliation, one of the Madman of Ü's monks stabbed one of them with a knife and he died. This caused the Madman of Tsang to lament how killing people was not the way to uphold the Teachings of the Buddha and ordered his students not to kill anyone in retaliation. $^{659}$ It is understandable that the relationship between the Madmen of Tsang and $\ddot{U}$ would have soured because of these incidents; this is the last mention of the Madman of Ü or his students in The Life of the Madman of Tsang, other than later mentioning that one of the Madman of Tsang's students, the realized one Lodrö Tashi (rtogs ldan blo gros bkra shis) was "shared" (thun mong ba) with the Madman of Ü. 660

Thus according to the standard version of The Life of the Madman of Tsang the relationship between the Madmen of Ü and Tsang followed a winding and ultimately

\footnotetext{
${ }^{659}$ Götsang Repa, pp 200.7 to 201.7.

${ }^{660}$ Götsang Repa, p 266.5.
} 
tragic trajectory. At first Künga Zangpo is mentioned as a sort of nobody, far from having achieved the status of one like the Madman of Tsang, whose fame had already spread far and wide. Then, the Madman of Tsang extended a helping hand to his counterpart, standing up for him when a royal family did not offer the ascetic from Ü the respect he deserved. Thanks to the Madman of Tsang's kindness at this moment, the king of Gungtang accepted the Madman of $\ddot{U}$ as a worthy yogi and his fame began to spread. Then sometime after this the Madman of Ü, still in a subordinate position, displayed impatience at a perceived slight while waiting to receive teachings from the Madman of Tsang, and because of this it was said that their relationship deteriorated. Then the Madman of Tsang requested that the Madman of Ü try to exorcise a malevolent spirit that that was afflicting one of his followers. Finally there was some sort of disagreement between the Madman of Tsang's disciples and those of the Madman of Ü (there is no mention of whether or not the Madman of Ü was ever present during this fighting) which escalated, and thanks to the unfortunate effects of alcohol, led to an open physical confrontation that resulted in a few deaths, and was followed sometime thereafter by a retaliatory murder. (This may have been just the sort of disorder in the Buddhist community Tsongkhapa felt so strongly about reforming.)

The Madman of Ü is thus a significant character in Götsang Repa's version of The Life of the Madman of Tsang. Interestingly, there is no mention of the Madman of Tsang anywhere in The Life of the Madman of $\ddot{U}$, which leaves much to ponder. Could it be that the Madman of Ü's disciples and compilers of his Life were resentful of the fame and success of the Madman of Tsang, and therefore excised him from the history of their guru? Was it that the Madman of Ü had long tried to emulate the Madman of Tsang and 
his loyal biographers were loathe to admit this source of influence on the ways of their beloved master? Or was the Madman of Tsang written out of the Madman of Ü's story as a result of lingering bitterness from the dispute that led to their students murdering one another? Was there resentment or embarrassment over the matter, which they preferred to simply exclude from the historical record they were creating? ${ }^{661}$ Given how famous he was, it seems unlikely that the Madman of Tsang was omitted because he was not seen as significant enough to be worth mentioning. We will never know the true reason; all we can do five hundred years after the fact is speculate. This issue raises the question of the nature of the biographies of the Madmen of Ü and Tsang that we have been relying on as our main source of information for this study, a matter that will be returned to in Chapter Six.

The version of events offered by Götsang Repa's version of The Life of the Madman of Tsang suggests that the Madmen of Ü and Tsang may have coordinated with one another in the performance of the eccentric behavior that would earn them reputations as "madmen." It seems that the Madman of Tsang led his younger counterpart into this lifestyle, as we know that it was during a period of contact between them that the Madman of $\ddot{U}$ first started to engage in the tantric fundamentalist behavior for which the Madman of Tsang was already famous. But over time their relationship may have soured, and there was some bad blood between their followers. We can only

\footnotetext{
${ }^{661}$ This is complicated by the fact that Part I of The Life of the Madman of Ü in which his violent encounter at Gungtang is described (with the Madman of Tsang suspiciously absent) was written in 1494, when the yogi was about 36 years old, long before the unfortunate incident between his students and those of the Madman of Tsang took place. This suggests that there may have been some ill-feelings between the camps of the two yogis before open fighting broke out between their students, or simply that it was more flattering to the image of the Madman of Ü to describe these events without the intervention of the Madman of Tsang.
} 
wonder what might have happened if they had all shown more restraint and these personal issues had not gotten in the way. Perhaps the Madmen of Ü and Tsang could have collaborated fruitfully together, and maybe been more successful in their attempt to redefine the Kagyü sect.

A wider consideration of the lives of the Madmen of Ü and Tsang's Kagyüpa contemporaries reveals that some of the distinctive behavior they engaged in was taken up by others as well. We will consider the biographies of two other Kagyü ascetics, the First Pawo and Drakpa Tayé, to get a better idea of the impact the Madmen of Ü and Tsang had on the religious culture of their day. How large did they loom in the religious landscape? To what extent was what they were doing unique? To what extent can we think of them as participants in a larger movement or trend?

\section{IV.2 The First Pawo, Chöwang Lhündrup}

The life of Chöwang Lhündrup (chos dbang lhun grub, 1440-1503), the first of the Pawo ( $d p a$ ' bo) or "Hero" incarnation lineage, mentions a number of interesting connections that characterize the role played by the Madmen of Ü and Tsang in the religious culture of their day. ${ }^{662}$

Chöwang Lhündrup's father was a kitchen master or head cook (gsol dpon) for the Pakmodru gongma Künga Lekpa (1433-1483). ${ }^{63}$ Chöwang Lhündrup was accompanying his father in serving the gongma, until one day he fell into a meditative state while making tea. The tea boiled over and Chöwang Lhündrup's father scolded him. He then fled to pursue a life of religion. He took novice (dge tshul) vows and

\footnotetext{
${ }^{662}$ His dates are from Richardson, "The Karma-pa Sect: A Historical Note," p 378. In The Scholar's Feast, 2006 version, the life of the First Pawo runs pp 597-610. Here I am drawing from the version given in the Karma Kamtsang history, which is based on the version given in The Scholar's Feast.

${ }^{663}$ Karma Kamtsang history, p 658.4.
} 
began to practice the Mahāmudra and the Six Dharmas of Nāropa. After a year and a half Chöwang Lhündrup went forward to practice "secret activity" (gsang spyod la 'byon pa), although we are not told what this entailed. Chöwang Lhündrup traveled around Lhasa and areas north of there, practicing and receiving teachings. He was instructed to study more formally (slob gnyer) and went to Drepung Monastery. However, he had some disagreement with them regarding work duties or some issue of rank (las tshan gyis 'khrug), and was not happy there, so he left for more isolated places. ${ }^{664}$

Chöwang Lhündrup showed great prowess in generating yogic heat (gtum mo). He is also said to have performed miracles, such as walking on water and leaving footand hand-prints in rock. According to his biography, people were amazed by these miracles. Some people thought he was crazy (smyo ba), but most said he was like a [celestial] "hero" (pawo, dpa' bo). This latter name was given to him and stuck, and would be the sobriquet by which his next incarnation, Pawo Tsuklak Trengwa (1504$1564 / 66)$, would be known. ${ }^{665}$

Chöwang Lhündrup is said to have done many eccentric things in his career. Sometimes he would sit for many days saying nothing. Usually he would say very little. At other times he would constantly intone "bhrüm, bhrūm!" Sometimes he would stare at the sky and praise the Buddhas and bodhisattvas, or sing songs expressing his grief with the world. Yet on other occasions he would say only the names of colors - "blue, yellow,

\footnotetext{
${ }^{664}$ Karma Kamtsang history, pp 659.7-660.1.

${ }^{665}$ Karma Kamtsang history, p 660.6-.7.
} 
red, green..." ${ }^{666}$ Sometimes he would throw away what was offered to him. In general, it is said that he did much "unpredictable activity" (ma nges pa'i spyod pa) like this.

Chöwang Lhündrup's eccentric behavior is referred to using a number of terms that are very similar to the ways the eccentric behavior of the Madmen of $\ddot{U}$ and Tsang is described in their biographies, as reviewed in Chapter Three. Chöwang Lhündrup performed "secret activity" (gsang spyod ${ }^{667}$ ); mi gcod drag po, "fierce human-cutting" on "fierce self-sacrifice," a term we saw applied to the Madman of Ü when he purposefully sought out physical abuse. Chöwang Lhündrup is also said to have performed the "engaged asceticism of a renunciant" (bya bral gyi brtul zhugs) during which time he dressed in a haphazard, unpredictable manner (sku'i cha byed ni nges med du mdzad). The general course of his spiritual development is described in terms we are already familiar with: it is said that until about the age of thirty he practiced "secret activity" (gsang spyod), "public activity" (tshogs spyod); "the engaged asceticism of awareness" (rig [pa brtul zhugs kyi] spyod), in its "with elaborations," "without elaborations" and "thoroughly without elaborations" (spros bcas, spros med, shin tu spros med) varietiesall categories used in the Guhyasamāja tantra commentarial tradition to describe advanced phases of practice. After the age of thirty Chöwang Lhündrup practiced "activity that is victorious in all respects" (phyogs las rnam par rgyal ba) and "great public activity" (tshogs spyod chen po), a term I have not come across anywhere else.

After many years of focusing on tantra, at some later point in his life the Chöwang Lhündrup intended to take full monastic ordination. The biographer describes the phases

\footnotetext{
${ }^{666}$ Karma Kamtsang history, pp 663.5, 661.4-.5.

${ }^{667}$ Karma Kamtsang history, p 661.3.
} 
of the Pawo's life in this manner: “... although at first he was a hearer-novice, in the middle phase he took on the unpredictable dress for the practice of tantra and did various manners of behavior, such as acting like a baby, acting like a madman (smyon pa lta bu), and acting like a lion." The biography states that later he had the intention of taking full ordination, but the master under whom he intended to take his vows passed away before he had the chance. ${ }^{668}$

Chöwang Lhündrup's biography indicates that much of his life was dedicated to practicing the kinds of ascetic practices that were most important for the Madmen of $\ddot{U}$ and Tsang. Like the Madmen of Ü and Tsang, these practices came to form an important part of Chöwang Lhündrup's public legacy. For example, the History of the Taklung Kagyü describes Chöwang Lhündrup as "one who had the performance of engaged asceticism that liberated phenomenal existence in/as Dharmabody..., 669

Thus it seems that Chöwang Lhündrup performed many of the same advanced tantric practices that were so distinctive to the Madmen of $\ddot{U}$ and Tsang. But the connections to the holy madman tradition do not end here. Chöwang Lhündrup's biography describes how he had a younger brother named Jamyang Lhündrup (’jam dbyangs lhun grub), whom he sent to study under the Madman of Tsang. In time he took to wearing the garb of a Heruka (he ru ka'i chas mdzad) and was given the name "the Great Cotton-clad One of Mountain Retreats" (ri khrod ras chen). ${ }^{670}$ Chöwang Lhündrup's brother's study under the Madman of Tsang is also mentioned in The Life of

\footnotetext{
668 ... dang por nyan thos kyi dge tshul yin yang bar du sngags spyod kyi sku cha lugs ma nges pas byis pa lta bu spyod pa dang smyon pa lta bu'i spyod pa dang / seng ge lta bu'i spyod pa sogs sna tshogs mdzad la... Karma Kamtsang history, p 668.1-.2

${ }^{669}$ stag lung chos 'byung, p 452. snang srid chos skur grol ba brtul zhugs spyod pa'i dbang po...

${ }^{670}$ Karma Kamtsang history, p 673.3-.4; also mentioned p 669.2.
} 
the Madman of Tsang, with some details added. In Götsang Repa's version of the Life, Jamyang Lhündrup went to study under the Madman of Tsang, but quickly went back to his brother. When Chöwang Lhündrup asked him why he came back, he answered that he "didn't get" (blo la ma song) the Madman of Tsang's way of dressing and practicing tantra. $^{671}$ Jamyang Lhündrup must have gone back to train under the Madman of Tsang and eventually took those odd ways of dressing and behaving as his own.

Pawo Chöwang Lhündrup shared a circle of supporters with the Madmen of Ü and Tsang. One of his most important patrons was Rinpungpa Dönyö Dorjé. Dönyö Dorjé and his ministers are mentioned as the patrons for a building project undertaken by Chöwang Lhündrup; Dönyö Dorjé is also the only patron mentioned by name as having made offerings after the yogi's death. ${ }^{672}$ Earlier, when the Pawo had visited the 7 th Karmapa's great encampment, he said that Dönyö Dorjé (the sde pa sgar pa) was an emanation (sprul pa) of Cakrasamvara himself. ${ }^{673}$

Lastly, we know that the Pawo's next incarnation, the famous Pawo Tsuklak Trengwa (dpa' bo gtsug lag 'phreng ba, 1504-1564/66), author of the history The Scholar's Feast (mkhas pa'i dga'ston) was taken care of by Dönyö Dorjé for the first five years of his life, until he ascended to the throne of Lodrak Drowolung Sekar Gutok Monastery (lho brag gro bo lung sras mkhar dgu thog). ${ }^{674}$ Pawo Tsuklak Trengwa also

\footnotetext{
${ }^{671}$ Götsang Repa, pp 126.6-127.3.

${ }^{672}$ Karma Kamtsang history, pp 668.6, 672.2.

${ }^{673}$ Karma Kamtsang history, p 669.5.

${ }^{674}$ This is from the life of Tsuklak Trengwa given in the second volume of the Karma Kamtsang history, p 55.4, Si-tu Pan-chen Chos-kyi 'byung-gnas (1700-1774) and his disciple 'Be-lo Tshe-dbang kun-khyab, sgrub brgyud karma kam tshang brgyud pa rin po che' $i$ rnam par thar pa rab 'byams nor bu zla shel gyi phreng ba zhes bya ba'i pu sti ka phyi ma (Kangra District, palpung sungrab nyamso khang, 1990), Vol. 12 ( $n a$ ) in the Collected Works (gsung 'bum) of si tu pan chen chos kyi 'byung gnas (TBRC W26630). Most references to this work in my research are from the Delhi, 1972 version, by D. Gyaltshan and Kesang Legshay (TBRC W23435).
} 
visited and received teachings from the Madman of Ü, which is described in the latter's biography and elsewhere. ${ }^{675}$

Thus between the First Pawo, Chöwang Lhündrup, his younger brother, Jamyang Lhündrup, and his next incarnation, Pawo Tsuklak Trengwa, there were multiple points of commonality and connection with the Madmen of Ü and Tsang. Chöwang Lhündrup performed some of the same distinctive practices as the Madmen of $\ddot{U}$ and Tsang (although perhaps without the same emphasis on tantric literalism) without showing any indication of having been directly influenced by them. Being between twelve and eighteen years older than the Madmen of Ü and Tsang, Chöwang Lhündrup was well into his religious career before they had established their fame. However he did send his younger brother to study under the Madman of Tsang, and he seems (perhaps after a period of adjustment) to have taken after the famous yogi in terms of lifestyle and practice. We also see that Dönyö Dorjé was interested in investing in the Pawos, who, like the holy madmen, represented an alternative to the Gelukpas in the religious marketplace.

\section{IV.3 Drakpa Tayé}

We get a better understanding of the robustness of the tradition the Madmen of Ü and Tsang were a part of when we consider the life story of another Kagyü ascetic, Drakpa Tayé (1469-1531). Born nearly thirty years after tho first Pawo and seventeen and eleven years after the Madmen of Tsang and Ü respectively, Drakpa Tayé came to spiritual maturity in a religious environment that bore the famous holy madmen's direct

\footnotetext{
${ }^{675}$ The Life of the Madman of $\ddot{U}$, p 635.1-.6. The Karma Kamtsang history (1990 printing), Part II (Vol. 12), p 56.4-.7. Dungkar Rinpoché dictionary, pp 1277-8.
} 
influence. His life also suggests that the holy madmen were a part of a broader movement.

In the opening homage Drakpa Tayé's main guru, Lhatsün Künga Chöki Gyatso (lha btsun kun dga' chos kyi rgya mtsho, 1432-1505) is praised as "supremely accomplished in engaged asceticism" (brtul zhugs grub pa mchog). ${ }^{676}$ We are then treated to a fascinating snapshot of 15th-century Tibetan religious culture when the author describes the disciples of Lhatsün Rinpoché in the following manner:

There were some who, by means of conquering all oppositions (phyogs las rnam par rgyal ba'i sgo nas) worked for the benefit of the Teachings and sentient beings. There were some who, by means of the performance of engaged asceticism (brtul zhugs kyi spyod pa'i sgo nas), wandered in the twenty four [holy] lands of Orgyen, Shambhala and so on; in the eight great charnel grounds; in the thirty-two divine abodes; or in towns, charnel grounds, haunted places (gnyan khrod) and sat in the midst of the external and internal dia kas and deakinis, and worked for the benefit of sentient beings. There were some who, in the manner of a beggar ${ }^{677}$ or a "hearer" in search of individual liberation, stayed in retreats in snowy places, slate mountains, forests and remote places, and by means of their disillusionment with the world and their renunciation, worked for the benefit of themselves and others. There were some who, maintaining the behavior of madmen, low castes ( $\mathrm{gdol} \mathrm{pa}$ ) or small children, stayed at crossroads, marketplaces, alleyways, in the middle of great plains, on islands and so on, and did their "activity" (spyod pa). There were some who, although they in a very secret manner stayed amongst ordinary people and worked for the vast benefit of themselves and others, [their true identities] were inconceivable.

-if these many male and female yogis who were all students of Lhatsün Rinpoché were like a cluster of stars, the subject of this biography, Drakpa Tayé, shone like the sun or

\footnotetext{
${ }^{676}$ rnal 'byor gyi dbang phyugs grags pa mtha' yas dpal bzang po'i rnam thar mgur 'bum ngo mtshar nor $b u$ ' $i$ 'phreng $b a$ (reproduced from tracings from prints of the Central Tibetan blocks from the Library of Burmiok Athing, Gangtok, 1977; also printed in Delhi), p 3.4.

${ }^{677} \mathrm{ku}$ sa li. In some contexts this word can have the general meaning of "virtuous one" (dge ba can), but here probably means "beggar," as is often the case in the context of the "Cutting" practice, and as it is clearly meant to be understood later in the biography when Drakpa Tayé meets stag lung smyon pa, who is living in the manner of a $k u$ sa li, p 101.5.
} 
the moon among them. ${ }^{678}$ What is significant about this passage is that the author asserts that many of the tantric practices described in Chapter Three that positioned the Madmen of $\ddot{U}$ and Tsang as eccentrics were actually quite commonplace among the students of Lhatsün Rinpoché. Thus as we read further of the eccentric practices performed by Drakpa Tayé, we are not to think of him as unique, but as only one among many of Lhatsün's disciples who took on this lifestyle.

As with the Madmen of Ü and Tsang, Drakpa Tayé's biographer describes the trajectory of his life using the successive phases of advanced tantric practice. According to the headings to the chapters of his Life, Drakpa Tayé progressed from "all-good activity" (kun tu bzang po'i spyod pa), to “secret activity" (gsang ba'i spyod pa), to "public activity" (tshogs kyi spyod pa) (during which time he performed the engaged asceticism of awareness, rig pa brtul zhugs), then progressed to performing "activity that conquers all oppositions" (phyogs las rnam par rgyal ba'i spyod pa). ${ }^{679}$ Further indicating the importance of these specific categories, during one of the many songs by Drakpa Tayé that are interspersed throughout the biography, the yogi gives a meaningful description of these categories. In short, he states that there are four types of this kind of higher tantric activity (spyod pa): "all-good activity," during which one meditates

\footnotetext{
678 Emphasis added. The quotation runs p 6.2-.6. 'ga' zhig ni phyogs las rnam par rgyal ba'i sgo nas bstan pa dang sems can gyi don mdzad/ 'ga' zhig ni rig pa brtul zhugs kyi spyod pa'i sgo nas u rgyan dang / sham + b+ ha la la sogs pa yul nyi rtsa bzhi dang / dur khrod chen po brgyad/ gnas sum cu rtsa gnyis dang / gzhan yang grong khyer dang / dur khrod dang / gnyan khrod rnams nyul bzhin phyi nang gi dpa' bo dang mkhro'i dbus na bzhugs shing sems can gyi don mdzad/ 'ga' zhig ni ku sa li dang / so thar nyan thos kyi tshul gyis gangs khrod dang / g.ya' khrod dang / nags khrod dang / bas mtha' rnams na bzhugs shing skyo shas dang nges par 'byung ba'i sgo nas rang gzhan gyi don mdzad/ 'ga' zhig ni smyon pa dang / gdol pa dang / bu chung lta bu'i spyod pa skyong zhing gzhi mdo dang / tshong 'dus dang / sgo srang dang / thang chen po'i dbus dang / chu gling la sogs pa rnams na bzhungs shing spyod pa mdzad/ 'ga' zhig ni shin tu sbas pa'i tshul gyis/ skye bo phal mo che'i khrod na rang gzhan gyi don rgya chen po mdzad cing bzhugs pa'ang bsam gyis mi khyab ste/...

${ }^{679}$ p 8.1-.6; the seventh chapter, describing his performance of "secret activity" ends p 162.5; the eighth chapter, describing his performance of engaged asceticism and "public activity" ends p 178.2.
} 
unwaveringly in an empty place; "secret activity," during which one makes offerings of what one holds dear while staying in a haunted place; "public activity," during which one submits oneself to difficult circumstances, and, through performing the behavior of a child or a madman (byis pa'i smyon pa'i spyod pa), one tames (brtul) grasping and entanglement and enters (zhugs) pure living (yang dag pa). Lastly, through performing "activity that is victorious in all directions," one establishes positive religious connections with all types of people, wherever and however they are most fit to be helped. ${ }^{680}$

There is too much that is pertinent about the religious practices of Drakpa Tayé to describe it all in detail here. Let us just note a few points that make for good comparisons with the Madmen of Ü and Tsang. In addition to the many occasions on which he is said to have followed the order of his teacher and practiced the general category of "secret activity," Drakpa Tayé also performs a specific meditative practice bearing the same name, in this case the "Secret Activity Reversing Meditation Instructed by Peṇchen Nāropa" (paN chen nA ro'i gdam pa gsang spyod bzlog sgom) ${ }^{681}$ As we saw in the previous chapter, some practices known as the Secret Activity of Näro were important to the Madman of Ü and Tsang; this may well be the same.

The notion of crazy behavior as a part of one's asceticism was certainly on the mind of Drakpa Tayé. This is most clearly expressed in some of his songs. For example, in one instance he sings:

\footnotetext{
${ }^{680}$ The song runs pp 316.1-318.3.

${ }^{681} \mathrm{p}$ 153.3. At other points in his biography Drakpa Tayé is said to have performed a "Reversing Meditation" (zlog bsgom): on one occasion, he and his students use it to prevent the spread of smallpox ( $p$ 346.1-.5); on another occasion, when he was performing a "Reversing Meditation" there was some mistake $(\log )$ in his practice; fortunately, by relying on a consort, he was able to get better ( $\mathrm{p} 204.1)$. In these cases the meditation he is performing may or may not be related to the specific "Reversing Meditation" text mentioned above, or to the "Secret Activity of Nāropa" practices described in Chapter Three, as practiced by the Madmen of Ü and Tsang.
} 
In the vast sky of the Dakpo Kagyü, there rises the sun that is the compassion of the glorious Drukpa; the light of the activity of Lord Lhatsün benefits the mind of this beggar monk named Drakpa.

In the vast cloudless sky of whatever arises, without fixation, there rises the sun that is the self-liberation of various beings; the shining light of engaged asceticism of mad activity (brtul zhugs smyon spyod) benefits the mind of one doing the activity of a little boy (bu chung spyod pa). ${ }^{682}$

In another song Drakpa Tayé mentions "the engaged asceticism of a madman" (smyon pa'i brtul zhugs) as one aspect of acting in the manner of a child (byis pa'i spyod pa), which exemplifies living in accordance with the ideal of taking all worldly phenomena as being of a single taste (ro snyoms). ${ }^{683}$

Like the Madmen of Ü and Tsang and some of their students, Drakpa Tayé adopted some eccentric forms of dress. One one occasion he smeared his naked body with ashes so that, according to the text, he looked like a zombie. He then sat on a hilltop blowing his thighbone trumpet. When some of his dharma brothers arrived they did not even recognize him. ${ }^{684}$ On another occasion it is said that, following the instructions of his master, Drakpa Tayé smeared himself with human ashes (thal chen) and adorned himself with the produce from trees (bark? leaves? shing 'bras); at that time he prostrated to no one, and with the confidence (gdeng tshad) arising from his practice of the performance of engaged asceticism of awareness (rig pa brtul zhugs), he subdued appearances with his brilliance (snang ba zil gyis gnan) and passed his time practicing the yoga of "activity" (spyod pa'i rnal 'byor). ${ }^{685}$

\footnotetext{
${ }^{682} \mathrm{pp} \mathrm{167.1-.2}$ and 167.6-168.1.

${ }^{683}$ The song runs p 289.1-.6; "the engaged asceticism of a madman" is mentioned p 289.3.

${ }^{684} \mathrm{pp} 114.6-115.5$.

${ }^{685} \mathrm{p} 165.1-.3$.
} 
We have no indication that Drakpa Tayé ever took on the garb of the Heruka during his lifetime, but it was clearly recognized as an option in the religious milieu in which he operated. On one occasion, when giving Drakpa Tayé advice on how to practice meditation on his own, his guru Lhatsün Rinpoché specifically stated that the special ornaments for higher tantric practice (spyod pa'i rgyan cha) were not really necessary. Rather, they are expedients for the purpose of casting off attachment, or for the purpose of representing the $d \bar{a} k a$ s and $d \bar{a} k i n \bar{s}$, and subduing appearances with one's brilliance (snang ba zil gyis gnon); however, one does not have to put on special bone ornaments; one can wear whatever torn clothing one has, and thereby naturally (ngang gis) become free from attachment, and thus subdue appearances with one's brilliance and make the $d \bar{a} k a$ s and $d \bar{a} k i n \bar{\imath}$ gather. After this Drakpa Tayé departed from his master wearing some old torn clothing and carrying only a skull cup $(\mathrm{ka} \mathrm{pAla}){ }^{686}$

Much later in his life, after he had become a renowned teacher and was based at Hao Monastery ( $h a$ 'o dgon), one morning many of the renunciants gathered there saw Drakpa Tayé fly into the air, with his cloth robes stretched out like wings, and adorned with the ornaments of a Heruka. ${ }^{687}$ Later, after Drakpa Tayé passed away, his followers decided to memorialize him in a statue one cubit $(k h r u)$ in height, bearing his likeness and wearing the ornaments of a Heruka. The statue was adorned with many pieces of turquoise. It is said that the statue was a very blessed object, shining with brilliance; it was placed as the central image in the shrine at Hao Monastery. ${ }^{688}$

\footnotetext{
${ }^{686} \mathrm{pp} \mathrm{128.2-130.2.}$

${ }^{687} \mathrm{p} 452.1-.5$

${ }^{688}$ pp 476.4-477.1.
} 
It thus seems that at times during his life Drakpa Tayé smeared himself with ashes and took on other odd forms of dress (like fashioning himself with produce from trees), but probably did not ever made a point of taking on the bone ornaments or other garb of a Heruka. This was certainly a known option during the time in which he lived, however, and his master discussed this possibility with him, ultimately concluding that it was unnecessary to take this step. Even though we have no indication that Drakpa Tayé ever actually dressed in the garb of a Heruka, it clearly represented a potent indicator of holiness that his followers felt moved to ascribe to him. This pious devotion can be seen as leading to the creation of the story of Drakpa Tayé flying above the monastery dressed in the garb of a Heruka, as well as the fact that he was memorialized with a statue in which he was wearing this garb. The garb of the Heruka thus represented a meaningful ideal in the milieu of the Kagyü sect in the late 15 th and early 16 th centuries during which Drakpa Tayé lived.

The Madmen of Ü and Tsang themselves loom rather large in The Life of Drakpa Tayé. Early in his religious education, on one occasion Drakpa Tayé went into a town to collect alms. There he met with a local official (nang so) who told him, "You and your master (or: you and your attendant) should be like the master Madman of Tsang and the Madman of Ü-will that be so?" The young Drakpa Tayé answered that he intended to be one called the Madman of "Chuk" (phyug smyon). This is probably a joke, saying that he wanted to be a "wealthy (phyug) madman." "689 This gives us some idea of the impact

\footnotetext{
${ }^{689}$ p 38.4-.6. der rje nyid kyis tshong 'dus su byon/ tshong 'dus nang so dang 'jal te chas len du byon pa' $i$ lo rgyus byas pas/ nang so na rel khyed dpon g.yog gnyis kyis/ bla ma rtsang [sic] smyon dbus smyon tsam cig gyis shog de 'dra e yong zer ba lal rje nyid kyis kyang bka' rgyud kyi bstan pa 'dzin pa'i skyes bu phyug smyon zer ba cig byed snyam pa yid gsungs/.
} 
the fame of the Madmen of Ü and Tsang had on the religious culture of their day. They were quite well known—a reference point for other Kagyü ascetics.

In time Drakpa Tayé would actually meet these famous holy madmen. He met the Madman of Tsang while staying at Mount Kailash. ${ }^{690}$ He also met the Madman of Ü on at least two occasions. The first was when Drakpa Tayé was staying at a retreat near Densa Til. ${ }^{691}$ Then much later Drakpa Tayé wished to meet Künga Rinchen, an important hierarch of Drikung Til Monastery ('bri khung dbon rin po che kun dga' rin chen). Drakpa Tayé requested an audience with him but for some reason it was not granted. Around this time he encountered the Madman of Ü, who heard of Drakpa Tayé's difficulty and said that he would personally see to it that he had the opportunity to meet the hierarch. It worked out, and everyone was very pleased. ${ }^{62}$ Before this Drakpa Tayé had received the "reading transmission" (lung) for The Life of the Madman of $\ddot{U}$ while staying at Nyukla. This must refer to part one of the yogi's life, written by Nyukla Penchen while the yogi was still middle-aged. ${ }^{693}$ This indicates that part of the Madman of Ü's biography was in circulation even during his lifetime, suggesting that he had already grown famous - or that his followers were making a conscious effort to make him so.

During a three-day stay at Ralung Drakpa Tayé met the lord of yogis, Künga Lekpa, also known as Drukpa Künlé. ${ }^{694}$ It is significant that he is not referred to by his more popular name of Druknyön, "the Madman of the Drukpa." Drukpa Künlé and his

\footnotetext{
${ }^{690} \mathrm{p}$ 105.2-.3. Much earlier he met two people who were known as disciples of the Madman of Tsang, $\mathrm{p}$ 27.6.

${ }_{692}^{691} \mathrm{p} 63.3$.

${ }_{692}$ pp 335.4-336.2.

${ }_{693}^{693}$ p 255.2. Drakpa Tayé receives the lung for rje dbus smyon pa'i rnam thar at smyug la. ${ }^{694}$ pp 150.2-151.2.
} 
relation to the 15 th- and 16 th-century madman movement will be discussed in the next chapter.

Drakpa Tayé had contact with individuals known as "madmen" other than the Madmen of Ü and Tsang. At Dingri in Tsang he met one called the Madman of Taklung (stag lung smyon pa), who was a heartson of Ngaki Wangpo (ngag gi dbang po) of Taklung. He was staying in a cave with some disciples, and living in the manner of a beggar ( $k$ u sa li). ${ }^{695}$ (The Madman of Tsang had a disciple called the Madman of Taklung; this is likely the same person.) Drakpa Tayé also had contact with a Madman of Üding (dbus sdings smyon pa), who it seems received teachings from him: at one time when Drakpa Tayé had given teachings to a hundred and fifty students, some twenty of them were doing the cloth-offering ceremony, to show off their prowess in generating yogic heat. A few of the students gathered there were chatting, and as punishment the master ordered them to dance naked in the middle of the entire assembly. They had no choice but to obey. Afterward, one called the Madman of Üding said, "Instead than enduring that unpleasantness, I would rather have offered three zhos of gold!" Everyone had a big laugh at that. ${ }^{696}$ This was probably not the same person as the Madman of Ü. (We should also take note that dancing naked and singing, which would often be understood as an expression of one's realization and freedom from worldly concerns, could actually be assigned as a punishment.)

Equally significant to our understanding of the extent to which we can talk of a madman "movement" taking place at this time is the fact that in his lifetime Drakpa Tayé

\footnotetext{
${ }_{695}^{69}$ pp 101.5-102.1.

${ }^{696}$ pp 234.5-235.5.
} 
encountered many Buddhist ascetics described as following some very eccentric lifestyles who were not specifically referred to as "madmen." While visiting a small town in Tsang he encountered one said to be a "secret siddha" (sbas pa'i grub thob) named Dritsampa ('bri 'tshams pa). He had abandoned concern for his life and was truly living in the manner of experiencing all phenomena as being of a single taste. He paid no concern to clothing and wore only the humblest scraps of sheepskin. Dritsampa displayed absolutely no grasping with respect to his own upkeep, and ate whatever he foundincluding human and dog feces, dirt and rocks. He was emaciated, covered with dirt, his hair filled with lice. He lived as a beggar with absolutely no shame, "like a dog or a donkey" (khyi'am bong bu bzhin). He had a yak horn that he sometimes urinated into, sometimes drank from. He taught no Dharma but said whatever nonsense or dirty thing that came to him — thus "day and night he maintained his practice of not according himself with anything thought or said by anyone in this world or this life" ('jig rten tshe 'di'i mi dang blo skad cig kyang mi bstun par nyin mtshan kun tu spyod pa skyong gin bzhugs pa).

When Drakpa Tayé met Dritsampa he offered him a lower garment. Dritsampa accepted it only reluctantly, then later gave it to a prostitute. The secret siddha said a number of seemingly meaningless things to Drakpa Tayé that were actually excellent instructions. From this encounter Drakpa Tayé drew a lot of inspiration to abandon concern for the present life. Later he would say that although Lhatsünpa was his lama, his understanding of renunciation came from this siddha Dritsampa. ${ }^{697}$

${ }^{697}$ pp 96.6-99.1. 
At one point Drakpa Tayé stayed for some time in the courtyard of the Jokang temple in Lhasa. Among the many beggars who were staying in that courtyard there was a yogi who was disguised as a beggar (sprang rdzus). At first Drakpa Tayé did not realize this man to be a religious practitioner. In time he did, and they spoke at length. They became friends. ${ }^{698}$

Another eccentric figure in the life of Drakpa Tayé was his own guru, Lhatsünpa (his full name is given as lha btsun kun dga' chos kyi rgya mtsho rol pa'i rdo rje). ${ }^{699}$ Lhatsünpa at times carried a khatvāinga staff and was not opposed to going about naked and engaging in various odd manners of personal conduct. ${ }^{700}$ He encouraged Drakpa Tayé to do the same, instructing him to "run naked in an uninhabited valley" (mi med kyi lung stong du gcer rgyugs gyis) and to practice "secret activity" in empty retreats ( $d a$ dung rgyal khams kyi dben gnas rnamsu gsang ba'i spyod pa skyong ba la 'gro). ${ }^{701}$

We have thus seen that Drakpa Tayé had meaningful contacts with some religious figures following non-traditional and non-monastic forms of Buddhist practice. They seem to have given him much inspiration for how he approached his own spiritual practice. Beyond meeting at least four religious practitioners who were popularly known as "madmen," there is a pronounced rhetoric of madness throughout the biography and the songs interspersed therein. This anticipates the major point to be made in Chapter Seven, but is worth considering briefly here.

The manner in which a rhetoric of madness is most commonly used in the course of The Life of Drakpa Tayé is as a term of endearment and respect for Drakpa Tayé's

\footnotetext{
${ }_{698}^{69} \mathrm{p} 131.1-.4$.

${ }^{699} \mathrm{p}$ 356.5-.6.

700 See, for example, pp 40.6-41.2.

${ }^{701}$ pp 54.1, 149.4.
} 
teacher. Throughout the biography Drakpa Tayé's guru is mostly referred to as Lhatsünpa or Lord Lhatsün (rje lha btsun) or Lhatsün Rinpoché. Yet in at least five of the songs interspersed throughout the latter parts of the biography, Drakpa Tayé refers to his teacher as "crazy Lhatsün" (lha btsun smyon pa). In one verse Drakpa Tayé says, "I supplicate at the feet of crazy Lhatsün!" (Iha btsun smyon pa'i zhabs la gsol ba 'debs). ${ }^{702}$ In a long song praising the many deeds of his guru, Drakpa Tayé begins with, "You, crazy Lhatsün, who gives forth a cloud of compassion..." (thugs rje sprin 'phro lha btsun smyon pa khyod). ${ }^{703}$ In the course of this song Drakpa Tayé mentions how his master at one point pretended to be insane (smyo rdzu mdzad); practiced the behavior of a child (byis pa'i spyod pa); achieved perfection in the practice of engaged asceticism (brtul zhugs); and wandered in various places "performing the engaged asceticism of a madman" (smyon pa'i brtul zhugs mdzad pa), among many other things. ${ }^{704}$ Drakpa Tayé clearly remembered his guru as one who performed some eccentric ascetic practices and at times even behaved in the manner of a madman. But his praiseful use of the word "madman" carries meaning that extends well beyond this direct, less figurative use of the term.

And just as Drakpa Tayé had done for his master, Mapam Dorjé (ma pham rdo rje), a disciple of Drakpa Tayé and the author of his biography, leaves open the door for Drakpa Tayé himself to be associated with the term "madman," well beyond his limited performance of "mad" asceticism that was described above. The biography relates how on one occasion Drakpa Tayé was riding a horse in a remarkably reckless manner in the

\footnotetext{
${ }^{702}$ p 364.1-.2.

${ }^{703}$ p 358.1.

${ }^{704} \mathrm{pp} 359-363$. For the other three instances of the use of lha btsun smyon pa, see pp 301.4, 302.1, 433.5 .
} 
Tsari area. Intoning a constant "aaaaa" sound, Drakpa Tayé rode his horse full steam ahead, without paying any attention to the surface he trod over, the forests or streams he passed through. All the people who encountered him riding in this manner said, "It's a crazy lama!" (bla ma smyon pa yin par 'dug) and fled "without even being able to request a blessing."705 We can interpret this passage the same way that we read the desire on behalf of Drakpa Tayé's followers to associate him with the form of a Heruka: in this tradition, having an association with being a "madman" tends to be a positive one, something one's students would be interested to cultivate, in homage to their teacher.

One last aspect of Drakpa Tayé's life that we must take into account is his patronage relationships. It will probably come as no surprise to discover that Dönyö Dorjé and some other Rinpungpas played significant roles as patrons throughout the career of the ascetic. Drakpa Tayé first met the "lord of the Dharma" (chos kyi rgyal po) Dönyö Dorjé when they were both staying in Lhasa. One night some people arrived bearing a personal invitation for Drakpa Tayé to go before Dönyö Dorjé (here called the sde pa). Dönyö Dorjé, who knew about Lhatsünpa (who had been spending a lot of time at Rinpung ${ }^{706}$ ), asked Drakpa Tayé many questions about points of doctrine. In the end he offered the young ascetic encouragement to continue the religious life. ${ }^{707}$

Their next encounter took place when Drakpa Tayé went to see his master, who was staying at Rinpung. Dönyö Dorjé held a great tantric feast during which they spoke

\footnotetext{
${ }^{705} \mathrm{p} 338.3-.5$.

706 See p 121.5.

${ }^{707}$ pp 134.1-138.6.
} 
of religious matters. ${ }^{708} \mathrm{~A}$ while later it is said that Dönyö Dorjé offered provisions for Drakpa Tayé and a handful of his students practice in a mountain retreat for some time. ${ }^{709}$ Later in his life Drakpa Tayé had the wish to finally take full monastic ordination. (The First Pawo, Chöwang Lhündrup, wanted to take full ordination later in his life too, but did not manage to do so.) He wanted to undergo this solemn rite in the presence of the 4th Red Hat (here called spyan snga rin po che zhwa dmar ba, recognizing the role he was playing as the head of Densa Til Monastery at that time). So Drakpa Tayé went to Rinpung and met with the lord of the Dharma, Dönyö Dorjé, who wrote a letter of request on his behalf. After a stop at Nyukla where he took novice ordination (dge tshul) before Pel Ngaki Wangpo (dpal ngag gi dbang po) (probably referring to Nyukla Peṇchen, who was likely a cousin of Dönyö Dorjé, as well as the disciple of the Madman of Ü and the author of the first half of his biography), he went to Yangpachen Monastery, where he showed the letter that had been written by Dönyö Dorjé. The Red Hat quickly gave him full ordination. ${ }^{710}$

Shortly after this Drakpa Tayé was traveling back to Tsang when one night in a dream he saw many ornamented women leading the depa Dönyö Dorjé to some other realm; he also had some other bad signs along the way. He planned to visit Dönyö Dorjé, but after just a few days the depa passed away. That summer as Drakpa Tayé went into

\footnotetext{
${ }^{708}$ pp 147.5-149.1. It seems that on this occasion one of Dönyö Dorjé's ministers (the dpon sa gnyer chen; mentioned again $\mathrm{p}$ 255.4-.5) offered a prayer of long life in the presence of the master. This minister is mentioned again on $\mathrm{p} 450$, where he is called nyang ral gyi gdung 'dzin dpon sa gnyer chen rnam rgyal rdo rje, on which occasion he invites Drakpa Tayé to Rinpung to give teachings. He was moved by such faith that he wanted to become a monk under Lhatsünpa, but he did not receive authorization from Dönyö Dorjé to do so. Instead, he pledged to serve the precious Kagyü and in particular the students of Lhatsünpa, and made many offerings of provisions to Drakpa Tayé from that time onward.

${ }_{709} \mathrm{p}$ 188.2-.4.

${ }^{710}$ pp 253.1-254.6.
} 
retreat with some of his students, although he received provisions for their upkeep from some other patron, he still felt very deeply the pang of having lost Dönyö Dorjé. Drakpa Tayé sang a song lamenting the nature of samsāra and remembering his deceased patron, the "dharmaking of the encampment" (chos rgyal sgar pa). ${ }^{711}$

Not long after this Drakpa Tayé and seventy of his students entered what they intended to be a three year retreat at Hao Monastery. But according to Drakpa Tayé's biography, because this was a time of time of disturbances (dus 'khrug), soldiers were roaming among the mountain retreats. They stole some sheep that had been set free by Drakpa Tayé, and all of the meditators' provisions. ${ }^{712}$ This prompted Drakpa Tayé to sing a long, woeful song. He laments the "military disturbances of the degenerate age" (dus ngan snyigs ma'i dmag ' $k h r u g$ ). After summarizing the sufferings experienced by beings in all the realms of samsāara, Drakpa Tayé arrives at an especially interesting verse:

During this time when the five degenerations are on the rise, thanks to our lack of merit, a time of disturbances has arisen; in all of Ü and Tsang military disturbances spreadno living being's life is safe.

Oh the sadness of what one hears and sees!

Oh what a degenerate time this is!

Some sinful kings, lords and ministers have caused trouble for the dharmakings and cast the Teachings of the Buddha into darknessthe well-being and happiness of all beings has been exhausted. Oh the sadness of what one hears and sees!

Oh what a degenerate time this is! $!^{713}$

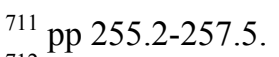

${ }_{712}^{712}$ p 270.3-.6.

${ }^{713}$ p 275.3-.5. The entire song runs pp 271.4-278.2.
} 
Drakpa Tayé goes on to lament how peoples' lands and homes had been destroyed, their livestock and wealth stolen; how people had been beaten and killed. Drakpa Tayé then states how, because of the passing of the dharmakings (chos rgyal rnams), all rule of law (rgyal khrims) had degenerated, and "the practice of giving and the other ten virtues have declined." But if the dharmakings were still alive, beings would have some refuge. While the dharmakings lose power, sinful kings grow in power, and set beings on the path to sin, making the sun of the Teachings fade. Drakpa Tayé again mentions the sinful soldiers who stole his sheep and modest possessions. Finally he laments the decline of the Dharma, saying that in the manner of selling flesh in the marketplace there are “deceitful realized ones and fake madmen” (rtogs ldan zog dang smyo rdzu byed), who cast spells.

This song expresses Drakpa Tayé's frustration with the ongoing military conflicts in central Tibet during the time in which he lived. It is clear that Dönyö Dorjé is included among the "dharmakings" whose passing he laments. We may assume that the troops who caused this trouble for Drakpa Tayé and his disciples were not those of the Rinpungpas, but of one of the factions against whom they were fighting. (In a very similar way, The Life of the Madman of $\ddot{U}$ also relates his having been harassed by troops while at his hermitage in Penyül.)

Drakpa Tayé would continue to have contacts with members of the Rinpung family even after the death of Dönyö Dorjé in 1512. At Rinpung Drakpa Tayé was twice received by the lord of the Dharma (chos kyi rgyal po) Ngawang Namgyel, Dönyö Dorjé's cousin and successor (on this occasion Drakpa Tayé was offered a blessing from the skull cup of Götsangpa; it seems that possession of this very blessed object for 
Drukpa Kagyüpas would have been an important source of charisma for the Rinpungpas). ${ }^{714}$ On another occasion Drakpa Tayé was invited to the "the Rinpung estate, the great place where the two traditions [i.e., worldly power and religion] come together" (lugs gnyis kyi mdun sa chen po gzhis kha rin dpungs) and gave teachings for a month. ${ }^{715}$ He came to Rinpung one last time slightly later, on which occasion he was treated to lavish offerings. ${ }^{716}$ The depa (whoever was the head of the Rinpungpas at the time) and other ministers from Rinpung took the lead in making offerings after Drakpa Tayé's death. $^{717}$

As we have seen, Drakpa Tayé's relationship with Dönyö Dorjé and the Rinpungpas was a meaningful one. They represent the only steady source of financial backing for the yogi, and were important supporters for his master and his disciples as well. But their relationship was about more than furnishing Drakpa Tayé with the means to pursue his goals in religious practice. Dönyö Dorjé used his influence to enable Drakpa Tayé to take ordination in the presence of the 4th Red Hat. And for this Drakpa Tayé was grateful to Dönyö Dorjé, whose death caused him to feel deep and poignant anguish. To Drakpa Tayé, Dönyö Dorjé's death constituted an indication that the affairs of central Tibet were taking a dramatic turn for the worse.

\section{IV.4 The Madman Movement}

By looking at the lives of the First Pawo and Drakpa Tayé we have gotten a sense of what kind of role the Madmen of $\ddot{U}$ and Tsang played in the religious culture of their

\footnotetext{
${ }^{714} \mathrm{p}$ 334.3-.4. Drakpa Tayé is also said to have gotten a blessing from this skull cup on an earlier visit to Rinpung, $\mathrm{p}$ 253.2. The second time he was received at Rinpung by an unnamed chos kyi rgyal po, who we can probably assume to be Ngawang Namgyel, p 340.6-341.1.

${ }_{715}$ pp 450.1-451.1.

${ }_{716}$ pp 452.6-453.2.

${ }^{717} \mathrm{p} 476.2-.4$.
} 
day. They were very active, well-known and well-connected. They were well-respected as worthy, enlightened beings (if not universally so). Even more importantly, by the peak of their careers they had come to represent an ideal that some other Kagyüpas aspired to. In this way they had a discernable effect in shaping the religious culture of their day.

Some aspects of the Madmen of Ü and Tsang's eccentric practices were also being performed by other Kagyüpas at this time. Performing engaged asceticism, living in the manner of a "secret yogi" and using a rhetoric of madness were all significant aspects of Buddhist culture in late 15th- and early 16th-century Tibet. The opening passage from The Life of Drakpa Tayé, quoted above, is a strong testament to this. The Madmen of Ü and Tsang remained unique in their particular use of the Highest Yoga Tantras and the way they presented themselves as Heruka incarnate-as opposed to the eccentric yogis met by Drakpa Tayé, who were pursuing their practices much more quietly, perhaps without the same ideological drive. In this way we can see that the Madmen of Ü and Tsang were part of a larger movement in eccentric ascetic activity. They were perhaps the more outspoken and successful members of the moment - the highest, most distilled expression of this trend. The Madmen of Ü and Tsang may have been figureheads for this broader movement. It did not begin or end with them, but historically speaking they were among its most significant players.

As will become clearer in Chapter Seven when we survey the entire breadth of the "holy madman" tradition in Tibet, the time of the Madmen of Ü and Tsang was the moment in Tibetan history when "holy madmen" were most numerous. In addition to the Madmen of Ü and Tsang there was the Madman of the Drukpa, the Madman of Taklung, the Madman of Üding (both mentioned above); there was also a Madman of Gampo 
(sgam smyon, more will be said about this figure in Chapter Seven) ${ }^{718}$ and surely many others who have not made it into the historical record. This is not to mention the many figures who would have been more informally said to have been "holy madmen," like Drakpa Tayé's master Lhatsünpa.

During the late 15 th and early 16 th century there was a vibrant culture of dedicated and eccentric ascetics within the Kagyü tradition, many of whom were supported financially by the Rinpungpas. The various "holy madmen" are only a subgroup among them. The Madmen of Ü and Tsang stand out among them because of the fact that they became so famous, and because of the nature of their "madness" as tantric fundamentalists - two things that were probably not unrelated. My research has not been broad enough to allow me to make the argument that this entire culture of eccentric asceticism among the Kagyü in the 15th and 16th centuries was a response to changes taking place in central Tibetan religious culture thanks to the rapid spread of the Geluk, but the specific formulation of eccentric asceticism articulated by the Madmen of $\ddot{U}$ and Tsang can certainly be understood in that way. To some extent it was the specific character of central Tibetan religious culture that prompted them to choose this particular form of asceticism; and it was likely in large part due to the political situation at the time that they were able to become as famous as they did. Much of their fame and many of their activities was dependent upon their strong associations with the Rinpungpas. And as I have been arguing throughout this chapter, the Rinpungpas' interest in the Madmen of $\ddot{U}$ and Tsang can to some extent be attributed to their political aspirations. Having

\footnotetext{
${ }^{718}$ re'u mig, p 48, sgam po pa grags rgyan sgam smyon was born in 1451 (lcags lug); p 58, sgam smyon died in 1502 (chu khyi).
} 
achieved this level of fame (accountable, to some extent, to the political situation of the time) the Madmen of Ü and Tsang became something of an inspiration to other Kagyü ascetics, some of whom were also motivated to take on the identity of "holy madman." This may be how we can explain the fact that there was such a wave of "holy madmen" at this particular moment in Tibetan history.

The Madmen of Ü and Tsang were trying to move the Kagyü in a new direction (which they were articulating as an old direction, as fundamentalists and as upholders of the Practice Tradition) as a response to what they perceived and felt as a threat to the fortunes of their sect. This may have been a somewhat coordinated effort between the Madmen of Ü and Tsang; there is too much overlap between the circles they inhabited to allow us to think they both took on this lifestyle without any knowledge of one another. And because of what they represented as an alternative to the model being put forward by the Gelukpas, they attracted the attention and support of the Rinpungpas. This support gave them the means to pursue certain goals, which only widened their fame, which would account for many of the lesser holy madmen who followed in their footsteps for years to come.

\section{V. Conclusion}

In the previous chapter we considered the behavior of the Madmen of Ü and Tsang only as it related to religious concerns. There we talked about them doing their eccentric asceticism as a part of religious practice, towards the goal of enlightenment. In this chapter we have developed a more historically-grounded understanding of their activities, seeing what perspective on their eccentric behavior is gained when we attend to the realities of the time and place in which it was enacted. Here I have argued that the 
Madmen of Ü and Tsang's decision to take on these practices and make them central to their public identities may have been to some extent for tangible ends related to the world-at-hand. We have tried to imagine the circumstances Künga Zangpo and Sangyé Gyeltsen lived in in 15th-century Tibet, including the larger changes taking place within their culture, as well as their many personal relations. In a sense, what we have tried to do in this chapter is develop an understanding of the Madmen of $\ddot{U}$ and Tsang as real people, attendant to basic human concerns and limitations, rather than idealized abstractions. What we have come to see is that economic circumstances, interpersonal rivalries, scandals, personal histories, and so on, played a very real part in influencing the trajectories of their lives. If we stopped at the vision of the holy madmen we got from Chapter Three, clearly a lot of significant details about them and their lives would never have been accounted for. Ignoring the historical circumstances surrounding Künga Zangpo and Sangyé Gyeltsen can only lead to an at best incomplete, at worst distorted understanding of the nature of their eccentric activity as the Madmen of $\ddot{U}$ and Tsang. Through mapping the webs of interpersonal connections between the Madmen of $\ddot{U}$ and Tsang, their students and teachers, their patrons, allies and detractors, we have gotten a feeling for how they fit into the 15 th- and 16th-century Tibetan world. This web of relations is a tight one, with more interconnections than anyone is likely to have imagined. We have considered how the life stories of the Madmen of Ü and Tsang were written in such a way as to portray them in the most favorable light, to make an argument for their holiness; we have also seen that among their biographers, two of them, Nyukla Peṇchen and Lhatsün Rinchen Namgyel, were relatives of some of their most heavilyinvested patrons (the Rinpungpas and the rulers of Ngari Gungtang, respectively). This 
shows how tight the web of interconnections shaping the lives of the Madmen of $\ddot{U}$ and Tsang really was. It also suggests that the holy madmen as we know them cannot be understood without paying close attention to the historical realities in which they lived, in order to understand how these narratives about the holy madmen were created, among so many other things.

This chapter has also shown the intimate and complex relationship between religion and politics in traditional Tibet. The fates of political regimes and religious sects were strongly tied up with one another, which made competing in the religious or political realm necessitate also participating in the other. We have seen patrons and priests brought together because of their shared interests that are both religious and political. We have seen major conflicts played out in the political and religious domains that cannot be reasonably spoken about as separate from one another. It is in light of these dynamics that we must understand the nature of the distinctive behavior of the Madmen of Ü and Tsang.

What I have argued here is that the tantric fundamentalism displayed by the Madmen of Ü and Tsang was a creative response to the particular circumstances faced by the Kagyü sect in the middle of the 15 th century. Of all the possible lifestyles available for them to choose from, they made the decision to embody the literal word of the Highest Yoga Tantras, to make themselves foils of the monastic norm that was so definitive of the up-and-coming Gelukpas. The Madmen of Ü and Tsang's extreme position vis-à-vis the Geluk and all that they represented helped them gain the attention of the Rinpungpas and Japa Tashi Dargyé, who needed to supplant the Pakmodru-Geluk partnership in order to ensure and expand their own power. This financial and practical 
backing enabled Künga Zangpo and Sangyé Gyeltsen to pursue this lifestyle, which helped them become even more significant players in the religious marketplace, and likely inspired others to imitate them in becoming "holy madmen."

Here I am arguing that the Madmen of Ü and Tsang's decision to take on this eccentric lifestyle was a calculated one. Some readers may feel resistant to this kind of view of 15 th-century Tibetan ascetics, preferring to see them as less wily than that. But what I am suggesting is not that Künga Zangpo and Sangyé Gyeltsen were manipulative or exploitative, but rather that they were eminently aware - enlightened perhaps not in a strictly Buddhist sense, but in the sense of having a prescient understanding of the world in which they lived. The other alternative is to assume that Künga Zangpo and Sangyé Gyeltsen were not aware of the worldly ramifications of their decision to take on this form of behavior - that they were not aware of how it would make them foils to Geluk scholar-monks, or how it would gain them the favor of rich and powerful patrons like Dönyö Dorjé. This is a less favorable view. Seeing these figures as completely naive to worldly concerns falls well short of paying our subjects the respect as creative and independent agents that they are due. I am not saying that the Madmen of Ü and Tsang are charlatans or fakes, because doing so would require making a hard distinction between "real" saints and "fake" ones. When we look at saints as real historical beings, we see that things are much more blurred, that sainthood itself is part of a social process, rather than the result of achieving an otherworldly state. I will make this same argument about the nature of "holy madness" in Chapter Seven.

Lastly we can turn to the question of how successful Künga Zangpo and Sangyé Gyeltsen were in their attempt to institute a unique form of Buddhistness through their 
tantric fundamentalist behavior. We know that they were influential during the time in which they lived and through their many students, but it does not seem that the idea of dressing up as a Heruka and embodying the Highest Yoga Tantras really caught on. Others certainly appropriated elements of this, but it does not seem that any took it as far as the Madmen of Ü and Tsang. In this sense we can conclude that they were not entirely successful in making such a thing catch on during their embodied activity. But where they were extremely successful was in their writing and printing projects, which we can see as an extension of what they were trying to achieve through their eccentric activity as yogis. These projects had an enduring effect, and in many ways shaped our understanding of the Kagyü sect that endures to this very day.

But before we come to this we must first consider the life and "madness" of perhaps the most famous of all Tibetan holy madmen, Drukpa Künlé. We will consider how he fits into and defies the pattern established by his contemporaries, the Madmen of Ü and Tsang. 


\section{Chapter 5: The Curious Case of Künga Lekpa, "Madman of the Drukpa"}

"Künlé, Madman of the Drukpa, you really seem to be an emanation of Māra! Either that, or you're an emanation of the Buddha!"

- $\quad$ an unnamed chieftain ${ }^{719}$

Drukpa Künlé is the most famous of all Tibetan "holy madmen" or "mad siddhas"

(grub thob smyon pa). He is commonly known as "Druknyön" or "the Madman of the

Drukpa [Kagyü sect]." This title is often mistakenly taken as meaning "the Madman of

${ }^{719}$ sde pa na rel 'brug smyon kun legs khyod yang na bdud kyi sprul pa dngos yin pa 'dral de min sangs rgyas kyi sprul pa gcig 'dra bas... In'gro ba'i mgon po kun dga' legs pa'i rnam thar mon spa gro sogs kyi mdzad spyod rnams (Dharamsala: Tibetan Cultural Printing Press, 1981; 128 pages), hereafter referred to as "Dharamsala printing," $\mathrm{p} 11$.

Compare with the same passage in another printing of the same collection: sde ba na rel 'brug smyon kun legs khyod yang na bdud kyi sprul ba dngos zhig yin pa 'dral de min sangs rgyas kyi sprul ba zhig nges par yin pa... In brug pa kun legs kyi rang rnam (this printing also bears the longer title grub pa' $i$ dbang phyug chen po rnal 'byor kun dga' legs pa'i dpal gyi rnam par thar pa; recent Chinese print, orange cover, no date; purchased in Lhasa in 2006; 83 pages), hereafter referred to as "Chinese printing," p 5.

The Dharamsala and Chinese printings of this text are very similar in terms of content; they contain the same stories in the same order. There are differences in terms of spelling and terminology. The Dharamsala version contains a colophon in the middle of the text, pp 102-3. The Chinese printing does not (if so, it would be located at $\mathrm{p}$ 66). The version of the text used by Andreas Kretschmar in his German translation ('Brug pa kun legs: Das wundersame Leben eines verrückten Heiligen, Sankt Augustin: VGH Wissenschattsverlag, 1981) has the same basic content as these two printings, but the stories are in a different order. The version used by Kretschmar begins with the stories told just after the colophon in the middle of the Dharamsala version, and ends with the stories just before it. The colophon comes at the end of the version of the text used by Kretschmar, $\mathrm{p}$ 64. These variations suggest that this has long existed as a contiguous collection of stories, although their ordering may have been rearranged at times.

Keith Dowman translates this as, "Drukpa Kunley, you madman! You are either the devil incarnate or a Buddha's emanation," in The Divine Madman: The Sublime Life and Songs of Drukpa Kunley (Varanasi and Kathmandu: Pilgrims Publishing, 2000), p 88. Dowman's translation is of 'gro ba' $i$ mgon po chos rje kun dga' legs pa'i rnam thar rgya mtsho'i snying po mthong ba don ldan, by brag phug dge bshes dge 'dun rin chen (Kalimpong, Printed at the Mani Printing Works, 1971). Geshé Chaphu's original Tibetan reads: sde pa na rel 'brug smyon kun legs khyod yang na bdud kyi sprul pa yin pa 'dral de min sangs rgyas kyi sprul pa yin pa'dra, p 63.2. 
Bhutan."720 He is the best known holy madman to Tibetans and non-Tibetans alike.

Because of his great popularity his legacy has had a disproportional influence in shaping the way people have come to think about Tibetan holy madmen, and for this reason he is worthy of a more sustained examination here. The case of Drukpa Künlé poses a major problem in that, despite his being wildly popular in the Tibetan and Bhutanese cultural imaginations, we know very little about the real historical Drukpa Künlé who provided the original basis for these many legends. There is a significant irony in that while being by far the most famous of all Tibetan holy madmen and having the greatest influence on peoples' understanding of the holy madman phenomenon, we actually know almost nothing about who he really was. In this chapter we will work to dig beneath the layers of popular perceptions of Druka Künlé to get closer to the real historical individual who lived as a contemporary of the Madmen of Ü and Tsang. As will be shown, we have reason to believe that the nature of Drukpa Künlé's "holy madness" was very different from that of his 15 th-century peers.

Our goal in this chapter is to determine what we can know about Drukpa Künlé, born in 1455, separate from the more popular perceptions of him that developed in later generations. This is an uncertain task and we must proceed with caution, for the notion that we may somehow uncover the "real” Drukpa Künlé is a problematic one.

Nevertheless, we have enough evidence to allow us to conclude that the Drukpa Künlé who was born in the middle of the 15 th century was quite different from the image of him

\footnotetext{
${ }^{720}$ This interpretation of the term 'brug pa is attested to in Stephan Beyer, The Classical Tibetan Language (Delhi: Sri Satguru Publications, 1992), p 380. Although Drukpa Künlé spent some time in areas that are today within the borders of Bhutan, there is no reason to think that he would have a special association with this place; moreover, the area was probably not even referred to as "Druk" ( 'brug) at the time. The area became referred to that name only later, after the sect Drukpa Künlé was born into became the dominant Buddhist tradition in that region.
} 
that looms in the Tibetan cultural imagination. Even if we cannot completely reconstruct who he was, we can plainly see who he was not. Readers familiar with the popular representation of Drukpa Künlé as a "madman” will be surprised by the very sane, thoughtful and almost conservative person we find when we look closely at the older writings and songs likely to have originated from him.

Towards this end, in the pages that follow we will try to answer the questions of how, in the late 15 th century, Künga Lekpa earned the epithet "madman." Based on the limited information we have about him, what was the nature of his eccentricity? How does he compare to his contemporaries, the Madman of Ü and the Madman of Tsang? The answers to these questions should give us some greater insight into the larger question of what is the nature of "holy madness" itself.

\section{I. Popular Representations of Drukpa Künlé in the Oral Tradition and Collections of "Dirty Stories"}

For many Tibetans, when asked if they know about any "holy madmen," stories of Drukpa Künlé spring immediately to mind. A famous story about Drukpa Künlé maintains that he once killed a herd of animals by chopping off their heads. Then, using his magical powers, he reanimated them. In the process of their coming back to life, the large-bodied animals picked up the heads of smaller animals, and vice versa, which resulted in the creation of an odd-looking species of animal with large bodies and undersized heads, or small bodies and oversized heads. Other popular stories speak more to Drukpa Künlé's infamous irreverence. One fondly-recalled tale relates how Drukpa Künlé was once staying as the guest of a family. He instructed the father to recite something resembling a Buddhist prayer, but including many uncouth and sexual 
references of the most vulgar type. As the man followed Drukpa Künlé's advice, the rest of his family was shocked by the things coming out of his mouth. Nevertheless, the man persisted, and because of the strength of his faith in the saint, achieved a rainbow body at the time of his death. Both of these stories were told to me by Tibetans in $2009 .{ }^{721}$ Research by Künchok Delek, Pelden Tashi and Kevin Stuart has shown that Drukpa Künlé is still widely known as a trickster figure among Tibetans living in Qinghai today. $^{722}$ Drukpa Künlé has been popular in the Tibetan imagination for a long time, as the Indian Tibetologist Sarat Chandra Das heard a story about Drukpa Künlé during a visit to central Tibet in $1882 .^{723}$

Drukpa Künlé is extremely popular in the Tibetan oral tradition, and has been for hundreds of years. The stories told about him are short and often funny. Many highlight his irreverent behavior, which is tinged with cleverness. Some stories (such as his reanimating the corpses of animals he had killed) have elements of magic, which serve as a testament to his status as a siddha. In his legacy as a trickster, Drukpa Künlé assumes a role similar to that played by the famous Tibetan folk hero Aku Tönpa. Because of the similarities between them, Aku Tönpa has at times been included in discussions of "holy madmen.",724

\footnotetext{
${ }^{721}$ The first story was related to me by Wangdül Rinpoché, interview at the retreat center above Rewalsar Lake, H.P, 28 September 2009. See Dowman, pp 87-9; Dharamsala printing, pp 8-12; Chinese printing, pp 3-7. The second story was related to me by Kenpo Tsülnam Rinpoché, interview at Sherab Ling Monastery, Bir, H.P., 9 September 2009. See Dowman, pp 134-6; Dharamsala printing, pp 44-50; Chinese printing, pp 26-30.

${ }_{722}$ Kun Mchog Dge Legs, Dpal Ldan Bkra Shis, and Kevin Stuart, "Tibetan Tricksters" in Asian Folklore Studies, Vol. 58, No. 1. (1999), pp 5-30. For more tales of Drukpa Künlé that were in circulation orally in recent decades, see Texts of Tibetan Folktales, Michiyo Hoshi, ed., Vol. V, Studia Tibetica, X (Tokyo: The Toyo Bunko, 1985), pp 149-204.

${ }^{723}$ See footnote below.

${ }^{724}$ R. A. Stein, Tibetan Civilization, translated by J. E. Stapleton Driver (Stanford: Stanford University Press, 1971), p 154. Stein refers to Aku Tönpa was a "mad saint."
} 


\section{I.1 The Southern Collection}

These oral traditions constitute the most important body of information about Drukpa Künlé for Tibetans. Many of these popular oral stories (including the two described above) are included in what seems to have been a relatively stable collection of stories about Drukpa Künlé that has been in circulation for some time in printed form (well before the Bhutanese Geshé Chaphu made his version in the 1960s, which will be described below). This short collection has been published under a variety of titles, such as The Life Story of the Protector of Beings, Künga Lekpa, Telling of his Activities in Mon, Paro, and so on ${ }^{725}$; or The Southern Cycle of the Extensive Life Story of the Dharmalord Drukpa Künle ${ }^{726}$; or the simpler and misleading, Autobiography of Drukpa Künlé. ${ }^{727}$ A note at the beginning of the text states that it was compiled in the manner of notes (brjed tho bkod) by a descendent (gdung 'dzin) of Drukpa Künlé, by the name of dharmalord Tsewang Tenzin (chos rje tshe dbang bstan 'dzin), carried out at Tago Monastery (rta mgo chos dbyings kyi pho brang) in Bhutan. ${ }^{728}$ Based on genealogical trees assembled by R. A. Stein and John Ardussi, it seems this may refer to Drukpa Künlé's grandson, 1574-1643, who went by this name. ${ }^{729}$ However, until a thorough study of the printings and history of this text has been carried out, we should remain skeptical of any such attribution. The text is unlikely to be so old. Moreover, we cannot

\footnotetext{
${ }^{725}$ This refers to the "Dharamsala printing," as described in the footnote above.

${ }^{726}$ chos rje 'brug pa kun legs kyi rnam par thar pa rgyas pa'i lho'i bskor. Kretschmar was working with a photocopy of a handwritten manuscript in 36 folios.

${ }_{727}$ This refers to the "Chinese printing," as described in the footnote above.

${ }^{728}$ Dharamsala printing, pp 3-4. See Kretschmar, pp 4-5.

${ }^{729}$ John Ardussi, 'Brug-pa Kun-legs, The Saintly Tibetan Madman (Master's thesis, University of Washington, 1972), p 204; R. A. Stein, Vie et chants de 'brug-pa kun-legs le yogin (Paris: G.-P Maisonneuve et Larose, 1972), pp 14-6. See Kretschmar, pp 4-5; Jamyang Namgyal [E. Gene Smith], "Vie et chants de 'Brug-pa Kun-legs le yogin, a Review," pp 91-9 in Kailash, Vol. I, No. 1 (1973), p 95. Drukpa Künlé's purported grandson, Tsewang Tenzin, will be discussed further below.
} 
be certain that Drukpa Künlé actually had a grandson called Tsewang Tenzin, because of varying accounts of his progeny. The reasons for this skepticism will be described below.

This collection of stories (which we will refer to as the Southern Collection) reads like a series of disconnected episodes that do not attempt to create a coherent narrative for the life of Drukpa Künlé. There is no account of his familial origins, birth, youth, or death. There are no essential elements of the story that carry over from one episode to the next, save for a loose geographic continuity: the stories are grouped in such a way that as we read them we travel with Drukpa Künlé from various places in Tsang south to Yamdrok (yar 'brog), to areas that are today part of Bhutan and other southern regions, and then back to central Tibet, ending with stories about Drukpa Künlé at Taklung and Sakya monasteries.

The Southern Collection is often referred to by Tibetans as Drukpa Künlé's “dirty stories" (gtsog gtam). (It is thus differentiated from the four-part Collected Works of Drukpa Künlé to be described below, which implicitly becomes the "clean" version of his life.) These more popular collections of stories are also sometimes referred to as the "secret biography" (gsang ba'i rnam thar) of the yogi. The Southern Collection involves stories of Drukpa Künlé singing dirty songs, coupling with many women, grabbing a giant demoness by her breasts, and so on. A fuller description of how Drukpa Künlé is characterized in this popular literature will be given below.

In the case of the Southern Collection and the later popular collection to be described presently, we know that much of their content was derived from oral traditions. The inclusion of these stories in widely-disseminated print collections helped ensure the 
continued recollection of these these tales in oral culture, as readers of these collections would retell the stories in less formal contexts. In the history of this literature there has always been a dynamic interplay between its oral and textual forms.

\section{I.2 Geshé Chaphu's Version of the Life}

The collection of stories about Drukpa Künlé that has had the greatest influence in shaping the non-Tibetan world's understanding of him and of the holy madman tradition in general was compiled by the Bhutanese scholar Geshé Drakpuk Gedün Rinchen (dge shes brag phug dge 'dun rin chen, 1926-1997), most often referred to as Geshé Chaphu. First published in 1966, the text bears the title The Essence of the Ocean of Stories About the Protector of Beings, the Dharmalord Künga Lekpa, which is Meaningful to Behold. ${ }^{730}$ This is the text that would be translated by Keith Dowman as The Divine Madman: The Sublime Life and Songs of Drukpa Künléy. Dowman's translation of Geshé Chaphu’s work has been printed four times in English (1982, 1983, 1998 and 2000). It has also undergone two printings in German translation (1983 and 2005), two in Spanish (1988 and 2001), one in French (1984) and one in Romanian (2005). ${ }^{731}$ The many printings and subsequent translations of Dowman's translation have made this a remarkably widespread and well-known work. It has had a vast influence in shaping how speakers of

\footnotetext{
${ }^{730}$ The full title is 'gro ba'i mgon po chos rje kun dga' legs pa'i rnam thar rgya mtsho' $i$ snying po mthong ba don ldan.

${ }^{731}$ First published by Rider \& Co, London, 1982; Dawn Horse Press, Middletown, California, 1983; second edition by Dawn Horse Press, 1998; published by Pilgrims Publishing (Varanasi and Kathmandu), 2000. Published in German as Der Heilige Narr (Barth, 1983); reprinted by Barth in 2005. Published in Spanish as La Divina Locura Drukpa Künléy: Andanzas de un Yogui Tántrico Tibetano del siglo XVI, Miraguano Ediciones, Madrid, 1988 and 2001. Published in French as Le Fou Divin (Albin Michel, Paris, 1984). Published in Romanian as Nebunul Divin: viața sublimă a marelui maestru tantric Drukpa Kunley, translated by Octavian Creț (Firul Ariadnei, 2006).
} 
European languages have come to think about Drukpa Künlé, about holy madmen, and Tibetan Buddhism more broadly.

What is the nature of the text by Geshé Chaphu, which has become so influential through its translation and retranslation? What kind of story does it tell about Drukpa Künlé?

Geshé Chaphu's version of The Life of Drukpa Künlé is in large part drawn from earlier collections of stories about the madman. In composing his version of the Life, Geshé Chaphu used all of the Southern Collection, save for a few pages. The material drawn from the Southern Collection takes up a little more than a third of the text (about 50 pages of Dowman translation). The material drawn from the Southern Collection describes Drukpa Künlé's exploits in areas that are today part of Bhutan, as well as Gyantsé and Lhasa in central Tibet, and at Taklung, Yangpachen and Sakya monasteries. $^{732}$ In creating his version of the Life, Geshé Chaphu divided up and reordered passages from the earlier Southern Collection, at times interspersing them with sections drawn from elsewhere.

In addition to using the Southern Collection, much of what Geshé Chaphu included in his version of the Life is of a very local character, clearly drawn from thencurrent oral traditions in Bhutan. For example, Geshé Chaphu interrupts a passage taken

\footnotetext{
${ }^{732}$ Dharamsala printing, pp 8-29 corresponds to Dowman, pp 87-97; Dharamsala, pp 29-33 to Dowman, pp 119-20; Dharamsala, pp 33-41 to Dowman pp 121-5; Dharamsala, pp 41-4 to Dowman, pp 128-30; Dharamsala, pp 44-50 to Dowman, pp 134-6; Dharamsala, pp 51-5 to Dowman, pp 143-4; Dharamsala, pp 55-6 to Dowman, pp 137-8; Dharamsala, pp 61-8 to Dowman, pp 125-8; Dharamsala, pp 68-70 to Dowman, pp 144-5; Dharamsala, pp 70-3 to Dowman, pp 146-8; Dharamasala, pp 73-7 to Dowman, pp 157-8; Dharamsala, pp 77-85 to Dowman, pp 159-63; Dharamsala, pp 85-8 to Dowman, pp 150-1; Dharamsala, pp 88-99 to Dowman, pp 165-8; Dharamsala, pp 100-1 to Dowman, p 148; Dharamsala, pp 101-2 to Dowman, p 145; Dharamsala, pp 103-10 to Dowman, pp 74-7; Dharamsala, pp 111-9 to Dowman, pp 64-70; Dharamsala, pp 119-27 to Dowman, pp 78-83.
} 
directly from the Southern Collection to insert a story about how Drukpa Künlé built a stūpa in a particular place in order to subdue the local malevolent spirits; a stick that Drukpa Künlé threw there is believed to have grown into a tree around which a stūpa was later built. ${ }^{733}$ What these instances reflect is Geshé Chaphu's interest to incorporate local legends into the life story of the great saint. Many of these stories incorporated into the text are folk tales explaining the origins of remarkable but natural phenomena: these include how a fresh water spring came into being, why one place has a very scarce water supply, and the origin of some strange rock formations. There are also stories explaining how certain places got their names. ${ }^{734}$ Some stories included in Geshé Chaphu's text were formulated to explain the origins of particular holy objects, like the stūpa just mentioned or when Drukpa Künlé urinated on a tanka (the urine turned to gold, of course) which, according to Geshé Chaphu, could still be seen at Dorden Tago temple in Thimphu at the time of his writing. ${ }^{735}$ As was mentioned above, there is a story, sometimes retold orally, that maintains that Drukpa Künlé instructed an old man to recite an iconoclastic version of the refuge prayer running:

I take refuge in an old man's chastened penis, withered at the root, fallen like a dead tree;

I take refuge in an old woman's flaccid vagina, collapsed, inpenetrable, and sponge-like;

I take refuge in the virile young tiger's Thunderbolt, rising proudly, indifferent to death;

I take refuge in the maiden's Lotus, filling her with rolling bliss waves, releasing her from shame and inhibition.

\footnotetext{
733 Dowman, pp 158-9.

${ }^{734}$ Dowman pp 169-70, 157-8, 164, 141-3 respectively.

${ }^{735}$ Dowman, pp 94-5. The story about Drukpa Künlé's urinating on a tanka was told to Surya Das (Wisdom Tales from Tibet, Harper SanFrancisco, 1992), but involved a woman instead of a man, pp 85-6.
} 
This story actually explains the construction of a stūpa and then a monastery that probably still stands today. ${ }^{736}$ It is not difficult to imagine the process through which ongoing oral folk traditions would drum up stories that associated the very famous (and very holy) Drukpa Künlé with the origins of these special objects and place names. Geshé Chaphu's inclusion of them in his version of the Life gives these stories a sort of canonical status.

Geshé Chaphu's version of the Life of Drukpa Künlé thus includes many stories derived from local oral traditions, mainly in the southern Tibetan cultural areas in and around Bhutan. Geshé Chaphu also draws about a third of his material from the text I have termed the Southern Collection, which in turn was in large part derived from an older set of oral traditions. Other parts of Geshé Chaphu's work are drawn from another early collection that seems to have developed in parallel to the Southern Collection, the four-volume "Collected Works" of Drukpa Künlé, which will be discussed at length below. ${ }^{737}$

Geshé Chaphu's version of the Life of Drukpa Künlé displays a not-fullycommitted attempt to add some narrative structure to story. Geshé Chaphu's text is at heart a series of disconnected episodes, which reflects the fact that it drew from disparate oral traditions and two textual collections of stories (the Southern Collection and the four-volume "Collected Works") that are themselves made up of disjointed episodes. In his use of the Southern Collection, Geshé Chaphu preserved Drukpa Künlé's

\footnotetext{
${ }^{736}$ Dowman, pp 134-6; Geshé Chaphu, p 114.4-.6. Curiously, where Dowman uses the words "Thunderbolt" and "Lotus" (from the Tibetan $r d o$ rje and $p a d+m a$ ), in the version of Chaphu's text at my disposal only the words mje, penis, and stu, vagina, are used. Was the version of the text used by Dowman different in these places, or is he imposing new meanings through a liberal translation?

${ }^{737}$ Kretschmar, p 2, also concludes that Geshé Chaphu was drawing from the Southern Collection and the four-volume "Collected Works".
} 
geographical movement from one region to the next, which he relied on in creating the chapter structure for his version of the Life. He rearranges the order of the episodes taken from the Southern Collection somewhat but still traces the same basic route for Drukpa Künlé's travels: from central Tibet to the southern regions and back again. But Geshé Chaphu added other narrative elements as well. He includes a brief account of Drukpa Künlé's familial origins, which may have been derived from the first volume of the fourvolume "Collected Works" (the "Biography" or "Autobiography” translated into French by R. A. Stein in 1972). ${ }^{738}$ Geshé Chaphu also includes a brief mention of the yogi’s death, which is lacking in detail except for its explicitly stating that he died in 1570 at the age of 115; Geshé Chaphu states that the "Collected Works” of Drukpa Künlé are unclear on the point of the date of his death, which is true. ${ }^{739}$

Despite these motions towards creating a more coherent narrative for Drukpa Künlé's life by at least giving it a beginning and an end (compared to the Southern Collection, which makes no attempt to give his life an arc of any kind), certain key details that might make Drukpa Künlé seem a more embodied historical being are missing from Geshé Chaphu's version of the text. In Geshé Chaphu's version of his life we never see Drukpa Künlé following a guru, doing religious practice, interacting with dharma brothers or teaching disciples. There is almost no mention of his family, save for when he mentions having lost his father at a young age. Most of the episodes read like fantasies, including his visits to historically significant places like Drepung Monastery, the Pelkor Chödé monastic academy in Gyantsé, or the original Rinpung estate. Geshé

\footnotetext{
${ }^{738}$ Dowman, pp 37-8; Stein, pp 42-4; 'brug pa kun legs kyi rnam thar (Beijing: bod ljongs mi dmangs dpe skrun khang, 2005); this is the 4-volume "Collected Works" of Drukpa Künlé, hereafter referred to as "2005 version," pp 4-5.

${ }^{739}$ Dowman, p 173.
} 
Chaphu's text maintains that when the yogi visited Rinpung, the chieftain was so overawed with the yogi's brilliance that he offered him the key to the treasury. ${ }^{740}$ The same air of fantasy prevails in Drukpa Künlé's purported meeting with the Madmen of Ü and Tsang at Tsari, which will be described below. Because of the lack of mundane elements of Drukpa Künlé's life, and the many miraculous or at least extremely unlikely events described, Geshé Chaphu's version of the Life gives one a feeling of a Drukpa Künlé completely disembodied from the realities of his own life, and from history.

The question of the historicity of Drukpa Künlé's Life as created by Geshé Chaphu is an important one. Because of his faith in the scholarly merits of Geshé Chaphu and the fact that a draft of the text was reviewed by other Bhutanese scholars before it was finalized, Keith Dowman concludes in the Introduction to his widely-read translation that "we may be reasonably certain of the authenticity of the stories, and that they did indeed originate in the sixteenth century." "741 Many Tibetans also hold the view that these stories represent historical fact. In his Foreword to Dowman's translation, Choegyal Gyamtso Tulku plainly states, "[t]he stories in this biography are not fiction or fable - the events described really happened."742 Contrary to these naïve claims, we have much reason to be skeptical about the historical validity of these stories. One can begin to make the argument that these stories do not relate historical facts about the life of Drukpa Künlé by observing that according to Geshé Chaphu, Drukpa Künlé met Tsongkhapa, who died in 1419, 36 years before Drukpa Künlé was born. Equally

\footnotetext{
${ }^{740}$ Dowman, pp 59-62.

${ }^{741}$ Dowman, p 31.

${ }^{742}$ Dowman, p 21.
} 
unlikely is Drukpa Künlé's purported meeting with Sakya Pạ̣dita, who died a full three

hundred years before the birth of the so-called madman. ${ }^{743}$

We thus have much reason to be skeptical about the stories related in Geshé

Chaphu's version of the Life of Drukpa Künlé as relating historically factual events. This

is point is worth emphasizing, as some Euro-Americans and Tibetans maintain that the

work is an accurate representation of history. ${ }^{744}$

Having established that Geshé Chaphu's extremely influential text is only

dubiously historical, we must ask how Drukpa Künlé is portrayed therein. What is

Drukpa Künlé like? What is the nature of his eccentricity?

In Geshé Chaphu's version of The Life of Drukpa Künlé, his perpetual wanderings

are framed as a search through the various regions of Tibet and present-day Bhutan for

${ }^{743}$ Drukpa Künlé meets Tsongkhapa, Dowman, pp 66-70; he meets Sakya Paṇdita, Dowman, pp 77-81.

Neither of these meetings is included in the Southern Collection.

We can also be skeptical about other less obviously fictional details in Geshé Chaphu's version of the Life of the yogi, as exemplified in how certain seemingly unimportant details of one story have gone through a few permutations. Geshé Chaphu's 1966 version of The Life of Drukpa Künlé contains a story in which Drukpa Künlé used a long anecdote about how in Nangyül (gnag yul) a man once tricked his friend out of his share of some gold they had found, and how the duped friend then tricked his deceitful friend into thinking that his two sons had turned into monkeys. According to Geshé Chaphu's version, Drukpa Künlé related this story while staying in a guesthouse in Lhasa, to prevent the mistress of the house from taking advantage of a trader from Yamdrok by replacing his amber with some imitations (Dowman's translation, pp 70-3). This same story was heard by Sarat Chandra Das in 1882 while staying at Tashi Lhünpo, except that in that version the story of the two friends took place in India rather than in Tibet, and the mistress intended to replace the amber with an apple (Das' trip took place between November 1881 and January 1883; he relates this story as having come to him in 1882; Journey to Lhasa and Central Tibet, edited by the Hon. W. W. Rockhill. Bibliotheca Himalayica, Series I, Vol. 1 (New Delhi: Manjuśrī Publishing House, 1970), pp 125-8). This same story is told in the first volume of the "Collected Works" of Drukpa Künlé, with a few variations: in that version the thieving woman is an inhabitant of Gyantsé (rgyal mkhar rtse); the man she is trying to rob is a yogi (rnal 'byor pa) from Ngari (mnga' ris); as in Geshé Chaphu's version, the drama between the two men takes place is Nangyül and the woman intends to replace the precious stones with fakes (2005, pp 302.4-306.6). The variations in the framing and content of these three versions of the story are slight, but exemplify very clearly how easily such substitutions can be made, and how wary we should be about taking any popular stories about Drukpa Künlé as relating historical fact.

${ }^{744}$ According to Michael Aris, these statements by Dowman and Choegyal Rinpoché insisting on the historicity of the Geshé Chaphu's text "completely misinterpret the basic nature of the collection as the product of Bhutanese sub-culture..." "The Boneless Tongue': Alternative Voices from Bhutan in the Context of Lamaist Societies" in Past and Present, No. 115 (May, 1987), p 145. 
the finest chang (a light alcoholic drink) and the most beautiful women. The two themes of alcohol and sex are present from start to finish. One encounters slang words for penis (mje) and vagina (stu) throughout the text; at times Drukpa Künlé substitutes such language into otherwise standard prayers. He is said to have had five thousand girlfriends. ${ }^{745}$ Some of the women who become his sexual partners are portrayed as having been lead into a spiritual life because of the experience. For example, one story relates how Drukpa Künlé meets a woman bearing the signs of a dākinī. After having sex with Drukpa Künlé the woman wants to leave her husband and follow the yogi. He allows her to. Later Drukpa Künlé uses the guilt she feels for having left her husband to encourage her to practice meditation diligently. ${ }^{746}$ In another story, Drukpa Künlé refuses to stop copulating with a woman even though a crowd had gathered to watch them. Through this shaming the woman receives some religious benefit. ${ }^{747}$ At one point Drukpa Künlé even threatens to have sex with his own mother-this was, of course, with the intention of teaching her a lesson and helping her overcome her faults. The theme of sex is so present that it descends into the egregious, such as when Drukpa Künlé smashes a pernicious demon in the mouth with his penis, or when he incapacitates a demoness by covering her with his foreskin. ${ }^{748}$

Another major current in Geshé Chaphu's version of the Life is Drukpa Künlé's persistently voicing criticisms of others. Drukpa Künlé often derides people for being too full of themselves. He takes pleasure in pointing out hypocrisy, especially in the

\footnotetext{
${ }^{745}$ Dowman, p 83.

${ }^{746}$ Dowman, pp 103-4. See also the story about the lady Sumchok, in Kongpo, who was the wife of a chieftain, pp 47-52.

${ }_{747}$ Dowman, pp 154-6.

${ }^{748}$ Dowman, p 120, also on p 126, 130; p 121.
} 
monastic community. At times he makes criticisms of representatives of all the major sects. For example, in one song he claims that the Kagyüpas waste their time with drinking, the Sakyapas with splitting doctrinal hairs, the Gelukpas with looking for boyfriends, and so on. ${ }^{749}$ Much fun is poked at Ngawang Chögyal, the abbot of Ralung and by some accounts Drukpa Künlé's cousin. ${ }^{750}$ The most pointed barbs, however, are reserved for the Gelukpas. One time Drukpa Künlé is said to have brought a donkey into the monastic assembly at Drepung Monastery. When the monks chased him out he shouted, "You people care more about chanting than meditation!" When two of those monks from Drepung later asked him, "What crime did you commit that hell wasn't deep enough for you?", Drukpa Künlé responded that the road to hell “was blocked by monks from Sera Monastery."751 A strong criticism of the Geluk is articulated when Drukpa Künlé tries to visit Tsongkhapa, who was residing at Ramoché temple in Lhasa. The monks ask Drukpa Künlé what he has to make an offering with, and he suggests that he offer his testicles to the great master. This is rejected. Drukpa Künlé then manages to gather some gold and is promptly granted a meeting with Tsongkhapa, who gives him a knotted thread to wear for protection. Drukpa Künlé then ties the thread around his penis and goes into the marketplace, shouting, "If you have fifty pieces of gold you can gain audience with the Buddha Tsongkhapa himself! He may even give you one of these!", waving his genitals with the thread attached. ${ }^{752}$ More will be said about Drukpa Künlé's critical stance with respect to the various religious groups populating the Tibetan religious marketplace when we consider his "Collected Works" below.

\footnotetext{
${ }_{749}^{74}$ Dowman, p 107. He further criticizes the Karmapa, pp 75-7, and the Sakyapas, pp 77-81.

${ }^{750}$ Namgyal [E. Gene Smith], p 95.

${ }^{751}$ Dowman, pp 63-4.

${ }^{752}$ Dowman, pp 64-70.
} 
From Geshé Chaphu's version of his Life one gets a vision of Drukpa Künlé as an irreverent, licentious trickster. There is nothing serious about him, save for his underlying motivation of leading people to the Dharma through whatever means necessary. He seems dedicated to having a good time and enjoying himself. There is no doubt that these stories would have provided great entertainment for those hearing and telling them. At times it seems these stories attempt to portray Drukpa Künlé as one of the most scatological persons to ever walk the earth. In the presentation given by Geshé Chaphu's and other collections of "dirty stories" (most of these observations hold for how he is presented in the Southern Collection as well), Drukpa Künlé's being called a "madman" is a natural result of his great irreverence and scatological behavior. When visiting Gyantsé, Drukpa Künlé is said to have refused to prostrate to the great stūpa or the monks of Pelkor Chödé Monastery, but only to a beautiful woman. At this the monks exclaimed, "Oh my! How disgusting! This Drukpa Künlé is truly crazy!"753 (a kha kha/ skyug bro ba la/ 'brug pa kun legs smyon pa rang du dug). In the world established by the stories in these collections, the "madness" of Drukpa Künlé could even rub off onto other people: when Drukpa Künlé instructed the old man to recite the dirty prayer quoted above, his wife asked the old man, "Are you crazy!",754 In these popular versions of his Life, Drukpa Künlé is labeled a madman because of his irreverent behavior in a relatively uncomplicated manner. This will stand in contrast to the story told by his four-volume

\footnotetext{
${ }^{753}$ Dowman, pp 90-2; Dharamsala printing, pp 15-8; Chinese printing, pp 9-10.

${ }^{754}$ Dowman, p 135; Dharamsala printing, p 47; Chinese printing, $p 28$.
} 
“Collected Works”, in which we see no such irreverent behavior and Drukpa Künlé becomes a "madman" for a different set of reasons.

Geshé Chaphu's Life of Drukpa Künlé can be seen as an example of the popular Tibetan perception of the saint because of its being based mainly on oral traditions and the widely circulated Southern Collection. And it has been the most influential document in shaping what the rest of the world thinks about Drukpa Künlé and the Tibetan holy madman tradition in general, thanks to Keith Dowman's translation of the text and his provocative introduction to it. Despite the great currency this presentation of Drukpa Künlé has gained, I will argue that the real Drukpa Künlé was probably very different from this. It is not the case that there is no connection between the 15 th-century figure and the one later imagined by Tibetans, but the latter is an exaggeration, a caricature of the former. As was mentioned above, in addition to drawing from the Southern Collection and local oral traditions, in creating his version of The Life of Drukpa Künlé Geshé Chaphu also drew from the "Collected Works" of the yogi. The "Collected Works" may well contain an older layer of material about the holy madman, and, as we will see, offers a very different picture of who he was.

\section{II. Drukpa Künlé's “Collected Works”}

Geshé Chaphu's and other printed versions of "dirty stories” about Drukpa Künlé give us a snapshot of the yogi based on popular tales that circulate across much of the Tibetan cultural area, some of which go back hundreds of years, while others are of more recent origin. Drukpa Künlé's “Collected Works” (gsung 'bum) provides another picture of the so-called madman. As we will see below, the "Collected Works" gives a quite different and perhaps more plausible characterization of the "mad" saint and may make 
possible some greater insight into what Drukpa Künlé was really like, depending on how reliable we decide the text is as a record of Drukpa Künlé's actual life and works.

\section{II.1 The Colophons and Structures}

The "Collected Works" of Drukpa Künlé is a four-part collection. Sometimes, as in the Beijing 2005 printing, the entire collection is referred to as the life story (rnam thar) of Drukpa Künlé. This is misleading. The second, third and fourth volumes are not presented in the manner of a biography. And although the first volume contains some of the trappings of a Tibetan hagiography (rnam thar), it is by nature very different from what we usually expect from the genre, because of its episodic nature and its lack of a coherent narrative. What's more, the first volume is written in the first person, on the basis of which it is sometimes called an autobiography (rang rnam), although characterizing it as such is also problematic. The question of the provenance of these four volumes remains an unsolved mystery. Let us take stock of what we know about the collection by looking at the colophon that comes at the end of the first volume, which is somewhat cryptic and the cause for much uncertainty.

This colophon has three parts. In the first part of the colophon, the one who arranged (bkod) the contents of the first volume of the "Collected Works" indentifies himself as one named Dorjé. He says that he completed the work in the manner of a supplication (... gsol 'debs su bkod pa) in an earth-female-ox year (sa mo glang). ${ }^{755}$ (Ardussi and Stein both read this as saying that the author composed the verse of praise, gsol 'debs, at this time, but based on the grammar and the context it seems more accurate

\footnotetext{
755 This first part of the colophon runs 2005 version, p 267.9-.17; Stein, p 417. Stein and Ardussi (1972, p 74) both take this section as saying that Dorjé completed the verse of praise ( $g s o l$ 'debs) that comes near the end of the first volume in this year. I believe the author is talking about the entire work.
} 
to read the statement as referring to the entire biography.) This may correspond to the year 1529, which provides the basis for the often repeated assertion that this is the year of Drukpa Künlé's death. As Ardussi has pointed out, we have no reason to assume that the year of this composition (whether it refers to the composition of the entire "Biography" or just the verse of praise that comes at the end) is the same as the year of Drukpa Künlé's death. This earth-female-ox year could just as well represent 1589 or some other later date at which the text was compiled, and may not, therefore, give us any indication about the year of Drukpa Künlé's death. Because of this uncertainty, we should list Drukpa Künlé's dates as 1455-1529?. This date probably only refers to putting the materials of the first volume together, and not their being carved into woodblocks for printing.

Second, there is a verse of praise to Drukpa Künlé, said to have been written by one Pema Karpo (pad dkar) at Ralung Til (ra lung thil). This is usually assumed to refer to the famous Drukpa Kagyü scholar Pema Karpo (1527-1592). ${ }^{756}$

Third, ${ }^{757}$ there is a long section that describes how the first three volumes of this collection (referred to as the rnam par thar ba [sic] dang zhal gdams bka' 'bum rnams ${ }^{758}$ ) came into being. The person writing the colophon mentions how there had been previous attempts at printing this collection (or a similar one), but that the woodblocks had been ruined or lost. He then describes his own story: from a young age he had acted and

\footnotetext{
756 This second part of the colophon runs 2005, pp 267.18-268.20; Stein, pp 417-8. Ardussi 1972, for example, accepts this attribution, $\mathrm{p}$ iv.

${ }^{757}$ This third part of the colophon runs 2005, pp 268.21-271.18; Stein 418-22.

758 2005, p 268.22.
} 
spoken in strange ways. When the master's disciples ${ }^{759}$ heard about this, they examined him and determined that he was the rebirth (skye ba) of Drukpa Künlé. He refers to himself by the name of the "Mad Monk of Mön" (mon ban smyon pa). He describes how he wished to make a printing (par du sgrub) of the teachings (gsung) of "the Great Mad siddha" (grub smyon chen po), in part because he had been encouraged to do so by others who had faith in Drukpa Künlé. So he gathered various versions (ma dpe) of the stories (rnam thar, this likely refers to individual stories about the yogi, rather than a coherent biography) of the yogi and examined them. He had hoped to compile everything into a single volume. However, he found that Drukpa Künlé's many students and patrons (yon bdag) had experienced so many stories (rnam thar) and teachings (zhal gdams) from Drukpa Künlé, in accordance with their individual capacities (blo), at different times and in different places, that it was not possible for him to put them all in just one volume. He describes how there were many scattered handwritten notes by those who had interacted with Drukpa Künlé, how there were oral traditions (zhal rgyun), and songs passed on by the elderly, and stories of miracles that Drukpa Künlé had performed (grub pa'i rol rtsed bstan tshul) - this was all more than he could possibly print in a single undertaking. $\mathrm{He}$ states that he wished he had had the opportunity to really gather all the original materials, but fearing that the work would never get accomplished, he started the process of printing anyway, maintaining the hope of continuing to publish more materials in the future. At the time of his decision to go ahead with the printing, he had at his disposal around twenty different written sources (dpe tshan mi 'dra ba) which he could compare. On the

\footnotetext{
${ }^{759}$ rje gong ma'i grwa slob rnams; can we assume this “master” to be Drukpa Künlé, or perhaps some other famous Drukpa Kagyüpa?
} 
basis of these, he put together the first volume, the "Biography", which includes many materials that follow a particular order. As for the materials that would comprise the other parts of the collection (i.e., volumes two and three), their nature and order are less certain (gshis go rim sogs mtha' gcig tu ma nges $\mathrm{pa}^{760}$ ), many of them being based on the remembrances of the master's disciples. The Mad Monk of Mön states that these teachings and stories have gained a lot of popularity among various types of individuals — monk and lay, of greater and lesser faculties — which has resulted in there bearing many textual errors, which he has worked to fix. As for what has gone into the third volume ( $g a$; nowhere did he specifically mention the second volume; we may perhaps assume that the last few sentences were meant to refer to the second volume specifically, but we cannot be sure) he put the miscellaneous parts that had no headings or closing sections.

The compiler then describes how, because of the way Drukpa Künlé spoke extemporaneously, using many local expressions, as well as in secret vajra language and profound statements that ordinary beings such as ourselves cannot fully fathom, he has compared the different manuscripts and made his version accord with the majority. Those parts that were unreliable, he did not include. For this reason, the contents of these volumes should be accepted as a reliable record of Drukpa Künlé's life and works.

Lastly, the Mad Monk of Mön explains how the woodblocks came into being, mentioning the scribe and the fifteen workers who started the carving process in the fourth month of the water-dragon year (chu 'brug; 1592? 1652? 1892?) and finished in

\footnotetext{
${ }^{760}$ Stein takes this as meaning that the proper order of episodes is not certain, "l'ordre est partiellement incertain," p 421.
} 
the eighth month. Some versions of the text, including that relied upon by R. A. Stein, mention that this work was accomplished at Driu Lhé Monastery (dri'u lhas), although not every version mentions this. ${ }^{761}$ (This may suggest that there were multiple Tibetan printings of this collection even before recent decades.) Nowhere in the colophon is there any mention of the fourth volume ( $n g a)$. Driu Lhe is in the Nyel (gnyal) valley in southeastern Tibet. ${ }^{762}$

We should quickly mention that the second volume of the "Collected Works" includes a brief colophon in which the compiler identifies himself as "the dharmaless one with the name Vajra Dhiggribhadra" (chos med pa badz+ra d+hi g+gri b+ha dra'i ming can). ${ }^{763}$ His work was carried out at the estate of Lhomö Rabten (lho mos rab brtan) in the Dokdé (dogs sde) valley, north of Lhasa. ${ }^{764}$ We cannot be certain of the identity of this individual, although it may be the same person as the compiler of the first volume of the "Collected Works", who went by the name of Dorjé (here rendered by its Sanskrit equivalent vajra). ${ }^{765}$ The compiler of volume II may be the same person as the compiler of volume I; and they both may be the same person as the Mad Monk of Mön, although we cannot be sure.

The long colophon to the first volume of the "Collected Works", despite its seeming thoroughness, leaves many gaps in our attempt to understand the provenance of this collection. The first big question (or set of questions) has to do with the dating of the

\footnotetext{
${ }^{761}$ The 2005 Beijing version, for example, does not mention Driu Lhé monastery, oddly enough. Is this a simple omission, or were they working from an earlier version of the text that did not mention the monastery?

${ }_{762}$ Ardussi 1972, pp 73-4.

${ }^{763} 2005$, p 399.4-.16.

${ }^{764}$ Ardussi 1972, p 74.

${ }^{765}$ Ardussi 1972, p 74, accepts that they are probably the same individual. Stein, p 417, says the same.
} 
texts. When was the life story (volume I) written? When were the other volumes

written? And when were they carved into woodblocks? Stein's research led him to believe that the woodblocks for the Driu Lhe edition were carved in either 1592 or 1652 . He identifies the "Mad Monk of Mön," the printer of the first three volumes, as being Depa Drubtop Rinpoché (sde pa grub thob rin po che), who was believed to have been a reincarnation of Drukpa Künlé. $^{766}$ E. Gene Smith (writing under the name Jamyang Namgyal) has disagreed with Stein about the dating. Smith believes the blocks to have been carved much later, in 1892, on the grounds of the style of the woodblocks and the oral tradition of the monks of Driu Lhe Monastery (which he admits is spotty).

Also, if the prayer (gsol 'debs) that constitutes the second part of the colophon to the first volume of the "Collected Works" is actually by the famous Pema Karpo, this would suggest that the first volume (the "Life Story" or "Autobiography") would have been complete in manuscript form by the time he lived (1527-1592). This is assuming that the prayer was appended directly at the end of the completed work. Of course the prayer may have been written during the time of Pema Karpo, then appended to a biography completed sometime later. ${ }^{767}$ Or these may be the words of some other Pema Karpo, or someose falsely using that name.

If the Mad Monk of Mön is the same person as the Dorjé who composed the first volume (and perhaps the second as well) it becomes the case that the earth-female-ox year (sa mo glang, often assumed to be 1529) date of the composition of the first volume

\footnotetext{
${ }^{766}$ Stein, $\mathrm{p} 25$. Stein says that he was told by E. Gene Smith that according to one of his informants, there were two or three incarnations of Drukpa Künlé, one of whom was named grub pa'i rdo rje. According to Stein, this grub pa' $i$ rdo rje, alias grub thob rin po che, is the same as the rdo rje who composed a prayer, dated 1529 or 1589, at the end of the first volume of the "Collected Works" and that he is also the editor of the second volume, who identifies himself as badz+rad+hig+gri b+hadra.

${ }^{767}$ Ardussi 1972, p 75, says that Drukpa Künlé's dates should be given as 1455-?1529.
} 
cannot be the year of Drukpa Künlé's death, since the Mad Monk of Mön was considered to be Drukpa Künlé's reincarnation. It thus must be 1589 or some other later date, in which case we have no idea when Drukpa Künlé died, and the commonly-cited date of 1529 has no backing whatsoever. The other possibility is that 1529 was in fact the date the "Biography" or verse of praise to Drukpa Künlé was completed, and the Dorjé who compiled the first volume is not the same person as the Mad Monk of Mön who would be responsible for making blockprints at some later date. This important question of dating the texts and their printings can only be resolved by undertaking a thorough study of the various printings of these texts.

The second big question the colophon leaves us with is the nature of these four texts and the sources from which they were derived. As with the issue of dating the text, there are many ambiguities and possibilities. For one, are we to assume that the compiler of volume I (named Dorjé) is the same person as the Mad Monk of Mön, editor and printer of the first three volumes of the "Collected Works"? If the Mad Monk of Mön was in fact the compiler of the first volume, this would mean that he was responsible for its contents. If the Mad Monk of Mön was not the compiler of the first volume, this would suggest that the contents of the first volume (the "Biography" or "Autobiography") were in a stable form before the time of the Mad Monk of Mön's decision to have woodblocks carved for it (whether in 1592, 1652 or 1892), making it an older text. We cannot be certain on any of these points.

Another issue is that the Mad Monk of Mön says that he had twenty manuscripts (ma dpe) to work with. Were these twenty independent collections of stories, songs and letters attributed to Drukpa Künlé, or twenty versions of the same collection? Was he 
working with collections of stories (rnam thar)? Or were they actually different biographies (rnam thar), or different versions of the same basic biography?

Aside from the question of who actually put these collections together, the Mad Monk of Mön suggests that the contents of the first volume are the materials that can be most reliably taken as the authentic words and activities of Drukpa Künlé. It seems that we are to understand volumes two and three as being comprised of materials somewhat less reliably authentic. As for the fourth volume, it is not mentioned by the Mad Monk of Mön and can therefore be taken as a later addition. Ardussi adds to this argument by noting that the style of the woodblocks for the version of volume four that he worked with was quite different from that of the first three volumes, and thus was probably not carved at the same time as the preceding three. ${ }^{768}$

After doing a thorough reading of the entirety of the "Collected Works", it is my opinion that much if not all of their contents date from the time of Drukpa Künlé or shortly thereafter. I have come to this conclusion because the "Collected Works" contain so much of Drukpa Künlé's interactions with other figures who lived during his time period, either in descriptions of his meetings with these people or a written record of their correspondence. And some of what is related in these passages is corroborated by other historical documents from the 16th century. For example, the second part of The Life of the Madman of $\ddot{U}$, written in 1537 , five years after the yogi's, death describes a meeting between the Madman of Ü and Drukpa Künlé at the former's monastery in Penyül, near Lhasa. It is said that on this occasion Drukpa Künlé offered to the Madman of Ü a supplication (gsol'debs) of the Aural Transmission (snyan rgyud) that he had composed.

\footnotetext{
${ }^{768}$ Ardussi 1972, p 63.
} 
The third volume ( $\mathrm{ga}$ ) of Drukpa Künlé's “Collected Works” contains the text of this supplication, an elegant verse of praise to the Aural Transmission that Drukpa Künlé says he composed at the direct request of the Madman of $\ddot{U}$, the Heruka (dbus smyon he ru $k a)$.

As we delve into the contents of Drukpa Künlé's “Collected Works” we will see a handful of connections of this type, which go a long way towards suggesting that much of the contents of this collection do derive from the life and times of the real Drukpa Künlé.

Let us now consider the form and contents of the "Collected Works" to see what insight may be gained about the history of the texts. Each of the four volumes of the "Collected Works" is comprised of discrete, disjointed episodes, with no overarching narrative. The first volume (the "Biography" or "Autobiography”) makes a motion towards creating a narrative structure by beginning and ending with accounts of Drukpa Künlé's early life and death, but throughout most of the text there is no apparent order to the events described. We may recall that the Southern Collection, by contrast, had a sort of geographic continuity; Geshé Chaphu's version had this same geographic continuity, plus a faint attempt at forming a fuller narrative by mentioning Drukpa Künlé's birth and death.

But despite having the same essentially disjointed episodic structure as the more popular collections of stories about Drukpa Künlé, the contents of the "Collected Works" seem to be quite different by nature. Rather than popular stories, they read more like reworked literary fragments. The many episodes that make up the four volumes of the "Collected Works" include songs, poems, conversations, thought pieces presented under 
the guise of being conversations, recollections of dreams, editorials, rants, and expositions on issues relating to Buddhist philosophy, conduct, and the most basic issues of Buddhist life. Often these passages are put one after another with no clearly marked transition between them; sometimes a mere "and then..." (yang) suffices. Other times there is no transition whatsoever, and the text wanders from describing dreams to letters to conversations without any sort of transition. (Stein's translation of the first volume belies the difficulty he had at times in determining shifts in subject or speaker.) These capricious shifts give the impression that the four volumes were indeed comprised of a series of short written pieces that were thrown together, at times with care, at times without. As one progresses through the first volume, the well-ordered episodes becomes less frequent and an increasing amount of the text is taken up by nearly random verses and compositions thrown in, said to have been songs sang by the yogi. This seems like the result of editorial fatigue. In the latter three volumes, there is even less of an attempt at order.

As an example of the kind of creativity displayed in the compositions included within the "Collected Works", on the occasion of some monks arguing about the sources of valid cognition (tshad ma), Drukpa Künlé retells the contents of a letter purportedly given to him by the Buddha Kāśyapa to deliver to Nāgārjuna, in which he discusses the means of valid cognition, ultimate and relative truths, and so on. The letter is dated the 8th day of the 8th month of a horse year, written at the summit of the Akanishta heaven ( $\operatorname{og}$ min lhun po rtse). The substance of letter is not particularly significant, but what is interesting is the fact that the words are put into the mouth of the Buddha Kāśyapa and addressed to Nāgārjuna. The pretext of this being brought up in the context of some 
monks having a scholarly discussion is a flimsy one, a half-hearted attempt to situate the composition in a live scene (even still, the episode does not make much sense: did Drukpa Künlé orally quote the entire letter to the monks on the occasion of their having this discussion? Or did the discussion with the monks remind the author of this letter, which he then pretends to cite later?). The author of this letter, whether it be Drukpa Künlé, someone close to him, or some other party, has displayed some real creativity in composing this piece. This kind of toying with expected and accepted forms of expression occurs throughout the "Collected Works" of Drukpa Künlé. 769

The episodes contained in the "Collected Works" are on the whole much less entertaining than those in the more popular collections. There is much less fantasy and obviously fictional elements; there is no mention of Drukpa Künlé's interacting with Tsongkhapa or Sakya Paṇdita, for example. There is much less dirty language, and no stories formulated for the purpose of explaining the existence of odd natural phenomena or place names. These facts combined give the feeling that much of the contents of the "Collected Works" may be plausible as a literary product of the time of Drukpa Künlé or not long thereafter.

Within the "Collected Works" there is consistent mention of Drukpa Künlé's meetings with patrons and exchanges with other historical personages. We see many letters exchanged, for example, with Nyukla Penchen, the disciple and biographer of the Madman of Ü. ${ }^{770}$ We also see Drukpa Künlé meeting with people like Dönyö Dorjé, Tashi Dargyé of Ja, and some important teachers of his time. His exchanges with and

\footnotetext{
${ }^{769}$ 2005, pp 141.14-142.17; Stein, pp 230-3.

${ }^{770}$ Citations for these letters will be given below.
} 
comments about the Madmen of Ü and Tsang, as we will see below, strike one as entirely plausible, unlike his fantastic meeting with them described in Geshé Chaphu's version of the Life. From the four volume "Collected Works" one gets the feeling that one is reading about Drukpa Künlé as a more historically situated person.

As for the contents of the four volumes, the first volume $(k a)$, which most resembles a biography (rnam thar) of Drukpa Künlé, bears the title The Life Story of Künga Lekpa, the One Called a Yogi, the Coarse Detailed Telling in Natural Terms of his Origins, Arranged in a Willy-nilly Fashion, Taken from Here and There ${ }^{771}$ (271 pages in the 2005 Beijing printing). This was translated by R. A. Stein into French and published in 1972.

The second volume ( $k h a$ ) bears the title A Few Drops Gathered from the Ocean of the Life Story and Collected Works of the Great Lord of Yogis, Künga Lekpa, by the Kusha grass of faith, Sweet Droplets of Marvelous Nectar ${ }^{772}$ (128 pages). This volume was translated in part by John Ardussi as part of his Master's thesis at the University of Washington, also in 1972. The contents of the second volume are similar to those of the first volume. There is no real attempt at narrative and it reads as if the contents were somewhat hastily put together.

The third volume ( $\mathrm{ga}$ ) bears the title Some Things that are Like the Momentary Dharmic Activities that Arose in the Experience of Künga Lekpa, the One who is Called Yogi, Along with Some Experiences, Written Just as they Happened, without any

\footnotetext{
${ }^{771}$ rnal 'byor pa'i ming can kun dga' legs pa'i rnam thar byung tshul lhug par smra pa zhib mo'i rtsing mo ha le ho le sna zin spu zin nas bkod pa.

772 rnal 'byor gyi dbang phyug chen po kun dga' legs pa'i rnam thar gsung 'bum rgya mtsho las dad pa' $i$ ku shas chu thigs tsam blangs pa ngo mtshar bdud rtsi'i zil mngar. My translation is based on Ardussi's (1972), p 84.
} 
Bullshit $^{773}$ (121 pages). The third volume contains many verses of praise to different people, letters written by Drukpa Künlé to various people, and some alphabet songs. It also contains some episodes describing encounters with various people, in the manner of the basic format of the contents of volumes I and II.

Lastly, the fourth volume (nga) bears the title Fragments of the Collected Works of Künga Lekpa, the Lord of Yogis ${ }^{74}$ (37 pages). The contents of this volume are the most random. There are songs (including a handful of alphabet songs), and a story about Drukpa Künlé's setting up an odd ritual in Ralung, which leads Ngawang Chögyal to call him a madman (smyon pa).

As their titles suggest, the last three volumes of these "Collected Works" contain somewhat random collected teachings, letters and songs of Drukpa Künlé, rather than a sustained life story. What's more, even the first volume, which most resembles a Tibetan rnam thar, does not bear many of the expected characteristics of the genre.

The big question that remains is where the materials that make up these four volumes came from. Did they come from the mouth or pen of Drukpa Künlé? Are they indirect accounts based on his notes, or remembrances from his disciples and those who met him? Are they folk traditions based on the real Drukpa Künlé? Or are they later fabrications?

One issue complicating our understanding of the origins of the text, and which has had an effect on how the text is thought of by later generations of Tibetans, is the fact that much of the first volume is written in the first person (hence its sometimes being referred

\footnotetext{
${ }^{773}$ rnal 'byor pa'i ming can kun dga' legs pa'i nyams la shar ba'i 'phral gyi chos spyod 'dra dang nyams 'char ci byung ma byung bris pa skyag gtad gang yang med pa ' $\mathrm{ga}$ ' zhig.

${ }^{774}$ rnal 'byor gyi dbang phyug kun dga' legs pa'i gsung 'bum 'thor bu.
} 
to as an autobiography, rang rnam). The verdict is out regarding whether or not we should think of these texts as actually representing the words of Drukpa Künlé himself. E. Gene Smith, in his review of Stein's translation written under the guise of Jamyang Namgyal, refers to the first volume as Drukpa Künlé's “autobiographical reminiscences," a characterization about which we cannot be certain. ${ }^{775}$ Ardussi, somewhat more cautious but still charitable, concedes that "[w]e have no reason to doubt that we are dealing with a collection of oral songs and narratives, written down perhaps in part by 'Brug-pa Kun-legs himself, but mostly by his disciples and patrons." ${ }^{, 776}$ In the course of my many conversations with learned Tibetans about this text, some insisted that we read it as the yogi's own work, taking it literally as an autobiography, while others thought of it as compiled by his disciples.

There are a number of instances in volume one of the "Collected Works" that may actually mention the process by which this text came into being. One telling episode in the "Autobiography" begins,

One time, there was one who was writing a well-ordered life story (rnam thar) [of someone], in which it was demarcated which events happened in which years. He asked, "In this life story of dharmalord Künlé, it doesn't seem like there is any specific order, just whatever happened (gang thod thod nas mdzad pa ma gtogs/ go rim zhig med pa 'dra)."

$$
\text { I said, "That's true..." }
$$

From here Drukpa Künlé describes how his life story was written, in a disorganized fashion, based on whatever events he could remember. He then comments on the highly detailed biographies of certain lamas, asking what is the purpose of including detailed dates, or how many measures of barley or beans they received as alms, or which horses

\footnotetext{
${ }^{775}$ Namgyal, p 91.

${ }^{776}$ Ardussi 1972, p 76.
} 
they received as offerings. He continues, saying how laughable it is that they include what food they ate during the day, and what kind of bowel movements they had at night. Instead, they should write things that are of religious benefit to others. This serves as a justification for the form Drukpa Künlé's “Autobiography” has assumed: short, pithy episodes, each dedicated to expressing a specific instructive point. ${ }^{777}$

This passage may be indicative of a few different possibilities. If we take it literally, it would suggest that Drukpa Künlé had a hand in the composition of some form of his autobiography (although we cannot be certain how closely the version penned by Drukpa Künlé would resemble the one that forms volume I of the "Collected Works"). Another possible reading is to see this episode as something composed by the person responsible for compiling the "Autobiography" in order to justify the fact that the text is a disjointed set of instructions rather than a coherent narrative in the manner of a traditional biography. If we pursue this latter reading, we see the author of the account as fictitiously putting words into Drukpa Künlé's mouth, making a pre-emptive response to questions that may be raised by later readers about the nature of the text.

Another episode begins by saying that, "There were some people who were writers (rtsom pa byed pa'i mi rigs 'ga') who said, 'You're a good writer. Tell us something about writing."’ Drukpa Künlé then quotes Gungtangpa Dewé Lodrö (gung thang pa bde ba'i blo gros) and Vasubandhu about the qualities good writing should have, and makes some brief comments of his own on the matter. ${ }^{778}$ As with the episode mentioned just above, depending on how we read it, this episode could be taken as

\footnotetext{
777 2005, pp 49.7-50.3; Stein, pp 101-2.

${ }^{778} 2005$, p 36.6-.18; Stein, pp 83-4. Stein discusses this issue in his Introduction, p 25.
} 
indicating that Drukpa Künlé was actively writing during his own lifetime, and that he was known by others to be doing so. This passage also brings up the significant point that Drukpa Künlé's “Collected Works” are filled with quotations from Buddhist scriptures and classic works of philosophy and conduct, as well as reasoned discussions of a wide variety of topics purported to have sprung from Drukpa Künlé's own mind. Because of this, from reading the "Collected Works" one gets a very different vision of who Drukpa Künlé may have been from that suggested by the more popular literature about him. (In creating his version of the Life, Geshé Chaphu drew from all four volumes of the "Collected Works". 779 Nevertheless, the overall character and tone of Geshé

779 The passages from the "Collected Works" that Geshé Chaphu decided to incorporate into his version of The Life of Drukpa Künlé tend to be the more enlivening tales, in keeping with Geshé Chaphu's entertaining presentation of the yogi. He does not include any of the passages showing the more learned side of the "madman." Because of the size of the "Collected Works" I have been unable to determine precisely how much Geshé Chaphu drew from it. One could do a much more systematic comparison of the works to try to plumb the logic with which Geshé Chaphu drew from earlier collections in putting together his version of the Life. Let the following examples of passages drawn by Geshé Chaphu from the "Collected Works" be a first step in such a project:

A song in which Drukpa Künlé criticizes all the major sects of Tibetan Buddhism. In the first volume ( $k a)$ of the "Collected Works", 2005, pp 105.11-107.17; Dowman 107-8. There is a similar song in the second volume, also re-used by Geshé Chaphu, 2005, pp 309.21-311.12; Dowman, p 111.

A story about Drukpa Künlé's sending a letter to the Lord of Death on behalf of the Gadra ( $\mathrm{sga}$ 'dra) people, regarding the fish in Yamdrok lake. In Geshé Chaphu's version, the story explaining the context for this letter is different. In the first volume $(k a)$ of the "Collected Works", 2005, pp 224.1-226; Dowman, pp 115-8.

An account of how while staying in Mön, Drukpa Künlé was attacked by the king's soldiers. In the "Collected Works" version, there is more detail, and it is said that they attacked Durkpa Künlé in order to test for signs of meditative accomplishment (grub rtags). In Geshé Chaphu's version this justification is left out. Both versions conclude that the teachings of the Drukpa Kagyü got spread in the area because of his activities there. Geshé Chaphu's version adds that Drukpa Künlé deflowered the virgins of Bhutan, and ever since then the consorts have had such soft skin. In the second volume ( $k h a)$ of the "Collected Works", 2005, pp 315.2-316; Dowman, pp 112-3.

A story set in India during the time of the Buddha, with the moral of teaching one to accept the reality of death. In the second volume (kha) of the "Collected Works", 2005, pp 340-2; Dowman, pp 1002.

One time in Nyukla (snyug la) Drukpa Künlé meets a destitute woman whom he tells a long story about old India, the moral of the story being that good things come to those who wait. In the second volume (kha) of the "Collected Works", 2005, pp 345.9-351.2; Dowman, pp 83-6.

A story about a woman with a mentally handicapped husband who couples with Drukpa Künlé, then goes off to meditate on her own. Drukpa Künlé then returns to visit her later. In the "Collected Works" version, the episode is given in one unbroken narrative. In Geshé Chaphu's version, Drukpa 
Chaphu's version is more in keeping with the Southern Collection and the popular oral

literature.) We will return to the question of the picture one gets of Drukpa Künlé from the "Collected Works" below.

Significant to the question of the provenance of the "Collected Works" is that the amount of material shared between the "Collected Works" and the Southern Collection is negligible. ${ }^{780}$ Based on how little shared content there is between them, we can be certain that the two collections developed independently of one another. As to the question of which is older, we have already seen the difficulties inherent to trying to date the "Collected Works", the printing of which has been dated anywhere from the late 16th to the late 19th century, with the date of its composition being even less certain. If the

Künlé's going back to visit the woman is not told until some pages after the first part of the story, thus simulating the passage of time. In the second volume ( $k h a)$ of the "Collected Works", 2005, pp 357-9; Dowman, pp 103-4, then again pp 110-1.

A visit to Rinpung, on which occasion Drukpa Künlé miraculously creates mixed black and white dogs and is offered the key to the Rinpungpas' treasury. This passage is included in the second volume $(k h a)$ of the "Collected Works", 2005, pp 387.14-390.8; Dowman, pp 59-60.

An instance when Drukpa Künlé does an exorcism on behalf of Ngawang Chögyel. In the fourth volume (nga) of the "Collected Works", 2005, pp 557.5-558.20; Dowman, pp 97-8.

${ }^{780}$ There are also certain episodes that appear in variant forms in the Southern Collection and the "Collected Works", which suggests not that one was drawn from the other, but that they were both drawing from some other body of material (perhaps oral tradition). One tale that appears in all three accounts of the Life of Drukpa Künlé discussed here- the Southern Collection, the "Collected Works", and Geshé Chaphu's version - involves his singing a song about all the characteristics he has in his current life (most of them bad) and the different past lives he must have lived. "Since now I am so mean, / Once I must have been a rich man; / Since now I am so shameless, Once I must have been a madman," and so on. Geshé Chaphu's version is based on that given in the Southern Collection. The version contained in the "Collected Works" is similar to the other two, but not exactly the same. The episode that frames the song is also different in the "Collected Works" and the Southern Collection (and the Geshé Chaphu version based on it). Dharamsala version, pp 13.13-15.15; Dowman, pp 89-90; 2005, pp 64.17-66.2.

The fourth volume of the "Collected Works" (nga), the kha 'thor, includes a famous story about how Ngawang Chöjé (ngag dbang chos rje) hung his robe (chos gos) on a ray of sunlight amidst a crowd of people. Drukpa Künlé then did him one better by hanging on a ray his bow, arrow and sword ( $m d a^{\prime}$ 'gzhu 'khor gsum). The Southern Collection and Geshé Chaphu's versions include the same basic story, except that Drukpa Künlé hangs his bow, arrow and hunting dog on the sunbeam (Dharamsala version, pp 83-5; Dowman, pp 162-3; 2005, p 559). Based on differences in the wording and the wider episodes in which this specific instance is embedded (in both cases Drukpa Künlé does this in public, in the midst of interaction with Ngawang Chöjé, but the circumstances and nature of their interaction are quite different in the two versions) it seems not that either of these stories is based on the other, but rather that they developed independently. 
Southern Collection was, as it says it its colophon, compiled by a grandson of Drukpa Künlé, it would appear to be quite old, although we should remain skeptical on this point until more evidence is found.

As we have gotten a sense of here, investigating the histories of these collections - the Southern Collection and the four-volume "Collected Works"-is a serious research project in its own right. It would involve gathering and comparing the many printings of these texts and trying to reconstruct their history. As this issue is only secondary to our task of examining the phenomenon of "holy madness," here we must be content with a summary of what we know and do not know about the texts. Having surveyed the difficulties we have in determining the origins and dates for the text, let us now look more closely at how Drukpa Künlé is portrayed in the body of his "Collected Works".

\section{II.2 The Contents of the "Collected Works"}

Having described the texts that comprise the "Collected Works" of Drukpa Künlé and what we know about them as historical or quasi-historical documents, we will now look at what information they have to offer about who Drukpa Künlé was. If we can take the "Collected Works" as reliable material associated with the so-called madman—most likely a mix of sections actually penned by Drukpa Künlé and passages written down by his disciples and other acquaintances — we will see that Drukpa Künlé was actually quite learned, a deep thinker who readily quotes from the Tibetan literary canon. Drukpa Künlé comes to seem like a stickler for how Buddhism should be practiced, with high standards for how people should conduct themselves. All of this runs completely contrary to the popular perceptions of the so-called "Madman of the Drukpa." 


\section{II.2.i Drukpa Künlé's Family and the Trajectory of his Life}

After the opening supplications Drukpa Künlé's “Autobiography” begins, "Now I will tell a little about the story of how I, Drukpa Künlé, took my birth (skye ba blangs)..."781 It states that Drukpa Künlé was a descendant of Tsangpa Gyaré (11611211; a disciple of Lingrpea and founder of Ralung Monastery), who was considered to be a reincarnation of Nāropa. ${ }^{782}$ (Drukpa Künlé himself was said to be an emanation or reincarnation of the Indian Siddha Shawaripa. ${ }^{783}$ ) It is said that Drukpa Künlé had been enjoying a happy childhood until his father was killed by his paternal uncle in the course of a dispute raised over the succession or inheritance of the family line. Drukpa Künlé's father was killed by the Neudzong faction (snel pa phyogs), who governed the Lhasa area under the auspices of the Pakmodrupas. After this Drukpa Künlé's life was turned upside-down. He was under the care of his paternal aunt and her husband, who put the boy into the service (phyag phyir slebs) of the Rinpungpa Küntu Zangpo, the father of the famous warlord Dönyö Dorjé and an important political figure in his own right. (This situation is reminiscent of the way Dönyö Dorjé would care for the young Pawo Tsuklak Trengwa, reincarnation of the first Pawo, Chöwang Lhündrup.) Drukpa Künlé, speaking in the first person, says that although he was not happy with Küntu Zangpo, because the Rinpungpas were being attacked by many factions on all sides, he had to stay in their service for six years. This basic course of events would be mentioned again later in the

\footnotetext{
${ }^{781}$ Stein, p 42; 2005, p 3.14.

${ }^{782}$ Dowman, pp 37-8.

${ }^{783}$ Drukpa Künlé refers to himself as Shawaripa at Śrī Parvata, 2005, p 171.16; Stein, p 275.
} 
"Autobiography", with the added detail that Drukpa Künlé was thirteen years old at the time of the death of his father. ${ }^{784}$

Having stayed with the Rinpungpas for six years in Tsang, at the age of nineteen or so Drukpa Künlé developed the urge to practice the Dharma and left for Ü. Drukpa Künlé's mother had in the meantime married his paternal uncle (perhaps the uncle responsible for his father's death). Drukpa Künlé imparted to his sister some jewels the Rinpung depa Küntu Zangpo had given him, gave his horse to his aunt's husband, and set off. There is little mention of his family (save for his son, or references to the death of his father) for the remainder of the four volumes. The "Autobiography" includes a song he sang on the occasion of his mother's death, at which time he also mentions his sister (sring $m o$ ), who apparently was a nun. ${ }^{785}$

After telling the story of Drukpa Künlé's early life and family, there are a few pages describing his studies under a handful of different masters as he traveled around $\ddot{U}$ and Tsang. These include Lhatsünpa (the main guru of Drakpa Tayé) ${ }^{786}$, the 7th Karmapa (while in Kongpo) and the Second Drukchen, Künga Peljor ( 'brug chen, kun dga' dpal 'byor; referred to in the biography as rgyal dbang chos rje). During this period it is said that Drukpa Künlé became a monk and took the novice vows at Nyingro Menchuka (nying ro sman chu kha) in Nenying (gnas rnying, which is a little south-east

\footnotetext{
${ }_{784}$ 2005, pp 4.22-5.7; Stein pp 43-4; Stein, Tibetan Civilization, p 103. See also 2005, pp 199.17-200.6, Stein p 317, when Drukpa Künlé describes the complexities of the situation surrounding his father's death when he was 13 years old. Dowman, pp 100-1 also mentions the death of Drukpa Künlé's father. ${ }^{785}$ 2005, pp 130.4-131.4; Stein pp 218-9.

${ }^{786}$ There is no mention of Drakpa Tayé in the "Collected Works", unless he is referred to by an alias. Drukpa Künlé is mentioned in the biography of Drakpa Tayé, when the latter meets him at Ralung. There Drukpa Künlé is referred to as rje rnal 'byor gyi dbang phyug kun dga' legs pa. In rnal 'byor gyi dbang phyugs grags pa mtha' yas dpal bzang po'i rnam thar mgur 'bum ngo mtshar nor bu' $i$ 'phreng ba (reproduced from tracings from prints of the Central Tibetan blocks from the Library of Burmiok Athing, Gangtok, 1977; also printed in Delhi), p 150.
} 
of Gyantsé). After relating this period of Drukpa Künlé's life in which he collected teachings from these masters, the narrative structure of the biography breaks down and we can no longer be certain to which period of Drukpa Künlé's life the events described pertain; from this point forward, there is little or no continuity between the episodes that make up the "Autobiography".

Over the years as he traveled around Tibet and Bhutan, Drukpa Künlé would turn down various requests to settle at some monastic community and assume a leadership role. On the occasion of being offered an estate connected with Ralung Monastery, Drukpa Künlé stated that taking control of any lands during this degenerate age could only lead to more suffering; and besides, it was because of a dispute over lands that his father had been killed. ${ }^{787}$ It seems that Drukpa Künlé would continue to travel around with no fixed residence for most of his life.

Drukpa Künlé's death in the area of Nakartsé (sna dkar rtse) is described as an event surrounded by many miracles, which attest to the yogi's greatness. The cremation of his corpse created many relics (ring $b s r e l$ ), which were placed inside a silver reliquary housed at Lampar Monastery (lam 'phar dgen) in Tölung (stod lung; in Bhutan, not in Ü), and watched over by his son, Zhingkyong Drukdrak. ${ }^{788}$

The vast majority of Drukpa Künlé's “Autobiography”, between the description of his studying under various masters and his death, is made up of disconnected episodes, with no clear indicators of when the events in question occurred in the yogi's life. The episodes seem randomly put together, with little geographical continuity. The second,

\footnotetext{
${ }^{787}$ 2005, p 5.12-.17; Stein, p 44.

788 2005, pp 265-6; Stein, pp 415-6.
} 
third and fourth volumes of the "Collected Works" tell us effectively nothing about the details or trajectory of Drukpa Künlé's life. In the whole of the "Collected Works" there are very few dates, save for those indicating when a few letters were composed.

Drukpa Künlé's “Collected Works” thus tell us frustratingly little about the basic facts of his life. By contrast, we know incomparably more about the events of the lives of the Madmen of $\ddot{U}$ and Tsang. But if we believe the contents of the "Collected Works" to be derived from Drukpa Künlé or those close to him, they offer the possibility of an understanding of Drukpa Künlé's thoughts and feelings that is much more intimate than that gotten from our sources about the other 15th-century holy madmen. As we are told so little about Drukpa Künlé in a straightforward fashion, we are left to piece together what we can about him based on the other contents of the "Collected Works", which is the task to which we now turn.

\section{II.2.ii Drukpa Künlé's Wife and Son}

One of the key features of Drukpa Künlé's character in the popular Tibetan imagination is his voracious sexual appetite and his use of sex as a means to lead women along the spiritual path. The picture of Drukpa Künlé that we get from the "Collected Works" is a much tamer one. One episode in the "Autobiography" relates how when asked by some masters (slob dpon) to tell about his life, Drukpa Künlé states that he had taken the pre-novitiate and the novitiate before the abbot of Nenying (gnas rnying chos rje), then later took the full ordination (dge slong) before the master of Zhalu Monastery, by the name of Kyenrabpa (zhwa lu rje mkhyen rab pa). ${ }^{789}$ Based on this we can

${ }^{789}$ 2005, p 184.15-.17; Stein, p 295. 
conclude that Drukpa Künlé lived as a fully ordained monk for some period of his life, before giving it up and having a family. ${ }^{790}$

In the course of the "Collected Works" there is mention of Drukpa Künlé's having a wife (yum chen) named Tsewang Dzom (tshe dbang 'dzoms) (although we should not assume that they were married in a modern Euro-American sense) and a son, Zhingkyong Drukdrak (zhing skyong "brug grags). ${ }^{791}$ In the "Collected Works" there is no mention of a second wife named Norbu Dzom (nor bu 'dzom; also called Pelzang Putri, dpal bzang bu khrid) or the son Drukpa Künlé is asserted by some to have had with her, named Ngawang Tenzin. ${ }^{792}$ Based on other sources, E. Gene Smith seems quite confident that Ngawang Tenzin was in fact the son of Drukpa Künlé, sired when the saint was in his 50s. ${ }^{793}$ The son of this Ngawang Tenzin, Mipam Tsewang Tenzin, is asserted to have been the compiler of the Southern Collection by a note included in that text. But the fact that neither Ngawang Tenzin nor his mother are mentioned in the "Collected Works" casts considerable doubt on the claims that he and his progeny in Bhutan were actually the descendents of Drukpa Künlé.

Drukpa Künlé's other son (or perhaps only son), Zhingkyong, is mentioned many times in the course of the "Collected Works". This suggests that the son played an ongoing role in Drukpa Künlé's life. We get a tantalizing glimpse into their domestic

\footnotetext{
${ }^{790}$ However, in the body of the contiguous narrative of Drukpa Künlé's life that takes up the first five pages (in Stein's translation) of the "Autobiography", it is described how after leaving his family situation to embark upon a religious life, at one point he took the pre-novice vows (bar ma rab byung) in the Nenying (gnas rnying) area, then the full novitiate (dge tshul). Here there is no mention of his taking full ordination (dge slong). 2005, p 7; Stein, $\mathrm{p} 46$. Not mentioning his having taken full ordination may have been a simple oversight.

${ }^{791}$ Tsewang Dzom is mentioned in the 2005 version, p 121.10.

${ }^{792}$ Stein, pp 14-6.

${ }^{793}$ Namgyal, p 95. Ardussi (1972) also discusses the difficulty of the possible second wife, and the descendents of this union, pp 6-7.
} 
lives when one episode begins with Drukpa Künlé's complaining that his son would not listen to him, which the boy's mother said was Drukpa Künlé's fault: Drukpa Künlé, evidently, had spoiled the boy (skyug lang la btang). This compels Drukpa Künlé to make a long excursus on human nature. ${ }^{794}$ Another episode begins with Drukpa Künlé's relating how on one occasion some people said to him, "You Drukpa [Kagyüpas] put too much effort into caring for women and children." In his response Drukpa Künlé explains how taking care of women and children is in fact a good way to practice the Six Perfections (pāramitās) of the Mahāyāna-generosity, ethics, patience, diligence, concentration and wisdom. ${ }^{795}$ Another episode records a song Drukpa Künlé sang describing a ritual to be used to prolong the life of his son (tshe khrid), who must have been sick at the time. ${ }^{796}$ Another passage in the "Autobiography" records a letter of safe passage (lam yig) Drukpa Künlé wrote for his son; it contains requests that people help Zhingkyong Drukdrak in his journeys, as well as advice for him. ${ }^{797}$ Given how often Zhingkyong Drukdrak is mentioned in the "Collected Works", it is suspicious that his other purported son, Ngawang Tenzin, gets no mention at all.

On one instance in the "Autobiography” Drukpa Künlé refers to himself as a "monastic householder" (ser khyim pa). ${ }^{798}$ As for how his being a family man affected his status as a religious authority, on one occasion some people asked Drukpa Künlé to give them a teaching in order to establish a dharmic connection between them. Drukpa Künlé responded by saying that only faultless people should teach the Dharma. If he

\footnotetext{
794 2005, p 75.21-78.8; Stein, pp 139-41.

795 2005, pp 101.9-102.4; Stein, p 175.

${ }^{796}$ 2005, pp 120.15-121.9; Stein pp 205-6.

${ }^{797}$ 2005, pp 220.18-222.3; Stein, pp 349-50.

${ }^{798}$ 2005, p 81.12; Stein, p 145.
} 
were to teach, it would anger the Buddha. The reason is that he has a wife and a child. (On this occasion Drukpa Künlé observes that the great translator and teacher Marpa also had a child, but since he was actually Hevajra incarnate, his son would not have come into being as a result of his having ejaculated. ${ }^{799}$ There is thus no comparison to be made between them.) Here Drukpa Künlé does not seem regretful about having these familial obligations, but is forthright about what bearing they have on his position within Buddhist culture.

Based on these instances one gets the feeling that Drukpa Künlé was a committed family man. He did not seem to regret his responsibilities to his wife and son. And despite his having at least one sexual partner and a child, there is no reason to believe that Drukpa Künlé was the kind of sexual libertine he is portrayed as in the more popular collections of stories about him. (In Geshé Chaphu's version of the Life, Drukpa Künlé had five thousand girlfriends.) The basis for the vision of Drukpa Künlé as an untamable libertine is probably based on the fact that he gave up his monkhood and had a female partner and child. Drukpa Künlé's deviation from the monastic norm was exaggerated and caricatured over time, resulting ultimately in the vision of Drukpa Künlé we get from a text like Geshé Chaphu's. Below we will see more examples of how some basic characteristics of who Drukpa Künlé was got exaggerated and distorted over time, resulting in the creation of the wilder popular image of him.

One last passage related to Drukpa Künlé's attitudes towards women is worth mentioning. Within the "Collected Works" there are many interesting and creative thought pieces, most of which are presented under the guise of being records of actual

\footnotetext{
${ }^{799}$ 2005, p 96.14-.22; Stein, pp 168-9.
} 
conversations. The one that is of interest here begins with Drukpa Künlé's mentioning how some people had been saying that in the degenerate age in which we live, women (skye dman) had become more powerful (dbang che ba) than men (skyes rgyal), which they regarded as a bad thing. Drukpa Künlé expresses his own thoughts on the matter, which are in disagreement with the assertions made by others. The mode of reasoning Drukpa Künlé employs is an interesting one. He states that the current state of affairs in which women are the dominant half is nothing new: since time immemorial in the pairings of various things the female counterpart has often been the dominant one. He offers the sun (which in Tibetan, nyi ma, bears a feminine linguistic marking) and the moon (zla $b a$, which bears a masculine marking) as an example: when the sun comes up, the moon disappears, making the former the dominant one in the pair. Wool made from female sheep is softer and better than that from the male. The dominance of the feminine aspect holds not only in worldly affairs but in the religious as well. There is a mother goddess of the Perfection of Wisdom - there is no father god of the Perfection of Wisdom. In the realm of tantra, the resting place of the body, speech and mind of all the Buddhas is the vagina of the Vajra Queen (rdo rje btsun mo) — there is no male equivalent. The word lama has a feminine marking; there is no masculine equivalent, la pho. ${ }^{800}$ And so on.

Here Drukpa Künlé uses an interesting form of reasoning to make what could be taken as a sort of proto-feminist argument. On one level Drukpa Künlé is saying that the female is better than the male (as in the case of wool). At the same time he may be suggesting that certain words in the Tibetan language belie an unconscious recognition of

${ }^{800} 2005$, pp 62.22-64.10; Stein, pp 120-2. 
the superiority of the feminine aspect in its gendering of terms (as in the case of the word bla ma, there being no male equivalent of bla pho). We should not read too far into this brief essay and assume that Drukpa Künlé espoused modern liberal attitudes about gender throughout his life. But it does suggest that Drukpa Künlé was a more thoughtful individual than the way he is characterized in more popular literature, such as in the version of his Life by Geshé Chaphu.

\section{II.2.iii Drukpa Künlé's Position in Politics}

Drukpa Künlé's attitude with respect to the political situation in central Tibet is difficult to encapsulate. On a handful of instances in his "Autobiography" and the other three volumes of his “Collected Works”, Drukpa Künlé addresses the political situation directly. Perhaps indicative of the tense rivalry between the two sides, Drukpa Künlé speaks (or writes) in a relatively sustained fashion regarding his feelings about the Pakmodru and Rinpung factions. In one episode Drukpa Künlé is asked by an unnamed interlocutor to explain the reasons for his attachment (zhen pa) to the Pakmodrupas. As becomes clear from his response, this is a question of his supporting the Pakmodrupas as opposed to the Rinpungpas, whom some of his contemporaries clearly would have thought a more natural fit given his various other affiliations. Drukpa Künlé begins by stating a few reasons why one should remain loyal to the Pakmodrupas, who are, in a sense, the rightful rulers of Tibet and have always been associated with the Kagyü. He then makes some comment about the Rinpungpas. Then he mentions the complexities of the position of Ralung Monastery in the midst of these affairs. Here Drukpa Künlé expresses criticisms of the 4th Red Hat for standing by as the military and political 
disturbances between the Pakmodrupas and Rinpungpas took place. ${ }^{801}$ On another occasion Drukpa Künlé makes similar comments about the conflict between the Pakmodrupas and the Rinpungpas, adding that the Rinpungpas are also worthy of his allegiance because of the fact that they would remain servants of the Pakmodrupas if it weren't for their being agitated by demons (bdud kyis dkrugs la brten pa ma gtogs)— "demons" here can be interpreted in any number of ways - and also because of the fact that they cared for him after his father had been killed. ${ }^{802}$

It seems that during his adult life Drukpa Künlé had contacts with representatives of both sides in the struggle for control over central Tibet. There are mentions of his visiting Rinpung and corresponding with various Rinpungpa lords, as well as his staying at Nedong Tsé, the capital of the Pakmodru regime. Based on various comments he makes in his "Autobiography" and the rest of his "Collected Works", it seems Drukpa Künlé was adamant in his support of the Pakmodrupas as the rightful rulers of central Tibet; he also expresses some criticisms of the Rinpungpas in their attempt to take power for themselves. At the same time, he feels himself personally indebted to the Rinpungpas for their role in his early upbringing after the death of his father. It seems that in this

\footnotetext{
${ }^{801}$ 2005, pp 52.19-54.3; Stein, pp 105-7.

${ }^{802}$ 2005, p 201.3-.8: dpal phag mo grub pa la gus zhen ma log pa gyis/ gzhis ka rin spungs pa 'di mi ci rigs kyi 'dod kha zhabs dang / sems can spy'i chag sgo bde ba dang / bdud kyis dkrugs la brten pa ma gtogs/ phag mo grub pa'i zhabs tog pa yin pa dang / sgos kyi rang gi pha rgan de 'das nas mgo 'don du gang 'gyur gnang bas gus zhen ma log pa gyis/.

At the same time, Drukpa Künle's “Autobiography” shows that he considered the belligerent activity of the Rinpungpas to be blameworthy. In passing he mentions their campaigns as exemplifying the opposite of good Buddhist behavior, in which one abandons harm towards other beings. Drukpa Künlé is purported to have said, "For example, the 'encamped governor' (nang so sgar pa, a term often used to refer to Rinpungpa Dönyö Dorjé) is attacking everyone. What difficulties they will face now and in the future!" This is likely a reference to Dönyö Dorjé, but may be a use of the term nang so sgar pa in a more generic sense. 2005, p 31.7-.8. Stein, p 77, does not take nang so sgar pa as referring to Dönyö Dorjé, but translates it as "un préfet, chef du camp militaire, qui a battu tout le monde."
} 
respect, as with so many others, Drukpa Künlé occupies a position of ambiguous

affiliation. $^{803}$

In the third volume of Drukpa Künlé's "Collected Works” there is a fascinating document that could potentially provide some insight into his thoughts about the complicated political situation in central Tibet at this time. The document is a letter of request (a sort of zhu yig). The first half or so is addressed to political heads of the Pakmodru and Rinpung regimes, as well as some lesser lords. In the opening verse Drukpa Künlé expresses his hope that both the Pakmodru and Rinpung factions can be victorious (phag mo gru pa chen po rgyal gyur cig... rin chen spungs pa zhes bya rgyal gyur cig). ${ }^{804}$ He again states the validity of the authority of the Pakmodrupas, then describes how the ambitious Rinpungpas came to take a share of the power by sowing discord among the various ministers through murder and so on. Having laid out this

${ }^{803}$ 2005, pp 11.14-12.5; Stein, pp 51-2. On this occasion Drukpa Künlé meets in Ü one nang so don yod rdo rje rgyal po dpal bzang po, which probably refers to the Rinpungpa Dönyö Dorjé. When Dönyö Dorjé asks Drukpa Künlé for a Dharma teaching, he refuses, saying "If you're not liberated from your actions, emptiness will not help," which then leads to some conversation. This initial refusal to give a teaching may have been a slight suggesting Drukpa Künlé's disapproval of Dönyö Dorjé's warlike activities.

On another occasion, while passing through Tsangrong (gtsang rong, the Rinpungpas' home territory) Drukpa Künlé observed how the Rinpngpas had raised a large army to fight against the administrator of Neudzong (nang so snel pa), who was in control of Lhasa; he observes that the Rinpungpas had become very powerful. 2005, p 18.17-.19; Stein, p 61.

For other contacts with the Rinpungpas drawn from the other volumes of Drukpa Künlé's “Collected Works", see 2005, p 364.12, when Drukpa Künlé is invited by Dönyö Dorjé (sgar pa don yod rdo rje), who is in Kongpo with the Karmapa; and 2005, pp 494.2-494.14, when Drukpa Künlé exchanges letters with Dönyö Dorjé, then sings a song for him. There is also a famous story of when Drukpa Künlé was invited to Rinpung, and upon his arrival miraculously turned a black dog and a white one into mixed black and white dogs. After this Drukpa Künlé sings some songs, and the governor (sde pa) is so moved by his faith that he offers Drukpa Künlé the keys to the treasury. After adorning himself momentarily with some jewelry, Drukpa Künlé gives it all back, saying he has no need for it. This passage is included in the second volume (kha) of the "Collected Works", 2005, pp 387.14-390.8; Dowman, pp 59-60. Drukpa Künlé has another exchang with a Rinpung official, 2005, p 544.7-.14.

Drukpa Künlé's having stayed at Nedong Tsé is mentioned 2005, p 156.4; Stein, p 253; and also on 2005 , p 366.16 .

On 2005, p 37.17, Stein, p 85, Drukpa Künlé meets khri dpon bkra shis dar rgyas, and may receive patronage from him on this occasion.

${ }^{804} 2005$, p 482.12, 482.19. 
situation, Drukpa Künlé then turns towards the possibility of finding a solution that would lead to an end to hostilities, suggesting that a border be established between the areas controlled by each side, and that the Rinpungpas "should re-assume their previous position of subservience to the [Pakmodru] gongma" (gzhis ka bas gong ma'i zhabs tog sngar lugs gzhin gnang dgos). He then addresses the other parties with some bearing on the political affairs of central Tibet — the rulers of Gongkar (gong dkar), Yargyab (yar rgyab), Taktsé (stag rtse), Drikung ( 'bri khung), Nakartsé (sna dkar rtse), and so on.

The document then takes a curious turn, leaving behind political affairs to address the people of Tibet more generally. Drukpa Künlé humbly requests reforms in the behavior of monks, meditators, nuns ("If a nun should get pregnant, she should not remain with the man"), sorcerers ("mantrikas propitiating deities and reciting mantras and setting up mandalas should not cast spells or cause hailstorms"), moving on to other people in society following non-religious vocations, like merchants, servants ("servants should assume a lower position and behave in the manner of servants"), and so on, for pages. The letter ends with his saying, "If all of this is done, I will be thankful. If not, everyone will have some hardships..." This letter is dated the third day of the third month of the Monkey year, dispatched from a place called Pelgyé (dpal rgyas), and signed, Künga Lekpa, the Madman of the Drukpa. ${ }^{805}$ Unfortunately no element is attached to the animal year, making it impossible to determine when this letter dates from.

Based on all the evidence available in the four volumes of his "Collected Works", it seems that Drukpa Künlé did not wish to take sides in the Pakmodru-Rinpung conflict.

${ }^{805}$ The entire passage runs 2005, pp 482.5-488.7. 
Rather, he tried to play the role of mediator. Regardless of whether or not Drukpa Künlé actually sent this long missive to the various people to whom it was addressed, and whether or not he actually thought it would have effected any change, if we accept that the letter came from Drukpa Künlé's pen it shows a playful wish to have peace and order restored to central Tibet. As one whose life was so disrupted by the ravages of factional violence, Drukpa Künlé surely felt the high cost of such fighting. Drukpa Künlé's somewhat noncommittal personal stance with regard to these matters is very much in line with what we might have expected, given the difficult position Ralung Monastery was in vis-à-vis the Pakmodru-Rinpung conflict. John Ardussi has described how the Ralungpas had longstanding ties with the Pakmodrupas, but at the same time were geographically closer to the power base of the Rinpungpas. This put the Ralungpas in the difficult position of not wanting to alienate either faction. ${ }^{806}$ Drukpa Künlé's personal position seems to belie this concern. How Drukpa Künlé's political stance compares with those of the Madmen of Ü and Tsang will be discussed below.

\section{II.2.iv Drukpa Künlé's Critical Attitude}

In the popular literature Drukpa Künlé is presented as the ultimate iconoclast. He prostrates to the beautiful women of Gyantsé but refuses to show respect to the monks. He offers his testicles to Tsongkhapa as a gift. He composes scatological prayers based on a traditional Buddhist form. As with his reputation as an insatiable womanizer, the perception of Drukpa Künlé as an iconoclast seems to be based on certain characteristics of who he was, but taken to an exaggerated degree. If we take the "Collected Works" as offering a relatively accurate portrayal of who Drukpa Künlé was (that is, if we take their

\footnotetext{
${ }^{806}$ Ardussi 1972, p 2.
} 
contents as having been composed by Drukpa Künlé himself, or based on notes left by him, or the remembrances of his disciples and other people he interacted with) we have reason to believe that Drukpa Künlé was, more than anything else, a critic, dissatisfied with many of the ills and abuses he saw in Tibetan society, especially when it came to the practice of religion.

In a passage representative of sentiments he expresses many times in his “Collected Works”, Drukpa Künlé says that he was once asked if there was anyone practicing the Dharma in a pure manner during the time in which he lived. His response is a grand tour of Tibetan religious communities, and he has criticisms to make about everyone. He says that he visited a monastery of the Kagyü sect where all the monks were drinking chang; he visited a Sakya monastery where the monks deprecated all other religious systems; he visited a Geluk (dga'ldan pa) monastery where all the monks were overly attached to their individual colleges; he visited a Nyingma monastery where all they did was masked dancing. He also visited charnel grounds and hermitages where people practiced the "Cutting" practice $(\operatorname{gcod} y u l)$, but he was concerned about becoming too caught up with worldly, unenlightened deities. He visited the Drukpa Kagyü monasteries, but did not want to get drawn into fighting with his relatives (pha spun). He visited those staying in meditative retreat, but all they have to say is, "How many more days?" The lamas he had visited are occupied with worldly concerns ('jig rten gyi pho khyer mdzad); the attendants (nye gnas) to those lamas are like tax collectors. The great meditators (sgom chen) have consorts, which they justify by saying that they are goddesses (thugs dam rig ma la re); on the other hand, the logicians (mtshan nyid pa) all 
have little monks to keep their spirits up (skyo grogs btsun chung). ${ }^{807}$ Drukpa Künlé has found fault with everyone.

In a similar passage Drukpa Künlé again expresses his criticism of the entire gamut of Tibetan religious practitioners, and some laypeople as well. He complains that some lamas teach religion to others, but do not actually practice it themselves; there are monks who express their devotion and faith with palms joined and eyes closed, but they really do not have it on the inside; there are mantrikas who excite demons but do not really have any meditative accomplishment; there are scholar-monks (dge bshes) who teach to others, but do not take the Dharma into their own minds. There are some who take on the appearance of realized ones (rtogs ldan rnam pa' $i$ spyod pa) who brazenly meditate on themselves a Herukas, without actually cultivating the proper good qualities of the deity. There are great meditators (sgom chen) who show fake signs of meditative accomplishment. There are attendants watching over the lama's treasury who are as desirous like hungry ghosts. There are worldly lords who apply the laws to others, but do not obey them themselves. There are servants who criticize others for not faithfully serving their lords, but do not actually do so themselves. There are patrons who give gifts only with the hope of getting repaid in return. There are lords holding religious estates who do not maintain any vows, and yet think themselves practitioners of religion. The song ends with Drukpa Künlé's directing his critical eye at himself, saying "I, the yogi, Künlé who travels the country having abandoned my homeland, whatever happens

\footnotetext{
${ }^{807} 2005$, pp 105.11-107.17; Stein, pp 181-4. For an example of another composition that begins by criticizing the different sects, then moves to more general categories, see 2005, pp 97.1-98.19; Stein, pp 169-71.
} 
it is amazing that I haven't given up attachment! I'm a liar going by the title 'renunciant'!',808

This kind of criticism is one of the most consistent themes throughout the entire "Collected Works" and there are many passages similar to these. Some of Drukpa Künlé's criticisms of the representatives of religion in Tibet are directed at the various sects, while others are about general categories of practitioners. Ultimately what drives these criticisms is Drukpa Künlé's distaste for hypocrisy. ${ }^{809}$ He clearly sees how people benefit from their status as monks or ritualists, but finds fault with the way they do not uphold the obligations that are supposed to be the basis for their status. Monks who are not actually celibate and ritualists who do not know the meanings of the rituals they perform have broken their basic contract with the society that supports them. In many ways it is this hypocritical disjunct between the outward display and the inner meaning that is the object of Drukpa Künlé's criticism. This concern about rectifying external appearances with the meaning that is supposed to lie behind them is repeated throughout Drukpa Künlé’s “Collected Works”. Drukpa Künlé comes across as a constant critic, attacking people (including himself) not simply for having faults, but for being what he considers hypocritical or false in some way, for pretending to be better than they actually are. He sees this not as a simple human mistake, but coming out of peoples' greed and ambition.

One of the groups Drukpa Künlé most often criticizes are monks, whom he charges with not actually upholding their vows spelled out by the Vinaya. He often

\footnotetext{
${ }^{808}$ 2005, pp 19.17-21.4; Stein, pp 62-4. nga rnal 'byor kun legs rgyal khams bskor/ yul pha yul spangs pas ci yong ba/ zhan pa ma thongs ngo mtshar chel bya btang zer ba'i ham pa la/

809 See John Ardussi and Lawrence Epstein, "The Saintly Madmen in Tibet," in Himalayan Anthropology: The Indo-Tibetan Interface, edited by James Fisher (The Hague: Mouton, 1978), p 336.
} 
expresses his suspicion that the older monks are having sexual relations with the younger ones. Drukpa Künlé is himself absolved from the criticism of being a false monk because he gave up the trappings of monkhood after taking a wife and having a child. Another group about which Drukpa Künlé voiced serious concerns are positioned on the other side of the religious marketplace: non-monastics outwardly displaying a tantric lifestyle. Let us explore these criticisms further, as they contribute to our understanding of Drukpa Künlé's position in Tibetan religious culture, and his position vis-à-vis the Madmen of Ü and Tsang.

One time when he was a guest at an assembly held by a official (nang so) in Jayul (bya yul) (a favorite haunt of the Madmen of Ü and Tsang), some scholar-monks (geshés) questioned Drukpa Künlé in the following manner: "Wearing neither the clothing of a monk (rab byung) nor that of a realized one (rtogs ldan; referring to the six bone ornaments and the like), but wearing whatever in this manner-it does harm to how people perceive you. What are you thinking?" Drukpa Künlé begins his response thus,

As for living in the manner of a monk (rab byung byed pa), one should live in accordance with the Vinaya. That is really difficult to achieve. Wearing the yellow robes while not maintaining the vows - that is more disgusting than just having inner faults (mtshang las skyug bro ba), so I don't want to do it.

As for living in the manner of a realized one (rtogs ldan byed pa), one should understand essential reality (gnas lugs rtogs dgos). For one to assume this appearance without understanding essential reality, it's like covering a donkey with the skin of a leopard. Without having the proper qualities on the inside $\left(?^{810}\right)$, I cannot wear the garb of a yogi, out of embarrassment (ngo tsha). ${ }^{811}$

Drukpa Künlé expresses a very similar sentiment in a verse, lamenting,

Being a monk without maintaining the vows,

\footnotetext{
${ }^{810}$ nang na bsdu zums med pa'i rnal 'byor pa'i chas ' $d i$; Stein was also unable to definitively understand the term bsdu zums med pa.

${ }^{811}$ 2005, pp 38.15-39.4; Stein, p 87.
} 
practicing engaged asceticism (brtul zhugs) without having realization, teaching the Dharma without thinking about cause and effectseeing these three things has made me oh so sad. ${ }^{812}$

Showing how persistent a concern this was for Drukpa Künlé, in another verse he ironically proclaims,

I prostrate to those who wear the Six Ornaments without understanding reality! I prostrate to those who wear monk's robes without maintaining the three sets of vows! $!^{813}$

Drukpa Künlé is thus very skeptical of many men living as monks, as he thinks it unlikely that they actually maintain the vows that in theory provide the basis for their being worthy recipients of the generosity of laypeople, which is essential for their upkeep. At the same time he is also skeptical of those who make a career out of their reputations as tantrikas. Drukpa Künlé specifically identifies aspects of the eccentric behavior that were important to the identities of the Madmen of Ü and Tsang. This includes their performance of engaged asceticsm and their mode of dress, made up of the six bone ornaments and other ritual paraphernalia. One should have a certain level of realization before one takes on this kind of lifestyle, and Drukpa Künlé is skeptical that many of them have it.

What leads people to wrongly take on this tantric lifestyle, according to Drukpa Künlé, is their own greed. Elsewhere he makes an extremely pointed criticism of people just like the Madmen of Ü and Tsang:

You who adorn yourselves with the pure ornaments for the practice of secret mantra

- the topknot, bone ornaments, khatamga, and tiger skin skirt—,

${ }^{812}$ 2005, p 99.19-.21; Stein, p 172. sdom pa med pa'i btsun khyer dang / rtogs pa med pa'i brtul zhugs dang / rgyu 'bras mi bsam chos bshad gsum/ gsum 'di gsum mthong bas skyo drags byung /.

${ }^{813}$ Vol. 2 (kha), 2005, p 360.20-.21. gnas lugs ma rtogs rgyan drug gyon pa la phyag tshal lo/ sdom gsum mi bsrung chos gos gyon la phyag 'tshal lo/. 
you donkeys who cover yourselves with lions' hides-

it seems to me that you are disclosing secret things for the sake of putting food on the table! $!^{814}$

This is not the only occasion on which Drukpa Künlé expresses a concern about people

"selling" tantra for the sake of wealth. At one point Drukpa Künlé addresses certain

tantric masters (slob dpon) who, thinking themselves great tantricists, give

empowerments for the sake of wealth, who dance and sing mantras in the marketplace,

who will draw a mandala anywhere, all while saying, "this is dangerous!" ${ }^{15}$ Elsewhere

Drukpa Künlé observes,

All the people who now teach religion, they sell Dharma for the sake of wealth. With no thought of helping anyone, they teach the Dharma for the sake of getting food and clothing, and thereby oppose the Word of the Buddha. I request that he protect them in their future lives. ${ }^{816}$

Drukpa Künlé's concern that people are "selling" the Dharma—teaching it, appropriating

it and using it in ways that are beneficial to them, but not necessarily driven by religious

motivations-is a persistent concern in his "Collected Works". The charge that one

falsely uses the Dharma is a serious one, and Drukpa Künlé makes it often. This

criticism overlaps with Drukpa Künlés concern about the motivations of those who

fashion themselves as tantrikas. The circle at whom this barb is directed may well have

${ }^{814}$ 2005, p 242.17-.20; Stein, p 380. thor tshugs rus rgyan kha TAM stag sham brgyan/ gsang sngags spyod pa'i rgyan cha rnam par dag bong bus seng ge'i pags pa gyon pa yis/ lto phyir gsang sgrog tshor ro ...

${ }_{815}$ 2005, pp 88.20-89.3; Stein, p 156. gsang ba'i dkyil 'khor zhal phye na/ skal ldan chos kyi rgyal srid gtod/ skal med brda dang thabs kyis skrod/ de min nor phyir dbang bskur ba/ snod min dag la gsang rgyu la/ khrom du bro brdung 'dzab glu 'then/ dkyil 'khor ra khyi'i tshang du'ang 'bri/ 'di ni shin tu gnyan no zer/ sngags 'chang chen por khas 'che ba' $i$ ' slob dpon de la bya cig thongs/.

${ }^{816} 2005$, pp 13.22-14.2; Stein, p 54. da lta'i chos 'chad pa 'di kun/ chos nor phyir 'tshong / phan sems med pa'i lto gos kyi phyir chos shod pa la/ shAkya thub pas bka' chad tshe phyi ma la bka' drin skyong ba zhu lags/.

In another song Drukpa Künlé sings ironically: "I prostrate to the ones who exchange the Dharma for wealth!/ I prostrate to the treasure revealers who bring shame to Orgyenpa!" (chos dang nor rdzas brje mkhan rnams la phyag 'tshal lo/ o rgyan khrel ba'i gter bton rnams la phyag 'tshal lo/) Vol. 2 (kha), 2005, p 360.18-.20. 
included the Madmen of Ü and Tsang, although he does not name anyone here. Drukpa Künlé's comments about and relationships with the Madmen of Ü and Tsang will be discussed separately below.

Because of his concerns about hypocrisy and about selling the Dharma for personal gain, Drukpa Künlé refused to fully participate in the formal trappings of Tibetan religious life. As we saw above, it was because of Drukpa Künlé's recognition of his own inability to truly live the life expected of a monk that he did not wear the monastic attire. And since Drukpa Künlé knew he did not have the proper level of meditative realization, he chose not to dress in the manner of a yogi. How, then, did Drukpa Künlé dress? One episode in Drukpa Künlé's “Autobiography” begins with some people asking Drukpa Künlé about his mode of dress and if he had dressed like a yogi when he was younger. Drukpa Künlé says that when he was younger he had the ability to control his inner, yogic winds and thus could get by wearing just a cotton cloth on his upper body. He used to wear maroon shorts and boots of some type. He traveled with a one-man tent, some basic implements (a flint and some tools), some tsampa, a small book, and a cushion. Interestingly, he said he used to carry with him a khatamga and a damaru made of sengdeng wood (seng ldeng). He had his hair tied back. He wore conch-shell earrings (dung long). He carried no more than three days worth of provisions, and traveled with four companions. ${ }^{817}$

Although we cannot be entirely certain that these are the words of Drukpa Künlé himself, it seems likely that Drukpa Künlé wore his own distinct manner of dress. He did

${ }^{817}$ 2005, p 218.2-.18; Stein, pp 345-6. Compare with Dowman, pp 47-8, when it says Drukpa Künlé has a bow and arrow, dog, etc. 
not dress like a monk, nor did he dress like a yogi in the manner exemplified by the Madmen of Ü and Tsang. Rather, he appropriated elements of both to make his own distinctive look: the maroon of monkhood; the long hair, khatamga staff and damaru of the meditator. As we have seen from Drukpa Künlé's own words, he recognized the importance of the way one dresses in exemplifying where one fits into the wider religious culture. It seems that based on how he dressed, Drukpa Künlé positioned himself in an ambiguous place in the middle, neither a monk nor one with pretensions of great success in tantric practice.

Drukpa Künlé's refusal to become a member or take leadership of a stable monastic community is driven by a similar concern. In the same way that by living as a monk or as a yogi the external form can get divorced from the meaning that is supposed to underlie it, monastic communities tend to get mired in worldly affairs and drawn away from their mission as communities dedicated to the practice of the Dharma. There are a number of instances in which Drukpa Künlé states that he would prefer not to take control of a monastic community, even when specifically asked to do so. In one passage Drukpa Künlé says that staying in one place for a long period of time is not the way of a true religious practitioner (chos pa'i bya ba). One will become attached to a place or to a particular patron. Then one will become concerned with the amount of respect shown to oneself, which leads to conflicts. He goes on to explain:

When a monastery is first founded, it is held up by the Dharma. In the middle, it is maintained through negotiations. In the end, it is taken over by sin (sdig); although it is called a monastery, [its inhabitants] are lazier than worldly peopleso why bother founding one? If Śākyamuni Buddha saw the round [i.e., shaved] 
head [of a monk] resting on the bosom of a woman, what would he say? If one is going to act in that way, it would be better to stay dressed like a layman. ${ }^{818}$

Drukpa Künlé observes that the ideal of the monastery as a place dedicated to the practice of religion is rarely realized in actuality. In time a religious community inevitably gets caught up in worldly concerns, so how can they maintain the pretension of being a monastery?

As Drukpa Künlé sees things, in the time and place in which he lived it was all but impossible to practice Buddhism through the readily available modes — as a monk or a yogi, as a logician or a meditator, or as a lay patron—without a degree of falsity. And because of this he refused to attach himself to any of these preexisting categories, which is why he refused to get tied down to any particular place, or dress in a prescribed manner. In order to avoid slipping into hypocrisy, Drukpa Künlé kept himself unattached and went his own way. And it is this going his own way that likely became the seed for the later stories about him as an iconoclast. In the body of the "Collected Works" there are no stories of Drukpa Künlé's doing the crazy, iconoclastic, scatological things that would become the centerpiece of his identity in the Tibetan imagination. Instead, it seems that these are exaggerations ultimately based on Drukpa Künlé's basic position as a critic and an outsider who refused to conform to others' expectations of him.

In fact, a reading of his “Collected Works” suggests that Drukpa Künlé was actually relatively conventional and even conservative in some ways. As was described above, his often-repeated criticisms of other Tibetan religious practitioners was

\footnotetext{
${ }^{818}$ 2005, p 39.7-.19; Stein, p 88. See also 2005, pp 44.21-45.13, Stein, p 95; and 2005, pp 118.2-119.20, Stein, pp 201-3, on which occasions Drukpa Künlé explains why he is not up to the task of taking control of a monastic community.
} 
ultimately driven by his own high standards for how Buddhism should be practiced. Thus instead of maintaining an anything goes attitude, Drukpa Künlé was actually something of a stickler. He asserts the importance of following the Vinaya. He voices scathing criticisms of those who practice tantric publicly, who he saw as breaking the rule of secrecy because of their own greed. He calls for maintaining the status quo in society, such as when he tells servants they should remain loyal to their masters, lest the entire social order be disrupted. This makes the Drukpa Künlé of the "Collected Works” very different from the norm-overturning trickster he would later become in the more popular literature.

What's more, although we are never told of his having a conventional monastic education, Drukpa Künlé was quite learned. Throughout the “Collected Works” Drukpa Künlé quotes from a wide variety of Buddhist texts. Given the scatological way in which Drukpa Künlé has been portrayed in more popular versions of his Life, one may be surprised to learn that the text most cited in his "Collected Works" is The Condensed Perfection of Wisdom Sutra (sdud pa). Other texts he cites include the Hevajra Tantra, the songs of Saraha, the Thirty-Seven Deeds of the Bodhisattva by Tokmé Zangpo (thogs med bzang po), works by Sakya Pạ̣dita, Tsangpa Gyaré, the words of Milarepa, and so on. Despite his popular portrayal as a hyperactive wanderer obsessed with sex and alcohol, Drukpa Künlé actually shows himself to be quite learned and capable as a thinker. Throughout his “Collected Works” Drukpa Künlé pursues sustained and at times brilliant discussions of a wide variety of topics, sometimes carrying on for pages. In the midst of his pithy explanation of the question of whether or not the dharmabody exists amongst conceptuality (rnam rtog chos sku) (which was a hot-button issue in the 
late 15 th and early 16 th centuries among Kagyü circles), Drukpa Künlé cites the Suvarṇaprabhāsa Sūtra (gser 'od). ${ }^{819}$ Elsewhere he describes and defends subtleties of the Drukpa Kagyü system on questions of methods and realization. ${ }^{820}$ He gives a brief but profound exposition on the ontological status of karma, arriving at the subtle observation that the relationship between karma and conditions (rkyen) is like that of the chicken and the egg: conditions arise from karma; karma arises from conditions, so who can say which comes first? ${ }^{821}$ Whereas in the popular versions of his Life we see Drukpa Künlé fighting with giant demonesses with gaping vaginas and hanging breasts, smashing them in the mouth with his penis, in the "Collected Works" Drukpa Künlé gives an interesting explanation of the many meanings of the word "demon" (bdud), stating that anything from the most abstract to the most concrete that does not accord with the practice of religion can be considered a demon, including students who do bad things, a master with no ethical discipline, and those who practice engaged asceticism (brtul zhugs) without having achieved yogic warmth. ${ }^{822}$

Drukpa Künlé was well aware of his position as a perpetual critic, as an outsider looking in. According to a passage in the "Collected Works", one time someone observed to Drukpa Künlé that in the stories about him (rnam thar rnams) it seemed that he was always criticizing (zur 'tshag) others. Drukpa Künlé responds,

I have no intention of hurting anyone. In general, this is a degenerate age, and I see no one who lives in accordance with the Teachings of the Buddha. And as for myself, I have no particular talent, so I write whatever appears in my mind. I

\footnotetext{
${ }^{819} 2005$, p 22.1-.12, Stein, p 66.

${ }^{820}$ 2005, pp 24.20-26.1; Stein, pp 69-70.

${ }^{821}$ 2005, p 43.5-.11; Stein, pp 92-3.

${ }^{822}$ 2005, pp 73.19-74.17; Stein, pp 136-7.
} 
don't say people are doing things that they aren't doing. I also don't not say things people are doing. ${ }^{823}$

Drukpa Künlé is fully aware of himself as a critic. He believes he does not deserve to be blamed for it - he is only pointing out the truth. He does not make anything up, nor does he hold anything back. His is a fresh and honest voice in a degenerate age.

A systematic reading of his "Collected Works" shows us a Drukpa Künlé who is astute and ultimately quite tame. There is no indication that he participated in the kind of crazy behavior his name would later become synonymous with. He took a contrarian attitude with respect to certain trends of his day and was critical of much that he saw taking place around him. But rather than an irreverent joker figure, he was purposeful and self-aware. His criticisms are consistent throughout the "Collected Works". They are not random but coherent and driven by a higher ideal. Drukpa Künlé's purpose was not just to criticize or make fun, but ultimately to reform how Buddhism was practiced in Tibet. $^{824}$

Drukpa Künlé's suggestion that he could offer Tsongkhapa his testicles is a crude joke, made famous in Geshé Chaphu's version of his Life. Based on what we know from the "Collected Works", we have no reason to believe the real Drukpa Künlé ever acted in such a way (apart from the fact that Tsongkhapa had died a few decades before Drukpa Künlé was born). Drukpa Künlé was critical of many aspects of Tibetan religious culture, including the pretensions embodied by those occupying the kind of revered position Tsongkhapa would have had. A story about Drukpa Künlé's offering his

\footnotetext{
${ }_{823}^{823} 2005$, p 110.2-.10; Stein, p 188.

${ }^{824}$ This brings us back to a fundamental characterization of Drukpa Künlé made by Dowman and many others (Ardussi and Epstein), but I would argue that Drukpa Künlé is still quite different from how they have described him.
} 
testicles to Tsongkhapa is a later fabrication, but ultimately based on the critical attitude the historical Drukpa Künlé actually embodied. The later picture of Drukpa Künlé as a wandering iconoclast is an exaggeration of his status as a critic, as one skeptical of the merits of many who profit in the realm of religion, as one unwilling to be tied down to any one place or set of expectations.

\section{II.2.v Drukpa Künlé's Attitude Towards Holy Madmen; Drukpa Künlé's “Madness”} Geshé Chaphu's version of the Life of Drukpa Künlé includes a brief episode in which Drukpa Künlé meets the Madman of Ü and the Madman of Tsang and the three travel to Tsari together. At Tsari the Madman of Ü leaves a footprint on a rock while the Madman of Tsang makes a handprint. Drukpa Künlé then says, "Even my dog has that kind of power!" and makes a paw print in solid rock with his hunting dog's leg. According to Geshé Chaphu these three prints could be seen at Tsari even in the time when he was writing. ${ }^{825}$ There is no episode similar to this in either the Southern Collection or the four volume "Collected Works". We have evidence that all three of these "holy madmen" spent time at Tsari, but no indication that they ever met there. It is most likely a story of folk origins that Geshé Chaphu decided to include in his biography of the mad siddha. What's more, if we consider the "Autobiography" of Drukpa Künlé and the other three volumes of his "Collected Works", a much less rosy and probably more realistic picture of the relationship between Drukpa Künlé and these other two "holy madmen" emerges. During a somewhat rambling monologue in his “Autobiography”, Drukpa Kunlé states: "There is no rivaling Sakya Pạ̣dita in intellect; .... there is no rivaling Atiśa and his students in terms of bodhicitta; there is no rivaling

${ }^{825}$ Dowman, p 110. 
the Dakpo Kagyü in terms of realization; there is no rivaling the Madman of Tsang or the Madman of Ü in engaged asceticism (brtul zhugs)..." ${ }^{826}$ Despite expressing these kind words for the Madmen of Ü and Tsang on this occasion, a wider reading of his "Collected Works" shows that Drukpa Künlé's relationship with his two "madman" peers may not have been such a positive one.

In his "Autobiography” Drukpa Künlé makes open criticisms of the lifestyle Künga Zangpo and Sangyé Gyeltsen embodied, and through which they became famous. In one verse he observes,

Asserting yourself to be a Heruka, you ask the hosts of evil spirits ('byung po'i lha tshogs) for refuge, [but] do not know appearances to be a product of the minda life like that has been taught by the Sage to be a contradiction. ${ }^{827}$

Imitating the manners of and even taking on the name of the deity Heruka was a key part of the Madmen of Ü and Tsang's fame. Here Drukpa Künlé questions the validity of individuals' associating themselves with this deity, on the basis of their not having the proper meditative realizations to justify it.

Elsewhere Drukpa Künlé voices a criticism of those trying to embody another important aspect of the Sangyé Gyeltsen and Künga Zangpo's apparent madness in the following manner:

Speaking of "one-taste," this is what you get:

You eat a mixture of excrement and urine, and take enjoyment in clothes from a corpse, and human flesh, doing the crazy behavior of whatever happens-

\footnotetext{
${ }^{826}$ sa skya paN+Di ta la rig pa ma 'gran/ .... jo bo rje yab sras dang byang chub kyi sems ma 'gran/ dwags po bka' brgyud dang rtogs pa ma 'gran/ gtsang smyon dbus smyon dang brtul zhugs ma 'gran/ 2005 , p 202; Stein, p 320.

${ }^{827}$ 2005, p 167.6-.8; Stein, p 269. rang nyid he ru ka ru khas blangs nas/ 'byung po'i lha tshogs rnams la skyabs gnas zhu/ snang ba sems su ma shes rnam thar tel'di yang 'gal rtags yin par thub pas gsungs/. For a similar passage, see 2005, p 20.9-.11; Stein, p 63.
} 
do not take that as [the meaning] of "one-taste"! $!^{828}$

Drukpa Künlé does not tell us how he believes the yoga of "one-taste" should be practiced, but clearly he believes that they way it was practiced by those like the Madmen of $\ddot{U}$ and Tsang was wrong. The basis of this criticism may well be Drukpa Künlé's often-repeated concern that these practitioners do harm to the Dharma by making an outward display of that which is meant to be a contemplative practice.

In a long missive addressed to various members of the Tibetan religious community, Drukpa Künlé addresses those called "Destroyers [of Illusion]" (zhig po, short for 'khrul zhig), a long-standing category that has a lot of overlap with the term “madman" (smyon pa),

To you all phenomena appear like a dream, like an illusion: with your mind to which gold nuggets and clods of dirt are the same, in the moment, you address things in the a manner of a madman.

But others abandon the victory banner of the maroon [robe], confuse Dharmic and worldly activities, treating everything with your senselessness, you take nothing into account. ${ }^{829}$

Here Drukpa Künlé makes a clear distinction between, on the one hand, legitimate "Destroyers [of Illusion]," who truly embody the ideal of regarding all phenomena as being of a single taste, whose activities look like those of a madman, and on the other hand those who are basically fakes. They have abandoned monasticism and taken on a

\footnotetext{
${ }^{828}$ 2005, pp 228.22-229.2; Stein, p 359. ro snyoms zer na de 'dras yong / stug pa dang gcin bsres za ba dang / ro gos dang mi sha la longs spyod cig gang byung gi smyon spyod byed pa la/ ro snyoms pa' $i$ thugs "khur ma bzhes mdzod/.

${ }^{829}$ 2005, p 89.18-.21; Stein, p 157. chos rnams rmi lam sgyu mar shar/ rdo gser bong bar mnyam pa'i blos/ 'phral gang smyon pa'i tshul yang 'dzin/ de min ngur smrig rgyal mtshan spangs/ chos dang jig rten bya ba'dzol/ kun la tho cos cir mi brtsi/ zhig po rnams la bya cig thongs/. These words are actually framed not as Drukpa Künlé's but those of a diviner (mo [pa]), but we have every reason to read this as Drukpa Künlé's own composition; Stein (p 149) says the same.
} 
life of questionable moral character, letting their "religious" activity become just another category of worldly affairs.

Taken together with the above-cited instances when Drukpa Künlé expresses skepticism regarding those who wear the bone ornaments of a yogi or a "realized one" (rtogs ldan), these statements constitute a significant criticism of individuals who based their religious identities on this type of tantric practice. And as we saw in Chapter Four, it was because of their enthusiastically and publicly taking on of this kind of lifestyle that Sangyé Gyeltsen and Künga Zangpo became famous as the Madmen of Tsang and U. We cannot be certain that the Madmen of Ü and Tsang are supposed to be considered among the groups criticized in these passages. However, elsewhere in his Collected Works Drukpa Künlé does mention the Madmen of Ü and Tsang specifically, and the criticisms he expresses on those occasions are very much in keeping with the sentiments expressed above.

If we consider the other three volumes of Drukpa Künlé's Collected Works (the three passages just cited are all from the "Autobiography", the first volume of the collection) we see that Drukpa Künlé was fully aware of the kind of lifestyle the Madmen of $\ddot{U}$ and Tsang embodied, and he directs specific criticisms at them on a number of occasions. In a song in the third volume of his Collected Works, Drukpa Künlé is attributed with having said

I am not one realized in the "domain of activity" (spyod yul) of agitating malicious spirits and the mental continuumI am a yogi for whom all appearances appear as the divine body.

I am not a masked dancer, a mantrika distributing secret mantras in the marketplace-

I am a yogi who understands all of existence in the mandala. 


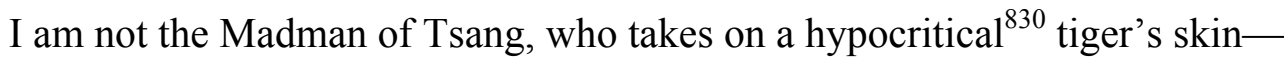
I am one with a relaxed mind, who tenderly cares for his son.

As we have seen many times now, Drukpa Künlé has major reservations about the

lifestyle embodied by the other holy madmen of his time, and he takes pains to

distinguish himself from them. Much of what he has to say about them focuses on their manner of dress. ${ }^{831}$

Another significant passage comes in the form of a pseudo-autobiographical song attributed to Drukpa Künlé in which he describes the many different things he has done in his life. He mentions that he once went before the Madman of $\ddot{U}$, then launches into a scathing criticism of the Madman of Ü's activities. According to Drukpa Künlé, the Madman of Ü rouses demons as enemies and blows thigh bone trumpets, but he also causes others to lose faith, lacks the correct inner qualities, and "teaches [tantric] Activity (spyod pa) to beggars." Directly after this he voices a similar critique of the Madman of Tsang, accusing him of, among other things, "showing off his wealth" (nor ngom byas) and "making a profit from his wrathful activity" (drag pa thams cad tshong par song). ${ }^{832}$

\footnotetext{
${ }^{830}$ Here we must read kha lding as kha gting. The words bu mad in the last line are unclear. This should probably read bu smad, in the sense of bud med, or ma bu. 2005, p 435.11-.15. 'dre srin sems rgyud dkrug pa'i spyod yul rtogs ldan ni min/ cir snang lha skur shar ba'i rnal 'byor pa cig lags so/ gsang sngags khrom du gyer pa'i sngags pa 'bag 'chams ni min/ snang srid dkyil 'khor du rtogs pa'i rnal 'byor pa cig lags so/ stag lpags kha lding 'dzin pa'i gtsang smyon ni min/ 'jam pos bu mad gso ba'i blo bde gu yangs pa lags sol

${ }^{831}$ On one occasion Drukpa Künlé was asked about his manner of dress (... khyed dpon slob kyi cha lugs 'di 'dra su'i lugs yin) (with words very similar to how the Madman of Tsang had been asked by Geluk monks about his own manner of dressing; Götsang Repa, 44.5-45.6). Drukpa Künlé responded by saying that "every lama has his own dharma system; every dharma system has its own manner of dress" (bla ma re la chos lugs re/ chos lugs re la cha lugs re 'dug). He then describes how dharmalord Lhatsünpa (one of Drukpa Künlé's main lamas, as well as that of Drakpa Tayé) and his disciples wear old rags; how the Madman of Tsang and his disciples wear long shorts and play their thigh bone trumpets softly; how the Madman of Ü and his students wear short shorts, wear their hair in a certain way, and play their thighbone trumpets in a different manner. Vol. 2 ( $k h a), 2005$, pp 274.16-275.9.

${ }^{832}$ Vol. 2 (kha), pp 367.14-.22. yang cig dbus smyon pa'i drung du phyin/ 'dug 'dre dgra ru slong gin phyin/ rkang dung sna tshogs 'bud kyin phyin/ mthong tshad dad pa slog tu phyin/lta ba he ru hu re byas/ sgom pa 'jungs gtad med pa byas/ spyod pa sprang po rnams la bslabs/ 'bras bu bsdu tshems med
} 
The "Collected Works" contain another fascinating passage in which someone, presumably a student of Drukpa Künlé's, asks him about the Madman of Tsang. Drukpa Künlé then describes the life of the Madman of Tsang in this way:

First, by means of practicing the text of the Two-Chaptered [i.e., Hevajra tantra] while staying in the Gurpa College [within the Pelkor Chödé monastic complex in Gyantsé], and in particular by wearing the garb of an ornamented Heruka, he illustrated the chapter on Activity [spyod pa, i.e., the sixth chapter of the first book of the Hevajra tantra]. In addition, he took great joy in virtuous activity when convenient (? 'dus byas kyi dge rtsa), practice (sgrub tshugs) and so on. His activities for the time being were good (phral tshugs bzang ba). He was good, except for the fault of his monks and disciples' aspiring for wealth. ${ }^{833}$

This passage is interesting for how accurately it portrays the life and activities of the Madman of Tsang. The significance of his trying to enact a literal reading of the sixth chapter of the first book of the Hevajra tantra would be forgotten by later generations of Tibetans in their understanding of the nature of his seemingly eccentric activity, but it was obvious during the time in which he lived. It seems that Drukpa Künlé had an accurate understanding of the Madman of Tsang's lifestyle, and he was critical of it, again making the suggestion that the Madman of Tsang may have been motivated to take on his particular lifestyle by greed.

pa byas/ yang cig ma bsdad yang cig phyin/ yang cig gtsang smyon drung du phyin/ skye sa mkhar kha lung par byas/ bsgom sa la phyi chu dbyar byas/ dbus gtsang gzhung la nor ngom byas/ grwa pa dbus pa'i sprang pos brdungs/ drag pa thams cad tshong par song/ yang cig ma bsdad yang cig phyin/. ${ }^{833} 2005$, p 473.9-.14. dang po gur pa'i grwa tshang du bzhugs 'dug pa'i brtag gnyis kyi gzhung dang / khyad sku chas he ru ka'i rgyan can mdzad pa'i stabs kyis spyod pa'i le'u gsal bshad pa re yang mdzad kyi 'dug gzhan yang 'dus byas kyi dge rtsa dang sgrub tshugs sogs kyang dga' rab yod pa 'dral phral tshugs bzang ba dang / grwa bu slob rnams kyang longs spyod don du gnyer ba'i skyon tsam ma gtogs bzang ba 'dug/.

This passage is interesting for the way it begins: "And Drukpa Künlé met my dharmalord, the Madman of Tsang..." (yang 'brug pa kun legs pa bdag gi chos rje gtsang smyon pa dang mjal). This suggests that this passage may have been written by a disciple of the Madman of Tsang, then added into Drukpa Künlé's "Collected Works", which is in keeping with how the colophons to the "Collected Works" suggest the body was compiled from disparate fragments. Directly after this there is some mention of the Madman of Ü. 
Let us consider one last passage, which offers a fascinating moment of intertextuality and a tantalizing artifact of the 15th- or 16th-century historical situation. Contained in Götsang Repa's version of The Life of the Madman of Tsang there is what seems to be a paraphrase of a letter of safe passage (lam yig) written by the Madman of Tsang and distributed across the land. The Madman of Tsang writes the letter in the manner of a general announcement, asking people all across Tibet to provide circumstances conducive to the travels and practice of his students. He requests that people give his disciples safe passage, while helping them with lodging and food. Included in Drukpa Künlé's "Autobiography" is what seems to be the full version of the Madman of Tsang's letter. ${ }^{834}$ The Madman of Tsang begins the letter by claiming that its contents represent an order of the Kagyü lamas, a command from the deity Hevajra, the speech of the protector deities (bka' bsrung dam can rgya mtsho'i ngag). Calling himself "the blood drinking king, the yogi who wanders in charnel grounds" (dur khrod nyul ba' $i$ rnal 'byor pa khrag 'thung rgyal po), the Madman of Tsang asks lords, soldiers, citizens and brigands to not impede the travels of his disciples, as they head into the mountains to raise the banner of meditation. He asks these laymen to give his disciples lodging at night, to give them food, help them cross rivers, and show them the way to their destinations. He promises these citizens good future results for this meritorious activity. However, if they disrupt the activities of his students, steal their belongings or block their travels, the Madman of Tsang will engage in wrathful activity and propitiate the blood

\footnotetext{
${ }^{834}$ The two versions are very similar, although not word-for-word the same. However, enough of the parts from the version included in Drukpa Künlé's "Collected Works" are worded exactly the same as in the Götsang Repa version that we can be fairly certain that Drukpa Künlé (or whoever wrote this) was looking at a written document containing the Madman of Tsang's letter. 2005, pp 79.17-83.15; Stein, pp 143-8. In Götsang Repa, pp 191.3-192.5.
} 
drinking deities, which will lead to disastrous results to those individuals and their descendents, including loss of livestock, wealth and even their lives.

Directly following this in Drukpa Künlé's "Collected Works" is an alternative letter of safe passage written by Drukpa Künlé. He calls himself "the monastic householder, the Madman of the Drukpa" (ser khyim pa 'brug pa smyon pa). He describes his disciples as those "who are neither lay nor properly ordained" (nged kyi grwa pa skya min ser min), who reside in their individual monasteries of attachment and aversion (chags sdang gi sde dgon che chung so sor), who beg along the roads, who think killing someone is an act of Dharma, who sell false goods, who expound upon the scriptures even though they do not know how to read or write, who give tantric initiations to others without having the empowerments themselves, who claim to have compassion but have no concern for the lives of animals. He requests that people give his disciples a little tsampa and show them where to find water. He requests that people not chase away the nuns, whether they are raising their babies or have already killed them. For those who fulfill his request, he hopes that they will not be deceived by others and they will be well. But for those who do not do as he has requested - those who give chang to his students, those who let them stay in their homes, those who bother them, ask them questions about the Dharma - he will enter into a meditation of fierce faith and... hope that the three defilements of hatred, desire and ignorance will be completely eradicated, for them and their descendents.

Drukpa Künlé's letter is a satirical takedown of the Madman of Tsang and the seriousness with which he took himself. In direct contrast to the pretension exemplified in the Madman of Tsang's letter, Drukpa Künlé is self-deprecating, pointing out the faults 
of his monks (although we can probably read this as a commentary not just about Drukpa Künlé's own disciples, but religious practitioners in Tibet in general). Drukpa Künlé points out the hypocrisy in the Madman of Tsang's position, in which he threatens to punish people for not acceding to his requests. In direct contrast, Drukpa Künlé purposefully maintains a compassionate attitude towards everyone. This passage including the two letters thus offers a fascinating insight into the relationship between two famous 15 th-century holy madmen. By all accounts it looks like Drukpa Künlé wanted to take the Madman of Tsang down a few pegs.

The relationship between Drukpa Künlé and Madman of Ü seems to have been less contentious. This may have been because the Madman of Ü did not achieve the same level of worldly success as the Madman of Tsang. According to the biography of the Madman of Ü, in around the year 1513 "the secret yogi, Madman of the Drukpa, Künga Lekpa” (sbas pa'i rnal 'byor 'brug smyon kun dga' legs pa) came to visit him at his monastery of Tsimar Pel in Penyül, near Lhasa. Drukpa Künlé gave vast material offerings, as well as a supplication ( $g s o l$ 'debs) of the Aural Transmission (snyan rgyud) that he had composed. This is said to have pleased the Madman of Ü very much. He then gave Drukpa Künlé some teachings and gifts. ${ }^{835}$

The evidence available in Drukpa Künlé's “Collected Works” goes a long way towards corroborating this account. The third volume of the "Collected Works" includes an elegant verse of praise to the Aural Transmission, which Drukpa Künlé says he composed at the request of the Madman of $\ddot{U}$, the Heruka (dbus smyon he ru ka). ${ }^{836}$

${ }_{835}$ The Life of the Madman of $\ddot{U}, \mathrm{p} 601$; manuscript version, $\mathrm{p} 15 \mathrm{a} 1$.

836 2005, pp 412.2-414.13. 
Preceding this in the "Collected Works" is a praise of the Dohā lineage (do ha'i brgyud $p a$ ), which Drukpa Künlé says he composed at the request of "the Heruka of Ü" (dbus pa he $r u k a) .{ }^{837}$ The Madman of Ü is included as the last member of the lineage. Ehrhard concludes that both verses were likely composed on the occasion of Drukpa Künlé's visit to his counterpart's monastery. ${ }^{838}$ Elsewhere in the third volume there is an imaginative verse in praise of the Madman of Ü written by Drukpa Künlé, in which he repeatedly refers to Künga Zangpo as a "Heruka." ${ }^{839}$ There is also a verse in praise of Tārā (sgrol ma) Drukpa Künlé says he wrote at the request of the Madman of Ü, and a record of a conversation between Drukpa Künlé and the Madman of Ü about conceptuality (rnam rtog). ${ }^{840}$ These latter three compositions do not seem to have been written on the occasion of their meeting that was described in The Life of the Madman of $\ddot{U}$.

Moreover, Nyukla Penchen, one of the Madman of Ü's closest disciples and the author of the first part of his biography (and who was perhaps a cousin of Rinpungpa Dönyö Dorjé) seems to have been someone with whom Drukpa Künlé had a lot of contact. They met on numerous occasions and exchanged letters and verses of praise. Based on the evidence available to us in the Collected Works, Nyukla Penchen seems to have been one of the most consistent and significant conversation partners for Drukpa Künlé. ${ }^{841}$

\footnotetext{
${ }^{837}$ 2005, pp 409.3-412.2.

${ }^{838}$ Franz-Karl Ehrhard, "The Holy Madman of dBus and His Relationships with Tibetan Rulers of the 15th and 16th Centuries" in Geschichten und Geschichte: Historiographie und Hagiographie in der asiatischen Religionsgeschichte, edited by Peter Schalk (Uppsala: Uppsala University Library, 2010), p 248.

839 2005, pp 416.22-418.8.

${ }^{840} 2005$, pp 423.16-425.7; pp 476.12-477.8.

${ }^{841}$ For example, see 2005, pp 50.12-51.12, Stein, pp 102-3; 2005, pp 161.18-162.12, Stein, pp 262-3; pp 251.12-253.20, Stein, pp 395-9; Vol. 3 (ga), 2005, pp 415.10-416.21; pp 423.11-.16; pp 440.7-441.6; and starting at $\mathrm{p} 456.7$.
} 
Based on the evidence available to us in Drukpa Künlé's Collected Works, it seems that he had somewhat complicated relationships with his contemporaries, the Madmen of Ü and Tsang, the other two most famous holy madmen in Tibetan history. Drukpa Künlé expresses some direct criticisms of both these figures, stemming from his concerns about their lifestyle, which was dedicated to a literal enactment of the Highest Yoga Tantras. He is especially critical of the Madman of Tsang, whom he sees as driven by greed and egoism. We cannot be certain that the two ever met, as there is no mention of Drukpa Künlé in any of the Madman of Tsang's biographies. At the same time, Drukpa Künlé seems to have had a mostly positive relationship with the Madman of Ü, as friends and interlocutors, in spite of certain criticisms he had of the yogi's lifestyle.

As we consider what may have been the actual relationships between Drukpa Künlé and his madman peers (as opposed to the more fanciful version given by Geshé Chaphu and popularized in Dowman's translation), and with political figures, teachers, and other of their contemporaries, like Nyukla Penchen, we get drawn into the actual historical moment in the 15th and 16th centuries that Drukpa Künlé and the other holy madmen inhabited. When we reconstruct these relationships based on the information we have at our disposal, it seems that Drukpa Künlé stands apart from the Madmen of Ü and Tsang. The nature of the eccentric-seeming behavior of the Madmen of Ü and Tsang,

The great Kagyü scholar Karma Trinlepa was also involved in this conversation. Karma Trinlepa composed a document with answers to a set of twenty-six questions Nyukla Penchen (here referred to as Pel Ngaki Wangpo, dpal ngag gi dbang po) had posed to Drukpa Künlé, about the nature of the mind, samsāra and nirvāna, liberation, and so on. This text was composed by Karma Trinlepa at Nyukla (snyug la). In The Songs of Esoteric Practice (mgur) and Replies to Doctrinal Questions (dris lan) of karma'phrin-las-pa, reproduced from prints of the 1539 Rin-chen-ri-bo blocks (printed by Ngawang Topgay, New Delhi, 1975), pp 198-210. Ehrhard (2010) mentions this correspondence, p 241. 
which would be the basis for their reputations as "madmen" was very similar. They were, I have argued, tantric fundamentalists. Drukpa Künlé stands apart in that he does not seem to have had earned his reputation as a "madman" for any similar reason.

Drukpa Künlé did not dress in the garb of a Heruka and was deeply skeptical of the motivations of those who did. He called those who dressed in the manner for which the Madmen of Ü and Tsang were famous (worthless) donkeys who cover themselves with (heroic) lions' hides. Drukpa Künlé was thus very skeptical of those pursuing the kinds of ascetic practices that made the Madmen of $\ddot{U}$ and Tsang famous. ${ }^{842}$

Making the charge that certain individuals might take on a tantric manner of dress and behavior due not to the proper religious motivation but rather for worldly gain is a matter of no small concern. This sentiment expressed by Drukpa Künlé validates the argument I made in the previous chapter, when I argued that the Madmen of Ü and Tsang's eccentric activity should be understood as being motivated, to some extent, by worldly concerns. I argued that one of the things motivating Künga Zangpo and Sangyé Gyeltsen to take on the garb of the Heruka and earn fame for themselves as holy madmen through their eccentric, tantric fundamentalist behavior might have been their aspirations for patronage, fame, power, and so on. Drukpa Künlé's statement shows this is not some modern idea unfairly being projected onto a more innocent past. Rather, this suspicion has long existed within Tibetan Buddhist discourse itself, which we should be less than

\footnotetext{
${ }^{842}$ A verse in praise of Drukpa Künlé at the end of his “Autobiography”, likely written by the compiler of the text, begins by calling Drukpa Künlé one who "works for the benefit of others through his performance of engaged asceticism" (brtul zhugs spyod pas gzhan don mdzad), 2005, p 264.10. However, the association between Drukpa Künlé and the practice of engaged asceticism is a weak one in comparison to the cases of the Madmen of $\ddot{U}$ and Tsang, for whom this practice was central to their public personas.
} 
surprised to find. It seems that some famous holy madmen had reason to be suspicious even of one another.

If Drukpa Künlé did not dress in the garb of the Heruka and create his reputation through publicly performing engaged asceticism (brtul zhugs spyod pa) or related tantric practices, for what reason was he known as a madman? First of all, if the contents of the “Collected Works" are accepted to be an accurate representation of Drukpa Künlé's own words, it seems that he did use the term "madman" with reference to himself, such as when he begins his letter of safe passage mocking that of the Madman of Tsang, calling himself "the monastic householder, the Madman of the Drukpa" (ser khyim pa 'brug pa smyon pa). ${ }^{843}$ But what sense does the term carry? As with the Madmen of Ü and Tsang, it seems that Drukpa Künlé would have been called a "madman" only in a very nonliteral sense. But whereas with the Madmen of Ü and Tsang, "madman" was a label applied in the process of peoples' reacting to their shocking behavior as tantric fundamentalists, it seems that Drukpa Künlé took on the name "madman" in connection with his being a perpetual critic of others. Calling himself a "madman" may have been an act of self-deprecation, an attempt to humble himself at the same time that he expressed such pointed criticisms of others. Perhaps calling himself a madman was a way for Drukpa Künlé to carve a space for himself as a wandering outsider who refused to conform to the categories presented to him by the culture in which he lived.

And as was the case with Drukpa Künlé's divergence from the celibate monastic norm, and his reputation as a perpetual critic of others, his "madness" would be

${ }^{843}$ It seems that others called him a "madman" too. On one occasion Gampo Chenga Rinpoché (sgam po spyan snga rin po che) says to Drukpa Künlé, "Some people casually say you're a madman ( mi kha dal ba kha cig smyon par 'dug), but they don't understand. You [should be] called a destroyer of illusion ('khrul zhig).” 2005, Vol. II (kha), p 362.16-.18. 
exaggerated and caricatured over time. This resulted in his becoming the sort of scatological iconoclast portrayed in a text like Geshé Chaphu's. The fact that Drukpa Künlé was known as a "madman" created an opening for all sorts of wild stories to be attributed to him. As these stories gained currency in the oral and written records, they came to completely overshadow any notion of who the real historical Drukpa Künlé may have been. Drukpa Künlé's reputation as a "madman," regardless of what that term actually meant in the context of his life, became the basis for later representations of him. And as these later representations took hold, our understanding of the real Drukpa Künlé got more and more lost beneath the popular tradition.

Here we are getting a sense of how malleable and changeable the meaning of the term "madman" could be. By comparing the "madness" of Drukpa Künlé with that of the Madman of Ü or the Madman of Tsang, we have seen that the term "madman" may have had different meanings for different individuals who have taken it on as part of their identity. This point will be made more emphatically in Chapter Seven.

\section{III. Conclusion: Who Was Drukpa Künlé?}

The eccentricity of the Madman of the Drukpa seems to have little in common with that of the Madmen of Ü and Tsang. Drukpa Künlé did not dress in the garb of the Heruka. Although he may have practiced in the manner of a secret yogi (this is how he is described when he makes his appearance in The Life of the Madman of $\ddot{U})$, there is little discussion in any of our sources of his practicing engaged asceticism (brtul zhugs kyi spyod pa), which was essential to the identities of the Madmen of Ü and Tsang. Rather, Drukpa Künlé's “madness” is of a altogether different sort. Drukpa Künlé was called a madman because of his refusal to conform to the norms for living as a religious 
practitioner that were available to him. He dressed neither as a monk nor as a tantrika. He expressed harsh criticisms of everyone, because of what he perceived as hypocrisy, greed and moral failings. Drukpa Künlé refused to associate himself with any one religious community, preferring to stay on the move his whole life. He was the ultimate critic, the voice of dissension. And because of this he always stood apart. He was called a madman, by himself and by others, not because of performing shocking behavior like going naked through the marketplace or throwing feces at people, but because of his criticisms. He was, in his own words, telling it like it is. And as we have seen, Drukpa Künlé's criticisms of others stem not from a laissez-faire idea of Buddhist life, but from exactly the opposite: exacting standards for how religious individuals should conduct themselves. Contrary to the popular image of him, we have much reason to believe that the historical Drukpa Künlé was actually a stickler for how Buddhism ought to be practiced.

Drukpa Künlé, the Madman of the Drukpa, was much less famous than the Madmen of Ü and Tsang during the time in which they lived. This may well have been a product of the fact that Drukpa Künlé did not engage in the sort of attention-grabbing and fame-generating behavior as his "madman" peers. His eccentricity was of a more subdued sort. As one who was first and foremost a critic, Drukpa Künlé made less of an immediate impact on the religious culture of the time than did the Madmen of $\ddot{U}$ and Tsang, who were walking about imitating wrathful deities and performing shocking behavior in the marketplace.

However, over time Drukpa Künlé's image would get distorted, eventually producing the kind of iconoclast presented by texts like Geshé Chaphu's Life. This 
popular Drukpa Künlé was a sort of composite figure. To some extent this popular Drukpa Künlé was based on the real historical Drukpa Künlé. The fact that Drukpa Künlé did not conform to the celibate norm and had at least one female partner and at least one child was caricatured and exaggerated over time, resulting in the popular perception of him as an insatiable womanizer. His basic critical stance would get exaggerated, making him a total iconoclast.

Another contributing factor to the creation of the popular image of Drukpa Künlé was probably the kind of eccentric activity the other holy madmen of his time were famous for. We have no evidence that the historical Drukpa Künlé performed crazy, norm-overturning behavior in the marketplaces of central Tibet. But we know that the Madmen of $\ddot{U}$ and Tsang did. Could it be that this aspect of the Madmen of $\ddot{U}$ and Tsang’s activity got attributed to Drukpa Künlé in the inexactitude of popular memory, over the course of generations? Then, because of the prominence it had achieved in the popular imagination, the version of Drukpa Künlé came to completely overshadow the real Drukpa Künlé of the 15th and 16th centuries, who, as we have seen in this chapter, was actually very learned, very reasonable, very sane. Over time, however, the nature of the real Drukpa Künlé would be forgotten and the exaggerated tales about him would run rampant. Elements of the kind of eccentric behavior for which the other holy madmen would become associated with Drukpa Künlé, and he would become the scatological madmen we know today.

Thus the figure who would become the quintessential "holy madman" for Tibetans was a fabrication - a caricature of the real historical Drukpa Künlé, combined with characteristics derived from his 15 th-century madman peers. Because of his great 
popularity, people have come to think of his madness (especially the version exemplified in the more recent and popular versions of his Life) have been taken as highly representative of the entire holy madman tradition. This is unfortunate, glossing over some key differences between the activities of the various holy madmen, ultimately making us miss the diversity and creativity they embodied.

The Madman of Tsang (1452-1507), the Madman of the Drukpa (1455-1529?) and the Madman of Ü (1458-1532) inhabited overlapping spheres of personal relationships of all types. They are sometimes collectively referred to as "the three madmen" (smyon pa gsum) ${ }^{844}$ Their being lumped together in this way suggests that their "madness" can be understood as being of a single type. Although the eccentric behavior of the Madmen of $\ddot{U}$ and Tsang and the motivation behind it was very similar, the "madness" of the Drukpa Künlé, I hope to have shown here, was of a quite different type. Although they were all called "madmen," we see that the term can carry a wide variety of meanings.

${ }^{844}$ Kenpo Könchok Namdak interview at Phyang Monastery, Ladakh, 22 July 2009. 


\section{Chapter 6: The Holy Madmen's Cultural Project: Constructing History}

Now the statement of the thoroughly-renowned Karmapa: Over time I have heard about how you, the holy lord of yogis, the Madman of Tsang have created woodblocks for printing the Life and Songs of Glorious Zhepa Dorjé [Milarepa], how you have established meditation centers in the mountains of the three Abodes, along with undertaking other deeds to spread and increase the Teachings of the Kagyü. I was thereby delighted and overjoyed. Since then you have taken the responsibility of spreading the Teachings by renovating the Swayambhūnāth stūpa in Nepal, establishing meditation centers in Drin Chuwar, and so on. I myself will do whatever I can to assist you; please do not come here. ${ }^{845}$ May the world be adorned with gloriously blazing auspiciousness!

- $\quad$ Letter sent to the Madman of Tsang by the 7th Karmapa, Chödrak Gyatso (1454-1506), after having visited Rinpung and heard of the yogi's many accomplishments ${ }^{846}$

\section{I. Text and Representations}

In Chapter Four we met Śākya Chokden (1428-1507), the famous Sakyapa

scholar who had been an associate of the Madmen of Ü and Tsang and the Rinpungpas, and also a major critic of Tsongkhapa. His biography tells of three encounters between the great scholar-translator and the Madman of Ü. A look at how these encounters are differently described in Śākya Chokden's and the Madman of Ü’s biographies will give

\footnotetext{
${ }^{845}$ Perhaps this can be read as "there is no need for you to come here" ( $d i r$ mi sleb pa $m d z o d$ ).

${ }^{846}$ Götsang Repa, p 214.5-.7: da ming yongs su grags pa skar ma pa'i gtam/ rnal 'byor gyi dbang phyug dam pa gtsang smyon pas/ dpal ldan gzhad pa rdo rje'i rnam thar mgur 'bum spar du gzhengs shing/ gnas gsum gyi ri la sgrub sde bdzugs pa sogs bka' rgyud kyi bstan pa dar rgyas su bgyis pa'i gtam rim par thos pas/ nged kyang sems spro zhing rjes su yid rangs/ slar yang bal yul 'phags pa shing kun gyi zhig bsos dang / brin chu bar du bsgrub sde sogs bstan pa'i khur che bar yong (yod?) 'dug pa/ nged rang gis kyang grogs su ci 'gyur byed pas/ 'dir mi sleb pa mdzod/ bkra shis dpal 'bar 'dzam gling rgyan du shog. This passage is mentioned in Andrew Quintman, Mi la ras pa's Many Lives: Anatomy of a Tibetan Biographical Corpus (Ph.D. dissertation, University of Michigan, 2006), p 258.
} 
insight into the nature of the hagiographical texts we have been relying on as our main source of information in this study. The question is about how faithfully these texts reflect the historical past. As we saw in the case of Drukpa Künlé, these sources must always be read with a degree of caution, seen neither as all-out fictions, nor as infallible records of historical events as they took place.

According to Śākya Chokden's biography, in 1493 the Madman of Ü, thirty years the scholar-translator's junior, came to Serdok Chen Monastery to meet him. The Madman of Ü waited for seven days but Śākya Chokden did not grant him an audience. According to the biography, Śākya Chokden's refusal to see the Madman was “for the purpose of testing whether or not he would be a worthy disciple." Eventually Śākya Chokden had one of his attendants deliver to the madman a chunk of molasses, without giving him any kind of teaching or personal message. The Madman of Ü was staying at a place nearby the monastery reciting manis. Upon receiving the molasses, the Madman of $\ddot{U}$ recited one last mani, blew his thigh bone trumpet loudly three times, and left. Back at the monastery Śâkya Chokden heard those three toots and said three times, "He is going to be a famous realized one!"

\footnotetext{
${ }^{847}$ The biography, composed by Künga Drölchok (kun dga' grol mchog), bears the title Detailed Analysis of the Liberation Story of the Great Pandit Śäkya (pandi ta chen po shākya mchog ldan gyi rnam par thar pa zhib mo rnam 'byed pa), pp 1-234 in the Collected Works of Sákya mchog ldan, Vol. 16 (ma) (Thimphu, Bhutan: Kunzang Tobgyey, 1975), p 173.3-.6: 'di skabs rje dbus smyon pa shangs nas mjal ba la phebs/ zhag bdun sgugs sdod gnang yang slob ma'i snod brtag phyir mjal kha ma gnang zhing / bka' lung sogs kyang bsgyur len gang yang ma gnang bar bu ram bsgar ma chen po zhig gsol dpon blo gros seng ge la skyol shog gi bka' lung gnang bas/ khong zhed nas 'gro ma nus par dge rgan Śakya khams gsar thob thob cig yod pas de btang bas/ der dbus smyon pa bya rgod phung po na ma Ni bskul gyin bzhugs snang ba'i phyag tu phul bas/ de 'phral rang rje dbus smyon pa rang gi zhal du shong tshad cig brdzangs rjes/ de na yod pa'i khrom yo la (khrom yol?) gnang nas/ bsgar ma zo la log rgyug oM kyang ma Ni pad +me hUM/ gsung nas rkang dung skad che bag sum bus nas gshegs song zhing / rkang dung gi skad paN chen rin po che'i snyan du dgongs res bzhin rtogs ldan grags pa can zhig yod (yong?) red lan gsum btud mar gsung /.
} 
The Madman of Ü is said to have arrived again the following year, in 1494. This time Śākya Chokden perceived the yogi as a worthy trainee with whom he had a karmic connection and therefore granted him an audience. Śākya Chokden gave the yogi a series of teachings, including the Seven-day Path and Fruit (lam 'bras zhag bdun ma), the Hevajra tantra, and others. The Madman of Ü made extensive offerings as payment for these teachings (chos yon du). According to Śākya Chokden's biography, a deer hide was laid out and the Madman of Ü’s long matted hair was laid out upon it. Sákya Chokden put his feet on top of the hair and sat for a long time making prayers. Sāakya Chokden then fulfilled the Madman of Ü's requests by composing a few texts, including the Levels of the Explanatory Tantras Summarizing the Meaning of the Two-Chaptered $[\text { Hevajra tantra }]^{848}$ and the Directions on Madhyamaka. ${ }^{849}$ Both of these texts can be found in Śākya Chokden's Collected Works; the colophon to the former mentions that it had been written at the request of the Madman of Ü. During this meeting the great pandita gave the yogi a new name, "the Madman of Ü, Dorjé Düdul (rdo rje bdud 'dul),

\footnotetext{
${ }^{848}$ Here the text is mentioned under the abbreviated title, the brtag gnyis kyi bsdus don. In Śăkya Chokden's Collected Works the fuller title is given: brtag gnyis kyi bsdus don bshad rgyud kyi rgyud pa' $i$ rim pa, pp 464-7 in Vol. 13 ( $p a$ ) in the Collected Works of Śäkya mchog ldan (Thimphu, Bhutan: Kunzang Tobgyey, 1975). Komarovski translates this as the Abbreviated Meaning of the '[Hevajra tantra] in Two Chapters': Transmission Stages of the Explanatory Lineage, pp 131-2.

${ }^{849}$ dbu ma'i lta khrid. The full title is dbu ma'i lta khrid/ zhi gnas dang lhag mthong zung du 'jug pa ngo mtshar rgyan gyi phreng ba; included in the Collected Works of Śäkya mchog ldan, Vol. 13 (pa), pp 190202. Komarovski translates this as Garlands of Wondrous Ornaments of the Union of Calm Abiding and Special Insight: Guiding Instructions on the View of the Middle; Komarovski states that he intends to translate and write an article about this text, $\mathrm{p} 112$.

Along with these two texts written on this occasion, Sākya Chokden's biography mentions rnam thar bstod pa.........dge legs kun 'byung ma. This may refer to a single text or two separate ones. I have not been able to find anything bearing these titles in Śākya Chokden's Collected Works.
} 
Vajra Subduer of Demons." ${ }^{\prime 850}$ Then all of the scholar's disciples praised the Madman of

$\ddot{U}$ as a worthy guru and bowed at his feet. ${ }^{851}$

Sometime later, when Sākya Chokden was 75 (around the year 1503) the

Madman of Ü met Śākya Chokden while he was staying at Langtang (glang thang). At

this time Śākya Chokden composed for the Madman of Ü the Drop of Ambrosia:

Clarification of the Eight Path Cycles and gave him the physical text of the Levels of the

Explanatory Tantras Summarizing the Meaning of the Two-Chaptered [Hevajra tantra],

which he had composed at the yogi's request in 1494, but had not set down onto paper

until 1501. Like the Levels of the Explanatory Tantras..., the Drop of Ambrosia can be

\footnotetext{
${ }^{850}$ As a general comment about the Madman of Ü, Śākya Chokden's biography states, phyir lam smyug la'i mi gcod gnang bas bar chod kyi g.yul las yongs su rgyal te grags pas 'dzam gling ma lus pa khyab par gyur..." (pp 178.7-179.1). I cannot offer an exact translation of this line, but it seems to refer to a specific instance in the life of the Madman of Ü during which he underwent a particularly severe beating at the hands of the people of Nyukla, which included his being thrown off a cliff, and how he achieved fame because of it (The Life of the Madman of Ü, pp 510.6-518.3). This line in The Life of Śäkya Chokden refers to the abuse he took on that occasion as "self sacrifice" (? mi gcod). The 16th-century history The Scholar's Feast by Pawo Tsuklak Trengwa (the Second Pawo) specifically mentions this instance from the life of the Madman of $\ddot{U}$ (in the context of telling the life of his disciple and biographer, Nyukla Penchen), also using the term mi gcod: rje dbus smyon pa rig pa brtul zhugs kyi spyod pa mdzad skabs smyug lar mi gcod mdzad dbu thod rag rug tu chag rdo phung chen pos mi mthong bar mnan yang har gyis bzhengs te rlung ro gcig bsal bas sku lus skyon med du gyur te mgur len zhing mgyogs par byon pa la thugs dad cher 'khrungs te chos mang du gsan zhing rigs drug 'khor lo'i khyab bdag rdo rje 'chang / zhes pa'i bstod dang rnam thar yang mdzad/2006 version, p 592. This passage is reused word-for-word in Situ Penchen and Belo Tsewang's history of the Karma Kagyü sect, when relating the life of Nyukla Penchen, bsgrub brgyud karma kaM tshang brgyud pa rin po che'i rnam par thar pa rab 'byams nor bu zla ba chu shel gyi phreng $b a$ (published by D. Gyaltshan and Kesang Legshay, New Delhi: 1972; TBRC W23435), p 648.3-.9.

The term mi gcod is used in similar ways in The Life of the Madman of $\ddot{U}(\mathrm{p} 520.2)$. The same term is used in Götsang Repa's version of The Life of the Madman of Tsang to describe when the Madman

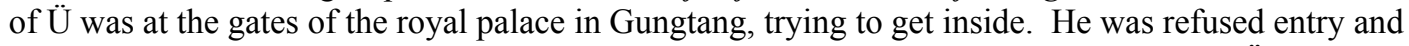
beaten. As Götsang Repa describes it, "Hearing that "there is one called the Madman of Ü and he is practicing self-sacrifice (mi spyod stong; read as mi gcod gtong)', many people gathered." The king wanted to test to see if the Madman of Ü was impervious to weapons and fire, but the Madman of Tsang dissuaded him from doing so, and even convinced him to respectfully receive the Madman of Ü.

A very similar term (mi gcod drag po) was used in the Life of Chöwang Lhündrup, the First Pawo, when he was purposefully seeking out physical abuse. Karma Kamtsang history (as above), p 661.

The idea of seeking out physical abuse, probably as part of the performance of engaged asceticism or some other related rubric of practices, is worth looking into further. Gathering more examples of the use of terms like mi gcod in a wider body of literature would be an appropriate place to start.

${ }^{851}$ The second meeting is described in Detailed Analysis, pp 178.3-179.1.
} 
found in Śākya Chokden's Collected Works, its colophon mentioning that it was composed at the request of the Madman of $\ddot{U} .^{852}$

In the course of these three encounters we see a clear progression in the relationship between Śākya Chokden and the Madman of Ü. At first, Śākya Chokden did not see the yogi as worthy of his time, and sent him off in a fashion that surely constituted a slight (although there is also some foreshadowing that Śākya Chokden would later hold the Madman of Ü in esteem). In their second meeting, Sāakya Chokden acted kindly towards the Madman of $\ddot{U}$, bestowing teachings on the yogi and honoring him by giving him a name. It is made clear by the biographer that Śākya Chokden is to be seen as the superior religious being among the two, as the Madman of $\ddot{U}$ assumed a subservient position by allowing Śākya Chokden to put his feet on his hair. (This is in precisely the same manner that the 9th-century Tibetan king Relpachen is storied to have let monks sit on his long hair, as an expression of his great reverence for them.) Some of Śākya Chokden's students would honor the Madman of Ü as a worthy guru, but still he would be secondary to Śākya Chokden.

Now we will look at how the encounters between Śākya Chokden and the Madman of $\ddot{U}$ are described in The Life of the Madman of $\ddot{U}$. In that text we are told of two meetings between the yogi and Śākya Chokden. The first took place sometime between 1488 and 1494. For a while the Madman of Ü had been seeing signs suggesting that he should visit the omniscient Śākya Chokden at Serdok Chen Monastery; the great pandit is described in the most flattering terms as a master of the Teachings, his great

\footnotetext{
${ }^{852}$ The third meeting is described in Detailed Analysis, p 179.1-.2. The lam skor brgyad kyi gsal byed bdud rtsi'i thig pa is pp 630-40 in Vol. 13 (pa) of the Collected Works of Śäkya mchog ldan. In this text's colophon the Madman of Ü is referred to by the name given to him by Śākya Chokden: lta ba rtogs shing grub mtha' snyogs pa'i rnal 'byor pa dbus smyon rdo rje bdud 'dul.
} 
qualities impossible to encompass with words. At this time Śākya Chokden imparted to the Madman of Ü the Oral Precepts of Glorious Baripa, Lord of Yoga (rnal 'byor gyi dbang phyug dpal ba ri pa'i man ngag); the profound Dharma of the noble Sakya family (rje btsun sa skya pa yab sras kyi zab chos); and the instructions (gdams) on the precious Oral Precepts of the Path along with the Fruit (gsung ngag rin po che lam 'bras bu dang bcas pa). Śākya Chokden also gave him an explanatory transmission (bshad lung) for the root text of the Hevajra tantra. At this time Śākya Chokden composed at the Madman of Ü's request the Directions on Madhyamaka (dbu ma lta ba'i khrid), the Levels of the Explanatory Tantras Summarizing the Meaning of the Two-Chaptered [Hevajra tantra] (brtag gnyis kyi bsdus don), and other texts. It then says that in a state in which "the minds of teacher and student were mingled together as one" (dpon slob thugs yid gnyis su med par 'dres pa'i ngang na), the Madman of Ü departed to go see the Rinpungpa Dönyö Dorjé. $^{853}$

The Madman of Ü's second visit to Śākya Chokden at Serdokchen Monastery took place a few years later. We are given few details about this visit, except that there were warm relations between the Madman of Ü and Śākya Chokden and the entire monastic community there. ${ }^{854}$

The question we must ask is which of these two versions of the relationship between the Madman of Ü and Śākya Chokden is the more accurate one? Which aspects of this story are true, and which are false? There is enough agreement between the texts to conclude that the Madman of Ü and Śākya Chokden certainly did meet (two or perhaps

${ }^{853}$ The Life of the Madman of $\ddot{U}$, pp 509.1-510.1. There is also mention of how in 1510, when the Madman of Ü was settled at Tsimar Pel, extensive offerings were made at Serdok Chen Monastery, some years after Śăkya Chokden died, pp 594.2-595.1. Here Śākya Chokden is again described in the most praiseful terms. ${ }^{854}$ The Life of the Madman of $\ddot{U}$, pp 549.5-550.1. 
three times). This is supported further by the fact that the two biographies are in agreement over most of the teachings transmitted by Sākya Chokden to the Madman of Ü and the treatises the scholar composed on the yogi's behalf. The historical veracity of this exchange is supported by the fact that these very texts can be found in the Collected Works of Śākya Chokden, and even further by the fact that some of their colophons identify them as having been written at the request of the Madman of $\ddot{U}$.

Despite the fact that certain details of this story can be believed with no cause for doubt, other aspects are much less certain. How many times did these two figures actually meet? We can question the veracity of the account of the Madman of Ü's assuming such a demonstratively, almost cartoonishly subservient position by letting Śākya Chokden put his feet on his hair. It is likely an exaggeration inserted into the story by Śākya Chokden's disciple and biographer, or perhaps a case of this biographer's taking poetic license in describing the relationship between the scholar and the yogi. It is also impossible to say whether in fact the Madman of Ü was spurned on an early visit to Serdok Chen Monastery. It is easy to imagine why the Madman of Ü's biographer would have wanted to leave this out of the account of his master's life.

We can ask similar questions about the differing accounts of the relationship between the Madman of Ü and the Madman of Tsang, as described in Chapter Four. Götsang Repa's version of The Life of the Madman of Tsang gives some rather unflattering mentions of the Madman of $\ddot{U}$, as being less famous than the Madman of Tsang and something of a hothead. The Life of the Madman of $\ddot{U}$ contains no mention of his ever having met the Madman of Tsang. We cannot be certain of the final historical truth in the matter, but we can easily imagine how the Madman of Tsang's disciples 
might have been inclined to portray the Madman of $\ddot{U}$ as a worse character than he really was, if indeed there was at some point a falling out between the two famous yogis. We can just as easily imagine why the Madman of Ü's disciples would have been inclined to remove any mention of the Madman of Tsang if there had been some bad blood between him and their master.

We can apply a similar kind of thinking to the descriptions of many miracles attributed to the Madmen of Ü and Tsang in their biographies - their flying to holy sites in South Asia, their walking on water, their withstanding brutal attacks that surely would have killed any ordinary person. I am not inclined to read these passages as accurate descriptions of history as it really happened, but as pious fictions composed or repeated by the biographers, for the purpose of bolstering the reputations of their masters as siddhas, those who have achieved enlightenment and miraculous powers through their meditation. We can read the Madmen of Ü and Tsang's entire biographies as having been written with this basic aim in mind. This larger purpose is signaled to us by the fact that the very title of the Madman of Ü's biography tells us that it is meant to "make the body hairs of everyone bristle with faith" (ris med dad pa'i spu long g.yo byed). ${ }^{855}$ Lhatsün Rinchen Namgyel's version of The Life of the Madman of Tsang (the second of the three), expresses the same purpose ( $d a d$ pa'i spu slong g.yo ba). The fact that the biographies were written with the intention of generating awe and faith in their readers does not completely discount them as historical records, but signals that they were written with a specific motive, an agenda. We must therefore read them with a critical eye. The

\footnotetext{
${ }^{855}$ Stearns, King of the Empty Plain, p 486, understands the title somewhat differently, taking it as Making the Body Hairs of Those with Impartial Faith Flutter. The difference comes down to how one reads the phrase ris med dad pa.
} 
dual nature of these biographies is best described using Dominick LaCapra's observation that texts can be both documentary, in their capacity to convey information about empirical reality, and work-like, in the way they actively shape that reality. ${ }^{856}$ These biographies, which are to some extent historical records, and to some extent polemical documents, perform both functions.

What this discussion highlights is that the Madmen of $\ddot{U}$ and Tsang as they are presented to us in their biographies are products of a purposeful rendering; we know them only as a selective representation created by their disciples. These are not purely objective accounts because they were written by individuals who were personally invested in the question of how their masters would be remembered by history. (It is not the case that Tibet was the only place where such alterations took place: changes were also made to the biography of Da Free John (adi da) over the years, as later versions tended to elide the fact that he had once studied Scientology on his way to becoming a great New Age $g u r u .{ }^{857}$ ) The fact is that we do not have a direct view into the actual lives of these men. But at the same time we have no reason to write off these accounts as complete fictionalizations, as there is a significant amount of agreement between them and enough verification from other sources that we can be certain that many of these things actually did happen as described. ${ }^{858}$

\footnotetext{
${ }^{856}$ Elizabeth C. Clark, History, Theory, Text: Historians and the Linguistic Turn (Cambridge: Harvard University Press, 2004), pp 126-9. Andrew Quintman (2006) articulates his understanding of this dual nature of texts when writing about how, in addition to the "preservation of the life story for the benefit of the subject's followers," "religious biographies also promoted a range of polemical agendas that need to be understood within the contexts of their individual religious, social, and political climates," p 13.

${ }^{857}$ Georg Feuerstein, Holy Madness: Spirituality, Crazy-Wise Teachers, and Enlightenment (Prescott, Arizona: Hohm Press, 2006), p 147.

${ }^{858}$ The arguments put forth in the third and fourth chapters of this dissertation do not rest on the veracity of any single moment as described in the biographies of the Madmen of Ü and Tsang, but are rather built upon
} 
In this chapter we will see how in precisely the same way that the holy madmen as we know them are the product of a selective representation carried out by their disciples, the holy madmen — in particular the Madman of Tsang — were also themselves active participants in the selective and purposeful portrayal of other saints. Between the Madman of Tsang and his close disciples we can account for the creation of many of the most important biographies of the Kagyü sect. (The Madman of Tsang writes that he intended his version of The Life of Milarepa to "make the body hairs bristle with faith." ${ }^{859}$ ) In Chapter One we saw the importance of Tilopa, Nāropa, Marpa and most of all Milarepa in shaping the way Tibetans and non-Tibetans think about the holy madman phenomenon. Those saints as we know them were created by the Madman and Tsang and those close to him, creating a complicated interplay of representations and identities. In this chapter we will explore the larger cultural project the Madmen of Ü and Tsang were involved in, including their writings, their printing projects, their construction projects, and those of their close disciples, which gives us an idea of the larger goals they were trying to achieve in their lives. This adds a significant dimension to our

patterns of activity described therein. The description of the Madman of Tsang's shocking behavior given in his biography may not be a completely veridical account of what he did, detail-by-detail, but there is enough consistency within and across these biographies and other contemporary sources in which the activities of the Madman of Tsang are described that we can be quite sure that these passages give us a generally reliable description of what the Madman of Tsang did. Did the Madman of Tsang really tie fingers he had cut from a human corpse into his matted hair? Did he really, on one particular occasion, walk through the marketplace with a piece of molasses in one hand and feces in the other, eating them both in the same manner? We cannot be certain, bet we can be sure that he engaged in plenty of shocking, antinomian behavior. A close examination of the three successive and expanding versions of The Life of the Madman of Tsang reveals an interesting history of textual construction and re-use. I hope to address this in an article in the near future.

${ }^{859}$ rnam thar tshig gis dad gus spu long g.yo. rnal 'byor gyi dbang phyug chen po mi la ras pa'i rnam mgur (Xining: mtsho sngon mi rigs dpe skrun khang, 2005), $\mathrm{p}$ 845.8. This suggests that the title to The Life of the Madman of $\ddot{U}$ might be better read as ris med dad pas spu long g.yo byed, a genitive particle being mistakenly inserted for an agentive, as often happens in Tibetan literature. 
understanding of the nature of the eccentric, tantric fundamentalist behavior of the "holy madmen."

The letter with which this chapter began is an index of what was seen as the most significant of the Madman of Tsang's achievements during his lifetime. We will talk about them in the order that they are mentioned by the 7th Karmapa: his writing and printing, his construction of retreat centers (briefly), then his renovation of the Swayambhūnāth stūpa in Nepal — all of which were seen as having been undertaken in order to "spread and increase the Teachings of the Kagyü."

\section{II. The Literary Project of the Madmen of Ü and Tsang and their Disciples}

From the late 19th century to the middle of the 20th the Tibetologists were aware of the famous biography The Life of Milarepa but were unclear on who its author was. In his Tibetan-English dictionary, published in 1881, H. A. Jäsche refers to the text as "Milarepa's autobiography." Sarat Chandra Das would later write of the text in the same way. In the succeeding decades other Tibetologists took the text as having been written by Rechungpa, one of Milarepa's foremost disciples. It was not until the 1960s that the name "the bone-adorned yogi who wanders in cremation grounds" (dur khrod nyul ba' $i$ rnal 'byor pa rus pa'i rgyan can) was discovered to refer to the Madman of Tsang and

announced as such by Garma C. C. Chang and Herbert Guenther. ${ }^{860}$ Since the 1960 s our awareness of the vastness of the literary corpus produced by the Madman of Tsang and his close disciples has steadily increased. In recent decades the literature produced by this circle has been an object of study for a number of Tibetolgists, including E. Gene

\footnotetext{
${ }^{860}$ Quintman 2006, pp 243-5.
} 
Smith, Francis Tiso, Everett Goss, Andrew Quintman, Stefan Larsson, Michela

Clemente, Marta Sernesi, Kurtis Schaeffer, and others. ${ }^{861}$ Our appreciation of the quality and significance of these works continues to grow apace. What follows is a description of these literary and printing projects, for the sake of better understanding the Madman of Tsang's life's work. As Kurtis Schaeffer has put it, the Madman of Tsang "built a career through the production of books." ${ }^{962}$ How do we reconcile this with the shocking, antinomian behavior he was famous for?

We can define what some scholars refer to as "the school of the Madman of Tsang" as the literary and printing activity of the Madman of Tsang, a few of his immediate disciples, and one grand-disciple. ${ }^{863}$ E. Gene Smith enumerates this "school" as comprised by the Madman of Tsang, Rabjampa Ngödrup Pelbar (author of the first Life of the Madman of Tsang), Lhatsün Rinchen Namgyel (author of the second), Wangchuk Gyeltsen (dbang phyug rgyal mtshan, a disciple of the Madman of Tsang about whom we know little), Śrī Lopẹ̣ Repa Jampel Chö-lha (zrI lo paN ras pa ‘jam dpal chos lha, a disciple of the Madman of Tsang who served for some time as the yogi's secretary and also worked as a scribe), Götsang Repa (author of the third Life of the

\footnotetext{
${ }^{861}$ See the bibliography for works by all these scholars.

${ }^{862}$ Kurtis Schaeffer, The Culture of the Book in Tibet (New York: Columbia University Press, 2009), p 53. Also, in "Dying Like Milarépa: Death Accounts in a Tibetan Hagiographic Tradition" (2007), Schaeffer summarizes the Madman of Tsang's career thus: "If we may judge from the immense popularity of Tsangnyön's Life of Milerépa, this late fifteenth-century religious leader was arguably the most influential biographer of the Kagyu (Bka' brgyud) schools of Tibetan Buddhism. In the late fifteenth and sixteenth centuries, Tsangnyön and his disciples actively promoted their school by compiling numerous biographies of early Kagyu masters from the eleventh through thirteenth centuries, including Milarépa and his students Réchungpa Dorjé Drakpa (Ras chung pa Rdo rje grags pa, 1085-1161), Lorépa Drakpa Wangchuk (Lo ras pa Grags pa dbang phyug, 1187-1250), and Götsangpa Gönpo Dorjé (rgod tshang pa mgon po rdo rje, 1189-1258), as well as their Indian forerunners, Tilopa and Nāropa," p 208. Much of what follows will be expanding on this summary.

${ }^{863}$ Franz-Karl Ehrhard, for example, refers to "gTsang smyon's school," in Early Buddhist Block Prints from Mang-yul Gung-thang (Lumbini: Lumbini International Research Institute, 2000), p 18.
} 
Madman of Tsang) and lastly Sangyé Darpo. Sangyé Darpo was the unofficial historian of the tradition, writing a useful but little-studied history of the Kagyü sect, beginning with the Buddha and tracing the lineage through the Madman of Tsang, Lhatsün Rinchen Namgyel and Götsang Repa. ${ }^{864}$ This "school" got its start at the time of the Madman of Tsang's printing the Life and Songs of Milarepa in 1488 and continued for about 80 years, to around $1570 .{ }^{865}$

The two most important members of this school in terms of the bulk of their literary production were Lhatsün Rinchen Namgyel (1473-1557) and Götsang Repa (d. $1570^{866}$ ), the authors of the second and third versions of the Madman of Tsang's Life. Lhatsün Rinchen Namgyel was the most prolific of the two; according to his biography, Lhatsün Rinchen Namgyel was responsible for the printing of 4,000 folios of text. ${ }^{867}$ This is a pious exaggeration, but Kurtis Schaeffer has counted at least 28 works edited or composed by Lhatsün Rinchen Namgyel (or overseen by him) over a period of 20 years, totaling over 1,500 folios, most of which were printed in the early- to mid-1550s. ${ }^{868}$ Lhatsün Rinchen Namgyel worked mainly at Drakar Taso (brag dkar rta so), the hermitage in Kyirong Valley, in Gungtang, on the border with Nepal, the site where Milarepa is held to have achieved enlightenment. ${ }^{869}$ Götsang Repa, on the other hand,

\footnotetext{
${ }^{864}$ Schaeffer, The Culture of the Book in Tibet, p 60. It seems that Sangyé Darpo may also have been a patron of some writing/printing projects. On Sangyé Darpo's History, see Peter Alan Roberts, The Biographies of Rechungpa: The Evolution of a Tibetan Hagiography (Abingdon, New York: Routledge, 2007), pp 47-9.

${ }^{865}$ E. Gene Smith refers to them as the Madman of Tsang "and his school," "Introduction to The Life of Gtsang smyon Heruka," pp 73-9.

For a succinct description of this school's printing activities, see Toni Huber, "A Guide to the LaPhyi Mandala: History, Landscape and Ritual in South-Western Tibet," pp 242-3.

${ }_{866}$ According to Roberts, Götsang Repa's dates should be (?1470-1543), pp 43-4.

${ }^{867}$ Schaeffer, The Culture of the Book in Tibet, $\mathrm{p} 54$.

${ }^{868}$ Schaeffer, The Culture of the Book in Tibet, $\mathrm{p} 58$.

${ }^{869}$ Schaeffer, The Culture of the Book in Tibet, $\mathrm{p} 58$.
} 
worked at Rechung Puk, just off the the Yarlung Valley in central Tibet, south of the modern city of Tsetang, close to Densa Til Monastery and the seat of the Pakmodru government. Rechung Puk was the site of the Madman of Tsang's death. ${ }^{870}$ (The Madman of Ü visited Rechung Puk a little after 1495, some ten years before the Madman of Tsang would die there and before printing activities had begun in earnest. ${ }^{871}$ ) Götsang Repa is responsible for publishing at least twelve works, totaling over 700 folios, in projects he either had a direct hand in or which he oversaw. ${ }^{872}$ Some of the projects that bear their names were certainly compiled or written by Götsang Repa and Lhatsün Rinchen Namgyel themselves. Their involvement in other projects was as overseers, and we can thus think of them as like publishers or executive producers, overseeing disciples working as writers, and teams of scribes and woodcarvers. Some texts produced by this school had up to ten woodcarvers working on them. The production of a text thus could have been a big project and would not have been possible without a singular vision and coherent oversight. ${ }^{873}$

It is remarkable to note that among the many works printed at Rechung Puk and Drakar Taso, we have no evidence of there ever being alternate printings of the same text. This suggests that there was ongoing communication between the individuals working at these two centers, which, by the standards of travel in the 15 th century, would have been

\footnotetext{
${ }^{870}$ Rechung Puk does not to my knowledge have any connection to Milarepa.

${ }^{871}$ The Life of the Madman of $\ddot{U}$, p 571.

${ }^{872}$ Schaeffer, The Culture of the Book in Tibet, $\mathrm{p} 58$.

We may be able to add to this list a 13th: a biography of Lorepa Wangchuk Tsöndrü (lo ras pa dbang phyug brtson 'grus, 1187-1250), titled chos rje lo ras pa'i rnam par thar pa bdud rtsi'i phreng ba, by Götsang Repa (pp 237-81 in Bka’ brgyud pa Hagiographies, edited by khams sprul don brgyud nyi ma, Tashijong, Palampur, H. P., 1972, Vol. 2, section 2). This may count as a 56th text attributable to the school of the Madman of Tsang. Götsang Repa is identified as the compiler of the text on p 281 (TBRC W20499). This text came to my attention via Ardussi, "The Beer of Enlightenment," in Journal of the American Oriental Society, Vol. 97, No. 2, 1977, p 120.

${ }^{873}$ Schaeffer, The Culture of the Book in Tibet, $\mathrm{p} 62$.
} 
weeks apart. The coordination between these two sites helps justify our thinking about their activities as constituting a "school.",874

One of the most important features of the literary school of the Madman of Tsang was their strong drive to carve their works into woodblocks, so that multiple printings could be made. Indicating the significance of this technology, in the colophon to his Life of Milarepa, the Madman of Tsang states that he has, by creating woodblocks for printing, produced an "inexhaustible print" of the text. ${ }^{875}$ Calling a woodblock an “inexhaustible print” was wishful thinking on the Madman of Tsang's part, as woodblocks eventually wore out from heavy usage, as they were utilized essentially as stamps, again and again to create new prints. ${ }^{876}$ A few decades after the Madman of Tsang had woodblocks made for The Life of Marpa and the Life and Songs of Milarepa, his disciple Sönam Lodrö (c. 1460-1541) had new woodblocks for those works made. ${ }^{877}$ (Sönam Lodrö is not typically counted among the members of the Madman of Tsang's school, but this school wrote and published a biography about him.) Sometime after Sönam Lodrö’s project Lhatsün Rinchen Namgyel also had new blocks made for the Life and Songs of Milarepa. Lhatsün Rinchen Namgyel may even have made another set of

\footnotetext{
${ }^{874}$ Schaeffer, The Culture of the Book in Tibet, $\mathrm{p} 60$.

${ }^{875}$ The Culture of the Book in Tibet, $\mathrm{p} 70$. Schaeffer does not provide the Tibetan spelling of the term here, although he has told me he suspects it may be dpar ma mi zad pa. Moreover, this phrase is not included in any of the printings of the text I have consulted. It falls on Schaeffer to provide a reference for this. ${ }^{876}$ Ehrhard, Early Buddhist Block Prints from Mang-yul Gung-thang, p 17, says reprints of the Life and Songs of Milarepa were made in 1540 and 1555. These are more likely reprints of the Madman of Tsang's versions than Lhatsün Rinchen Namgyel's.

${ }^{877}$ Is this the same as the Sönam Drupa (bsod nams grub pa) the Madman of Tsang charges with making copies of the Life and Songs and the accompanying tangkas, then sending them to "Ü, Tsang, Tsari, and so on" (Götsang Repa, pp 161.7-162.1)? The Madman of Tsang also charges Sönam Drupa with looking after his community of disciples after his death, Götsang Repa, pp 271.5-272.1.
} 
woodblocks some years after that. ${ }^{878}$ This means that three or perhaps four sets of woodblocks were carved for the Life and Songs of Milarepa within a period of about seventy years, which is truly remarkable given the amount of work such an undertaking would have required. This serves as a testament to just how popular and effective the Madman of Tsang's versions of these texts were in the 16th century. It seems that Milarepa was just as popular then as he is today.

The productivity of the Madman of Tsang's school was truly remarkable. Kurtis Schaeffer has found 55 extant texts that were printed by this school; surely there would have been others that have not yet been located, or may be lost forever. ${ }^{879}$ This number includes only printings of individual texts. If we counted the multiple printings of a single text (like the Life and Songs of Milarepa, for which woodblocks were carved three or four times by members of this school) it would be an even greater number. Moreover, this number includes only texts that were printed by this school; surely there were other compositions that only ever existed in hand-written manuscript form, some of which are lost to the world today.

The 55 texts printed by the school of the Madman of Tsang can be grouped into three main categories: 1) biographies and poetry collections (most of what is included as

\footnotetext{
${ }^{878}$ Schaeffer, The Culture of the Book in Tibet, p 70. Schaeffer here is unclear: Lhatsün Rinchen Namgyel may have been responsible for up to three printings of the Life and Songs of Milarepa. But we also know that he printed his own collection of Milarepa's Songs, including songs that had not been included in the Madman of Tsang's version. Do these various printings all refer to reprinting of the Madman of Tsang's version, or of Lhatsün Rinchen Namgyel's own version, or both? On Lhatsün Rinchen Namgyel's version of the Songs, see Quintman 2006, p 80; Schaeffer, The Culture of the Book in Tibet, p 54. On Lhatsün Rinchen Namgyel's reprinting the Madman of Tsang's version, see Schaeffer, The Culture of the Book in Tibet, p 59.

${ }^{879}$ Schaeffer, “The Printing Projects of Gtsang Smyon He ru ka and his Disciples,” forthcoming, p 5.
} 
"poetry" here is intended to be read as originally having been songs); 2) teachings; and 3) histories.

Of the 55 texts for which woodblocks were carved, the vast majority (45) belong to this first category. These ${ }^{880}$ include biographies about and poetry purportedly by: Vajradhāra (the divine source of the Kagyü tradition); Saraha (the famous Indian siddha and the first human of the Kagyü lineage); Tilopa (the Indian siddha); Nāropa (c. 10161100, the Indian siddha); Marpa (1012-97, the Tibetan who traveled to India to get the teachings from Nāropa); Milarepa (1040-1123); Rechungpa (1083-1161); Gampopa (1079-1159); Pakmodrupa (1110-70); Lingrepa Pema Dorjé (gling ras pa padma rdo rje, 1128-88); the First Drukchen, Tsangpa Gyaré Yeshé Dorjé ( 'brug chen, gtsang pa rgya ras ye shes rdo rje, 1161-1211); Götsangpa Gönpo Dorjé (rgod tshang pa mgon po rdo rje, 1189-1258); Yanggönpa Gyeltsen Pel (yang dgon pa rgyal mtshan dpal, 1213-58); Kodrakpa Sönam Gyaltsen (1182-1261, who will be discussed in Chapter Seven); then, after a gap of a century and a half, Shara Rabjampa Sangyé Sengé (sha ra rab 'byams pa sangs rgyas seng ge, 15 th century, the Madman of Tsang's main guru); the Madman of Tsang (including the three biographies about him and a collection of his songs); Lhatsün Rinchen Namgyel (1473-1557, one of the Madman of Tsang's disciples and biographers); Götsang Repa Natsok Rangdröl (1494-1570, another of the Madman of Tsang's disciples and biographers); Sönam Lodrö (d. 1541, a disciple of the Madman of Tsang); and lastly, the 4th Drukchen, Pema Karpo (1527-92).

The school of the Madman of Tsang also printed collections of teachings by Gampopa, Yanggönpa, Potowa ( $p o$ to $b a$ ), Lhatsün Rinchen Namgyel and Götsang Repa.

\footnotetext{
${ }^{880}$ For full references, see Schaeffer, "The Printing Projects of Gtsang Smyon He ru ka and his Disciples."
} 
Eight of the 55 printed texts would fall under this category. The final category includes two histories, by Sangyé Darpo (in 1568) and Götsang Repa.

We see that the Madman of Tsang's literary school laid emphasis on composing or compiling and then printing the biographies and poetry of the great masters of their tradition. The greatest emphasis was on hagiography (of the 55 texts produced by this school, at least 29 are essentially hagiographical in nature). ${ }^{881}$ Their main focus was on the Lives of early masters of the Kagyü sect, from the 11th through 13th centuries. After this there is a gap, until the narrative resumes with Shara Rabjampa, who was active in the middle of the 15 th century. ${ }^{882}$ A possible reason for this gap will be suggested below. The body of literature produced by the school of the Madman of Tsang makes a point of telling a comprehensive history of the Kagyü as the Ka-gyü (bka' brgyud, the “Oral Transmission”) — as essentially based on teachings passed down from Vajradhāra to Tilopa to Nāropa to Marpa to Milarepa to Gampopa and to many others from there. (As was mentioned in Chapter One, the lineage of "crazy adepts" as understood by Georg Feuerstein is precisely this one: from Tilopa to Nāropa to Marpa and on to Milarepa.) These biographies, among other things, tell the story of how this transmission took place. This body of literature thus constitutes something like a "golden rosary" (gser "phreng) text telling the lives of a lineage of masters, writ huge. ${ }^{83}$ It is in effect a single story, a single history, told over the course of these dozens of texts.

\footnotetext{
${ }^{881}$ This includes texts referred to as rnam thar, rnam thar gsol 'debs, rnam mgur and rtogs brjod.

${ }^{882}$ Schaeffer, The Culture of the Book in Tibet, pp 59-60.

${ }^{883}$ Schaeffer, "The Printing Projects of Gtsang Smyon He ru ka and his Disciples," p 16; Quintman 2006, p 85. The comparison of this body of hagiographic literature to a "golden rosary" breaks down when we consider the fact that most golden rosary texts are short on details about the actual lives of the figures in question and focus more on establishing the legitimacy of the lineage. The hagiographic literature created by the school of the Madman of Tsang certainly achieves this, but adds much more flesh to the accounts.
} 
This literature tells the history of this transmission in great detail, and thereby cements the Kagyüpas' claim that their teachings are of authentic Indian (and before that, primordial) origins. As we know, the ability to claim an unbroken link to India is extremely important for Tibetan Buddhist sects' ability to establish their legitimacy - a key move in the competitive religious marketplace. We know that the Madman of Tsang was aware of this important role his literature was to play. The compendium of the Aural Transmission he compiled (to be discussed below) contains a series of brief biographies of the great masters of the lineage - a sort of summary of his school's greater work. As a comment on the importance of these biographies, the Madman of Tsang writes,

If a student neither hears nor reads about the qualities in the life stories of the gurus, [even though] he receives and engages in the teachings, he will not attain the state of ripening and liberation. Therefore, in order that confidence in the lineage and the instructions, as well as a recognition of their authenticity, arise, and in order that the special qualities of students arise effortlessly in their mindstreams through the blessings of the lineage, I will describe, roughly and in brief, ... the life stories of the gurus of the lineage. ${ }^{884}$

This passage shows that the Madman of Tsang thought of this hagiographical literature as being of critical importance to peoples' success in practicing the Buddhism of his tradition, because of the necessity of having faith in the validity of the lineage. This validity is proven by the remarkable lives of the tradition's past masters. The biographies of the Madmen of Ü and Tsang, we have seen, were written with the same basic intent.

The school of the Madman of Tsang told what was from their perspective a comprehensive history of the Kagyü, from its time- and space-less origins to its Indian masters to their Tibetan disciples who transplanted those teachings to the snowy land to the north. The main Kagyü lineage according to this school lineage ran as follows:

\footnotetext{
${ }^{884}$ Translation taken from Quintman 2006, p 76.
} 
Saraha, Tilopa, Nāropa, Marpa, Milarepa, Gampopa, Pakmodrupa, Lingrepa, Tsangpa Gyaré, Götsangpa and Yanggönpa. (The school of the Madman of Tsang also published works about figures like Rechungpa and Kodrakpa, but they are not treated as members of this primary lineage. ${ }^{885}$ As we will see below, the Madman of Tsang took specific steps in his writing the Life and Songs of Milarepa to marginalize Rechungpa in favor of Gampopa.) In articulating their lineage in this way, the Madman of Tsang made a clear assertion of the validity and the strength of the lineage that would become, from the perspective of slightly later Tibetans, the lineage of the Drukpa subsect of the Kagyü.

The fact that the versions of these Lives produced by the school of the Madman of Tsang would become the standard accounts of these figures' lives is quite remarkable given the fact that it is usually earlier sources and versions that are viewed as the most genuine. For example, it was by no means a foregone conclusion that the Madman of Tsang's version of the Life of Milarepa, written more than 300 years after Milarepa's death, would become the standard account of his life. The fact that the Madman of Tsang and his disciples were successful in establishing their versions as the definitive records of these figures' lives — writing these stories hundreds of years after the fact — is a testament to their skill and tact in constructing convincing and effective narratives. ${ }^{886}$

In the process of compiling, composing and printing these biographies, the school of the Madman of Tsang was not just creating stories, but rather history. ${ }^{887}$ Many of

\footnotetext{
${ }^{885}$ Kodrakpa, remembered as a teacher of Yanggönpa, is associated with the Drukpa Kagyü. Lorepa, a disciple of Tsangpa Gyaré, who Götsang Repa wrote about (see footnote above), is a more important figure in the history of the Drukpa Kagyü sect.

${ }^{886}$ Quintman (2006) makes this observation, p 271.

${ }^{887}$ Milarepa, 2005 version, p 33. When one of Milarepa's later black magic teachers does not fully believe the young man's story about his family history and his murdering so many people, he sends one of his disciples to investigate the story. Thet disciple later returns and verifies that everything Milarepa had said
} 
these biographies would become the standard histories of these individuals, to be read and used by Tibetans all the way into the present. That the Madman of Tsang was unknown to the modern Tibetological world as the author of The Life of Milarepa is an indication of how successful he was in removing himself, as author, from the horizon of the text. The text was so convincingly presented as the real history of Milarepa that the fact that it had been authored more than three centuries after Milarepa's death by the Madman of Tsang became invisible. The Life of Milarepa is read as history rather than as a story authored by the Madman of Tsang. Tibetans are often reluctant to question the veracity of these accounts. Thus a remarkable amount of what is "known" about the Kagyü from its very beginnings up to the 16th century comes from texts produced out of this school.

Because of the comprehensiveness of these narratives and the way they have been read by later generations, we could say that the Madman of Tsang's literary school created the Kagyü sect as we know it. This is not to say that they fabricated their version of the Kagyü out of nothing; in many cases they were working with stories and texts that were already in circulation. ${ }^{888}$ The members of the Madman of Tsang's school put their own individual stamp on those stories, as we will see in the next section of this chapter when we look at how the Madman of Tsang's version of The Life of Milarepa differs

was true. A device like this functions as a testament to the historicity of the text, telling the reader that he is reading fact rather than fiction, which is what the Madman of Tsang is trying to achieve in his presentation of the Life.

${ }^{888}$ We know that there were earlier versions of these stories in circulation early in the lives of the Madmen of $\ddot{U}$ and Tsang, and on their cultural horizon. When the Madman of Ü was just five or six years old, when his mother would carry him to a nearby monastery on her back, "he listened to many different teachings, including the life stories of the past lamas of the Precious Kagyü called The Brilliance that Opens the Eyes, Mountain Dharma: Origin of all Good Qualities," and so on. The Life of the Madman of Ü, p 391. See Dan Martin, Tibetan Histories: A Bibliography of Tibetan-Language Historical Works, pp 66-7, on The Brilliance that Opens the Eyes. 
from earlier versions, thanks to his selectively shaping the past through his editorial decisions. In creating these new versions of the lives of past masters, the Madman of Tsang and the other members of his school drew from an earlier set of narrative traditions, keeping what was useful, dropping what was not, re-ordering events, changing details, and improving literary style through more effective plotting, stronger thematic development, and more uniform language. ${ }^{889}$ Their influence ranges from their decisions about how to characterize past masters to the very question of what and what not to take the trouble of printing. These decisions had discernable effects on their present circumstances in the 15 th and 16 th centuries, and would continue to play a role in the history of Tibetan Buddhist culture into future generations, all the way into the present.

In addition to telling the history of the transmission of the teachings (and making an argument for the legitimacy of their lineage), another theme repeated in many of these biographies is the notion that meditation should be emphasized over other forms of Buddhist practice, especially scholasticism. We see this exemplified in The Life of Nāropa, the great saint who left his position at Nālandā monastery to wander in pursuit of tantric instructions after realizing that scholasticism was not a valid means for achieving the highest truth. This is a major theme in the Dohās of the Indian saint Saraha, and also, as we will see, in The Life of Milarepa. All of these texts were compiled (or composed) and printed by the school of the Madman of Tsang and reflect their specific agenda in 15th- and 16th-century Tibet. This body of literature ensured that these stories would be preserved for posterity. But these accounts were derived not from a simplistic process of representing the past, but rather a strategic process of choosing from among possible

${ }^{889}$ On the Madman of Tsang's role in creating Milarepa's Life Story see Quintman 2006, pp 219-20. 
pasts. These accounts are the result of a more or less conscious process of selecting from and manipulating the past, in the same way that the biographies of Sākya Chokden and the Madmen of Ü and Tsang were, as we saw at the beginning of this chapter.

In a stark contrast to the Madman of Tsang, we have no record of the Madman of Ü's ever having composed or worked on the printing of anything. ${ }^{890}$ His main cultural accomplishment was establishing three monasteries: the Fortress of the Dharma-realm Sky (chos dbyings nam mkha 'i rdzong), Liberation Park (thar pa gling) and Tsimar Pel (rtsi dmar dpal). Tsimar Pel was the most important of these three, as it is where the Madman of Ü lived for the last thirty years of his life, many of those years sealed in meditative retreat. This monastery does not seem to have been very significant, however, as I have never seen it mentioned anywhere other than in The Life of the Madman of $\ddot{U}$. It may not have stayed in operation for long after the Madman's death.

Despite not having written anything significant enough to have survived up to the present, the Madman of Ü was fully aware of the significance of texts and printing. In 1509, Nyukla Penchen, Ngagi Wangpo Drakpa Pelden (1458-1515), one of the Madman of Ü's main disciples and the author of the first part of his biography, visited his master at Tsimar Pel. The Madman of Ü instructed his disciple to pass on to his followers the special teachings of the Kagyü sect, including the Mahāmudrā, the Six Dharmas of Nāropa, the Dohās (of Saraha), the Secret Activity of India (rgya gar gsang spyod) and so on. He then told Nyukla Penchen to make a printing (par cig bzhengs) of the Life and

\footnotetext{
${ }^{890}$ The 1973 printing of the first half of the Madman of Ü's rnam thar is mislabeled his mgur 'bum, his Collected Songs. This is a mistake. No Collected Songs or any other text composed by the Madman of Ü has come to light.
} 
Songs of Milarepa, the Dohā Trilogy (do ha skor gsum), the Secret Activity of India, and so on. ${ }^{891}$ This probably means that he wanted Nyukla Penchen to make printings of these texts based on woodblocks produced by the school of the Madman of Tsang; the Madman of Tsang's first woodblocks for Life and Songs of Milarepa had been completed 21 years earlier, in 1488 .

Some of the Madman of Ü's disciples took an interest in the production of literature, some of which would become quite influential, although not comparable to that produced by the Madman of Tsang and his circle. The above mentioned Nyukla Penchen also wrote a Life of Lhatsünpa Künga Chöki Gyatso (lha btsun pa kun dga' chos kyi rgya $m t s h o, 1432-1505)$, the guru of Drukpa Künlé and Drakpa Tayé. ${ }^{892}$ The second half of the Madman of Ü's biography was written by Latong Lotsāwa Shényen Namgyel (lha mthong lo tsA ba bshes gnyen rnam rgyal), based on notes left by the Madman of Ü's nephew and successor, Künzang Nyida Pelbar (kun bzang nyi zla dpal bar). A disciple of Shényen Namgyel, Gyurmé Dechen ('gyur med bde chen, 1540-1615), composed the most significant version of The Life of Tangtong Gyelpo. ${ }^{893}$ The Second Pawo, Tsuklak Trengwa, who composed the very important history The Scholar's Feast, at one point received teachings from the Madman of Ü.

Thus the disciples of the Madman of $\ddot{U}$ were responsible for the production of some influential literature, although they were not nearly as prodigious as the Madman of Tsang's circle. As with the Madman of Tsang and his disciples, they had a clear interest

\footnotetext{
${ }^{891}$ The Life of the Madman of $\ddot{U}$, pp 592-3.

${ }^{892}$ This work is titled ngo mtshar ut+pa la'i do shal byin brlabs kyi zil mngar 'ba byed. See Jamyang Namgyal [E. Gene Smith], 1973, p 97.

${ }^{893}$ This is the only biography of Tangtong Gyelpo that was carved into woodblocks and published in Tibet, perhaps in the 17th century, Stearns 2007, pp 8-9.
} 
in playing a role in chronicling and shaping the history of their lineage through the composition of biographies.

The holy madmen and their disciples created a massive amount of literature that to this day remains our main source of information and characterizations of many generations of Kagyü masters. Clearly they felt a strong, purposeful drive to create this literature. We now turn to trying to gain some insight into their thinking about the value and purpose of composing and mass-producing these narratives.

\section{II.1 The Agenda of the Madman of Tsang's Literature}

\section{II.1.i The Madman of Tsang's Compositions}

The Madman of Tsang is famous for having compiled or written four main things:

the Life and Songs of Milarepa, The Life of Marpa ${ }^{894}$, and the twelve-volume Compendium of the Dākin̄i-Samvara Aural Transmission (bde mchog mkha' 'gro snyan rgyud yig cha), which will be discussed separately below. There is also a volume of the Madman of Tsang's Collected Songs (mgur 'bum). The Madman of Tsang also wrote versions of the Lives of Tilopa, Nāropa and other masters of the Kagyü tradition, included within his Compendium of the Dākini-Samvara Aural Transmission.

We should pause for a moment to consider how surprising it is that the Madman of Tsang spent so much of his life writing and publishing texts, given the fact that he is also famous for performing the most shocking forms of antinomian behavior imaginable. There seems a contradiction in how the Madman of Tsang is thought of. Indeed, one

\footnotetext{
${ }^{894}$ In his biography of the Madman of Tsang, Götsang Repa appears to say that he was once called into the presence of the madman and told to make additions (kha skongs [sic]) to the life stories of Tilopa and Nāropa, and to say that they are the compositions of the Madman of Tsang himself, p 246.1-.3.

The Madman of Tsang seems not to have prioritized The Life of Marpa much. At one point it is said that The Life of Marpa was carved into woodblocks and printed with resources the Madman of Tsang had leftover from some other project, Götsang Repa, p 235.5.
} 
could argue that writing was the central theme in the Madman of Tsang's life. According to Ngödrup Pelbar's version of his Life, shortly before his death the Madman of Tsang said that he had taken this human life solely for the purpose of producing the Life and Songs of Milarepa and the compendium of the Dākin̄ Aural Transmission; with those projects finished, his life's work was complete and he was ready to die. ${ }^{895}$ Why were these compositions so important to him?

Here we want to get an idea of what the Madman of Tsang was trying to achieve through his compiling or composing and then mass-printing his most influential work, the Life and Songs of Milarepa. This will involve looking at the Madman of Tsang's own statements about what he wanted to achieve through this project, then analyzing the form and content of the text itself. The Madman of Tsang's biographies tend to portray his writing and printing work as the enlightened activity of a Buddha, pre-ordained and divinely inspired. ${ }^{896}$ But as we will see, the Madman of Tsang made statements suggesting that he had a very specific idea of the value and function of this work.

The Madman of Tsang first wrote about Milarepa when he was about 32 years old. According to Götsang Repa's version of his Life, while returning to central Tibet from a visit to Mount Kailash, the Madman of Tsang made a pilgrimage to the village where Milarepa was believed to have been born. There at a small temple dedicated to Milarepa, the Madman of Tsang was asked by the caretaker to "compose a biographical prayer for Lord Mila.” After this was confirmed as a worthy undertaking by the miraculous sign of a butter lamp burning for three whole days, the Madman of Tsang

\footnotetext{
${ }^{895}$ Ngödrup Pelbar, 23b. rje btsun mi la'i rnam thar mgur 'bum dang / mkha' 'gro snyan rgyud kyi spo ti 'di'i phyir/ nga'i lus 'di blangs pa yin pas/ snyan rgyud kyi yig cha rnams tshar tsa na nga'i tshe tshad rdzogs/

${ }^{896}$ Quintman 2006, p 195.
} 
composed an encomium ( $b$ stod pa) to the life of Milarepa. In this his first writing about Milarepa the Madman of Tsang split the events of the life of the saint into twelve great deeds (mdzad pa bcu gnyis kyi sgo nas...), thus mimicking traditional accounts of the life of the Buddha, a device he would use in his later writing on Milarepa as well. ${ }^{897}$

More pertinent to our concern here are the circumstances surrounding the Madman of Tsang's composing and printing the Life and the Collected Songs of Milarepa later in his life. The significance of this affair is signaled by the fact that each of the three versions of The Life of the Madman of Tsang devotes an entire chapter to describing these events. ${ }^{898}$ According to Lhatsün Rinchen Namgyel's version of his Life, the Madman of Tsang's decision to compile and print full versions of the Life and Songs of Milarepa was precipitated by his having a vision of Nāropa while staying at Dröpuk (grod phug), a cave associated with Milarepa. When the Madman of Tsang was in a state that was a mixture of dreaming and lucidity, Nāropa appeared before him, in a giant form, wearing the six bone ornaments (Nāropa's mode of dress will be discussed below). The Madman of Tsang asked Nāropa to impart to him his Six Dharmas, but he responded speaking in Sanksrit. A translator appeared and told the Madman of Tsang that the great Indian siddha had been instructing him to compile the biography and the songs of Milarepa, carve them into woodblocks, make prints, and distribute them. The Madman of Tsang's immediate response was to say that he did not have the patrons needed to undertake such a project. Nāropa looked in the direction of the western Tibetan regions of Lowo Möntang (glo bo), Ngari Gungtang, and Latö (la stod), assuring the yogi that patronage

\footnotetext{
${ }^{897}$ Quintman 2006, pp 195-6; Götsang Repa, p 73.2. This will be discussed further below.

${ }^{898}$ Quintman 2006, p 197.
} 
would arrive from those places. The Madman of Tsang then said that he did not have the capacity to undertake such a project, which would require preparing wood and supervising scribes and carvers. This time Nāropa indicated five women sitting nearby, who vowed to help the Madman of Tsang in his endeavor. ${ }^{899}$ (According to his own biography Lhatsün Rinchen Namgyel would have a similar vision of a woman who commanded him to compile and print his own anthology of Milarepa's songs that had not been included in the Madman of Tsang's version. ${ }^{900}$ )

Götsang Repa's version of The Life of the Madman of Tsang does not tell of his having such a vision, but states that one morning the Madman of Tsang awoke inspired to create and print a version of The Life of Milarepa. He had the following thoughts:

"At present in this snowy land there exist numerous biographies and collected songs of Rje btsun Bzhad pa rdo rje [Milarepa]. However, the [transmission of] his extraordinary biography ${ }^{901}$ has been interrupted. I should rectify this, teach the

\footnotetext{
${ }^{899}$ Lhatsün Rinchen Namgyel, p 96.3-97.6; Quintman 2006, pp 197-8; Schaeffer, The Culture of the Book in Tibet, pp 54-5. This story is not included in Ngödrup Pelbar or Götsang Repa's versions of the Madman of Tsang's Life. It is worth noting that Näropa's prophecy to Marpa about Milarepa's future arrival is partially quoted in this exchange. This prophecy is included in the Lives of Nāropa and Marpa produced by the Madman of Tsang's school. It seems that literary creations about the mythology of Nāropa and Marpa now shape how the Madman of Tsang himself is remembered. See Quintman 2006, p 200.

${ }^{900}$ Schaeffer, The Culture of the Book in Tibet, $\mathrm{p} 54$.

${ }^{901}$ Quintman (2006) speculates on what it meant to say that the Madman of Tsang took on the task of writing "the extraordinary biography" of Milarepa (thun mong ma yin pa'i rnam thar 'di...; pp 202, 246-9). Quintman suggests (following Döndrup Gyel) that the Madman of Tsang understood his version of the Life to be "extraordinary" because of the unique stamp put on the work by the Madman of Tsang, and the way the boundaries between his life and Milarepa's collapsed.

Quintman is certainly correct in seeing a complex relationship between Madman of Tsang's life and The Life of Milarepa, although I am not convinced that this meaning is expressed in the use of the term "extraordinary" here. Rather, I believe a possible gloss on the term "extraordinary" is offered a few pages earlier in Götsang Repa's version of The Life of the Madman of Tsang, where it is said that the Madman of Tsang "composed a biography of Milarepa as it was told by the mouths of extraordinary lamas" (rje bstsun mi la'i rnam thar thun mong ma yin pa'i bla ma'i zhal nas byung ba ltar gyi thugs rtsom mdzad..., Götsang Repa, p 135.3). Quintman states that Lobsang Lhalungpa was incorrect in suggesting that the Madman of Tsang saw his version of The Life of Milarepa as "extraordinary" because of having been passed on through oral tradition (Quintman 2006, p 247). This suggests that Quintman may have missed the gloss on this term offered by Götsang Repa's text. I believe there is much credence to Lhalungpa's reading of the term.
}

It is certainly the case, as Quintman states, that the Madman of Tsang's version of The Life of Milarepa was extraordinary in the sense of being a fresh presentation of the Life, and one that is to some 
profound and vast dharma and instructions to my worthy disciples, and then bring them to liberation; indeed that is what [such a work] does. All agree on the need to accumulate merit. Yet from the king, too busy for the proper activity of authentic dharma, ministers, and important leaders full of arrogance, to the majority of common people, all are proud of their dharma activity; and even if they have time to practice and do so, they don't know how to practice the profound key points. Rather than stirring up bubbles of technical jargon, [such a biography] would be a wish fulfilling gem, an exceptional means for leading them to buddhahood in one lifetime. It would thus awaken the inner potential for virtue (rnam dkar kyi rigs) in arrogant geshes who are on the verge of becoming nonBuddhists.

"If those attached to desirable things and their own lives had before their eyes such a biography of Rje btsun Bzhad pa rdo rje, it would serve as a visual aid to endure hardship and carry on through suffering. For those who take pleasure in distraction it would serve as a visual aid to practice one-pointedly; for those who doubt the possibility of attaining buddhahood in one lifetime or say they have no time for meditation on the profound, it would serve as a pure example of those very things. They would have confidence in the authentic dharma of definitive meaning and the most capable individuals would be liberated in their lifetime or in the intermediate state at the moment of death. People of intermediate ability, even though they have no personal experience, would develop faith and devotion in experienced individuals, thereby attaining favorable circumstances; having made a connection through pure aspirations, they would practice in future lifetimes and on that basis reach liberation. Even the least capable would abandon perverted views and engender exceptional faith and then develop certainty that they would reach the limits of life's round. Once this publication is finished it will benefit limitless beings." 902

As these words are being put into the mind of the Madman of Tsang by his disciple, we must be careful not to assume they are a completely veridical representation of his thoughts. But we also have no reason to think that this could not have been a fair description of the Madman of Tsang's motivations for taking on the project. Here the

extent animated by the author's own personal understanding of the meaning of that life, as one who lived as an ascetic and modeled his behavior — to a debatable extent — on Milarepa's. At the same time, it is very unlikely that the Madman of Tsang or his biographer Götsang Repa would have wanted to highlight the fact that this version of Milarepa's Life was in some way particularly original. To the contrary, the Madman of Tsang's version of The Life of Milarepa is presented as an accurate retelling of past events, not as a literary product wrought by the Madman of Tsang, bearing his unique stamp. For these reasons it seems more likely that the term "extraordinary" here indicates that this version of Milarepa's Life was as told by “extraordinary" lamas (perhaps including the Madman of Tsang's guru, Shara Rabjampa?), as is suggested by Götsang Repa and Lhalungpa, and not the more evocative meaning posited by Quintman.

902 Götsang Repa, pp 137.7-138.7; here I am using Quintman's translation of the passage, pp 200-1. For an alternate translation, see Schaeffer, The Culture of the Book in Tibet, pp 56-7. 
Madman of Tsang states that The Life of Milarepa would serve as a model for how to transmute worldly experiences into religious training. It would serve as a testament to the power of meditation and the possibility of achieving liberation in a single lifetime- - a counter-argument against those who marginalized the practice of tantra and posited a more gradualist model of the Buddhist path. The Life of Milarepa would affect people of all different capacities for religious practice, even those holding the most erroneous views. It would also be applicable for people of many different social strata, from kings to "the majority of common people"-everyone can participate in the religious life exemplified by Milarepa in some way, even if only on the level of achieving faith in him. The Madman of Tsang wanted everyone to have access to the story of the life of Milarepa. This had not always been the case, as earlier versions of Milarepa's Life created in centuries past were supposed to be to be kept secret, specifically not for public consumption. $^{903}$

In 16th-century Tibet only a small minority of the Tibetan population would have been literate, but the stories contained in the textual biographies would have come to the ears of a slightly wider circle. Moreover, the more important dignitaries getting copies of

${ }^{903}$ Quintman 2006, p 202.

R. A. Stein, Tibetan Civilization, p 276, talks about Tibet's holy madmen as being connected with popular forms of expression and literature. John Ardussi and Lawrence Epstein say the same, "The Saintly Madmen in Tibet," $\mathrm{p}$ 333. This perception is in large part derived from the notion that Tangtong Gyelpo was involved in the creation of Tibetan opera (Ardussi and Epstein mention this). It is perhaps also supported by the fact that the Madman of Tsang wrote the Life and Songs of Milarepa, which became-and remains today - an extremely popular work. This idea is likely supported by popular perceptions of Drukpa Künlé as well.

Ultimately I believe the idea that the holy madmen were populists is misguided. Although they voiced criticisms of institutionalized and scholastic Buddhism, the form of Buddhism they promoted was no less inaccessible to the common man. Moreover, the role the historical Tangtong Gyelpo might have played in the creation of Tibetan opera has yet to be substantiated, and the historical Drukpa Künlé, we saw in the last chapter, was much less of a fun-filled bawd than the popular, ahistorical presentations of him would have us believe. 
the Madman of Tsang's version of The Life of Milarepa received a series of tankas with it as well. Quintman characterizes the Madman of Tsang's work as "visual biography," "Tibet's first concerted multi-media approach to life writing." The fact that visual images accompanied the written text would have made Milarepa's Life accessible to a larger population, even non-literate communities, which seems in agreement with the Madman of Tsang's stated goal of creating a story that would speak to people from all strata of society. ${ }^{904}$ In addition to helping tell the story of Milarepa, these visual images also would have become devotional objects (as would the actual printed texts themselves), further fostering the cult of Milarepa.

The fact that this writing and printing project was something like a missionary endeavor is signaled by the fact that the Madman of Tsang had copies of the text and the accompanying images sent to monasteries, important religious figures (like the 4th Red Hat) and patrons (like Dönyö Dorjé) all over Tibet. ${ }^{905}$ In Schaeffer's understanding, the Madman of Tsang "strategically employed biography—and especially printed biography — as a means to expand his network of patrons, disciples, and holy cites." ${ }^{906}$ We will look at how this worked below. First, to get a better understanding of how the Madman of Tsang wanted to accomplish this, let us look at what kind of message is encoded in the Life and Songs of Milarepa themselves.

\footnotetext{
${ }^{904}$ Quintman 2006, pp 206-8; Götsang Repa, p 147.

${ }^{905}$ Quintman 2006, p 206; Götsang Repa, p 162.4. Others mentioned as having been given copies of the Life were the [lords of] Lowo Möntang and Gungtang, long-standing patrons of the Madman of Tsang, Götsang Repa, pp 161.6-.7.

${ }^{906}$ Schaeffer, The Culture of the Book in Tibet, $\mathrm{p} 56$.
} 


\section{II.1.ii The Madman of Tsang's Strategic Innovations in the Life and Songs of Milarepa}

The Madman of Tsang's agenda in writing and mass-disseminating the Life and Songs of Milarepa is further revealed to us when we consider specific characteristics of his versions of those texts. In creating his versions of the Life and Songs of Milarepa the Madman of Tsang drew from many existing stories and songs about the yogi, some of them written, some of them passed on orally. But as we will see, the Madman of Tsang did not simply relay narratives about Milarepa as he had received them, but rather modified them to create his own version of that story, that history. ${ }^{907}$

\section{II.1.ii.1 Stylistic and Structural Changes to Milarepa's Life}

One set of ways the Madman of Tsang altered earlier versions of the story of Milarepa is stylistic. As was mentioned above, the Madman of Tsang brought a new dimension to the Milarepa narrative tradition by dividing that story into twelve chapters. In doing so the Madman of Tsang mimicked traditional accounts of the life of Buddha Śăkyamuni, in which his life is understood as comprised of twelve great acts. The Madman of Tsang was thereby making an implicit suggestion about the significance of Milarepa. ${ }^{908}$

The Madman of Tsang made another innovation by framing the Life as an oral account. The text is presented as a transcription of Milarepa's telling the events of his life to a circle of disciples at Rechungpa's request (hence leading some Euro-American Tibetologists to talk about the text as Milarepa's autobiography or a composition by

\footnotetext{
${ }^{907}$ Quintman 2006, p 214.

${ }^{908}$ Quintman 2006, pp 216-7.
} 
Rechungpa). ${ }^{909}$ This adds an element of immediacy to the story as it is told - transmuting it into history and removing the Madman of Tsang as the author of the account. ${ }^{910}$ This change to the text also makes it similar in form to a Buddhist sütra, with Milarepa filling the role of the Buddha and his disciple Rechungpa acting like Sāriputra. Another of Milarepa's disciples, Ngendzongpa, was said to have had perfect memory, and thus plays the role of the Buddha's other close disciple, Ānanda. ${ }^{911}$ The Madman of Tsang's version of The Life of Milarepa begins with the phrase that begins all Buddhist sütras: "Thus did I hear." And in its final pages there is some dispute over what to do with the master's relics after his cremation, just as after the Buddha's own demise. ${ }^{912}$

Another important innovation in the Madman of Tsang's work was dividing the Milarepa narrative into two separate texts: the Life and the Collected Songs. The Collected Songs, comprised of short episodes depicting songs Milarepa sang to his disciples on various occasions, are more than twice as long as the Life. By moving these discrete episodes out of the main narrative of the Life, the Madman of Tsang created a much more streamlined and engrossing story. ${ }^{913}$

\section{II.1.ii.2 Content Changes to Milarepa's Life}

Other changes made by the Madman of Tsang are in the actual content and details of Milarepa's life, rather than how the text itself is presented. For example, in an earlier version of The Life of Milarepa, there is a story about his mistaking a burning lamp for a meditative experience. In creating his version of the text, the Madman of Tsang

\footnotetext{
${ }^{909}$ Quintman 2006, pp 215-6.

${ }^{910}$ Quintman 2006, p 216.

911 Quintman 2006, p 54.

912 Donal Lopez, introduction to Andrew Quintman's translation of The Life of Milarepa (New York: Penguin Classics, 2010), $\mathrm{p}$ x.

${ }^{913}$ Quintman 2006, pp 215, 217-8.
} 
transformed this story into a lamp being put on Milarepa's head and never going out. ${ }^{914}$ The Madman of Tsang also chose to portray Milarepa as physically invulnerable. ${ }^{915}$

Through making small changes like these, the Madman of Tsang portrayed Milarepa in a more perfect light than earlier versions had.

\section{II.1.ii.2.a Gampopa Over Rechungpa: Strengthening the Lineage}

Another strategic change the Madman of Tsang made to the narrative concerns Milarepa's two main disciples, Rechungpa and Gampopa. In short, the Madman of Tsang essentially rewrote the history of the Kagyü sect in order to make Gampopa appear to be Milarepa's foremost disciple, when earlier accounts had portrayed Rechungpa in that position.

Peter Alan Roberts has shown that there were a few related aspects to the Madman of Tsang's changes to the narrative in this regard. According to Roberts, in the course of the Collected Songs the Madman of Tsang portrays Rechungpa as "gifted but seriously flawed," in order to justify his making Rechungpa take a back seat to Gampopa. In the process the Madman of Tsang gives Rechungpa a more negative portrayal than earlier authors had. ${ }^{916}$ For example, in one episode the Madman of Tsang's version distinctly includes Rechungpa’s having more evil thoughts about his guru Milarepa than earlier versions had. ${ }^{917}$ In another episode in the Madman of Tsang's version of the Collected Songs, Rechungpa, thinking that he is superior to Milarepa in instruction and

\footnotetext{
914 Quintman 2006, pp 70-1.

${ }^{915}$ Whereas in earlier versions Milarepa had gotten sick from some bad water, the Madman of Tsang removed this from his version of the Songs. This actually creates a glitch in the narrative, for in the Madman of Tsang's version of the story, no reason is given for why Milarepa has Rechungpa go somewhere else to fetch water. Roberts, pp 184, 199.

${ }^{916}$ Roberts, p 183.

${ }^{917}$ Roberts, p 199.
} 
logic, expects Milarepa to prostrate to him and is displeased when he does not. In earlier versions of this story, it is said that Rechungpa wanted Milarepa to prostrate to him in order to honor the Aural Transmission teachings that he had gone to India to collect. The Madman of Tsang omits this line from his version of the story, and in the process makes it seem that Rechungpa wanted Milarepa to prostrate to him solely out of pure egoism. ${ }^{918}$ This change to the narrative also helps downplay the importance of Rechungpa as having a unique association with the Aural Transmission teachings, which we will see is an ongoing issue. Also, in the Madman of Tsang's portrayal Rechungpa had a following distinct from Milarepa's, which threatened the harmony of the community. ${ }^{919}$ This is probably highlighted by the Madman of Tsang in order to further justify his marginalizing Rechungpa.

The Madman of Tsang goes out of his way to make the relationship between Milarepa and Rechungpa worse than earlier versions had. In earlier versions of the narrative, Milarepa admonished Rechungpa for bringing back from India texts on logic and sorcery, in addition to the Aural Transmission. In the Madman of Tsang's version of the narrative, Milarepa also says that Rechungpa's understanding of the teachings is incomplete. ${ }^{920}$ It seems that it the Madman of Tsang's version of the narrative, Milarepa was afraid of Rechungpa's getting too caught up in scholasticism. ${ }^{921}$

This is not to say that the Madman of Tsang completely fabricated the idea that there was friction between Rechungpa and Milarepa. Earlier versions of the narrative suggested as much, but the Madman of Tsang exaggerated this aspect of the story. As we

\footnotetext{
918 Roberts, p 198.

${ }^{919}$ Roberts, p 149.

${ }^{920}$ Roberts, p 201.

${ }^{921}$ For example, see Roberts, p 184.
} 
will continue to see in this chapter, most of the aspects of the unique stamp the Madman of Tsang put on the Life and Songs of Milarepa were not completely unprecedented, as some germ of them existed in earlier versions of those texts. But the Madman of Tsang nevertheless exercised significant agency in the decisions he made in creating his own version of the story.

We must also observe that the Madman of Tsang's version of the narrative does not portray Rechungpa's relationship with Milarepa as all bad. They still maintain a close guru-disciple relationship and Milarepa has many flattering things to say about Rechungpa amongst the criticisms. After Milarepa's death, his disciples are unable to light a fire to burn his corpse until Rechungpa arrives, suggesting that the relationship between Rechungpa and Milarepa was of cosmic significance. (This constitutes another comparison between Milarepa and the Buddha, as the latter's body could not be burned until his disciple Mahākāśyapa arrived. ${ }^{922}$ ) Nevertheless, Milarepa and Gampopa’s relationship is a complicated one. This can be taken as an example of the Madman of Tsang's great adroitness in constructing the narrative: he does not bluntly demonize Rechungpa, but subtly marginalizes him in favor of another.

Let us consider one last example of how the Madman of Tsang altered the narrative of the relationships between Milarepa, Gampopa and Rechungpa. There is a famous story often cited by Kagyüpas even today about how Milarepa, after giving his disciple Gampopa all of the teachings he had to impart, then said that there was one final lesson to teach him. Milarepa turned around and lifted up the lower part of his robe, showing Gampopa his rear end, which was worn raw from so many years of sitting in

\footnotetext{
${ }^{922}$ Quintman, Introduction to The Life of Milarepa, p xxvii.
} 
meditation. The final teaching was that meditation must always be the cornerstone of one's practice. This story also helps establish Gampopa as Milarepa's closest disciple and the principal holder of his lineage.

Readers familiar with this story may be surprised to learn that in earlier versions of the tale Milarepa imparted his ultimate teaching not to Gampopa but to Rechungpa. ${ }^{923}$ The Madman of Tsang changed these names and thereby single-handedly changed the history of the Kagyü sect. What could have motivated him to do this?

It seems that the Madman of Tsang's portraying Rechungpa in a generally negative way and emphasizing Gampopa in his stead was ultimately motivated by his concern to further validate his spiritual lineage. As we have seen, one of the main goals of the Madman of Tsang's school in all of the literature they wrote and published was to tell the story of the Kagyü lineage, from time immemorial up to 12th-century Tibet and beyond. If the historical record maintained that Milarepa treated Rechungpa and Gampopa equally or even favored Rechungpa over Gampopa, then the lineage passing through Gampopa and thence to Pakmodrupa, Lingrepa, Tsangpa Gyaré, Götsangpa and Yanggönpa would be diluted somewhat. It would no longer be the primary, most important lineage, as it would have to be treated as of equal significance to or perhaps even subservient to the parallel lineage passing through Rechungpa. To avoid this complication, the Madman of Tsang rewrote the history, making Gampopa — and thus the lineage stemming from him-more important, while relegating Rechungpa to a less important role. The Madman of Tsang even goes so far as to insert into his version of Milarepa's Collected Songs a prophecy voiced by the dākinīs that Gampopa would be

${ }^{923}$ Roberts, pp 217-9. 
superior to Rechungpa. ${ }^{924}$ The Madman of Tsang thus rewrote the early history of his sect in order to streamline his lineage and make it seem stronger, more direct. We see this happen often in Tibetan Buddhism, as later writers of history change details about the specifics of a lineage's past. Oftentimes the lineage gets streamlined, made to seem as if the teachings went directly from one teacher to one disciple in each generation, rather than going to a number of disciples and dispersing in various branches. Once the lineage is streamlined there are fewer detours, and fewer questions about the legitimacy and origins of that sect's teachings.

The Madman of Tsang's taking these steps to portray Rechungpa in such a negative light and to make him secondary to Gampopa might seem counterintuitive given the fact that the Madman of Tsang put such an emphasis on the Aural Transmission teachings and that Rechungpa had a special relationship with those teachings, having gone all the way to India to retrieve some of them. ${ }^{925}$ It would thus seem odd for the Madman of Tsang to marginalize Rechungpa in this way. But as Roberts has argued, the Aural Transmission teachings had been incorporated into the general Drukpa Kagyü lineage and thus marginalizing Rechungpa did not mean casting out the teachings he was associated with. The lineage coming from Gampopa (and from him to the important early Drukpa Kagyüpas) had by the time of the Madman of Tsang become the principal

\footnotetext{
${ }^{924}$ Roberts, p 210.

${ }^{925}$ In the Madman of Tsang's version of this history Rechungpa's getting the Aural Transmission teachings from India becomes a less significant affair. The way the Madman of Tsang portrays it, Marpa had already instructed Milarepa to go to India and get the remainder of the Aural Transmission, but he never did. Thus Rechungpa's going to India to get these teachings is to fulfil Milarepa's destiny, which downplays Rechungpa's significance, in a way. Lobsang P. Lhalungpa, trans., The Life of Milarepa (New York: Penguin Compass, 1992), pp 91-2.
} 
propagator of Rechungpa's Aural Transmission teachings. ${ }^{926}$ By changing the history the way he did, the Madman of Tsang can be seen as working to justify this latter-day situation. Moreover, the Madman of Tsang found a clever way to have it both ways at once: in the Madman of Tsang's version of this history, Rechungpa gives the Aural Transmission teachings to Gampopa after Milarepa's death (Gampopa invited Rechungpa to come to him, and not the other way around). ${ }^{927}$ The main transmission of teachings (Marpa to Milarepa to Gampopa) and the transmission of the Aural Transmission (Rechungpa to Gampopa) thus converge in the person of Gampopa and nothing is lost. This device allows the Madman of Tsang to marginalize Rechungpa in order to portray Gampopa as the main lineage holder after Milarepa, and yet at the same time maintain a direct transmission of the Aural Transmission teachings Rechnugpa had gone to such great lengths to get.

In his explanation of why the Madman of Tsang replaced Rechungpa with Gampopa in the story of Milarepa's meditation-hardened butt, Roberts writes:

This could not have been an error due to Tsangnyön's [the Madman of Tsang's] lapse of memory, as he was evidently familiar with The Life and Songs of Shepay Dorje [an earlier version of the Life of Milarepa], and knowingly created this version, which may have been based on one of his visions of Milarepa's life, or, more probably, was influenced by an oral narrative that was already in circulation, inspired by the Rechungpa version. The Gampopa version need not have been cynically created, but could have been spontaneously formed from a natural osmosis between memories, where events and details are unconsciously transferred from one person to another to form a subjectively more pleasing or inspiring version of events. ${ }^{928}$

\footnotetext{
${ }^{926}$ Roberts, p 218.

${ }^{927}$ Roberts, p 220. Lhalungpa, p 199; 2005 version, pp 843.18-844.1.

${ }^{928}$ Roberts, p 218.
} 
In this passage Roberts suggests a few possible reasons for why the Madman of Tsang replaced Rechungpa with Gampopa in this story. First off, according to Robetrs it could not have been an accident. Rather, Roberts suggests that the change could have been prompted by the Madman of Tsang's having a vision of Milarepa that suggested the teaching had indeed been given to Gampopa. Or the change may have been motivated by the Madman of Tsang's having heard a story passing through the oral tradition that the teaching was given to Gampopa instead of Rechungpa. If this latter possibility were the case, this change in the narrative would have come about as part of a "natural," “unconscious" process. In Roberts' thinking, to see the Madman of Tsang's making this change as the result of a purposeful decision is "cynical."

Whether or not the Madman of Tsang's change to the narrative may have been motivated by a mystical vision of Milarepa cannot be proven or disproven. We know that there is little in The Life of the Madman of Tsang to suggest that his particular portrayal of Milarepa was meant to be understood as based on a set of visions. Ultimately this possibility must be bracketed and set aside, as it involves nothing but pure speculation.

The next possibility suggested by Roberts asserts that this change came about as the result of an essentially accidental process. This posits the Madman of Tsang as free from any ulterior motive in composing the text. I think, given the greater pattern displayed in the production of this literature, that there certainly was a larger motive in the project. If we cannot accept this view because it is "cynical," then the Madman of Tsang cannot have individual agency of his own, which is an unfortunate and unwanted consequence. In my understanding it does Sangyé Gyeltsen, the Madman of Tsang, more 
justice as a creative and intelligent human being if we see his acts and decisions as purposeful.

\section{II.1.ii.2.b Milarepa as Anti-Institutional}

In this section we will look at some interrelated aspects of the Madman of Tsang's version of The Life of Milarepa that, taken together, reveal one of the Madman of Tsang's main agendas in writing the piece. We will describe each of these four aspects of the Madman of Tsang's version of the Life, then analyze their significance below.

First, one important change made to the narrative by the Madman of Tsang was to strongly emphasized Milarepa's not being an emanation of a deity or an enlightened master from the past, but rather an ordinary person — in fact, a great sinner - who achieved total liberation thanks to his own diligence. Earlier versions of the Life had stated that Milarepa was an emanation of the Indian saints Nāgārjunagarbha (klu grub snying po) or Mañjuśrīmitra ( 'jam dpal bshes gnyen). ${ }^{929}$ The Madman of Tsang openly repudiated the tradition of viewing Milarepa in such a way, which changes the way one understands Milarepa and the liberation he would eventually achieve. (Taking a very different perspective than Roberts, Quintman states that this change was "strategic."

Second, another change in the content of The Life of Milarepa made by the Madman of Tsang was to place great emphasis on the fact that Milarepa exemplifies how one can achieve enlightenment, via the practice of tantra, in a single lifetime. The Madman of Tsang expressed explicitly that the text would serve to change the minds of "those who doubt the possibility of attaining Buddhahood in one lifetime." Milarepa's

\footnotetext{
${ }_{929}$ Quintman 2006, pp 222-31.

${ }^{930}$ Quintman 2006, pp 221, 232.
} 
life would stand as a model—indeed, an argument — for how Buddhahood can be attained in a single lifetime and that it is possible during the period of history in which we live. (As with many of the remarkable characteristics of the Madman of Tsang's version of the Life and Songs of Milarepa, this way of portraying Milarepa did exist in earlier versions of the Life; what made the Madman of Tsang's version unique was the way he foregrounded these aspects of his Milarepa, making them central, unifying themes in the narrative. ${ }^{931}$ ) Throughout the Madman of Tsang's version of the Life, an inherent tension is created by the fact that Milarepa is portrayed as the equivalent of the Buddha, and at the same time as an ordinary person. What transmutes Milarepa from an ordinary person into a Buddha is the value of the unique teachings he became a vessel for and his diligence in meditation.

Third, the 7th chapter of the Madman of Tsang's version of The Life of Milarepa, which tells of his "meditating without distraction in the mountains" (yengs med du ri la bsgoms pa), contains an arc that is extremely pertinent to our discussion here, and indicative of the implicit argument about Milarepa the Madman of Tsang wanted to make. The 7th chapter tells of a period in Milarepa's life when he was practicing the most austere form of asceticism. The arc begins when Milarepa is visited by the girl to whom he had been betrothed as a boy, Dzesé (mdzes se). When she asks him about why he has given up all of his possessions, so that he does not even have the means to provide for his own food, he says that he will do ascetic practice and find food "as mice and birds do." He states his commitment to living alone in a cave. Dzesé observes that in doing so

${ }^{931}$ Quintman 2006, pp 177, 234. 
Milarepa lives in a way that is the opposite of most other religious practitioners.

Milarepa explains his position,

First of all, there are ones who think only of worldly goals and are content with studying a few religious books; thinking only about the present, they rejoice in their own success and in the failures of others. They amass as much wealth and fame as they can. Called "religious practitioners" (chos pa), they put on yellow robes. I turn away from them and always will.

Milarepa goes on to say that there are others who are not like this, whose minds and practice are not corrupted. To them he has no reason to turn his back. Dzesé says that she has never before seen a religious practitioner take on austerities the way Milarepa has, and that he appears to be worse off than even a beggar. She asks, "What kind of Mahāyāna is this manner of dressing from?" ('di theg pa chen po gang gi cha lugs yin). She goes on: "As you say, your way and theirs are quite opposites; one of them must be false. If they are both equally true, I would prefer their way to yours." ${ }^{932}$

This exchange sets up the idea of there being two distinct ways of practicing religion. There are those who study books, wear yellow robes and amass wealth, and then there are those like Milarepa who embody true asceticism. These two ways of practicing religion are opposites, and they cannot both be efficacious. Milarepa's entire Life, as written by the Madman of Tsang, constitutes an argument that his is the true way to Buddhist salvation.

Milarepa goes on with his austerities. Years pass. He becomes as thin as a skeleton and his skin turns green, the color of the nettles that were his sole source of sustenance. Some hunters who happen upon his cave mistake him for a ghost. Over time

\footnotetext{
${ }^{932} 2005$ version, pp 140.9-142.8; Lhalungpa, pp 111-2. My translations are based on Lhalungpa's, with some changes.
} 
his clothes fall apart, leaving him naked as he meditates. (The fact that he can live naked in frigid Tibet is an indication of Milarepa's success in inner-fire, gtum mo, meditation.) Eventually Milarepa's sister Peta ( $p e$ ta) finds him, having heard someone repeat a song he had sang to some hunters. Without knowing that the words had originated from her brother, Peta exclaimed, "Whoever spoke these words is a Buddha!"933 When Peta finds Milarepa in his cave, emaciated and green, she is saddened by seeing him reduced to such a miserable state. He sings a song reassuring her that it is all for the Dharma:

My food is like that of dogs and swineat the sight of it, others would be moved to nausea.

My body is like a skeletonat the sight of it, even an enemy would shed tears.

If you look at my behavior, it's like that of a madman, and my sister blushes with shame.

But if you look at my mind, it is that of a real Buddhaat the sight of it, the Victorious One rejoices. ${ }^{934}$

Peta responds by saying that it is difficult to accept Milarepa's words as true. If this is the authentic practice of the Dharma, why is it that she has never seen anyone else as miserable as this before?

This song and Peta's response return us to the theme that defines this arc in the story: that Milarepa's form of religious practice puts him at direct odds with the ways of others. It may even make him appear, to others, like a madman.

\footnotetext{
9332005 version, p 154.18; Lhalungpa, p 123.

${ }^{934}$ zas la bltas na khyi phag dra/ /gzhan gyis mthong na skyug bro ldang / lus la bltas na keng rus 'dra/ /sdang dgras mthong yang mchi ma 'chor/ /spyod lam bltas na smyon pa 'dra/ /sring mo yi mug kha skyengs skye/ /sems la bltas na sangs rgyas dngos//rgyal bas gzigs na spro ba skye/. 2005 version, $\mathrm{p}$ 156.14-.18. My translation is based on Lhalungpa, p 124.
} 
After some days Peta returns again, this time accompanied by Dzesé. Together they implore Milarepa to relax his asceticism somewhat, to eat real food and put on some clothing. Having consumed some of the food and beer the two women brought to him, Milarepa has even greater success in his meditation and experiences the highest peak of realization. ${ }^{935}$ (This may constitute an implicit comparison between Milarepa and the Buddha, who achieved enlightenment only after ending his years of fasting, having discovered the necessity of adhering to a middle way between extreme laxity and extreme asceticism.) Now Milarepa is a fully realized siddha, and has the miraculous powers, like being able to fly, that come with it. ${ }^{936}$

Sometime later Milarepa's sister Peta finds him again, naked, staying at Drakar Taso (which would centuries later be the site of Lhatsün Rinchen Namgyel's printing activities). (This time she found him by hearing word that a there was "a yogi like a nettle-bug," rnal 'byor pa zwa'i 'bu 'dra ba zhig. Knowing that this could only refer to her brother, she set out in search of him.) In the course of her traveling to Drakar Taso Peta saw one Lama Bari Lotsāwa (bla ma ba ri lo tsA ba), who was dressed in rich silk garments and sat upon a throne under a canopy. When his monks blew horns, people gathered to give him chang and tea and lavish offerings. When Peta finds Milarepa she suggests that he try to live in a way more like Bari Lotsāwa. Crying, she says that even if Milarepa were to become the lowest of Bari Lotsāwa's monks, his life would be

\footnotetext{
${ }^{935}$ Lhalungpa, pp 126-7.

${ }^{936}$ Shortly after this Milarepa encounters some girls along the road. In the course of the song he sings to them he says: "In the middle, on man's realm, Earth, / wise teachers are ignored, and false ones preferred. / In the four horns of $U$ and Tsang / meditation is ignored, and teaching preferred. / In the degenerate age of the Kali Yuga / good people are ignored, and wicked ones preferred. / In the eyes of these beautiful girls / the yogi is ignored, and the handsome man preferred." These lines continue the theme of Milarepa's criticisms of the wider religious culture that surrounded him at the time he lived, and the dichotomy Milarepa sets up to express this. 2005 version, p 168.8-.13. My translation is based on Lhalungpa, p 134.
} 
incomparably better than the way he lives now. What is the purpose of Milarepa's putting himself through so much hardship, when other religious practitioners can live a life of greater ease?

In response Milarepa questions the nature of his sister's suggestion, asking her if she is ashamed of his nakedness. He asserts that his nakedness is no cause for shame. The real cause for shame is committing sin. Living off temple offerings and the lama's wealth - that is a cause for shame. Milarepa states that he has chosen this life of extreme austerities because he is so disgusted with the ways of worldly people. He quotes his master Marpa, who told him, “Abandon the busying distractions of the eight worldly concerns. Do without food, clothing and fame. Wander in solitary places without a fixed abode. Above all else, meditate with intense devotion and determination, abandoning concern for this life. ${ }^{937}$ (According to Götsang Repa's account, the Madman of Tsang's own master, Shara Rabjampa would instruct him with very similar words: "Assume a humble position; wear tattered clothing; make yourself destitute of food, clothing and conversation..."938) Milarepa states that he could live exactly as Bari Lotsāwa does, but he chooses not to. Instead, he fully dedicates himself to meditation in his quest to achieve enlightenment in his present lifetime. He then sings a song restating his choice to renounce worldly pleasures, including the joys of monastery life, with the perks of tasty butter tea, young monks eager to serve, and eloquent discourses to listen to. ${ }^{939}$

\footnotetext{
937 'jig rten gyi chos brgyad 'du 'dzi'i g.yeng bas pongs/ gyang lto gos gtam gsum la thongs/ gnas nges med kyi dben pa 'grims la/ tshe 'di blos btang gi bsam sbyor drag pos sgrub pa gtso bor thon cig. 2005 version, p 171.2-.4. My translation is based on Lhalungpa, p 136.

${ }^{938}$ Götsang Repa, p 25.6 ... sman pa'i sa zung / lhul po'i gos gyon/ gyong lto gos gtam gsum la thong /

9392005 version, pp 169.4-173.13; Lhalungpa, pp 135-8.
} 
Milarepa's sister is not swayed or convinced by this. She charges that Milarepa could never achieve a state like Bari Lotsāwa's and all his words are just an excuse. Unhappy with Milarepa, she leaves, but not before giving him some fabric out of which to make a simple loincloth. When Peta returns a few days later, she sees that instead of a loincloth Milarepa has made a very practical hood to cover his head and crude sheaths for his fingers and penis. Shocked, she exclaims, "Look at him! My brother has nothing human left in him!" Milarepa again states that he has nothing to be ashamed of, that he regards all the parts of his body as the same, and thus has no reason to hide his sexual organ. Does Peta's anger at him not ultimately come from her shame at her own sexuality? Milarepa restates his position that it is worldly ways that are a cause for real shame, not the fact that he has come at odds with samsāric norms in the course of his religious practice. ${ }^{940}$

Throughout this chapter of the Life a contrast is established between Milarepa's extreme ascetic lifestyle and the ways of pretty much all other religious practitioners. As Peta herself says, they both cannot be valid at the same time: one of these must represent the true way to practice religion, while the other is deluded. The argument made by the whole Life is that the true way must certainly be Milarepa's. Peta has great trouble accepting this, as she is unable to see the need for such extreme asceticism. If other lamas can live so differently, in such ease, why must Milarepa insist on making himself so destitute? Peta and Dzesé represent what ordinary people might well think. But Milarepa is adamant, arguing that just because Bari Lotsāwa's life of luxury is common and almost expected, that does not make it right. Milarepa stands at stark odds with what

9402005 version, pp 173.14-175.6; Lhalungpa, pp 138-9. 
is normal and expected in religious practice. Through the way he lives, Milarepa presents a new model of Buddhism. It is not entirely new, for it is said to represent the ways of great meditators of the past, but it is new in the sense that few were living this way during Milarepa's time. Milarepa's way of practicing religion is not the norm, but he and the Madman of Tsang want it to be.

We will return to talk about the story of Milarepa's refusal to properly clothe himself later in this chapter, amidst discussion of his role in defining the idea of holy madness.

Fourth, perhaps most telling of the Madman of Tsang's agenda in writing The Life of Milarepa are the circumstances surrounding Milarepa's death. In earlier versions of his biography, Milarepa's death came as a result of his being poisoned by a jealous Bönpo priest with whom he had an argument. The Madman of Tsang changed this, substituting a jealous geshé, a scholar-monk, in the Bönpo's place. ${ }^{941}$ According to the Madman of Tsang, the relationship between the Madman of Tsang and the geshé proceeded like this (as this is the end of Milarepa's Life, the narration has switched to the third person, no longer presented as Milarepa's first-hand oral account):

There was a rich and influential geshé Tsakpupa (rtsag phu pa), living at Drin (brin). At first he honored Milarepa but in time became envious of Milarepa and wanted to embarrass him in the presence of a crowd of lay patrons.

It came about that Milarepa was asked to preside over a wedding. Geshé Tsakpupa was also there. The geshé prostrated to Milarepa, but Milarepa, having only

\footnotetext{
${ }^{941}$ Quintman 2006, p 202, reads this change as part of the Madman of Tsang's broader attack on "arrogant geshes," merely "stirring up bubbles of technical jargon." On how this account diverges from earlier versions of Milarepa's Life, see Quintman 2006, pp 108, 113, 156.
} 
ever prostrated to his lama, did not return the courtesy. This incensed the geshé. He handed Milarepa a text on Buddhist logic and asked for a word-by-word explanation. Milarepa responded by saying that the geshé himself knew the conceptual meaning of the text (tshig rigs kyi 'bru gnon), but not the inner meaning (don gyi 'bru gnon). The inner meaning is that one should abandon worldly attachments and meditate. Otherwise one is only arguing over words, engaging in sophistry, which is ultimately useless. Milarepa then sings a song based on a long series of pairs with starkly contrasting elements: having meditated on his tutelary deity, he has forgotten the world of the senses. Having done tantric meditation, he has forgotten the books on dialectics. Having taken the Teachings into his mindstream, he has forgotten to engage in doctrinal polemics. Having dwelt in the unaltered state of naturalness, he has forgotten the ways of hypocrisy. Having made a monastery inside his body, he has forgotten the monastery outside. Here again we see the setting up of a stark dichotomy between the Milarepa's true religion and the false religion of nearly everyone else. Milarepa's is one that eschews conventional meanings and external displays of religiosity in favor of putting the teachings into actual practice. ${ }^{942}$

After hearing this song the geshé expresses disappointment with Milarepa, who refuses to engage him in debate. He says, "In the tradition of great meditators, one can get away with that kind of talk. But if one were to engage it with my logical reasoning, your words wouldn't go anywhere."943 The patrons present take Milarepa's side and say to the geshé, "However learned you may be, the world is full of ones like you. You are not equal to even a pore on [Milarepa's] body. So please be silent and sit in the line with

\footnotetext{
9422005 version, pp 788.2-790.7; Lhalungpa, pp 153-5.

${ }^{943}$ khyed rang sgom chen rnams kyi lugs la de skad yin pa srid/ nged mtshan nyid pa'i rigs pas ded na chos skad rnams kyis gang du'ang mi phyin par 'dug/. 2005 version, p 790.8-.10; Lhalungpa, p 155.
} 
everyone else. Increase your wealth as much as you can, since there isn't even a whiff of religion about you." 944

As we see in the course of this exchange, the conflict between Milarepa and the geshé is one of two mutually-exclusive discourses. The geshé's is the discourse of philosophers; Milarepa's, that of meditators. The geshé's discourse is pedestrian. He accumulates wealth. Milarepa, on the other hand, represents something exceptional. Milarepa's entire style of Buddhism, the truth regime of which he is a representative, is a direct threat to the system embodied by the geshé. The difference between these two discourses is ultimately about competing understandings of the true meaning of the teachings of the Buddha.

The exchange goes on. In his anger the geshé thinks,

By acting in this way-doing nonsense things and acting like a madman (smyon pa) who doesn't know anything, saying false and deceitful things-Milarepa degrades the Teachings of the Buddha. Fooling people, he brings in a lot of money. I have so much knowledge, am the richest, most influential person in this area, and yet am seen as less than a dog. I must do something about this. ${ }^{945}$

Although the geshé here accuses Milarepa of accumulating wealth, the reader knows this is not true. After it is revealed that the geshé has secret plans to marry a woman (another jab at the monastic tradition), he has some poison mixed with curdled milk and sent to Milarepa. The enlightened, omniscient Milarepa knows that the food is poisoned, but eats it anyway, out of compassion for the unfortunate messenger who had brought the food to him, who would have been shamed if she did not complete her mission. Milarepa's accepting death at the hands of the evil geshé is one last compassionate,

\footnotetext{
9442005 version, p 790.11-.16; Lhalungpa, p 155.

9452005 version, pp 790.17-791.3; Lhalungpa, p 155. ci yang mi shes pa'i smyon spyod dang tho co...
} 
selfless act. ${ }^{946}$ Before dying, Milarepa leaves some final advice to his followers, exhorting them to take up a non-institutional form of religious life like his. He instructs them not to build a reliquary for his remains, not to set up a monastery, but rather to stay in solitary spots in the mountains and meditate, always maintaining the proper mindset. ${ }^{947}$ He assures them that even if in the course of practicing in this way they go against the literal words of religious texts, they are not opposing the intentions of the Buddha. ${ }^{948}$ The question of differentiating between the word-level meaning of a teaching and its inner meaning is an issue that runs throughout the articulation of the dichotomy between Milarepa's way of living and that of other religious practitioners.

Before he dies Milarepa receives one last visit from the evil geshé Takpupa, during which the great yogi shows the scholar that he ultimately does have control over this illness and has allowed it to afflict him voluntarily. To prove his miraculous abilities to the doubtful geshé, Milarepa expels the illness from himself and puts it into the geshé for a moment. The geshé collapses in pain, paralyzed, on the verge of death. Milarepa takes the illness out of the geshé, informing him that he had only felt half its strength. The geshé, now realizing Milarepa's incomparable superiority as a spiritual being, throws himself at the yogi's feet and apologizes for the sin of having poisoned him. Milarepa forgives him, and the geshé promises to dedicate himself to meditation and leave off sinning for the sake of accumulating wealth in the future. ${ }^{949}$ After some final miraculous displays to his disciples, and some more final teachings ("Dress in rags, and content

\footnotetext{
${ }^{946}$ Lhalungpa, pp 155-7.

${ }^{947}$ Lhalungpa, p 164; 2005 version, p 804.

${ }^{948}$ de ltar byas na yig nag gi dpe cha 'ga' zhig dang 'gal rung / rgyal ba gong ma'i dgongs pa dang mi 'gal ba... 2005 version, pp 804.19-805.2; Lhalungpa, p 165.

9492005 version, pp 806.14-810.2; Lhalungpa, pp 166-9.
} 
yourselves with little food, clothing, and recognition," 950 echoing his guru Marpa's own instructions to him, and Shara Rabjampa's words to the Madman of Tsang), Milarepa passes away.

In choosing to make the person who killed Milarepa a geshé rather than a Bönpo, the Madman of Tsang has made a strategic change to the narrative, and in fact the history of Milarepa. This is not the only instance where an anti-scholastic sentiment is expressed. Let us not forget that the Madman of Tsang explicitly stated (according to Götsang Repa) that one purpose of composing and printing his Life of Milarepa was to counteract the influence of the "arrogant geshés," who were, Quintman writes, "favored antagonists under [the Madman of Tsang's] pen."951 Why was the Madman of Tsang compelled to demonize scholastic Buddhism in this way? We have to understand this as part of the Madman of Tsang's greater agenda in writing The Life of Milarepa, exemplified in the four characteristics of his narrative just described, which we will now interpret.

Here we have looked at four aspects of the Madman of Tsang's version of The Life of Milarepa: 1) Milarepa's not being a reincarnation of an already-enlightened master, but rather an ordinary being; 2) Milarepa's achieving liberation in one lifetime through the power of tantra and the strength of his meditation; 3 ) the arc told in the 7th chapter of the Life, concerning Milarepa's extreme asceticism; and 4) the fact that he was killed by a scholar-monk. Taken together these four things indicate one of the most

\footnotetext{
${ }_{950}^{950} 205$ version, p 813.15-.17; Lhalungpa, p 171.

${ }^{951}$ Quintman 2006, p 202.
} 
important aspects of the Madman of Tsang's agenda in composing The Life of Milarepa. To understand what compelled the Madman of Tsang to make these changes and shape the Life in this way, we must look at the state of religion in Tibet in the 15th century when the Madman of Tsang wrote his composition, and how it had been transformed in the preceding few centuries.

At the time of Milarepa, in the loosely-defined tradition that would later become the Kagyü, religious authority was embodied first and foremost by charismatic individuals. Their authority was based on their claims to meditative realization, displays of great learning or virtuosity as translators, and their possession of teachings said to have originated in India. There was very little in terms of institutional structure surrounding these individuals. Over the next few centuries after the time of Milarepa, this would change dramatically.

This process of institutionalization involved a few different changes taking place within Tibetan religious culture, in a series of steps. During and for a few centuries after the time of Milarepa most of the monasteries founded in central Tibet were essentially the property of the families or clans that sponsored them. The abbotship of the monastery would usually be passed down from a celibate uncle to his nephew, and thus the monastery's resources would remain under the family or clan's control. This was the case with the Khön ( 'khon) family at Sakya Monastery, and the Lang (rlangs) clan at Densa Til Monastery (seat of the Pakmodrupas). Most of the monasteries at the center of the various "sub-branches" of the Kagyü would operate on this model.

Over time a new vehicle for the transmission of authority would develop: the reincarnation or emanation (sprul sku, sprul pa) model. At monasteries where this model 
was in place, control over the monastery would no longer be passed down from uncle to nephew, but rather from a master to one who was considered to be his reincarnation. Turrell Wylie has argued that the reincarnation model offered some advantages over the older family-based model in terms of the formation of stable institutions. The familybased model had an inherent flaw, which is that sibling rivalries and infighting would be a perpetual issue. (Was this the kind of trouble that caused Drukpa Künlé's uncle to kill his father?) Moreover, seeing the situation from a Weberian perspective, Wylie observes that in the family-based model, the position of controlling such a monastery would essentially be based on the charisma associated with that individual and his family, generation after generation. With the transition to the reincarnation model of succession, the position was no longer defined by the charisma of the individual but the charisma of the office itself. The individual did not necessarily bring charisma to the position, but derived his charisma from it. This would create a more stable institution and ensure its long-term survival. ${ }^{952}$

In some cases the same families and clans would continue to dominate the affairs of the monastery if these reincarnations were continually found within their ranks. Sometimes new families were brought into the fold. At other times reincarnations were found among unimportant families, which allowed the monks holding positions in the monastery's administration to strengthen their control over the institution. There were many monastic corporations based on the reincarnation model (in some cases, the resources at stake were much more than just a single monastery), including the Karmapas

952 Turrell V. Wylie, "Reincarnation: A Political Innovation in Tibetan Buddhism" in Proceedings of the Csoma de Korös Memorial Symposium, held at Mátrafüred, Hungary, 24-30 September 1976, edited by Louis Ligeti (Budapest: Akadémiai Kiadó, 1978), p 584. See also E. Gene Smith, "Padma dkar po and His History of Buddhism," in Among Tibetan Texts, p 81. 
(the second Karmapa was recognized an the reincarnation of the first at the beginning of the 13 th century), and much later the Dalai Lamas (who in the middle of the 17 th century would become the most powerful of all reincarnation lineages in Tibet).

Throughout the period from the 11 th century to the 15 th, both of these models for the transmission of religious resources existed in central Tibet. During the time of the Madman of Tsang, both systems were fully intact, with the reincarnation model gaining ground and the familial system gradually becoming less common. Together they constituted a shift away from religious authority being passed on through charismatic leaders and an increase in institutionalism, as the emphasis was on the stability of religious life at a specific place with a set of material resources at their disposal - in most cases, a monastery or a network of monasteries, and all of their contents. (Someone must own the golden Buddha statues and other precious objects in the temples.) This created a situation in which, in the words of E. Gene Smith, a "hereditary religious nobility" ruled Tibet during the time of the famous 15 th-century holy madmen. ${ }^{953}$ (That the literary school of the Madman of Tsang did not write biographies of figures between the middle of the 13 th century and the middle of the 15 th may be a commentary on these developments.)

This shift towards a more institutionalized Kagyü sect started in the 12th century. ${ }^{954}$ As this took place, as Carl Yamamoto observes, the prototype on which Kagyüpas modeled themselves shifted from being based on a siddha figure like Nāropa during the time of Milarepa, to later being based on figures like Gampopa's disciples,

\footnotetext{
953 Smith, "Introduction to The Life of Gtsang smyon Heruka," p 60. Quoted in Quintman 2006, p 234.

${ }^{954}$ Quintman 2006, pp 83-4. Carl Shigeo Yamamoto, Vision and Violence: Lama Zhang and the Dialectics of Political Authority and Religious Charisma in Twelfth-Century Central Tibet (Ph.D. dissertation, University of Virginia, 2009), pp 169-70.
} 
who set up fixed and long-lasting monastic institutions. As I will now show, the four aspects of the Madman of Tsang's version of The Life of Milarepa described above are all part of his attempt to repudiate this more institutionalized form of religion and articulate an alternative model based on an older precedent.

Andrew Quintman has argued that the Madman of Tsang's motivation for portraying Milarepa as one who achieved religious supremacy on his own merits - as opposed to because of his being a reincarnation of an already-enlightened being - was to articulate a rejection of the standing power structures in Tibetan religious culture, "a commentary on the degree of power and prestige that the institutionalized incarnation traditions had garnered." 955

In the same vein, we can see the Madman of Tsang's emphasis on the fact that Milarepa achieved liberation in a single lifetime as attendant to his assertion that Milarepa was not an emanation of an already-enlightened figure. It is thus another element of the Madman of Tsang's commentary on reincarnation-based institutions.

Milarepa's — and the Madman of Tsang's — rejection of this more institutionalized form of religion is signaled in the dichotomy established in Milarepa's conversation with his sister Peta about two opposite models of religious life: that represented by Bari Lotsāwa and that represented by Milarepa. Bari Lotsāwa represents institutionalized Buddhism. It is comfortable and requires no great sacrifices on the part of the practitioner. They wear clean yellow robes; they engage in scholasticism and much empty pomp. Milarepa's model of religious life involves assuming great hardship —at

${ }^{955}$ Quintman 2006, p 240. 
most he wears a simple loincloth and eats nothing more than nettles. And Milarepa's model of religious life emphasizes meditation above all else.

As this dichotomy and many other aspects of Milarepa's Life indicate to us, it is not just institutionalism that is the object of the Madman of Tsang's concern, but its handmaiden, scholasticism. The Madman of Tsang's disdain for scholasticism is shown above all else in his changing Milarepa's killer from a Bönpo to a geshé. The fact that the Madman of Tsang changed the Milarepa narrative in this way suggests that he perceived the foremost threat to his tradition to be something quite different than his forebears had. It would seem that to the Madman of Tsang's mind, the greatest threat to the tradition of which Milarepa and he were a part was not non-Buddhists or Nyingmapas upholding an older set of teachings (Nyingmapas having often borne the brunt of other sects' polemics ${ }^{956}$ ), but geshés upholding a different style of Buddhism. As was shown above, one of the Madman of Tsang's motivations in writing and printing The Life of Milarepa was, according to Götsang Repa, to promote a dramatic change in some "arrogant geshés who are on the verge of becoming non-Buddhists." Just whose ways it was that the Madman of Tsang hoped to change by illuminating them with The Life of Milarepa, we cannot be sure, but the issue of the Madman of Tsang's position vis-à-vis scholastic Buddhism will come up multiple times as we consider what was unique and significant about his version of the Life.

The point about Milarepa's being able to achieve enlightenment within a single lifetime even within our current world age (as Milarepa points out, we live in the Kali

\footnotetext{
956 The Madman of Tsang's Life of Milarepa does contain a jab at the Nyingmapas, but this was derived from an earlier version and reflects concerns from an earlier time period, Quintman 2006, p 148.
} 
Yuga, the degenerate age) contributes to the Madman of Tsang's argument against scholasticism and in favor of a form of Buddhism that puts a greater emphasis on meditation. This brings to mind moments in Götsang Repa's version of The Life of the Madman of Tsang, when the yogi is forced to justify his mode of acting and dressing to geshés of the Geluk sect who charge that the world-period they lived in was not one in which tantra should be practiced so literally (da lta gsang sngags dngos su nyams su len pa'i dus min). To this the Madman of Tsang responds, "If now is not the time to practice tantra [literally], when is?" (da lta gsang sngags nyams su ma len na nam nyams su len). The issue in Milarepa's Life about achieving Buddhahood in a single lifetime is best read as the Madman of Tsang's attack on more gradualist approaches to Buddhism that were dominant (or on their way to becoming dominant) in Tibet during his own time.

We can see how the Madman of Tsang's portrayal of Milarepa as out-of-step with the way most practitioners during his time lived is an expression of the position he adopted in his own life vis-à-vis the broader Tibetan religious culture around him. Milarepa's words are the Madman of Tsang's own, and they register equally in both of their time periods. Thus The Life of Milarepa as produced by the Madman of Tsang itself constitutes something like a polemic against institutionalized and scholastic forms of Buddhism. We cannot read too far into this as referring specifically to Gelukpas, but it does seem that the Madman of Tsang feared the advances being made by the sort of Buddhism of which the Gelukpas were the foremost representative.

In the process of formulating a Life of Milarepa that contained within it criticisms of institutionalism and scholasticism, the Madman of Tsang was not just criticizing the dominant models of religious authority in Tibet, but also making an argument for an 
alternative one. In Quintman's words, these changes “stem from a desire to return the Bka' brgyud [Kagyü] tradition to its core values, rooted in the early tradition of yogic meditation and retreat." 957 This alternative is exemplified by the model of Buddhistness enacted by Milarepa in his extreme asceticism, his refusal to accept a position of comfort, and his emphasizing meditation and the practice of tantra above all else. This argument - that the Madman of Tsang was a reformer, promoting a return to an older form of religious life that had been embodied by past masters of the Kagyü sect-has been articulated before. One of the most influential and quoted characterizations of the Madman of Tsang and other 15th-century holy madmen comes from E. Gene Smith, who writes,

The smyon $\mathrm{pa}$ is a phenomenon that suddenly flowered during the fifteenth century during an age of fervent religious reform and doctrinal systematization. The smyon pa is the antithesis of the scholastic monk; yet to view the phenomenon simply as a reaction against monastic reforms and Dge lugs pa rationalism misses much of the point. The smyon pa, too, represented a force for reform. Just as the movement of Tsong kha pa attempeted to reorient the Bka' gdams pa tradition toward the fundamental contributions of Atiśa - the Graduated Path (Lam rim), with its emphasis on the exoteric as an indispensable foundation for the esoteric - so the smyon pa represents an attempt to re-dedicate the Bka' brgyud pa sects to old truths and insights that were being forgotten. ${ }^{958}$

Smith states that the holy madmen were trying to "re-kindle the incandescent spirituality of the early yogis." 959 This passage highlights many of the points being made in this

\footnotetext{
${ }^{957}$ Quintman 2006, p 234.

${ }^{958}$ E. Gene Smith, "Introduction to The Life of Gtsang smyon Heruka," pp 59-60. John Ardussi (who cites Smith) makes a similar statement: "The expression of saintly madness in the fifteenth and sixteenth centuries of Tibet should not be viewed, however, as being merely a literal interpretation and public exhibition of the tenets of the standard Tantric texts. What seems to have motivated these men was a sense of duty to restore the tradition of the solitary, wandering yogi to the level of its former greatness in India," 'Brug-pa Kun-legs, The Saintly Tibetan Madman (Master's thesis, University of Washington, 1972), p 39.

The slight change that I want to make to this argument here is to highlight the active role the holy madmen played in creating this older tradition, rather than simply restoring or reenacting it.

${ }^{959}$ Smith, "Introduction to The Life of Gtsang smyon Heruka," p 60. See also Quintman 2006, p 14: "The works of Gtsang smyon Heruka, author of Mi la ras pa's standard life story... marked a renewed and
} 
dissertation and presents a balanced interpretation of the Madmen of Ü and Tsang. I would like to qualify Smith's statement slightly by emphasizing that saying the holy madmen represented "an attempt to re-dedicate the Bka' brgyud pa sects to old truths and insights that were being forgotten" suggests that the "old truths and insights" of the Kagyü sect were somehow a static, pre-determined body of ideas. What I am emphasizing in this consideration of the literary creations of the Madman of Tsang is that he was actively involved in the process of selecting and creating those "old truths and insights." The Madman of Tsang and his circle did not simply adhere to a standard narrative of the history of their sect that had been passed down to them, but took an active role in creating that narrative. For this reason I argue that it is most accurate to see the eccentric behavior of the Madmen of $\ddot{U}$ and Tsang not as about reliving the past of the Kagyü sect so much as it was about redefining the Kagyü in their present moment, in large part by rewriting its history. The Madman of Tsang was not just a reformer in the sense of going back to the past, but one who created something new during the time in which he lived.

We should emphasize, as Smith has, that the 15th-century madman movement was not one of just criticizing other Buddhist traditions, but one that asserted its own model of Buddhistness. As I argue, an integral part of how they achieved this was through composing and mass-disseminating narratives about the earlier masters of their tradition. Those narratives function as, among other things, polemics against institutional and scholastic forms of Buddhism. But we should not take this so literally as to think that

concerted attempt at reinvigorating the representations of the early founders from which his own tradition had sprung." 
the Madman of Tsang wanted to revert back to some primitive, completely antiinstitutional form of religious life for the Kagyü. On the contrary, the Madman of Tsang displays a great concern for the Kagyü as a corporate body. His purposeful composing and mass-disseminating this body of literature enabled the ideas of anti-institutionalism and an emphasis on meditation to become commodified as tropes that helped define and characterize the Kagyü in the midst of the competitive religious marketplace of 15 th- and 16th-century Tibet. The Madman of Tsang did not want the Kagyü to go back to the way it was at the time of Milarepa. Rather, he wanted to use a vision of Milarepa to strategically characterize the Kagyü in the 15th century. (In the Madman of Tsang's rendering of him, Milarepa rails against those who make outward displays of religiosity. Is anyone actually more guilty of this than the Madman of Tsang, who walked around Tibet dressed in the garb of a wrathful tantric deity, and performed such provocative behavior in the most public of places? The penniless Milarepa is set up as a foil to the rich and evil Geshé Takpupa. But wasn't the Madman of Tsang himself more like the geshé than Milarepa in financial matters?)

As Yamamoto has noted, in the centuries after Milarepa there was a shift in which the prototypical Kagyüpa went from being a figure like Nāropa to someone more like Drikungpa Jikten Sumgön or the First Karmapa, Düsum Kyenpa-from a great meditator to a great founder of an institution. The argument has been voiced that the 15 th-century holy madmen wanted to go back to this earlier model. I argue that this understanding comes from too literal a reading of the literary production and activities of the holy madmen, failing to see their real-world ramifications in a 15th- and 16th-century context. It is not the case that the Madman of Tsang really wanted all members of the Kagyü sect 
to "Do without food, clothing and fame," as Marpa had instructed Milarepa, and Milarepa

his many disciples, and as he was instructed by his own teacher. Quite to the contrary, the Madman of Tsang was ultimately commodifying the ideas of meditation and asceticism, embodied in the story of Milarepa, in order to strategically position the Kagyü sect in the competitive marketplaces of 15th- and 16th-century Tibet.

If we were to take seriously the idea that the Madman of Tsang wanted to create a completely non-institutional form of the Kagyü, it would seem ironic that the literature he and his school produced would come to be so important for the Kagyü's self-definition as a corporate body. However, I believe we have reason to believe that the Madman of Tsang intended for this very thing to happen. We will see this more clearly in the following section.

Much remains to be discovered regarding the decisions made by the Madman of Tsang in producing his great works of literature. Asking these questions requires comparing the Madman of Tsang's versions of narratives with earlier ones, in order to identify what changes and innovations he made. This is very labor intensive work, but based on research done by Quintman and Roberts, some insight into the agency the Madman of Tsang exercised can be gained. What this work uncovers is that the Madman of Tsang had an agenda that he was trying to further through his compositions. ${ }^{960}$ The

\footnotetext{
${ }^{960}$ Roberts' explanation of how this might have taken place is worth considering. On the question of why in the Madman of Tsang's version of this history Milarepa gives this teaching to Gmapopa rather than to Rechungpa, Roberts states: “This could not have been an error due to Tsangnyön's lapse of memory, as he was evidently familiar with The Life and Songs of Shepay Dorje, and knowingly created this version, which may have been based on one of his visions of Milarepa's life, or, more probably, was influenced by an oral narrative that was already in circulation, inspired by the Rechungpa version. The Gampopa version need not have been cynically created, but could have been spontaneously formed from a natural osmosis
} 
changes he made were systematic. For the most part he got away with these changes, as

they became the standard history (the story in most peoples' minds is that Milarepa gave

his final, bare-butt teaching to Gampopa, and not to Rechungpa). But the Madman of

Tsang did get called out for some of the changes he made to the historical record, once in

a great while. ${ }^{961}$

In this section I have shown that the Madman of Tsang had a greater agenda in composing his Life and Songs of Milarepa beyond merely retelling that story. His larger

purpose was to postulate a form of religious life that was anti-institutional, anti-scholastic and valued asceticism and meditation above all other aspects of religious practice. I have argued that what motivated the Madman of Tsang in this regard was a set of issues he

between memories, where events and details are unconsciously transferred from one person to another to form a subjectively more pleasing or inspiring version of events," $\mathrm{p} 218$. What is fascinating about Roberts' explanation for how this switch may have taken place is that he is so resistant to ascribing the Madman of Tsang any agency in the matter. Roberts does not consider that the change may have come about as the result of an intentional switch on the part of the Madman of Tsang, which does, after all, constitute the simplest explanation for why this took place. We can perhaps assume that Roberts resists this most simple explanation because it would ascribe potentially worldly motivations to the Madman of Tsang's actions. Unfortunately Roberts' characterizing the Madman of Tsang in this way actually does the yogi a great disservice, robbing him of all agency in the production of this literature, insisting on seeing the changes to the texts that took place under his watch as accidental or pre-conscious.

${ }^{961}$ It is not the case that the Madman of Tsang got away scot-free in all of the changes he made in this important body of literature. In his version of The Life of Marpa, the Madman of Tsang has the evil Nyö Lotsāwa, once a friend and companion to Marpa on his journey to India, throw the Sanskrit manuscripts Marpa had collected over twelve years of study in India and Nepal into the Ganges. Later Kagyü historians (like Belo Karma Tsewang Künkyab in his supplement to Situ Paṇchen's great history of the Kagyü) attacks this passage, stating that he had consulted earlier versions of the story and there was no mention of Nyö Lotsāwa's having the books thrown in the river. This part of the story was "nothing but a corrupt [interpolation] by some later fool." Hubert Decleer, "The Melodious Drumsound All-Pervading: Sacred Biography of Rwa Lotsāwa: about early Lotsāwa rnam thar and chos 'byung" in the Proceedings of the 5th Seminar of the International Association for Tibetan Studies, Narita 1989, Vol. I, edited by Ihara Shōren and Yamaguchi Zuihō (Naritasan Shinshoji, 1992), p 21.

Decleer's article came to my attention thanks to a footnote in Cyrus Stearns' Luminous Lives (Boston: Wisdom, 1996), p 220. It seems that the Madman of Tsang has taken specific steps to demonize Nyö Lotsāwa, and was later called out for doing just that. Tāranātha and later Belo Tsewang also expressed some criticism of the way the Madman of Tsang chose to portray the death of Darma Dodé, Marpa's son, and for the fact that Ra Lotsāwa (rwa lo ts $A b a$ ) is nowhere mentioned in the Madman of Tsang's version of The Life of Marpa, Decleer, pp 23-7. 
faced during his own time. Let us now look at how the Madman of Tsang's writing and printing efforts would have addressed these greater concerns.

\section{II.2 The Material Circumstances of Printing; the Madman's Bigger Picture}

Towards answering the question of why the Madman of Tsang made these changes to The Life of Milarepa, portrayed him the way he did, and took such pains to mass produce and disseminate the text, let us look at the material circumstances of this printing project, which will lead us to a better understanding of the historical situation the Madman of Tsang lived in, and what may have motivated his project.

We should begin by noting that carving woodblocks for the printing of a text was a big, costly undertaking. One would have to get wood (always a rare commodity in western and central Tibet), and cut that wood into thin blocks on which individual pages text could be carved. One would need a lot of paper (also costly) for each printing. One would need tools for carving, and ink. Perhaps most costly of all, one would need to provide for the upkeep (and perhaps salaries) of all involved in the project. This would include scribes and most of all woodcarvers. We know that up to thirteen woodcarvers would work on carving the woodblocks for a single text - and there would be up to fifty different sponsors paying for it all. ${ }^{962}$

The immediacy of these material circumstances are signaled to us by the fact that when Nāropa visited the Madman of Tsang in a dream and told him to make a print of the Life and Songs of Milarepa, the Madman of Tsang's first reaction was to say that he did not have the sponsors to make such an endeavor possible. His concern was not that he

\footnotetext{
${ }^{962}$ Schaeffer, The Culture of the Book in Tibet, $\mathrm{p} 60$.
} 
did not have the skill or the wisdom or the time, but money. And as we will see, the issue of who would pay for the project would be a pressing issue until its final completion.

The work of the Madman of Tsang's compiling and printing the Life and Songs of Milarepa proceeded by a few stages. First, the Madman of Tsang had to gather the existing biographies and songs of Milarepa, which were circulating in oral and written forms. Some were readily available while others were quite difficult to find. To gather all these texts, stories and songs, the Madman of Tsang sent disciples all over Tibet, to Ngari, Ü, Tsang, Dakpo and Kongpo; this came at a substantial personal cost to the Madman of Tsang, who is said to have "made use of his material possessions without hesitation" in sponsoring the search. He also sent out wood-block cutters to search for scribes and printers. According to Götsang Repa's version of these events, the Madman of Tsang was himself engaged in collecting offerings and begging for donations of money and materials. He is even said to have fallen ill because of the effort exerted in begging (in part because of harmful spirits; fortunately the Five Long-life goddesses, who had been appointed to help him in the project, came to his aide). Eventually all of the Madman of Tsang's helpers and emissaries reconvened at Shelpuk Cave (a site associated with Milarepa) and began their work. ${ }^{963}$

The project did not always proceed smoothly after that. According to Götsang Repa's version of these events, midway through the carving of the woodblocks some of the Madman of Tsang's disciples complained that all of their wealth had already been

${ }^{963}$ Quintman 2006, pp 202-3. Lhatsün Rinchen Namgyel, p 98; Götsang Repa, p 139. 
exhausted on the project. ${ }^{964}$ Moreover, there was great unrest in the area of Latö Lho (la stod lho), which meant that one important source of funding might be cut off. Some of the Madman of Tsang's disciples suggested that the project be abandoned, and they should instead enter into meditative retreats with the hope of becoming realized ones (rtogs ldan). The Madman of Tsang's response was unequivocal: "You all shut up!" The Madman of Tsang stated that the five goddesses had promised that the project would be completed. He scolded these quarrelsome students and told them to get back to work. Work resumed, the Madman of Tsang gathered more offerings, and the project was completed two years after it began, in 1488. (We will see similar bellyaching on behalf of the Madman of Tsang's disciples in the lead-up to his renovating the Swayambhūnāth stūpa, and also when he intended to build up a retreat site in western Tibet.)

Clearly this printing project was a big, ambitious task. The resources required to employ and equip enough woodcarvers to carve a few hundred woodblocks to print the text would have been vast. According to the Madman of Tsang's biographers, the project nearly bankrupted them all (in spite of promises of divine assistance). But the Madman of Tsang pushed the project through with sheer determination.

In the almost-revolt among some of the Madman of Tsang's students who were convinced that the project should be abandoned we get an indication of the unique motivation that drove the madman in this project. When the Madman of Tsang's disciples make the charge that they should be in meditation somewhere rather than wasting their time producing the Life and Songs of Milarepa, they are expressing the

\footnotetext{
${ }^{964}$ Götsang Repa, p 148. I read this as referring to the Madman of Tsang's wealth, but Quintman 2006, p 204 , takes this as referring to the personal wealth of the great yogi's disciples.
} 
same sentiment expressed and highlighted in the very text they were working on. They are, in fact, trying to follow Milarepa's command to put meditation first and forget about all worldly concerns. The Madman of Tsang essentially tells them to ignore Milarepa's message — which he himself had penned — and get back to work. Why would the Madman of Tsang do this?

The difference of opinion between the Madman of Tsang and his complaining disciples reveals to us the Madman of Tsang's greatest motivation in composing and printing the Life. Whereas his disciples operate under the more simplistic understanding that success in their endeavors would be achieved by personally committing to meditation, the Madman of Tsang has an almost post-modern understanding of the task at hand. In the Madman of Tsang's understanding, printing and mass-disseminating copies of the Life and Songs of Milarepa would have a bigger long-term impact than if he and his disciples were to spend all of their time in meditation. The Madman of Tsang possessed a complex understanding of the workings of representations and renown. Printing this text would benefit the teachings, benefit the sect, and their own fortunes in between. The difference between the Madman of Tsang and his disciples is ultimately about his understanding of the power of representations.

We see a comparable situation then the Madman of Ü set about acquiring the monastery of Tsimar Pel and establishing a stable institution with himself at the head. The disciple whom he instructed to bring the monastery into their possession balked, saying, "Would it not be better if we stayed on random mountains, as we did in the past?" (rang re dpon slob sngar lugs bzhin phyogs med kyi ri la bzhugs pa legs). The Madman of Ü said that there were different types of worthwhile activity, and establishing a 
monastery dedicated to "the Teachings of the "Practice Tradition"' (sgrub rgyud kyi bstan $p a$ ) would be something of great value. Here again we see a case of the disciples of the holy madman wanting to take the rhetoric of renunciation and anti-institutionalism more literally than their masters really intended. ${ }^{965}$

Ultimately what the Madman of Tsang understood while his disciples fail to see is that the idea of renunciation, commodified and continually reasserted through a body of printed literature, is more powerful than actually living as such a renouncer. ${ }^{966}$ The Madman of Tsang is aware that successfully creating the perception of the Kagyüpas as great meditators is just as important—if not more important — than their actually being great meditators. The Madman of Tsang is aware that in the long run more charisma can be drawn from these stories than can be created by actually engaging in these practices. In the eyes of the Madman of Tsang's disciples, The Life of Milarepa is the history of a famous saint from their sect. In the eyes of the Madman of Tsang, it is a powerful piece of propaganda.

Let us consider briefly the sectarian implications of the Madman of Tsang's greater cultural project. How was his concern to benefit the Kagyü embodied in his school's production and mass-dissemination of a certain body of literature? As the comment by the Karmapa indicates to us, the sectarian implications of this cultural project were obvious even to those living in the 15 th and 16 th centuries. What were those implications?

\footnotetext{
965 The Life of the Madman of $\ddot{U}, \mathrm{p} 586$.

966 This is the version of these events given by Götsang Repa, himself one whose greatest deed was in printing. The words he puts into the Madman of Tsang's mouth here are likely as much his own as they are those of his master, as Götsang Repa probably shared many of the Madman of Tsang's ideas on these matters.
} 
Woodblock printing technology had only been in use for sixty or so years in Tibet before the Madman of Tsang published his Life and Songs of Milarepa. ${ }^{967}$ The use of woodblocks for printing was, as Schaeffer puts it, "a self-consciously significant affair."968 Among the many different types of merit-making activity Tibetan Buddhists have traditionally engaged in, making woodblocks and mass-printing texts was unique in how it enabled ideas and versions of history to be spread. In 15th- and 16th-century Tibet there was nothing remotely comparable in terms of how quickly block printing allowed a message to be disseminated, and over so wide a geographic area. Moreover, block printing was even more potent than oral teachings (the other main way of quickly spreading a message) in that it produced a physical text that could be read and reread, shared, copied and worshipped. Seen in this light, we can see how the printing projects of the school of the Madman of Tsang were a potent means to spread literature professing the greatness of the Kagyü sect, and can therefore be thought of as a form of propaganda. ${ }^{969}$ Seen from this angle, Schaeffer refers to the school of the Madman of Tsang's printing projects as "missionizing" activity. Whereas the term missionizing suggests that they were actively trying to convert non-Buddhists to Buddhism, the vast majority of the audience for these texts was already unquestionably Buddhist. Rather than missionizing, this printing activity can better be thought of as a strategically positioning one's lineage or sect in an already crowded Buddhist world. The school of the Madman of Tsang was making aggressive use of this new technology to spread their

\footnotetext{
${ }^{967}$ Schaeffer, "The Printing Projects of Gtsang Smyon He ru ka and his Disciples," p 5.

968 Schaoffer, "The Printing Projects of Gtsang Smyon He ru ka and his Disciples," p 12.

${ }^{969}$ Schaeffer, The Culture of the Book in Tibet, $\mathrm{p} 55$.
} 
compositions, and thereby spread the renown and influence of the Kagyü sect in 15thand 16th-century Tibet. ${ }^{970}$

The most important point to draw from this discussion is that the Madman of Tsang and his school were not just writing about a hypothetical past, but writing about who they themselves were in the present - and not so much who they were, but how they wanted to be perceived. ${ }^{971}$

\section{II.3 For the Good of the Kagyü; Redefining the Kagyü}

In this chapter I have argued that the Madman of Tsang's writing and printing

activities were part of his larger concern to work for the benefit of the religious

corporation of which he was a part. How, specifically, did the Madman of Tsang define

that corporation? To what sects or subsects or lineages, most specifically, did the

Madman of Tsang pay allegiance? Were the Madman of Tsang and his disciples devoted

primarily to the Kagyü? Or a branch of the Kagyü sect called the Rechung Kagyü? ${ }^{972}$ Or

to the Drukpa Kagyü? Or to the Aural Transmission teachings themselves? Our interest

here is to reconstruct the intentions of the Madman of Tsang and his school, and the

Madman of $\ddot{U}$, based on what we know about them from their biographies, rather than

\footnotetext{
${ }^{970}$ Schaeffer, The Culture of the Book in Tibet, p 59. The publication of Kagyü works at Drakar Taso in Gungtang and Rechung Puk in Ü was part of a larger rise of printing throughout the central and southwestern Tibet, exemplified especially in Mangyül Gungtang. See Franz-Karl Ehrhard, Early Buddhist Block Prints from Mang-yul Gung-thang (Monograph Series 2. Lumbini: Publicatinos of the Lumbini International Research Institute, 2000). The broader increase in printing in Tibet during the 15th and 16th centuries was mentioned in Chapter Four.

${ }^{971}$ Kurtis Schaeffer has made the further argument that one purpose of such printing projects may have been to raise the profiles of the places at which the printings were carried out, namely Drakar Taso and Rechung Puk, as places of pilgrimage, hubs of regional reputation, The Culture of the Book in Tibet, p 69.

${ }^{972}$ Because of his special concern for the Aural Transmission teachings, E. Gene Smith says that the Madman of Tsang and his guru Shara Rabjampa "belonged to the Ras chung Bka' brgyud pa, a subsect of the Bka' brgyud pa," although in time the Aural Transmission teachings would be practiced mainly by Drukpa Kagyüpas, "Introduction to The Life of Gtsang smyon Heruka," p 61.
} 
relying on how they were appropriated by a certain subsect or lineage hundreds of years after the fact.

\section{II.3.i Kagyü and Drukpa Kagyü Affiliations?}

The Madmen of Ü and Tsang both had a strong sense of corporate identity. At least three of the Madman of Ü's close disciples died relatively young, before they would have had an opportunity to pass on his most advanced teachings in their entirety to another generation. The Madman of Ü was so concerned about his lineage dying out that he came out of a ten-year retreat in order to teach more actively again. He would repeat this call again some years later, so that "substitutes" (tshab) for those deceased disciples could be appointed. ${ }^{973}$ The Madman of Ü had a clear sense that he was part of some larger structure that ought to be perpetuated. But how would he have labeled that structure?

The affiliation most often expressed by the Madmen of Ü and Tsang is to the Kagyü sect in general. Often they say the Dakpo Kagyü, meaning the tradition that passed from Milarepa to Gampopa, and onward from there. The term Dakpo Kagyü is used interchangeably with Kagyü. When the Madman of Tsang met one Lama Namka Wangpo (bla ma nam mkha' dbang po), he was asked, "What is your Dharma-tradition?" (khyod kyi chos rgyud [sic] gang yin), to which the Madman of Tsang replied, "My tradition is the one renowned as the Dakpo Kagyü' (ngas [sic] rgyud pa dags po bka' rgyud du grags pa de yin). ${ }^{974}$ More plentiful than open declarations of allegiance to the Kagyü are instances where the biographers of the Madmen of Ü and Tsang describe their

\footnotetext{
${ }^{973}$ The Life of the Madman of $\ddot{U}$, pp 597.3-595.1, 619.6-620.2.

${ }^{974}$ Lhatsün Rinchen Namgyel, p 125.1-.2; Roberts, p 218.
} 
activity as being undertaken for the purpose of benefitting the Kagyü sect in some way. Many examples of this were given in Chapter Four. In Ngödrup Pelwar's version of his biography, the activities of the Madman of Tsang and his disciples are often stated as having the purpose of making the teachings of the Kagyü sect "shine like the sun."975 In Götsang Repa's version, the Madman of Tsang is visited in a dream by five goddesses (tshe rings $m c h e d \operatorname{lng} a$ ) who assure him that his writing and printing projects would directly benefit the Kagyü Teachings. ${ }^{976}$ As we saw in the letter quoted at the outset of this chapter, the 7th Karmapa was very pleased hearing about the Madman of Tsang's efforts "to spread and increase the Teachings of the Kagyü." When the Madman of Ü gave back his monastic robes and took on the garb of the Heruka, it was said to have been for the purpose of benefitting the Kagyü.

Thus throughout the biographies of the Madmen of $\ddot{U}$ and Tsang their actions for the benefit of a larger corporate body are almost always articulated as being for the sake of the Kagyü sect.

The question of the Madmen of Ü and Tsang's sectarian affiliation is more complicated than this, however. For one, the Madmen of Ü and Tsang are often seen as having been part of the Drukpa Kagyü subsect of the Kagyü. One major reason for this is that some of the figures whose biographies and literature the school of the Madman of Tsang wrote and published were associated with the Drukpa Kagyü tradition specifically. The early members of the lineage about whom they wrote-Vajradhāra, Tilopa, Nāropa, Marpa, Milarepa, Gampopa and Pakmodrupa - were all part of the lineage shared by

\footnotetext{
${ }^{975}$ Ngödrup Pelbar, bka' rgyud kyi bstan pa nyin mor mdzad pa..., p 17a7; spyir sangs rgyas kyi bstan pa/ dgos bka' rgyud kyi bstan pa 'di nyin mor mdzad pa yin..., p 30a1.

${ }^{976}$ Götsang Repa, p 140.
} 
most of the Kagyü subsects. But the later figures about whom they wrote-Lingrepa, Tsangpa Gyaré, Götsangpa, Yanggönpa, Shara Rabjampa and so on-are not universally shared in all the Kagyü subsects and are most strongly associated with the Drukpa Kagyü. By some accounts, the Drukpa Kagyü subsect began with Tsangpa Gyaré. ${ }^{977}$

The notion that the Madmen of Ü and Tsang may have paid a special allegiance to the Drukpa Kagyü is undermined, however, by the important fact that nowhere in their biographies do the Madmen of Ü or Tsang speak of their activities as being dedicated to benefitting the Drukpa Kagyü. In fact, the term 'brug pa, in the sense of the Drukpa Kagyü, is hardly even used in their biographies. ${ }^{978}$ Although the Madmen of Ü and Tsang would most often be labeled as Drukpa Kagyüpas by later Tibetans, they did not seem to have the perception that they were actively taking part in the Drukpa Kagyü during their lifetimes. They saw themselves as part of the Kagyü in general, although, as we will now see, they had a specific notion of what the Kagyü should be.

\section{II.3.ii The Aural Transmission}

A key aspect of the Madmen of Ü and Tsang's religious identity was a set of teachings called the Aural Transmission (snyan rgyud or snyan brgyud). These teachings expanded on the rituals and meanings expressed by the Cakrasamvara tantra. This body of teachings is often referred to by more specific titles, such as the Aural Transmission of

\footnotetext{
${ }^{977}$ E. Gene Smith, "Padma dkar po and His History of Buddhism," p 81.

${ }^{978}$ On a number of occasions the Madman of Ü receives or gives a set of teachings called "the Eight Great Instructions of the Drukpa" ( 'brug pa'i khrid chen brgyad), which are transmitted and practiced in the Drukpa Kagyü. At one point the Madman of Tsang has a conversation with a Dharmalord Yamchilwa (chos rje g.yam sbyil ba) in which they "talked at length about the Teachings of the Druk[pa Kagyü] and the Aural Transmission of Rechungpa" ( 'brug chos rnams dang ras chung snyan rgyud sogs 'grel [sic] gtam mang du mdzad...), Götsang Repa, p 132.2.

Given how routinely the Madmen of Ü and Tsang are labeled Drukpa Kagyüpas by later Tibetans and Euro-American scholars, one would be surprised to see that they professed no special connection with the Drukpa Kagyü, according to the evidence given by their biographies.
} 
Rechungpa (ras chung snyan rgyud) or the [Cakra]samvara-Dākinī Aural Transmission (bde mchog mkha' 'gro snyan rgyud), or the [Cakra]samvara Aural Transmission (bde mchog snyan rgyud), or, for good measure, the Dākinī Aural Transmission (mkha' 'gro snyan rgyud). ${ }^{979}$ There is also some discussion — and much confusion-over whether the term used her should be brgyud (meaning lineage or transmission) or the homophonous rgyud (meaning tantra). ${ }^{980}$

The traditional story repeated within Kagyü circles is that these teachings were transmitted by the primordial Buddha Vajradhāra to Tilopa, who gave them to Nāropa, who gave them to Marpa. Marpa gave a complete set of these teachings to Tiphupa. Then before returning to Tibet, Marpa lost part of his set of the teachings. He gave the incomplete set (four out of the nine cycles of teachings) to Milarepa. He then instructed Milarepa to go to India to get the rest of them. Milarepa did not go, but sent his disciple Rechungpa, who got the five missing cycles of teachings from Tiphupa. After returning to Tibet, Rechungpa gave those teachings to Milarepa, who gave them to a handful of disciples. After Milarepa's death, Rechungpa gave the complete set of the teachings to Gampopa, who passed them on through the lineage descending from him. In time these teachings, through various transmissions, would be passed on to the Madmen of $\ddot{U}$ and Tsang. The three main transmissions of these teachings would be those passed through Milarepa’s disciples Rechungpa, Ngendzongpa and Gampopa. ${ }^{981}$

\footnotetext{
${ }^{979}$ Based on the evidence presented in the biographies of the Madman of Ü and Tsang, it seems likely that all of these terms were used synonymously. There are a few passages in The Life of the Madman of Tsang where this is explicitly said to be so. See Götsang Repa, pp 24.7-25.2; Lhatsün Rinchen Namgyel, p 13. For more on this body of teachings, see the work of Torricelli and Sernesi.

${ }^{980}$ For a discussion of whether this should actually be brgyud or rgyud, see Roberts, pp 1-2; Quintman 2006, pp 55-6.

${ }^{981}$ Quintman 2006, pp 57-8, tells much of this history.
} 
Based on the evidence offered by their biographies, it seems that for the Madmen of Ü and Tsang, the Aural Transmission was comparable in importance to the Six Dharmas of Nāropa and the Mahāmudrā (in its various forms). The Madman of Ü’s biography mentions his having received Aural Transmission teachings at least four times. One one occasion it simply says that he received the Aural Transmission; other times it is said that he received the Aural Transmission of Rechung, the Aural Transmission of Ngendzong, and the Aural Transmission with the Father Teachings and the Mother Teachings (snyan rgyud kyi yab bka' yum bka'). On another occasion it says that he received in their entirety the "unwritten instructions of the Aural Transmission" (snyan rgyud kyi zhal gdams yi ge med pa rnams), as they had passed through Pakmodrupa. ${ }^{982}$ After the Madman of $\ddot{U}$ matured as a teacher and became a transmitter of teachings, he continued to lay special emphasis on the Aural Transmission. He gave teachings specifically connected to the Aural Transmission of Rechung three times and the Aural Transmission of Ngendzong once. ${ }^{983}$ He also gave the Aural Transmission with no specific transmission specified. ${ }^{984}$ He also gave the original root text the Aural Transmission was based on, the Vajra Verses on the Aural Tantra (snyan gryud rdo rje' $i$ tshig rkang). ${ }^{985}$ When he visited the Madman of Ü, the secret yogi Drukpa Künlé composed a supplication of the Aural Transmission (snyan rgyud kyi gsol 'debs) on his behalf. $^{986}$

\footnotetext{
${ }^{982}$ The Life of the Madman of $\ddot{U}, \mathrm{pp} \mathrm{406,} \mathrm{408,} \mathrm{409,} 480$.

${ }^{983}$ The Life of the Madman of $\ddot{U}$, pp 599, 601, 631; 599.

${ }^{984}$ The Life of the Madman of $\ddot{U}, \mathrm{p} 622$.

${ }^{985}$ The Life of the Madman of $\ddot{U}, \mathrm{p} 582$.

${ }^{986}$ The Life of the Madman of $\ddot{U}, \mathrm{p} 601$.
} 
We are told of the Madman of Tsang's receiving the Aural Transmission teachings, then later giving them on a number of occasions to disciples and lay patrons. ${ }^{987}$ News of the Madman of Tsang's special interest in the Aural Transmission teachings must have preceded him, as we are told of how a man heard about the Madman of Tsang as one who was "very learned (shin tu mkhas pa) in the Two-Chaptered [Hevajra Tantra] and the Aural Transmission of Rechungpa" before ever having met him. ${ }^{988}$

More significant than the Madman of Tsang's teaching the Aural Transmission was his publishing a twelve-volume collection of these teachings. This project involved gathering the existing texts relating these teachings, setting oral teachings onto paper, writing his own additional texts, then organizing and editing them all. Included in the collection were texts composed by the Madman of Tsang that were meant to organize one's understanding of the entire set of teachings, putting them together in a coherent, useful way. Despite this collection's being divided into twelve volumes, it is not as extensive as many have assumed. A hand-written manuscript of the collection, including all twelve "volumes" of the text, runs only 416 folios. ${ }^{989}$

There are suggestions throughout his biographies that the Madman of Tsang was divinely ordained to carry out this project. When Sangyé Gyeltsen was one year old his mother had a dream in which she was visited by a black man with his hair tied in a topknot (ral pa'i gcod paN), wearing ornaments made of bone-an emanation of Cakrasamvvara, we are told — who imparted to her instructions on the Dākini-Samvara

\footnotetext{
${ }^{987}$ Götsang Repa, pp 24.7-25.3; 130.7, 142.3, 166.4, 172.4-.5. They gave these teachings to all different communities of people, from their close followers, to lay patrons, to the Jozang (jo bzang; byo bzangs, in Lhatsün Rinchen Namgyel, p 92) people living in the Tsari area. On the Aural Transmission, see Lhatsün Rinchen Namgyel, pp 13, 123.

${ }^{988}$ Götsang Repa, p 58.1-.2.

${ }^{989}$ This is the bya btang 'phrin las dpal 'bar manuscript.
} 
Aural Transmission and other unspecified Kagyü teachings. ${ }^{990}$ Later the Madman of Tsang himself would be visited in the middle of the night while staying at Tsari by a black man who identified himself as (an emanation of) four-armed Mahākāla (mgon po phyag bzhi pa), who served as a protector of the Aural Transmission (here called the mkha' 'gro snyan rgyud). The apparition promised to be the Madman of Tsang's personal protector in dharmic activities from then onwards (khyed kyi chos skyong byed pa). He told the Madman of Tsang that people would soon arrived to offer texts explicating ritual practices in which he figures (nga yi bsgrub bskor rnams kyi yig cha yang sang 'bul mkhan yong). Surely enough the next day people arrived with books to offer to the Madman of Tsang. This suggests that the Madman of Tsang was actively collecting sources connected to the Aural Transmission even at this early phase of his life. ${ }^{991}$ In his role as protector of the Aural Transmission teachings, Mahākāla will appear again later in the Madman of Tsang's life as well.

Indeed, compiling the Aural Transmission teachings was a project that spanned many years of the Madman of Tsang's life. The initial motivation is said to have come from a divine source: we are told of how the Madman of Tsang, while residing at Shelpuk (shel phug), went to a nearby monastery and stayed for some time reading tantras. During this period he started to think about writing a commentary on the Hevajra tantra (which, as we saw is Chapter Three, was a major motivation for the Madmen of Ü and Tsang's eccentric behavior). While he was considering this undertaking the Madman of Tsang was visited by Vajrayoginī and her retinue. She told him that there were

\footnotetext{
${ }^{990}$ Götsang Repa, p 16.7-17.2.

${ }^{991}$ Götsang Repa, p 38.2-.4.
} 
already many commentaries on the Hevajra tantra, and therefore he should focus his efforts on explicating the meanings of the wish-fulfilling Aural Transmission (snyan rgyud yid bzhin nor bu'i don). ${ }^{992}$ From then on the Madman of Tsang worked to explain and disseminate the Vajra Verses on the Aural Tantra (snyan rgyud rdo rje'i tshig rkang), which functions as something like the root text for all the Aural Transmission teachings. We also see when, later in his life, the Madman of Tsang was in the process of composing an outline of the Aural Transmission teachings (the mkha' 'gro snyan rgyud kyi sa spyad ma rig mun sel). ${ }^{993}$ The Madman of Tsang eventually wrote some texts on the Hevajra tantra, but spent much more of his career working on the Aural Transmission associated with the Cakrasamvara. ${ }^{994}$

After this initial work on the Aural Transmission the Madman of Tsang put the task aside in order to work on his Life and Songs of Milarepa. Once he was finished with Milarepa, he returned his attention to the Aural Transmission. An entire chapter of Götsang Repa's version of the Madman of Tsang's Life is about his “putting the Aural Transmission in writing" (snyan rgyud yi ger bkod pa...). ${ }^{995}$ This is sandwiched between the chapters on his writing and publishing the Life and Songs of Milarepa and on his restorations of the Swayambhūnāth stūpa.

\footnotetext{
992 This might refer to a specific text, but I am inclined to read it as referring to the Aural Transmission in general.

Götsang Repa, pp 115.6-116.2. In Lhatsün Rinchen Namgyel's version, the Madman of Tsang's decision to teach, debate and compose ('chad rtsod rtsom gsum) the mkha' 'gro'i snyan rgyud is also prompted by his having a vision of Vajrayoginī, who instructs him to do just that, $\mathrm{p} 86$.

${ }_{993}$ Götsang Repa, p 127.4. This is told in Ngödrup Pelbar, p 15b, and Lhatsün Rinchen Namgyel, p 31. The Madman of Tsang's writing about the snyan rgyud at Tsari, which would make the Teachings of the Kagyü "shine like the sun," is mentioned again in Ngödrup Pelbar, p 17a.

${ }^{994}$ For the Madman of Tsang's writing texts on the Hevajra tantra, including an "outline" (sa spyad) on that tantra, see Götsang Repa, p 135.4.

${ }_{995}$ Götsang Repa, pp 153.5-208.4. Roberts, pp 36-7. The Madman of Tsang thus began work on the Aural Transmission texts before he wrote and printed the Life and Songs of Milarepa (completed in 1488), then did the bulk of that project between 1490 and his death in 1507, Roberts, pp 36-7.
} 
Götsang Repa gives a description of the history of the Aural Transmission and the Madman of Tsang's position within it. Götsang Repa says that the Aural Transmission had been stamped with an oral seal $\left(b k a^{\prime} r g y a\right)$ so that it would be kept in a single-stream lineage for thirteen master-student generations, meaning that during this stretch of time each master would only give those teachings to one disciple. For this reason, until the time of Milarepa the teachings were given in this single-stream transmission, and only transmitted orally (gcig rgyud dang snyan rgyud kho na mdzad). But Milarepa had had been visited by Vajrayoginī (in the same way that the Madman of Tsang would be hundreds of years later) who gave him some instructions on these teachings and instructed him to put them (or the entire Aural Transmission?) into writing. Vajrayoginī told Milarepa he could make those the Aural Transmission a little more widespread, so he set into writing the Vajra Verses (rdo rje tshig rkang) and the other most essential texts of the Aural Transmission. ${ }^{996}$ According to Götsang Repa, Milarepa then gave those teachings to Rechungpa, Ngendzongpa and Gampopa. They each wrote a little bit about these teachings (yig cha cung zad re mdzad), which resulted in there being what are renowned as the Rechungpa Aural Transmission, the Ngendzongpa Aural Transmission and the Dakpo Aural Transmission (from Gampopa). Götsang Repa states that although there were these and other early writings on the Aural Transmission, they were not widely disseminated, and thus Vajradhāra's command that the teachings be kept in a single-stream lineage was nevertheless obeyed. By the time of the Madman of Tsang, enough master-student generations had passed so that the teachings could be spread more widely without negative consequences. Thus the Madman of Tsang started working

\footnotetext{
${ }^{996}$ Quintman 2006, p 58.
} 
concertedly on the compendium of the Aural Transmission, composing such texts as the gzhung 'brel nor bu skor gsum, the rmi lam yid bzhin nor bu, the thun mong yid bzhin nor bu and the mgon po'i bsgrub thabs. ${ }^{997}$ (Note that according to Götsang Repa's account, although the transmission went through Rechungpa, he does not play a special historical role. There is no mention of his going to India to get the teachings or his having given them to Milarepa or Gampopa. Was it assumed that readers would know this part of the story, or is it being elided from history by Götsang Repa?)

After this initial period of writing we would see the Madman of Tsang composing various texts associated with the Aural Transmission, most of which would presumably end up in his compendium. At various points over the following years we see the Madman of Tsang writing the mkha' 'gro snyan rgyud kyi las byad yid bzhin nor bu smin lam sdoms tshig; the mkha' 'gro snyan rgyud kyi yig cha'i kha skongs; the snyan rgyud tshigs gcad yid bzhin nor bu; and the snyan rgyud kyi yig cha rnams kyi bzhug. ${ }^{998}$

\footnotetext{
${ }^{997}$ Götsang Repa, p 159.2-.7. de nas gnas der mdo rgyud thams cad kyi snying po bcom ldan 'das dpal 'khor lo sdom pa'i rgyud kyi yang snying / kha' 'gro snyan rgyud 'di rdo rje 'chang chen gyi rgyud pa bcu gsum gyi bar du gcig rgyud kyi bka' rgya btab pa las/ rje btsun chen po mi la 'i bar du khrid ngo bo la gcig rgyud dang snyan rgyud kho na mdzad/ rje btsun la gnya' nang grod phug du yum rdo rje rnal 'byor mas zhal mngon gsum du bstanas/ snyan rgyud yid bzhin nor bu del rnal 'byor rtsa ti'i [rtsi ta' $i$ ?] dkyil nas phyung / badzra kir ?a'i spyi bor zhog 'od zer dga' bas 'thung par 'gyur/ ces pa'i tshigs gcad dang / da yi ger yang bkod cig rgyud las kyang cung yangs par byas chog gsung ba la rten nas/ rdo je'i tshig rkang sogs rgya gzhung bod gzhung rnams dang / zab khrid rnams la'ang dmigs pa'i rtsaba rtsam (?) rje btsun chen pos yi ger bkod nas rje btsun ras chung pa dang ngan rdzong ston pa dags po rin po che gsum la gnang/ skyes mchog dam pa de gsum kyis yig cha cung zad re mdzad pas/ ras chung snyan rgyud ngan rdzong snyan rgyud/ dags po snyan rgyud du gragso/ de nas kyang rgyud pa gong ma rnams kyis yig cha cung zad re yod kyang / rdo rje 'chang gi dgongs pa yongs su rdzongs pa 'di gcig rgyud du gnas pa las bka' rgya bkrol nas/ gzhung 'brel nor bu skor gsum/ rmi lam yid bzhin nor bu/ thun mong yid bzhin nor bu/ mgon po'i bsgrub thabs skangs dang bcas pa rnams kyi yig cha mdzad do/

${ }^{998}$ Götsang Repa, pp 1) 170.7; 2) 198.4; 3) 207.3; 4) 235.5-.6.

In Lhatsün Rinchen Namgyel's version, we see the Madman of Tsang, at the age of 47, at Chuwar, working on the second of these four texts. We also see the Madman of Tsang writing other Aural Transmission texts at various points: the rdo rje'i tshig rkang gi tshig 'bru'i don shigs thung ba' $i$ sa bcad is mentioned $\mathrm{p} 31$; the $m k h a$ ' 'gro snyan rgyud kyi rtsa ba' $i$ rgyud and rdo rje'i tshig rkang are mentioned $\mathrm{p}$ 100. This latter passage is also in Ngödrup Pelbar, p 17a.
} 
In general the teachings contained in the Aural Transmission are ultimately meant to explicate the meaning and practices of the Cakrasamvara tantra. But the Aural Transmission has many parts in its own right. One important text in this collection is the Vajra Verses on the Aural Tantra (*karnatantravajrapada, extant only in a Tibetan translation as snyan rgyud rdo rje tshig rkang), which serves as a sort of root text for the collection. ${ }^{999}$ There were a series of ancillary instructions which, according to traditional accounts, Tilopa received as a series of symbolic one-line verses from the formless dạkinīs. Also included in the Madman of Tsang's compendium of the Aural Transmission is a series of biographies recording lives of lineage holders of the Aural Transmission. ${ }^{1000}$

Towards the end of his life the Madman of Tsang had the idea to have the text of the Aural Transmission (the snyan rgyud yid bzhin nor bu'i glegs bam) written in gold. He got gold and paper from patrons in western Tibet. But the paper got wet, so he could not go through with the project; instead he thought he might have the text written on silk (? gser ma). Unfortunately the circumstances or signs (rten 'brel) were not quite right, so he would have to try again at some later time. (He would not get the chance to do this, and expressed some regret about it before his death. ${ }^{1001}$ ) He had a few volumes put on white paper and instructed his disciples to edit the texts (zhus dag) and told them, "If there are any doubts that need to be cleared up [regarding the text], do it now! [Otherwise] after the Madman of Tsang has died, you will have a lot of regrets!" After

\footnotetext{
${ }^{999}$ Quintman 2006, p 56. The root text is said to have originated from the primordial Buddha Vajradhāra, then was later recorded by Tilopa. This text is included in the Tengyur (Toh 2338). For study and critical edition, see Torricelli 1998.

1000 Roberts, pp 36-7.

${ }^{1001}$ Götsang Repa, p 246.6.
} 
they finished editing the texts, a final version was made in twelve volumes. About this text the Madman of Tsang said that it was the quintessence of all the sütras and tantras, the most profound of all teachings. ${ }^{1002}$ Ngödrup Pelbar's version of this story suggests that the compendium of the Aural Transmission (snyan rgyud kyi yig cha) was not quite finished at the time of the Madman of Tsang's death. ${ }^{1003}$

In the midst of a list of a series of teachings the Madman of Tsang received early in his life, Götsang Repa mentions his receiving the Aural Transmission teachings, which are "the quintessence of all sütras and tantras, the secret words of the $\frac{d \bar{a} k i n \bar{\imath} \mathbf{s}}{\text {; }}$ which are like the essence or the heart of all the profound Dharmas of the precious Kagyü." As Götsang Repa puts it, these teachings were known alternatively as the Samvara Aural Transmission, the Dākin̄̄ Aural Transmission, the Rechungpa Aural Transmission, the Ngedzongpa Aural Transmission, the Dakpo Aural Transmission, and so on, and it was passed through various lineages. ${ }^{1004}$ This suggests that the Madman of Tsang's work on the Aural Transmission was not just writing about one of these specific transmissions of teachings, but rather trying to write something that was representative of - and to speak for-all of these lineages. What he was essentially doing is taking a series of oral instructions and some written things that were being passed on through various lineages, and bringing them together-reunifying these disparate elements while organizing and

\footnotetext{
1002 Götsang Repa, p 245.6.

${ }^{1003}$ Ngödrup Pelbar, p 23b.

1004 Götsang Repa, pp 24.7-25.3: khyad par mdo rgyud thams cad kyi snying po mkha' 'gro'i gsang tshig bka' rgyud rin po che'i zab chos thams cad kyi rtsa ba'am snying po lta bu/ bde mchog snyan rgyud mkha' 'gro snyan rgyud/ ras chung snyan rgyud ngan rdzong snyan rgyud/ dags po snyan rgyud sogs mtshan dang rgyud tshul du mar grags pa'i yin bzhin gyi nor bur in po che zab pa las kyang ches shin tu zab pa kun dang thun mong ma yin pa yang gsang bla na med pa'i khyad chos rgyud pa rang rang gi lugs dang phyag len cha lags dang bcas pa yongsu rdzongs shing ma lus par lung khrid du gnang zhing...
} 
supplementing them with his own writings. This is very similar to the Madman of Tsang's role in creating the Life and Songs of Milarepa.

We should not assume that in creating the compendium of the Aural Transmission the Madman of Tsang was simply setting down to paper what was already a coherent body of texts. As we saw above, the Madman of Tsang exercised considerable agency in creating his versions of the Life and Songs of Milarepa. His compiling his compendium of the Aural Transmission would not have been any different. The Madman of Tsang had leeway in choosing what to include, and what to say in his new compositions. These teachings were certainly in a more coherent form when they left the hands of the Madman of Tsang then they had ever been before. Could calling these texts the Aural Transmission teachings not have been a convenient way for the Madman of Tsang to give his own ideas an air of orthodoxy?

The very fact of writing about the Aural Transmission was itself a self-conscious affair, which signals to us the Madman of Tsang's great importance in the history of these teachings. The Madman of Tsang occupies an important position in the history of these texts because of his efforts to transform the Aural Transmission teachings from something passed on through a single-stream lineage to something that was widely disseminated. The Madman of Tsang's connection to the Aural Transmission is so important that Götsang Repa introduces the Madman of Tsang to the reader in terms of his position in that lineage at the beginning of his version of the Life. After telling how the Madman of Tsang's existence was prophesized by the Buddha and Changchub Lingpa (byang chub gling pa), Götsang Repa describes the Aural Transmission lineage. In his version of history, the transmission went from Tilopa to Marpa to Milarepa to 
Rechungpa to Khyungtsangpa (note that here the Aural Transmission teachings are not said to have gone through Gampopa, which contradicts Götsang Repa’s comments elsewhere) and so on, down to the Madman of Tsang. There were seventeen ${ }^{1005}$ holders of the transmission, which is like a single thread, after Tilopa and before the Madman of Tsang. After these seventeen generations, the "oral seal" was complete (bka' brgya rdzogs), which meant that the Madman of Tsang could then disseminate the texts in written form, as he did. ${ }^{1006}$

The fact that the Madman of Tsang was setting to paper and disseminating (even if he did not have them block printed, we know that the Madman of Tsang was interested to have hand-written copies made, and one copy easily begets another) this set of especially esoteric teachings would normally be problematic, but we are told that it was not an issue because Vajradhāra had only insisted that the teachings be kept secret for a fixed number of generations, and those generations had now passed. Moreover, on one of the Madman of Tsang's short visits to Nepal before the one in which he oversaw the renovations of the Swayambhūnāth stüpa, he had the stūpa whitewashed. Then he went before the statue of the Protector of the Tibetan Fields (bod thang mgon po), who was the protector (chos bdag) of the Aural Transmission. The Madman of Tsang expressed thanks (btang rag) that the seal demanding that the teachings of the Aural Transmission be kept in a single-stream lineage had been released, and he could now set them to

\footnotetext{
${ }^{1005}$ This accounting of history contradicts that given by Götsang Repa later in the Life and mentioned above, in which he said that there were thirteen generations between Vajradhāra and Milarepa. In the accounting that posits seventeen teacher-student generations between Vajradhāra and the Madman of Tsang, there are only three generations separating Vajradhāra and Milarepa. Perhaps there is an alterantive way of counting the history of these teachings, seeing them as having been passed through many generations between Vajradhāra and Tilopa, rather than the more common version in which Vajradhāra gives them to Tilopa directly?

${ }^{1006}$ Götsang Repa, pp 6-8.
} 
writing without any obstacles coming in his way. The Madman of Tsang requested the deity to continue to be a protector of the Aural Transmission, even now that the nature of its transmittal had changed so radically. ${ }^{1007}$ Again we see the Madman of Tsang purposefully spreading something, increasing access.

As Andrew Quintman has shown, there was a strong connection between the biography of Milarepa and the Aural Transmission teachings. This connection went back to the earliest versions of The Life of Milarepa, as his biography was included as introductory material to some teachings associated with the Aural Transmission that had been set down into writing long before the Madman of Tsang created his version. ${ }^{1008}$ As Quintman puts it, “early representations of Mila's life developed in concert with literature documenting the aural transmission lineages."1009 Even The Blue Annals, a late publication relative to Mlia's biographical tradition, records his life not in the context of his guru's lineage (the Kagyü tradition passing through Marpa) but specifically in terms of the promulgation of the Aural Transmission. ${ }^{1010}$

Thus the Madman of Tsang's dual literary interests in The Life of Milarepa and the Aural Transmission were in fact part of a larger single project, with the two texts ultimately supporting one another. In both cases the Madman of Tsang began with some fragments and disparate elements, but made each more complete in its own right. ${ }^{1011}$

\footnotetext{
${ }^{1007}$ Götsang Repa, p 175.5-.6.

1008 Quintman 2006, p 144.

${ }^{1009}$ Quintman 2006, p 44.

${ }^{1010}$ Quintman 2006, p 43; Roerich, pp 427-51.

1011 Quintman 2006, pp 238-9.
} 
Returning to our point of departure, because of the Madmen of Ü and Tsang's special ongoing connection with the Aural Transmission teachings, E. Gene Smith has suggested that they be understood as part of what he terms the Rechung Kagyü. ${ }^{1012}$

Complicating the question of affiliation further, as was shown in Chapter Four, the Madmen of Ü and Tsang also vocalized support for a vaguely-defined "Practice Tradition" (sgrub brgyud). This might simply be another term for the Kagyü, or it may refer to a more specific trend within the Kagyü which they saw themselves as a part of.

The question that remains is to which of these entities did the holy madmen pay their primary allegiance? Are they best understood as representatives of the Drukpa Kagyü, or the Rechung Kagyü? Is their primary allegiance to the Aural Transmission teachings in general, regardless of the confines of sectarian discourse? I think none of these possibilities in itself offers the final answer.

It is not the case that the holy madmen saw the more specific lineages to which they paid allegiance to simply be branches of the Kagyü or one possibility within the greater Kagyü. In spite of latter day characterizations, they did not align themselves with something they understood as the Drukpa Kagyü or the Rechung Kagyü; nor did they pigeonhole themselves by calling themselves upholders, first and foremost, of the Aural Transmission. On the contrary it is clear that they intended for their actions, teachings and writings (in particular, the biographies and the Aural Transmission penned by the Madman of Tsang and his school) to be seen a speaking for the Kagyü as a whole. The

\footnotetext{
1012 "Introduction to The Life of Gtsang smyon Heruka," p 61. Roberts treats the term Rechung Kagyü as synonymous with the Aural Transmission. This may be technically right in some sense, but I do not think it is an accurate representation of how the Madman of Tsang thought of himself.
} 
Kagyü sect as the Madman of Tsang envisioned it would model itself in the image of the past masters whose lives he and his school wrote—Nāropa, Marpa, Milarepa and others. They would be a tradition dedicated to practice above all else, rightly living up to the name "Practice Tradition" (sgrub brgyud). One special body of teachings that defined their tradition, among others, was the Aural Transmission. This was their vision of the Kagyü, and they intended to speak for it. They were, in a sense, trying to reshape the Kagyü in this way.

This matches the interpretation of the 15th-century holy madmen's eccentric behavior that was offered in Chapter Three: they were enacting a seemingly-eccentric, tantric fundamentalist lifestyle in order to assert a new model of Buddhistness. According to his biography, it was "for the sake of initiating a tradition dedicated to the definitive meaning of the precious Kagyü” that the Madman of Ü turned in his monk's robes and put on the garb of the Heruka. Here it does not necessarily mean that the Madman of Ü was benefitting the Kagyü as a static, clearly defined entity, but rather that he was benefitting the Kagyü by redefining it an a new way (walking around central Tibet bathed in ashes was, although not unprecedented, far from normative behavior). The benefit of that new way of defining the Kagyü can only be seen by understanding the greater competitive environment in which it was enacted, as described in Chapter Four. As we saw there, the Madmen of Ü and Tsang and other Kagyü holy madmen of the late 15 th and early 16th centuries lived in a very competitive religious marketplace, in which the long-term survival of any group or lineage or sect was far from guaranteed. The rapid spread of the Geluk sect and their strong hold of the Lhasa area put pressure on the Kagyü as they saw themselves lose their position as the most powerful sect in central 
Tibet. Their proposal of a new and radically different model of Buddhistness (and in fact of Kagyüness) was undertaken in the midst of these very real circumstances. They could not compete with the Gelukpas at their own game, and thus looked for a way to distinguish themselves from them. The ways of the scholar-monk and the hermitmeditator are set up as polar opposites of one another. We know on which side of this divide Milarepa — as created by the Madman of Tsang-falls.

\section{III. Milarepa the Madman}

As was mentioned in Chapter One, Milarepa plays an extremely significant role in the history of the holy madman phenomenon in Tibet. E. Gene Smith calls him the "chief symbol for this movement." Ronald Davidson has said that the holy madmen "invok[ed] the behavior or Mila Repa."1013 We should not be too quick to accept that the situation was simply one of the holy madmen imitating Milarepa; nor should we accept that Milarepa provided a direct prototype for the holy madmen. Milarepa's relationship to the idea of holy madness is ambiguous and in this way extremely telling about the larger complexities of the phenomenon. Let us consider the rhetoric of madness as it is employed in Milarepa's Life and Songs by the Madman of Tsang. As we will now see, there are a few important episodes in Milarepa's Life and Collected Songs that contribute to later Tibetans' thinking of Milarepa as representative of the holy madman tradition.

The event from the Madman of Tsang's versions of the Life and Songs of Milarepa that is most important in shaping the way Tibetans and some modern EuroAmericans think about the holy madman tradition was described briefly in Chapter One

\footnotetext{
${ }^{1013}$ Smith, "Introduction to The Life of Gtsang smyon Heruka," p 60; Davidson, The Tibetan Renaissance,
} p 11. 
and earlier in this chapter. Once when Milarepa was in the depths of meditative retreat, his food and clothing were completely exhausted. When his sister found him bone-thin and naked, she was appalled. She left him with a length of cloth out of which she asked him to make a loincloth, for the sake of modesty. When she returned some time later, she found that he had not made a loincloth but crude sheaths for his fingers and penis. Angry, she said that he was no longer human and did not know what shame (ngo tsha) was, chastising him for wasting the cloth she had worked so hard to acquire. Mila responded by saying that he, a yogi dedicated only the practice of virtue, had nothing to be ashamed about. He saw no difference between any of the parts of his body, so what is there to cover up? His nudity is natural. On the other hand, the ones who should be ashamed are worldly people, who never cease to engage in sinful activity. Milarepa's asceticism is for the sake of practicing religion, and he refuses to be judged by a system that is so hypocritical and dedicated to all the wrong things.

This story was told to me on numerous occasions during my conversations with Tibetans about the holy madman phenomenon, indicating the important role it plays in their collective understanding of the phenomenon, in terms of what it means, and where this "madness" comes from. The story exemplifies the fact that we are the ones who are truly mad, not the great saints who may appear crazy in our conventional, deluded way of thinking. ${ }^{1014}$ Milarepa's eccentricity is an indication of his transcendence. The dictates of Buddhist practice may put one at odds with social conventions, but this is no reason to not pursue them.

\footnotetext{
${ }^{1014}$ Kenpo Losel Rinpoché interview; Kenpo Nyima Gyeltsen interview; Kenpo Tsülnam Rinpoché mentioned this on multiple occasions; Kenpo Sönam Tashi interview.
} 
This story was not the brainchild of the Madman of Tsang, as we have evidence that he was drawing from a similar version of the story that was present in earlier versions of The Life of Milarepa, going back to the time of Lama Zhang (g.yu bra pa brtson 'grus grags pa, 1123-1193), who will be discussed in Chapter Seven. ${ }^{1015}$

What is most interesting about this episode is that when retelling this story, Tibetans often quote a line from the mouth of Milarepa that goes something like, "The world sees Mila as crazy, but Mila sees the world as crazy." For example, in the process of telling about his life during the Cultural Revolution (1966 to 1976), one Tibetan who had been imprisoned writes of the chaos he saw taking place across the land:

It was the middle of the Cultural Revolution, and I was able to read about it in the newspapers. I was shocked by what I read. I was not only angry at how unjustly I was being treated, but also angry at what was happening in China in the name of communism. When I saw pictures of thousands of people holding Mao's small red book to ask for instructions in the morning and report their actions in the evening, I believed they must have lost their minds. I remembered the ancient Tibetan yogi, Milarepa's words, "The world sees Mila as crazy, but Mila sees the world as crazy." [tib. "khor bas bltas na mi la smyo, mi la bltas na "khor ba smyo]. It was an accurate description of how I perceived my situation as I sat helpless in prison watching the madness rage outside. ${ }^{1016}$

What is most interesting here is that this line is not actually in the Madman of Tsang's version of The Life of Milarepa. ${ }^{1017}$ There may be a few places in the Life and Songs

\footnotetext{
${ }^{1015}$ Quintman 2006, pp 98-100.

${ }^{1016}$ Melvyn C. Goldstein, Dawei Sherap, and William R. Siebenschuh, A Tibetan Revolutionary: The Political Life and Times of Bapa Phüntso Wangye (Berkeley: University of California Press, 2004), p 254. A similar comment, drawn from the story of the shameless Milarepa and his sister, is mentioned in Beyer, $\mathrm{p}$ 213.

${ }^{1017}$ In a personal communication, November 2006, Andrew Quintman brought this to my attention: Tibetans often say this line as part of their retelling the story, but it is not actually in textual versions of the narrative.

There is an episode in Lhatsün Rinchen Namgyel's version of The Life of the Madman of Tsang when a scholar-monk (slob dpon) says to the Madman of Tsang, "They say there's a mad renunciant around-is it you?" The Madman of Tsang replies, "If you look at it from a different perspective, it is you who is crazy" (slob dpon gzhan zhig byung nas bya bral smyon pa cig 'dug zer ba khyed yin nam zer ba la/
} 
where Milarepa says something in a similar vein, but never anything that comes recognizably close to this line. Here the oral tradition seems to have inserted this line as a summation of what it means for Milarepa to be "mad." This line would enter into the basic discourse about all Tibetan holy madmen and would become a key part in how Tibetans understand the phenomenon, all the way into the present.

The second most important story in attaching Milarepa with the tradition of the holy madmen comes in his meeting with Padampa Sangyé, as told in his Collected Songs. ${ }^{1018}$ As the story goes, Padampa called Mila "like one who acts crazy" (smyon pa'i spyod pa 'dra ba) for sitting in such a way that his penis was exposed. Mila then responded by singing the song of the "crazy tradition" (smyon lugs). He begins the song (after the formulaic supplication) by saying

Others say I am crazy; I too think I am crazyso I'll explain the crazy tradition of the crazy one. ${ }^{1019}$

Milarepa then goes on at some length saying that basically everything on which his tradition rests is crazy:

The father is crazy; the son is crazy; the lineage is crazy; the lineage holder Mahā Vajradhāra is crazy; the forefather Telo[pa] She[rab] Zang[po] is crazy; the forefather Nāropa, the great Paṇitita is crazy; my old father Marpa the translator is crazy; I, Milarepa, am also crazy.

mthong tshul mi 'dra bas ltas na khyed smyo 'dug byas pas...), Lhatsün Rinchen Namgyel, pp 47.6-48.1. Mentioned in Stearns, King of the Empty Plain, p 74.

${ }^{1018}$ The episode (titled thong la'i skor) begins on p 729 in the 2005 edition; the song is on $\mathrm{p} 734$. In Chang's translation this is episode number 53, titled "The Meeting With Dhampa Sangje," with the song beginning on $\mathrm{p} 610$.

${ }_{1019}$ gzhan yang smyo'am smyo'am zer/ rang yang smyo'am snyam pa byung/ smyo ba'i smyo lugs bshad tsa nal 
In short, all the forefathers (Tilopa, Nārpoa and Marpa) and every significant member of the lineage (brgyud pa) direct from Vajradhāra are all "crazy." The next few lines elaborate on why they are each crazy: each is made "crazy" by an evil spirit (a gdon), but they are the "evil spirits" of assuredly benevolent entities. Vajradhāra is made crazy by the "evil spirit" of the four bodies of the Buddha; Tilopa by the "evil spirit" of the Mahāmudrā; Marpa, by the four classes of the tantras; Mila, by yogic winds and mind (rlung sems gnyis). Interesting for our purposes, Nāropa is said to be "crazy because of the evil spirit of the performance of engaged asceticism of awareness" (rig pa brtul zhugs gdon gyis smyo). Does this refer to performing eccentric forms of behavior, or simply dressing in the garb of the Heruka?

Milarepa then comes to what for our purposes may be considered the climax of the song:

The impartial view is crazy; the self-clear meditation is crazy; the non-grasping self-liberating conduct is crazy; the result free of expectation or fear is crazy. ${ }^{1020}$

The mysterious reversals continue throughout the remainder of the song, as Milarepa states that he punishes demons with the master's teachings; that the Mahāmudrā hurts his back while the Great Perfection hurts his chest; that he catches illnesses through doing vase-breathing in meditation; that the fever of wisdom and the cold of meditation afflict him. After hearing the song Padampa Sangyé observes, "Your kind of craziness is very good." 1021

\footnotetext{
${ }^{1020}$ phyogs ris med pa'i lta ba smyo/ dmigs med rang gsal sgom pa smyo/ 'dzin med rang grol spyod pa smyo/ re dogs med pa'i 'bras bu smyol

${ }^{1021}$ On this song see Goss, pp 67-9.
} 
What exactly Milarepa means by all this is difficult to determine. Clearly the purpose of the song is to enact a series of reversals, where good is bad and bad is good. It is certain that Milarepa is not intending for people to think that the enlightened masters of his lineage are literally crazy. The intended meaning seems to be that Milarepa's behavior may appear crazy to other people (as his lack of modesty seemed crazy to Padampa Sangyé, and to his sister Peta), but his behavior is in fact in line with an approach that has characterized his spiritual tradition. If that means his entire lineage and all of their teachings are "crazy," that simply means that they have transcended samsāra.

This song plays an important role in Tibetans' understanding of Milarepa in connection with the "holy madness" tradition. The Mongolian Ngawang Kedrup (17791838), a scholar and abbot of the Hevajra Practice College of Urga (Ulan Bator) wrote an eleven-folio commentary on this song titled "Dispelling Insanity: A Commentary on the Crazy Song Sang my Lord Mila, Zhepé Dorjé.” In this commentary Ngawang Kedrup explains that thanks to his high level of realization, Milarepa lived in a manner completely at odds with worldly ways. He needed only nettles and water to sustain himself, could get by wearing only a single piece cloth, and spoke true things that did not agree with the way people usually talk, and for these reasons "people saw him as a crazy person who did not accord with the ways of the world." ${ }^{1022}$ As Ngawang Kedrup explains, it is in fact the people of the world, trapped lifetime after lifetime in samsāra, who are the truly mad ones. The entire lineage from Vajradhāra down to Milarepa

\footnotetext{
${ }^{1022}$ rje btsun mi la bzhad pa'i rdo rje'i gsung mgur smyo ma'i 'grel pa myo ba sangs byed. pp 75-97 in The collected works of Nag-dban-mkhas-grub, Kyai-rdor Mkhan-po of Urga, reproduced under the instructions of Glin Rin-po-che from a set of the manuscripts and xylographic prints from the Urga blocks, Vol. II ( $k h a$ ) of five (Leh: S.W. Tashigangpa, 1972-1974, Smanrtsis shesrig spendzod) (TBRC text W16812). Perhaps the most essential line in the commentary reads: yul mi rnams kyis jig rten thams cad dang mi mthun pa'i smyon pa zhig tu mthong..., p 79.4.
} 
himself were "mad" in the same way as Milarepa, i.e., appearing crazy because of embodying wisdom in a deluded world. Vajradhāra is "crazy" because his efforts to liberate beings are misrecognized by them. ${ }^{1023}$ Tilopa is made crazy by his pure wisdom derived from the Mahāmudrā. The great paṇịta Nāropa was the wisest of scholars and a pure monk, but then left to do [tantric] activity ( spyod pa): he removed his clothes, tied up the plaits of his hair, adorned himself with human bones, wandered from place to place, and coupled with a slender-waisted woman. From the perspective of common people, it would appear as if he was made crazy by a malevolent force (gdon gyis smyo ba dang mtshungs so snyam) — this is how Ngawang Kedrup explains how Nāropa is "crazy because of the evil spirit of the performance of engaged asceticism." Marpa is crazy because of the effort he put into collecting the tantric teachings in India: in the eyes of ordinary people, paying so dearly for something you cannot eat or wear on your body is pointless. As for Milarepa, he so mastered the instructions given to him by Marpa that his body was filled with blissful warmth (bde drod), his mind was filled with experiential realization (sems la nyams rtogs 'bar), and so his activity became pure. The precepts (gdams ngag) flowed effortlessly from his mouth; his body was filled with the warmth of Caṇụālī at all times. He obtained omniscience and other supernatural powers. As a result, people came to see his actions as like a magician's tricks or the behavior of a madman. ${ }^{1024}$ As Ngawang Kedrup explains the lines when Milarepa states the highest Buddhist views to be "crazy," he gives voice to how he imagines Milarepa's thought

\footnotetext{
1023 Ibid., p 82.3-.5.

${ }^{1024}$ mig 'phrul mkhan gyi sgyu 'am smyo spyod du mthong ba..., p 85.4.
} 
process: "If you [ignorant, worldly people] assert me to be crazy, then I have other things to list as 'crazy'.,"1025

Ngawang Kedrup's commentary on Milarepa's song about the "crazy tradition" confirms that the primary understanding of Milarepa's "madness" in this context is that it functions as a symbol or an expression of his enlightenedness. As we will see in Chapter Seven, this idea of madness as enlightenment is a key thread of meaning that remains throughout the entire history of the holy madman phenomenon. Milarepa (or those writing the various versions of his Life and Songs) plays an important ongoing role in that history.

We should also pause to note that in the literature produced by the school of the Madman of Tsang there is a strong association between Nāropa and the sort of engaged asceticism performed by the Madmen of Ü and Tsang. In Götsang Repa's version of The Life of the Madman of Tsang, when Nāropa visits the yogi in a vision with the purpose of instructing him to write and print a version of The Life of Milarepa, he is wearing the bone ornaments of the charnel ground. It would be worthwhile to look into the question of whether or not this association was articulated strongly before the time of the Madman of Tsang, or if portraying Nāropa in this way was a part of the Madman of Tsang's greater literary agenda, and thus something that would shed light on how he understood or justified his own eccentric behavior.

There are other places where a rhetoric of madness enters into narratives about Milarepa. In a 13th-century version of The Life of Milarepa, by Gyeltangpa (rgyal thang

\footnotetext{
${ }^{1025}$ khyed rnams kyis bdag la smyo bar 'dod pa de 'dra yin na/ bdag la smyo ba'i rnam grags gzhan yang
} mand du yod de/, p 85.5. 
$p a$, when a man plowing a field with his son sees Milarepa flying around, showing off his yogic super powers, he calls him a "madman" (smyon pa). ${ }^{1026}$ When this story is repeated in the Madman of Tsang's version of the Life, with some of the elements changed, the man's calling Milarepa a madman is no longer included. ${ }^{1027}$ Was this change in the narrative enacted by the Madman of Tsang, or at some earlier point in its development? In the Madman of Tsang's version of the Life, the evil geshé Takpupa who eventually kills Milarepa says he "acts and jests like a madman who knows nothing.",1028 In this do we hear an echo of the Madman of Tsang's labeling himself a "madman" in the 15 th century?

The underlying meaning of the two main narratives connecting Milarepa with the holy madman tradition in the Tibetan discourse (the story of Milarepa and his sister and the song about his "crazy tradition") is that a holder of great wisdom may live in disagreement with the ways of most people. But it is in fact the world that is mad in its attachment to delusion, and not the yogi holding the truth. As we will see in Chapter Seven, this idea persists throughout the entirety of the Tibetan holy madman tradition.

Despite the importance Milarepa would play in the greater holy madman phenomenon, in creating his version of the Life and Songs of Milarepa the Madman of Tsang incorporated very little rhetoric of madness. One might expect there to be more, considering the way the Madman of Tsang was using the Life and Songs of Milarepa to justify the position he himself held in the late 15 th century. The relationship between Milarepa and the holy madmen is actually quite complex, as we will see after a brief

\footnotetext{
${ }^{1026}$ Goss, p 69. Gyelthangpa's text is described in Quintman 2006, pp 108-13.

1027 This episode as it has been transformed in the Madman of Tsang's version of the text is told in the 2005 version, pp 162.16-163.6; Lhalungpa, p 129.

${ }^{1028}$ ci yang mi shes pa'i smyon spyod dang tho co..., 2005 version, p 790; Lhalungpa's translation, p 155.
} 
detour.

The Madman of Tsang was quite restrained in his use of a rhetoric of madness in The Life of Milarepa. But he and his school were more enthusiastic in injecting the rhetoric and symbolism of Hevajra and Heruka into the history of their tradition. For example, when Milarepa goes to Ngok (rngok), another of Marpa's disciples, to try and get some teachings, at the moment Milarepa arrives Ngok is reciting some key lines from the Hevajra tantra in which the deity describes himself. Ngok observes that Milarepa's arriving at the moment he recited these lines was "an excellent sign" (rten 'brel yang shin tu legs ... ). ${ }^{1029}$ Moreover, in the opening line of the Life the Madman of Tsang introduces Milarepa to the reader as "the Heruka." "1030 In Quintman's view, this may constitute the Madman of Tsang's "quietly acknowledging his own identification with the yogin.",1031 The Madman of Tsang also, in the course of The Life of Milarepa, portrays the guru Marpa as the deity Hevajra in a number of ways. ${ }^{1032}$ For example, in the Madman of Tsang's version of The Life of Milarepa, Marpa's wife goes by the name Dakmema (bdag med $m a$ ), which is the Tibetan rendering of Nairatmyā, the consort of the deity Hevajra. A sensitive reading of the Lives of Milarepa and Marpa would likely reveal other implicit or explicit comparisons between Milarepa and Marpa, and the divine forms Heruka and Hevajra. In order to determine the real significance of this, one would have

\footnotetext{
10292005 version, p 80 .

${ }^{1030}$ The text begins: e ma ho/ 'di skad bdag gis thos pa'i dus gcig na/ rnal 'byor gyi dbang phyug rje btsun mi la bzhad pa rdo rje zhes mtshan yongs su grags pa'i he ru ka chen po de nyid/ yul gnya' nang grod pa phug ces bya ba'i bsti gnas dam pa na/, 2005 version, p 8.

${ }_{1031}$ Quintman 2006, p 269.

1032 Quintman 2006, p 235. According to Quintman, Marpa is also characterized as (an emanation of?) the Indian adept Dombi Heruka.
} 
to compare the Madman of Tsang's versions of these Lives with earlier ones, to see if he introduced the Heruka and Hevajra theme himself, or if it was already present in the narrative. But clearly the Madman of Tsang was interested to include the themes of being the deity Hevajra or Heruka in the Lives of Milarepa and Marpa.

Explicit and implicit comparisons between the holy madmen and the early saints of their tradition are made throughout this body of literature, making for an even more complex interplay of representations. On one occasion in Götsang Repa's version of The Life of the Madman of Tsang, the Dharmalord Yamchilwa had a dream in which he saw a yogi "adorned with the garb of the charnel ground and bones" (dur khrod kyi chas dang rus pas rgyan pa), playing a damaru with one hand and a thighbone trumpet in the other, carring a khatvamga staff, striking dancing poses. Yamchilwa thought, "Who is this?" at which time he was told by two women, "It's lord Tilopa, returned to benefit beings" ( 'di rje btsun te lo pa 'gro ba'i don la byon pa yin). The women told him to prepare a feast. When Yamchilwa awoke, he told his attendants to wait and see if a yogi like this would arrive. That day the Madman of Tsang arrived there, playing a damaru and blowing a thighbone trumpet, dancing like a deity and singing vajra songs. Dharmalord Yamchilwa told the Madman of Tsang he was "like an emanation of Tilopa" (rnal 'byor dbang phyug nyid rje btsun te lo'i sprul pa yin pa 'dra). The Madman of Tsang responded by saying that he was certainly one who upheld Tilopa's lineage (rgyud 'dzin), but he could not say whether or not he was an emanation (sprul pa) of him. ${ }^{1033}$

There are a number of things taking place exegetically in this passage. First, Tilopa is asserted to have been one who wore the various bone ornaments so essential to

\footnotetext{
${ }^{1033}$ Götsang Repa, pp 131.5-132.5.
} 
taking on the identity of a Heruka. Second, the Madman of Tsang is asserted to be the equivalent of or a stand-in for Tilopa. In large part what connects the Madman of Tsang with Tilopa is their shared manner of dress. Third, perhaps the most significant thing this passage asserts is that imitating the manner of a Heruka was not unique or novel to the Madman of Tsang, but had a thorough precedent in their tradition. Indeed, it helped define the Kagyü tradition's early saints. Further indicative of this concern, according to Götsang Repa, when the Madman of Tsang had visions of Nāropa and Tilopa, they are described as wearing the bone ornaments that are indicative of a Heruka. It may be the case that Götsang Repa included these details in The Life of the Madman of Tsang in order to make the Madman of Tsang's distinctive modes of dress and behavior seem congruent with the precedent of the past masters of their tradition.

The Madman of Tsang would be asserted as the equivalent of Tilopa in other ways as well. At one point, according to Götsang Repa's version of his Life, the Madman of Tsang was instructing a disciple who was a geshé with great textual learning, and in the process of imparting to him an instruction on the Mahāmudrā, tried to teach him the nature of the mind. The disciple simply was not getting it, so the Madman of Tsang hit him in the head with a stick. This is said to have led him to later have the full realization of the Mahāmudrā. ${ }^{1034}$ Here the Madman of Tsang is implicitly compared with Tilopa, who imparted a great teaching to Nāropa by hitting him in the face with a shoe.

Nyukla Peṇchen would also compare the Madman of Ü with Nāropa, saying that when the young Künga Zangpo met his master Chuwo Ripa at Tsari, it was like Nāropa's

${ }^{1034}$ Götsang Repa, pp 136.4-137.5. 
first meeting Tilopa. ${ }^{1035}$ Later the Madman of Ü would himself say that his guru Drakchokpa Rinchen Zangpo was in fact Chakrasaṃvara, that his master Chuwo Ripa was Tilopa, that other of his masters were in fact Nāropa and Padampa Sangyé. ${ }^{1036}$

The point to be taken from this is that one of the agendas of the body of literature created by the school of the Madman of Tsang was to establish a circularity of identities between the Madman of Tsang, the early siddhas of the Kagyü, and the deities Heruka/Hevajra. (We see this happen to a lesser degree in the literature about the Madman of Ü.) The early saints are associated with those deities; the Madman of Tsang is associated with those saints; and the Madman of Tsang is associated with those deities. Their identities all interpenetrate. This serves to establish the Madman of Tsang's eccentric behavior in the late 15th century as normative, even essential.

\section{III.1 The Madman of Tsang as Milarepa}

Further contributing to peoples' thinking about Milarepa as connected with the "holy madman" phenomenon — and in fact, a "holy madman" himself—is the fact that he and the Madman of Tsang tend to be conflated with one another. There is a complicated relationship between the Madman of Tsang and Milarepa. We will now try to unravel the various ways their identities interpenetrate.

As we saw above, the Madman of Tsang in effect created Milarepa as we know him today. In creating his version of the Life and Songs of Milarepa, the Madman of Tsang was drawing from earlier accounts, but exemplified great creativity and leeway in putting his own spin on the narrative. When we compare the Madman of Tsang's version

${ }^{1035}$ The Life of the Madman of $\ddot{U}, \mathrm{p} 397$.

${ }^{1036}$ The Life of the Madman of $\ddot{U}, \mathrm{p} 620$. 
with the ones that preceded it, we see the unique stamp he put on the story, how he shaped Milarepa for the world. Considering how important the Madman of Tsang was in shaping Milarepa as we know him, and the sheer amount of energy he put into working on Milarepa during his lifetime (from his early encomium to the writing and massdissemination of his Life and Songs), it should come as no surprise that some people would assert the Madman of Tsang to be a reincarnation of Milarepa.

There are a number of moments in Götsang Repa's version of The Life of the Madman of Tsang when that yogi is said by others or himself to be an incarnation of Milarepa. While the woodblocks for the Life and Songs of Milarepa were in the process of being carved, one Lodrö Tashi (blo gros bkra shis), who would later become one of the Madman of Tsang's close disciples, was afflicted by a black pox ('brum nag). While preparing to enter a meditative retreat to counteract the illness, he heard from a merchant about there being a "Powerful Lord of Yogis, the Madman of Tsang, an emanation (sprul pa) of Lord Mila, who is printing the Life and Songs of Lord Mila." Here the Madman of Tsang is said to be an emanation of Milarepa and is also called by the same title that Milarepa often is: rnal 'byor gyi dbang phyug (in Sanskrit: yogeśvara). This story could be taken as suggesting that the Madman of Tsang had a wide reputation as being an emanation of Milarepa even during his lifetime. ${ }^{1037}$

Shortly after this, when the woodblocks for his versions of the Life and Songs were being consecrated, some people asked the Madman of Tsang who he was an emanation of - was it Rechungpa or Ngendzongpa or someone else? The Madman of

\footnotetext{
${ }^{1037}$ Quintman 2006, p 257; Götsang Repa, p 148. It is also worth noting that the Madman of Tsang had been having visions of Milarepa throughout much of his life, starting when he was just two years old. Some of these encounters are summarized in Quintman 2006, pp 253-7.
} 
Tsang told them to look at the footprint at Lapchi Rechung Puk (la phyi ras chung phug) and they would find their answer. The footprint in question is one believed to have been left in solid rock by Milarepa, which the Madman of Tsang had had gilded some years earlier. This constitutes an implicit admission on behalf of the Madman of Tsang that he was in fact an emanation or a reincarnation of Milarepa. ${ }^{1038}$ The Madman of Tsang thus may have encouraged people to associate him with Milarepa.

After the Life and Songs of Milarepa were printed the 4th Red Hat and some other high-ranking Kagyüpa masters went to visit the Madman of Tsang. One of them had a dream in which five beautiful women told him to ask Milarepa for a teaching, and that Milarepa could be found sitting on a flat, white boulder. He and the maidens (presumably to be understood as emanations of the five long-life sisters) went forth and found the Madman of Tsang, dressed in the bone ornaments of the charnel ground, sitting on a boulder. He was then assured by the women that the Madman of Tsang is Milarepa. ${ }^{1039}$

According to the earliest version of the Madman of Tsang's biography (that by Ngödrup Pelbar), the Madman of Tsang proclaimed himself to be Milarepa while on his deathbed. Then in his final instructions, just before passing away, the Madman of Tsang states, "Monks and disciples, together with my patrons, you have directly met Milarepa himself during the degenerate age, and so you have good karma and excellent fortune. $" 1040$

\footnotetext{
1038 Quintman 2006, pp 257-8; Götsang Repa, p 152.

1039 Quintman 2006, pp 258-9; Götsang Repa, p 161.

${ }^{1040}$ Quintman 2006, p 260; Ngödrup Pelbar, p 26 b.
} 
Later, when composing his version of The Life of the Madman of Tsang, Götsang Repa would state explicitly from the outset that Sangyé Gyeltsen was the rebirth of Milarepa. ${ }^{1041}$ Thus based on these accounts, depending on which stories or parts of these stories we accept as historically accurate, the Madman of Tsang may have been widely renowned as an emanation of Milarepa during his lifetime; he may have been seen as Milarepa by his students; and he may even have explicitly referred to himself as an emanation of Milarepa. Later Tibetans would continue to assert the Madman of Tsang to be an incarnation of Milarepa, but also of other figures as well. ${ }^{1042}$

(In a similar vein, one of the Madman of Ü's masters, Sharmepa Sönam Tashi (shar smad pa bsod nams bkra shis), wondered at the miraculous things the Madman of Ü had achieved and said he was “an emanated being” (sprul pa'i skyes bu), without specifying who of. ${ }^{1043}$ The Madman of Ü's biography would also compare him implicitly with Milarepa. When the young Second Pawo, Tsuklak Trengwa, who was considered a reincarnation (sku skye) of Gampopa, visited the Madman of Ü in the 1520s, it is described as being was "like” ( 'dra) Gampopa's first going before Milarepa himself. ${ }^{1044}$ )

Thus the relationship between the identities of the Madman of Tsang and Milarepa is ultimately circular in nature. The Madman of Tsang created an image of Milarepa. The Madman of Tsang would then behave in such a way that people interpreted his activity as imitating that of Milarepa. This would go so far that people thought of the Madman of Tsang as Milarepa incarnate. Ultimately the Madman of Tsang is being seen as an incarnation of Milarepa, whose identity he himself created.

1041 Götsang Repa, p 13. Quintman pp 262-3.

1042 Quintman 2006, pp 262-4.

1043 The Life of the Madman of $\ddot{U}, \mathrm{p} 572$.

${ }^{1044}$ The Life of the Madman of $\ddot{U}, \mathrm{p} 635$. 
Thus the Madman of Tsang is skillfully writing his own identity, using Milarepa as a conduit. There is a circularity in their identities, with each a representation of the other, and each having an effect on how the other is understood. Milarepa was the Madman of Tsang in many ways; in many ways, the Madman of Tsang was Milarepa. ${ }^{1045}$ This is very similar to the interpenetrating relationships between the Madman of Tsang, the early siddhas of the Kagyü, and the deities Hevajra and Heruka, as mentioned above, but even more potent and forcefully articulated.

The fact that the Madman of Tsang may have fostered the notion that he was an emanation of Milarepa is somewhat ironic considering how roundly the Madman of Tsang repudiated the notion that Milarepa was a reincarnation of some past master. But encouraging his own personal association with Milarepa may have been an expedient, a part of the Madman of Tsang's greater agenda. As articulated by the Madman of Tsang, Milarepa is the most central and defining figure for the Kagyü sect. The Madman of Tsang used Milarepa as a means to work towards remaking the Kagyü sect into what he wanted it to be. In his own life the Madman of Tsang was trying to enact a specific vision of the Kagyü. By allowing himself to be associated with Milarepa, or even suggesting it himself, the Madman of Tsang accrued further credibility for the model of Buddhistness (and Kagyüness) that he was enacting in the course of his life.

In the same way that the Madman of Tsang rewrote Milarepa by penning his version of Milarepa's Life and Songs, he skillfully rewrote Milarepa by enacting a certain model of Buddhistness and claiming himself to be Milarepa.

\footnotetext{
1045 On this issue, see Quintman 2006, pp 260-1. As Quintman put it, p 243: "The relationship between Mi la ras pa and Gtsang smyon Heruka was intimate — so close that the boundaries between biographical author and subject, the crafting of a Life and the telling of one's own life story, were effectively broken down."
} 
Seen from a slightly different perspective, the Madman of Tsang's accepting (if not hinting at or openly asserting) the notion that he was a reincarnation of Milarepa can be taken as proof of the fact that the Madman of Tsang did not seriously intend to create a completely non-institutional form of the Kagyü. To the contrary, the Madman of Tsang's greater project was to make skillful use of the narratives about the Kagyü's past to create a stable, better-defined Kagyü in the time in which he lived. The fact that the Madman of Tsang did not flat-out deny being a reincarnation of Milarepa suggests that he was not looking to the past but to the future. This is analogous to the way that the Madman of Tsang told his students that printing the Life and Songs of Milarepa was more important than their meditating in caves at that moment. The Madman of Tsang's greatest intention was not to put the rhetoric of renunciation and anti-institutionalism into practice literally, but rather to make skillful use of that rhetoric and those narratives to rebuild the Kagyü in a new form.

The Madman of Tsang and Milarepa as portrayed by the Madman of Tsang both live as ones embodying a form of religious life that was rare (or at least said to be rare) in their respective times. They define themselves against everyone else's norms. They both had analogous positions vis-à-vis the greater religious culture that surrounded them. And for this reason they both became "madmen" (smyon pa) in almost the same sense, in terms of how they were positioned structurally.

This circularity in the identities of the Madman of Tsang and Milarepa plays a big role in why Tibetans think of Milarepa as so important to the holy madman tradition. One would not naturally connect Milarepa with the holy madman tradition simply by reading the text of his Life and Songs. People are compelled to think of Milarepa as a 
"madman" not so much because of the evocative power of the story of the almost-naked Milarepa and his sister or the inscrutable song about the "crazy lineage," but because of the underriding idea that the Madman of Tsang was in fact reenacting a life modeled by Milarepa — a model we know the Madman of Tsang himself skillfully created.

\section{IV. The Swayambhūnāth stūpa}

Another important part of the Madman of Tsang's long-term cultural project, as indicated by the Karmapa's letter, was his directing the renovation of the Swayambhūnāth stūpa in Kathmandu in 1504, three years before his death. The Swayambhūnāth stūpa was a place of great importance for the Madmen of Ü and Tsang, the wider circle of Kagyüpas in which they circulated, and Tibetans in general. The Kathmandu Valley had long been an important destination for Tibetan traders. ${ }^{1046}$ It was also a major pilgrimage destination. ${ }^{1047}$ (As we see so often in the history of Buddhism, those two pursuits often go together.) Tibetans liked to make this visit during the winter months, perhaps to avoid the heat of the lowlands at other times of the year. One of the places Tibetans would have often visited during their sojourn in Kathmandu was the Swayambhūnāth stūpa. Meditators also would have visited cave sites around the valley, like Yangleshö and Pharping, which were believed to have once been blessed by the presence of great Indian siddhas like Nāropa.

Drakpa Tayé (1469-1531), the dharma brother of Drukpa Künlé whose life we learned about in Chapter Four, was commanded by his guru to travel to Nepal to make a

\footnotetext{
${ }^{1046}$ Much of Todd Lewis' research has carried the goal of creating wider recognition of the extensiveness of these connections.

1047 The yogi to whom Milarepa's mother secretly entrusts seven measures of gold to be transported to her son is said to have been returning to Ü from central Nepal (bal po), 2005 version, p 41.
} 
prayer in front of the Swayambhūnāth stūpa (the text of that prayer is contained within his biography). Drakpa Tayé's biography mentions his meeting many Tibetan pilgrims on their way to Nepal when he was on his way back to Tibet. ${ }^{1048}$

According to his biography, before he was known as the Madman of Ü Künga Zangpo was instructed by his lama, Drakchokpa Rinchen Zangpo, to meditate in sites in central Nepal, including "Indian” Pharping. ${ }^{1049}$ In time Künga Zangpo made two visits to central Nepal (bal yul mthil), the Kathmandu Valley, in the course of which he visited such places as the Swayambhūnāth stūpa, "Indian" Pharping (rgya gar pham thing), Asura's cave (a su ra'i brag phug), Yangleshö cave (yang le shod), and the Dhana and Ramadoli boneyards. ${ }^{1050}$ Later, after he had established himself as a master in his own right, residing at Tsimar Pel monastery, the Madman of Ü had some of his students pledge to go meditate at the Swayambhūnāth stūpa. ${ }^{1051}$ The Swayambhūnāth stūpa was of comparable importance to other Buddhist pilgrimage sites for Tibetans in the 15 th and 16 th centuries.

According to Götsang Repa's version of his Life, the Madman of Tsang made three visits to Nepal. On the first occasion, after meditating at Lapchi and Chubar, he joined some pilgrims (gnas bskor ba) and went with them to the Swayambhūnāth stūpa. After this he visited "the Protector of the Tibetan Fields" (bod thang mgon po), a stone statue of Mahākāla. When the Madman of Tsang went before the statue the earth shook,

\footnotetext{
${ }^{1048}$ The Life of Drakpa Tayé, pp 162.5-169.1. On Vulture Peak, see Dowman, A Buddhist Guide to the Power Places of the Kathmandu Valley, pp 15-7.

1049 The Life of the Madman of $\ddot{U}, \mathrm{p}$ 420.1-.2.

1050 The Life of the Madman of $\ddot{U}$, the first visit is pp 443-53; second visit is pp 493-5. On why it is called "Indian" Pharping, see Dowman, A Buddhist Guide to the Power Places of the Kathmandu Valley, pp 51-2; on the Ramadoli boneyard, see pp 31-2; on Asura cave, see pp 52-4; on Yangleshö, see pp 48-51.

${ }^{1051}$ The Life of the Madman of $\ddot{U}, \mathrm{p} 599$.
} 
there was a great sound, and the Madman had a vision of the statue (mgon po'i sku) becoming the size of Mount Meru, and dancing a fierce dance (bro brdung drag po). The Nepalese and Tibetans who were there saw the Madman of Tsang holding hands with the deity and dancing. ${ }^{1052}$ (As was mentioned above, Mahākāla had earlier paid a visit to the Madman of Tsang while staying at Tsari, when he was first starting to gather texts on the Aural Transmission.) It is also said that on this visit to the Kathmandu Valley the Madman of Tsang sat cross-legged in meditation for seven days on the third of the thirteen brass rings atop the Swayambhūnāth stūpa. In the midst of these seven days there was an earthquake, but even still the yogi did not waver from his meditation. People were very impressed by this feat and requested dharma-connections (chos 'brel) from him. Then he went back to Tibet. ${ }^{1053}$

On his second visit to Nepal the Madman of Tsang went directly to the Protector of the Tibetan Fields, and stayed there for a night. When the local people came to make offerings at the statue, they were amazed to again see the Madman of Tsang holding hands with the deity (mgon po dang rje grub thob chen po phyag sbrel) and dancing. Those people told about this miraculous occurrence to others and the Madman of Tsang's fame spread. During this visit to Kathmandu the Madman of Tsang also meditated at a charnel ground near Swayambhūnāth, again attracting much attention through his miraculous activities. Then while staying at a temple near the stūpa, the Madman was visited by the god Gaṇapati (Gạ̣eśa), who requested that he renovate the stūpa. This story will be told in greater detail below. The Madman of Tsang would not renovate the

\footnotetext{
1052 This first visit is told in Götsang Repa, pp 49.1-50.3.

1053 In 1680 a real madman would climb up the rings atop the stūpa one night, but he slipped and fell and died as a result, Śri Svayambhū Mahācaitya, by Hem Raj Shakya; translated by Min Bahadur Shakya (Kathmandu: Svayambhu Vikash Mandal, 2004), p 203.
} 
stūpa until a later visit, but he had whitewash (sku dkar) applied to the stüpa (the biography makes clear that whitewashing the Swayambhūnāth stūpa was in fact the purpose of the Madman of Tsang's visit to Nepal on this occasion). ${ }^{1054}$ He again visited the Protector of the Tibetan Fields (bod thang mgon po), then returned to Tibet. ${ }^{1055}$

The Madman of Tsang's third visit to Nepal was the occasion of his restoring the Swayambhūnāth stūpa. The events of this visit will be described in detail below.

In addition to his own personal visits to Nepal and the Swayambhūnāth stūpa, the Madman of Tsang also sent his students there at various times. After his second visit to Nepal but before he returned there for his great renovation project, during one winter the yogi sent some of his students on pilgrimage to the Swayambhūnāth stūpa while he stayed in retreat. During this pilgrimage his students had an encounter with some students of the Madman of Ü, which led to a physical altercation and deaths on both sides, as was described in Chapter Four. ${ }^{1056}$

As was mentioned above, on his first and second visits to the Kathmandu Valley ${ }^{1057}$ the Madman of Tsang paid visits to a statue referred to in his biography as the "Protector of the Tibetan Fields" (bod thang mgon po), which seems to have had a potent cultic significance. This refers to the large stone statue of Tundikhel Mahākāla. (There is no mention of the Madman of Ü or Drakpa Tayé's having gone there. ${ }^{1058}$ ) According

\footnotetext{
1054 Götsang Repa, pp 172.2, 176.3 .

${ }^{1055}$ Götsang Repa, pp 172.2-175.7.

${ }^{1056}$ Götsang Repa, pp 200.7 to 201.7 .

${ }^{1057}$ Schaeffer, The Culture of the Book in Tibet, p 65, states that the Madman of Tsang visited the statue on his third trip to Nepal, before beginning renovations on the stüpa. This would be mentioned on Götsang Repa, pp 215 or 216 , but I do not see his visiting the statue mentioned there.

${ }^{1058}$ See Franz-Karl Ehrhard, Life and travels of Lo-chen Bsod-nams Rgya-mtsho (Lumbini: Lumbini International Research Institute, 2002), p 68. On Ramadoli boneyard and Tundikhel Mahākāla, see A. W. Macdonald and Dwags po rin po che, "Un guide peu lu des Lieux-saints du Nepal. IIe Partie," in Tantric and Taoist Studies in Honour of R.A. Stein, Vol. I, edited by Michel Strickmann (Bruxelles: Institut belge
} 
to Götsang Repa, this deity had a special connection to the Aural Transmission teachings. In his biography of the Madman of Tsang, Götsang Repa refers to the Protector of the Tibetan Fields as the "wish-fulfilling dharmalord of the Aural Transmission." On the Madman of Tsang's second visit to Kathmandu he thanked (btang rag) the deity for the fact that the seal demanding that the teachings of the Aural Transmission be kept in a single lineage had been released (gcig rgyud kyi bka' rgya las dkrol nas), so that he could now set them to writing without the lineage being brought to an untimely end. ${ }^{1059}$ The Madman of Tsang's worshipping this statue is even mentioned in a Newari source, indicating the significance of his relationship with the deity. ${ }^{1060}$ This corroborates Götsang Repa's statement that the Madman of Tsang had become famed among the local population after they saw him holding hands and dancing with the statue come to life.

The Swayambhūnāth stūpa was held sacred by Buddhists and Hindus alike, with a rich mythology imbuing it with significance. Over the years Tibetans have believed the stūpa to contain relics of the Buddha, of his disciple Kaśyapa, that Nāgārjuna cut off his hair and scattered it there, that the stüpa was not manmade but arose spontaneously during the time of a previous Buddha, and so on. ${ }^{1061}$ From the perspective of Tibetans, it

\footnotetext{
des hautes études chinoises, 1981), pp 255-7. On this Mahākāla statue, see Dowman, A Buddhist Guide to the Power Places of the Kathmandu Valley, pp 42-4. Some traditionally believed the statue to have been self-arisen, while others thought of it as made by Nāgārjuna. The statue is of a protector (mgon po) deity and is located at a place called the "Tibetan fields" (bod thang) because of having been (according to legend) the spot where the ministers of the Tibetan king Songtsen Gampo waited for the king of Nepal to hand over his daughter, Bhrkuti, for marriage in the early 7 th century.

${ }^{1059}$ Götsang Repa, p 175.5-.6: 'di'i res la gtso bor bod thang mgon po snyan rgyud yin bzhin nor bu'i chos bdag yin phyir/ gcig rgyud kyi bka' rgya las dkrol nas yig ger bkod pa la bar chad med pa'i btang rag dang / slar yang bsrung mar mnga' gsol ba bu slob rnams la ye shes mgon po'i dbang dang rjes su snang ba rnams mdzad/

${ }^{1060}$ Alexander von Rospatt, "A Historical Overview of the Renovations of the Svayambhūcaitya at Kathmandu" in Journal of the Nepal Research Centre, Vol. 12, 2001, p 205.

${ }^{1061}$ See Alexander von Rospatt, "On the Conception of the Stüpa in Vajrayāna Buddhism: The Example of the Svayambhūcaitya of Kathmandu" in Journal of the Nepal Research Centre 11, 1999, pp 130-2. See
} 
seems to have been of comparable significance to the Boudhanāth stūpa, on the other side of Kathmandu. Alexander von Rospatt has shown that a few of the Tibetans who over the years undertook renovations of the Swayambhūnāth stūpa did so only after they found they had funds leftover after completing work on the Boudhanāth stūpa. ${ }^{1062}$ Nevertheless, the Boudhanāth stūpa does not figure into the lives of the holy madmen or other 15th-century Kagyüpas we are considering here. The two stūpas may well have been of varying levels of importance to different groups of Tibetans, and likely shifted during different historical periods.

As will be seen below, the Madman of Tsang was just one among many Kagyüpas who took pains to renovate the Swayambunath stūpa or see to its upkeep over the years, suggesting that it may be of some particular cultic significance. The biographies of the 15 th-century holy madmen are surprisingly mute on what that significance might be. One possibility for why the Swayambhūnāth stūpa may have had a special significance for the Madman of Tsang and other Kagyüpas is that famous saints of their lineage's past may have had associations with that place. When the Madman of Ü visited Swayambhūnāth stūpa on his second visit to Nepal it is said that a vast tantric feast was being held, during which the Madman of Ü had visions (gsal snang) of various past masters, who imparted to him teachings, prophecies (lung bstan) and more. ${ }^{1063}$ Among those past masters mentioned by name are Shawari[pa], the siddha of whom Drukpa Künlé is sometimes said to have been an emanation, and the lord Mitra Yogi (rje

also Keith Dowman, A Buddhist Guide to the Power Places of the Kathmandu Valley (Thamal: Himalayan Buddhist Meditation Centre, 2007), pp 17-21, 29. For the most comprehensive study of the history and mythology of the stūpa, see Śri Svayambhū Mahācaitya, by Hem Raj Shakya; translated by Min Bahadur Shakya (Kathmandu: Svayambhu Vikash Mandal, 2004).

1062 von Rospatt, "Svayambhūcaitya."

${ }^{1063}$ The Life of the Madman of $\ddot{U}, \mathrm{p} 494$. 
mi tra dzo gi; c. 12th century), whose biography was written or compiled by Götsang Repa at Rechung Puk. ${ }^{1064}$ This suggests that part of the reason why the site may have been important to those in the holy madmen's circle was that it was believed to have special associations with the great Buddhist siddhas of the past. The evidence for this is limited, however. Nowhere, for example, do the biographies of the Madmen of Ü and Tsang say that the Swayambhūnāth stūpa "had been blessed by Nāropa..." or anything of the sort, although this is said of a charnel ground nearby. ${ }^{1065}$ Nowhere do we see any evidence that the Madman of Tsang saw the stüpa as having some special connection to the tantras, or that it in some way connected him with the siddhas of the old days. ${ }^{1066}$ The lack of a clearly-articulated reason for what special cultic significance the stüpa may have had for the Madman of Tsang suggests that it may have been a different sort of factor that motivated the Madman of Tsang to take on the project.

We can get a better understanding of the significance and meaning of the Madman of Tsang's renovating the monument when we look at the long history of Tibetans involved in renovating the site, both before and after the time of the Madman of Tsang.

The Swayambhūnāth stūpa stands atop a hill on the western side of the city of Kathmandu. We can date the first construction of the stüpa to the 11 th or 12 th century,

\footnotetext{
${ }^{1064}$ Schaeffer, "The Printing Projects of Gtsang Smyon He ru ka and his Disciples" (forthcoming), p 19. 1065 Götsang Repa, p 174.2.

${ }^{1066}$ The long verse commemorating all the many donors to the stüpa restoration project begins with a few lines on the significance of the stüpa, which we may assume were penned by the Madman of Tsang. They read: dus gsum rgyal ba kun kyi thugs kyi rten/ glang (glad?) ru lung bstan mdo'i (?) bstan bya'i gtso/ go ma sa la g+ha d+ha'i mchod rten ni/ mchog gi gdul bya'i mchod yul 'jig mi srid/ dman pa'i snang ngor snang ba'i rnam pa 'di/ sngar yan nongs tshul bstan pa du ma las/ 'byor ldan dad can rnams kyi rims par bsos/ da lta zhig bsos dus la bab pa las... Götsang Repa, pp 220.6-221.1. There is nothing really special said about the stūpa, other than it being prophesized in the sütras and a representation of the minds of all the Buddhas of the three times. Götsang Repa, p 218.5 again refers to the stüpa as go ma la sa la g+ ha $d+h a$ 'i mchod rten; and a slight variant on p 220.7, go ma sa la g+ha $d+h a$.
} 
although there is some evidence and native traditions that suggest a much earlier origin for the monument. ${ }^{1067}$ The stüpa has a long history of falling into disrepair-by the natural ravages of time, or because of being struck by lightening, or attacked by some of the many invaders who visited the Kathmandu Valley over the centuries. Within a period of roughly 450 years, from 1370 to 1820 , the stüpa was disassembled and rebuilt at least twelve times. ${ }^{1068}$ This number does not include numerous occasions on which only more superficial repairs were carried out. The stūpa was enlarged in the process of these rebuildings; at the time of the Madman of Tsang the monument would have been visibly smaller than it is today.

The Madman of Tsang was just one in a long line of famous Buddhist masters to undertake renovations of the Swayambhūnāth stüpa. Many of them were Tibetan, and many of those Tibetans were associated with the Kagyü sect. The first of these renovation projects under the direction of a Tibetan took place in probably the first half of the 13 th century when the stüpa was completely rebuilt by a member of the Tselpa branch of the Kagyü (tshal pa bka' brgyud) named Jotsün Trepa (jo btsun spras pa), who was associated with the western Tibetan principality of Gungtang. ${ }^{1069}$ On this occasion the stūpa was completely disassembled. A new central pillar (yaști) fashioned from a tree-trunk was installed, and then the dome of the stūpa built around it. Jotsün was present throughout the renovation process and was honored with gifts from the king and the nobles of Kathmandu, then returned to Tibet. ${ }^{1070}$

\footnotetext{
1067 von Rospatt, “Svayambhūcaitya,” pp 119-200.

1068 von Rospatt, "Svayambhūcaitya," p 195.

1069 von Rospatt, "Svayambhūcaitya," pp 200-1.

${ }^{1070}$ Accounts of later renovations of the stüpa record how the tree that was to form the central pillar (yaști) was dragged from the place it was cut down to the site of the stüpa, which included dragging it up the hill
} 
In the second half of the 13th century the stüpa was again completely disassembled and rebuilt, down to the central pillar, by another Tibetan who was a Sakyapa. Pönchen Śākya Zangpo (dpon chen śākya bzang po) was the deputy appointed by the Mongols to handle their administration of Tibet, and he was the main sponsor of the project, although it is uncertain whether or not he was personally present in Kathmandu to oversee the work, or if it was handled by his representatives. ${ }^{1071}$

A few reconstructions later, when the stüpa was rebuilt down to the central pillar in 1413, the main sponsor was the king of Kathmandu, Jyotir Malla, with additional funds having been sent by various regional rulers in Tibet and the emperor of China. The man who oversaw the project was Mahāpaṇịita Śākyaśrī Śāriputra, the abbot of the monastery at Bodhgaya. He was passing through Nepal on his way to visit the Chinese emperor at the Ming court, and stopped to take on the project. The circumstances of this renovation are a testament to the fame and significance of the stüpa, with a ruler living as far away as China seeing the renovation as a project worthy of his largesse. As a project of international significance, it is only fitting that it would be overseen by someone with as much bearing as this internationally-renowned scholar and abbot of such an important Buddhist site. ${ }^{1072}$

The next person to oversee significant work on the stüpa, 93 years later, was the Madman of Tsang. His role in the project will be discussed in detail below.

atop of which the stūpa is perched. The inhabitants of different neighborhoods of Kathmandu took turns dragging the tree to Swayambhūnāth after it had been cut. This took something like six weeks, with each group of workers (volunteers or conscripts?) spending six days dragging the giant tree, von Rospatt, "Svayambhūcaitya," pp 208-10.

${ }^{1071}$ von Rospatt, "Svayambhūcaitya," p 201. See Dowman, A Buddhist Guide to the Power Places of the Kathmandu Valley, p 20

1072 von Rospatt, "Svayambhūcaitya," p 203. 
The connection between the Madman of Tsang's lineage and the Swayambhūnāth stūpa did not end with his death. In the 1520s the stūpa was damaged by invaders, who tore off the copperwork that sits atop the stūpa, and tried to set fire to the entire monument. It was badly damaged, but not completely destroyed. The person who took responsibility for dismantling the stūpa and rebuilding it from its central pillar was Lhatsün Rinchen Namgyel (1473-1557), one of the Madman of Tsang's foremost disciples who, as we have seen, was a leading figure in their school's printing projects. According to Rinchen Namgyel's biography, the Madman of Tsang appeared to him in a dream and requested that he restore the monument. The work was carried out over the course of ten years. This was a complete reconstruction, and more extensive than the better-documented work carried out under the direction of the Madman of Tsang. Rinchen Namgyel seems not to have been very well funded for this endeavor, as he did not have enough copper to cover the harmikā or the thirteen rings. This work was later picked up by one of Rinchen Namgyel's disciples, who covered the remaining sides of the harmikā and the thirteen rings with gilded copper sheets in 1570. The stūpa was finally was consecrated, bringing Lhatsün's work to conclusion, in $1572 .{ }^{1073}$ Thus after the Madman of Tsang, his disciple and a grand-disciple also took first-hand roles in seeing to the upkeep of the monument.

Nearly sixty years later, the 6th Red Hat, Garwang Chöki Wangchuk (gar dbang chos kyi dbang phyug, 1584-1630) was responsible for some minor work being done to the exterior of the stüpa, in 1629 or $1630 .^{1074}$

\footnotetext{
1073 von Rospatt, “Svayambhūcaitya,” pp 206-7.

1074 von Rospatt, "Svayambhūcaitya," pp 215-6.
} 
The next person to undertake work on the Swayambhūnāth stūpa was Rangrik Repa (rang rig ras pa, d 1683), a Drukpa Kagyüpa hailing from Spiti. He was in Kathmandu with the purpose of overseeing repair work being done on the great Boudhanāth stūpa on the opposite side of the city. Finding himself with leftover funds from his work on Boudhanāth, he decided to have some repairs done on the Swayambhūnāth stūpa, carried out between 1681 and $1683 .^{1075}$

In 1751 to 1758 work was carried out on the Swayambhūnāth stūpa by Kaḥtok Rikdzin Tsewang Norbu (kaH thog rig 'dzin tshe dbang nor bu, 1698-1755), a Nyingmapa from Kham. Like Rangrik Repa, he too decided to sponsor work on Swayambhūnāth only after finding himself with leftover funds from work on Boudhanāth. ${ }^{1076}$ In 1755 Kahtok Rikzin Tsewang Norbu left Kathmandu to return to Tibet, with the project still unfinished. Oversight of the project was taken over by Kargyü Trinlé Shingta (dkar brgyud 'phrin las shing rta, 1718-1766), the 7th Drukchen Rinpoché, who had been a close friend of Kaḥtok Rikzin Tsewang Norbu’s. ${ }^{1077}$ When the work on the stüpa was finally finished, the 7th Drukchen had already returned to Tibet, so the 7th Pawo, Dorjé Tsuklak Gawa (rdo rje gtsug lag dga' ba), who had come to Nepal for pilgrimage, served as the principal officiant for the consecration ceremony. ${ }^{1078} \mathrm{He}$ is best thought of as a representative of the Karma Kagyü school. (We met the First Pawo, Chöwang Lhündrup in Chapter Four; the Second Pawo was Tsuklak Trengwa, author of the famous Tibetan history, The Scholar's Feast. The Second

\footnotetext{
1075 von Rospatt, "Svayambhūcaitya," pp 216-7.

1076 von Rospatt, "Svayambhūcaitya," pp 221-8. See also Keith Dowman, A Buddhist Guide to the Power Places of the Kathmandu Valley, p 16.

1077 von Rospatt, "Svayambhūcaitya," p 226.

1078 von Rospatt, "Svayambhūcaitya," pp 227-8.
} 
Drukchen, Künga Peljor, was a teacher of the Madman of Ü, the Madman of Tsang and Drukpa Künlé.)

When the stūpa was renovated from 1814 to 1817 , the project was again overseen by lamas of the Drukpa Kagyü, this time from Bhutan rather than Tibet. ${ }^{1079}$ A Drukpa Kagyüpa from Kham was also a major player in the renovation of the stūpa carried out in 1918. Tokden Śākyashri (rtogs ldan ŚākyashrI, 1853-1919), too old to travel from eastern Tibet to Nepal, nevertheless oversaw the project by sending emissaries to carry out the work. They were met and aided by individuals sent by the King of Bhutan (who was a devotee of Tokden Śākyashri) and also the 13th Dalai Lama. ${ }^{1080}$

Thus the Madman of Tsang was just one among many Tibetans who were personally involved with the reconstruction or renovation of the great Swayambhūnāth stüpa over the years. That the majority of the Tibetans involved with these projects were of the Kagyü sect is not insignificant.

Having established this broader understanding of the history of Tibetans renovating the monument, let us now look at the specifics of the Madman of Tsang's work in this regard. One of the fifteen chapters of Götsang Repa's version of his Life is dedicated to the Madman of Tsang's restoration of the Swayambhūnāth stūpa. ${ }^{1081}$ The amount of detail given in this account is remarkable, providing many fascinating and useful details about what this renovation process entailed.

\footnotetext{
1079 von Rospatt, "Svayambhūcaitya," pp 228-9.

1080 von Rospatt, "Svayambhūcaitya," p 232.

1081 This is chapter 13, pp 208.4-226.7.
} 
According to Götsang Repa's account, the Madman of Tsang received a few requests to take on the reconstruction of the Swayambhūnāth stūpa. ${ }^{1082}$ (Let us recall that earlier, on the Madman of Tsang's second visit to the Kathmandu Valley, he was purportedly visited by the god Ganapati, who asked him to renovate the stüpa and pledged his assistance in such an endeavor.) King Ratna Mala (ra da na ma la) of Kathmandu and his ministers, other Nepalese and Tibetan translators, and other masters, had all sent letters of request to the Madman of Tsang via the Tibetan pilgrims who visited Kathmandu each year. When the Madman of Tsang received an especially urgent request, he finally agreed to take on the project. He sent a messenger to Kathmandu bearing a letter, saying, "Now I will do the renovation, so gather the wood and other materials." The king of Kathmandu and his retinue (bal bo 'khor bcas) were very pleased, and the king sent a letter back to the Madman of Tsang saying that he would provide the Madman and eighty of his disciples with the provisions they needed until the project was finished.

The Madman of Tsang then called for all of his students to gather. At this time his disciples voiced a wide range of opinions about this project. Some noted that the chances of failing in this project were great, and if they failed, they would become an object of scorn. Some thought it could be done, but would take three or four years. Some feared that it would be too wearying for the Madman of Tsang. Some expressed their concern that it would be detrimental to their religious practice (dge sbyor 'chag). Some worried over the number of deaths such a project would cause, as spending time in

\footnotetext{
1082 Götsang Repa's version may suggest that the Madman of Tsang himself was responsible (inadvertently) for the destruction of the stūpa, as there had been a great earthquake (destroying the stüpa?) while the Madman sat on top of it meditating. Did this make the Madman of Tsang obligated to later repair the monument? pp 49.4-52.2.
} 
Nepal was a dangerous prospect for Tibetans. A major concern was the question of who should be sent out to do the fundraising. Some thought the more famous of the Madman of Tsang's disciples should do it; some thought that unless the Madman of Tsang himself visited these Tibetan dignitaries and asked for donations, they would not be able to gather enough. There was thus some very strong and well-reasoned opposition to the project from among the Madman of Tsang's disciples.

The Madman of Tsang tried to allay their fears by saying that the $d \bar{a} k i n \bar{s}$, the dharma protectors, and the eight classes of gods and demons (lha srin bde brgyad) would ensure the success of his activity. The Madman of Tsang then sent out some of his current students carrying a letter he wrote to visit some of his more famous disciples who had studied with him in the past, now staying in places as far away as Tsari in the east and Mount Kailash in the west (the Madman of Tsang was at the time staying in Chuwar). Other disciples were sent to visit "famous lords and ministers" (grags pa can gyi rgyal po dang blon po) and other faithful patrons. ${ }^{1083}$

The dissension in the ranks of the Madman of Tsang's disciples regarding the value of undertaking the renovation of the Swayambhūnāth stūpa is very similar to that which he faced when working on printing the Life and Songs of Milarepa. He would face this kind of dissent from his students again shortly after this, when trying to establish some meditation centers in western Tibet. ${ }^{1084}$ As before, these disagreements belie the

\footnotetext{
1083 Götsang Repa, pp 208.5-210.1.

1084 Just after receiving such flack from his students about the Swayambhūnāth project, the Madman of Tsang was also criticized by some of his students for wanting to build dwellings at retreat sites in western Tibet. He asked a local lord for permission to build a meditation hut at a certain site, but was told no, because he was a fallen monk (btsun log) and because the administrator had faith in the Dharma system of Ngor (ngor pa'i chos lugs la dad), and had no faith in the Kagyü. Still the Madman of Tsang would not give up, trying to negotiate to get control of the site. Frustrated, the Madman of Tsang's disciples wanted
} 
disjuncture between the Madman of Tsang's thinking and that of his disciples. The disciples, more literal-minded, are concerned primarily with the question of their religious practice in the present. The Madman of Tsang sees a much bigger picture, thinking about the various positive effects such a project could bring. Most biographers would be quick to elide from their narratives stories of their masters facing dissension from their disciples. But Götsang Repa-himself an author of biographies and a printer - understood and shared the Madman of Tsang's outlook on the value of these cultural projects and highlighted it accordingly.

In time the Madman of Tsang's disciples returned from their fundraising trips. The Madman of Tsang and some of his students departed for Nepal, while others stayed behind in retreat performing rituals to ensure the longevity of the Madman of Tsang and the favor of the dharma protectors.

The long section that follows in Götsang Repa's version of The Life of the Madman of Tsang describing the renovation of the stüpa is said to have been extracted from a certain description of the Swayambhūnāth stūpa called the kun rang gi dkar

to resort to using black magic to bring the recalcitrant lord to heel. The Madman of Tsang would not allow them to. A few of his students, concerned about all the distraction this was causing, argued to the Madman of Tsang that this building project was being detrimental to their religious practice, that the lord's mind would not be turned, and they should give up. Their only option, they said, was for the Madman of Tsang himself to perform some sort of miracle ( $r d z u$ 'phrul) or kill the recalcitrant lord by casting a spell ( $m$ thu stobs). Lastly they suggested he contact Dönyö Dorjé (the sde pa sgar pa) to ask his help, as he was "not one who ever did not listen" to the Madman of Tsang's requests. The Madman of Tsang chastised his students for lacking vision, for making the mistake of seeing their lama as a mere mortal. He said that his work of spreading the teachings took many lifetimes. He would not cast magic or send someone to visit Dönyö Dorjé. It seems that eventually Dönyö Dorjé did get involved with the situation, sending the Madman of Tsang a letter stating that the site had indeed been imparted to him. The Madman of Tsang seems to have become quite disappointed and bitter with his students for being unable to withstand even a little hardship. By contrast, the Madman of Tsang stands out as highly ambitious, Götsang Repa, pp 212-3. 
chag. ${ }^{1085}$ As the Madman of Tsang and his followers made their way into Nepal via Kyirong they were received by many Nepalese, some of them playing instruments. When they got to the Kathmandu Valley, the Madman of Tsang was received by king Ratna Malla and his ministers, and people from all classes of society. There was a lavish reception, with banners and parasols, drums, cymbals, horns and the widest possible variety of instruments. There were 556 women, richly adorned and as beautiful as goddesses. The Madman of Tsang then visited some temples and had an audience with the king, then went to the Swayambhūnāth stūpa to begin preparations for the work. He was then visited by a commoner who we are told was actually an emanation of the deity Viśvakarman ( 'bi sho dkar ma), the lord of building (bzo bo'i rgyal po). ${ }^{1086}$ The deity in the form of this man respectfully sang a song to the Madman of Tsang, stating his personal pledge to see that the project was a success. Then he disappeared. As we will see, the deity Viśvakarman plays an ongoing role in the story of the renovation of the Swayambhūnāth stūpa under the Madman of Tsang's direction. This deity was also associated with the carving of woodblocks for the printing of books, and thus unites the two aspects of the Madman of Tsang's cultural project that are the subject of this chapter. $^{1087}$

The Madman of Tsang performed a pre-construction ritual (ar dga'i cho ga); the local priests also performed the ritual in the Newari fashion ('byu 'byu rnams kyis kyang bal po rang gi lugs kyi ar dga' cho ga byas). Then the real work began by tearing down

\footnotetext{
1085 Götsang Repa, pp 213.5-220.6. See Schaeffer, The Culture of the Book in Tibet, pp 65-7 for a summary of the Madman of Tsang's renovation project.

1086 Götsang Repa, p 216.2.

1087 See Schaeffer, The Culture of the Book in Tibet, p 62, on Viśvakarma's relationship with woodblock carvers.
} 
the upper part of the stüpa and the copper rings (mchod rten gyi rtse nas gdugs dang chos 'khor). This was an inauspicious time in the process of the renovations, and many of the Tibetans, fearing disease, returned home. The author of this passage, speaking in the first person, says that he was one of about three hundred Tibetans who remained. The monks among them made a vow that they would not leave until the stüpa was finished, even if it cost them their lives.

We are told that working on the project there were: 72 woodworkers; 640 wood preparers (? kha phra 'khrig mkhan); each day there were eight hundred people conscripted ( ' $u$ lag) to carry wood; 130 wood cutters (shing spyod [sic] mkhan); twelve iron workers (? lcags 'gar ba); twenty five metal beaters (? 'phul pa); 25 copper workers (zangs 'gar ba); and twelve gold workers. Some of the Madman of Tsang's disciples headed work teams, while others spent their time performing rituals. ${ }^{1088}$

The author comments that in general the Nepalese ( $b a l$ po) went about things slowly. In particular, the man working as translator between the Tibetans and the Nepalis was extremely lazy and spent much of his time drunk, which caused delays in their progress. ${ }^{1089}$ The Madman of Tsang gave him some gold and made him promise not to drink during the day. The translator gave the gold back to the Madman of Tsang and cried, stating his commitment to seeing the project through and promising to obey the commands of the Madman of Tsang.

When the workers had finished remaking twelve of the thirteen rings atop the stüpa, the workers were attacked by a swarm of bees. The Madman of Tsang issued a

\footnotetext{
1088 Götsang Repa, p 216.5-.7.

1089 Götsang Repa, p 217.4.
} 
command and the bees immediately went away. ${ }^{1090}$ At one point work was being slowed down by rain, but the Madman of Tsang made a supplication in the Śantapuri temple to ensure that it not rain again until the project was finished, and from then on they had sunshine every day. ${ }^{1091}$ When they had some problems with fires, the Madman of Tsang made a pronouncement, blinked his eyes and snapped his fingers, and then fire was a problem no more.

According to this account, everywhere the Madman of Tsang went there were 500 or 600 beautiful women. ${ }^{1092}$ On a few occasions innumerable people showed up bearing remarkable amounts of offerings. In time the work was finished. It seems that it consisted of replacing the thirteen rings, the canopy on top of that, as well as various other adornments. In general this was a small-scale project, with work only being done to the outside of the monument. They did not tear down the bulbous part of the stūpa or replace the central pillar, as was done at so many other points in the monument's long history. In the course of the renovations the Madman of Tsang actually made some slight alterations to the form of the stüpa. This included adding a copper parasol on top of the existing parasol, in order to protect it from rain, and some other superficial changes. ${ }^{1093}$ The work on the stüpa was completed in two months and thirteen days; the Madman of Tsang's entire visit to the Kathmandu Valley would last a total of three and a half months. ${ }^{1094}$

\footnotetext{
${ }^{1090}$ Götsang Repa, p 218.1-.2.

${ }^{1091}$ On this temple, see Dowman, A Buddhist Guide to the Power Places of the Kathmandu Valley, pp 21-4. See Shakya, pp 537-45, including a list of the variant spellings of its name and the images housed within it. ${ }^{1092}$ Götsang Repa, p 219.1.

${ }^{1093}$ Götsang Repa, p 224.3-.5. von Rospatt, "Svayambhūcaitya," pp 197, 205, 217.

${ }^{1094}$ Götsang Repa, pp 220.5. Work on the project began on the 15th day of the 12th month in the woodmale-mouse year (shing pho byi), 1504, p 225.2.
} 
Just before everyone was to gather for the whitewashing of the stūpa and the consecration ritual, a miraculous wind swept through the area, wiping away all the dirt and refuse left behind by their work. Everything became perfectly clean. On the day of the actual ritual the Madman of Tsang went to the king's palace, where he was given golden ornaments, lavish clothing and other offerings. There was, as at the time of the Madman of Tsang's arrival in Kathmandu, offerings, music, dancing and singing. Nepalis ${ }^{1095}(b a l)$ and Tibetans (bod) bearing offerings filled the entire area from the town out to the Swayambhūnāth stūpa. The sky was filled with deities. There was a procession out to the stūpa and then the consecration ritual was performed. There were many miraculous signs, like clouds and multi-colored mists, which pleased everyone; there were uncountable people and deities performing circumambulations and prostrations. When those performing the consecration all threw flowers into the air, divine flowers and a pleasing rain fell miraculously from the sky, all while the sun continued to shine. Later when they held the celebratory party (dga'ston gyi tshogs 'khor), the sun shone and there was a rainbow in the sky, even though there was no rain. There were many other miraculous signs as well.

Here Götsang Repa's text leaves off quoting from the stüpa's dkar chag and begins a two-and-a-half folios long versified list of the various donors for the renovation project and what they each gave. This passage appears to have been composed by the Madman of Tsang himself. It then offers an astonishing feat of accounting, adding up the cost of the entire project: for the cost of all the gold and copper that went onto the actual stüpa, the fees and upkeep for all the workmen, the cost of sending letters and gifts, and

\footnotetext{
${ }^{1095}$ Is this more accurately rendered as Newaris?
} 
paying for the food and so on for the Madman of Tsang's retinue, it cost 2751 zho of gold. ${ }^{1096}$ The author of the passage discusses in a very general way how the project was accomplished; he thanks Guru Sāntikara (shan ta spu gri, who had once renovated the Swayambhūnāth stūpa and remained a divine presence there ${ }^{1097}$ ) and the god Viśvakarman (bi sho kar ma), who had previously been appointed as protectors of the stüpa, for preserving the forces of good to allow the project to come to completion. Lastly, he states the purpose for writing this letter ( $\left.b c a^{\prime} y i g\right)$ : it is so that in the future, all the Tibetans who come to the stūpa on pilgrimage - monks and nuns, yogis and yoginis, householders and so on-will be informed of the facts of the stūpa's renovation.

The authorial voice then switches back to Götsang Repa's, as he describes how the Tibetans and Newaris present at the time of the renovation reflected on how amazing it was that the project was completed so quickly, how some of them had visions in their dreams, how the Madman of Tsang had been seen meditating in the midst of a great fire, and some people saw him as Guru Śāntikara (shan ta spu gri), while others saw him as glorious Heruka. Some of the Nepalis, who could not wrap their minds around the accomplishment of the project, said, "Your guru is not human. He is Mahākāla himself." This further suggests the significance of the Madman of Tsang's relationship with Tundikhel Mahākāla, "Protector of the Tibetan Fields," the protector of the Aural Transmission with whom the Madman of Tsang was earlier seen dancing.

Before leaving to return to Tibet the Madman of Tsang knelt before the images in the Śantapuri temple and circumambulated the stūpa three times. He took a damaru in

\footnotetext{
1096 Götsang Repa, pp 220.6-226.3.

${ }^{1097}$ Shakya, pp 538-42. This is a rich, fascinating story.
} 
his right hand and a thighbone trumpet in his left, which he blew three times. With his right leg extended and his left leg bent, he struck a divine pose, literally enacting the behavior of tantric deities, as we have seen so many times before. Before the Madman of Tsang left the area he had one last royal audience during which he was showered with gifts. As he left town the Newari ( off; they cried, sad to see him go. ${ }^{1098}$

This was not the end of the Madman of Tsang's efforts to take care of the stüpa. A few years after the renovation project the Madman of Tsang "exchanged some leftover possessions" (phyag rdzas kyi lhag rnams) for gilded copper (gser zangs). He then sent some of his students to see that the four pillars supporting the upper part of the stūpa were wrapped with the gilded copper. ${ }^{1099}$ (He used other leftover resources (lhag gis [sic] phyag rdzas rnams) to make woodblocks for the Life and Songs of Marpa, and perhaps to have manuscripts prepared for some of his Aural Transmission compositions. ${ }^{1100}$ ) It seems that the Madman of Tsang intended to establish an endowment to sponsor regular whitewashings of the Swayambhūnāth stūpa. He was unable to accomplish this and expressed some regret over the matter. ${ }^{1101}$ Lastly, the winter after the Madman of Tsang's death, special offerings were made at the Swayambhūnāth stūpa on his behalf, on which occasion central Nepal (bal po) was said to have been filled with rainbow light. ${ }^{1102}$

\footnotetext{
1098 The Madman of Tsang's time in Nepal ends Götsang Repa, p 227.6.

1099 'phags pa shing kun gyi gdugs 'degs pa'i ka ba bzhi gser zangs kyi 'phur ba la/ ..., Götsang Repa, p 235.4-.6.

1100 The Tibetan here is difficult.

1101 shing kun la sku dkar gyis [sic] bdag rkyen gcig 'dzugs bsam pa sngar ma grub..., Götsang Repa, p 246.6.

${ }^{1102}$ Götsang Repa, p 281.5.
} 
We are left with the question of why the Madman of Tsang acceded to the request that he take on this renovation project. The Madman of Tsang says that he restored the stūpa because the deity Ganapati had asked him to, referring to the deity's visit to him during his first visit to the Kathmandu Valley. ${ }^{1103}$ The Madman of Tsang talks about wanting to preserve the stupa so that it could benefit the Teachings and be a support for others. There is also the possibility that it could have been for gaining merit, although the Madman of Tsang does not describe his motivations in these terms.

These explanations seeing the Madman of Tsang's reason for taking on this project as motivated by his religious convictions tell only part of the story. There are many other concerns for the Madman of Tsang that should be taken into account. As we saw above, the Swayambhūnāth stūpa was an important stop on the busy pilgrimage-andtrade route between Tibet and Nepal. As a famous Buddhist holy site, it would have been an important cultural node. In light of this we could perhaps compare its importance with that of the Jokang temple in Lhasa, but with an even greater international significance. As we saw in the history of its renovations, the Swayambhūnāth stūpa became at times the concern of Indians, Nepalese, Tibetans, Chinese, Bhutanese and others. It was, in this way, a center of attention in the Buddhist world, and a site of exchange and activity, holiness and money. Because of the stūpa's having this kind of significance, a lot of cache would have been accrued by the one who oversaw its renovation. Fame would come to whoever was remembered as being associated with the project.

${ }^{1103}$ Götsang Repa, p 227.7. 
Moreover, the project would not have been offered to just anyone. It had to be overseen by someone of great spiritual power. The overseer's ceremonial role as a representative of Buddhism was just as important as his role as overseer of construction work. For one, this person had the responsibility of performing rituals at specific moments in the disassembling and reconstructing of the stüpa (most important among these, the consecration ceremony once all the work has been finished). These rituals were seen as essential to ensure the success of the physical work, including protecting the well-being of the workers, and that the reconstructed stūpa would be just as holy and efficacious as the previous one had been. The overseer would also be responsible for preserving order at the work site through ritual means. The importance of the Madman of Tsang as overseer in this sense is suggested by the tales of his putting an end to the pernicious swarm of bees, stopping disruptive rains and destructive fires.

For these reasons we can think of the Madman of Tsang as having served as spiritual foreman in addition to overseeing the actual construction work of the project. It is implied throughout this account that if the Madman of Tsang had been any less of a siddha the project would not have been accomplished, as his yogic abilities were indispensable. We are also told in a variety of ways that the Madman of Tsang had divine assistance in this project. That he had this assistance is again a testament to his own religious efficacy. The fact that the Madman of Tsang was successful in this endeavor, and that the work was completed so quickly (and with so few deaths!), would have been taken as an indication of his status as an awakened being. In fact, he was nothing short of a deity himself (or so the locals thought). 
It is clear from the Madman of Tsang's biography that the general perception was that the renovation of the Swayambhūnāth stūpa was a difficult task and could only be brought to completion by someone with great spiritual power. It was flattering to the Madman of Tsang and the Kagyü sect that he was respected enough to be invited to take on this project in the first place. That he brought the project to a successful completion could only have brought him even greater fame and renown. The tale of his accomplishment reached all the way to the ear of the Karmapa, who paid the Madman of Tsang the great honor of sending him a personal letter. For the same reason that there was a purpose to committing the story of Milarepa to writing, for the same reason that there was a reason to compose a letter listing all the various benefactors for the stūpa restoration project, the Madman of Tsang was keenly aware that he would be remembered for his role in renovating the Swayambhūnāth stūpa.

In addition to this less tangible element of prestige, the Madman of Tsang received a material benefit from taking on the restoration of the Swayambhūnāth stūpa. The Madman of Tsang was feted on his arrival to and departure from the Kathmandu Valley. The Madman of Tsang's followers were provided for during their stay in the area. The king gave the Madman of Tsang gold jewelry and some lavish clothing just before the consecration ritual was to be performed. Surely this was a respectful offering, but perhaps also can be thought of as payment for a job well done. There is no mention of the Madman of Tsang's receiving any specific material payment beyond these gifts and the many, many offerings that were brought to him during the course of the renovations. By the time the Madman of Tsang took on this project he was nearing the end of his life, but it is likely that the king of Kathmandu would have remembered the 
yogi's efforts and taken special care of his disciples and later members of his lineage as they would make their pilgrimages to Nepal in years and generations to follow, visiting the Swayambhūnāth stūpa and meditating in the nearby holy sites.

Here I have posited a host of reasons that likely compelled the Madman of Tsang to take on the task of renovating the Swayambhūnāth stūpa. In addition to being moved by religious faith, there were also material and social concerns as well. ${ }^{1104}$ The Madman of Tsang undertook the renovation of the Swayambhūnāth stūpa for the same basic reasons we saw expressed for his eccentric behavior and his writing and printing projects: to benefit Buddhism and to spread the drumsound of his name and that of his sect, all of which would have had long-term positive effects for the Madman of Tsang and later members of the corporate body of which he was a part.

\section{V. Conclusion: Reconsidering Mad Behavior}

The purpose of this chapter has been to describe the cultural projects of the Madmen of Ü and Tsang, ultimately with the purpose of shedding light on the distinctive behavior that would earn them the title "madman." Here we are developing way of viewing the holy madmen that sees their eccentric behavior as part of their larger life's works, rather than treating it as an aberration.

First of all, the scale of the Madman of Tsang's cultural projects reveal him to be a very ambitious and driven man, in spite of engaging in such antinomian and shocking

\footnotetext{
${ }^{1104}$ Todd Lewis and Lozang Jamspal, "Newars and Tibetans in the Kathmandu Valley: Three New Translations from Tibetan Sources," in The Journal of Asian and African Studies, No. 36, 1988, p 189. The authors see the Madman of Tsang's traveling to Nepal as being motivated by pilgrimage, looking for patronage from the kings of the Valley, building political alliances, and to "popularize and propagate his religious viewpoint." Lewis and Jamspal think it possible that the great influence in Nepal had by later Kagyüpas (like Situ Penchen, two centuries later) may to some extent have been a result of seeds planted there by the Madman of Tsang.
} 
behavior earlier in his life. The cultural projects of the Madman of Ü and his disciples were of comparatively limited scope, but do display some interest in writing and publishing, and the founding of a series of small monasteries - the sort of purposeful activity that disproves any notion of Künga Zangpo as an unrepentant wildman, or one completely divested of worldly concerns.

Moreover, there are a set of agendas that are consistently furthered in the course of the Madman of Tsang's cultural projects. There is a clearly expressed concern to maintain and increase the fame and renown of the Kagyü sect. One of the means through which the Madman of Tsang and his disciples achieved this was their writing and printing biographies of the past masters of their sect. All of this literature was written in such a way as to generate awe and respect in their readers (and hearers) for the accomplishments of these great saints. This literature was also written and manipulated so as to selectively shape and characterize the Kagyü sect. This literature encouraged people to view the Kagyü as a pure meditative tradition, empowered by the blessings of the lineage stretching back to India and the tantric deities. In characterizing the Kagyü sect as a tradition dedicated almost exclusively to tantra and the practice of meditation, the Madman of Tsang and his school were contrasting it with more institutionalized and scholastic forms of Buddhism. Kurtis Schaeffer has described the biography of a contemporary of our famous 15 th-century holy madmen, Shalu Lotsāwa (1441-1527), as a "laudatory defense of scholarly ideals." 1105 We can read much of the literature created by the Madman of Tsang and his school as a laudatory defense of meditative ideals. These competing models of Buddhistness are in large part defined by where, according to

${ }^{1105}$ The Culture of the Book in Tibet, $\mathrm{p} 50$. 
each, religious charisma is derived from. Is it the fact of being an incarnation of someone famous from the past? Does it come from making displays of learning? In Milarepa's case, as articulated by the Madman of Tsang, his authority came from meditation and the power of the teachings that were transmitted to him. Ultimately the Madman of Tsang's own claim to authority is based on the very same.

The key question to consider here is what purpose rewriting the history of the Kagyü sect in such a way served during the time of the Madman of Tsang and his disciples. Why were they moved to write the history of the Kagyü in the particular way they did? I argued in Chapter Three that that through their seemingly-eccentric behavior the Madmen of Ü and Tsang were in fact enacting a literal reading of certain Highest Yoga Tantra texts, and thereby embodying a form of tantric fundamentalism. In Chapter Four I argued that the Madmen of Ü and Tsang were motivated to enact this tantric fundamentalism by their wish to articulate a new model of Kagyüness for the sake of distinguishing their sect from — and make it more competitive against — other religious movements gaining strength in the religious marketplace of their day. The model of religious activity embodied by the Madmen of Ü and Tsang was formulated as the polar opposite of that embodied by the scholar-monk, the scholar-monks par excellence being members of the aggressively-spreading Geluk sect. I think it clear that the same basic concerns expressed in the Madmen of Ü and Tsang's eccentric behavior and tantric fundamentalism are expressed in the Madman of Tsang's writing and printing projects. The Madman of Tsang's cultural projects are best seen as motivated by the same concerns as the Madmen of Ü and Tsang's seemingly-eccentric behavior, and vice versa. Ultimately the purpose is to articulate a new model for what the Kagyü sect could be by 
claiming it to be based on a specific set of ideals. The eccentric behavior and the cultural projects are thus best understood as part of the same long-term project, constituted by the entirety of the holy madmen's bodies of work - from how they lived their lives, to what they wrote, and inspired in their disciples.

Asceticism and meditation were defining features of the new (but not created ex nihilo or unprecedented) form of the Kagyü proposed by the Madmen of Ü and Tsang. And surely the Madmen of $\ddot{U}$ and Tsang and their followers did diligently apply themselves in meditation and submit themselves to ascetic hardships for many, many years. But an aspect of the Madmen of Ü and Tsang's project that must be kept in mind is that in spite of all rhetoric of renunciation and anti-institutionalism, they displayed an obvious concern for institution-building. Here I mean institution-building in the literal sense, as in the Madman of Ü's founding of three monastic centers in the course of his career, but also in a more abstract sense, as in the way the Madman of Tsang's producing literature telling the history of the Kagyü would help sustain that sect for decades and centuries to come.

Because of this fact we must be careful not to take the rhetoric of antiinstitutionalism and renunciation at face value, but rather consider what purpose that rhetoric served in social, political and economic contexts. In the Madman of Tsang's version of his Life, Milarepa's last words to his disciples were the instructions to, "Dress in rags, and content yourselves with little food, clothing, and recognition." This statement is presented as the most essential teaching offered in the life of the most important figure for defining the Kagyü sect. It would be a grave mistake, however, to 
assume that all subsequent Kagyüpas have spent their careers actually striving to do without these comforts. The Madman of Tsang, we have seen, was not one who strove for anonymity in any of his endeavors. Instead we must think of the rhetorical significance of the ideals of renunciation and anti-institutionalism. For as we have seen, perhaps above all else the Madman of Tsang was masterfully attuned to the dynamics of performance and representations. Kurtis Schaeffer has described the decision by the Madman of Tsang and his literary school to make blockprints of important texts (most of them biographies) as "a self-consciously significant affair." I would argue that walking into the marketplaces of central Tibet dressed in the gruesome attire of a Heruka or purposefully shocking a crowd of people by eating brains from a corpse - these are also self-consciously significant affairs. Götsang Repa recognized this dynamic and thus wrote about the Madman of Tsang's activities towards "spreading the drumsound of his fame."

To restate this point, we should not take too literally the notion that the Madmen of $\ddot{U}$ and Tsang (and Milarepa and their other forbears) were actually openly antimonastic and anti-scholastic. ${ }^{1106}$ The fact is that the holy madmen saw value in learning. The Madman of Ü had good relations with Śākya Chokden, the consummate scholar, even requesting him to write texts on his behalf. And the Madman of Tsang, despite railing against scholasticism in his own life, and despite his creating a Milarepa who did the same in the 11th century, was actually very textually minded in his own right.

\footnotetext{
${ }^{1106}$ Ardussi and Epstein note that a characteristic common to most of Tibet's holy madmen is a "professed disdain for scholasticism. The saintly madman preached that the best instruction was not to be gained from studying books, or even from one's guru, but rather from one's self, or any other phenomenal appearance," p 333. I believe this is an overly literal reading of the activity of the holy madmen, failing to take into account the real-world circumstances of their self-representations.
} 
Although the version of Milarepa that he popularized saw the yogi arguing with a scholar-monk that Buddhism was not to be found in the words of texts but in the implementation of its teachings, the Madman of Tsang spawned a whole school of literary production - taking pains to print those texts sometimes to the profound displeasure of his disciples who wondered why they were allowing themselves to be so distracted from their meditation. It is more accurate to think of the Madmen of $\ddot{U}$ and Tsang not as truly anti-scholastic or anti-institutional, but rather as individuals who found reason to portray themselves and their forbears as such.

In light of this discussion we can consider Andrew Quintman's description of famous 15 th-century holy madmen, in which he states: "It was a movement, however symbolic, away from the rising tide of corporate religion back to the solitary, itinerant yogin, an ideal upon which the Bka' brgyud tradition was founded, and an image embodied in the figure of Mi la ras pa."1107 I would emphasize what Quintman refers to as the movement's "symbolic" promotion of the solitary, itinerant yogin. The movement established by the Madmen of Ü and Tsang was founded on a rhetoric of renunciation and practice, but was nevertheless as socially- and politically-embedded as any other religious movement operating at the time. The rhetoric of renunciation and practice should not be taken at face value, but understood as the result of a strategic decision.

Through their "crazy" behavior the holy madmen were trying to relive the early days of the Kagyü tradition. But the vision of the Kagyü they were enacting in their lives was actually their own creation. Through their literary production they created a vision of what the Kagyü lineage had been, and through their mad behavior they put that vision

${ }^{1107}$ Quintman 2006, p 190. 
into practice, going back in a very direct and literal way to a mode of religious life that they themselves had a strong hand in creating and propagating. In short, they strategically created the history that they were reenacting.

Because the Madman of Tsang's writings were mass-produced and disseminated, we should not make the mistake of reading them as his private, heartfelt instructions to his followers, his loving suggestions on how they should live their religious lives. Rather, we must read these teachings as public declarations. They represent not necessarily how the Madman of Tsang wanted his followers and those who came after him to live, but how he wanted them to be perceived. The idea of a set of teachings being passed on generation to generation, from the mouth of the master to the ears of just one disciple has been replaced by a culture of mass media. But the notion of the secret, aural transmission was not abandoned or written out of the history. Rather, it came to form the basis for the validity of those very public teachings and declarations. The fact that they could claim these teachings to have come down via this lineage that kept them secret lent these teachings a certain power, a certain charisma that — the Madman of Tsang hopedwould make them desirable to others. It was not so much about the actual content of the teachings themselves, but the tradition they represented. 


\section{Chapter 7: Who's Mad? A Survey of Tibet's "Holy Madmen," and Almost Madmen}

Because I am not deluded by ignorance, the sun of the wisdom of no-self has risen [in my mind]. In the perception of ordinary beings I am seen as a crazy woman (smyon $\mathrm{ma}$ ) with an ugly mind.

- Sang by Sönam Peldren, recorded in her Life $e^{1108}$

The Madman of Tsang and Drukpa Künlé, Madman of the Drukpa, are the Tibetan holy madmen par excellence. They are almost universally known and beloved among Tibetans. One would be hard pressed to find someone who would question their status as madmen or as siddhas.

And yet in the preceding chapters of this dissertation we have seen that Drukpa Künlé did not have much of a reputation as a madman or a siddha during his lifetime. We saw that the Madman of Tsang had many detractors. There were scholar-monks with whom he argued about the Buddhistness of his eccentric ways, not to mention Drukpa Künlé himself, who charged the Madman of Tsang with being a charlatan. Although the popular thinking among Tibetans and many modern Euro-Americans who have addressed the topic of Tibetan holy madmen may hold that there is a clear distinction to be made

\footnotetext{
${ }^{1108}$ ma rig 'khrul pas ma gos pa'i / bdag med ye shes nyi ma shar / so so skye bo'i snang yul du / yid mi sdug bud med smyon mar mthong /. Quoted in Suzanne Bessenger, Echoes of Enlightenment: The Life and Legacy of Sonam Peldren (1328-1372) (Ph.D. dissertation, University of Virginia, 2009), pp 163-4.
} 
between "real" holy madmen and everyone else (real holy madmen being those whose eccentric was "a natural expression of the deconstruction of social artifice in the face of the overwhelming experience of the absolute," or a genuine skillful means, or a form of practice), the fact that even those most unimpeachable as holy madmen may not have been unanimously accepted as such during their lifetimes should give us pause. ${ }^{109}$ What do we do with Drukpa Künlé's assessment of the Madman of Tsang as a fake? Do we ignore it? Do we assume that Drukpa Künlé was mistaken? Or is the line between real holy madmen and fake ones much more blurred?

Complicating the matter further, throughout the history of Buddhism in Tibet there have been many individuals held in highest regard for their religious accomplishments who occasionally called themselves "madmen" or were labeled so by others, and yet never became famous as holy madmen. These examples challenge the dominant thinking about Tibetan holy madmen among Tibetans and Euro-American

\footnotetext{
${ }^{1109}$ Here by "real" holy madmen we mean those who were known as madmen because of their having achieved a state of enlightenment such that they transcended all worldly concerns, and consequently acted in sometimes outlandish ways; those who acted in outlandish ways only as part of their religious training; or those who acted in outlandish ways solely out of their concern to teach other beings. As an example of a scholar who maintains a firm distinction between "real" holy madmen and fake ones, Ronald Davidson writes, "It was common, then as now, for such eccentric personalities to rationalize their behavior, regarding it as a natural expression of the deconstruction of social artifice in the face of the overwhelming experience of the absolute. This was no doubt the case for some, but it is equally true that the defense not only was self-serving but also cultivated a sense of entitlement among the poorly socialized and attracted to the lineage others with severe mental problems. Consequently, by midcentury, Padampa-lineage [i.e., Pacification and Cutting tradition] tantric feasts must have seemed as much a psychiatric outpatient support group as a gathering of awakened masters. Although such individuals may have been entertaining, they were dangerous progenitors of public policy, and the specter of legions of dancing naked clerics wielding weapons seemed to hang like the sword of Damocles over the leaders of most orders at this time," Tibetan Renaissance: Tantric Buddhism in the Rebirth of Tibetan Culture (New York: Columbia University Press, 2005a), p 331, emphasis added.

If we read this passage closely we see that Davidson offers a few different possibilities for understanding Tibetan holy madmen. First Davidson suggests that it is part of a conscious process through which individuals "rationalize" their eccentric or inappropriate behavior through the existing idea that true realization brings one to a state in which social artifices fall away. Key here is the part where Davidson writes, "This was no doubt the case for some..." stating explicitly that there were in fact real holy madmen in Tibet's past, whose odd behavior was truly a byproduct of their enlightenment.
} 
commentators, which holds that there is a hard distinction to be made between those who should be counted among this category and those who should not. In this chapter I will suggest a way of looking at Tibet's holy madmen that does not distinguish between legitimate and illegitimate examples of the phenomenon, between "real" and "fake" holy madmen.

To this end, based on the discussion of the famous 15 th-century "holy madmen" given in the preceding chapters of this dissertation and the discussion of other "holy madmen" and almost holy madmen of Tibet's past and present that is the subject of this chapter, I argue that what makes a person a holy madman (or madwoman) is not his having achieved an unimpeachable state of enlightenment that puts him at odds with worldly ways, or his teaching through an eccentric skillful means, or his use of shocking training methods in his own personal religious practice. Rather, becoming known as a holy madman is the result of a dialogical process of self-representation and collective remembering. It is the result of a social process.

This final chapter will begin with a survey of some of the many individuals commonly referred to as holy madmen in the history of Tibetan Buddhism, from the earliest cases about whom we have textual records to those told about through oral literature in more recent times. We will then consider some of the other ascetics from Tibetan history who employed a rhetoric of madness but were not remembered as madmen per se. These figures on the periphery of the holy madman tradition call into question many of the assumptions about holy madmen that have long shaped the way Tibetans and non-Tibetans have thought about the phenomenon. To further complicate the idea of holy madness, we will also consider the popular practice of using "madman" 
as a pen name. Lastly, we will look at the way a recent influential lama, Chögyam Trungpa Rinpoché, employed a rhetoric of madness in his life and teachings to great effect. A close look at what meanings Trungpa applied to "madness" and the way he used the idea of crazy wisdom to negotiate certain challenges in his own life will prompt a reconsideration of what holy madness is on the most basic level.

\section{I. Other "Madmen" in Tibetan History}

Two generations before Drukpa Künlé, born into the same illustrious family, was another "madman," the "Madman of Ra[lung]" (rwa smyon), also known as Namka Pelzang (nam mkha' dpal bzang, 1398-1425). As told in his brief biography included in The Golden Rosary of the Ralung Kagyü, Namka Pelzang was born into the ruling family of Ralung Monastery, became a monk at about six, then underwent a standard monastic education. ${ }^{1110}$ In 1413 , at the age of about 16, he took the throne at Ralung, which he would hold until his death at 28. In 1422 he took a wife (khab bzhes) and gave up his monkhood ( jig rten bstun). Directly following this the biography states how, for the sake of teaching sentient beings during the degenerate age in which we live, the Madman of Ralung assumed both peaceful and wrathful modes and was called a "secret yogi.","111 His time on the throne is said to have been a period of prosperity and wellness in the area

\footnotetext{
${ }^{1110}$ Rwa lung dkar brgyud gser 'phreng: brief lives of the successive masters in the transmission lineage of the Bar 'brug-pa Dkar-brgyud-pa of Rwa-lung. Reproduced from a set of prints from the 1771-1772 Spungs-than xylographic blocks (Palampur: Sungrab Nyamso Gyunphel Parkhang, Tibetan Craft Community, 1975-1978, 4 volumes), pp 99-106 (5 ff.), Vol. 3. He is mentioned in R. A. Stein, trans., Vie et chants de 'brug-pa kun-legs le yogin, $\mathrm{p} 9$.

1111 'on kyang snyigs dus sems can 'dul slad du/ zhi khro la sogs gang la gang 'dul gyis/ 'gro ba'i don mdzad bla ma de nyid ni/ sbas pa'i rnal 'byor pa zhes bya ba'am/, p 102.3-.4.

A small image of him in the woodblock shows him with long hair, earrings, wearing lay clothes, and holding what appears to be an arrow. His example raises the possibility that being a "secret yogi" may at times have meant a practitioner who had a wife. Is this what is meant in The Life of the Madman of $\ddot{U}$ when it describes Drukpa Künlé with this term when arrives at Tsimar Pel to pay his respects to the Madman of Ü?
} 
around Ralung, but in time he got sick and died quite young. The Madman of Ralung's biography was written in 1432, in verse, by Sherab Zangpo (shes rab bzang po, 14001438), his younger brother and the one who took the throne of Ralung after his death. Their younger brother, Drung Dorwa (drung rdor ba), was Drukpa Künlé's grandfather, making the Madman of Ralung Drukpa Künlé's great uncle (his grandfather's eldest brother). ${ }^{1112}$

From this account we have no reason to believe that Namka Pelzang, although famous as the Madman of Ralung, ever engaged in antinomian behavior comparable to that of the Madmen of Ü and Tsang. We have no reason to believe he partook of any particularly wild behavior, such as dressing in the manner of a Heruka or haunting the Tibet's marketplaces with his antics. Namka Pelzang assumed various personas and was called a "secret yogi" by some, but he nevertheless remained the abbot of Ralung Monastery and seems to have lived a relatively conventional life-compared, at least, to the lives of some other holy madmen. Based on what we can glean from the biography we have at our disposal, it may be that the reason Namka Pelzang was called a "madman" was the fact that he gave up his monkhood and took a wife, which constituted a deviation from the celibate norm expected of him. Drukpa Künlé, born a few decades later into the same family and with similar rights to taking a monastic seat, also refused to conform to others' expectations, took a wife, and was called a "madman." From the information we have, the "madness" of the Madman of Ralung and that of the Madman of the Drukpa may have been very similar.

\footnotetext{
${ }^{1112}$ Stein, Vie et chants de 'brug-pa kun-legs le yogin, genealogical charts, between pp 9 and 10. John Ardussi, 'Brug-pa Kun-legs, The Saintly Tibetan Madman (Master's thesis, University of Washington, 1972), p 204.
} 
Historical records also tell us of a Madman of [Dakla] Gam[po] (sgam smyon, 1451-1502), who was an almost exact contemporary of the Madmen of Ü and Tsang and Drukpa Künlé. $^{1113}$ The Madman of Dakla Gampo was the 12th abbot of Dakla Gampo Monastery, which had been founded by Gampopa in the early 12 th century. According to the brief biography of the Madman of Dakla Gampo included in the history of that monastery (written in 1662) ${ }^{1114}$, Mipam Drakpa Gyeltsen was born into monastic royalty as a member of the Nyiwa (rnyi ba) clan. (In time his younger brother, then two of his sons would take the throne after him; the 14th, 15th and 16th abbots respectively. This is a clear example of how a family could have ownership over an important central Tibetan Kagyü monastery, as was discussed in the previous chapter.) After having been born into a position of power, entering the monkhood at eight and taking the throne of Dakla Gampo at the age of ten, it seemed that Mipam Drakpa Gyeltsen's life as a monastic hierarch was assured. As he continued his education Mipam Drakpa Gyeltsen wowed people with his intelligence; some said he was an emanation (sprul pa) of Gampopa himself. But after the death of his predecessor, when he was about sixteen, things began to change for the young hierarch. It seems that Drakpa Gyeltsen started to no longer live

${ }^{1113}$ Commonly known as Gampo Mipam Drakpa Gyeltsen (sgam po mi pham grags pa rgyal mtshan) or Daö Rinchen Lhündrup Gyeltsen Pelzangpo (zla 'od rin chen lhun grub rgyal mtshan dpal bzang po). ${ }^{1114}$ gangs can 'dir ston pa'i rgyal tshab dpal sgam po pa'i khri gdung 'dzin pa'i dam pa rnams kyi gtam bai DUrya'i phreng ba, pp 45-50, 191-247 (Text F) in Rare Texts from Tibet: Seven Sources for the Ecclesiastic History of Medieval Tibet, edited by Per K. Sørensen and Sonam Dolma (Lumbini International Research Institute, 2007). The section about the Madman of [Dakla] Gam[po] runs pp 56b6$65 \mathrm{a} 5$.

The Madman of [Dakla] Gam[po] is also mentioned in the 1617 guidebook to Dakla Gampo Monastery and the surrounding retreat centers, titled gdan sa chen po dpal dwags lha sgam po'i ngo mtshar gyi bkod pa dad pa'i gter chen, by sgam po pa mi pham chos kyi dbang phyug phrin las rnam rgyal dpal bzang po (1589-1633), pp 248-73 (Text G) in Sørensen and Dolma (2007). He is mentioned in a manner similar to his contemporaries the Madmen of Ü and Tsang, as having had various visions at locations around that place, pp 28b6-29a2; p 263.

The Madman of Dakla Gampo is mentioned in Stein, Vie et chants de 'brug-pa kun-legs le yogin, p 9. According to Sumpa Kenpo's re'u mig, he lived 1451-1502 (TZCM, p 3249). 
up to the expectations his monastic community had of him. He spent much of his time at the holy sites in the environs surrounding the monastery, where he had some divine visions. When members of the community chided him for playing archery during one of his excursions away from the monastery, saying it might result in his breaking his vows (presumably by accidentally killing an animal), he answered them sharply. When he went back to Dakla Gampo Monastery, he had lost their devotion. A few years later, at about the age of 19, he abdicated in favor of the Second Drukchen, Künga Peljor, who held the throne for the next six or so years until his death. After abdicating Mipam Drakpa Gyeltsen spent most of his time away from Dakla Gampo, although he did return from time to time, and made it his full-time residence again after his eldest son took the throne.

The existing biography tells of many miracles performed by Mipam Drakpa Gyeltsen in the course of his life: from a young age he showed signs of meditative accomplishment (grub rtags), such as being able to walk on water; later he is said to have brought some dead deer ( $r i d w a g s)$ and even a man back to life. Sometime after having lost his position as abbot, he took a consort (phyag rgya), and from then on presumably no longer lived under the guise of monkhood.

Summarizing his life, the biography states that "because of his performing miracles and signs of accomplishment, he was renowned undisputedly as a siddha.... Because he performed various types of activity (spyod pa), in terms of dress and outward manifestation, he was also renowned by the name 'the Dharmalord, Madman of [Dakla] 
Gam[po]." ${ }^{\prime 115}$ This biography opens by relating a prophecy about Mipam Drakpa

Gyeltsen that, it was believed, foretold the year of his birth, his name, his birthplace, and the fact that he would be

One who performs the senseless activity of whatever, who would wear whatever clothing, like a charlatan, whose performance of whatever happened is like that of a madman, who would defeat the enemies who do harm to the Teachings. ${ }^{1116}$

Another prophecy foretold that Mipam Drakpa Gyeltsen would wander about performing engaged asceticism (kho bo brtul shugs spyod pas rgyu).

Unfortunately the biography does not describe the sort of "senseless activity" or engaged asceticism Mipam Drakpa Gyeltsen performed that resulted in his earning the sobriquet "Madman." We have no indication that he lived the kind of wandering lifestyle exemplified by the Madmen of Ü and Tsang; we have no description of any strange mode of dress he may have taken on (although the summary given at the end of his biography tells us that he did dress oddly). Was it the case that Mipam Drakpa Gyeltsen is best understood as a "madman" more in the style of the Madman of Ralung and Drukpa Künlé, as monastic hierarchs (or would-be hierarchs) who after a certain point no longer conformed to the behavioral norm expected of them and took a wife or a consort? Or did Mipam Drakpa Gyeltsen engage in the kind of tantric activity (spyod pa) that made the Madmen of Ü and Tsang famous, but it has simply been omitted from his biography? Or is the assertion that he performed engaged asceticism a later addition, a post facto explanation of his "madness" formulated during the more than hundred and fifty years

\footnotetext{
1115 de ltar rdzu 'phrul dang grub rtags mang du bstsal bas grub thob rtsod med du grags/ ... cha lugs dang snang tshul gyi spyod pa sna tshogs su mdzad pas/ mtshan yang sgam smyon chos rjer grags/, p 64a664b1; 221.

1116 ci byung tho co byed pa zhig chas la nges med zog po 'dral spyod pa ci byung smyon pa 'dra/ bstan pa gnod pa'i dgra bo 'dul/, p 57a1-57a2; p 217.
} 
between his death and the composition of his biography? Further research into the history of Dakla Gampo during this time period may yield an answer to this question.

As mentioned in Chapter Four, the late 15th and early 16th century was the moment in Tibetan history witness to the greatest number of "holy madmen." In addition to the Madman of Ü, the Madman of Tsang, Drukpa Künlé, and this Madman of Dakla Gampo, there were the Madman of Tsang's disciples, the Madman of the Charnel Ground (dur khrod smyon pa) ${ }^{1117}$ and the Madman of Taklung (stag lung smyon pa), who is remembered as one who performed engaged asceticism, dressed as a Heruka, ate feces and so on. ${ }^{1118}$ There was also the Madman of Üding (dbus sdings smyon pa), who, as we saw in Chapter Four, was encountered by the famous ascetic Drakpa Tayé. ${ }^{1119}$ About some of these late 15th- and early 16th-century "holy madmen" we know a great deal; about some of them we know only very little. We can safely assume that there were other "madmen" living at the time who did not make it into the historical records we currently have at our disposal.

The tradition of the holy madman continued past the early 16th century, all the way into the present. In a slightly later period, there was Namka Jikmé, also known as the Madman of Kong[po] (kong smyon nam mkha' 'jigs med, 1597-1650), who was sometimes called a Heruka, and a Destroyer of Illusion ('khrul zhig). There are many writings attributed to the Madman of Kongpo, including one on the topic of engaged asceticism (brtul zhugs). In this text the Madman of Kongpo mentions wearing the garb

\footnotetext{
${ }^{1117}$ Götsang Repa, p 261; Lhatsün Rinchen Namgyel, p 109.

${ }^{1118}$ Götsang Repa, p 260; Lhatsün Rinchen Namgyel, p 108. As was mentioned in Chapter Four, a Madman of Taklung, presumably this same one, was also mentioned in The Life of Drakpa Tayé, pp 101.5102.1 .

${ }^{1119}$ The Life of Drakpa Tayé, pp 234.5-235.5.
} 
of the Heruka and eating repulsive substances like the five meats and the five nectars (see Chapter Three); he specifically mentions doing this before the four-doored Kakṇi stūpa (kaM Ni sgo bzhi) in the Lhasa Barkor. ${ }^{120}$ (This same stūpa was a site of some eccentric activity performed by earlier "madmen"- - Tangtong Gyelpo and the Madman of Tsangas will be detailed below.) When Namka Jikmé performed this antinomian behavior he was confronted by a monk (here called a "philosopher" or a "logician," mtshan nyid pa) who questioned him about his activity, asking where in the Buddha's teachings on tantra is this manner of dress taught, or this manner of drinking alcohol, or eating such repulsive things. In his response the Madman of Kongpo questioned the orthodoxy of the monk's own lifestyle. ${ }^{1121}$ The Madman of Kongpo discusses various aspects of the performance of engaged asceticism, justified through numerous quotations of canonical texts, foremost among them being the Hevajra tantra. Later in this same text Namka Jikmé responds to others' saying he was a madman by addressing his "madness" in a song. In this song he asserts a connection between his activities and the Aural Transmission of the Madmen of Ü and Tsang (gtsang dbus smyon pa'i snyan rgyud bsgom pa...) and the life story of Künlé, Madman of the Drukpa ('brug smyon kun legs rnam thar skyong ba...). ${ }^{1122}$

The Madman of Kongpo was self-consciously aware of being influenced by the legacies of the famous 15 th-century holy madmen. (Surely Drukpa Künlé would have also had a similar knowledge of his great uncle, the Madman of Ralung.) The fact that we have evidence of a holy madman engaging in eccentric behavior with full knowledge

\footnotetext{
${ }^{1120}$ kong smyon 'khrul zhig nam mkha' 'jigs med rig pa brtul zhugs kyi spyod la gzhol pa'i tshul chos brgyad tshul chos kyi mnya' gnon rig pa gcer mthong ngo sprod kyi thol glu, pp 369-474 in rnal 'byor gyi dbang phyug chen po lha btsun nam mkha' 'jigs med kyi gsum 'bum, Vol. I of four (New Delhi: Jurme Drakpa, 1974; TBRC W20865), pp 366-7.

${ }_{1121}$ ibid., pp 367-70.

1122 ibid., p 422. The song runs pp 421-3; this text runs pp 363-469.
} 
of the precedent established by holy madmen of earlier generations suggests that we may think of holy madness as something other than the byproduct of a state of enlightenment, an example of skillful means, or a training method. Rather than a spontaneous response arising out of a moment in time, perhaps this divine eccentricity can be thought of a trope transmitted through history. We see this exemplified more clearly in the case of the famous saint, Tangtong Gyelpo.

Tibetans remember Tangtong Gyelpo as an unexcelled siddha, as one who lived for a hundred and twenty five years $\left(1361-1485^{1123}\right)$, as one who built iron and wooden bridges all across Tibet, who founded Pel Chuwori (dpal chu bo ri) Monastery, who founded of Tibetan opera (lha mo), and who was also a holy madman. ${ }^{124}$

The biography of Tangtong Gyelpo by Lochen Gyurmé Dechen (lo chen 'gyur med bde chen, 1540-1615) titled A Jewel Mirror in which All is Clear (kun gsal nor bu'i me long) contains a consistent rhetoric of madness. Tangtong Gyelpo's "madness" follows a trajectory we saw exemplified in the biographies of the Madmen of $\ddot{U}$ and Tsang, and which will see below in the life of Sönam Peldren: early in the figure's life he

\footnotetext{
${ }^{1123}$ On the question of Tangtong Gyelpo's dates, see Stearns, King of the Empty Plain, pp 11-4, and Janet Gyatso, The Literary Transmission of the Traditions of Thang-stong rGyal-po: A Study of Visionary Buddhism in Tibet (Ph.D. dissertation, University of California at Berkeley, 1981), pp 50-1.

${ }^{1124}$ For examples of people asserting Tangtong Gyelpo to be among Tibet's "holy madmen," see Manfred Gerner, translated from German by Gregor Verhufen, Chakzampa Thangtong Gyalpo: Architect, Philosopher and Iron Chain Bridge Builder (Thimphu: the Centre for Bhutan Studies, 2007), p i; Tashi Tsering (Dharamsala), in Gerner, p ii; Tashi Tsering calls him a sgrub smyon and a 'khrul zhig; Roberto Vitali, Early Temples of Central Tibet (London: Serindia Publications, 1990), p 123: "Thang.stong rgyal.po [Thangtong Gyalpo] embodies, as well as few other masters, the Tibetan tradition of the smyon.pa, the 'madman' whose activities, code of behaviour, mystical and magical experiences exceed words and transcend common understanding. sMyon.pa, more than ascetics, need human consensus in order to enhance their unconventional teachings, wherein by breaking the rules one enters the path of liberation." None of the Tibetan kenpos and lamas I interviewed immediately mentioned Tangtong Gyelpo when I asked them to name some "holy madmen" from Tibet's past, but he was often mentioned in this context in conversations with Tibetan who were not religious specialists.

For popular accounts of his life, see Dungkar Rinpoché dictionary, pp 1031-5; the ming mdzod, pp 787-9; padmarāga (1996), pp 702-9.
} 
or she acts in an odd way and is called "mad" in a pejorative sense, then over time the term "mad" is transformed, becoming a positive characteristic.

Tangtong Gyelpo was first called a madman by his father and other members of their village when he disturbed an earth spirit in the process of his subduing a malicious spirit that was causing an epidemic. Not believing that his unconventional ritual would be efficacious (which of course it was), people called him crazy. ${ }^{1125}$ A little later, when studying at Sakya Monastery the young man did not take to his studies the way the other monks did. He was obviously intelligent but took no interest in textual learning. According to his biographer Gyurmé Dechen, people said, "This little monk is poor in the treatises"- his not being ashamed at this was, Gyurmé Dechen asserts, an example of his engaged asceticism (brtul zhugs). ${ }^{1126}$ Because of his nonconformity he began to be known as Crazy Tsöndrü (brtson 'grus smyon pa), a name that would stick with him for some time. ${ }^{1127}$ Much later, when he returned to his home village after claiming to have spent the previous eighteen years in Nepal and India receiving the Teachings, people called him a madman and a liar. ${ }^{1128}$ He was called a madman again when he slept on Dolpopa's throne at Jonang Monastery. ${ }^{1129}$ In time, however, Tangtong Gyelpo would be

\footnotetext{
1125 Stearns, King of the Empty Plain, pp 65, 109.

${ }^{1126}$ Practices like engaged asceticism and secret activity (gsang spyod) are mentioned occasionally throughout Tangtong Gyelpo's biography. His biography also states that, motivated by the Hevajra tantra, he pretended to be crazy (Stearns, King of the Empty Plain, p 118). Later Padmasambhava would visit him and tell him to perform engaged asceticism ( $\mathrm{p} 131$ ). In the course of his life Tangtong Gyelpo feigned madness along with other aspects of the performance of engaged asceticism (brtul zhugs spyod pa), p 66.

${ }_{1127}$ Stearns, King of the Empty Plain, pp 65, 117.

1128 Stearns, King of the Empty Plain, p 149.

1129 Stearns, King of the Empty Plain, p 162.

All the examples given here are drawn from the later version of the Life of Tangtong Gyelpo, that composed by Gyurmé Dechen in 1609. But some stories about Tangtong Gyelpo being called a madman in the course of his life are present in the earlier versions of his biography as well: the version by Tangtong Gyelpo's disciple, Sherab Pelden tells a story of when Tangtong Gyelpo was called “crazy” by some people because of his eating dog feces, sat on the trone of Dolpopa, when he promised to build a stüpa, and so on,
} 
visited by some dẹkinīs, who gave him five special names. One of those names was the Madman of the Empty Valley (lung stong smyon pa). ${ }^{1130}$ "Madman," which earlier had been an insult, has now become a mark of honor. When Tangtong Gyelpo was called a "madman" at any point for the rest of his life the term would carry more praise than insult.

A few different biographies of Tangtong Gyelpo were composed over the years in Tibet. Lochen Gyurmé Dechen's was the latest, written in 1609. ${ }^{131}$ Gyurmé Dechen was a disciple of Latong Lotsāwa Shényen Namgyel (lha mthong lo tsA ba bshes gnyen rnam rgyal, b 1512), who was a disciple of the Madman of Ü and the author of the second part of his biography. Gyurmé Dechen was also believed to be a descendent of Tangtong Gyelpo himself. ${ }^{1132}$ Gyurmé Dechen's version of The Life of Tangtong Gyelpo, based on the earlier ones, was the only version cut into woodblocks and would become the standard account of the mahāsiddha's life. It contains many elements that are very similar to and perhaps derived from passages in the biographies of the Madmen of $\ddot{U}$ and Tsang. For example, when Tangtong Gyelpo was staying in Bodhgaya, the people saw a fire blazing at night. When they came to investigate the cause of it, they saw that the fire was actually just Tangtong Gyelpo meditating on the yogic fire wind (me rlung). ${ }^{1133}$ Almost the same exact thing occurs in The Life of the Madman of Tsang when the yogi was staying near Kathmandu. ${ }^{1134}$

King of the Empty Plain, pp 67-8.

${ }_{1130}^{1130}$ Stearns, King of the Empty Plain, pp 58, 160.

${ }_{1132}$ Stearns, King of the Empty Plain, pp 2-11.

${ }_{1132}^{1132}$ Stearns, King of the Empty Plain, p 2.

${ }_{1133}$ Stearns, King of the Empty Plain, p 139.

${ }^{1134}$ Ngödrup Pelbar, p 18b; Lhatsün Rinchen Namgyel, p 44; Götsang Repa, p 174. The name of the boneyard where this takes place changes across the three versions of the Life. 
There is an even more striking case of intertextuality. In the biographies of Tangtong Gyelpo and the Madman of Tsang, an often-repeated trope is that of the yogi meeting someone along the road who asks him where he has come from and where he is going. One time Tangtong Gyelpo encountered a chieftain (dpon po) who asked him:

"Where have you come from?"

"I came from behind," [Tangtong Gyelpo] replied.

"Where are you going now?"

"I'm going forward."

"You're a very coarse-mouthed person."

After this the chieftain and his attendants attacked Tantgong Gyelpo with stones and arrows and threw him into the river, from which he emerged unscathed. ${ }^{1135}$

This is almost word-for-word the same as an event included in all three versions of The Life of the Madman of Tsang, in which he is asked by a governor (nang so):

"Where do you come from? What knowledge do you have? Where are you going?" The Madman of Tsang answers, "I come from behind; now I go to what's in front of me."

The governor then responds, "He's a coarse-mouthed one!" (khong mi kha gyong zhig

'dug). (There are many instances in The Life of the Madman of Tsang in which he is savagely beaten, but fortunately for him this was not one of them. ${ }^{1136}$ )

1135 Stearns, King of the Empty Plain, p 271.

1136 ... gang nas yongs yon tan ci shes dgar 'gro dris zer 'dug pa la/ .... rgyab phyogs nas yongs da mdun phyogs su 'gro gsungs pas/ khong mi kha gyong zhig 'dug gsung pa la/... This is how it is presented in Lhatsün Rinchen Namgyel, p 17; Stearns 2007, p 543, points out this connection, but gives the wrong page number from Lhatsün Rinchen Namgyel's account. It is also given in the Ngödrup Pelwar version, p 8a$8 \mathrm{~b}$, and in Götsang Repa, $\mathrm{p}$ 30. The Madman of Tsang has encounters in which similar questions are asked multiple times, including Lhatsün Rinchen Namgyel pp 47, 58, and many other occasions throughout the three versions of his Life.

For examples of Tangtong Gyelpo being asked the same basic questions, see King of the Empty Plain, pp 254 and 201; in this latter instance he is asked, "Where have you come from? Where are you going now? What qualities of knowledge do you have?", which is almost precisely the same as the account from The Life of the Madman of Tsang given above. In the version of the Life of Tangtong Gyelpo translated by Stearns, the questioner in this case is a scholar-monk from Drepung Monastery; in earlier versions it was a disciple of the Sakya master Rangtön Sherab Künrik (rang ston shes rab kun rig, 1367- 
A suspiciously-similar encounter is described in Geshé Chaphu's 20th-century version of The Life of Drukpa Künlé. While traveling along the road Drukpa Künlé meets five girls who ask him, "Where are you from and where are you going?" He answers, "I come from behind and I'm going on ahead."1137 These stories are too similar to be a mere coincidence. They must represent later authors' drawing from earlier biographies, either by copying the text directly or by drawing from a more prototypical model passed down through time.

The relationship between the literary representations of the Madman of Tsang and Tangtong Gyelpo was a two-way street, however. As we saw just above, Tangtong Gyelpo's later biographer, writing in 1609, likely drew from the versions of The Life of the Madman of Tsang that had been written decades earlier. But the popular image of Tangtong Gyelpo played an important role in shaping the cultural landscape the Madman of Tsang himself inhabited. For example, Gyurmé Dechen's version of Tangtong Gyelpo's Life tells of the mahāsiddha's staying at the Four-Doored Kakṇi stūpa in the Lhasa Barkor, sitting perfectly still for one year without moving. ${ }^{1138}$ This story must have had currency long before Gyurmé Dechen's Life was penned, as it had a direct impact in shaping the biographies of the Madman of Tsang. All three versions of The Life of the Madman of Tsang tell of his staying at the Four-Doored Kakṇi stüpa, at which time some people exclaimed, “It's a demon!” while others said, "It's Tangtong

\footnotetext{
1449).

1137 The wording in Geshé Chaphu's version of this story is slightly different from the earlier versions involving the Madman of Tsang and Tangtong Gyelpo. Dowman, p 45; 1971 version, p 15.6: bu mo rnams na re/ khyod gang nas 'ong gang du 'gro zhus pas/ rgyab brten sa nas 'ong / gdong brten sar 'gro gsungs... I do not believe this passage is in either the Sothern Collection or in the "Collected Works". ${ }^{1138}$ Stearns, King of the Empty Plain, p 70, 193.
} 
Gyelpo!"1139

If we believe that the Madman of Tsang actually did meditate at this stūpa, it may exemplify his being aware of the precedent established by Tangtong Gyelpo. If people really did confuse the Madman of Tsang with Tangtong Gyelpo, this would suggest that Tangtong Gyelpo was an influential figure in Tibetan religious culture in the late 15 th century. If this story is a literary creation fabricated by the first author of The Life of the Madman of Tsang (Ngödrup Pelbar), it would indicate his interest to associate or compare the Madman of Tsang with the other famous saint who preceded him by half a generation.

The association or comparison between the Madman of Tsang and Tangtong Gyelpo is made even more explicitly. All three versions of The Life of the Madman of Tsang relate how, shortly after this time in Lhasa, the yogi arrived at Pelchen Riwoché (dpal chen ri bo che), Tangtong Gyelpo's monastery, where the famous mahāsiddha was in the midst of performing a tenth-of-the-month ganacakra ritual (tshes bcu'i tshogs

\footnotetext{
${ }^{1139}$ The name of this stūpa is spelled a few different ways. I have used the spelling attested to by Dungkar Rinpoché in his dictionary. Ngödrup Pelwar, p 10b, ka ka Ni sgo bzhi ma la bzhugs pas...; Lhatsün Rinchen Namgyel, p 40, kag Ni sgo bzhi ma la bzhugs...; Götsang Repa, p 44.6, ka ka ni sgo bzhi ma la gzhugs pas la la srin pho 'dug zer...

The Madman of Tsang's staying at the Kakni Goshi stüpa and peoples' wondering if he was Tangtong Gyelpo, is told in Lhatsün Rinchen Namgyel, p 40; Ngödrup Pelwar, pp 10a7-10b1. The latest version of the Life of the Madman of Tsang, by Götsang Repa, expands upon this moment in the yogi's life, saying that there were two occasions in quick succession in which the Madman of Tsang was mistaken by people for Tangtong Gyelpo: just before arriving in Lhasa, when he was sitting in the middle of the road eating tsampa mixed with urine from his skull cup (p 44.1-.2), and then when he was staying at the Kakni Goshi stūpa near the Barkor (p 44.5-.7).

An earlier version of the Life of Tangtong Gyelpo, by Sherab Pelden, a disciple of the mahāsiddha, tells of his circumambulating the Tashi Gomang stūpa at Jonang Monastery, naked, for three days (Stearns, King of the Empty Plain, p 68). Lhatsün Rinchen Namgyel's version of The Life of the Madman of Tsang contains a passage, just before the one describing the yogi's stay at the Kakni Goshi stüpa, in which it may be read (the passage is opaque) as saying he circumambulated the Jowo statue naked one hundred times. If this is the correct reading, it may be another case of an author of The Life of the Madman of Tsang (in this case, Lhatsün Rinchen Namgyel; his other two biographers omit this passage) drawing from the precedent of Tangtong Gyelpo (Lhatsün Rinchen Namgyel, p 40).
} 
'khor mdzad pa). The Madman of Tsang went right up to him, took a huge wooden cup that was covered, inside and out, with a floury paste (skyo mas gos pa) and filled with chang, and drank from it. Everyone was shocked by the impertinence shown in this. Tangtong Gyelpo thought for a moment, then said, "It's a good symbolic connection (rten 'brel). Give that dirty thing (gos) to me." The Madman of Tsang responded, "It is indeed a good symbolic connection. You already have plenty, so give this one to me" (khyod mod pa 'dug pas nga la 'di phul), and grabbed a basket (? sle ben) that belonged to the mahāsiddha. According to Lhatsün Rinchen Namgyel's version, Tangtong Gyelpo then said, "He is a yogi with engaged asceticism! (rnal 'byor pa brtul zhugs can zhig 'dug). I don't need you, and you don't need me, so leave" (nga la yang khyod mi dgos la khyod la yang nga mi dgos par 'dug pas da byon). ${ }^{1140}$ According to Cyrus Stearns, this line echoes words spoken by Padampa Sangyé to Milarepa at the time of their parting nearly four hundred years earlier. ${ }^{1141}$

Götsang Repa's version of The Life of the Madman of Tsang includes an additional mention of Tangtong Gyelpo, saying that the miraculous signs that occurred at the time of the Madman of Tsang's death were even more amazing than those that occurred at the time of the deaths of the Red Hat, the Karmapa, and the mahäsiddha

\footnotetext{
${ }^{1140}$ Lhatsün Rinchen Namgyel, pp 46.7-47.4.

${ }^{1141}$ Stearns, King of the Empty Plain, pp 489-90.

The story is also told, in a slightly different way, in Ngödrup Pelwar's version, the earliest of the three, pp 10b5-11a1. The second version of the Life of the Madman of Tsang (by Lhatsün Rinchen Namgyel) tells the same story (pp 41.5-42.3; translated by Stearns, King of the Empty Plain, p 79), but adds a few details, saying that the Madman of Tsang was 25 years old at the time, and that while Tangtong Gyelpo was staring at him in wonderment, the Madman of Tsang plucked the mahassiddha's beard and put it in his mouth, which caused Tangtong Gyelpo to cry out in pain. At this the Madman of Tsang exclaimed, "What kind of siddha is this, if he cries out, unable to bear his moustache being plucked!" Tangtong Gyelpo laughed and was a little ashamed. From here the conversation continues in a way similar to the other versions, with Tangtong Gyelpo asking the Madman of Tsang to give him the dirty cup from which he had drank.
} 
Tangtong Gyelpo. ${ }^{1142}$

In these encounters and comparisons between the Madman of Tsang and Tangtong Gyelpo we can detect a desire by the authors of the Lives of the Madman of Tsang to assert the Madman of Tsang to be equal if not superior to the other great saint in his status as a siddha. This can be read as evidence of Tangtong Gyelpo's fame and significance in the decades after his death, as he was an exemplar of siddhahood to which other Tibetan saints would be compared.

Despite Tangtong Gyelpo's fame and significance in Tibetan religious culture we know very little about him as a historical figure. Tangtong Gyelpo is shrouded behind a greater degree of mystery than the Madmen of Ü and Tsang, for example. Gyurmé Dechen's version of Tangtong Gyelpo's biography is quite fantastic, with little that reads like real historical fact. Tangtong Gyelpo is very similar to the more popular representations of Drukpa Künlé in this regard.

In this section we have seen a few examples of literary borrowing between biographies: a passage from The Life of the Madman of Tsang (which may be of even earlier provenance) also appears in The Life of Tangtong Gyelpo, and also in a 20thcentury version of The Life of Drukpa Künlé. An encounter between the Madman of Tsang and Tangtong Gyelpo includes a quotation of a centuries-earlier encounter

\footnotetext{
${ }^{1142}$ sku gshegs nas ngo mtshar ba'i ltas sam cho 'phrul 'di 'dra'i 'phrin las dang byin rlabs kyi stag tshan rang sprul sku zha dmar nag dang / grub chen thang stong rgyal po phebs dus yang ma byung zer/, $\mathrm{p}$ 276.5-.6.

Nowhere in the latest and most extensive version of the Life of Tangtong Gyelpo is this meeting with the Madman of Tsang mentioned. Tangtong Gyelpo is not mentioned in The Life of the Madman of $\ddot{U}$. He is mentioned in the "Collected Works" of Drukpa Künlé: when someone asks Drukpa Künlé what was the most amazing thing (ngo mtshar) he had seen in all his wanderings, he mentions many masters of different religious sects, including Tangtong Gyelpo, whom he describes as having helped people cross the river of suffering by building his many iron bridges (2005 version, pp 155.21-156.1; Stein, Vie et chants de 'brug-pa kun-legs le yogin, $\mathrm{p} 252$ ).
} 
between Milarepa and Padampa Sangyé. We can add to our consideration here a moment in The Life of Tangtong Gyelpo when the mahäsiddha reflects, "Half of Tibet will see me as an actual Buddha; half will see me as a demon." ${ }^{1143}$ We can compare this to a line contained in various versions of the Life of Drukpa Künlé, given as the epigraph to Chapter Five, when a chieftain observes, “Künlé, Madman of the Drukpa, you really seem to be an emanation of Māra! Either that, or you're an emanation of the Buddha!"

What we are starting to get a sense of here is the way certain stories (this includes bits of dialogue) are passed on through the literary culture surrounding Tibetan saints. The idea of a yogi responding to the question, "Where do you come from and where are you going?" with the saucy, "I come from behind me and go where I'm headed," can be best understood as a trope or a meme, passed on through generations of Tibetan religious culture. Here I have only shown three examples of this particular meme's use; it would come as no surprise if we saw very similar passages in the lives of other Tibetan ascetics as well. What this shows is that in the moment of writing these biographies, their authors are not necessarily directly describing the yogis' lives exactly as they perceived them to have happened, but writing about them while engaging in a dialogical conversation with the past, drawing from the existing body of stories about earlier saints.

The example of how certain memes are carried and passed on through the biographies of these saints provides a fitting metaphor for how their "holy madness" might be understood. We have gotten an idea of how the image of Tangtong Gyelpo helped shape the religious culture inhabited by the Madman of Tsang (or imagined by his

\footnotetext{
${ }^{1143}$ Stearns, King of the Empty Plain, p 76. This line is included in at least two versions of the Life: those by Sherab Pelden and Gyurmé Dechen.
} 
biographer): the story of Tangtong Gyelpo's having stayed at the Kakṇi Goshi stūpa is surely why the Madman of Tsang was later said to have stayed there and been mistaken for Tangtong Gyelpo — and after that, why the Madman of Kongpo discussed performing antinomian behavior at that very same place more than a century later. The images of the Madman of Ü, the Madman of Tsang and Drukpa Künlé all influenced the Madman of Kongpo, who explicitly cites them as constituting a precedent for his behavior, and for his becoming a "madman." We are starting to see how "madmen" at different moments in Tibetan history acted in ways that drew from and imitated earlier exemplars of the "madman" tradition. The Madman of Tsang drew from the precedent established by Tangtong Gyelpo, and the Madman of Kongpo self-consciously drew from the precedent established by Drukpa Künlé, the Madman of Ü, the Madman of Tsang, and, via the latter, Tangtong Gyelpo himself. The tradition of "holy madness" was literate and selfaware, as ironic or counter-intuitive as that may sound. This suggests that "holy madness" is not be born out of an individual's enlightenment, a spontaneous desire to teach an unconventional lesson to others, or from the exigencies of his private meditative practice. Rather it is a meme passed down from one generation of ascetics to the next. In the same way that the authors of biographies of mad saints cannot resist reusing similar tropes, century after century, in fashioning the lives of their saintly subjects, certain Tibetan ascetics enacted "holy madness" in reference to and influenced by that tradition's past. This argument will be developed and made more explicit below.

Tangtong Gyelpo also brings together a few other strains of the holy madman tradition, as one who is associated with both the Kagyü and the Nyingma sects, as one remembered as a treasure revealer (gter ston), and a practitioner of Cutting (gcod) and 
Pacification (zhi byed). As we will now see, these latter three traditions have had longstanding connections with the holy madman phenomenon.

\section{I.1 Madmen in the Cutting, Pacification and Treasure Revelation Traditions}

Many of the "madmen" in the Tibetan tradition have had associations with the meditative and ritual practices of Cutting $(g c o d)$ or the closely-related Pacification ( $z h i$ byed), both of which were initiated by Padampa Sangyé (late 11th, early 12th century). ${ }^{1144}$ The Cutting and Pacification traditions have been associated with "holy madness" since their earliest days on Tibetan soil. Holy madness is like a gene passed down through these meditative traditions' histories. According to The Blue Annals' chapter on the history of the Cutting tradition, there was a "Madwoman of Lhasa" (lha sa'i smyon ma), who was one of four dẹkinīs (along with Machik Labdron) who were important in Padampa Sangyé's life. She is also known for having shown Atīśa (9801052?) where to find a text inside a beam in the Jokang temple. ${ }^{1145}$ According to one version of the story of king Lang Darma's murder (glang dar ma), the Madwoman of Lhasa pointed out the escape route taken by the hero, Pelki Dorjé (dpal gyi rdo rje). ${ }^{1146}$ This latter story places the Madwoman of Lhasa in the 9th century, significantly earlier than the other stories. The topic of "madwomen" will be discussed separately below.

\footnotetext{
${ }^{1144}$ Davidson, Tibetan Renaissance, points out this connection, $\mathrm{p}$ 331. Davidson imagines that by the middle of the 12th century "Padampa-lineage tantric feasts must have seemed as much a psychiatric outpatient support group as a gathering of awakened masters." Here Davidson probably takes the language of "madness" a little too literally.

${ }^{1145}$ The text was the rgyal po'i bka' chems. Roerich, p 984; deb ther sngon po (Sarnath: wA Na badzra bidyA dpe mdzod khang, 2002), p 1143; Jamgön Kongtrul, The Treasury of Knowledge, Book Eight, Part Four: Esoteric Instructions: A Detailed Presentation of the Process of Meditation in Vajrayāna, translated by Sarah Harding and the Kalu Rinpoché Translation Group (Ithaca: Snow Lion Publications, 2007), p 256.

The text purportedly unearthed by the madwoman is described in Dan Martin, Tibetan Histories: A Bibliography of Tibetan-Language Historical Works (London: Serindia, 1997), text \#4.

${ }_{1146}$ Per K. Sørensen and Guntram Hazod, with Tsering Gyalbo, Thundering Falcon: An Inquiry into the History and Cult of Khra-'brug, Tibet's First Buddhist Temple (Wien: Österreichische Akademie der Wissenschaften, 2005), pp 250-51, footnote \#4.
} 
According to The Blue Annals, a grand-disciple of Padampa Sangyé, a master of the Cutting practice, was called "Mad Beré" (smyon pa be re), although we are told nothing of what kind of "crazy" behavior he may have performed. ${ }^{1147}$ The Blue Annals also tells of how one of Machik Labdrön's three sons achieved the state of a zhig po (synonymous with "khrul zhig?), a "destroyer [of illusion?]." "1148 He had a grandson (i.e., Machik's great-grandson) called Samdrup, the Mad Skull Cup (thod smyon bsam grub). ${ }^{1149}$ He earned the epithet "snowman" (gangs pa) because he used to sleep naked on the snow. For a period he consumed nothing but water; one time he ate the flesh of a corpse (ro gsol). He cured people, including himself, of leprosy, and built a guesthouse ('gron khang), supplying free food for the people. ${ }^{150}$

The Blue Annals mentions one called the Little Madman of Gya (rgya smyon chung) and an Accomplished Madman (smyon pa ldon ldan), both of whom were part of the Pacification (zhi byed) tradition, which was, like Cutting, initiated by Padampa Sangyé. $^{1151}$

\footnotetext{
${ }^{1147}$ Roerich, pp 997-8.

${ }^{1148}$ Two terms that are worth further study in their own right are zhig po and 'khrul zhig. What remains to be determined is whether or not the two are considered synonymous, what meanings they have been said to have, and how they have been used historically. In general it can be said that in practical terms their meaning seems to have been quite similar to that carried by the term "madman," although with less obvious potential for implying a meaning of overturning norms. The terms "khrul zhig and zhig po have come up a number of times in relation to "holy madmen" and their near associates. The history of the terms zhig po and "khrul zhig are worth sustained study in their own right, along with the histories of those who have employed them.

${ }^{1149}$ Ardussi (1972) says that according to another text, the grub mtha' shel kyi me long, Samdrup, the Mad Skull Cup, was actually Machik's son, p 27.

${ }^{1150}$ George N. Roerich, trans., The Blue Annals (Delhi: Motilal Banarsidass, 1996; first printed 1949), p 986; Vajra Vidya version, p 1145. In the The History of Taklung Monastery he is referred to as smyon bsam 'grub, stag lung chos 'byung (brgyud pa yid bzhin nor bu'i rtogs pa brjod pa ngo mtshar rgyo mtsho) (bod ljongs bod yig dpe rnying dpe skrun khang, 1992), p 716. In some versions of the history of the Pacification tradition, an early member of the lineage was a Madman of Chokro (cog ro smyon pa; cog ro could refer to a place or a clan), stag lung chos 'byung, $\mathrm{p} 715$.

${ }^{1151}$ Roerich, $\mathrm{p} 876$. This Accomplished Madman may well be the same as that mentioned in the context of the life of Nyangrel Nyima Özer (1124-92), Davidson, Tibetan Renaissance, p 330.
} 
As we saw in Chapter Three, the Madmen of Ü and Tsang both performed and taught a practice called the Secret Activity of Nāro, which was a Cutting-style practice. Tangtong Gyelpo is also associated with the Cutting teachings. ${ }^{1152}$

There were later madmen who were connected with the Cutting practice as well. This includes Dharma Sengé, the Madman of Kham (khams smyon d+harma seng ge) (b. 19th century), who was a famous teacher and scholar of Tibetan medicine. And in The Life of Amgön Rinpoché of Drikung Til (to be discussed in detail below) there is mention of a "mad lama" (bla ma smyon pa) who traveled around practicing Cutting. While visiting Drikung Til this mad lama used his special abilities to make the vultures eat the corpse of a person who had died from a disease, when otherwise they would have avoided it. ${ }^{1153}$ This would have been in the late 19 th or early 20 th century.

Kenpo Tsülnam Rinpoché of Sherab Ling Monastery in Bir, H.P., India, tells of an odd ascetic he knew of in his youth in Nangchen, Kham, in the 1970 s or 80 s. ${ }^{1154}$ The man was known as the Latsé Madman (la rtse smyon pa), or the Latsé Powerful One (la rtse stobs ldan), or by his proper name, Latsé Kyenrab (mkhyen rab). Latsé refers to the man's clan (rus), a departure from the norm by which the madman is most often named for his home area or monastery. According to Rinpoché, the Latsé Madman was highly accomplished in the Cutting practice. He lived in a cave, had long hair and a beard, and wore tattered old clothes. He never washed and did not care about what he ate. He had no concern about unclean things (btsog $p a)$, as it was all the same to him. When

\footnotetext{
1152 Stearns, King of the Empty Plain, pp 18-20, 63.

${ }^{1153}$ grub pa'i dbang phyug chen po a mgon rdo rje 'chang gi rnam thar rags bsdus bka' brgyud bstan pa' $i$ mdzes rgyan, by 'bri gung dkon mchog rgya mtsho (bod ljongs mi dmangs dpe skrun khang, 2004), pp 478.

${ }^{1154}$ Interview at Sherab Ling Monastery, Bir, H.P., 23 September 2009.
} 
someone died and there was no one to deal with the corpse, the Latsé Madman would take it away and prepare it for burial, sky burial or cremation. If someone died from a disease and no one else wanted to touch the corpse, the Latsé Madman would handle it. He had a miraculous ability to heal sick people, which is often attributed to practitioners of Cutting. He would take the disease into himself and destroy it. He could also cure people who had gone mad. Sometimes people tried to invite him to take a position of honor somewhere, but he refused. People would sometimes bring him food; often he would not accept it. He could drink however much alcohol and never get drunk.

According to Kenpo Tsülnam Rinpoché, the Latsé Madman would not do crazy things when he was alone. Alone he simply did his religious practice. But when the villagers gathered for some occasion, he would arrive and do his crazy behavior, which included taking off his clothes, drinking a lot, dancing around, sitting where he was not supposed to, and saying contrary things. If everyone said it was good, he would say it was bad; if everyone said it was bad, he would say it was good. Kenpo Tsülnam Rinpoché says that everyone in the area had faith $(\mathrm{dad} p a)$ in the Latsé Madman. Nevertheless, Rinpoché states that he and the other children were afraid of the unpredictable ascetic, and when they had to go up the mountain they would take a longer route around, so as to avoid the place where he lived.

As with the Cutting and Pacification traditions, there has also long been a confluence between the treasure revealer (gter ston) and holy madman traditions. Orgyen Lingpa was called the "madman of the treasures" (gter smyon) in the colophon to one of 
his revelations. ${ }^{1155}$ Pema Lingpa referred to himself as a "mad treasure revealer" (gter ston smyon pa). ${ }^{1156}$ Tangtong Gyelpo is believed to have revealed treasures. ${ }^{1157}$ The Madman of Kongpo is said to have revealed some treasure texts as well. ${ }^{1158}$ According to Cyrus Stearns, most of the "mad yogins" of the Nyingma tradition were treasure revealers. $^{1159}$

In this chapter we have considered some of the ascetics of the Tibetan Buddhist tradition who were during their lives and after popularly referred to as "madmen" or "madwomen" with positive connotations. Most of these figures were ascetics who at times engaged in some form of eccentric behavior. Even still, there is a lot of diversity in the sort of lives they lived, ranging from thoughtful critics like Drukpa Künlé to those enacting a literal reading of the tantras like the Madmen of Ü and Tsang, to the Madman of Kham, who was a doctor and a scholar. If we look closely at the lives of these madmen we will see that each was a "madman" in a different way. These differences were sometimes subtle, sometimes drastic. The meaning and use of the term "madman" was flexible. What we are starting to get a sense of here is that "madman," even when applied to religious beings in an exalted sense, did not mean just one thing. "Holy madness" is, rather than a clear-cut designation, an idea with a history. What's more, we have seen that some of Tibet's "holy madmen" were fully aware of the madmen who preceded them and even admit to finding them a source of inspiration.

\footnotetext{
${ }^{1155}$ This is The Five Chronicles ( $b k a^{\prime}$ thang sde lnga). Stein, Tibetan Civilization, p 276; Stearns, King of the Empty Plain, p 62.

${ }^{1156}$ Stearns, King of the Empty Plain, p 62.

${ }^{1157}$ Stearns, King of the Empty Plain, p 23.

${ }^{1158}$ TBRC, P1961

${ }^{1159}$ Stearns, King of the Empty Plain, p 62.
} 
Another treasure revealer connected with the holy madman tradition was a teacher of Shabkar Tsokdruk Rangdröl (zhabs dkar tshogs drug rang grol, 1781-1851), who was sometimes known as Madman Tekya (rtas skya smyon pa). This man went by a number of other names as well, including Guyang Lodé Dechen Dongak Lingpa, Dönyö Dorjé and so on. ${ }^{1160}$ The important question here is this: does the fact that this man was only sometimes known as Madman Tekya make him less of a "madman" than someone like the Madman of Tsang, who is almost always called by that epithet? Should Madman Tekya therefore not be counted among the other holy madmen? What about the Madman of Kongpo, who was more often referred to as Namka Jikmé? Were they each somehow less of a "madman" than the Madman of Ü or the Madman of Tsang, or the Madman of the Drukpa, or the Madman of Ralung? Was Madman Tekya only a madman at the moments when he was called a madman and operating under that mode?

The questions raised here exemplify how slippery one's identity as a madman can be. This slipperiness stands in direct contrast to the pervasive notion that one becomes a madman as a result of success in one's religious practice and the subsequent achievement of a new ontological state. Was Madman Tekya an enlightened being who had transcended all worldly concerns in the moments when he was called the Madman of Tekya, and just an ordinary treasure revealer at the moments when he was not? Where does one draw the line between "madman" and not-madman? Towards interrogating this question further, in the next section we will consider a number of ascetics in the history of Tibetan Buddhism who have employed a rhetoric of madness and even been called

\footnotetext{
${ }^{1160}$ gu yangs blo bde bde chen mdo sngags gling pa. Matthieu Ricard, trans., The Life of Shabkar: The Autobiography of a Tibetan Yogin (Ithaca: Snow Lion Publications, 2001), pp 558, 563. Apparently the word Tekya has no meaning.
} 
"madmen" during the course of their lives, or in the popular memory of their lives, but are not famous as madmen per se. As we will quickly see, the line between who is remembered as a madman and who is not is vague and capricious, which opens the door to a reconsideration of the nature of holy madness itself.

\section{II. Not Quite Crazy? Would-Be Madmen of Tibet's Past}

The importance of Milarepa in connection with the holy madman tradition was discussed in the previous chapter, as it cannot be understood without considering the Madman of Tsang and his greater cultural project. One of the most important aspects of Milarepa in this regard is his use of the theme of "madness" in the sense that one's enlightenment can put one at odds with worldly conventions. The idea of madness was used in a very similar way by another early Tibetan anchorite and poet, Kodrakpa, or "the Hermit of Ko Cliffs.” Kodrakpa Sönam Gyeltsen (ko brag pa bsod nams rgyal mtshan, 1170-1249) became famous during his time because of his asceticism and realizations. ${ }^{1161}$ It is difficult to definitively place Kodrakpa in a specific tradition, as he had associations with the Path and Fruit (lam 'bras), the Kālacakra, Pacification, the Mahāmudrā, and other meditative systems. ${ }^{1162}$ Later he would be remembered primarily as an important early Drukpa Kagyüpa, as he was one of the main teachers of Gyelwa Yanggönpa (1213$58)$.

\footnotetext{
${ }^{1161}$ For a discussion of the various sets of dates provided for Kodrakpa by different Tibetan authors, see Cyrus Stearns, trans., Hermit of Go Cliffs: Timeless Instructions from a Tibetan Mystic (Boston: Wisdom Publications, 2000), pp 21-2. He earned his epithet from spending a lot of time at the cave of Kodrak ("Ko cliffs"), in the Upper Nyang region (nyang stod), near Shalu.

According to his biography, Kodrakpa once saw the corpse of a leper woman and although he was disgusted, he ate some of her brains. This freed him from conceptualizations about cleanliness and filth, Hermit of Go Cliffs, $\mathrm{p} 8$.

${ }^{1162}$ Stearns, Hermit of Go Cliffs, pp 3, 7.
} 
Kodrakpa is comparable to Milarepa in many ways, from his emphasis on the primacy of meditation to his poetic style to the fact that he meditated in many of the same places as Milarepa in southwestern Tibet. Kodrakpa even made allusions to some of Milarepa's words in his own songs. ${ }^{1163}$ Kodrakpa also toyed with the idea of madness in a way very similar to how Milarepa had. In one song Kodrakpa talks about himself as one living in the manner of a beggar, having renounced his home, family, and good food and wealth. Instead of enjoying these simple comforts Kodrakpa has chosen to stay in holy places, to cultivate his connection with all sentient beings, and to find contentment within. Because of his living in this way, Kodrakpa writes of himself,

Some people say, "He's insane-insane!" I wonder whether this beggar has gone insane. ${ }^{1164}$

Here Kodrakpa points out that his insistence on following a serious ascetic lifestyle places him at odds with worldly conventions. If his insistence on following a dedicated religious life qualifies him as a "madman" in the eyes of others, it is a designation he is willing to accept. Like Milarepa, Kodrakpa is toying with the very idea of madness, reappropriating the word and turning it on its head. In fact, Kodrakpa's words here are similar to those at the beginning of Milarepa's "crazy song," described in Chapter Six. ${ }^{1165}$ Milarepa and Kodrakpa gave a specific meaning to the word "madman" (smyon $p a)$ when used to refer to a dedicated religious practitioner. This meaning would remain attached to the term "madman" for its entire history since. For example, one time in The

\footnotetext{
${ }^{1163}$ Stearns, Hermit of Go Cliffs, $\mathrm{p} 15$.

${ }^{1164}$ Stearns, Hermit of Go Cliffs, pp 46-7: mi la la smyon pa smyon pa zer/ sprang bdag rang dang smyo nas 'dug gam mnos/. Kodrakpa uses the term "madman" in other senses as well. See pp 38-9, 106-7.

${ }^{1165}$ Compare Kodrakpa's: mi la la smyon pa smyon pa zer/ sprang bdag rang dang smyo nas 'dug gam mnos/ (Stearns 2007, p 46), with Milarepa's: gzhan yang smyo'am smyo'am zer/ rang yang smyo'am snyam pa byung/ smyo ba'i smyo lugs bshad tsa na/
} 
Life of the Madman of Tsang a scholar monk (slob dpon) says to the Madman of Tsang, “They say there's a mad renunciant around-is it you?" The Madman of Tsang replies, "If you look at it from a different perspective, it is you who is crazy." "1166 When asked to elaborate, the Madman of Tsang asks the monk if wasting the precious opportunity of a rare human rebirth is not what is truly crazy. When people (including himself) called Sangyé Gyeltsen a “madman," primarily because of his shocking, eccentric behavior, the meaning given to the term "madman" by Milarepa and Kodrakpa would also present on some level. ${ }^{1167}$ As we consider the remaining eight hundred years of the history of the term, we will see how over time it would be given a wide range of meanings, as it was picked up and used in different ways to different ends by many Tibetan ascetics and writers. Each case of its use was something historically specific and new, but the meaning given to the term by Milarepa and Kodrakpa would always be one of the various meanings expressed by the term. The fact that so many Tibetans today cite Milarepa as one who exemplified "holy madness" is a testament to his ongoing importance in defining the meaning of the term. ${ }^{1168}$ This has probably been the case since just a few generations after his death. Later the efforts of the Madman of Tsang in printing and popularizing his Life and Songs cemented Milarepa's role in this context for centuries to come. $^{1169}$

\footnotetext{
${ }^{1166}$ From Stearns, King of the Empty Plain, p 74; Lhatsün Rinchen Namgyel, pp 47.6-48.1; slob dpon gzhan zhig byung nas bya bral smyon pa cig 'dug zer ba khyed yin nam zer ba lal mthong tshul mi 'dra bas ltas na khyed smyo 'dug byas pas...

${ }^{1167}$ In this case we cannot be certain if this episode actually represents an encounter had by the Madman of Tsang or a composition by his disciple, Lhatsün Rinchen Namgyel. Even if the latter is the case, it still means that those close to the Madman of Tsang wanted to present his "madness" in this way.

${ }^{1168}$ Stearns, King of the Empty Plain, p 64, refers to Milarepa as being, "in many ways the perfect mad yogin."

${ }_{1169}$ In the cases of Milarepa and Kodrakpa, we cannot be certain that the texts of their lives and songs we have now are a veridical record of their actual histories and words. But in both cases it is reasonable to
} 
On the topic of printing projects, the case of Kodrakpa also fits into our history of the "holy madman" tradition in another way: his Collected Songs (mgur 'bum) were compiled and printed in the 16th century at Drakar Taso thanks to the efforts of Lhatsün Rinchen Namgyel (1473-1557), the disciple and second biographer of the Madman of Tsang. ${ }^{1170}$ The printing of Kodrakpa's works, as an early adopter of the rhetoric of madness in the Kagyü tradition, must then be considered part of the larger cultural project of the Madman of Tsang and his inner circle, as they strived to gather, preserve and fashion in a particular way the songs and lives of their Kagyü predecessors. To this end we can note how in a brief verse at the beginning of Kodrakpa's Collected Songs Lhatsün Rinchen Namgyel praises Kodrakpa as one who performed engaged asceticsm (brtul shugs [sic] spyod pa). This term, however, is never used by Kodrakpa in any of his songs. Based on this we can question the extent to which Kodrakpa understood his activity and asceticism as coming under that heading. This may be a case of Lhatsün Rinchen Namgyel's projecting the idea of engaged asceticism into the life of a past master, fashioning Kodrakpa in such a way that he constitutes a precedent for later yogis like the Madman of Tsang who would make the performance of engaged asceticism such a key component of their public personas. In Chapter Six I argued that the Madman of Tsang did this with his depiction of Milarepa.

think that the kind of rhetoric of madness discussed here was, if not directly attributable to the yogis themselves, part of the popular imagination of them during the time in which they lived or within a few generations of their deaths.

1170 According to Stearns, this was probably the first xylograph printing of Kodrakpa's works. Considering the many misspellings and irregularities in the text, Stearns believes the text to be original and un-edited, perhaps comparable to earlier versions of Milarepa's collected songs before they were edited by the Madman of Tsang. 
And yet despite the role Kodrakpa played in giving meaning to the term "madman," he is not considered to be an example of a holy madman.

The siddha Nyakré Sewo (grub thob nyag re se bo, also known as nyag se rin chen rgyal mtshan, 1141?-1201; Nyakré is also spelled nyag bre) is an example of someone who used the term "madman" in a way slightly divergent from how Milarepa and Kodrakpa did. Born in Drakyab (brag g.yab) in Markam in the Kham region, he traveled to central Tibet and became one of Pakmodrupa's four main disciples. ${ }^{1171}$ Nyakré Sewo then returned to Kham and founded Le Monastery, which would be associated with the Martsang (smar tshang) sub-branch of the Kagyü. ${ }^{1172}$ (There is also a tradition stating that Nyakré Sewo founded the Tāra temple, sgrol ma lha khang, in the Lhasa Barkor.) Nyakré Sewo is attributed with performing various magical feats that were taken as signs of his meditative accomplishment ( $g r u b$ rtags). These include causing an avalanche by urinating on a pile of dirt, hauling away a boulder by tying it to a horse's tail, miraculously healing people, and leaving a footprint on a boulder. ${ }^{1173}$

Throughout his writings (which include songs, prophecies about the future, and various oral testaments) Nyakré Sewo refers to himself as "the Madman of Nyak" (nyag smyon) on many occasions. ${ }^{1174}$ He mainly uses the term madman in a playful mode. He writes,

\footnotetext{
${ }^{1171}$ grub thob nyag re se bo. grub thob nyag re se bo'i skyes rabs rnam thar ma 'ongs lung bstan zhal chems nyams mgur bzhugs ('gro phan gtsug lag dpe skrun kdang dang / a myes rma chen bod kyi rig gzhung zhib 'jug khang gnyis zung 'brel spar du skrun pa, 2008), p 108.4. See also the sangs rgyas dar po chos 'byung, $\mathrm{p} 110.7$, where he is referred to as myang re se bo.

1172 gle dgon; also referred to as La Monastery, bla dgon, gla dgon; Tashi Tsering calls it brag g.yab la dgon.

${ }_{1173}$ grub thob nyag re se bo'i skyes rabs rnam thar ma 'ongs lung bstan zhal chems nyams mgur bzhugs, pp 188-89, 192; 188, 192; 192; 205.

${ }^{1174}$ ibid., for example, pp 19, 22, 23, 29, 30, 33, 39.
} 
I, Madman of Nyak, who does whatever he wants,

I, Madman of Nyak, whom nobody wants;

I, the conceited Madman of Nyak;

I, the Madman of Nyak who has attained the twofold goal [for self and others]...

Nyakré Sewo also makes reference to performing "crazy activity" (smyon pa’i bya spyod)

and engaged asceticism (brtul zhugs). ${ }^{1176}$ Karma Pakshi relates how Nyakré Sewo

"performed various types of engaged asceticism" (brtul zhugs kyi spyod pa sna tshogs

byas) in Kham. ${ }^{1177}$

And yet despite his calling himself a madman, performing "crazy activity" and engaged asceticism (the practice that motivated the eccentric behavior of the Madmen of Ü and Tsang), Nyakré Sewo is rarely recalled as being among the ranks of Tibet's holy madmen. This raises the main question this chapter seeks to ask: what is it that qualifies someone as a holy madman in the Tibetan tradition? Nyakré Sewo, for example, is widely recognized as a siddha (he is often referred to as "the siddha Nyakré Sewo"). He called himself a madman and was sometimes referred to as a madman by others. ${ }^{1178}$ And yet he has never come up in any discussion of "holy madmen" in Tibet that I am aware of, neither in written or oral accounts by Tibetans or others. One might argue that this is because he was simply less famous than many of the other figures we are discussing here

\footnotetext{
1175 ibid., p 39. ci bsam 'grub pa'i nyag smyon nga/ sus kyang mi 'dod nyag smyon nga / rang mthong byed pa'i nyag smyon nga / don gnyis mthar phyin nyag smyon nga /. One place Nyakré Sewo writes: "In the manner of Mañjuśrī, I have stainless wisdom; / In the manner of a bodhisattva, I have ceaseless compassion.../ In the manner of samsāra, I have attachment to my fatherland.../ In the manner of a madman, I will do as much as possible of whatever is bad (smyon pa'i tshul gyis ci ngan gang brgyag byas), / In the manner of a monk, I will shave my hair and beard; / In the manner of a great meditator, I will train the mind single pointedly; / In the manner of a siddha, I will perform a lot of asceticism (grub thob kyi tshul du brtul zhugs du ma bsten)...”, p 54.

1176 ibid., p 19; pp 32, 49, 54.

${ }^{1177}$ Quoted in ibid., pp 192-3.

${ }^{1178}$ There is one example of someone calling him "the Madman of Nyak" in some later generation, but it is impossible to determine in what sense the person used this name, $\mathrm{p} 104$.
} 
(even Dungkar Rinpoché states that he could not find any account of the siddha's life) and that that his writings may not have been accessible until recently. But more central than any of these factors, what Nyakré Sewo's case exemplifies is that what turns someone into a holy madman is the perception of him in the collective consciousness, in popular memory, in the constructed history of the sect. It is not necessarily being enlightened or even referring to oneself as a "madman" that gets one remembered as a madman by one's tradition. It is, rather, a product of popular perception and memory. As we consider more "madmen" or almost-madmen in the history of the Tibetan tradition, we will see more and more how arbitrary the distinction between those who qualify and those who do not really is. It has less to do with what they did or said than it does with how they were perceived by others.

The situation regarding the Tibetan mahāsiddha Urgyenpa (grub chen u rgyan pa, 1230-1309) further problematizes the issue of what qualifies one as a holy madman. Urgyenpa trained under Bodong Rinchen Tsémo, Karma Pakshi and other famous figures before taking Götsangpa Gönpo Dorjé (rgod tshang pa mgon po rdo rje) as his main guru. Because of this, Urgyenpa would be remembered primarily as a master of the Drukpa Kagyü tradition. After a thorough religious training Urgyenpa spent the remainder of his life traveling, visiting holy places in South Asia, including Kashmir and the holy land of Urgyen/Oḍ̣iyāna, for which he got his name. He repaired a stūpa in Bodhgaya. According to his biography, later in his life he was invited to teach the Dharma to the Mongolian emperor of China.

In the course of his biography Urgyenpa gets called a "madman" by other people on a number of occasions. When invited into the home of a lord in Mangyül (mang yul) 
the yogi arrived wearing only a short robe in poor condition (na bza' thung ngu ngan pa) which made the lady of the house wonder to herself if he were a madman (snyon pa [sic]) or a siddha. Knowing exactly what she was thinking, the yogi asked, "Am I the crazy one, or is it you?" (nga ni mi smyo khyed rang smyo 'am). This left her ashamed. ${ }^{1179}$ Here we again see the notion that the ways of an enlightened being may appear to be the ways of a madman in the eyes of worldly-minded people, as was expressed by Milarepa and Kodrakpa.

Urgyenpa also gets referred to as a madman for performing eccentric behavior. One time he banged on a nobleman's door while howling or laughing ( $k$ u co chen po ston), which caused everyone to flee, saying "He's a madman!" (rnyon [sic] pa zhig 'dug zer bros so). ${ }^{1180}$ Another time the yogi took the staff out of the hand of a minister and leapt directly next to a king, which cause the king to exclaim, “There's a madman!" (rnyon pa [sic] byung). ${ }^{1181}$ Later a companion of the siddha refers to him as "Urgyenpa the Madman" (u rgyan pa rnyon pa [sic]) while they traveled together through Nepal. ${ }^{1182}$ Finally, when he went to visit the Mongolian emperor of China, King Sechen (se chen rgyal po ${ }^{1183}$ ) the emperor praised Urgyenpa for how learned he was in the Dharma. The Emperor explained that although people said Urgyenpa was a madman (rnyon pa [sic])

\footnotetext{
1179 grub chen u rgyan pa'i rnam thar, by Sönam Özer (bod ljongs bod yig dpe rnying dpe skrun khang, 1997), pp 105-6.

1180 Ibid., p 59.

${ }^{1181}$ Ibid., p 135. This is reminiscent of the engaged asceticism performed by the Madmen of Ü and Tsang, when they confronted authority figures with wrathful behavior. A tale about Urgyenpa's desecrating a nonBuddhist temple somewhere in India with feces and urine is also reminiscent of the Madman of Ü's activities in Nepal. grub chen u rgyan pa'i rnam thar, p 136; Life of the Madman of Ü, p 445. 1182 p 177. As for Urgyenpa's performing brtul zhugs, it is mentioned on pp 2, 70.

${ }^{1183}$ Dungkar Rinpoché dictionary, has yon rgyal rabs kyi gong ma hu pi li se chen han, p 565.
} 
and a charlatan $(\operatorname{zog} p o)$, because of his wisdom and conduct, clearly he was neither of those. Urgyenpa's reputation as a "madman" must have preceded him. ${ }^{1184}$

Urgyenpa was widely accepted and remembered as learned and supremely accomplished in meditation ${ }^{185}$ And according to his biography, "madness" was a theme that ran throughout his life. People misrecognized him as a madman because of the way his religious pursuits put him at odds with worldly ways. Sometimes this was his general kind of asceticism (such as when the noblewoman did not know what to make of his shabby dress), and sometimes it was his acting out in unexpected ways (such as when he took the staff from the king's minister). And yet Urgyenpa is not remembered as a madman by the tradition. It is unlikely that anyone would say he was any less realized than famous madmen like the Madman of $\ddot{U}$ or the Madman of Tsang, as he is often referred to as a mahāsiddha. Rather, the difference is that he did not take measures to cultivate an image of himself as a madman, and was not remembered as a madman by the tradition.

The Blue Annals tells of one called "Great Renunciant" (bya bral chen po), who was associated with the the Mahāmudrā that Cuts the Stream of Samsāra (phyag rgya chen po 'khor ba rgyun gcod) tradition. He probably lived in the 10th or 11th century, spending most of his life in Kongpo. ${ }^{1186}$ He started off as a very fastidious person (gtsang sbra che ba). However, in the course of his practice he "achieved a state of being without fixations" (gtad med du grol bas...) and as a result started eating feces, smearing

\footnotetext{
1184 pp 241-2.

1185 The writings of Nyakré Sewo considered above are attributed to the siddha directly. The biography of Urgyenpa was written by one Sönam Ozer (bsod nams 'od zer); I have not been able to identify who this was or when he lived. Nevertheless, this is, from the perspective of the Tibetan Buddhist tradition, the definitive account of Urgyenpa's life.

1186 The account given in The Blue Annals maintains that he met Milarepa and Gampopa.
} 
his body with it (dri chen za zhing lus la 'jug), and offering it to the Three Jewels. He thereby enacted "acting like a madman" (smyon spyod mdzad). ${ }^{1187}$

In the Great Renunciant we have a figure who is said to have achieved a state of non-duality through his practice of the Mahāmudrā, which lead him to perform some of the most shocking behavior imaginable — behavior that was typical of many of Tibet's holy madmen. This was even called "acting like a madman" in the account of his life given by a very popular source. And yet we have no indication that he or others ever called him a madman. Why not? How does one explain why some noted eccentrics become "madmen" while others come so close but never cross that line?

We should also remember how, as described in Chapter Four, the first in the Pawo reincarnation lineage, Chöwang Lhündrup (1440-1503), performed miracles and did some eccentric tantric activity similar to that of the Madmen of Ü and Tsang, which got people to wonder if he was crazy (smyo ba); he is even said to have acted like a madman (smyon pa lta bu). Like the Great Renunciant, Chöwang Lhündrup is not remembered as a holy madman. The same goes for Drakpa Tayé, who engaged in some eccentric forms of asceticism, sang of performing "the engaged asceticism of a madman" (smyon pa' $i$ brtul zhugs), and walked around smeared with ashes. And with Drakpa Tayé's master, whom he praised as "crazy Lhatsün” (lha btsun smyon pa). None of these figures are remembered by the tradition as "holy madmen." Were they not enlightened enough? Was their activity not shocking enough?

One figure whose story has multiple connections to this subject is Amgön Rinpoché (1853-1945), an ascetic who spent most of his life at Drikung Til Monastery.

${ }^{1187}$ Roerich, p 1040; Vajra Vidya, pp 1209-10. 
Amgön Rinpoché is remembered as a hermit who achieved miraculous powers and performed many miracles over the years. He could travel in an instant to Lhasa to buy momos or to Tsari to pick flowers. Sometimes he took the form of a young monk and spoke to people when they were traveling in other places. On many occasions he displayed supernatural understanding (mngon mkhyen), accurately foretelling future events and knowing peoples' thoughts before they voiced them. Amgön Rinpoché is also attributed with various sorts of eccentric behavior. Sometimes when people brought him offerings he refused to take them. Sometimes when people brought nothing he asked them what they had to offer. He smashed precious stones that were brought to him as gifts. He plastered the walls of his cell with the paper money that was offered to him, as he refused to recognize it as being of any value.

Amgön Rinpoché is sometimes brought up in conversation about holy madmen, particularly among those familiar with the oral culture of the Drikung Kagyü tradition. ${ }^{1188}$ A rhetoric of madness is sometimes applied to his eccentric behavior. On one occasion the monastery's disciplinarian (dge bskos) said to him, “Amgön, you are crazy.” Amgön Rinpoché responded, "Kwa-ye! I'm not crazy. The crazy one is you. One-upping is crazy.” The reason Amgön Rinpoché said this, we are told, is that the disciplinarian had established a sumptuous residence for himself, and Amgön Rinpoché wanted to point out that this was ultimately more problematic than any of the odd things he himself had done. ${ }^{1189}$

\footnotetext{
${ }^{1188}$ Kenpo Tinlé Tarchen mentioned Amgön Rinpoché to me and showed me a photograph of him (interview at Drikung Kagyü Monastery, Rewalsar, H.P., 29 September 2009). Some American practitioners staying at Songtsen Library near Dehradun also knew stories of Amgön Rinpoché. ${ }_{1189}$ dge bskos mar ril gyis/ a mgon khyed smyon pa red 'dug ces zhus par/ kwa ye/ nga smyo med/ smyon pa khyod rang red/ rkyal thog rkyal rtsegs byas te smyo 'dug ces gsungs/ khong gi shag tshang
} 
Popular tradition maintains that one time Amgön Rinpoché brought an ox (? chu glang) into the assembly hall and put it at the head of the line before all the retreatants. Some of the retreatants exclaimed, "Now Amgön is crazy! What to do?" Others said he had belittled the retreatants by placing them all in such a lowly position behind the ox. Others interpreted it as a symbolic teaching ( $b r d a^{\prime}$ chos): if the retreatants embodied the qualities of renunciation and realization, what difference would it make to them who or what was seated at the head of their line ${ }^{1190}$ Drukpa Künlé is attributed with having done the exact same thing with a donkey while visiting Drepung Monastery four hundred years prior. ${ }^{1191}$ If we take this story about Amgön Rinpoché as veridical (which we probably should not), it may be that Amgön Rinpoché was imitating a famous madman of the past. If we take this story as a fabrication, it would suggest that those around Amgön Rinpoché were interested to associate him with a famous holy madman of the past.

According to another story one time when Amgön Rinpoché was staying in retreat there was a single wall separating his cell from that of Drubwang Tseten Rinpoché. According to the author, Amgön Rinpoché was motivated by the lines in the sixth chapter of the first book of the Hevajra Tantra, which read, "Having achieved some warmth, / if you want to do some Activity..." ${ }^{1192}$ And because of this, Amgön Rinpoché started shouting loudly ( $k$ u co chen po 'don pa) through the hole leading to Drubwang Tseten

rgyu nor che gras yin pa der gsungs snang /, grub pa'i dbang phyug chen po a mgon rdo rje 'chang gi rnam thar rags bsdus bka' brgyud bstan pa'i mdzes rgyan, by 'bri gung dkon mchog rgya mtsho (bod ljongs mi dmangs dpe skrun khang, 2004), p 43. For another version of Amgön Rinpoché's life see 'bri gung mtshams pa grub thob a mgon rin po che'i rnam thar, by 'bri gung pa chos 'byor, Oral Histories Series, No. 1 (Dharamsala: Library of Tibetan Works and Archives, 1996). All citations are from the former text, referred to as The Life of Amgön Rinpoché.

${ }^{1190}$ The Life of Amgön Rinpoché, p 17.

${ }_{1191}^{11}$ Dowman, pp 63-4.

1192 cung zad drod ni thob pa na/ gal te spyod pa byed 'dod na/ zhes yon tan gyi khyad par thob nas gsang sngags ki spyod pa byed dgos par gsungs pa... For these lines from the Hevajra tantra in their original source, see Rangjung Dorjé, p 143; Snellgrove, The Hevajra Tantra, Vol. II, p 19. 
Rinpoché's cell, blowing his thighbone trumpet and doing all manner of inappropriate things. The next morning Amgön Rinpoché went to apologize, bringing with him a container of tea and a basket full of precious leaves gathered from trees in India. He said, "I confess to going crazy yesterday and annoying Rinpoché." This pleased Drubwang Tseten. According to the author, Drubwang Tseten Rinpoché then thought of the famous lines from Milarepa when he said,

The father is crazy; the son is crazy; the lineage is crazy; the Sixth Buddha Mahā Vajradhāra is crazy; the forefathers Tili[pa] and Nāro[pa] are crazy; my old father Marpa the translator is crazy.

Drubwang Tseten Rinpoché then said, “[Amgön Rinpoché] is not crazy. It is a sign of his having achieved siddhis through tasting from the skull cup of blood of the bliss and emptiness of taking Vajrayoginī as his consort in the context of the Generation Phase practices. This is not like ordinary madness." The author continues, saying that in the eyes of the unrealized, Amgön Rinpoché's way of conducting himself through body and speech appeared like that of a mad person, and therefore it became widely said that, "The retreatant Amgön is mad!" The members of the monastic college (grwa tshang) seized Amgön Rinpoché and locked him up. When Drubwang Tseten Rinpoché heard about this, he told the monastic college, "Let Amgön do as he will. He is a siddha." They had no choice but to let him go. ${ }^{1193}$

${ }^{1193}$ The Life of Amgön Rinpoché, pp 17-8. de dus mthams khang ga par bzhugs yod cing de dang mtshams khang kha pa dang thog 'brel yin la/ der grub dbang tshe brtan rin po che 'og ma bzhugs yod/ brtag gnyis las/ cung zad drod ni thob pa na/ gal te spyod pa byed 'dod na/ zhes yon tan gyi khyad par thob nas gsang sngags ki spyod pa byed dgos par gsungs pa bzhin spyod par gzhol nas tshe brtan rin po che'i sgrub khang dang nyid kyi sgrub khang bar gyi rtsigs par bug sgo zhig yod pa de nas ku co chen po 'don pa dang I rkang gling pur ba sogs mi 'tshams pa'i spyod pa mang du mdzad kyang sgrub dbang nas ci yang ma gsungs/ sang zhogs der snga po nas ja bsrub ma khog ldir gang dang / rgya gar nas btog ma thag pa'i a ru ra rlon pa lo ma yal ga dang bcas pa slo ma gang bsnams nas/ kha sang nga smyo bas rin po che la 
This story, composed by Rasé Dawa Könchok Gyatso in the year 2003, is like a window into the Tibetan discourse about holy madmen. The story is based on oral traditions about Amgön Rinpoché but certain key parts of it must be seen as Rasé Dawa’s own contribution, such as when he inserts the thoughts and motivations of the parties concerned. Through what he adds to the story Rasé Dawa shows that he recognizes the importance the Hevajra tantra has historically played in motivating the behavior of Tibetan "holy madmen," the importance of Milarepa's precedent in shaping how this kind of behavior would be interpreted, and the idea that the madness of a siddha is not to be confused with that of a more mundane type.

The case of Amgön Rinpoché is complicated further by the fact that the author, Rasé Dawa Könchok Gyatso, has, over the years, sometimes referred to himself as a madman. He signs his Life of Amgön Rinpoché "the mad attendant of Drikung, Rasé Könchok Gyatso."1194 In what sense did Rasé Dawa refer to himself as a madman? Was he using it only as a pen name or was he suggesting something more? One gets the feeling that there is a sort of circularity inherent to the self-referential act of calling oneself a "madman." The relationship between Rasé Dawa and Amgön Rinpoché is reminiscent of the relationship between the Madman of Tsang and Milarepa. At the

thugs bsun po bzos pa'i mthol bshags yin/ gsung nas phul bas/ tshe brtan rin po che thugs dgyes pa'i rtse mor son/ de nas rje mi las/ pha smyo bu smyo brgyud pa smyo/ drug pa rdo rje 'chang chen smyo/ yang mes ti li na ro smyos/pha rgan mar pa lo tsA smyo/ [Rasé Dawa's retelling of these lines differs slightly from the way the verse is given in Milarepa's Collected Songs] zhes pa sogs gsungs pa'i don la gzhol bas rje bla mas/ kho smyo ba ma red/ bksyed rim skabs su yum rdo rje rnal 'byor mas phyag gi bde stong gi thod khrag zhal du bstab pas dngos grub brnyes pa'i rang rtags red ma gtogs phal ba'i smyo ba de 'dra ma red/ ces gsungs pa ni gsang ba'i rnam thar yin noll ma rtogs pa'i ngor sku' i spyod lam/ gsung gi brjod stangs sogs la gzhigs tshe smyo ba ltar snang bas/ mtshams pa a mgon smyo 'dug zer ba byung zhing / grwa tshang gis kyang bzung nas lcag tu bcug te bla dbye'i lcam khang du btson 'jug lta bu byas pa nal grub dbang tshe brtan rin po ches gsan nas grwa tshang la/ a mgon gyis gang byed kyang byed du chug khong grub thob yin gsungs pas glod par gyur/

${ }^{1194}$ The Life of Amgön Rinpoché, p 101. 
moment Rasé Dawa and the Madman of Tsang write about their subjects, they are also in a sense writing about themselves. These are people who are fully aware of the power and the adaptability of representations, and consciously toy with them. These complexities will be returned to below.

There are also lamas of more recent times that Tibetans see as exemplifying many of the qualities of a holy madman but are not considered to be "madmen." In some cases a rhetoric of madness is used in reference to these figures, and in some cases not.

One important lineage connected to this issue is that passing from Do Kyentsé Yeshé Dorjé to his disciple Patrul Rinpoché. These figures are very popular in the oral traditions of eastern Tibet and are sometimes mentioned in discussions of holy madmen. Oral tradition maintains that one time Do Kyentsé went to a place where there were a lot of vicious dogs, two of which attacked him—one black and one white. Defending himself, he chopped the dogs into little pieces. When the owners of the dogs got angry with him, he told them not to worry, and magically put the dogs back together. In the process of this miracle the pieces got mixed up, so that mixed black and white dogs were created. Black and white dogs can still be found in this area today, thanks to that moment. The same exact story is commonly told of the Madman of the Drukpa; it is contained in Geshé Chapu's version of his Drukpa Kunle's Life, as well as his “Collected Works", making it centuries old. ${ }^{1195}$

Another story maintains that one day Do Kyentsé was teaching his disciple about the Great Perfection, when he all of a sudden grabbed him by the shirt and started beating

\footnotetext{
${ }^{1195}$ The kenpo who told me this story about Do Kyentsé himself noted that it was just like the Drukpa Künlé story. See the second volume ( $k h a)$ of Drukpa Künlé's "Collected Works", 2005 version, pp 387.14-390.8; Dowman, pp 59-60.
} 
him. At that moment Patrul Rinpoché had a great realization. ${ }^{1196}$ It is the kind of eccentricity displayed on this occasion by Do Kyentsé that gets him compared to famous holy madmen of Tibet's past.

In a way perhaps similar to how some ascetics called themselves "madmen," Patrul Rinpoché called himself "Patrul the Old Dog" (khyi rgan pha sprul). A popular story maintains that one time Patrul Rinpoché happened upon a monk meditating in a monastery. Patrul Rinpoché asked the monk what he was meditating on. "Patience (bzod pa)", he replied. So Patrul walked away, came back and asked the monk again, to which he again said, "Patience." Patrul Rinpoché kept asking the monk again and again, challenging him to manifest real patience instead of just meditating on it as an abstract quality. ${ }^{1197}$ Because of stories like this, some Tibetans will say that Patrul Rinpoché was a madman, while others are reluctant to make this association. At the same time, in his famous guide to the Buddhist path, the Words of My Perfect Teacher (kun bzang bla ma' $i$ zhal lung), which is popular among Tibetans and Euro-American readers alike, in the context of describing the kinds of teachers that should be avoided, Patrul Rinpoché warns people to "watch out for mad guides..." These are ones who, rather than develop true good qualities, are lax in their religious commitments, yet "ape the siddhas and behave as if their actions were higher than the sky" (grub pa'i mdzad spyod ltar byed pas kun spyod gnam du gshegs pa). ${ }^{1198}$ It is not clear to whom Patrul Rinpoché is referring here, but it

\footnotetext{
${ }^{1196}$ Kenpo Tsülnam Rinpoché interview, 22-8-09.

1197 Kenpo Tsülnam Rinpoché interview, 22-8-09.

1198 Patrul Rinpoché, The Words of My Perfect Teacher, translated by the Padmakara Translation Group (Altamira Press, 1998), p 140; kun bzang bla ma'i zhal lung (snying thig sngon 'gro'i khrid yig) (si khron mi rigs dpe skrun khang, 1991), p 215.3-215.9. smyon pa'i lam mkhan lta bu'i bshes gnyen. Patrul Rinpoché uses the word again on p 216, smyon pa'i lam mkhan.
} 
may be those like our holy madmen who took on a lifestyle imitating the great Buddhist siddhas of India.

In the course of my research I was told of an eccentric lama from Nyarong, in Kham, named Tulku Pema Namgyel, or Penam Rinpoché (sprul sku padma rnam rgyal, pad rnam rin po che), who once reverentially circumambulated a cow. He did this because he had pure vision (dag snang), seeing in that moment that the cow has the same buddhanature as any great lama. ${ }^{199}$ In this story we hear echoes of the popular representation of Drukpa Künlé.

I was also told of a monk named Tobchu (stobs bcu), who used to live at Lungkar Monastery (lung dkar dgon pa) in Nangchen, Kham. This monk did many strange things. He ate and slept with the dogs. When the weather was cold he would walk outside with no shirt on, singing. The other monks would say he had good practice (nyams len). And because of these strange things he did some called him Madman Tobchu (stobs bcu smyon $p a$ ). They did not see his madness as of an ordinary, mundane sort. It was a mark of his realizations, although they did not go so far as to suggest he was a siddha. ${ }^{1200}$

One famous lama on the periphery of the holy madman tradition was Kunu Lama Tenzin Gyeltsen (khu nu bla ma bstan ‘dzin rgyal mtshan, 1895-1977). Born in Kunu, near Manali in India, he traveled to Tibet to study and practice. ${ }^{1201}$ He spent most of his life in India, at Varanasi and so on. The kenpo who told me of Kunu Lama said that he

\footnotetext{
${ }^{1199}$ Kenpo Losel Tsegyel, interview at Mindröl Ling Monastery, Clement Town, Uttaranchal, 10 October 2009.

${ }^{1200}$ Kenpo Nyima Gyeltsen, interview at Kagyü College, Dehradun, 4 October 2009.

${ }^{1201}$ In Tibet he met Amgön Rinpoché at Drikung Til. When Kunu Lama asked Amgön Rinpoché for a set of instructions (gdams ngag) called the Five-fold (lnga ldan), Amgön Rinpoché touched their noses together, then their ears, chins, foreheads and cheeks - a five-pointed transmission, but not the one he was expecting.
} 
was renowned for some crazy behavior, but his was no ordinary madness. His eccentric behavior was always exactly the teaching (ngo sprod) the student needed. Sometimes people call him a "mad lama" (bla ma smyon pa) as an expression of faith ( dad pa). ${ }^{1202}$ Kunu Lama trained under Amgön Rinpoché at Drikung Til when he was in Tibet.

One kenpo, born in 1948 in Nyarong, told a story about a famous ascetic called Shara Siddha (sha ra grub thob), who lived Drango, near Ganzé. One time this kenpo's grandmother went to see the siddha. When she arrived the ascetic expressed great pleasure at her arrival, saying, “Oh! This is great! I'm glad you came!” Then, saying he would make some tea, he built a fire using horse dung, then threw some of the dung into a pot with water. He never put any tea in the pot-just water and horse dung. When the yogi gave the woman some of the concoction to drink she was reluctant, but tried it anyway so as not to be rude. To her surprise she found that it was exactly like normal tea. This miracle was taken a sign that the ascetic was a real siddha. ${ }^{1203}$

There are also stories of 20th-century ascetic who was renowned as "Dog-Skin Lama" (khyi lpags bla ma), who lived near Dartsedo. He would sit on the side of a road upon a dog skin, naked. ${ }^{1204}$

A few decades ago there was an ascetic living in Sikkim called Gangri Lagen (“Old Lama of the Snow Mountain,” gangs ri bla rgan), who some said was like a second Milarepa. He lived in a bamboo hut and showed no concern for rain or snow or hot or cold, wearing a thick wool garment all year long, no matter how hot the weather. He wanted no possessions: whatever people brought and offered to him, he gave right back,

\footnotetext{
1202 Kenpo Nyima Gyeltsen, interview at Kagyü College, Dehradun, 4 October 2009.

${ }^{1203}$ Kenpo Orgyen Tsering, interview at Nyinggön Pelyül Chökor Ling, Bir, H.P., 22 September 2009. The story was told to Kenpo's mother, who then told it to him.

1204 Kenpo Orgyen Tsering interview.
} 
except maybe taking a little tsampa or other simple food to eat. Some said he was a madman (smyon pa). Others respected and had faith in him and did not call him a madman. His position in the estimation of others was complicated. ${ }^{1205}$

In this section we have looked at the lives of some Tibetan lamas who were known to have performed some very eccentric behavior. In some cases others called them "madmen," in either a positive or at least ambiguous sense (like Urgyenpa). In some cases they called themselves madmen (like Nyakré Sewo). In other cases they performed behavior very similar to that exemplified by famous "holy madmen" of Tibet's past, but did not come to be known as madmen (like the Great Renunciant told of in The Blue Annals, who ate and smeared himself with feces and "behaved in the manner of a madman"). The question is why have none of these individuals become famous as "holy madmen"? It is not the case that the Madman of Ü, the Madman of Tsang, and Drukpa Künlé were all somehow more eccentric than these other figures; nor is it likely that anyone would say that they were more enlightened than them. In the end what distinguishes "holy madmen" from these other eccentrics is simply that they are remembered as holy madmen, first and foremost.

A consideration of some other figures who are remembered as holy madmen will help show how arbitrary this attribution ultimately is. There are myriad other "madmen" in Tibet's history that I do not have space to discuss in this chapter. This includes the Wensa Madman Chö Dorjé (dben sa smyon pa chos rdo rje, b. 14th or 15th century), who

\footnotetext{
${ }^{1205}$ Lama Tsültrim Topden Rinpoché, interview at Karma Dupgyud Choeling Monastery, Choklamsar (near Leh), Ladakh, 19 July 2009.
} 
was associated with the Kadampa tradition. ${ }^{1206}$ There was the Madman of Ko or Karma Sidrel (sgo smyon, karma srid bral, b 16th cent), who was a famous sculptor in the Karma Kamtsang tradition. ${ }^{1207}$ There was the Mad Monk of Mön (mon ban smyon pa), compiler of Drukpa Künlé's “Collected Works”. There was the Madman of Ur (dbur smyon), who was the first Chungtsang of Drikung, Chöki Drakpa (1595-1659); he occupied the throne at Drikung from 1626 until his death. ${ }^{1208}$

There are others who were called "mad" in Tibet's past who stretch the category even further. For example, some Tibetan historical records tell of a female leader of a popular religious movement, active in the mid-11th to mid-12th century. She is said to have been possessed by a spirit called zhang mo rgya 'thing ma. She held some strange beliefs about life, death and causality. Her disciples were known as "the crazies" (smyon tsho pa) according to one source, and as "crazy yogis" (rnal 'byor smyon pa) according to another. ${ }^{1209}$ Having such limited information about this circle it is impossible for us to reconstruct if these disciples were labeled "mad" by others in a way meant to be

\footnotetext{
${ }^{1206}$ E. Gene Smith notes that this may be the first case of a Geluk lama who was considered to be a "madman" (smyon pa), although at this time it may be better understood as the proto-Geluk, "Siddha Groups and the Mahāsiddhas in the Art and Literature of Tibet" in Holy Madness: Portraits of Tantric Siddhas, Rob Linrothe, editor (New York: Rubin Museum of Art, 2006), p 69.

${ }^{1207}$ karma kam tshang gi lo brgyud, by si tu paN chen dang 'be lo tshe dbang, Vol. II, p 65, line 7: dwags po sgo pa'i zhal ngo karma srid bral lam sgo smyon zhes pa ni/ rje nyid kyi sku'i sprul par grags pa des sgar lugs sku gzugs 'bur bzo'i srol btsugs pa yin no/. As for the "Master" whose reincarnation he was, it probably refers to dpal khang lo tsA ba, the reincarnation of karma 'phrin las pa, or perhaps to sprul sku ba nam mkha' bkra shis.

1208 chos kyi grags pa'i rnam thar cha shas tsam brjod pa (dpal ldan bla ma dam pa rdo rje slob dpon chen po rig pa 'dzin pa'i 'khor los bsgyur ba chos kyi grags pa'i rnam par thar pa'i cha shas tsam brjod pa), The Collected works (gsun 'bum) of Kun-mkhyen Rig-pa 'dzin-pa Chen-po Chos-kyi-grags-pa, written by Stag-lung-pa Ngag-dbang-bkra-shis-dpal-grub at the behest of Lung-rings-pa Ngag-dbang-las-grub, Rgyalba'i-myu-gu, and Phyag-mdzod Drung Dkon-mchog-rgyal-mtshan, Collected writings of the First Drigung Chungtsang Rigdzin Chokyi Dragpa (1595-1659) (Kulhan, Dehradun: Drikung Kagyu Institute, 1999), pp 247-302 in Vol. I.

${ }^{1209}$ Dan Martin, "The Star King and the Four Children of Pehar: Popular Religious Movements of the 11thto 12th-Century Tibet" in Acta orientalia academiae scientiarum hungarica 49, Nos. 1-2, 1996, p 186.
} 
derogatory, or if it was part of their own self-representation, toying with the idea of madness, as we have seen so many times before.

The Tibetan intellectual and renegade Gedün Chöpel is also sometimes referred to as a "madman" (see Donald Lopez's The Madman's Middle Way). ${ }^{1210}$ This may well stem from the fact that when Chöpel was in his twenties, studying at Drepung Monastery, his teacher called him "madman" because of his contrarian views about fine points of Buddhist philosophy. ${ }^{1211}$ At Drepung he would sometimes disguise himself as an illiterate bodyguard monk (ldab ldob). Sometimes during debates he would argue from the position of non-Buddhist schools. ${ }^{1212}$ Around this time he would even state that Buddhahood did not exist, which caused a group of monks to beat him up. ${ }^{1213} \mathrm{He}$ is also known to have performed some unpredictable behavior. One time Chöpel got drunk, stripped naked, sat on the ground and began to draw. ${ }^{1214}$ As one who bore knowledge that put him at odds with those around him, in 1938 Chöpel wrote a Tibetan-language newspaper article explaining to his countrymen that the world was round, and not flat as the Buddha had maintained. ${ }^{1215}$

\footnotetext{
${ }^{1210}$ Goss, p 72. In her examination of the life of Gedün Chöpel, Heather Stoddard (Le mendicant de l'Amdo. Paris: Société d'ethnographie, 1985) raises the question of whether he should be understood as a mad saint, a dreamer or a revolutionary, pp 248-67.

${ }^{1211}$ Jeffrey Hopkins, trans., Tibetan Arts of Love: Sex, Orgasm and Spiritual Healing, by Gedün Chöpel (Ithaca: Snow Lion Publications, 1992), p 15; Donald S. Lopez, Jr., The Madman's Middle Way: Reflections on Reality of the Tibetan Monk Gedun Chopel (Chicago: University of Chicago Press, 2006), pp 11,235 . This same teacher would later call Chöpel a "madman" in a refutation to one of his philosophical treatises, Lopez, p 236.

${ }_{1212}^{12}$ Lopez, The Madman's Middle Way, pp 11-2.

${ }^{1213}$ Hopkins, p 16. Comparison to another famous holy madman of the past can be seen in the fact that the verse of praise that opens Chöpel's Treatise on Desire (bdod pa'i bstan bcos), considered by many to be "the Tibetan Käma Sütra," is very similar to the crude verse attributed to Drukpa Kunle, Lopez, The Madman's Middle Way, p 34.

${ }^{1214}$ Hopkins, p 17.

${ }^{1215}$ Lopez, The Madman's Middle Way, pp 15-8.
} 
When Gedün Chöpel's teacher called him a "madman" the term seems to have carried with it an element of playfulness at the same time that it chided. At other times Chöpel was called a "madman" in a less positive sense. In a vicious response to a philosophical treatise in which Gedün Chöpel contested many traditional Geluk views, someone called him "Ge[dün] Chö[pel] the madman" (dge chos smyon pa). This author went further, saying that Gedün Chöpel was an emanation of Māra, sent forth to destroy the teachings of the Buddha. ${ }^{1216}$

As with the Madmen of $\ddot{U}$ and Tsang, it was living a life and espousing views that challenged those of the institutionalized, philosophical and monastic norm that got Chöpel called a "madman." The term could be the worst sort of criticism or a badge of highest honor, depending on the esteem in which one held that norm. Defenders of Geluk orthodoxy called Chöpel a "madman" in the process of pointing out his mistaken positions. Chöpel himself, who knew full well the contrarian position he inhabited, may have embraced the term. It is unlikely that anyone would claim Gedün Chöpel to have been a siddha, but clearly "madness" was a theme in his life and in the way he has been remembered and imagined by later generations. ${ }^{1217}$ (This provocative identification of Gedün Chöpel as a "madman" has shaped the way some English-language commentators have interpreted his activity. As a recent book about Gedün Chöpel carries the title The Madman's Middle Way, it is certain that Euro-Americans will continue to think about Gedün Chöpel in this light.) He was an eccentric, and widely-respected, and played with a rhetoric of madness, but is not thought of as a madmen in the way that the Madmen of

\footnotetext{
${ }^{1216}$ Lopez, The Madman's Middle Way, pp 230-3.

${ }^{1217}$ I have not yet taken an exhaustive look at his writings to determine whether or not Gedün Chöpel ever referred to himself as a "madman," but he did sometimes call himself "a discerning beggar" (sprang po dpyod ldan), which may have carried similar connotations.
} 
Ü and Tsang and Drukpa Künlé are. Ultimately it is more a question of the values held by the individuals and the discourse that labels one a "madman" than anything the “madman" may have himself done or said.

As we have now seen, the figures remembered as "madmen" by the Tibetan tradition displayed a wide variety of types of behavior that contributed to their being called "madmen" - from those like the Madmen of Ü and Tsang who performed engaged asceticism and acted like fearsome Herukas, to those like the Madman of Ralung and Drukpa Künlé who simply did not conform to the monastic norm, to those like the Madman of Kham, who, in addition to being a "madman" was also a learned doctor and a scholar of Tibetan medicine. Thus among those called "holy madmen," there are many different types, and not a single model to which they all conformed. Complicating the issue further is the fact that throughout Tibet's history there have been many ascetics who performed all manner of eccentric behavior, who called themselves and were called by others "madmen," but nevertheless did not gain full-blown reputations as holy madmen. One might have a relatively uncomplicated idea that there are certain individuals who deserve to be thought of as holy madmen, and certain ones who clearly do not, but we have seen here that in reality the situation is much more blurred. One may even sense some hesitation within the tradition, at times uncertain whether calling someone a "madman" should be thought of as a positive or a negative thing.

Based on the examples we have reviewed in this chapter we see that the difference between a holy madman and a not-holy madman is rhetorical rather than ontological. Whether or not one falls into the category of "holy madman" is determined not by how realized he is or what religious practices he does or the way he teaches 
through skillful means. Rather, it is a product of his self-presentation- the extent to which he asserts himself to be a "madman" and the way he is remembered and imagined to be so by others, as will be seen even more clearly below.

\section{III. "Madwomen"}

There were a handful of women who have been associated with the term "madwoman" (smyon ma) in a positive or at least ambiguous sense in the course of Tibetan Buddhist history. Surely there were others who did not make it into the textual or oral record that we have access to today. There was the above mentioned Madwoman of Lhasa, the only one among these women who was known, first and foremost, as a madwoman. Nevertheless, a rhetoric of madness was employed by a number of other female Tibetan religious figures over the years.

Suzanne Bessenger has chronicled the life of one of these women, Sönam Peldren (bsod nams dpal 'dren, 1328?-1372?). Sönam Peldren was illiterate and seems to have had no formal education or religious training. She had a husband and children and spent most of her adult life living as a nomad, but she nevertheless gained a cult following after her death. She claimed to be an emanation of Vajravarāhi and was attributed with many miracles. The theme of madness is present throughout her biography, which is one of the earliest about a Tibetan Buddhist woman. Early in her life, after singing a song occasioned by an argument with her family about her choice of a husband, the text states that everyone wondered, "Is she mad?",1218 The term would follow her throughout her life, in large part because of her pretensions of being highly realized without having

\footnotetext{
1218 der kun gyis snyo [sic] be e yin zher/, Suzanne Bessenger, Echoes of Enlightenment: The Life and Legacy of Sonam Peldren (1328-1372) (Ph.D. dissertation, University of Virginia, 2009), p 140.
} 
undergone any formal religious training. In songs she would even address the fact that others saw her as mad, saying, "In the perception of ordinary beings / I am seen as a crazy woman..." (smyon ma). ${ }^{1219}$ In this same song Sönam Peldren explains that it is her various religious accomplishments (not being deluded by ignorance, being fully dedicated to tantra, and so on) that put her at odds with worldly expectations. ${ }^{1220}$ Thus Sönam Peldren, as she is presented in her biography, actively engaged with a rhetoric of madness, turning the meaning into a positive rather than a pejorative in a manner highly reminiscent of Milarepa and Kodrakpa. If we trace the arc of the various meanings and connotations the term "mad" carries in the course of her life, we see it to be very similar to that exemplified by the lives of the Madmen of Ü and Tsang, Tangtong Gyelpo and Urgyenpa.

Sönam Peldren is storied to have acted in ways demonstrating a disregard for social conventions. One time she took off all her clothes outside with other people around. $^{1221}$ When her husband wondered at how she was not the least bit ashamed (ngo... tsha) by her nakedness, she justified her behavior as a sort of symbolic teaching. Bessenger sees this passage as similar to the famous one from The Life of Milarepa when he was chastised by his sister for going about naked. The passages are so similar that the one from the Life of Sönam Peldren was likely based on the one from the Life of Milarepa (although from the literature about Milarepa that predated the Madman of

\footnotetext{
${ }^{1219}$ Ibid., pp 163-64.

${ }^{1220}$ Another story of her response to others' saying she was a madwoman is given on ibid., pp 164-6.

${ }^{1221}$ Ibid., pp 159-60.
} 
Tsang's version of the Life). In some of the songs attributed to Sönam Peldren, she praises the performance of engaged asceticism (brtul zhugs spyod pa). ${ }^{1222}$

Shukseb Jetsün (or Ani Lochen or Shukseb Lochen Rinpoché, 1853-1950, shug gseb rje btsun, a ni lo chen, shug gseb lo chen rin po che) is one of the most famous Tibetan Buddhist nuns of all time. Born in Tsopema, India, she spent many years meditating in various places throughout the Himalayas, then settled in central Tibet. (Her father, born in Tibet, was the disciple of a Bhutanese lama and for some time looked after the Swayambhūnāth stūpa. Later, Ani Lochen herself would be responsible for having the stūpa whitewashed. ${ }^{1223}$ ) After her arrival at the Shukseb hermitage, near Lhasa, it grew and became something resembling a nunnery. ${ }^{1224}$ Her connections to the tradition of holy madness were many. She is attributed with having sung songs (although these may well have been composed by a later editor of her "autobiography") in which she uses the term "crazy" (smyo) and speaks about the performance of engaged asceticism (brtul zhugs spyod pa). ${ }^{1225}$ There is discussion of putting on the "garb of the charnel ground."1226 At one point her lama tells her, "Tie your hair on top of your head, then go naked in the Barkor!" (She did not do it, saying her dharma siblings did not let her.) ${ }^{1227}$

\footnotetext{
1222 Ibid., pp 154-8.

${ }^{1223}$ Hanna Havnevik, The life of Jetsun Lochen Rinpoche (1865-1951) as Told in Her Autobiography (University of Oslo, 1999), Vol. II, pp 137, 287.

${ }^{1224}$ Hanna Havnevik, Tibetan Buddhist Nuns: History, Cultural Norms and Social Reality (Oslo: Norwegian University Press, 1989), pp 41-2.

${ }^{1225}$ I have not had an opportunity to compare the different versions of Ani Lochen's Life, having had access to the Lhasa version only briefly during my fieldwork. I draw from both versions of the Life here (the Lhasa version, and Havnevik's translation). shug gseb rje btsun sku zhabs kyi rnam thar (gangs shug ma Ni lo chen rig 'dzin chos nyid bzang mo'i rnam par thar pa rnam mkhyen bde ster), edited by blo bzang tshe ring (Lhasa: mi rigs dpe skrun khang, 1997). For songs in which she uses the word "mad," see pp 110, 145; songs about brtul zhugs, pp 110,175 .

${ }^{1226}$ Lhasa version, p 163.1.

${ }^{1227}$ Havnevik, Vol. II, pp 458-9.
} 
She writes of herself as being "like a mad person" or being "labeled mad."1228 There is one especially interesting, tantalizing but ultimately inscrutable passage in Ani Lochen's Life that goes as follows: "Because I seemed to be mad (smyo ba lta bu), my dharma siblings asked Kham La[ma] Longchen Öser Dorjé to make a prognostication and he said that if I carried a khatvam[ga], it would help. Shakjang promised to make the khatva $[\mathrm{mga}] . " 1229$ Unfortunately we have no indication of what the nun may have done to make her seem mad. The notion that taking up a khatvāniga would rectify whatever was wrong with her is a fascinating one; we are not told of why it would have been efficacious. Sometime later she was in fact given a khațvāinga staff, which Kham Lama Longchen Öser Dorjé consecrated for her. She carried it during a religious procession, while others carried divine images and offerings.

Ani Lochen is attributed with some eccentric behavior. Her dharma siblings and the local people observed that she said strange things and danced about and was thus not like ordinary people (mi dang mi mthun pa zhig 'dug), which made them wonder, "If she is mad or whatever, I don't know" ( 'di smyo ba yin nam gang yin ha mi go). She sang a song pretending to be mad (ngas smyo ba yin lugs kyi glu 'di smras so). ${ }^{1230}$ The discussion of Ani Lochen's ontological status continued, with some people saying she

\footnotetext{
${ }^{1228}$ nga smyo lta bu..., Lhasa version, $\mathrm{p} 130.6$; smyo ru btags, $\mathrm{p}$ 131.12. See also: rlung smyon lta $b u, \mathrm{p}$ 193 and similar on $\mathrm{p} 268 ;$ smyon, p 196; a verse saying, "this crazy song...", p 219; smyo nad lta bu..., p 231; nga smyo skabs yin kyang..., p 236; references to thod smyon bsam 'grub, pp 197, 269.

Unfortunately I only had the opportunity to read this biography quickly while doing fieldwork and have not been able to get access to another copy; I will flesh out this section at a later date.

${ }^{1229}$ Havnevik, Vol. II, pp 376-83. khams bla klong chen 'od zer rdo rje la nga smyo ba lta bu de la mched grogs rnams kyis thugs rtags zhus pa la kha tvam zhig brdung 'chang na phan tshul gsungs pas bshag byang nas kha tvam brdung rgyu khas len byas/

${ }^{1230}$ Havnevik, Vol. II, pp 410-1.
} 
was a siddha, while others wondered if she was really insane. ${ }^{1231}$ On another occasion Ani Lochen's mother jokingly called two of the nun's teachers "mad siddhas" (sgrub smyon) because of the way they tended to interrupt Ani Lochen's meditation. ${ }^{1232}$

Like the case of Sönam Peldren, a rhetoric of madness shows up many times in the life of Ani Lochen. Others called her mad and she followed suit, playfully adopting the idea and applying it to herself. She was not, however, remembered primarily as a madwoman.

In 1969, at the tail end of the Cultural Revolution, bloody revolts broke out in many districts of Tibet. The most famous of these incidents took place in Nyemo, not far from Lhasa. Over the course of two days hundreds of Tibetan villagers attacked local officials and troops of the People's Liberation Army. The villagers were led by a young nun named Trinlé Chödrön, who claimed to have been possessed by gods. Many people thought she was mentally unstable. But in the eyes of others, her madness was a byproduct of her having entered an altered state that enabled her to communicate with the deity. Her being called "the madwoman" (smyon pa) was complex and open to differing interpretations. $^{1233}$

One kenpo I interviewed in India in 2009 told me of a woman who had been a student of Kusum Lingpa (sku gsum gling pa) and Trulshik Rinpoché (khrul zhig rin po che). She went to a Tibetan Children's Village school in India when she was young, then spent some time in the U.S., and is now living in the Tibetan exile community at

\footnotetext{
${ }^{1231}$ Havnevik, Vol. II, pp 412-3. la las rang byung gi grub thob mo zhig 'dug zer/ la la smyo ba 'dra thugs rtag zhu zer/la las ci zer la las ci mi zer/

${ }_{1232}$ Havnevik, Vol. II, pp 492-3.

${ }^{1233}$ Melvyn C. Goldstein, On the Cultural Revolution in Tibet: The Nyemo Incident of 1969 (University of California Press, 2009).
} 
Tsopema/Rewalsar ( $m$ tsho pad $m a$ ), in northwestern India. She spends most of her time in retreat. She is quite reclusive and does not like to meet with people. Some say she is a dākinī (mkha' 'gro ma). Others say she is a madwoman (smyon ma) because of things she says. She sees peoples' conceptual formations (rnam rtog) and has a way of saying things that expose them fully. Her mode of dress varies. Some days she wears nun's clothes, but not always. I was told that at some point in the future she will relocate to the U.S. to teach, as she had been commanded to do by her teachers. ${ }^{1234}$

We have looked at five examples of women in the history of Tibetan Buddhism that were known as "madwomen" in either a positive or an ambiguous sense: the Madwoman of Lhasa, Sönam Peldren, Shukseb Jetsün, Trinlé Chödrön and the unnamed inhabitant of Tsopema. These cases exemplify something we have seen across all the cases of madmen and almost-madmen: among those who employ a rhetoric of madness with respect to themselves, or whom others commonly call "mad," the line dividing those who are remembered as "madmen" or "madwomen" (like the Madwoman of Lhasa) and those who were not (like Sönam Peldren) cannot be said to be a question of what kind of religious state they achieved, but more a question of the public's perception of them. More so than a question of how enlightened they may have been, it is a question of the extent to which the term "madman" or "madwoman" stuck, how effective the rhetoric was.

\footnotetext{
${ }^{1234}$ My informant would not tell me the woman's name or where she stayed. He said explicitly that she would be angry with him if she found out he had been telling people about her. For this reason, I will omit the kenpo's name, but say that he resided in a Kagyü monastery at Tsopema and the interview took place in September, 2009.
} 


\section{IV. Are there "Madmen" Today?}

In addition to the woman of local celebrity living at Tsopema/Rewalsar who is considered by some to be a madwoman, a number of the Tibetans I interviewed in India told stories of eccentric lamas, occasionally called "madmen," that they knew of in eastern Tibet a few decades past. When I asked Tibetan religious specialists the pointed question of whether or not there were any holy madmen (grub thob smyon pa) living in Tibetan cultural areas today I got a wide range of responses. Some asserted that there likely are holy madmen out there, but they remain invisible. One lama I interviewed stated that "holy madmen" are difficult to find, but as long as there is good meditative practice in the world, they will exist somewhere. ${ }^{1235}$ One lama said that they surely existed, but that they are very rare (dkon po); they were easier to find in old Tibet. ${ }^{1236}$ One lama said that there was more likely to be holy madmen in Tibet than in other places, because of the political situation, but would not elaborate on why. ${ }^{1237}$ It was unclear whether he meant a lama would be operating under the disguise of a madman, or the restrictions on religious freedom under Chinese rule would naturally create holy madmen. Many said that there may be those who look like madmen, but it is impossible to determine whether or not they are real siddhas (grub thob). Although a siddha might choose to reveal himself through miraculous activity, a siddha might also conceal himself as a madman indefinitely. ${ }^{1238}$

\footnotetext{
${ }^{1235}$ Choegyal Rinpoché interview, Changchub Jong, H.P., India, 15 August 2009.

${ }^{1236}$ Lama Tsültrim Topden Rinpoché, interview at Karma Dupgyud Choeling Monastery, Choklamsar (near Leh), Ladakh, 19 July 2009.

${ }^{1237}$ Kenpo Könchok Namdak, interview at Phyang Monastery, Ladakh, 22 July 2009.

${ }^{1238}$ Kenpo Nyima Gyeltsen, interview at Kagyü College, Dehradun, 4 October 2009. Öntrul Rinpoché (interview at Drikung Kagyü Monastery, Rewalsar, H.P. 30 September 2009) said that today there may be some doing smyon pa'i spyod pa, but he did not know who or where or how one would recognize them.
} 
This brings us back to where this dissertation began: analyzing the common understanding of "holy madness" among learned Tibetan lamas and kenpos today. As was shown in Chapter One, Tibetans with a religious education tend to think of holy madness as a state one achieves, or part of their personal practice, or a sort of skillful means for teaching others. Thinking of holy madmen in this way creates a clear distinction between real holy madmen (those who conform to these categories) and everyone else. The responses to the question of whether or not there are holy madmen in the world today also belie that kind of thinking. The notion that there could be holy madmen whose identities are utterly concealed is indicative of Tibetans' most basic understanding of the phenomenon. In their thinking it is possible to be a completely invisible holy madman.

Since taking that initial point of departure I have tried to show that, in contrast to many popular ideas about what holy madmen are, Tibet's holy madmen are better understood as the result of a dialogical process of self-presentation and public interpretation. I have sought to develop a new understanding of what holy madness is based on what we know about the actual lives of "holy madmen," rather than making assumptions about what might have motivated their "madness." And we have seen, the holy madmen we know about are by definition not invisible. Rather than a state of private being, "madman" is a manner of public identity. The process through which this takes place will be shown by taking a close look at one last famous Tibetan sometimes remembered as a madman, Chögyam Trungpa Rinpoché. But first we must make one 
brief detour.

\section{V. "Madman" as a Pen Name}

This study must take into account the fact that one of the most consistently used pen names (smyug ming) in the history of Tibetan literature is "Madman." Calling oneself a "madman" is a mainstay of Tibetan literary culture. The Second Dalai Lama signed many of his writings "the Mad Beggar Gedün Gyatso."1239 The 5th Dalai Lama sometimes referred to himself as za hor sngags smyon zil gnon bzhad pa rtsal (16171682). The author of one Tibetan epic calls himself "the madman of Dingchen." 1240 This term is still used by present day Tibetans who are producing literature, both in Tibet and in India. It may be more popular now than ever before. ${ }^{1241}$ One of the most active of

${ }^{1239}$ sprang smyon dge 'dun rgya mtsho. Glenn H. Mullin, Mystical Verses of a Mad Dalai Lama (Wheaton, IL: Quest Books, The Theosophical Publishing House, 1994), p xiii.

${ }_{1240}$ sding chen smyon pa. Stein, Tibetan Civilization, pp 275-6.

${ }^{1241}$ Beyer, The Classical Tibetan Language, p 380, calls smyon pa a "generic" epithet, comparable to a yogi with the name ras pa, "cotton-clad one."

For an interesting discussion of the use of the pen name (smyug ming) "madman" in Tibetan literature, see khrag thigs las skyes pa'i ljang myug: deng rabs bod kyi rtsom rig dang de'i rgyab ljongs, 1980-2000, by hor gtsang 'jigs med (Dharamsala: Youtse Publications, 2000), pp 97-9.

For a discussion of Tibetan authors using "madman" as a pen name, see comments by various authors in Lauren Hartley and Patricia Schiaffini-Vedani, editors, Modern Tibetan Literature and Social Change (Durham: Duke University Press, 2008), pp 143, 153, 248-51, 272-3.

Some examples include: a smyon bkra shis don grub (b 1967), author of ston gyi rang sgra (Xining: mtsho sngon mi rigs dpe skrun khang, 1999).

'brug smyon klu gdong (the Mad Dragon with the Nāga face?), otherwise knows as yar kaH 'jam dbyangs phrin las. Born in 1975 in northern Kham, at the time of the publishing of his book of poems gtsang gsum 'phyo ba'i skya rengs in 2003 ('dzam gling zhi bde par khang and bod gzhung shes rig par khang) he was residing at the Sakya College in Dehradun, India.

rtsam pa (Tsampa Magazine), Vol. 13, 2004 (put out by the Tsampa Literature Group, at the College for Higher Tibetan Studies, Sarah, Kangra, H.P., India) includes a poem by one calling himself bya smyon pa (pp 87-88) and a story by dga' klu gangs 'od titled "grwa smyon bstan rab kyi gtam rgyud," which is about the thoughts of a "crazy monk" sitting outside a teashop (pp 31-2).

Another author, bya dor phun tshogs dbang phyug, uses the pen name gangs smyon, "the Madman of the Snow[land]." He is the author of a volume called skyug bro ba'i 'jig rten (Delhi: Archana, 2007). He was born in 1974 in Tibet and now writes in India. Jador Puntsok Wangchuk uses the word "madman" in a number of his compositions, such as in the verse poem bearing the title "smyon pa snang ba skyid pa' $i$ mgur" (p 11-3) and "smyon pa'i rang gtam" (pp 62-7). In a composition titled " "brug pa kun legs," a series of eight brief descriptions of the saint, he refers to him as "drunk on emptiness" (stong nyid kyis myos pa' $i$ bzi bo), pp 141-2. 
these writers is "Mad Lu, the Heruka" (klu smyon he ru kaH), also known as Yeshé

\author{
Gyatso Rinpoché. ${ }^{1242}$
}

Closely related to the use of "madman" as a pen name is the tradition of calling

one's compositions “crazy words" (smyo tshig) or a "crazy song” (smyo glu). ${ }^{1243}$ Often

the contents of these works have nothing whatsoever to do with the theme of madness, in

spite of their titles.

What is expressed by the use of the word "mad" in these contexts? To some

extent it is motivated by humility, whether that humility is genuine or simulated. But the

use of the term "mad" in this way is so well worn that we should not be too quick to

In the third volume of the literary magazine srong btsan tshangs dbyangs (published by srong

btsan dpe mdzod khang nas bskrun, Dehradun, 2005) there is a poem called "rang yul bral ba' $i$ smre ngag" by ar tha ral smyon $p a, \mathrm{p} 32$.

${ }^{1242}$ According to Pema Bhum, in Hartley and Schiaffini-Vedani (2008), $k l u$ here is a tribal name, probably not carrying the meaning of a serpent spirit, $\mathrm{p} 143$. One of his compositions, "dus rabs dang sha mog mog las "phros pa'i gtam rgyud" is in rtsam pa (Tsampa Magazine), Vol. 13, 2004 (put out by the Tsampa Literature Group, at the College for Higher Tibetan Studies, Sarah, Kangra, H.P., India), pp 15-8.

As told by in his autobiography, titled Homeless Person: A Rough Account of 30 Years of Life, Yeshé Gyatso Rinpoché was born in Kokonor, Amdo, in 1969. His father often read to him and his brothers and invested in books; two of his brothers are also writers. He writes of his experiences in school, first learning the alphabet, then when a strong desire to be a writer arose in him. He fled to Kathmandu in 1994, and now resides in India. At some point he would be recognized as the reincarnation of Dzogchen Gyeltsab Thodo Rinpoché by Kyabje Trulshig Rinpoché. At no point in his account does Yeshé Gyatso Rinpoché mention when or why he took the name the Mad Lu. However, in the closing words of his autobiography he writes, "In the midst of the grove of the long history of the Tibetan people, [this little book about the first thirty years of my life] is only a sprout of such little consequence; it is a distant star radiating a dim light. But this is a summary of rough notes of thirty years of life, and although it is possible that in the story of a mad person there may not be a cloud of offerings that appeals to the minds of people who are not deranged, it cannot be that herein there is not some bit of medicine that is helpful to the minds of those who are crazy like me." Here the Mad Lu casts his "madness" in such a way that it is an expression of humility and self-effacement, rgyal khab med pa'i mi (homeless person): mi lo sum bcu'i rags zin (1969-2002), by Yeshi Gyatso Rinpoché, klu smyon he ru kaH (no publication information; 219 pages), p 219.

${ }^{2243}$ See, for example, the verse composition by "bri gung lam mkhyen rgyal po titled "smyo glu a ho ma" in "char ka'i 'bod pa, Vol. 3, 2009 (published by the Kagyu College, bka' brgyud mtho slob rtsom sgrig khang, Dehradun, Uttarakhand, India), pp 15-7. There seems to be nothing particularly "crazy" about this song, which seems a relatively standard praise of the masters and teachings of the lineage, except for in the final verse when the author states that what had preceeded was a "crazy song remembering whatever arose freely" in his mind (bag med gang shar dran pa'i smyo glu zhig shor bas...).

The Collected Works of the 15th Karmapa, mkha' khyab rdo rje, contain a collection of songs called zhal gdams su btags pa'i smyon tshig nam mkha'i sprin sgra (Paro: Lama Ngodrup; TBRC W28676; Vol. $t a$, pp 823-78). Despite the title of the colloction, madness is not a significant theme therein. 
accept it as a simple expression of humility. The word carries with it such a rich field of connotations that accepting this most immediate reading would be overly simplistic. To some extent the use of this pen name expresses the author's commitment to being one who thinks differently, in this way perhaps connected with the meaning famously given to the term by Milarepa. At the same time, use of the term at a given historical moment can probably be seen as to some extent expressive of homage to all the "madmen"- both the "mad yogis" and those who used the term only as a pen name- of generations past.

As was mentioned above, Rasé Dawa Könchok Gyatso sometimes called himself a madman. To assume that he meant this only as a pen name would be too simplistic, because there is a complex interplay between madman as a pen name and madman as an accomplished being. As the compiler of the biography of an eccentric ascetic like Amgön Rinpoché, Rasé Dawa was surely aware of these dynamics.

As an example of how the two meanings of the term interpenetrate one another let us consider the case of the Second Dalai Lama, who referred to himself as a "mad beggar" when signing some of his writings. It is quite clear that the Second Dalai Lama was using the term "mad beggar" as a pen name, as an expression of humility (or at least faux humility). But this is not how it would be interpreted by the tradition. As the current Dalai Lama explains:

The implication of "Mad" here is that when a person gains experience of emptiness, the ultimate mode of existence of all phenomena, his perception is as different from that of ordinary people as a madman's. Due to his or her realization of emptiness, a practitioner completely transcends the conventional way of viewing the world.

\footnotetext{
${ }^{1244}$ Mullin, p xiv. The Dalai Lama's words would directly influence Richard Gere's explanation of the term, given in a blurb on the back of the paperback.
} 
This represents the standard thinking about Tibetan holy madmen, as has been repeated a number of times throughout this dissertation. But we can question whether or not this is the sense in which the Second Dalai Lama used the term in reference to himself. Would he have been so boastful, claiming himself to be enlightened in this way? I think it more likely that the Second Dalai Lama was using the term in a humilific sense. But over the years the term "madman" has acquired so much more meaning, which is why it gets interpreted in this way. Because of the accumulated history of the term, when one calls oneself a "madman" as a pen name, other meanings are liable to be read into the term by others.

Lama Zhang (1122-1193), founder of the Tselpa (tshal pa) sub-branch of the Kagyü, is another example of one whose rhetoric of madness was taken out of context and blown out of proportion many centuries after his death. Lama Zhang signed many of his compositions "this crazy beggar-monk Zhang” (zhang gi sprang ban smyon pa 'di). We have no reason to believe Zhang referred to himself as a "madman" in any way other than as a pen name, in a way that, as we have seen, was playful, self-denigrating, and perhaps ironically boastful at the same time. And yet Ronald Davidson has placed Lama Zhang among other "holy madman" of the Tibetan tradition because of his use of the term. Davidson suggests that Lama Zhang saw his warlike activities in the Lhasa area as justified because of his high state of realization. Carl Yamamoto sees this characterization of Lama Zhang as a scandalous and dangerous figure to be mistaken. ${ }^{1245}$ It seems that a factor leading to this inaccurate description of the lama is Davidson's

\footnotetext{
${ }^{1245}$ Davidson, Tibetan Renaissance, pp 327-31; Carl Shigeo Yamamoto, Vision and Violence: Lama Zhang and the Dialectics of Political Authority and Religious Charisma in Twelfth-Century Central Tibet (Ph.D. dissertation, University of Virginia, 2009), p 253.
} 
reading too far into Zhang's relatively pedestrian use of the term "madman" as a pen name. But we cannot blame Davidson for this misreading, as the lines between “madman-as-enlightened-being” and "madman-as-pen-name” are purposefully blurred, always existing in relationship to one another.

The idea that one could take on the name "madman" for the purpose of one's writings, in a playful, self-effacing manner, raises a key question we have been asking throughout this chapter: where does one draw the line between "real" mad siddhas and everyone else? If Tibetans recognize that there have traditionally been people who called themselves "madmen" who in fact had no real claim to being mad because of being enlightened, or to acting like madmen because it was part of their religious practice, or acting in crazy ways as a part of their skillful means, how can we be so confident that certain others are of a qualitatively different sort? The difference between those employing a rhetoric of madness and those considered to be real holy madmen, I argue, is not ontological. "Holy madness" is a specific form of rhetoric, employed by each holy madman who promotes himself as such, or by each community who remembers him in that way. We will end this chapter with a close look at one specific case, seeing how "holy madness" was so important for a lama's self-presentation, and how it affected the way the community around him interpreted his actions and has remembered him since.

\section{VI. Chögyam Trungpa Rinpoché}

We will bring this dissertation to a close by considering one last example of a Tibetan lama employing a rhetoric of madness, and how his doing so affected the trajectory of his life. In this case, the lama would go on to become one of the most important voices in global Buddhism in the 20th century, and one of the most important 
in the entire history of the holy madman tradition. Chögyam Trungpa Rinpoché was born in 1939 in Eastern Tibet, the 11th in the Trungpa reincarnation lineage. In 1959 he fled to India, then went to study at Oxford. He emigrated to Canada and then to the U.S., setting up in Vermont and Boulder, Colorado. He would teach in North America for seventeen years, from 1970 until his death in 1987. His accomplishments during this time were remarkable. He established a vast network of meditation centers, either under the name of Tibetan Buddhism or the quasi-Buddhist "Shambhala International." He wrote thirty books, including the famous Cutting Through Spiritual Materialism. Trungpa has been one of the most important players in shaping how Tibetan Buddhism would be received by Euro-Americans, through his skillful blending of old and new, and his framing of Buddhist concepts in terms of modern psychological discourse.

Trungpa had some eccentric tendencies. Later in his life he took to wearing military uniforms, which he had custom made by a tailor in England. ${ }^{1246}$ He created a retinue of guards, who attended an annual boot camp where they learned to march in formation. ${ }^{1247}$ He tried to train some of his American students to speak with an Oxford accent. $^{1248}$ Trungpa composed a Shambhala anthem and would sometimes have the people around him sing it over and over again for up to an hour. ${ }^{1249}$ Sometimes when traveling by plane Trungpa would tell the pilot he was the king of Bhutan and suggest that this be announced to all the passengers. ${ }^{1250}$

Trungpa was also a man of considerable controversy because of behavior that

\footnotetext{
${ }^{1246}$ Fabrice Midal, Chögyam Trungpa: His Life and Vision. Translated into English by Ian Monk (Boston: Shambhala, 2005), pp 311, 464.

${ }_{1247}^{12}$ Life and Vision, pp 466-7.

1248 Life and Vision, pp 340, 342.

1249 Life and Vision, pp 346-7.

${ }^{1250}$ Life and Vision, p 164.
} 
could not be written off as so innocently eccentric. Trungpa was a heavy drinker for most of his adult life- by some accounts an alcoholic. He sometimes showed up to give teachings visibly drunk. When he was fleeing to India at the age of 20, although an ordained monk he began to have a sexual relationship with a nun, who became pregnant and bore him a son. ${ }^{1251}$ When he was about 30, Trungpa married a 16 year old Scottish girl. ${ }^{1252}$ Later Trungpa had sexual relationships with some of his disciples. Trungpa's disciples and latter-day followers have always readily admitted to these facets of his life. Even still, most do not waver in seeing Trungpa as an enlightened being. In fact, many of Trungpa's followers have come to see these abuses in a positive light. For example, I was once told by a devoted follower that Trungpa could give brilliant teachings while "drunk off his ass." The fact that he could be so lucid while drunk simply proved how enlightened he was. Let us explore this hermeneutical situation - how Trungpa created specific circumstances ensuring that his behavior would be interpreted in this way. ${ }^{1253}$

\footnotetext{
${ }^{1251}$ Life and Vision, p 434.

${ }^{1252}$ Life and Vision, p 313.

${ }^{1253}$ In the long history of Chögyam Trungpa's scandals, one incident stands out as the most notorious. In 1975 Trungpa was holding a three month Vajrayāna seminary in Colorado. At the Halloween party Trungpa got drunk, took off his clothes, and began ordering others to disrobe as well. One student of the seminary and his girlfriend left the party to return to their room. When Trungpa heard that they had left, he ordered his guards to bring them back to the party. When they refused, Trungpa had his guards smash a plate glass door to bring them out. The man resisted and fought back, cutting some of the guards with a broken beer bottle. The man and his girlfriend were dragged back to the party. Meanwhile, Trungpa talked to the other partygoers about the importance of "exposing [one's] neurosis." Trungpa threw a glass of sake in the man's face and made offensive racial remarks about the woman (who was Hawaiian). He told the couple to take off their clothes. When they refused, Trungpa had them pinned to the floor and forcibly stripped. They pleaded for someone to call the police - no one did. When one man tried to stop what was happening, Trungpa punched him and had him taken away. Trungpa began punching the man who had been charged with stripping the woman, telling her to do it faster. The next morning Trungpa had a letter put in everyone's mailboxes. It said, "You must offer your neuroses as a feast to celebrate your entrance into the vajra teachings." The Great Naropa Poetry Wars, With a copious collection of germane documents assembled by the author, by Tom Clark (Santa Barbara: Cadmus Editions, 1980), pp 23-4.
} 
The most important factor in shaping how Trungpa's supporters would interpret his behavior is the idea that, since Trungpa was an enlightened master who had completely given over his life to teaching the Dharma, everything he did was a teaching. Every gesture, every word was part of Trungpa's enlightened activity, his attempt to transmit the Dharma to those around him. And because everything Trungpa did was a teaching, he was by definition infallible. His actions could not be judged based on our usual conventions, because he was not an ordinary man living in the world but an enlightened being beyond the world, doing what he could to help liberate others. For these reasons, Trungpa was perfect and beyond judgment. Once during a business meeting Chögyam Trungpa stopped mid-conversation and asked the nun Pema Chödrön, “Do you masturbate?" Chödrön explains this as having been a deep and profound teaching. ${ }^{1254}$ As Fabrice Midal states in his 2001 biography of Chögyam Trungpa, "Certain surprising things he did can seem shocking today, and may also have seemed brutal or crazy at the time, but thanks to them the persons they were aimed at were able to open fully." 1255 Everything Trungpa did was a teaching. According to Midal, simply by helping Trungpa get dressed in the morning one could receive "a powerful transmission."

As news of this event got out, it caused a minor scandal among Trungpa's community of followers. Some lost faith and left the community. But the great majority of Trungpa's followers defended his actions. When justifying Trungpa's behavior on this occasion and many others, followers would often say Trungpa's actions constituted some sort of a teaching, that this was all in line with tradition. When asked about this incident in an interview, the poet Alan Ginsberg referred to it as part of a "consciousmaking" tradition stretching back thousands of years. Ginsberg said it that this was "a traditional Buddhist practice applied in America in as gentle a way as possible" (pp 59-60). When asked about the unfortunate couple's pleas for help as Trungpa ordered them forcibly stripped, Alan Ginsberg said, "In the middle of that scene, to yell 'call the police' - do you realize how vulgar that was? The Wisdom of the East was being unveiled, and she's going 'call the police!' I mean, shit! Fuck that shit! Strip 'em naked, break down the door!" (p 60).

${ }^{1254}$ Recalling Chögyam Trungpa, edited by Fabrice Midal (Boston: Shambhala, 2005), p 246. See also, Life and Vision, p 161: when asked, "[W]ould you say that the intention behind [Trungpa's] unconventional behavior, including his sexual exploits and his drinking, was to help others?" Pema Chödrön replied, "As the years went on, I felt everything he did was to help others."

${ }^{1255}$ Life and Vision, $\mathrm{p}$ xxv. 
Trungpa's sexual relationships with his female students were "a very precious communication. ${ }^{1256}$

One key element in Trungpa's creation of a hermeneutical situation in which anything he did would be seen as acceptable was his promoting the notion of "crazy wisdom." This idea has come to play a major role in determining how Trungpa's actions would be interpreted by his disciples and followers today.

Trungpa was never entirely clear on what he intended "crazy wisdom" to mean.

He variously described it as "the action of truth," or as "controlling psychic energies." 1257 He described crazy wisdom as "very timid or cowardly," but also as "what characterizes a saint in the Buddhist tradition." ${ }^{, 258}$ Trungpa said that the "essence" of crazy wisdom is "hopelessness." $" 1259$ At the same time Trungpa talked about crazy wisdom as the totality of the good qualities manifested by the eight forms of Padmasambhava. ${ }^{1260}$ Trungpa also asserted crazy wisdom to be a pedagogical mode, a sort of skillful means or upāya. ${ }^{1261}$

Trungpa also said that one can only experience crazy wisdom by coming into contact with "the crazy-wisdom lineage."1262 This lineage was passed on to Trungpa by the second Jamgön Kongtrül. ${ }^{1263}$ Trungpa said that crazy wisdom is especially present in the Nyingma sect and connected with the Great Perfection. ${ }^{1264}$ Later, Chögyam

\footnotetext{
${ }^{1256}$ Life and Vision, pp 311, 153.

${ }^{1257}$ Crazy Wisdom, by Chögyam Trungpa, edited by Sherab Chödzin (Boston: Shambhala, 2001), pp 12, 173

${ }^{1258}$ Crazy Wisdom, pp 118, 10.

${ }^{1259}$ Crazy Wisdom, p 10. See also pp 84, 86, 88, 95.

${ }^{1260}$ Crazy Wisdom, pp 21, 29, 63, 111, 112, 167. Trungpa also speaks of crazy wisdom as one specific aspect of Padmasambhava, p 53. He says "the unique quality of crazy wisdom in Padmasambhava's case is that of sudden enlightenment," $p 111$.

${ }^{1261}$ Crazy Wisdom, pp 112, 126-7, 169, 175.

1262 Crazy Wisdom, p 59.

${ }^{1263}$ Crazy Wisdom, pp 66-7, 100-101.

${ }^{1264}$ Crazy Wisdom, p 58.
} 
Trungpa's followers would see crazy wisdom as something especially exemplified by the early masters of the Kagyü tradition, like Tilopa, Nāropa, Marpa and Milarepa, whose lives we know about primarily thanks to the literary activity of the Madman of Tsang and his school. Was this idea perhaps based on Milarepa's famous song in which he refers to everyone in his lineage as "crazy"?

Trungpa said that crazy wisdom could "only be taught in [a] savage count[ry]." In the same way that Padmasambhava once brought crazy wisdom to Tibet, now Trungpa is bringing it to the U.S. He made this comparison explicitly. ${ }^{1265}$

These inconsistent comments about crazy wisdom were made by Trungpa in the course of one month in 1972. The transcripts from these teachings show that Trungpa's students were confused by his presentation, in which crazy wisdom seemed to mean so many contradictory things at once-a process of building up the ego? A state of hopelessness? ${ }^{1266}$ It seems that Trungpa himself did not have a fixed idea of what he wanted "crazy wisdom" to mean. Rather, it functioned as a catch-all for a variety of positive qualities. ${ }^{1267}$ Trungpa could change what it meant from one moment to the next in order to suit his needs. When Trungpa was trying to homologize himself with Padmasambhava, "crazy wisdom" was a special characteristic of that saint. When Trungpa wanted to talk up the greatness of his lama and his lama's lama, "crazy wisdom" was unique to that lineage. It was highly adaptable. Later in his career Trungpa would claim that "crazy wisdom" was the equivalent of a Tibetan term, ye shes 'chol ba,

\footnotetext{
${ }^{1265}$ Crazy Wisdom, pp 174, 179. See also pp 79, 80.

${ }^{1266}$ Crazy Wisdom, p 180. See also p 105.

${ }^{1267}$ I believe a similar argument could be made about another term coined by Chögyam Trungpa, "spiritual materialism," which at times is used to refer to something to specific, while at other times it is used in such a way that it encompasses a whole host of negative things.
} 
which I have never come across anywhere. ${ }^{1268}$

Despite the lack of coherence in how "crazy wisdom" was explained, over time it became clear to Trungpa's followers that "crazy wisdom" had long been a part of the Tibetan Buddhist tradition, that it was embodied by enlightened beings, that it was a profound teaching method, and most important of all, that Trungpa had it. In 2005 Fabrice Midal said that Trungpa was "a master in the "crazy wisdom' school."1269 Other devotees casually call Trungpa a "holder of crazy wisdom." ${ }^{270}$ A film released in 2009 about the life and times of Chögyam Trungpa is titled, appropriately enough, Crazy Wisdom.

Thus "crazy wisdom" has come to take a central role in shaping how Trungpa is thought of by the inheritors of the tradition he initiated. It was a key ingredient in forming the perception that Trungpa should not be judged for anything he did. (For a good example of how the notion of "crazy wisdom" functioned in this regard, one should see Reggie Ray’s article "Chögyam Trungpa as a Siddha."1271) Through his skillful presentation of certain ideas Trungpa created a situation in which it was not just accepted that he would act in ways that challenged other peoples' notions of propriety, but it was actually expected of him. The idea that a siddha might display unconventional or eccentric behavior has been around for a long time; Trungpa drew from this precedent and modified it to suit his own needs. Part of this modification involved his emphasizing the rhetoric of madness. The notion that siddhas should be associated with a rhetoric of

\footnotetext{
${ }^{1268}$ Life and Vision, p 154. According to Janet Gyatso, Trungpa was using this term as early as 1974. Personal communication, October 31, 2010. 1269 "Introduction" to Recalling Chögyam Trungpa, p 5.

${ }^{1270}$ Françoise Bonardel, "Tantric Alchemy and the Transmission of Dharma: At the Heart of the Western Mandala" in Recalling Chögyam Trungpa , p 52.

${ }^{1271}$ pp 197-219 in Recalling Chögyam Trungpa.
} 
"madness" (and this includes “crazy wisdom") has, since the time of Trungpa, become more prominent than it ever was before in the whole history of Indian and Tibetan Buddhism. $^{1272}$

Chögyam Trungpa did not explicitly compare himself with famous "holy madmen" or "mad siddhas" (grub thob smyon pa) of the Tibetan tradition, like the Madman of Tsang or Drukpa Künlé. (Trungpa preferred to compare himself to Padmasambhava, who embodied his own form of "crazy wisdom.”) Nevertheless, after Trungpa had put all this information on the table, it is easy to see why people would naturally see Trungpa as a latter-day version of the famous holy madmen of Tibet. Fabrice Midal compares Trungpa to Drukpa Künlé. ${ }^{1273}$ An article posted on the online Elephant Journal (a sort of Huffington Post for the new-age, yoga and organics set) in 2010 is called "Fat, Naked, and Enlightened: The Crazy Yogis of Love." It states matterof-factly that, "The Buddhist tradition is of course well known for its crazy wisdom teachers. Marpa, Milarepa, and Drukpa [Künlé] are some of the more famous of the wild

\footnotetext{
${ }^{1272}$ One interesting aspect of Chögyam Trungpa's situation worth taking into account is the fact that Trungpa was for his students an unquestioned source of authority. Moreover, for most of his followers Trungpa was their only source of contact with what they perceived to be the Tibetan tradition. There were no other major voices or sources of information to discount Trungpa or anything he said or did. Today when Trungpa's followers articulate justifications of his behavior, explain what a great teacher he was, how what he has done is entirely traditional, they almost always cite his own works in support of this (for example, see Midal, Life and Vision, p xxv). Because of this virtual monopoly on his followers' ideas of Tibetan Buddhism, and their trusting faith in him as an authentic voice, Trungpa had a remarkable degree of control over their perceptions, with no real checks or balances on anything he might say. This allowed Trungpa to create the notion that he was creating an entirely new form of Buddhism, and one that was directly passed down to him by the authentic Tibetan tradition, and that he was going back to the earliest form of Buddhism, direct from the mouth of the Buddha — all at the same time. Chögyam Trungpa was able to have it every way at once. Because of his being one of a small handful of Tibetan masters on the scene in North America, Trungpa had a degree of control over how his followers perceived him rarely matched in Buddhist history.

${ }^{1273}$ Life and Vision, $\mathrm{p} 154$.
} 
ones from the past, while Chögyam Trungpa was contemporary." ${ }^{\prime 274}$ Many people have thus come to see Trungpa as a latter-day Tibetan holy madman.

We must also take into account how at the same time that Chögyam Trungpa was seen as a latter-day Tibetan holy madman, his specific articulation of "crazy wisdom" would have a great impact on how people think about the "holy madmen" of Tibet's past. The article from the Elephant Journal quoted above sees Trungpa as part of a lineage including Marpa, Milarepa and Drukpa Künlé. But it is Trungpa’s formulation, “crazy wisdom," that unites them. One of the most read, most influential books in shaping how the non-Tibetan world thinks about "holy madmen" is Keith Dowman's translation of The Life of Drukpa Künlé. A cursory glance at the Introduction shows how much Dowman's explanation of the holy madman phenomenon is influenced by Trungpa's articulation of crazy wisdom. Dowman's words would go on to influence many, as this is one of the most read and cited sources for information on the "holy madman" tradition in Tibet.

The point I want to make here is that Trungpa's recent articulation of "crazy wisdom" has had a significant impact on how Euro-Americans have understood the whole of the Tibetan "holy madman" tradition. In Chapter One I described this as a feedback loop. And yet to understand why Trungpa emphasized this notion of "crazy wisdom," and why he chose to articulate it in the way he did, we need to look at the specifics of his life and what very real, tangible ramifications this notion of crazy wisdom had for him. Trungpa did not articulate his idea of crazy wisdom in a vacuum. Trungpa

\footnotetext{
${ }^{1274}$ By Ramesh Bjonnes, October 17, 2010. http://www.elephantjournal.com/2010/10/fat-naked-andenlightened--ramesh-bjonnes/
} 
did not present the idea of crazy wisdom from a position of disinterestedness, based on an objective, detached understanding of the Buddhist tradition. Rather, Trungpa proclaimed it in the midst of ongoing controversy regarding his own behavior. His success in promoting the idea of "crazy wisdom" played a key role in resolving issues surrounding his personal conduct.

Clearly Trungpa was drawing from the precedent existing within the Tibetan Buddhist tradition when he articulated his idea of crazy wisdom, and thereby suggested to people that they interpret his actions in that light. And yet the specific meaning he gave to the term "madman" is not the same meaning it always carried. Among the most famous of the holy madmen — the Madman of Tsang, the Madman of Ü, and Drukpa Künlé - we do not have evidence that they ever claimed themselves to be the bearers of any special "crazy wisdom" or that they meant for their "madness" to be interpreted as a sign of their enlightenedness in as direct a way as Trungpa did. Although the idea, popularized by Milarepa, of madness-as-enlightenedness would always to some extent be present, the Madmen of Ü and Tsang were called "madmen" most often in response to their shocking behavior, as was shown in Chapter Three- not because of their claims to bearing anything approximating "crazy wisdom." The term ye shes 'chol ba does not appear in any of their biographies or writings.

Above I suggested that Ronald Davidson's comments about Lama Zhang's using the idea of himself as a holy madman to justify his warlike behavior was inaccurate. As Carl Yamamoto has pointed out, we have no evidence that Lama Zhang used the term "madman" in reference to himself in this way. Instead, he used it as a pen name. When Lama Zhang used "madman" as a pen name he may have been making reference to a 
broader tradition of "holy madmen" in the image of Milarepa, we should be cautious of assuming that this would have been the case at so early a moment in the tradition's development. The term "madman" would surely accumulate meaning over time, but during Lama Zhang's life it would not have had the sort of associations it would after perhaps the 15 th century.

The interpretation Davidson has offered of Lama Zhang might be more accurately applied to one like Chögyam Trungpa (the "warrior-king”). As Davidson writes of Lama Zhang,

Perhaps most disturbing in all of this [the events of Lama Zhang's rise to power in the Lhasa area and engaging in militaristic violence], and revealing in the manner of its employment, was Lama Zhang's attempt at tantric justification for his aggression. Although religious rationalization for personal power, gain, and selfaggrandizement has been common in human history, it has been thankfully rare in Buddhism. Lama Zhang and his disciples, though, determined that they would not be held to the standards of discipline appropriate for the rest of the world, a justification articulated in India for siddhas in general but in Tibet by Ra-lotsāwa and others in particular. This self-serving excuse was based on the idea that the siddha was superior knowledge and is above the mundane standards of the world. ${ }^{1275}$

We can clearly see how Trungpa was successful in making people perceive him as a siddha and establishing a tantric justification for his morally questionable behavior. In Trungpa's case, this behavior was about sexual licentiousness more so than aggression and violence, although acts of physical brutality did occasionally occur under Chögyam Trungpa's direction.

What Davidson has highlighted is the fact that Tibetan lamas like Lama Zhang and Chögyam Trungpa are not passive observers to the creation of Tibetan religious culture and the shaping of the minds of those who come into contact with it. Rather, they

${ }^{1275}$ Tibetan Renaissance, p 329. 
are key players in the ongoing process of spinning out ideas and influencing the way people think. They do not simply pass on eternal truths, but rather purposefully select from the cultural repertoire that is given to them and make use of the tropes and memes that seem most useful at any given moment. Wisdom, compassion, emptiness, karma, generosity — these memes are nearly ubiquitous in Buddhist discourse and it is often difficult to interpret what significance lies in individual instances of their use. But "holy madness" is a meme made use of less often, and as such stands out more strikingly when it is employed.

With Chögyam Trungpa, who died only in 1987, who gave public lectures called "Crazy Wisdom," it is not hard to see how his decision to promote the idea of holy madness affected how his followers interpreted his activity. With "madmen" who lived longer ago, like the Madman of Tsang, or the Madman of Ü, or Drukpa Künlé, or the Madman of Dakla Gampo or the Madman of Taklung, or the Madman of Kongpo, or the Madman of Kham or any other smyon pa of the Tibetan tradition- the conscious or semiconscious decision to promote themselves as holy madmen is the same. However, the meaning carried by the term, and how that "madness" functioned during their lives, may be unique in each case.

Trungpa's case is a poignant moment in the history of the Tibetan holy madman tradition, exemplifying how malleable the term can be (in the sense of what connotations could be applied to it) and how it can be employed to any variety of ends, not always as naïve and innocent as we might like to imagine. Although I would not charge all of Tibet's past "holy madmen" with using their "madness" to justify potentially corrupt behavior, it remains a fact that the term could at times have been used in this way. 


\section{VII. Conclusion: "Madman": A Floating Signifier}

While doing research in India in 2009 I had an audience with His Holiness the

Karmapa for the purpose of talking to him about "holy madness." I wanted to get a feel for what he thought about the tradition, what reasons he saw underlying the behavior of famous mad saints like the Madman of Tsang and Drukpa Künlé. At the end of our conversation about smearing oneself with ashes and eating the brains of corpses, I asked the Karmapa to give me a new Tibetan name. He told me to wait downstairs. After a while a little red card with golden lettering on it arrived. I opened it and saw that it read, Karma Dröndül Nyönpa (karma 'gro 'dul smyon pa). In English this means, "Karma, Subduer of Beings, Madman." Like those I have been studying, evidently I too am a madman.

What did the Karmapa mean by giving me this name? Was he suggesting that I was somehow an enlightened being? Surely not. Was it perhaps a commentary on what he thought of me or the odd things I had come to him to talk about? Was the Karmapa, who seems so stifled in the position he occupies as a leader-in-waiting, just being playful? If I were to use the name "madman" in reference to myself, it would be a tongue-in-cheek, self-aware declaration of independence, a commitment to thinking differently, and at the same time an homage to the Kagyü tradition and the famous "madmen" of its past. I believe the Karmapa gave me this name with these various meanings and connotations in mind.

What this episode reminds us of is the fact that, smyon pa, "madman," is after all just a word, waiting to be used and interpreted in almost limitless ways at any given time. There is no meaning attached to the term: it is a floating signifier, but one with a history. 
What I have tried to show in this chapter and throughout this dissertation is that over the years many Tibetans have taken steps to get themselves known as madmen, and have projected "mad" personas onto others as well. This is always part of an ongoing dialogical process. Milarepa may have used the theme of madness in some of his songs, which created a certain precedent for how the term "madman" could be used. As later individuals took steps to gain fame as madmen, this earlier meaning was to some extent implied, but there was also some meaning, some purpose to their wanting to be connected to the idea of "madness" at that particular historical moment. To some extent this was asserting a connection to the past, but even that act of establishing a connection to the past must be understood in the historical moment in which it occurs.

The "madman" or "madwoman" is not the only agent in this process, however. Just as important are the eccentric's contemporaries, those among whom his or her fame spread. It was also their choices in what they would remember and highlight about the person in question that determined whether or not they were remembered as madmen. Otherwise they would have become just another among the many ascetics and authors in the history of Tibetan Buddhism who employed a rhetoric of madness but were not thought of having achieved a state of true enlightened madness. What we see here is that one's existence as a "holy madman" is just as contingent, just as dependent upon factors outside of himself as any other phenomenon according to the Mahāyāna Buddhist worldview.

One notion that seems to prevail in some peoples' thinking about Tibet's "holy madmen" is that they achieved their fame and renown in spite of being "madmen." What I have tried to argue here is precisely the opposite - that their "madness" was, in fact, the 
vehicle on which their fame was carried. Holy madness is not a way of being in the world, but a way of presenting oneself to the world. ${ }^{1276}$ The term "madman" was one that has had a number of different meanings in Tibetan society. It was a term that was actively played with, used as a tool, a weapon, a disguise, an alibi.

When an author uses the pen name "madman" he is not asserting himself to actually be crazy, but is using the term in a way that it is at the same time self-effacing and boastful. To call oneself a "madman" is a self-referential act. The "madness" of many of the "crazy yogis" of the Tibetan tradition can be understood in a similar way. Their "madness" is a performance, a playful approach to identity, and inherently selfreferential. They do not mean for themselves to be taken as madmen, but as "madmen." Using the term "madman" brings immediate attention to the gap between normalcy and subversion - a gap crossed and straddled in many different ways by these crazy yogis of the Tibetan tradition.

\footnotetext{
${ }^{1276}$ Ehrhard, "The Holy Madman of dBus...", p 227, describes the Madman of Ü's taking on the garb of the Heruka: "By now the yogin, who was retracing the footsteps of Mi-la-ras-pa, had changed his appearance, having assumed the outer trappings of a fearful Heruka arrayed in bone ornaments. This shocking appearance was the visible expression of his advanced spiritual practice of the tantric teachings." Does Ehrhard mean to say that the Madman of Ü's dress was an expression of his level of religious attainment, or that it would be interpreted as such by others? I think it critical that we think of the Madmen of Ü and Tsang's taking on this form of dress more as a declaration of spiritual practice rather than an expression of it. The difference may be subtle, but it is of critical importance.
} 


\section{Conclusion}

I began Chapter One by reviewing the ways Tibetans typically interpret the behavior of so-called "holy madmen," and the Euro-American commentators who have echoed them. The dominant understanding is that this holy madness comes as the result of one's having achieved a different mode of existing in the world. Then in the succeeding six chapters I built the argument that this holy madness is more accurately understood as something that is quite the opposite. Rather than denoting an alternative ontological state, "madness" in this context is a floating signifier. Rather than a state of being, holy madness is an idea, a trope, liable to be appropriated for any number of ends at almost any time. "Madman" is nothing more than a word with a history.

These views lead to two fundamentally different ways of answering the central question this dissertation has asked: what motivated the "madness" of these individuals? In my introduction I stated that the chapters that followed would be the site of a clash between two very different discourses. My task has been to interpret the Tibetan, traditional, Buddhist discourse about holy madmen from the perspective of one far removed from it in time and space. The discourse from which I speak is secular, modernist and rationalist. By relying on the kind of thinking espoused by this modernist discourse I have formulated a way of understanding Tibet's holy madmen that is quite different from traditional Tibetan ones (which have been so influential in shaping the way scholars have explained the phenomenon). In a sense, the modernist way of viewing Tibet's holy madmen that I have espoused turns the traditional views inside-out. It achieves this by putting the assertions of the traditional discourse in historical context, to 
the extent that this is possible.

Each of these discourses has its own norms and assumptions, allowing one to see things in ways precluded by the other. There are a few most basic criteria that differentiate these two discourses with respect to the issues we have been dealing with is this dissertation.

First, the traditional Tibetan discourse is willing to accept that there are happenings in this world that are beyond what the rational human mind can grasp, such as the many miracles attested to in the biographies of the Madmen of Ü and Tsang. In contrast, I have been operating under the assumption that all phenomena can be reconstructed using the building blocks constituted by the knowledge I already have of human history and the natural world.

A second criteria that distinguishes these two discourses in what they might have to say about Tibet's holy madmen is what they assume motivated the holy madmen's behavior. The traditional Tibetan discourse has tended to see these holy madmen as beings whose actions are shaped solely by religious truths and concerns. In contrast, I have argued that the behavior of the holy madmen can be more accurately understood as motivated by a wide variety of concerns, some of which are shared with lay people and are decidedly "worldly" in nature.

Expanding on this point, the traditional discourse assumes that the holy madmen were motivated by their wish to teach other beings, or by their wish to further their religious training, or that their religious training had put them in a different ontological state from which their eccentric behavior naturally arose. In formulating my argument in this dissertation I have assumed that, although the holy madmen may have been 
motivated by these first two concerns to some extent, they were also motivated by financial and social concerns as well. The crux of the difference in our perspectives has to do with how sincere and honest we assume individuals to be in the way they present their own actions. The holy madmen and their disciples presented their eccentric behavior as essentially religious activity, and Tibetans have traditionally seen little reason to question this. My perspective is more skeptical by nature. I assume that the holy madmen had motives that were left unexpressed, which I can nevertheless reconstruct by considering the greater pattern of their behavior.

Third, the two worldviews I am discussing here can be defined by their basic differing attitudes about the sorts of texts that have been our main source of information in this study. Their respective feelings about these texts are corollaries of their basic assumptions about the sincerity with which these Buddhist masters presented their own activities. The traditional Tibetan view on these holy madmen is defined by a tendency to take their hagiographic texts at face value as records of their lives. This view assumes that these texts can be trusted as accurate depictions of history because they were written by individuals whose primary goal was to compose reliably truthful accounts. Attendant to my greater skepticism about the honesty of people's self-presentations in general, I approach the texts through which we know about these holy madmen with a more critical eye. As we saw in chapters Five, Six and Seven these biographies are the result of a process of purposeful rendering — manipulation, basically — carried out by their various authors. The modernist, secular view insists that we ask the question of what the authors of these accounts had to gain or lose as a result of their editorial decisions. This view is, in a sense, cynical, as it sees even the representations of the lives of famous saints as 
open to willful manipulation. This leads to seeing these texts not as descriptions of history, but as historical artifacts themselves. This shift in perspective comes from trying to understand these documents in their respective historical contexts.

One of the most important consequences of the attitude I have espoused about these texts is that we do not read them as offering insight into what the holy madmen actually thought or felt or did. We do not have direct access to the lives of these yogis. Rather, we have presentations of these yogis - we have their Lives. We know only what people thought and felt about these yogis — or, more accurately, what people said they thought and felt about them. Because of the nature of the texts we rely on for our understanding of the holy madmen, we do not know them privately. We do not have direct insight into what they actually thought or felt, only how they presented themselves to others. We only know who these holy madmen were as public beings.

Let us consider the consequences of this as it pertains to a specific example. One rather typical act attributed to many of the holy madmen is eating repulsive substances like human brains or feces. What do we assume about an act like this, on the most basic level? It is conceivable that a person could, through years of training exercises geared towards this goal, enter into a mental state such that he could eat such things without experiencing a feeling of revulsion. His eating filth would then be a testament to his having achieved such a state. This cannot be precluded as a possibility. But we know for a fact that if one were to go into the Lhasa Barkor and eat repulsive things, it would constitute a claim about having achieved such a state. If one were to walk naked in the marketplace it could be a natural result of one's no longer feeling concerned about societal expectations, but we can never be sure. But we can be quite sure that one's 
doing this constituted a public statement about having achieved such a state, whether or not one really had, which cannot be proven anyway. The difference between these two ways of thinking about the nature of people's actions is subtle but integral.

In a sense what defines the approach taken in this dissertation is seeing the process of becoming a saint as a social one. Becoming a saint is not about one's internal transformation but about changes in how one is perceived by others. (One is labeled "madman" by people, and not, as suggested in the Life of Tangtong Gyelpo, by the dakinīs.) I cannot disprove the possibility of internal transformation or achieving a different ontological state through religious practice, but because of the nature of the sources by which we might come to know about such a transformation, we only ever have statements about such a transformation, rather than descriptions of it. We do not know whether or not any of these so-called "holy madmen" were enlightened, whether they had transcended all worldly distinctions, saw truths to which the rest of us remain blind. All we know is that the holy madmen or their disciples asserted them to have done so.

Above I stated that my project has been to explain the traditional Tibetan discourse about holy madmen from the perspective of a modern secular one. In the course of this dissertation I have made many assertions about holy madmen that were never suggested to me in any of the conversations I had with Tibetans about the topic. Many of the Tibetans I have spoken with, ordained and lay, would surely disagree with much of what I have said. Nevertheless, the distinction that I have made between my and their ways of viewing things is in a key way a false one. Although few present-day 
Tibetans would likely see the behavior of the holy madmen the same way I have, there is evidence indicating that historically some Tibetans did. And not just any Tibetans, but some of the holy madmen themselves, as I will now show.

There are a few key aspects of the lives of these holy madmen suggesting that some of them also saw their rise to sainthood as part of a social process (rather than one of ontological transformation). The Madman of Tsang's biographer discusses his performing eccentric activity in order to "spread the drumsound of his fame." Drukpa Künlé criticized the Madman of Tsang for using his asceticism to gain attention and resources for himself. This point is pregnant with meaning. In the perspective of Drukpa Künlé, the Madman of Tsang was treating the rise to holiness as a social process. This belies a recognition on behalf of Drukpa Künlé himself that the rise to holiness was or could be social in nature.

The strongest evidence that the Madman of Tsang saw the rise to sainthood as a transformation in how one is viewed by others rather than the result of a transformation taking place within oneself is found in his literary activities. In Chapter Six we saw that the Madman of Tsang changed the contents of The Life of Milarepa in order to create a particular characterization of that saint and a particular version of history. The Madman of Tsang was fully aware that Milarepa's sainthood would be achieved through the production and mass-dissemination of an evocative narrative about him. The Madman of Tsang's perspective on this matter is highlighted in the argument he had with some of his students regarding the value of producing his version of Milarepa's Life. His students wondered if their time wouldn't be better spent in meditation, which was, as career religious practitioners, their stated purpose. The Madman of Tsang had a different 
perspective on things, seeing the production of a powerful narrative about the life of a famous meditator as, at that moment, more important than actually practicing meditation himself. The Life was more important than their lives.

The Madman of Tsang also knew full well that his own sainthood would be achieved through composing a narrative about himself. He wrote this narrative not with quill and ink but with moments of provocative and outlandish activity. He wrote this narrative not on paper but in the minds of the individuals who were witness to his mad persona. His narrative was mass-disseminated not by woodblock printing but by word of mouth. After the Madman of Tsang's death three of his disciples would compose and print versions of his Life, amidst their constructing the histories of other saints of their lineage. But during his lifetime the Madman of Tsang wrote his own biography, with just as much skill and purpose as he wrote Milarepa's.

Throughout this study I have maintained that we should see the actions of holy madmen throughout history as being, above all else, purposeful, motivated by a variety of ends, with "religious" concerns not necessarily taking pride of place among them. This way of thinking about these saints is suggested by a modernist, secular discourse. But it is also begged by the actions of the holy madmen themselves. The Madmen of $\ddot{U}$ and Tsang were not individuals who thirsted after private lives or anonymity. By massproducing their literary compositions or performing their shocking behavior in the most public of forums, and thereby winning renown or infamy for themselves, they displayed a cunning awareness of the power of representations. Their "madness" was not a private affair but called attention to itself, demanding to be interpreted. These were brilliant men with complex goals and motivations. To insist on viewing them as motivated only by 
religious concerns pays them a great disservice, glossing over what is in the end the most remarkable thing about them.

What best defines the fundamental approach taken towards Tibet's holy madmen in this dissertation is that it insists on seeing figures like the Madmen of $\ddot{U}$ and Tsang as themselves very much aware of how their actions - performed in the most public of spaces - would be received, interpreted and retold by others. This seems a commonsense thing to think about our subjects, but most descriptions of Tibet's holy madmen by Tibetans and Euro-Americans alike do not consider the possibility of the holy madmen's having this kind of attunement. To interpret the actions of the holy madmen as individuals who may have had such an awareness we must understand their "madness" in the real-world context in which it was enacted. As such, we cannot understand holy madness as something that can be separated from the historical moments in which it is appealed to. Nor should we try to understand it as a phenomenon somehow separable from the circumstances of the lives of the holy madmen who shaped the idea, and thus shaped how they themselves would be viewed by the world. When any individual begins promoting himself as a holy madman, "madman" carries with it a history of past associations and meanings. But nevertheless it is a unique act located in that historical moment. The "holy madman" himself is the central agent in the sleight of hand that causes other people to lose sight of the fact that he is a creative agent after all. He achieves this sleight of hand by making an appeal to tradition, to truths established before his time. It is our job as researchers to identify the choices made by the agent in question - the madman, the treasure revealer, the medium, the delok ('das log) returned from the dead - to understand his active role in the cultural process that envelopes him, to 
point out how skillfully he has played the game.

What, then, can we say is the real drive behind the madman's eccentric behavior? This is left for each individual reader and interpreter of this history to decide. We can never get to the level of knowing peoples' actual thoughts beneath what is expressed by their words, so we can only ever imagine. Our work as scholars must be to explore what is visible to us in hopes of gaining some insight into that unplumbable invisibleness. This study of Tibet's holy madmen is seen to be just another meditation on the relationship between the internal and the external, the invisible and the visible. It is in this space that language and culture play. This study of the religious history of Tibetans is an inquiry into how they have made use of the freedoms offered by that space.

As I stated above, the different perspectives I have been discussing in this conclusion are not defined as mine and theirs. In the end the real distinction is not between my (modernist) discourse and their (traditionalist) one, for as we have seen, there have been within Tibet's history plenty of people who espoused many of the same ideas as me — not lest among them some of the holy madmen themselves. The essential difference is, then, is between people who are willing to take into account the social and material circumstances in which religion plays out (this includes many of the holy madmen), and those who willfully ignore them. 


\section{Afterword}

The study of Tibet's holy madmen brings together a number of my long-standing interests: the history of the Kagyü sect; the relationship between world-renouncing religious practitioners and the society they never fully leave behind; the tension between pro- and anti-institutional, pro- and anti-rational tendencies within Buddhism; the social ramifications of religious practice; literary production; the performative nature of identity; eccentric individuals.

Many people have asked how I came to fixate on the topic of holy madmen, the investigation of which has taken up three years of my life. There were three distinct moments that contributed to my deciding to take on this project.

The first came in 2005, shortly after my arrival at Tibet University in Lhasa. We were reading The Life of Milarepa in one of my classes and I could not have been more engrossed in the text. I had read Milarepa in English translation, but going through the story in a new language allowed me to experience its genius all over again. (Some months after this I remember seeing a Chinese translation of the Life in a monastery bookshop in Lijang. At that moment I felt a very palpable regret that I had not chosen to study Chinese as part of my graduate training, as knowing that language would have enabled me to read Milarepa again for the first time.) I spent my afternoons pouring over every word of the text in preparation for the next day's class. I re-read portions of the text over meals and most nights before going to sleep. The book was my constant companion. Some of my professors at Tibet University told of how when they were in 
college they carried around copies of Döndrup Gyel's stories, as he gave them inspiration and represented ideals they wanted to pursue. Milarepa played a similar role for me. I wanted to understand the text completely, and so I carried it everywhere. Half of the book's blue cover rubbed off. Inside the pages were a mess, with notes scribbled everywhere I could fit them. The affair dragged on for months.

At moments when I felt especially smitten with the story I would flip back to the title page and look at the name of the author, there listed as rus pa'i rgyan can, "the one wearing bone ornaments.” My very venerable and animated teacher had, after I asked him about the origin of the text, written the author's more commonly used name just above this in pencil: gtsang smyon he ru ka. I remember sitting and pondering how something so masterful could have been written by a madman. Why did he dress in bones? Something was amiss. There was a mystery to be solved.

The second moment occurred a year later. Back at the University of Virginia, I found myself reading the work of two of my heroes, E. Gene Smith and J. Z. Smith, both at the same time. The former Smith summarized what was known and not known about the Tibetan madmen back in the 1960s and made some suggestions about how they might be understood. More importantly, his article opened the door to an understanding of these figures as real historical beings. The latter Smith gave me big ideas about what the study of religion should be. The question of Tibetan holy madmen seemed the perfect means to dramatize some issues about which I had particularly strong feelings. The essential message I took away from both Smiths was to be unfailingly historical in my approach. It was shortly after this that I decided to pursue this topic for my dissertation. 
There is a third moment in the story of how I came to fixate on this topic that is worth mentioning. On three different Halloweens during graduate school I went to parties dressed as a yogi. I smeared myself with ashes, put on a loincloth, and draped a $m \bar{a} l \bar{a}$ around my neck. I walked barefoot, carried a broom handle as a staff, and drank liquor from a bowl. Dressing in this way I was imitating the Kāpālikas or the Pāśupatas I had done a little research on for a course on Śaivism. I thought these sects were neat. The first year I went dressed like this I won the award for best costume. My prize was about three dollars in quarters, poured into my bare hands by a classmate who happened to be dressed as the Pope. A few years after that when I was beginning to read The Life of the Madman of $\ddot{U}$ I realized that he and the Madman of Tsang were doing essentially the same thing I was. I was just like them-or they were just like me. We had something very distinctive in common, despite the five centuries separating our lives. And so as I explored the central question my research asks - Why did the holy madmen dress and act in this way? - I was asking the same thing about myself. 


\section{Bibliography}

\section{Tibetan-language Sources}

\section{I.1 Biographies of the Madman of $\ddot{\mathbf{U}}$}

(1) dpal ldan bla ma dam pa grub pa'i khyu mchog phyogs thams cad las rnam par rgyal ba'i spyod pa can rje btsun kun dga' bzang po'i rnam par thar pa ris med dad pa'i spu long g.yo byed. Part I by gnyug la paN chen ngag dbang grags pa (14581515); part II by lha mthong lo tsA ba bshes gnyen rnam rgyal (b. 1512). Published in volume 2 of $b k a$ ' brgyud pa hagiographies: a collection of rnam thar of the eminent masters of Tibetan Buddhism. Compiled and edited by khams sprul don brgyud nyi ma. Palampur, Himachal Pradesh, India: Sungrab Nyamso Gyunphel Parkhang, Tibetan Craft Community, 1972.

(2) Also available in unpublished manuscript version, Nepal-German Manuscript Preservation Project, manuscript number L7894. Private library of Labrang Dondrup. 86 folios. Handwritten, dbu can script.

(3) dbus smyon kun dga' bzang po'i mgur 'bum. By gnyug la paN chen ngag dbang grags pa. Although bearing the title the Collected Songs, the text is actually part I of the biography of the Madman of Ü. Delhi: 1973.

\section{I.2 Biographies of the Madman of Tsang}

(1) rje btsun gtsang pa he ru ka'i thun mong gi rnam thar yon tan gyi gangs ril dad pa' $i$ seng ge rnam par rtse ba. By dngos grub dpal 'bar. Xylograph completed in 1508. Have scan of a copy owned by E. Gene Smith.

(2) grub thob gtsang pa smyon pa'i rnam thar dad pa'i spu slong g.yo ba. By lha btsun rin chen rnam rgyal. Published in Bde mchog mkha' 'gro snyan rgyud (Ras chung snyan rgyud): Two Manuscript Collections of Texts from the Yig cha of Gtsangsmyon He-ru-ka. Smanrtsis Shesrig Spendzod: Leh, India. 1971. pp. 1-129. Xylograph completed in 1543.

(3) gtsang smyon ke ru ka phyogs thams cad las rnam par rgyal ba'i rnam thar rdo rje theg pa'i gsal byed nyi ma'i snying po. By rgod tshang ras pa sna tshogs rang grol. Edited by Lokesh Chandra. New Delhi: Sharada Rani, 1969. Written in 1547.

\section{I.3 Biographies of the Madman of the Drukpa}

'gro ba'i mgon po kun dga' legs pa'i rnam thar mon spa gro sogs kyi mdzad spyod rnams. Dharamsala: Tibetan Cultural Printing Press, 1981. 128 pages. 
'gro ba'i mgon po chos rje kun dga' legs pa'i rnam thar rgya mtsho'i snying po mthong ba don ldan. By brag phug dge bshes dge 'dun rin chen. Kalimpong, Printed at the Mani Printing Works, 1971.

'brug pa kun legs kyi rnam thar. This is the four-volume "Collected Works" of Drukpa Künlé. Beijing: bod ljongs mi dmangs dpe skrun khang, 2005.

'brug pa kun legs kyi rang rnam (grub pa'i dbang phyug chen po rnal 'byor kun dga' legs pa'i dpal gyi rnam par thar pa). Recent Chinese print, orange cover, no date; purchased in Lhasa in 2006. 83 pages.

\section{I.4 Other Tibetan Texts}

kun bzang bla ma'i zhal lung (snying thig sngon 'gro'i khrid yig). By rdza dpal sprul rin po che. si khron mi rigs dpe skrun khang, 1991.

kong smyon 'khrul zhig nam mkha' 'jigs med rig pa brtul zhugs kyi spyod la gzhol pa'i tshul chos brgyad tshul chos kyi mnya' gnon rig pa gcer mthong ngo sprod kyi thol glu. By nam mkha' 'jigs med (kong smyon). In rnal 'byor gyi dbang phyug chen po lha btsun nam mkha' 'jigs med kyi gsung 'bum (TBRC W20865), pp 369474 in Vol. 1 of 4. New Delhi: Jurme Drakpa, 1974.

skyug bro ba'i 'jig rten. By bya dor phun tshogs dbang phyug, also known as gangs smyon. Delhi: Archana, 2007.

khams gsum chos kyi rgyal po mnyam med 'bri gung skyob pa jig rten gsum mgon gyi bka' 'bum nor bu'i bang mdzod bzhugs so. 'jig rten gsum mgon. Edited by bri gung skyabs mgon che tshang 'phrin las lhun grub. Dehradun: srong btsan dpe mdzod khang, 2008.

khrag thigs las skyes pa'i ljang myug: deng rabs bod kyi rtsom rig dang de'i rgyab ljongs, 1980-2000. By hor gtsang 'jigs med. Dharamsala: Youtse Publications, 2000 .

gangs can mkhas grub rim byon ming mdzod. By ko zhul grags pa 'byung gnas and rgyal ba blo bzang mkhas grub. kan su'i mi rigs dpe skrun khang, 1992.

gangs can 'dir ston pa'i rgyal tshab dpal sgam po pa'i khri gdung 'dzin pa'i dam pa rnams kyi gtam bai DUrya'i phreng ba. Multiple authors. pp 45-50, 191-247 (Text F) in Sørensen and Dolma, eds., 2007.

grub chen u rgyan pa'i rnam thar. By bsod nams 'od zer. bod ljongs bod yig dpe rnying dpe skrun khang, 1997. 
grub thob nyag re se bo'i skyes rabs rnam thar ma 'ongs lung bstan zhal chems nyams mgur bzhugs. Published jointly by 'gro phan gtsug lag dpe skrun khang and a myes rma chen bod kyi rig gzhung zhib ‘jug khang, 2008.

grub pa'i dbang phyug chen po a mgon rdo rje 'chang gi rnam thar rags bsdus bka' brgyud bstan pa'i mdzes rgyan. By 'bri gung dkon mchog rgya mtsho, also known as ra se zla ba. bod ljongs mi dmangs dpe skrun khang, 2004.

rgya bod du bstan pa'i sbyin bdag rgyal blon ji ltar byung tshul gyi mtshan tho. By klong rdol ngag dbang blo bzang. pp 419-460 in Vol. 2, text ' $a$, in the gsung 'bum of klong rdol ngag dbang blo bzang. bod ljongs bod yig dpe rnying dpe skrun khang, 1991. Also printed in Delhi, by Lokesh Chandra, 1973.

rgyal khab med pa'i mi (homeless person): mi lo sum bcu'i rags zin (1969-2002). By Yeshi Gyatso Rinpoché, klu smyon he ru kaH. No publication information; 219 pages.

rgyud kyi mngon par rtogs pa rin po che'i ljon shing (kye rdor rgyud kyi mngon rtogs rin po che'i ljon shing). By grags pa rgyal mtshan. pp 1-139 in volume III of the sa skya bka' 'bum. Tokyo: Toyo Bunko, 1968.

sgra bsgyur mar pa lo tsA'i rnam par thar pa mthong ba don yod. Attributed to gtsang smyon he ru ka. Varanasi: E. Kalsang, 1970.

bsgrub brgyud karma kaM tshang brgyud pa rin po che' $i$ rnam par thar pa rab 'byams nor bu zla ba chu shel gyi phreng ba. By si tu paN chen chos kyi 'byung gnas and 'be lo tshe dbang kun khyab. New Delhi: D. Gyaltshan and Kesang Legshay, 1972 (TBRC W23435). There is another version of this text, in volumes 11 and 12 of the gsung 'bum of si tu paN chen. Kangra District: palpung sungrab nyamso khang, 1990 (TBRC W26630). All references are to the former printing unless noted.

nges don phyag rgya chen po'i rnam gzhag bstan pa'i sgron me. By mkhan chen tshul khrims rin po che. Beijing: mi rigs dpe skrun khang, 2006.

chos kyi grags pa'i rnam thar cha shas tsam brjod pa (dpal ldan bla ma dam pa rdo rje slob dpon chen po rig pa 'dzin pa'i 'khor los bsgyur ba chos kyi grags pa'i rnam par thar pa'i cha shas tsam brjod pa). pp 247-302 in Vol. 1 of the Collected works (gsun 'bum) of Kun-mkhyen Rig-pa 'dzin-pa Chen-po Chos-kyi-grags-pa, the First Drigung Chungtsang (1595-1659). Written by Stag-lung-pa Ngagdbang-bkra-shis-dpal-grub at the behest of Lung-rings-pa Ngag-dbang-las-grub, Rgyal-ba'i-myu-gu, and Phyag-mdzod Drung Dkon-mchog-rgyal-mtshan. Kulhan, Dehradun: Drikung Kagyu Institute, 1999. 
chos rje lo ras pa'i rnam par thar pa bdud rtsi'i phreng ba. By Götsang Repa. pp 237-81 in Vol. 2 of Bka' brgyud pa Hagiographies, edited by khams sprul don brgyud nyi ma. Tashijong, Palampur, H. P., 1972 (TBRC W20499).

chos 'byung mkhas pa'i dga' ston (dam pa'i chos kyi 'khor lo bsgyur ba rnams kyi byung ba gsal bar byed pa mkhas pa'i dga' ston). By dpa' bo gtsug lag phreng ba.

Beijing: mi rigs dpe skrun khang, 2006. Occasional reference to the Beijing: mi rigs dpe skrun khang, 1986 version, in two volumes, is made.

Collected Works of Śākya mchog ldan. Thimphu, Bhutan: Kunzang Tobgyey, 1975. Reprinted 1978, 1988, 1995.

'char ka'i 'bod pa. Vol. 3, 2009. Published by the Kagyu College, bka' brgyud mtho slob rtsom sgrig khang, Dehradun, Uttarakhand, India.

rje btsun byams pa mgon po'i sku brnyan bzhengs pa'i dkar chag lo rgyus. By paN chen shAkya mchog ldan. pp 243-76 in Vol. 17 (tsa) of the Collected Works of Śäkya mchog ldan.

rje btsun mi la bzhad pa'i rdo rje'i gsung mgur smyo ma'i 'grel pa myo ba sangs byed. By ngag dbang mkhas grub. In The collected works of Nag-dban-mkhas-grub, Kyai-rdor Mkhan-po of Urga, reproduced under the instructions of Glin Rin-poche from a set of the manuscripts and xylographic prints from the Urga blocks. pp 75-97 in Vol. 2 ( $k h a)$ of 5. Leh: Smanrtsis shesrig spendzod, 1972-1974 (TBRC text W16812).

stag lung chos 'byung (brgyud pa yid bzhin nor bu'i rtogs pa brjod pa ngo mtshar rgya $m t s h o$ ). By stag lung ngag dbang rnam rgyal. bod ljongs bod yig dpe rnying dpe skrun khang, 1992.

ston gyi rang sgra. By a smyon bkra shis don grub. Xining: mtsho sngon mi rigs dpe skrun khang, 1999.

brtag gnyis kyi bsdus don bshad rgyud kyi rgyud pa’i rim pa. By shAkya mchog ldan. pp 464-67 in Vol. 13 (pa) in the Collected Works of Säkya mchog ldan.

brtag gnyis rnam bshad dri med 'od. By rang byung rdo rje, the Third Karmapa. Seattle: Nitartha International, 2006.

bstan pa'i sbyin bdag chen po sa skyong rin spungs pa'i skor. By sa skya'i spyi 'thus ga zi tshe rings po. pp 39-41 in chos kyi blo gros, No. 2, 2009. Printed by chos kyi blo gros rtsom sgrig khang (Choekyi Lodoe Editorial Section) Dzongsar Institute, Distt. Mandi (H.P.), India.

dag yig gsar bsgrigs. Xining: mtsho sngon mi rigs dpe skrun khang, 2003. 
dam chos dgongs pa gcig pa'i gsal byed: A detailed explanation of the 'Bri-gun Bka'brgyud Dgonis gcig teaching, reproduced from a copy of ancient manuscripts from the Library of Yudra Rinpoche. By chos grags ye shes, the 4th Red Hat. Bir: D. Tsondu Senghe, the Bir Tibetan Society, 1992.

dung dkar tshig mdzod chen mo (mkhas dbang dung dkar blo bzang 'phrin las mchog gis mdzad pa'i bod rig pa'i tshig mdzod chen mo shes bya rab gsal). By dung dkar blo bzang 'phrin las. Beijing: krung go'i bod rigs dpe skrun khang, 2002. Referred to in the above footnotes as Dungkar Rinpoché dictionary.

deb ther kun gsal me long. By phun tshogs tshe ring. bod ljongs mi dmangs dpe skrun khang, 1987.

deb ther sngon po. By 'gos lo tsA ba gzhon nu dpal. Sarnath: wA Na badzra bidyA dpe mdzod khang, 2002. Two volumes.

deb ther dmar po gsar ma. By bsod nams grags pa. See Tucci, trans., 1971.

dri lan the tshom mun sel zhes pa khams ri bo che'i dge slong gi zhu lan. By karma 'phrin las pa. In The Songs of Esoteric Practice (mgur) and Replies to Doctrinal Questions (dris lan) of karma-'phrin-las-pa. Reproduced from prints of the 1539 Rin-chen-ri-bo blocks. New Delhi: Ngawang Topgay, 1975.

gdan sa chen po dpal dwags lha sgam po'i ngo mtshar gyi bkod pa dad pa'i gter chen. By sgam po pa mi pham chos kyi dbang phyug phrin las rnam rgyal dpal bzang po (1589-1633). pp 248-273 (Text G) in Sørensen and Dolma, eds., 2007.

mdo sngags kyi gzhung chen chen mo'i tshig mdzod ris med mkhas pa'i zhal lung. By sgom sde lha rams pa dge bshes thub bstan bsam grub. Delhi: Sherig Parkhang, 2005 .

mdo smad lo rgyus chen mo las lo rgyus spyi'i gzhung shing gi skor. By hor gtsang 'jigs med. Vol. 1 of 6. Dharamsala: Library of Tibetan Works and Archives, 2009.

$n$ A ro gsang spyod kyi 'don dmigs bya tshul. Published in Rtsib-ri spar-ma: the collected instructional material on the practice of the teachings of the Dkar-brgyud-pa and Rdzogs-chen traditions (collected and arranged into a coherent structure and carved on to xylographic blocks at La-stod Rtsib-ri from 1934 through about 1958 by La-dwags Khrid-dpon 'Khrul-zhig Padma-chos-rgyal. pp 485-99 in Vol. 7. Darjeeling: Kargyud Sungram Nyamso khang, 1978-1985. Also included in the gsung 'bum of 'kun gzigs chos kyi snang ba, the 8th 'brug chen (1768-1822). pp 745-53 in Vol. 3. Rewalsar, Distt. Mandi: Zigar Drukpa Kargyud Institute, 1985. 
nA ro gsang spyod kyi dmigs rim. Published in the Collected works (gsung 'bum) of Kunmkhyen Padma-dkar-po. Reproduced photographically from prints from the 19201928 Gnam 'Brug Se-ba Byan-chub-glin blocks. pp 1-19 in Vol. 17 of 24.

Darjeeling: Kargyud Sungrab Nyamso Khang, 1973-1974. Also published in the Rtsib-ri spar-ma collection mentioned above. pp 501-527 in Vol. 7.

rnal 'byor gyi dbang phyugs grags pa mtha' yas dpal bzang po'i rnam thar mgur 'bum ngo mtshar nor bu'i 'phreng ba (The biography (with interspersed songs of esoteric realization) of the 15th century 'Brug-pa Dkar-brgyud-pa master, Grubdbang Grags-pa-mtha'-yas). By ma pham rdo rje. Reproduced from tracings from prints of the Central Tibetan blocks from the Library of Burmiok Athing, Gangtok, 1977. Also printed in Delhi.

rnal 'byor gyi dbang phyug chen po mi la ras pa'i rnam mgur. By gtsang smyon he ru ka. Xining: mtsho sngon mi rigs dpe skrun khang, 2005.

[padmaraga] bod kyi lo rgyus spyi don pad +ma rA ga'i lde mig. By thub bstan phun tshogs. 2 volumes. si khron mi rigs dpe skrun khang, 1996.

paṇdi ta chen po shäkya mchog ldan gyi rnam par thar pa zhib mo rnam 'byed pa (Detailed Analysis of the Liberation Story of the Great Pandit Sákya). By kun dga' grol mchog. pp 1-234 in Vol. 16 ( $m a$ ) of the Collected Works of Śăkya mchog ldan.

dpag bsam ljon bzang. By sum pa mkhan po ye shes dpal 'byor. Sarnath: Mongolian Lama Guru Deva, 1965.

dpal kye'i rdo rje zhes bya ba'i rgyud kyi rgyal po'i 'grel pa. By dwags po paN chen bkra shis rnam rgyal. Also known as sgam po bkra shis rnam rgyal. si khron mi rigs dpe skrun khang, 2002.

dpal ldan rin chen spungs pa sger gyi gdung rabs che long tsam zhig. By yar lung pa a 'bum. pp 125-134 in bod kyi rgyal rabs phyogs bsdebs kyi nang gses.

Dharamsala: Library of Tibetan Works and Archives, 1985. The title for the collection given on the coverboard reads mi rje 'ba' nyag a thing mchog nas phyogs bsdus gces gsog gnang ba'i bod dpe'i khongs rim pa bdun pa'o: sngon gyi gtam me tog gi phreng ba. Another version, which is a scan of a handwritten manuscript, is available from TBRC (W24188).

dpal nA ro chos drug gi khrid kyi rim pa sbas pa'i don mtha' dag gsal bar byed pa brgyud sde'i snying po kun las btus pa: A detailed intsructional manual for the practice of the six doctrines of Näropa according to the system of the Kam-tshan $B k a$ '-brgyud-pa, Reproduced from a rare manuscript which had once belonged to 'Jam-mgon Kon-sprul recently found by Lama Nor-bla. By chos grags ye shes, the 4th Red Hat. Delhi: Karlo, Tibetan Camp, Majnukatilla, 1985. 
dpyid kyi rgyal mo'i glu dbyangs kyi 'grel pa yid kyi dga'ston (gangs can yul gyi sa la spyod pa'i mtho ris kyi rgyal blon gtso bor brjod pa'i deb ther rdzogs ldan gzhon nu'i dga' ston dpyid kyi rgyal mo'i glu dbyangs kyi 'grel pa yid kyi dga' ston). By nor brang o rgyan. Beijing: mi rigs dpe skrun khang, 1993.

bod kyi chos srid zung 'brel skor bshad pa. By dung dkar blo bzang 'phrin las.

Dharamsala: Library of Tibetan Works and Archives, 1982. First published in Beijing, mi rigs dpe skrun khang, 1981.

bod kyi lo rgyus dris lan brgya ba. By cha ris skal bzang thogs med. kan su'i mi rigs dpe skrun khang, 1997.

bod rgya tshig mdzod chen mo. Beijing: mi rigs dpe skrun khang, 1996.

dbu ma'i lta khrid (dbu ma'i lta khrid/ zhi gnas dang lhag mthong zung du 'jug pa ngo mtshar rgyan gyi phreng ba). pp 190-202 in Vol. 13 (pa) of the Collected Works of Śäkya mchog ldan.

'bum chung nyi ma (dpal mar pa lo tsA'i kye'i rdo rje'i rtsa rgyud brtag pa gnyis pa'i 'grel pa). Attributed to mar pa chos kyi blo gros. Dehradun: srong btsan dpe mdzod khang, 2005.

'bri gung chos 'byung. By 'bri gung dkon mchog rgya mtsho. Beijing: mi rigs dpe skrun khang, 2003.

'bri gung gdan rabs gser phreng (nges don bstan pa'i snying po mgon po 'bri gung pa chen po'i gdan rabs chos kyi byung tshul gser gyi phreng ba). By 'bri gung bstan 'dzin pad ma'i rgyal mtshan. bod ljongs bod yig dpe rnying dpe skrun khang, 1989.

'bri gung mtshams pa grub thob a mgon rin po che'i rnam thar. By 'bri gung pa chos 'byor. ngag rgyun lo rgyus deb phreng dang po. Oral Histories Series, No. 1. Dharamsala: Library of Tibetan Works and Archives, 1996.

gtsang rong byams chen chos sde'i par gsar pa rnams kyi dkar chag tu gnang ba. By paN chen shAkya mchog ldan. pp 229-38 in Vol. 17 (tsa) of the Collected Works of Śākya mchog ldan.

gtsang gsum 'phyo ba'i skya rengs. By yar kaH 'jam dbyangs phrin las. Also known as 'brug smyon klu gdong. Published jointly by the 'dzam gling zhi bde par khang and the bod gzhung shes rig par khang, 2003.

rtsam pa (Tsampa Magazine). Vol. 13, 2004. Published by the Tsampa Literature Group at the College for Higher Tibetan Studies, Sarah, Kangra, H.P., India. 
zhal gdams su btags pa'i smyon tshig nam mkha'i sprin sgra. By mkha' khyab rdo rje, the 15th Karmapa. pp 823-78 in Vol. ta. Paro: Lama Ngodrup (TBRC W28676).

gzhis ka rin spung kyi phyag mdzod du bsdu ba'i deb gter chen mo'i shis brjod. By paN chen shAkya mchog ldan. pp 238-9 in Vol. 17 (tsa) of the Collected Works of Śäkya mchog ldan.

rab brtan kun bzang 'phags kyi rnam thar (rgyal rtse chos rgyal gyi rnam par thar pa dad pa'i lo thog dngos grub kyi char 'bebs). By 'jig med grags pa, bo dong paN chen phyogs las rnam rgyal. bod ljongs mi dmangs dpe skrun khang, 1987.

[re'u mig,] dpag bsam ljon bzang. By sum pa mkhan po ye shes dpal 'byor. Vol. III. Edited by Lokesh Chandra. New Delhi: International Academy of Indian Culture, 1959.

rwa lung dkar brgyud gser 'phreng: brief lives of the successive masters in the transmission lineage of the Bar 'brug-pa Dkar-brgyud-pa of Rwa-lung. Reproduced from a set of prints from the 1771-1772 Spungs-than xylographic blocks. pp 99-106 in Vol. 3 of 4. Palampur: Sungrab Nyamso Gyunphel Parkhang, Tibetan Craft Community, 1975-1978.

lam skor brgyad kyi gsal byed bdud rtsi'i thig pa. By shAkya mchog ldan. pp 630-40 in Vol. 13 (pa) of the Collected Works of Śäkya mchog ldan.

shug gseb rje btsun sku zhabs kyi rnam thar (gangs shug ma Ni lo chen rig 'dzin chos nyid bzang mo'i rnam par thar pa rnam mkhyen bde ster). Edited by blo bzang tshe ring. Lhasa: mi rigs dpe skrun khang, 1997.

shes bya kun khyab (theg pa'i sgo kun las btus pa gsung rab rin po che'i mdzod bslab pa gsum legs par ston pa'i bstan bcos shes bya kun khyab). By 'jam mgon kong sprul blo gros mtha' yas. Also known as kong sprul yon tan rgya mtsho. Beijing: mi rigs dpe skrun khang, 2002.

sa skya bka' 'bum. Tokyo: Toyo Bunko, 1968.

sangs rgyas dar po chos 'byung (bka' brgyud chos 'byung rin po che spungs pa'i 'od stong 'khyil or bde gshegs bstan pa'i gsal byed bka' rgyud chos kyi 'byung gnas rin po che spungs pa' $i$ 'od stong ' $k$ hyil ba). By sangs rgyas dar po. Unpublished manuscript; available from NGMPP; hard copy lent to me by Tashi Tsering (Dharamsala).

srong btsan tshangs dbyangs. Vol. 3, 2005. Published by srong btsan dpe mdzod khang, Dehradun. 
he ru ka'i chas drug. By grags pa rgyal mtshan. pp 265-4.1 to 271-2.4 in Vol. III of the sa skya bka' 'bum. Tokyo: Toyo Bunko, 1968.

lha sa'i dgon tho rin chen spungs rgyan. By bshes gnyen tshul khrims. Lhasa: bod ljongs mi dmangs dpe skrun khang, 2001.

\section{European-language Sources}

Ardussi, John. 1972. 'Brug-pa Kun-legs, The Saintly Tibetan Madman. Master's thesis, University of Washington.

----- 1977. "Beer of Enlightenment," pp 115-124 in Journal of the American Oriental Society, Vol. 97, No. 2.

Ardussi, John and Lawrence Epstein. 1978. "The Saintly Madmen in Tibet," pp 327-37 in Himalayan Anthropology: The Indo-Tibetan Interface, edited by James Fisher.

Aris, Michael. 1987. “"The Boneless Tongue': Alternative Voices from Bhutan in the Context of Lamaist Societies" in Past and Present, No. 115.

-----, ed. 1998. High Peaks, Pure Earth: Collected Writings on Tibetan History and Culture. London: Serindia.

Beal, Samuel, trans. 1957. Chinese Accounts of India. 4 volumes. Calcutta: Susil Gupta (India) Ltd; first printed in 1883.

Bessenger, Suzanne. 2009. Echoes of Enlightenment: The Life and Legacy of Sonam Peldren (1328-1372). Ph.D. dissertation, University of Virginia.

Bjonnes, Ramesh. 2010. "Fat, Naked, and Enlightened: The Crazy Yogis of Love" in Elephant Journal. Posted October 10. http://www.elephantjournal.com/2010/10/fat-naked-and-enlightened--rameshbjonnes/.

Bonardel, Françoise. 2005. "Tantric Alchemy and the Transmission of Dharma: At the Heart of the Western Mandala" in Recalling Chögyam Trungpa, edited by Fabrice Midal.

Beyer, Stephan. 1992. The Classical Tibetan Language. Delhi: Sri Satguru Publications.

Borg, Marcus and N. T. Wright. 1999. The Meaning of Jesus. New York: HarperSanFrancisco.

Braverman, Marcy. 2003. Possession, Immersion, and the Intoxicated Madness of Devotion in Hindu Traditions. Ph.D. dissertation, University of California, Santa Barbara.

Buffetrille, Katia and Charles Ramble, eds. 1998. Tibétains: 1959-1999: 40 ans de colonization. Paris: les Éditions Autrement.

Campany, Robert Ford. 2009. Making Transcendents: Ascetics and Social Memory in Early Medieval China. Honolulu: University of Hawai'i Press.

Caplan, Lionel. 1987a. "Introduction," pp 1-24 in Studies in Religious Fundamentalism, edited by Lionel Caplan.

-----, ed. 1987b. Studies in Religious Fundamentalism. Albany: State University of New York Press.

Chang, Garma C. C., trans. 1962. The Hundred Thousand Songs of Milarepa. 2 volumes. New Hyde Park, New York: University Books. 
Chakraborti, Haripada, trans. 1970. Pāśupata Sūtram, with Pañchārtha-bhyāṣa of Kaundinya. Calcutta: Academic Publishers.

Choegyal Rinpoché (Choegyal Gyamtso Tulku). 1982. "Foreword" to The Divine Madman: The Sublime Life and Songs of Drukpa Kunley, translated by Keith Dowman.

Chögyam Trungpa. 2001. Crazy Wisdom. Edited by Sherab Chödzin. Boston: Shambhala.

Clark, Elizabeth C. 2004. History, Theory, Text: Historians and the Linguistic Turn. Cambridge: Harvard University Press.

Clark, Tom. 1980. The Great Naropa Poetry Wars, with a copious collection of germane documents assembled by the author. Santa Barbara: Cadmus Editions.

Cuevas, Bryan and Jacqueline Stone, eds. 2007. The Buddhist Dead: Practices, Discourses, Representations. Honolulu: University of Hawai'i Press.

Das, Sarat Chandra. 1970. Journey to Lhasa and Central Tibet, edited by the Hon. W. W. Rockhill. Bibliotheca Himalayica, Series I, Vol. 1. New Delhi: Manjuśrī Publishing House.

-----. 2000. A Tibetan-English Dictionary. Delhi: Motilal Banarsidass. Printed multiple times since 1970.

Das, Surya. 1992. Wisdom Tales from Tibet. Harper SanFrancisco.

Davenport, John T., trans. 2000. Ordinary Wisdom: Sakya Pandita's Treasury of Good Advice. Boston: Wisdom Publications.

Davidson, Ronald. 2002. Indian Esoteric Buddhism: A Social History of the Tantric Movement. New York: Columbia University Press.

-----. 2005a. Tibetan Renaissance: Tantric Buddhism in the Rebirth of Tibetan Culture. New York: Columbia University Press.

-----. 2005b. "Reflections on the Maheśvara Subjugation Myth: Indic Materials, Sa-skyapa Apologetics, and the Birth of Heruka," pp 1-31 in Buddhism: Critical Concepts in Religious Studies, edited by Paul Williams, Vol. 6. Originally printed in Journal of the International Association of Buddhist Studies, 14.2, pp 197-235.

Decleer, Hubert. 1992. "The Melodious Drumsound All-Pervading: Sacred Biography of Rwa Lotsāwa: about early Lotsāwa rnam thar and chos 'byung," pp 13-28 in the Proceedings of the 5th Seminar of the International Association for Tibetan Studies, Narita 1989, Vol. I, edited by Ihara Shōren and Yamaguchi Zuihō, Naritasan Shinshoji.

Diemberger, Hildegard. 1991. 'Ihakama [lha-bka'-ma] and khandroma [mkha'-'gro-ma]: the Sacred Ladies of Beyul Khenbalung [sbas-yul-mKhan-pa-lung]" pp 137-153 in Tibetan History and Language: Studies Dedicated to Uray Géza on his Seventieth Birthday, edited by Ernst Steinkellner.

DiValerio, David. 2011. Subversive Sainthood and Tantric Fundamentalism: An Historical Study of Tibet's “Holy Madmen”. Ph.D. dissertation, University of Virginia.

Doniger O'Flaherty, Wendy. 1981. The Rig Veda: An Anthology. One Hundred and Eight Hymns, Selected, Translated and Annotated. London: Penguin Books.

Dowman, Keith, trans. 2000. The Divine Madman: The Sublime Life and Songs of Drukpa Kunley. Varanasi and Kathmandu: Pilgrims Publishing. Previous printings include: Rider \& Co, London, 1982; Dawn Horse Press, Middletown, 
California, 1983; second edition by Dawn Horse Press, 1998; published by Pilgrims Publishing (Varanasi and Kathmandu) 2000. Published in German translation as Der Heilige Narr, Barth, 1983; reprinted by Barth in 2005. Published in Spanish translation as La Divina Locura Drukpa Künléy: Andanzas de un Yogui Tántrico Tibetano del siglo XVI, Miraguano Ediciones, Madrid, 1988 and 2001. Published in French translation as Le Fou Divin, Paris: Albin Michel, 1984. Published in Romanian as Nebunul Divin: viața sublimă a marelui maestru tantric Drukpa Kunley, translated by Octavian Creț, Firul Ariadnei, 2006.

-----. 1983. Sky Dancer: The Secret Life and Songs of the Lady Yeshe Tsogyel. London: RKP. Reprinted by Penguin 1991, and Snow Lion 1997.

----- 1985. Masters of Mahāmudrā: Songs and Histories of the Eighty-Four Buddhist Siddhas. Albany, NY: State University of New York Press. Translated into German as Die Meister der Mahamudra, Munchen: Diederichs, 1991.

-----. 2007. A Buddhist Guide to the Power Places of the Kathmandu Valley. Thamel: Himalayan Buddhist Meditation Centre.

The Dragon Yogis: A Collection of Selected Biographies and Teachings of the Drukpa Lineage Masters. No editor named. Gurgaon: Drukpa Publications, 2009.

Dreyfus, Georges. 2003. "Cherished Memories, Cherished Communities: Protonationalism in Tibet," pp 492-522, in The History of Tibet: Volume II, The Medieval Period: c.850-1895, The Development of Buddhist Paramountcy, edited by Alex McKay. This article was originally published in Tibetan Studies: Proceedings of the 6th International Seminar of the International Association for Tibetan Studies, Fagernes 1992, edited by Per Kvaerne, Vol. 1, pp 205-218.

Ehrhard, Franz-Karl. 2000. Early Buddhist Block Prints from Mang-yul Gung-thang. Lumbini: Lumbini International Research Institute.

----. 2002. Life and travels of Lo-chen Bsod-nams Rgya-mtsho. Lumbini: Lumbini International Research Institute.

----- 2010. "The Holy Madman of dBus and His Relationships with Tibetan Rulers of the 15th and 16th Centuries" in Geschichten und Geschichte: Historiographie und Hagiographie in der asiatischen Religionsgeschichte, edited by Peter Schalk.

Feuerstein, Georg. 2006. Holy Madness: Spirituality, Crazy-Wise Teachers, and Enlightenment. Prescott, Arizona: Hohm Press. First printed in 1991 as Holy Madness: The Shock Tactics and Radical Teachings of Crazy-Wise Adepts, Holy Fools, and Rascal Gurus. Penguin.

Fisher, James, ed. 1978. Himalayan Anthropology: The Indo-Tibetan Interface. The Hague: Mouton.

Flood, Gavin. 1996. An Introduction to Hinduism. Cambridge: Cambridge University Press.

Germano, David. 1997. "The Elements, Madness, and Lettered Subjectivity," pp 313-334 in Religions of Tibet in Practice, edited by Donald Lopez.

Gerner, Manfred. 2007. Chakzampa Thangtong Gyalpo: Architect, Philosopher and Iron Chain Bridge Builder. Translated from German by Gregor Verhufen. Thimphu: the Centre for Bhutan Studies.

Gethin, Rupert. 1998. The Foundations of Buddhism. New York: Oxford University Press. 
Goldstein, Melvyn C. 1989. A History of Modern Tibet, 1913-1951: The Demise of the Lamaist State. University of California Press.

-----. 2009. On the Cultural Revolution in Tibet: The Nyemo Incident of 1969. University of California Press.

Goldstein, Melvyn C., Dawei Sherap, and William R. Siebenschuh. 2004. A Tibetan Revolutionary: The Political Life and Times of Bapa Phüntso Wangye. Berkeley: University of California Press.

Goss, Robert Everett. 1993. The hermeneutics of madness: A literary and hermeneutical analysis of the "Mi-la'i-rnam-thar" by Gtsang-smyon Heruka. Th.D. dissertation, Harvard University.

Gray, David B. 2007. The Cakrasamvara Tantra (The Discourse of Śrī Heruka) (Śrīherukābhidhāna): A Study and Annotated Translation. New York: The American Institute of Buddhist Studies, Columbia University Press.

Gutschow, Kim. 2009. "The Practice of Tibetan Medicine in Zangskar: A Case of Wind Disorder" in Healing the Periphery: Ethnographies of Tibetan Medicine in India, edited by Laurent Pordie. Durham, NC: Duke University Press.

Gyatso, Janet. 1981. "The Literary Transmission of the Traditions of Thang-stong rGyalpo: A Study of Visionary Buddhism in Tibet." Ph.D. dissertation, University of California at Berkeley.

Hardy, F., ed. 1990. Religions of Asia. Routledge.

Hartley, Lauran and Patricia Schiaffini-Vedani, eds. 2008. Modern Tibetan Literature and Social Change. Durham: Duke University Press.

Havnevik, Hanna. 1989. Tibetan Buddhist Nuns: History, Cultural Norms and Social Reality. Oslo: Norwegian University Press.

----. 1999. The life of Jetsun Lochen Rinpoche (1865-1951) as Told in Her Autobiography. 2 volumes. University of Oslo.

Herriot, Peter. 2007. Religious Fundamentalism and Social Identity. New York: Routledge.

Hinnells, John R., ed. The Routledge Companion to the Study of Religion. New York: Routledge.

Hopkins, Jeffrey, trans. 1992. Tibetan Arts of Love: Sex, Orgasm and Spiritual Healing, by Gedün Chöpel. Ithaca: Snow Lion Publications.

Huber, Toni. 1997a. "Ritual and Politics in the Eastern Himalaya: The Staging of Precessions at Tsa-ri," pp 221-260 in Les Habitants de Toit Du Monde: Études Recueillies en Hommage à Alexander W. MacDonald, edited by Samten Karmay and Phillipe Sagant.

-----. 1997b. "A Guide to the La-Phyi Mandala: History, Landscape and Ritual in SouthWestern Tibet," pp 233-286 in Mandala and Landscape, edited by A. W. Macdonald.

-----. 1999. The Cult of Pure Crystal Mountain: Popular Pilgrimage and Visionary Landscape in Southeast Tibet. New York: Oxford University Press.

Ihara Shōren and Yamaguchi Zuihō, eds. 1992. Proceedings of the 5th Seminar of the International Association for Tibetan Studies, Narita 1989. Vol. I. Naritasan Shinshoji. 
Ingalls, David H. H. 1962. “Cynics and Pāśupatas: The Seeking of Dishonor,” pp 281-98 in Harvard Theological Review 55.

Jamgön Kongtrul. 1998. Buddhist Ethics. Translated by the International Translation Committee. Ithaca: Snow Lion Publications. Reprinted as The Treasury of Knowledge, Book Five: Buddhist Ethics. Ithaca: Snow Lion Publications, 2003. The text of this is Kongtrul's Encompassment of All Knowledge (shes bya kun khyab).

-----. 2007. The Treasury of Knowledge, Book Eight, Part Four: Esoteric Instructions: A Detailed Presentation of the Process of Meditation in Vajrayāna. Translated by Sarah Harding and the Kalu Rinpoché Translation Group. Ithaca: Snow Lion Publications.

Kapstein, Matthew. 2006. The Tibetans. Malden, MA; Oxford: Blackwell Publishing. Karmay, Samten and Phillipe Sagant, eds. 1997. Les Habitants de Toit Du Monde: Études Recueillies en Hommage à Alexander W. MacDonald. Nanterre: Société d'ethnologie.

Kerouac, Jack. 1986. The Dharma Bums. New York: Penguin Books.

Kinsley, David. 1974. "“Through the Looking Glass': Divine Madness in the Hindu Religious Tradition,” pp 270-305 in History of Religions, Vol. 13, No. 4.

Komarovski, Yaroslav Lvovich. 2007. Echoes of Empty Luminosity: Reevaluation and Unique Interpretation of Yogācāra and Nihsvabhāvavāda Madhyamaka by the Fifteenth Century Tibetan Thinker Śākya mchog ldan. Ph.D. dissertation, University of Virginia.

Kun Mchog Dge Legs, Dpal Ldan Bkra Shis, and Kevin Stuart. 1999. “Tibetan Tricksters," pp 5-30 in Asian Folklore Studies, Vol. 58, No. 1.

Kretschmar, Andreas. 1981. 'Brug pa kun legs: Das wundersame Leben eines verrückten Heiligen. Sankt Augustin: VGH Wissenschattsverlag.

Krueger, Derek. 1996. Symeon the Holy Fool: Leontius's Life and the Late Antique City. University of California Press.

Kvaerne, Per. 1977. An Anthology of Buddhist Tantric Songs. Oslo.

-----, ed. 1992. Tibetan Studies: Proceedings of the 6th Seminar of the International Association for Tibetan Studies, Fagernes, 1992. Oslo: Institute for Comparative Research in Human Culture.

Larmer, Brook. 2008. "Bhutan's Enlightened Experiment," pp 124-149 in National Geographic, March 2008.

Larsson, Stefan. 2009. The Birth of a Heruka: How Sangs rgyas rgyal mtshan became gTsang smyon Heruka: A Study of a Mad Yogin. Ph.D. dissertation, University of Stockholm, Institutionen för etnologi, religionshistoria och genusstudier.

Lewis, Todd and Lozang Jamspal. 1988. "Newars and Tibetans in the Kathmandu Valley: Three New Translations from Tibetan Sources," pp 188-90 in The Journal of Asian and African Studies, No. 36.

Lhalungpa, Lobsang P., trans. 1992. The Life of Milarepa. New York: Penguin Compass.

Ligeti, Louis, ed. 1978. Proceedings of the Csoma de Korös Memorial Symposium, held at Mátrafüred, Hungary, 24-30 September 1976. Budapest: Akadémiai Kiadó.

Linrothe, Rob, ed. 2006. Holy Madness: Portraits of Tantric Siddhas. New York: Rubin Museum of Art. 
Lopez, Donald S., Jr. 1995a. "Foreigner at the Lama's Feet," pp 251-95 in Curators of the Buddha: The Study of Buddhism Under Colonialism, edited by Lopez.

-----, ed. 1995b. Curators of The Buddha: The Study of Buddhism Under Colonialism. Chicago: University of Chicago Press.

-----. 1997a. "Introduction" to Religions of Tibet in Practice.

-----, ed. 1997b. Religions of Tibet in Practice. Princeton: Princeton University Press.

-----. 1998. Prisoners of Shangri-La: Tibetan Buddhism and the West. Chicago: University of Chicago Press.

-----. 2006. The Madman's Middle Way: Reflections on Reality of the Tibetan Monk Gendun Chopel. Chicago: University of Chicago Press.

Lorenzen, David. 1972. The Kāpālikas and Kālāmukhas. Berkeley and Los Angeles: University of California Press.

----. 2000. "A Parody of the Kāpālikas in the Mattavilāsa," pp 81-96 in Tantra in Practice, edited by David Gordon White.

Macdonald, A. W., ed. 1997. Mandala and Landscape. Emerging Perceptions in Buddhist Studies, No. 6. Delhi: D. K. Printworld.

Macdonald, A. W. and Dwags po rin po che. 1981. "Un guide peu lu des Lieux-saints du Nepal. IIe Partie," pp 237-73 in Tantric and Taoist Studies in Honour of R.A. Stein, Vol. 1, edited by Michel Strickmann.

Martin, Dan. 1996. "The Star King and the Four Children of Pehar: Popular Religious Movements of the 11th- to 12th-Century Tibet," pp 171-95 in Acta orientalia academiae scientiarum hungarica 49, Nos. 1-2.

-----. 1997. Tibetan Histories: A Bibliography of Tibetan-Language Historical Works. London: Serindia.

Marty, M. E. and R. S. Appleby. 1991a. "The Fundamentalism Project: A User's Guide," in Fundamentalisms Observed.

-----. eds. 1991b. Fundamentalisms Observed. Chicago: University of Chicago Press.

Mayer, Robert. 1996. A Scripture of the Ancient Tantra Collection, The Phur-pa bcugnyis. Oxford: Kiscadale Publications.

McCleary, Rachel M. and Leonard W. J. van der Kuijp. 2010. "The Market Approach to the Rise of the Geluk School, 1419-1642," pp 149-180 in The Journal of Asian Studies, Vol. 60, No. 1.

McDaniel, June. 1989. The Madness of the Saints: Ecstatic Religion in Bengal. Chicago: The University of Chicago Press.

McKay, Alex, ed. 2003. The History of Tibet: Volume II, The Medieval Period: c.8501895, The Development of Buddhist Paramountcy. New York: RoutledgeCurzon.

Michiyo Hoshi, ed. 1985. Texts of Tibetan Folktales, Vol. V, Studia Tibetica, X. Tokyo: Toyo Bunko.

Midal, Fabrice. 2005a. Chögyam Trungpa: His Life and Vision. Translated into English by Ian Monk. Boston: Shambhala.

-----, ed. 2005b. Recalling Chögyam Trungpa. Boston: Shambhala.

Miller, Beatrice D. 1978. "Tibetan Culture and Personality: Refugee Responses to a Tibetan Culture-Bound TAT," pp 365-394 in Himalayan Anthropology: The IndoTibetan Interface, edited by James Fisher. 
Minoru Hara. 2002. Pāśupata Studies. Edited by Jun Takashima. Vienna: De Nobili Research Library.

Monier-Williams, Sir Monier. 2005. A Sanksrit-English Dictionary. Delhi: Motilal Banarsidass. First printed in London: Oxford University Press, 1899.

Moti Lal Pandit. 1987. Śaivism: a Religio-Philosophical History. Delhi: The Theological Research and Communication Institute.

Mullin, Glenn H. 1994. Mystical Verses of a Mad Dalai Lama. Wheaton, IL: Quest Books, the Theosophical Publishing House.

Mumford, Stanley Royal. 1989. Himalayan Dialogue: Tibetan Lamas and Gurung Shamans in Nepal. Madison: University of Wisconsin Press.

Munson, Henry. 2005. "Fundamantalism," pp 337-354 in The Routledge Companion to the Study of Religion, edited by John R. Hinnells.

Namgyal, Jamyang [E. Gene Smith]. 1973. "Vie et chants de 'Brug-pa Kun-legs le yogin, a Review," pp 91-99 in Kailash, Vol. I, No. 1.

Napper, Elizabeth. 2001. "Ethics as the Basis of a Tantric Tradition: Tsong kha pa and the Founding of the dGe lugs order in Tibet," pp 107-131 in Changing Minds: Contributions to the Study of Buddhism and Tibet in Honor of Jeffrey Hopkins, edited by Guy Newland.

Newland, Guy, ed. 2001. Changing Minds: Contributions to the Study of Buddhism and Tibet in Honor of Jeffrey Hopkins. Ithaca: Snow Lion Publications.

Nolan, Albert. 1978. Jesus Before Christianity. Maryknoll: Orbis Books.

Patrul Rinpoché. 1998. The Words of My Perfect Teacher. Translated by the Padmakara Translation Group. Altamira Press.

Pordie, Laurent, ed. 2009. Healing the Periphery: Ethnographies of Tibetan Medicine in India. Durham, NC: Duke University Press.

Quintman, Andrew. 2006. Mi la ras pa's Many Lives: Anatomy of a Tibetan Biographical Corpus. Ph.D. dissertation, University of Michigan.

-----, trans. 2010. The Life of Milarepa. New York: Penguin Books.

Ray, Reginald A. 1994. Buddhist Saints in India: A Study in Buddhist Values and Orientations. New York: Oxford University Press.

Rhoton, Jared Douglas, trans. 2002. Sakya Pandita Kunga Gyaltshen's A Clear Differentiation of the Three Codes: Essential Distinctions among the Individual Liberation, Great Vehicle, and Tantric Systems. State University of New York Press.

Ricard, Matthieu, trans. 2001. The Life of Shabkar: The Autobiography of a Tibetan Yogin. Ithaca: Snow Lion Publications.

Richardson, Hugh. 1998. "The Karma-pa Sect: A Historical Note," in High Peaks, Pure Earth: Collected Writings on Tibetan History and Culture, edited by Michael Aris.

Roberts, Peter Alan. 2007. The Biographies of Rechungpa: The Evolution of a Tibetan Hagiography. Abingdon, New York: Routledge.

Roerich, George N., trans. 1996. The Blue Annals. Delhi: Motilal Banarsidass. First printed in 1949.

Ruthven, Malise. 2004. Fundamentalism: The Search for Meaning. New York: Oxford University Press. 
Samuel, Geoffrey. 1994. Civilized Shamans: Buddhism in Tibetan Society. Washington,

D.C.: Smithsonian Institution Press.

-----. 2008. The Origins of Yoga and Tantra. New York: Cambridge University Press.

Sanderson, Alexis. 1988. "Śaiva and Tantric traditions" in The World's Religions, edited

by S. Sutherland, et. al.; also in Religions of Asia, edited by F. Hardy.

Schaeffer, Kurtis, ed. 2001. Among Tibetan Texts: History and Literature of the

Himalayan Plateau. Boston: Wisdom Publications.

----. 2007. "Dying Like Milarépa: Death Accounts in a Tibetan Hagiographic Tradition,"

pp 208-233 in The Buddhist Dead: Practices, Discourses, Representations, edited

by Bryan Cuevas and Jacqueline Stone.

-----. 2009. The Culture of the Book in Tibet. New York: Columbia University Press.

-----. forthcoming. "The Printing Projects of Gtsang Smyon He ru ka and his Disciples."

Schalk, Peter, ed. 2010. Geschichten und Geschichte: Historiographie und Hagiographie

in der asiatischen Religionsgeschichte. Uppsala: Uppsala University Library.

Sernesi, Marta. 2004. "Milarepa's Six Secret Songs: The Early Transmission of the

bDemchog snyan brgyud," pp 251-87 in East and West 54 (1-4).

-----. 2007a. The Aural Transmission of Samvara and Ras chung pa's Legacy. Ph.D.

Dissertation, Università degli Studi di Torino.

-----. 2007b. "A Tibetan Text on the Cakrasamvara Tradition from the Tucci Fund (IsIAO

): Preliminary Remarks on Its Authorship, Dating and Contents." Paper presented at the Journée d'études études Indiennes, ètudes Bouddhiques, June 20, EPHE.

Paris.

-----. Forthcoming. Textual Compendia of the Aural Transmission: An Introduction to the Less-Known Sources for the Study of the Early $b \mathrm{Ka}^{\prime}$ ' brgyud. In Proceedings of

the 11th International Association for Tibetan Studies, Bonn 2006, edited by Matthew Kapstein.

Shakabpa, Tsepon W. D. 1967. Tibet: A Political History. New Haven, Conn.: Yale

University Press.

Shakya, Hem Raj. 2004. Śrī Svayambhū Mahācaitya. Translated by Min Bahadur

Shakya. Kathmandu: Svayambhu Vikash Mandal.

Smith, E. Gene. [See also Jamyang Namgyal, 1973.]

-----. 2001a. "Introduction to The Life of Gtsang smyon Heruka," in Among Tibetan

Texts: History and Literature of the Himalayan Plateau, edited by Kurtis

Schaeffer. Article originally published with rgod tshang ras pa sna tshogs rang

grol's version of The Life of the Madman of Tsang, published by Lokesh Chandra,

New Delhi: 1969. All citations are from the 2001 reprint.

-----. 2001b. "Padma dkar po and His History of Buddhism," in Among Tibetan Texts.

-----. 2006. "Siddha Groups and the Mahāsiddhas in the Art and Literature of Tibet" in

Holy Madness: Portraits of Tantric Siddhas. Edited by Rob Linrothe..

Snellgrove, David and Hugh Richardson. 1968. A Cultural History of Tibet. George

Weidenfeld and Nicolson Ltd. Reprinted in Boston and London: Shambhala,

1995. All citations are from the 1995 version.

Snellgrove, David. 1959. The Hevajra Tantra: A Critical Study. 2 volumes. London, New

York, Toronto: Oxford University Press.

-----. 2002. Indo-Tibetan Buddhism. Boston: Shambhala. 
Sørensen, Per K. 2003. "Lhasa Diluvium: Sacred Environment at Stake: The Birth of Flood Control Politics, the Question of Natural Disaster Management and their Importance for the Hegemony over a National Monument in Tibet," pp 85-134 in Lungta (16) Spring 2003, special edition titled Cosmogony and the Origins.

Sørensen, Per K. and Guntram Hazod, with Tsering Gyalbo. 2005. Thundering Falcon: An Inquiry into the History and Cult of Khra- 'brug, Tibet's First Buddhist Temple. Wien: Österreichische Akademie der Wissenschaften.

-----. 2007. Rulers on the Celestial Plain: Ecclesiastic and Secular Hegemony in Medieval Tibet: A Study of Tshal Gung-thang. Wien: Österreichische Akademie der Wissenschaften and the Tibetan Academy of Social Sciences of the Autonomous Region Tibet.

Sørensen, Per K. and Sonam Dolma, eds. 2007. Rare Texts from Tibet: Seven Sources for the Ecclesiastic History of Medieval Tibet. Lumbini International Research Institute.

Stearns, Cyrus. 1996. Luminous Lives. Boston: Wisdom.

-----, trans. 2000. Hermit of Go Cliffs: Timeless Instructions from a Tibetan Mystic. Boston: Wisdom Publications.

-----, trans, 2007. King of the Empty Plain: The Tibetan Iron-Bridge Builder Tangtong Gyalpo. Ithaca: Snow Lion.

Stearns, Maruta. 1985. The Life of gTsang smyon Heruka: A Study in Divine Madness. M.A. Thesis, University of Washington.

Stein, R. A. 1964. "Un saint poète tibétain," pp 485-501 in Mercure de France, JulyAugust.

-----, trans. 1972. Vie et chants de 'brug-pa kun-legs le yogin. Paris: G.-P Maisonneuve et Larose.

-----. 1972. Tibetan Civilization. Translated into English by J. E. Stapleton Driver. Stanford: Stanford University Press.

Steinkellner, Ernst, ed. 1991. Tibetan History and Language: Studies Dedicated to Uray Géza on his Seventieth Birthday. Wien: Arbeitskreis für tibetische und buddhistische studien universität wien.

-----, ed. 1997. Tibetan Studies: Proceedings of the 7th Seminar of the International Association for Tibetan Studies, Graz 1995. Graz, Austria.

Stoddard, Heather. 1985. Le mendicant de l'Amdo. Paris: Société d'ethnographie.

Strickmann, Michel, ed. 1981. Tantric and Taoist Studies in Honour of R.A. Stein, Vol. 1. Bruxelles: Institut belge des hautes études chinoises.

Sutherland, S., et. al., eds. 1988. The World's Religions. Routledge.

Tagare, G. V. 1996. Śaivism: Some Glimpses. New Delhi: D. K. Printworld, Ltd.

Tiso, Frances. 1989. A Study of the Buddhist Saint in Relation to the Biographical Tradition of Milarepa. Ph.D. dissertation, Columbia University.

-----. 1994. "The Rdo rje 'chang rnam thar in the Bkha' brgyud gser 'phreng Genre" in

Tibetan Studies: Proceedings of the 6th Seminar of the International Association for Tibetan Studies, Fagernes, 1992, edited by Per Kvaerne.

-----. 1996. "The Biographical Tradition of Milarepa," pp 10-21 in The Tibet Journal 21 (2). 
-----. 1997. "The Death of Milarepa: Towards a Redaktionsgeschichte of the Mila rnam thar Traditions," in Tibetan Studies: Proceedings of the 7th Seminar of the International Association for Tibetan Studies, Graz 1995, edited by Ernst Steinkellner.

Torella, Raffaele, ed. 2001. Le Parole e i Marmi. Studi in Onore di Raniero Gnoli nel suo $70^{\circ}$ Compleanno. 2 volumes. Serie Orientale Roma, XCII, 1-2. Rome: IsIAO.

Torricelli, F. 1998. "The Tibetan text of the Karnatantravajrapada," pp 385-86 in East and West 48 (3-4).

-----. 2000. "Padma dkar po's Arrangement of the bDe mchog snyan brgyud," pp 359-86 in East and West 50.

-----. 2001. "Zhang Lo tsā ba's Introduction to the Aural Transmission of Śamvara," in Le Parole e i Marmi. Studi in Onore di Raniero Gnoli nel suo $70^{\circ}$ Compleanno. Edited by Raffaele Torella.

Tucci, Giuseppe. 1949. Tibetan Painted Scrolls. 2 volumes. Rome: La Libreria della Stato.

-----, trans. 1971. [The New Red Annals:] Deb Ther Dmar Po Gsar Ma: Tibetan Chronicles, Volume I. Serie Orientale Roma XXIV. Rome: ISMEO.

Tribe, Anthony. 2000. "Mantranaya/Vajrayāna - tantric Buddhism in India," pp 192-244 in Paul Williams, Buddhist Thought: A Complete Introduction to the Indian Tradition.

van der Kuijp, Leonard W. K. 2006. "On the Composition and Printings of the Deb gter sngon po by 'Gos lo tsā ba gzhon nu dpal (1392-1481)" in Journal of the International Association of Tibetan Studies 2.

van Manen, Johan. 1922. "A Contribution to the Bibliography of Tibet," pp 445-525 in Journal and Proceedings of the Asiatic Society of Bengal. Volume XVIII (New Series). Calcutta.

Vitali, Roberto. 1990. Early Temples of Central Tibet. London: Serindia Publications.

von Rospatt, Alexander. 1999. "On the Conception of the Stūpa in Vajrayāna Buddhism: The Example of the Svayambhūcaitya of Kathmandu," pp 121-147 in Journal of the Nepal Research Centre, Vol. 11.

-----. 2001. "A Historical Overview of the Renovations of the Svayambhūcaitya at Kathmandu," pp 195-241 in Journal of the Nepal Research Centre, Vol. 12.

Wedemeyer, Christian K. 2007. Aryadeva's Lamp that Integrates the Practices Caryāmelāpakapradīpa): The Gradual Path of Vajrayāna Buddhism According to the Esoteric Community Noble Tradition. New York: The American Institute of Buddhist Studies, Columbia University Press.

White, David Gordon, ed. 2000. Tantra in Practice. Princeton: Princeton University Press.

-----. 2005. "Review of Indian Esoteric Buddhism, by R. M. Davidson,” pp 1-11 in Journal of the International Association of Tibetan Studies 1.

Williams, Paul, ed. 2005. Buddhism: Critical Concepts in Religious Studies. Vol. 6. New York: Routledge.

Williams, Paul, with Anthony Tribe. 2000. Buddhist Thought: A Complete Introduction to the Indian Tradition, London and New York: Routledge. 
Wylie, Turrell V. 1978. "Reincarnation: A Political Innovation in Tibetan Buddhism," pp 579-86 in Proceedings of the Csoma de Korös Memorial Symposium, held at Mátrafüred, Hungary, 24-30 September 1976, edited by Louis Ligeti.

-----. 1980. "Monastic Patronage in 15th-century Tibet," pp 319-28 in Acta Orientalia Academiae Scientiarum Hung., XXXIV (103). Reprinted in The History of Tibet: Volume II, The Medieval Period: c.850-1895, The Development of Buddhist Paramountcy, edited by Alex McKay, 2003.

Yamamoto, Carl Shigeo. 2009. Vision and Violence: Lama Zhang and the Dialectics of Political Authority and Religious Charisma in Twelfth-Century Central Tibet. Ph.D. dissertation, University of Virginia.

\section{Interviews}

Choegyal Rinpoché, interview at Changchub Jong, H.P., India, 15 August 2009. His Holiness the 17th Karmapa, interview at Gyutö Monastery, H.P., 4 August 2009.

Kenpo Könchok Namdak, interview at Phyang Monastery, Ladakh, 22 July 2009.

Kenpo Losel Rinpoché, interview at Kamgar Druk College, Tashijong, H.P., 13 August 2009.

Kenpo Losel Tsegyel, interview at Mindröl Ling Monastery, Clement Town, Uttaranchal, 10 October 2009.

Kenpo Nyima Gyeltsen, interview at Kagyu College, Dehradun, 4 October 2009.

Kenpo Orgyen Tsering, interview at Nyinggön Pelyül Chökor Ling, Bir, H.P., 22 September 2009.

Kenpo Sönam Tashi , interview at Zigar Monastery, Rewalsar, H.P., 29 September 2009.

Kenpo Tinlé Tarchen, interview at Drikung Kagyu Monastery, Rewalsar, H.P., 29 September 2009.

Kenpo Tsülnam Rinpoché, interview at Sherab Ling Monastery, Bir, H.P., numerous interviews between 16 August and 28 September 2009.

Lama Tsültrim Topden Rinpoché, interview at Karma Dupgyud Choeling Monastery, Choklamsar (near Leh), Ladakh, 19 July 2009.

Menpa Tsewang Tamdrin, interview at Mentsi Kang, Mcleod Ganj, H.P., 7 September 2009.

Öntrul Rinpoché, interview at Drikung Kagyu Monastery, Rewalsar, H.P. 30 September 2009.

Wangdül Rinpoché, interview at the retreat center above Rewalsar Lake, H.P, 28

September 2009. 